UNIVERSIDADE DE SÃO PAULO

FACULDADE DE FILOSOFIA, LETRAS E CIÊNCIAS HUMANAS

DEPARTAMENTO DE SOCIOLOGIA PROGRAMA DE PÓS-GRADUAÇÃO EM SOCIOLOGIA

\title{
RISO, LÁGRIMA, IRONIA E TRATADOS: \\ PEDRO ALMODÓVAR - GENIALIDADE E PARADOXO EM CONSTRUÇÃO PERMANENTE
}

Gilmar Santana

Tese apresentada ao Programa de Pós-Graduação em Sociologia do Departamento de Sociologia da Faculdade de Filosofia, Letras e Ciências Humanas da Universidade de São Paulo, para obtenção do título de Doutor em Sociologia.

Orientador: Prof. Dr. Sérgio Miceli Pessôa de Barros

São Paulo

2007 
"Ah! bruta flor do querer! ah! bruta flor, bruta flor:

Onde queres o ato eu sou espírito E onde queres ternura eu sou tesão

Onde queres o livre, decassílabo E onde busca o anjo sou mulher Onde queres prazer sou o que dói E onde queres tortura, mansidão Onde queres um lar, revolução E onde queres bandido sou herói [...] Onde queres comício, flipper-vídeo $E$ onde queres romance rock'n'roll Onde queres a lua eu sou o sol Onde a pura natura, o inseticídio E onde queres mistério eu sou a luz Onde queres um canto, o mundo inteiro Onde queres quaresma, fevereiro E onde queres coqueiro eu sou ubus [...]

0 quereres e o estares sempre a fim Do que em mim é de mim tão desigual Faz-me querer-te bem, querer-te mal Bem a ti, mal quereres assim Infinitamente pessoal E eu querendo-te aprender o total Do querer que há e o que não há em mim."

(Caetano Veloso) 
A todos aqueles que fazem da amizade efetiva uma realidade vivida e sem fronteiras.

Em especial à memória de

Maria José dos Santos Stein, uma amiga que, ao transcender a frágil trajetória da vida terrena, se tornou eterna para brilhar em meu coração. 


\section{SUMÁRIO}

RESUMO

INTRODUÇÃO

\section{PANORAMA CRIATIVO}

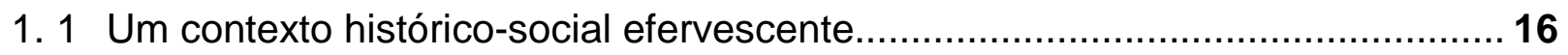

1. 2 Uma opção por sobrevivência - O gênero cinematográfico......................... 22

1. 3 Artífices de um novo panorama cinematográfico - perfis.............................. 35

\section{ESCALADAS POR AUTONOMIA}

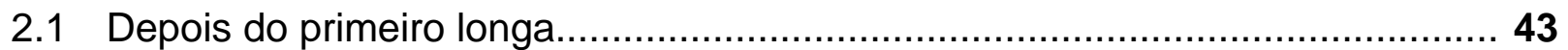

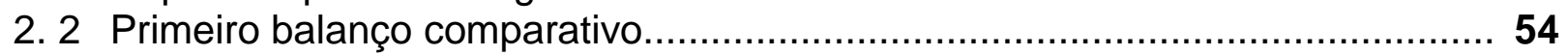

2. 3 Filmar somente o que se deseja.................................................. 60

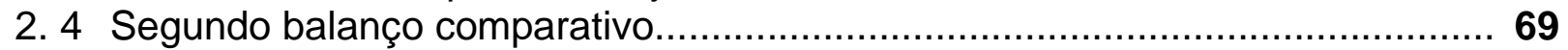

\section{COLEGAS, CONTEMPORÂNEOS E DISTINTOS}

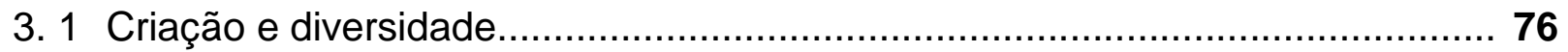

3. 2 Quase um jogo de espelhos - semelhanças e distinções.......................... 79

3. $3 \mathrm{O}$ diálogo entre as diversas ironias e linguagens.................................. 81

3. 4 Os diretores lutam - a manutenção da difícil autonomia............................. 102

\section{TEMÁTICAS E PERSONAGENS - VERSÕES DE UMA GERAÇÃO}

4. 1 Estilos e temáticas - quando rir conta mais...................................... 117

4. 2 Estilos e temáticas - sofrer não basta.................................................. 129

4. 3 Uma exceção valiosa e necessária - o drama num impasse......................... 139

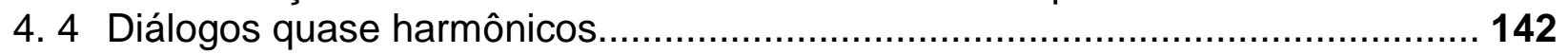

\section{DESCONSTRUINDO E RECONSTRUINDO PEDRO - O ENTORNO}

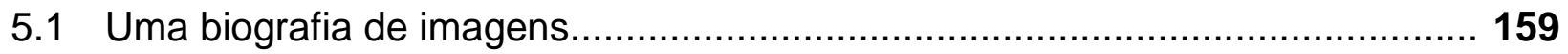

5.2 Adeus, Movida? - Referências e projeções mitológicas............................ 163

5.3 A cidade que nasceu da Movida - um diálogo físico com o mito..................... 185 


\section{DESCONSTRUINDO E RECONSTRUINDO PEDRO - MITO E HUMANO}

6.1 Da Movida para a maturidade - nasce um gênio? .......................................... 196

6.2 Autodidata e popular - ônus conflitivo...................................................... 204

6.3 Ter nascido em La Mancha - um acaso sem predestinações........................... 215

\section{AUTÊNTICO E INCOMPREENDIDO}

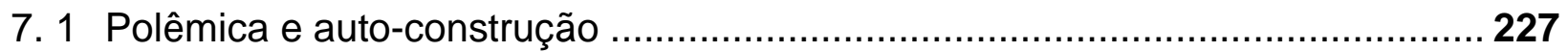

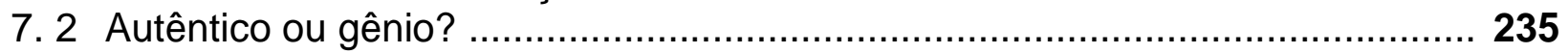

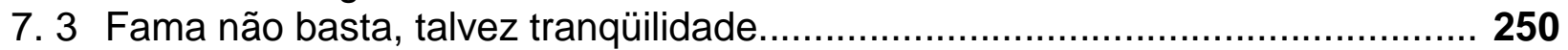

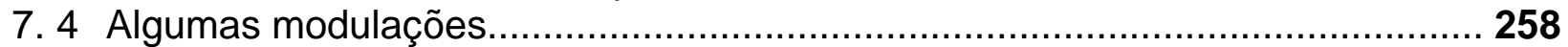

\section{ACADÊMICOS E CRÍTICOS}

8. 1 Detentores de poder simbólico e artístico.......................................................... 264

8. 2 Depoimentos - a relevância dos especialistas e intelectuais........................... 268

8. 3 Legado acadêmico - contribuições e questionamentos em pauta...................... 299

\section{GAZPACHO NÃO É COCA-COLA}

9. 1 Uma negociação de economias culturais......................................................307

9. 2 Um trabalho familiar - intensas relações entrelaçadas..................................... 319

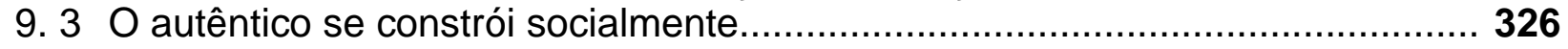

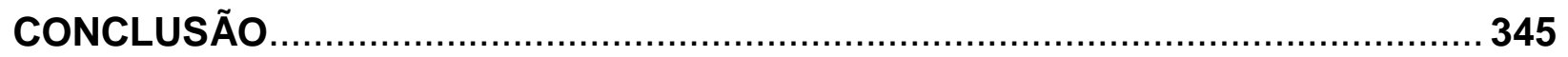

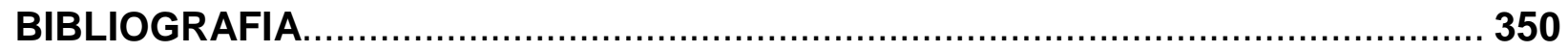

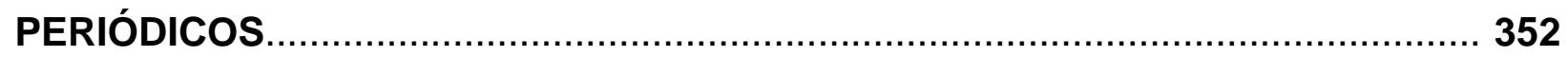

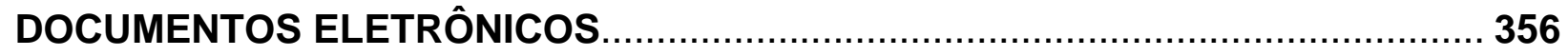

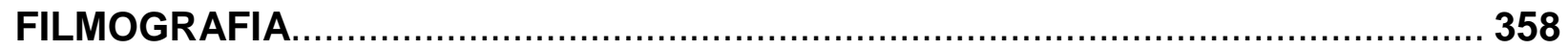




\section{AGRADECIMENTOS}

Sempre busco ser breve nesses momentos de gratidão e geralmente me estendo. Espero desta vez conseguir, mesmo com uma quantidade maior de pessoas em relação ao mestrado - que partilharam comigo mais uma etapa de pesquisa e de aprendizado desta vida acadêmica. Agradeço à CAPES pelo auxílio da bolsa de estudos no Brasil, mas, principalmente, pela atenção que dispensou no período em que estive na Espanha. Exatidão, prontidão e simpatia. Sem toda essa ajuda humana e financeira, certamente o trabalho não teria tomado o rumo que me orientou para tantas novas perspectivas e análises. A toda equipe - são muitos os que tive oportunidade de contatar -, muitíssimo obrigado. Aos funcionários da secretaria de pós-graduação da Sociologia da Faculdade de Filosofia, Letras e Ciências Humanas da Universidade de São Paulo, em especial à Angela, pelo grande profissionalismo com que desenvolve seu trabalho e pela constante solicitude, meus sinceros agradecimentos.

Ao consulado espanhol de São Paulo, pela total atenção dispensada e prontidão nos trâmites de documentos para a obtenção do visto. À Universidade de Barcelona, pelos serviços prestados e pela estrutura que me permitiu uma pesquisa tranqüila. Aos funcionários da Filmoteca do Departament de Cultura da Generalitat de Catalunya, por possibilitarem o acesso à documentação e aos filmes disponíveis. Aos funcionários da biblioteca da Universidade Pompeu Fabra, pela amável concessão de consulta ao acervo de filmes espanhóis e estrangeiros, sem os quais não teria sido possível meu olhar mais global sobre a cinematografia do país. À Biblioteca Nacional de Madrid, apesar da rigidez do atendimento.

A minha família e amigos próximos, que tanto me incentivaram e acreditaram em mim, sobretudo quando de minha partida para os estudos fora do país - e tantos "botas-fora". Em especial, a minha querida sobrinha Natália que me acompanhou torcendo muito por mim desde a minha entrada no curso do doutorado até o dia da defesa. Aos meus amigos de Barcelona: às "chicas" Marisa, Vero, Sonia e Patrícia, que me receberam gentilmente em sua casa na primeira semana quando cheguei à cidade. A Tomas Gamarra - literalmente um grande homem -, que já possuía vínculos com meus amigos do Brasil e se transformou quase num irmão para mim, bem-humorado, sempre presente, ajudando-me nos momentos necessários. A Carlos e Rosa, queridos amigos brasileiros que conheci em Rubi, pelos lindos passeios e pelas conversas encantadoras, mesmo sendo pouquíssimas as vezes que nos encontramos, e por mostrarem que na Espanha já praticamente existe nosso feijão fradinho. 
A Joaquim Rius e Ingo Michael von Sundal, ex-orientandos de meu orientador espanhol, que me ajudaram em vários momentos, inclusive para algumas traduções depois de meu retorno ao Brasil. Em especial a Quim e sua família, por me apresentarem diversas informações sobre a Espanha, ou melhor, sobre a Catalunha, as quais eu sequer poderia imaginar observando sozinho. Ao padre Carles e aos vários amigos de Bellvitge, pelo espírito de solidariedade reinante nas reuniões e pelas noites de excelentes conversas, filmes, gazpachos, tapas e copas. A Miriam Delgado García, minha querida amiga da região de Burgos, que me acolheu em sua casa em Madrid, praticamente me fazendo sentir como se esta fosse minha, durante as vezes em que precisei desenvolver minhas pesquisas na cidade. Linda, gentil, inteligente e humana, não há atributos suficientes para qualificá-la e agradecê-la.

Ao meu orientador espanhol, professor doutor Arturo Rodríguez Morato, pela disposição e atenção em orientar-me em meio a tantas atividades. Pelos apontamentos e indicações bibliográficas extremamente preciosos e pela amistosidade ímpar, serei muito grato, sempre. Aos professores que entrevistei para este trabalho: José Enrique Monterde, José Maria Caparrós Lera, Daniela Aronica - da Universitat de Barcelona -, Sasa Markus - da Universitat Pompeu Fabra -, María Antonia Garcia de Leon - da Universidad Complutense de Madrid -, Fran A. Zurian - da Universidad de Castilla-La Mancha -, Jean-Claude Seguin - da Université Lumière e Lion 2 -, Fancesco Cassetti da Universidade de Milano, pelo grau de seriedade que demonstraram em seus ofícios e pela disposição para longos diálogos e observações durante e depois das entrevistas. Vários dos quais me tornei também amigo pela partilha de perspectivas e de dilemas pessoais e acadêmicos.

À Núria Vidal, respeitada jornalista e escritora, coordenadora do festival de San Sebastián, que saiu exclusivamente de sua residência - distante de Barcelona - para conceder-me valiosa entrevista. Aos coordenadores do Centro Cultural Pedro Almodóvar, localizado em Calzada de Calatrava, pelas entrevistas expressivas, mostrando seus projetos, e pela simpatia em me apresentar a alguns familiares do diretor, durante o dia em que visitei a cidade.

Aos amigos que me auxiliaram em traduções e revisão de textos, mas que na verdade também me acompanharam nas reflexões sobre o tema e estiveram sempre presentes de alguma maneira vendo o desenvolvimento de meu trabalho, portanto, mesmo aqueles que também não contribuíram diretamente para sua confecção: Herbert Rodrigues, Camilo D'Angelo, Lisane Valdo, Angelo Edward Batistini Marques, Paula Cristina Veneroso, Vera Lúcia Loyola, Célia Cecília Domingos dos Santos, Edson 
José da Silva, Rose Ferrera, Walmir Pavam, Maria Auxiliadora Elias, Branca - ou carinhosamente, Branquinha - minha querida irmã de coração e seu marido, grande amigo Jesus Carlos Delgado García, por desde longa data me incentivarem nessa análise, e Flávio César Novo, talvez o primeiro a saber de minhas intenções sobre esse estudo. A todos, muito obrigado.

Às integrantes da banca examinadora de qualificação, professora doutora Maria Arminda do Nascimento Arruda e professora doutora Élide Rugai Bastos, pelas preciosas observações. Estas me fizeram refletir durante um ano os caminhos possíveis para aprofundar meus olhares sobre o objeto da pesquisa e alterar sensivelmente seu rumo, sob enfoques mais precisos e criteriosos dentro do universo sociológico e cinematográfico.

Aos ilustres membros da comissão julgadora dessa tese: professora doutora Mariarosaria Fabris, professora doutora Maria Arminda do Nascimento Arruda, professor doutor Marcelo Siqueira Ridenti e professor doutor Marcius César Soares Freire, pelos valiosos apontamentos que discorreram num ambiente de sérias análises, concomitante a um clima de simpatia e tranqüilidade. Buscarei incorporar a esse trabalho o maior número de suas sugestões quando publicá-lo. A precisão com que observaram vários detalhes só ampliou o grau de responsabilidade que percebi possuir uma produção intelectual. A todos, meu sincero obrigado.

Ao meu prezado orientador, professor doutor Sérgio Miceli Pessôa de Barros, ou, como ele mesmo prefere, apenas Sérgio Miceli, pela paciência comigo e minhas preocupações, pela segurança de grande intelectual que sabe os penosos, mas louváveis, passos do conhecimento. Sua firmeza me tranqüilizou, sua clareza me abriu horizontes, sua sinceridade abalou meus condicionamentos e me fez não só vislumbrar minha estatura como repensá-la diante dos desafios que eu mesmo busquei enfrentar para seguir adiante. Ele me ensinou a olhar para a vida, não só acadêmica, com mais naturalidade, reconhecendo sua dureza, mas também seus benefícios humanos. Minha admiração por ele é muito grande. Não tenho palavras à altura para explicar aqui minha gratidão. Muitíssimo obrigado!

Agradeço à Universidade de São Paulo, em geral, tanto a seus funcionários como a sua estrutura, por proporcionar-me com estimada qualidade todas essas experiências acumuladas: viagens, professores, congressos, bibliotecas e amigos. Para cada esfera, uma história singular e um crescimento pessoal. Serei sempre muito grato a todos. Toda essa trajetória universitária marcou e influenciou sensivelmente minha vida atingindo também os que conviveram e convivem comigo. 
Enfim, retomo meu franco agradecimento a todo esse conjunto de pessoas e outras que indiretamente também contribuíram para os resultados desta tese. Como apresentei na dedicatória, é graças a vocês que ela pôde se realizar. Só a amizade consolida bons caminhos. Cada vez mais me convenço de seu poder e, para aqueles que não acreditam nela, creio que já é tempo de reformular suas práticas. O autor estudado é alguém que fala muito sobre a solidão e a importância dos amigos. Talvez seja um bom contraponto para pensar a vida. Nós - seres emancipados - constituímos um universo interno e ele é inteiro, porém, para ficar mais rico, só a amizade o completa. Obrigado a todos meus queridos amigos! 
O êxito de uma obra artística autêntica depende de vários mecanismos sociais que possibilitem sua permanência. Muito além de comprovar qualidade, o autor precisa deixar claras as condições de sua proposta diante do universo criativo que elegeu e, sobretudo, aprender o funcionamento de suas regras. Assimiladas, ele deve - a cada novo trabalho - articular contínuas negociações que viabilizem a ampliação da mensagem produzida. É o que tem feito Pedro Almodóvar no decorrer de sua trajetória no cinema, desde a estréia do primeiro longa-metragem no circuito comercial em 1980. Esta análise demonstra como foram - e são - os caminhos - complexos e estreitos - dentro do campo cinematográfico que o conduziram ao sucesso.

Palavras-chave: Sociologia da cultura, Sociologia da arte, Cinema, Pedro Almodóvar, História do cinema espanhol.

\section{ABSTRACT}

The outcome of any authentic artistic work depends on various social mechanisms that make its permanence possible. More than just validating quality, an author needs to highlight the conditions of his proposal against the creative universe that he has chosen and, more than anything, to learn the functionality of its rules. Once this is assimilated, the must - in every single new work - articulate continuous negotiations that make possible an extension of the resulting message. That is what Pedro Almodóvar has done throughout his cinematic career since his first long film was released to the commercial circuit in 1980. This analysis highlights how cinematographic fields were complex and narrow in the past and continues to be - paths that have nonetheless led him to succeed.

Keys-Words: Sociology of Culture, Sociology of Art, Cinema, Pedro Almodóvar, History of the Spanish Cinema.

\section{RESUMEN}

El éxito de una obra artística auténtica depende de variados mecanismos sociales que la hagan permanecer como tal en el tiempo. Además de manifestar significativa cualidad artística, el autor necesita esclarecer las condiciones socioculturales de su propuesta frente al universo creativo que ha elegido $y$, sobretodo, aprender el funcionamiento de sus reglas. Asimiladas esas normas, él debe - a cada nuevo trabajo - enlazar continuas negociaciones que posibiliten la ampliación del mensaje producido. Es lo que ha hecho Pedro Almodóvar a lo largo de su trayectoria en el cine, desde el estreno de su primero largometraje en el circuito comercial en 1980. Este análisis demuestra cómo fueron - y cómo son - los caminos - complejos y estrechos - dentro del campo cinematográfico que le conduceron al triunfo.

Palabras-llave: Sociología de la cultura, Sociología del arte, Cine, Pedro Almodóvar, Historia del cine español. 
Le réussite d'une oeuvre artistique authentique dépend de plusieurs mécanismes sociaux qui rendent possible sa durabilité. Bien au-delá de vérifier qualité, láuteur a besoin de laisser claires les conditions de as proposition devant l'univers créatif le quel il a élu et, surtout, apprendre le fonctionnement de leurs règles. Assimilées, il doit - à chaque nouveau travail - articuler de continues négociations qui viabilisent l'élargissement du message produit. C'est ce qui a fait Pedro Almodóvar pendant as trajectoire dans le cinéma, depuis il étrenne de son premier film dans le circuit commercial en 1980. Cette analyse démontre comme ont été et sont - les chemins - complexes et étroits - à l'intérieur du champ cinématographique qui l'ont conduit au succès.

Mots-clés : Sociologie de la culture, Sociologie de l'art, Cinéma, Pedro Almodóvar, Histoire du cinéma espagnol

\section{RESUM}

L'èxit d'una obra artística autèntica depèn de varis mecanismes socials que el fan perdurar com a tal al llarg del temps. A més de manifestar una significativa qualitat artística, l'autor necessita esclarir les condicions socioculturals de la seva proposta front a l'univers creatiu que ha elegit $i$, sobretot, aprendre el funcionament de les seves regles. Assimilades aquestes normes, ha de - a cada nou treball - enllaçar contínues negociacions que possibilitin l'ampliació del missatge produït. És el que ha fet Pedro Almodóvar al Ilarg de la seva trajectòria en el cine, des de l'estrena del seu primer llargmetratge en el circuit comercial el 1980. Aquest anàlisi demostra com van ser - i com són - els camins - complexos i estrets - dins del camp cinematogràfic que el van conduir al triomf.

Paraules clau: Sociologia de la cultura, Sociologia de l'art, cinema, Pedro Almodóvar, Història del cinema espanyol.

\section{SINTESI}

II successo di un'opera autentica dipenda da vari meccanismi sociali che rendono possibile la sua durata. Molto più che dar prova di qualità, l'autore deve mostrare chiaramente le condizioni della sua proposta di fronte all'universo creativo che ha scelto e soprattutto apprendere il funzionamento delle sue regole. Dopo averle assimilate egli deve, in ogni nuovo lavoro, mettere in moto continue mediazioni che rendano possibile l'ampliamento del messaggio prodotto. É quanto ha fatto Pedro Almodóvar lungo il suo percorso cinematografico, fin dal debutto suo primo metraggio nel circolo commerciale del 1980. Questa analisi mostra come sono state - e sono - complesse e tortuose nel campo cinematografico le vie che lo hanno condotto al successo.

Parole chiavi: Sociologia della cultura, Sociologia dell'arte, Cinema, Pedro Almodóvar, Storia del cinema spagnolo. 


\author{
"Yo no creo que haya nadie \\ más cercano a Dios que un director, \\ que se pueda permitir el lujo de dar una \\ vida a una fantasia y hacerla crecer"1 \\ Haz lo que quieres hacer, \\ confia en ti mismo, ten paciencia, \\ no te vendas y obtendrás lo mejor. \\ Pero no la he seguido por integridad o \\ por razones morales. Lo he hecho \\ porque era lo que me apetecía, \\ lo que quería hacer realmente. ${ }^{2}$
}

O hábito de compreender o sucesso de um indivíduo como mérito unicamente pessoal - mais do que em qualquer outra época - tem sido moldado de maneira crescente como valor de prestígio na sociedade contemporânea. No conteúdo dessa idéia incluem-se perspicácia, inteligência e determinação. Com ela, o sujeito vitorioso é colocado num patamar de destaque para que o resultado do desenvolvimento de suas potencialidades - vistas como inatas - seja, reiteradas vezes, celebrado. Assim, 0 triunfo individual reconhecido socialmente se apresenta como condição indispensável para que alguém se sinta realizado e, ao mesmo tempo, fortaleça seus valores na sociedade.

Quanto mais uma pessoa descobrir e aprimorar em si o talento que a promoveu e adequá-lo mais rápido às necessidades e regras sociais, maior será sua consagração. Um exercício que se desenvolve aos poucos nas atividades cotidianas. No campo artístico, as chances se afunilam. Não bastam sensibilidade e sagacidade. Novamente, aparece o pré-requisito do talento e do mérito pessoal, agora mais exigente, sobretudo num mundo competitivo em que a novidade norteia as obras artísticas. O cinema tenta de diversas maneiras suprir os desejos de público amplo, alimentando e construindo tecnicamente os sonhos da vida contemporânea e, para cada exemplar bem-sucedido, mais abre alternativas que possibilitem divulgá-lo e, com isso, estender seus mercados.

Este trabalho parte do princípio de que nessa estrutura artística a qualidade que mais se revela de um criador é a que possibilitará a ele sua ascensão, desde que a descubra e a desenvolva em suas atividades e a faça dialogar com o universo que a recebeu. Como objeto de análise na esfera cinematográfica, escolhi o cineasta Pedro Almodóvar e sustento a idéia de que sua expansão internacional se deve em razão de

\footnotetext{
${ }^{1}$ ALMODÓVAR, Pedro. La Vanguardia Magazine. Madrid, 18 jul 1993, p. 17
} 
sua autenticidade. Seu comportamento irreverente e suas atitudes polêmicas são ações que se desdobram em suas histórias e se processam nas relações que desenvolve com o mercado audiovisual. A maturidade tornou-o mais brando em vários sentidos: depoimentos, filmes. Talvez, para os novos projetos, ele e o irmão tenham sido mais incisivos.

A questão que busco esclarecer aqui gira em torno dessa afirmação. Ser autêntico, para Almodóvar, significou garantir sua marca e seu trabalho. Porém, não foi e não é um ponto de estabilidade para ele. Diferente do que afirmei há pouco, os resultados vitoriosos não o mantiveram sob respeitabilidade diante de todo o complexo criativo edificado no círculo dos membros pertencentes ao universo cinematográfico e em suas ramificações. O diretor precisa continuamente mostrar e justificar suas capacidades. Devido ao tom irônico que possui e às suas origens de classe social, algumas situações que poderiam ser simplificadas transformam-se em grandes debates por questões que se encontram subjacentes ao contexto estabelecido. Mas não o aborrecem, ao contrário, acabaram também fazendo parte de sua mise en scène e incorporadas ao seu repertório. Seu modo de articulação com todo este campo artístico é peculiar e criou, lentamente, caminhos que o favoreceram.

Os capítulos a seguir compõem este grande mosaico em constante movimento e conflito entre o diretor, seu campo artístico e a sociedade. No primeiro, é traçado um panorama social e político da época em que surgiu o cinema de Pedro Almodóvar, os caminhos da cinematografia, as opções narrativas dos diretores espanhóis e a geração que nasceu no mesmo período do cineasta. No segundo, são apresentados os caminhos trilhados pela geração de Almodóvar, sua busca por autonomia, tanto econômica com criativa, e um quadro comparativo entre os cineastas. O terceiro discute o processo criativo de cada um desses cineastas, suas semelhanças e distinções com a cinematografia de Pedro Almodóvar, e, dentro destas, as especificidades deste diretor; sobretudo em torno da ironia. A discussão segue demonstrando a forma como cada um dos cineastas busca manter sua autonomia.

O quarto capítulo se atém à discussão das temáticas levantadas por esses contemporâneos de Almodóvar e a suas leituras sobre a sociedade. Novamente, surgem as diferenças e similaridades das narrativas, em geral sobre os mesmos assuntos. Delineiam-se personagens que revelam posições de classe social e suas perspectivas sobre suas vidas. Comédia, drama, melodrama, próximos ou distantes dos gêneros, as visões se cruzam e definem um quadro permeado pela diversidade.

\footnotetext{
${ }^{2}$ STRAUSS, Frédéric. Conversaciones con Pedro Almodóvar. Madrid: Akal, 2001, p. 186.
} 
O quinto e o sexto capítulos discutem os fatores que contribuíram para construir as imagens de Pedro Almodóvar, desde seu contexto histórico, geográfico até seu perfil pessoal. Neles se encontram: o momento da Movida, a influência da cidade de Madrid sobre sua filmografia, seu autodidatismo e os mitos criados ao seu redor, sobretudo sobre suas origens. O sétimo capítulo avança sobre suas relações com a imprensa, as polêmicas que construíram sua auto-imagem, numa trajetória que remete a um comportamento excêntrico desde a infância, fácil de ser moldado miticamente. Elementos como solidão, ironia e ousadia o acompanham em suas relações e, simultaneamente, compõem sua personalidade. Seus embates tornam-se inevitáveis e o aprendizado que acumula nessa trajetória o amadurece. Diferencia-se nesse momento a idéia de autêntico e de gênio, paralelamente às reações diante da fama e do sucesso. A imagem de incompreendido se reproduz.

No oitavo, a crítica especializada - acadêmicos e profissionais de cinema - fala sobre o diretor, e torna-se possível visualizar os diferentes olhares sobre sua obra e seu perfil profissional. Finalmente, o nono capítulo versa sobre a relação de Almodóvar com o mercado nacional e internacional de cinema, acentuando suas ligações com as grandes estruturas empresarias e as saídas encontradas pelo diretor, que possui uma forma peculiar de trabalho. Nessa etapa também são apresentados como se processam as relações entre este cineasta e os profissionais de sua produtora, relações estas traduzidas posteriormente nos resultados de sua produção.

Com esse quadro, acredito demonstrar que o tão almejado sucesso implica numa dinâmica incessante de novas atitudes e na conservação de outras. Uma constante busca de equilíbrio que nunca se concretiza em razão do próprio fluxo de novidades, novos filmes que ficam sob o julgamento dos grupos sociais já indicados aqui e diferentes mecanismos de mercados que também se renovam. Dentro deles, Pedro Almodóvar sobrevive e mantém seu lugar de criador autêntico. Será esse jogo de tantas nuances que esse trabalho apresentará a partir deste momento. 


\section{PANORAMA CRIATIVO}

A obra de Pedro Almodóvar origina-se num panorama de mudanças circunscrito naquilo que politicamente se denominou "transição democrática" espanhola. Período compreendido entre a morte do ditador general Francisco Franco e a redemocratização do país. Por conseguinte, inserido num momento de retorno aos mecanismos constitucionais de representação, de liberdade organizativa e do exercício dos direitos políticos de todos os cidadãos, livres da censura. As histórias contadas nos filmes do cinema espanhol dessa época refletiram tal processo de transformações sociais, revelando novos cineastas e linguagens. Porém - ainda que inovadoras -, ao lado deste diretor suas obras não possuíram as especificidades capazes de explicitar e abalar valores e costumes que até então vigoravam.

De maneira irônica e irreverente, em 1980, o primeiro longa-metragem de Almodóvar, Pepi, Luci, Bom y otras chicas del montón, caracteriza significativamente aquele contexto, inaugurando uma forma ousada e inédita de enfoque e de percepção das circunstâncias históricas vigentes. O filme questionou comportamentos, descondicionou olhares tradicionais da vida e da cinematografia do país e trouxe a público os modos cotidianos de viver uma transição que transcorria em vários níveis da sociabilidade espanhola, não apenas no político. Não foram poucas as polêmicas causadas diante deste trabalho e seus posteriores.

Suas abordagens provocaram escândalo e admiração de amplos setores sociais na Espanha durante e depois de sua data de estréia. Uma trajetória, porém, que não começou ali. O diretor já vinha percorrendo seu próprio circuito cinematográfico desde meados dos anos 70. Entre 1974 e 1977 realizou, com sua câmera de super-8 mm, onze curtas-metragens e, em 1978, um longa-metragem também em super-8 $\mathrm{mm}$ e um curta-metragem em $16 \mathrm{~mm}$ - películas em sua maioria perdidas pelo cineasta.

Eram em geral filmes de tom pornográfico resultantes da influência do underground madrilenho, do qual Almodovar participava com amigos que desenvolviam atividades artísticas no campo da música, quadrinhos, artes plásticas, teatro e fotografia. Como as películas eram mudas, o próprio diretor se encarregava de fazer as falas, imprimindo características muito especiais aos trabalhos, determinadas também pela figura singular do então cineasta iniciante. Pedro fazia apresentações para amigos, projetadas em Madrid ou em Barcelona dentro de festas organizadas com o intuito de assistir às histórias. Um grupo expressivo de pessoas sempre prestigiava as 
"sessões" com o simples desejo de se divertir. Assim, nessa fase - que prefiro denominar "pré-inicial de Almodóvar" -, não há como enquadrar seus trabalhos entre os cineastas que já desenvolviam suas produções no circuito comercial do cinema da "transição". No entanto, seu primeiro longa-metragem transformou rapidamente essa situação - para ele e para o cinema.

\subsection{Um contexto histórico-social efervescente}

O cinema da "transição democrática" pode ser compreendido de várias maneiras quando, se demarcado por filme, for possível estabelecer uma periodização que demonstre suas características. Uma situação delicada, pois de um modo ou de outro acabará sendo sempre excludente. Incluirá ou eliminará películas importantes para o período compreendido entre 1974 e 1984. A título de demarcação geral, Luis Alonso García indica que este pode ser um período que abrange, por um lado, El Espíritu de la Colmena de Víctor Erice (1973) ou Lo Verde Empieza en los Pirineos de Vicente Escrivá (1973) e, por outro, de Qué he Hecho Yo para Merecer Esto? de Pedro Almodóvar (1984) ou Los Santos Inocentes de Mario Camus (1984) ${ }^{3}$. Filmes que na verdade possuem características muito próprias, mas que já refletem nos anos 70 um olhar aberto para uma nova reflexão sobre a Espanha - ainda que repleto de metáforas - e que, nos 80, demonstram os conflitos entre os antigos e os novos agentes sociais.

Estas e outras produções registram uma época que se firmou como uma das mais complexas para o cinema espanhol, tanto pela variedade de obras e estilos como pela pluralidade de visões e suas relações com o público. Um período que permanece na memória cultural espanhola como sendo de profunda e intensa criação, recordes de bilheteria e filmes cultuados como marcos históricos de discussão e de reflexão que, enfim, ficará eternizado entre os cinéfilos do país e em sua cinematografia. Talvez, nem tanto pela qualidade dos trabalhos ou pelo valor econômico que arrecadaram, mas pela imagem que projetaram de um cinema que chegou a um limite insuperável. Basta olhar sua construção como um mito existente no imaginário coletivo hispânico: ultrapassa descrições históricas, mas a quantidade de registros dos filmes, curiosamente, não é extensa.

O historiador Hopewell, em 1989, considerava que o período edificava um momento de "normalização" do cinema espanhol com seu reconhecimento e integração dentro do cinema europeu. Monterde, em 1993, descreve o momento como de difícil busca de dignidade para uma arte e uma indústria que durante décadas fora

\footnotetext{
${ }^{3}$ GARCÍA, Luis Alonso. Revista ABC Cultural, Madrid,.p.42,16 mar.2002.
} 
massacrada e desvalorizada tanto pelo aparato franquista como pelo mundo cinematográfico. Em sua análise, somente por suas exceções este cinema acabou demonstrando ser digno do registro de pertencer e de compor uma história da cinematografia espanhola.

Foi uma época singular. de um lado, o cinema espanhol ganhava o "status quo" de cinema europeu, superando longos anos de atraso. De outro, o cinema mundial passava por uma profunda crise de definição de seu papel cultural. A concepção hollywoodiana de que cinema era entretenimento e que outras leituras não significariam nada deixou vários artistas incomodados. Claro, uma definição pragmática e objetiva que anulava crises de consciência criativa e facilitava, em muito, a entrada de novas atitudes mais lucrativas, além de menor tempo para a ampliação de mercados.

Paradoxalmente, depois da transição política, o cinema espanhol caiu numa espécie de escassez, como conseqüência da própria falta de proteção estatal e da fragilidade industrial que o impedia de mergulhar em riscos. Somente em 1999 esta leitura se transformou, muito em razão da análise que as relações entre política e meios de comunicação viam no potencial imaginário do cinema: uma forma de provocar reflexões e discussões que levassem a mudanças de mentalidade e trouxessem à tona os novos comportamentos. Na prática, uma análise que revelava um processo de ressocialização dos indivíduos que viviam o desgaste das instituições tradicionais como a escola e a família e que tiveram no cinema o papel de atualizações e integração de novos valores.

Somente dentro desse contexto cinematográfico é possível considerar seu valor mitológico como cinema da transição espanhola. Um período vivido com grande intensidade em vários níveis sociais e que teve no cinema da transição a geração de um valor cultural, social e político signifcativo, pois representou a diversidade de anseios que pairava pelas cidades que respiravam os ares de liberdade. Um valor que não se circunscreve ao cinema comprometido ou alienado, de "arte", experimental, de esquerda ou de direita, mas num veículo que se transformou numa grande tela imaginária onde o espectador se reconhecia. Que despertou o diálogo sobre novos tempos de uma Espanha em mudança, um momento em que ir ao cinema representava uma cumplicidade com as transformações sociais em andamento ${ }^{4}$.

Para as intenções dessa análise, a localização histórica da produção cinematográfica que se inicia no tardo-franquismo e segue até as desilusões com o processo democrático nos anos 80 tem um sentido específico. Busca situar qual

\footnotetext{
4 Ibidem, p.42-43.
} 
terreno social e cultural possibilitou o desenvolvimento criativo de alguns cineastas que, nascendo num período próximo a Pedro Almodóvar - com influências e percepções sociais de uma mesma época -, tiveram diferentes caminhos e olhares sobre a mesma realidade. Um contexto permeado pela contínua e conflituosa relação entre política e setores culturais, com seus reflexos na produção da arte.

Embora tal fato não se constitua como novidade, afinal já é antigo e de reconhecimento público o jogo de forças na Espanha - assim como em épocas anteriores -, os efeitos políticos ocorridos no país durante o período de transição e busca pela consolidação democrática não só repercutiram na cinematografia nacional como provocaram um movimento de mudanças de mesma equiparação no plano cultural. O mês de junho de 1977 celebrou as eleições livres após quarenta anos de ditadura. $\mathrm{E}$ a onda democrática que se alastrou por todo o país teve seu paralelo no cinema. Em outras palavras, da mesma forma com que as opções políticas se expandiram, também o cinema se ramificou em várias vertentes e novos processos criadores, cada qual com sua ideologia e interesse, tanto de mercado como de liberdade expressiva.

Se de um lado as posturas cinematográficas identificavam-se e se definiam com partidos de esquerda ou de direita, de outro se abandonava a cinematografia ideológica política para dar conta do legado franquista em suas influências e conseqüências sobre o cotidiano. Via-se a mudança de produção cinematográfica em decorrência das circunstâncias sociais e políticas que se transformavam, porém estruturada numa apenas aparente indústria do cinema. Os ventos democráticos trouxeram Luis Buñuel de volta à Espanha, mas não conseguiram retirar a crise de infra-estrutura vivida pelo cinema. Dessa forma - não por acaso -, verifica-se um período de produção em pequena escala e a expansão de diversos curtas-metragens, sobretudo entre os novos diretores.

As cotas de distribuição do Estado - subvenções do período franquista - foram anuladas no governo pós-franquista, levando a indústria cinematográfica espanhola à sua pior crise até aquela época classificada por Hopewell (1989, p.281) como "uma crise da qual os cineastas tentaram sair mediante diversas estratégias encaminhadas à conquista de mercado entre as quais se destacou o cinema de gênero" ${ }^{\mathbf{5}}$

Nos anos 70 a economia espanhola se desmantelava. Porém, o alto grau de subordinação tecnológica, a grande dependência de energia importada, o forte protecionismo da indústria nacional, o baixo custo dos créditos, a exploração da mão-

\footnotetext{
${ }^{5}$ HOPEWELL, John. El cine español después de Franco. Madrid: Edicones El arquero, 1989, p. 281.
} 
de-obra e a progressiva prosperidade das economias do norte da Europa sustentaram o "milagre econômico" espanhol. A recessão mundial oriunda crise do petróleo nos anos 70 derrubou estes pilares de desenvolvimento, provocando uma explosão de desemprego que recaiu em grande parte sobre uma juventude que buscava o primeiro emprego. Vários filmes do final dos anos 70 e princípio dos 80 demonstram os sentimentos de desilusão e de impotência naquele contexto ${ }^{6}$. Os trabalhos de Eloy de la Iglesia apresentando a delinqüência juvenil das periferias de Madrid refletem muito deste panorama.

Assim, a crise cinematográfica apenas acompanhou esse processo políticoeconômico nacional, pois de fato ela já vinha ocorrendo internamente em detrimento da falta de mercados internacionais e da perda de público, o que se deve em enorme medida ao boicote a filmes espanhóis imposto pela Motion Picture Export Association (MPEA) desde 1955. Esta e outras multinacionais determinavam claramente o que queriam exibir no país, inclusive filmes espanhóis ${ }^{7}$. As distribuidoras nacionais, tanto para importação como para a produção de filmes, ficaram sob seu total controle.

A dublagem obrigatória de todos os filmes estrangeiros - imposta por Franco desde 1941 - permaneceu e excluía dos cinemas qualquer filme que não fosse falado em castelhano. Isso acabou por provocar a ruína das produções nacionais, pois o público sentia-se confortável em assistir a qualquer filme norte-americano com atores e atrizes falando perfeitamente a língua oficial espanhola. Por outro lado - apesar de não se configurar em termos gerais como vantagem para o cinema e seus diretores -, esse fator "técnico" e cultural trouxe às produtoras de dublagem a possibilidade de se transformarem num setor extremamente rentável e promissor, consolidando uma indústria que se mantém forte até os dias atuais.

O cinema aparecia frente às touradas e ao futebol como um tipo de lazer muito popular, sobretudo porque os preços das entradas eram controlados pelo governo. As salas de cinema espanhol possuíam um dos índices mais altos de freqüência de público dentro da Europa. Esse dado caminha unido ao fim da censura em 1977 e à entrada de filmes antes proibidos na Espanha, como $O$ último tango em Paris e Emanuelle. Um período em que se verifica a expansão das importações de filmes e a ampliação dos espectadores nas salas de exibição em oposição à busca por filmes nacionais. Esse fator "liberalizante" acabou por motivar o aumento de produções nacionais eróticas no período.

Aos espanhóis que não se enquadravam nesta proposta restava realizar

\footnotetext{
${ }^{6}$ Ibid., p. 281-282.
} 
produções mais baratas e trabalhar com co-produções, dirigindo-se ao mercado interior, desenvolvendo películas de cunho regionalista ${ }^{8}$. Dessa forma, enquanto as subvenções estatais se esvaziavam, o protecionismo entre multinacionais e a produção independente espanhola se ampliavam - claro: em vetores desproporcionalmente desiguais.

No final dos ano 70, devido a escassez de mercado estrangeiro, restava ainda à indústria cinematográfica nacional as subvenções estatais para sua sobrevivência. Porém, a situação governamental também não era animadora. O total orçamento do ministério da cultura na Espanha era inferior ao que na França se destinava apenas ao centro Pompidou de Paris. E a metade das verbas desse orçamento era gasta com a mídia espanhola (rádio e TV estatais). Ideologicamente se defendia o patrocínio cultural, mas na prática a direção estava voltada para a economia de mercado ${ }^{9}$.

Comprometida com as mudanças políticas, apesar de se compor num governo de direita sem coesão política, a UCD (Unión de Centro Democrático) tomou medidas aparentemente protecionistas e democratizantes a fim de alterar o quadro da indústria cinematográfica espanhola. Em novembro de 1977 o governo baixou um decreto-lei que acabou com a censura, aboliu as cotas de distribuição e instituiu as cotas de "pantalla" [cotas de exibição na tela grande ] de 3 para 1: para cada lote de três películas distribuídas, duas seriam estrangeiras comerciais e uma - mesmo ruim deveria ser espanhola.

Até então, as cotas de distribuição subvencionavam aos produtores cerca de 30 a 50\% do orçamento dos filmes, retirados da arrecadação das bilheterias depois que estreassem. Após o decreto, as cotas foram eliminadas e substituídas por medidas que propunham uma subvenção de $15 \%$ a fundo perdido e automática para qualquer filme espanhol sobre as arrecadações da bilheteria durante cinco anos ${ }^{10}$. Ocorreu que, para garantir um valor monetário em suas mãos, os exibidores sonegavam ao governo as verdadeiras cifras obtidas, prejudicando os produtores nacionais.

O que havia até ali era uma aliança entre as multinacionais e os empresários independentes nacionais, cujo interesse comum era expandir seus próprios mercados. O acordo era uma troca de gentilezas. A existência de um cinema livre só viria a criar uma permissividade maior com o cinema estrangeiro - em particular o norteamericano. A Espanha garantiria às distribuidoras norte-americanas exibirem seus

\footnotetext{
${ }^{7}$ Ibid., p. 283.

${ }^{8}$ HOPEWELL, 1989, p. 284-285.

${ }^{9}$ Ibid., p. 285.

${ }^{10}$ MONTERDE, J. E. Veinte años de cine español - un cine bajo la paradoja. Barcelona: Paidos, 1993 , p. 83-84.
} 
filmes cobrando altos valores e, em troca, os produtores espanhóis fariam produções nos moldes europeus, portanto exportáveis, e ainda amparados pelas subvenções. Como já vinha ocorrendo a fraude nas bilheterias, tal tratado acabou não se estabelecendo. Os distribuidores e exibidores também reagiram contra a lei de pantalla. Naquelas circunstâncias, o Supremo Tribunal aboliu as cotas por considerálas inconstitucionais ${ }^{11}$. Sucederam-se, ao longo dos anos, novas batalhas entre distribuidores, exibidores e produtores. Em 1980, a lei de pantalla voltou a vigorar para favorecer a produção nacional, mantendo a proporção de 3 para $1 .^{12}$

A crise cinematográfica cada vez mais agravada gerou diversas mudanças no comportamento e na forma de elaborar filmes. Várias películas respondiam muito mais a questões econômicas e a acordos de produção do que a posições estéticas ou políticas. Tigres de pape ${ }^{13}$ (1977) de Fernando Colomo é um exemplo que caracteriza esta prática. Nele, foi utilizado o menor número possível de cenários e de planosseqüência ${ }^{14}$, para adequar o filme ao orçamento do diretor, além de favorecer uma montagem mais simples.

A marca da luta ideológica contra a censura nos anos 60 foi substituída pela luta pela sobrevivência do cinema nos anos 70 e sua diversidade teve reflexo nas várias alternativas encontradas para atrair um público já bastante familiarizado com a linguagem técnica e a narrativa hollywoodianas. Assim, envoltos e motivados pela onda liberalizante e interessados na produção nacional - mesmo sem uma exigência crítica -, vários realizadores cinematográficos espanhóis apelaram para campos mais pseudopopulares, como o gênero pornográfico.

No entanto, apesar da aparente oferta de atração de bilheteria numa Espanha que exercia seus direitos de liberdade em vários níveis das relações sociais, a produção de filmes pornográficos não se constituiu numa indústria. Até o início dos anos 80 nem salas especiais para a exibição de tais produtos estavam claramente designada como promulgava o mesmo decreto-lei de 1977 que havia retirado a censura. Nem tampouco os filmes possuíam uma estética tão forte para se classificarem como pornôs ${ }^{15}$.

Os próprios produtores conservadores se encarregaram de sua censura e tornaram os filmes mais brandos. Mesmo nas cenas mais engenhosas, muitas das

\footnotetext{
${ }^{11}$ HOPEWELL, 1989, p.286.

${ }^{12}$ MONTERDE, 1993, p. 84.

${ }^{13}$ HOPEWELL, 1989, p.286

${ }^{14}$ Tecnicamente, o termo segue a própria expressão da palavra: um plano bastante longo, articulado de uma maneira que represente uma seqüência, em tese sem cortes, reduzindo a necessidade de vários ambientes ou de movimentos e deslocamentos de câmera.
} 
saídas elaboradas pelos diretores atendiam às suas próprias moralidades. Desse modo - para as intenções do gênero -, estes filmes aparecem como bastante frágeis, com atrizes pouco ou nada eróticas, sobressaindo-se raras exceções tanto em películas como em interpretações ${ }^{16}$. Outros apelos dentro dessa temática fugiam totalmente a este contexto, como o filme Bilbao (1979) de Bigas Luna, que narra a personificação do desejo de Leo, um personagem obcecado por uma jovem prostituta chamada Bilbao, pela qual se apaixona e com a qual mantém uma relação que mistura voyerismo, platonismo e sadismo.

\subsection{Uma opção por sobrevivência - O gênero cinematográfico}

O desenvolvimento de um cinema de gêneros significou a alternativa de maior êxito para os cineastas espanhóis. Mesmo a crítica de esquerda via nessa saída uma forma de "acabar com a monotonia das películas de consenso defendendo um cinema de gêneros que refletisse uma realidade mais conflituosa"17. Opinava-se que o período final dos anos 70 poderia ser representado com mais eficácia caso seguisse fórmulas derivadas dos filmes western ou noir ${ }^{18}$ norte-americanos ${ }^{19}$. E as comédias, que já carregavam uma tradição no país desde os anos 40 com diferentes fases em sua trajetória - crítica esperpêntica ${ }^{20}$, rosa (excessivamente melodramática), folclórica, infantil, desenvolvimentista, subgênero ou "terceira via" -, também possuíam grande respaldo ${ }^{21}$.

A falta de uma escola de cinema - fechada em Madrid nos anos 70 pelo regime de Franco - e a ausência de instalações cinematográficas na Faculdade de Ciências da Informação levou os novos diretores - caracterizados como a "Escuela de Argüelles" -, como Fernando Colomo, Fernando Trueba e Oscar Ladoire, a utilizarem como material para sua formação apenas o ato de assistir a filmes, em geral películas de gênero

\footnotetext{
${ }^{15}$ HOPEWELL, 1989, p. 287.

${ }^{16}$ Idem, p. 288-289.

${ }^{17}$ Idem, p. 290.

${ }^{18} \mathrm{O}$ gênero noir ou filme negro teve origem nas ficções policiais no cinema dos anos 30 nos Estados Unidos, caracterizando-se por uma visão amarga e desiludida da sociedade liberal na época da depressão. Nesse gênero, a investigação do mistério é mais interessante do que a forma como se mergulha nele. Marcado por personagens característicos, como detetives viris, mas sentimentais, mulheres fatais, uma estética que recorre a um acentuado jogo de luzes e sombras e uma narrativa que confunde pistas ou sua compreensão, o filme noir fixou-se como um subgênero do filme policial, e, talvez por seu caráter de decifração, um dos mais apreciados pelo público.

${ }^{19}$ Idem, p. 291.

${ }^{20}$ Em linhas gerais, o esperpêntico se traduz como uma literatura de forte tom corrosivo de sátira social da qual Valle-Inclán é um de seus principais expoentes. Mais adiante, este esse termo será discutido como um dos elementos incorporados por Pedro Almodóvar, apontado por muitos críticos como um dos principais cineastas que dialogam com essa narrativa.

${ }^{21}$ MONTERDE, 1993, p. 130-131.
} 
norte-americano ${ }^{22}$.

Não por acaso, a produção inicial desses diretores e de outros da mesma geração, quando trata da vida urbana e de seus costumes cotidianos, demonstra inspiração estética e filiação narrativa norte-americanas. Pedro Almodóvar seguiu 0 mesmo caminho em seu autoditadismo. Inúmeras obras de cineastas que não conhecera em Cáceres - de onde saiu aos 16 anos - começaram a compor seu repertório imagético com os filmes a que assistia na "Filmoteca Española de Madrid". Foi o período em que tomou contato com várias películas espanholas de Bardem, Berlanga e Fernán-Gomez, além das outras norte-americanas de diretores que já conhecia desde a infância. Todavia, a produção de diretores já consagrados também mostrava uma renovação, como a película Deprissa, deprissa (1980) de Carlos Saura, premiada no Festival de Berlim com o "urso de ouro" em 1981.

No restante da Europa, a Nouvelle Vague $^{23}$ francesa vinha rompendo a dicotomia estabelecida pelos críticos até os anos 50 sobre cinema de arte e cinema popular, adaptando-se a convenções de Hollywood, sobretudo acerca do conceito de gênero ${ }^{24}$. De certa forma, essa atitude resumia uma mescla de mito e fascinação que os franceses alimentavam duplamente pelos norte-americanos no pós-guerra. De um, lado pelo que representava aquele cinema. De outro, pela imagem de libertadores e "benfeitores da humanidade". Aos espanhóis que se formaram durante o franquismo, "os filmes de Hollywood representavam a riqueza material e, se não libertadores, ao menos a liberdade"25. Olhando tais fatos em dimensões mais amplas, significava que produzir ou assistir a filmes nos moldes hollywoodianos provocava um efeito imaginário de conexão com um universo de liberdade política e comportamental que aparecia como regra mundial.

Entretanto, apesar desta propaganda, aparentemente vitoriosa, de mercado e estética norte-americanos, vale lembrar que nos anos 70 houve uma sensível queda de espectadores nas salas de exibição também nos Estados Unidos. Na intenção de atraílos novamente, sua indústria cinematográfica desenvolveu um novo cinema em Hollywood, dando abertura a diretores como Robert Altman e Francis Ford Coppola,

\footnotetext{
${ }^{22}$ HOPEWELL, 1989, p. 291.

${ }^{23}$ O termo Nouvelle Vague, do francês: Nova Onda, se configurou sobretudo em finais dos anos 50 na França como uma reação ao cinema psicológico então produzido no país. Resultado da nova ndústria que produziu equipamentos leves, mais fáceis de serem transportados diante dos anteriores que exigiam uma estrutura técnica maior e cara, este cinema estava preocupado em contar histórias simples, despojadas, buscando experimentações e desafiando as regras de filmagens impostas até então. Algo semelhante - considerando-se suas proporções - ao que aconteceu no Cinema Novo no Brasil, quase no mesmo período. Entre seus principais representantes estão: Jean-Luc Godard, Eric Rhomer, François Truffaut, Claude Chabrol, Louis Malle, entre outros.

${ }^{24}$ Idem, p. 291.

${ }^{25}$ Idem, p. 291.
} 
dentre outros. Aquele momento marcava, assim, um novo processo narrativo, apresentando personagens cujos perfis combinavam influências européias e norteamericanas $^{26}$.

Houve, portanto - mesmo que economicamente e industrialmente desigual -, uma certa "barganha" de linguagens e inspirações neste entremeio criativo. Mesmo com a atenção do círculo empresarial cinematográfico centrada na bilheteria, se desdobravam em sua prática os resultados habituais de uma indústria cultural que constantemente se vê obrigada a buscar novidades narrativas. Naquele período, se estabeleceu a utilização de recursos híbridos que resgataram encontros culturais elaborados com nova roupagem.

Muitas das películas espanholas nos anos 80, também seguiram essa prática, aproximando e misturando a linguagem norte-americana com o cinema espanhol. Contudo, mais do que um exercício de aproximação estética, ou voltados para a ampliação de público - aproveitando e incorporando o cinema de gênero -, os criadores viam nessa alternativa a possibilidade de levantar de maneira inovadora a questão social no país. Era assim, por exemplo, que a experiência do filme noir na época pós-franquista favorecia a crítica à corrupção dos altos círculos sociais.

Durante estes anos, houve um aumento crescente da produção de thrillers, coincidindo não casualmente com a eclosão da literatura noir da qual muitos trabalhos foram levados às telas ou seus escritores transformados em roteiristas. Eram filmes que ou exaltavam a polícia ou eram moralizantes. Tratava-se de produções baratas, com poucas "estrelas" e atores secundários da produção espanhola, feitas nos estúdios de Barcelona, onde vários cineastas acabaram por contribuir para a formação de uma pequena tradição preservada por Gonzalo Suárez, conhecida como Escuela de Barcelona, indo até o tardo-franquismo, com Bigas Luna em Tatuaje (1976) ${ }^{27}$.

A produção madrilenha, que oscilava entre os thrillers psicológicos de Eloy de la Iglesia, García Dueñas ou Francisco Regueiro, somente no final dos anos 70 se consolidou no cinema espanhol, indo desde diretores secundários até os mais reconhecidos. Várias histórias baseadas em romances policiais ou históricos foram transformadas em roteiros cinematográficos. Outro grupo mais irregular se compunha de cineastas iniciantes - muitos de segunda linha - que penetravam nos abismos da corrupção policial $^{28}$.

A democratização política se fazia lenta ainda em 1978 e o receio de atos de

\footnotetext{
${ }^{26}$ Idem, p. 292.

27 MONTERDE, 1993, p. 143.

${ }^{28}$ Idem, p. 144-145.
} 
indisciplina na polícia - bem como a falta de confiança nos membros da instituição - se refletia com certos matizes nos filmes envolvendo corrupção nacional e internacional. El crack I e II (1980 e 1983) de José Luis Garci ou El arreglo (1983) de Antonio Zorrilla fornecem uma boa noção das pretensões dos cineastas envolvidos neste gênero. Sobretudo em Zorrilla há uma interpretação política da transição, ao mostrar a continuidade dos modelos de ordem e a corrupção na esfera do Estado, por intermédio do protagonista Cris, que investiga uma série de assassinatos sem saber que está sendo usado pela polícia ${ }^{29}$.

Houve também tentativas de thrillers psicológicos inspirados no estilo de Alfred Hitchcock que, no entanto, não possuíam estrutura para o empreendimento. Por último, se desenvolveu um outro bloco de filmes ocupados com um cinema criminal baseado em fatos reais vinculados a uma chave de leitura sóciopolítica, narrados em função de um certo espetáculo em torno da popularidade dos assuntos tratados ${ }^{30}$.

Gênero envolvente. Porém, com uma estrutura insuficiente para atender aos requisitos exigidos pelo formato de filmes noir. Os baixos recursos e as deficiências técnicas da produção cinematográfica interna tornavam este modelo inviável na Espanha. Além disso, havia uma diferença cultural em torno da personagem feminina que dificultava o desenvolvimento e a compreensão dessa narrativa para os espanhóis. A mulher no gênero noir norte-americano aparece como sedutora e falsa. Já, para a construção espanhola, esses atributos não podem ser admitidos na imagem feminina. Assim, as películas não adquiriam a consistência necessária para o conjunto dos resultados pretendidos. A ação dramática e a composição geral das imagens mostravam-se inadequadas diante de uma estrutura narrativa já estabelecida e os filmes acabavam repercutindo negativamente na recepção do público. Dessa forma, o conjunto de elementos desfavoráveis impediu a expansão do gênero no país ${ }^{31}$.

Foi dentro desse jogo de tentativas que o gênero da comédia acabou garantindo o êxito cinematográfico pós-franquista. Seguindo uma seqüência de tradições até esse período - com algumas modificações -, ele se manteve buscando aproximações com a realidade em vários estilos, como a busca pela sexualidade e a utilização da linguagem coloquial (incluindo termos apelativos). Numa tendência continuísta encontram-se as comédias políticas claramente reacionárias, a comédia "sexy" com toques pornográficos e as paródias baseadas em filmes ou programas televisivos de sucesso.

\footnotetext{
${ }^{29}$ HOPEWELL, 1989, p. 293-294.

${ }^{30}$ MONTERDE, 1993, p. 146-147.

${ }^{31}$ HOPEWELL, 1989. p. 294.
} 
As comédias militantes de direita ilustram as sucessivas fases de degradação intelectual e fílmica de seus realizadores e seu público. Em geral refilmando histórias de sucesso do período franquista, pareciam buscar um passado imaginário irreconhecível utilizando-se de uma sátira política conservadora crítica do período de transição política (1977-1983). Na mesma linha ideológica seguiram-se comédias de costumes que criticavam os novos hábitos sociais da transição, sobretudo em torno da família, mesmo sendo produções residuais (1980-1991) ${ }^{32}$.

Algumas modas, como filmes infantis e paródias remotamente inspiradas nos filmes de Monty Python e Mel Brooks, tiveram curta duração. A "terceira via" significou o bloco de comédias pós-franquistas motivadas pelas mudanças nos campos político, moral e sexual, e embaladas pelo clima reinante de maior liberdade. Representou uma estratégia cinematográfica para atrair um público que estivesse interessado em sair da programação da TV para ir a salas de cinema.

Não se trata de um conceito ou de um movimento de ruptura. Suas histórias eram de abertura moral e política moderada, sem qualquer extremismo estético ou ideológico. Em geral comédias, os filmes marcaram uma seqüência de paródias e narrativas sem nenhuma profundidade crítica que, no entanto, revelavam os fins do período franquista e o desenvolvimentismo. As histórias traziam - ainda que timidamente - os germes do que viria a ocorrer depois da morte de Franco, com a "nova comédia espanhola"33.

Havia ali, também, uma certa frustração de uma geração que, mesmo vivendo a reforma, ainda não tinha perdido as heranças do passado sem ressentimentos ${ }^{\mathbf{3 4}}$. Essas circunstâncias geraram uma fase de comédias de costumes despolitizadas que, no entanto, revelaram o cotidiano da vida na transição espanhola, incluindo-se nesse contexto sonhos e desencantos tanto da sociedade como dos cineastas. Nelas ocorre uma série de referências - respeitando-se claras diferenças estilísticas e geográficas às comédias clássicas norte-americanas, como as de Billy Wilder ou as de Woody Allen, e mesmo européias, como as de Eric Rohmer.

Os curtas-metragens de Fernando Colomo em meados dos anos 70, depois continuados com seus longas, se reproduziram em outros filmes, influenciando o que se costumou rotular de "comédia madrileña". Com Tigres de papel (1977), Fernando Colomo joga com elementos de identificação e distância irônica revelando personagens que descortinam a falsa maturidade e libertação política, além do esnobismo dos

\footnotetext{
${ }^{32}$ MONTERDE, 1993, p. 131-133.

33 Idem, p. 55-60.

${ }^{34}$ Idem, p. 134-135.
} 
pseudo-esquerdas que protagonizam a história da película. Temas como ateísmo e liberdade, dentre outros, aparecem com longos diálogos não comuns para roteiros até então. Carmen Maura, protagonista da história - antes de transformar-se na musa de Almodóvar -, havia, inclusive, comentado negativamente surpresa aquela estrutura.

A "nova comédia espanhola" ou, em particular, "comedia madrileña", alcançou seu auge com La mano negra e Opera-prima de Fernando Trueba, ambas de 1980, avançando com sucesso seu estilo em filmes de vários diretores até 1985. As obras de Pedro Almodóvar surgem também - com suas especificidades - em meio a essas produções. Embora não se enquadrem na linha dessas comédias, possuíam várias semelhanças com elas e traziam ecos de outras produções do período, como o noir e o pornô, todos ironizados e carnavalizados na linha esperpêntica. Portanto, mesmo inovador, Almodóvar fez uma certa reciclagem das produções de seu período para mostrar sua novidade estilísticas que, no entanto, veio carregada da herança de um presente muito próximo e de uma tradição cultural que misturava vida urbana e rural.

O contexto de êxito dessas comédias trouxe também certo desconforto com relação aos rótulos impostos pela crítica e mídia que, em geral, costumam diluir a particularidade e a originalidade dos trabalhos. Historicamente, não é nova a prática de grupos que se encarregam de avaliar e de incluir numa mesma produção artística diferentes autores somente pelo fato de possuírem características semelhantes, passando a classificá-los como a revelação de um movimento ou de uma época. Essas atitudes, em geral, forjam traços que acabam obscurecendo a inovação, a liberdade ou a originalidade de seus criadores. Fernando Colomo protestava com razão:

O simples fato de ter algo a ver com a comédia, ter feito (logicamente) alguma película em Madrid, em que se trata de temas atuais, não é suficiente para que nos coloquem todos no mesmo saco ${ }^{35}$.

Apesar desta observação recorrente, os produtores dessas películas enquadradas como "comedia madrileña" tinham muitas semelhanças. Economicamente, suas produções eram feitas entre amigos e familiares, ambientadas - não poucas vezes - na própria casa dos produtores e diretores. Os temas e propostas artísticas também atendiam a uma certa característica localista, só ampliada depois com as subvenções fornecidas pela política cinematográfica do Partido Socialista Espanhol (PSOE) ${ }^{36}$ - no poder a partir da eleições de outubro de 1982 -, que deu a alguns cineastas a possibilidade de rodarem suas películas fora do país.

Entretanto, a novidade dessa "nova comédia espanhola" deu-se não por essas

\footnotetext{
${ }^{35}$ Apud. HOPEWELL, 1989, p. 295.

${ }^{36}$ Idem, p. 295.
} 
características, mas por suas abordagens e pelo tom com que se mostrava: otimista diante da visão política, disposta a enterrar seu passado e indicar o novo contexto social vigente. Cenários familiares ao dia-a-dia dos espectadores, com propagandas e espaços públicos reconhecíveis. Seus inúmeros novos e bons atores e atrizes davam vida aos comportamentos libertários daquele período vivido na Espanha. As temáticas centradas na família revelavam as novas visões diante da sexualidade livre, da vida boêmia, dos bares e das drogas, ao lado de uma juventude distante da herança da guerra civil e do pós-guerra. Resgatou-se o cotidiano, as pessoas comuns, rejeitandose o "cinema de arte" dos anos 50. Havia uma nostalgia, muito mais do presente do que do passado, livre do peso moralizante do período anterior.

Inovadora nos elementos sociais nas quais faz referência, a "nova comédia espanhola" é totalmente neoclássica em seu estilo, refletindo a multiplicidade das influências cinematográficas. Uma delas é a espontaneidade, a concentração de personagens jovens e marginalizados, própria dos primeiros tempos da Nouvelle Vague ${ }^{37}$

Os dilemas dos jovens refletiam muito mais as conseqüências políticas do país do que sua participação: desencanto, poucas pretensões revolucionárias, vida entediante, porém permeada de aventuras estruturadas narrativamente nesse cinema de gênero. O diálogo com o cinema de Hollywood aparece, porém perfazendo filmes de gênero dentro do gênero específico criado. Essa "nova comédia espanhola" articulava, misturava ou privilegiava, no diálogo com o cinema holywoodiano, ora a pornografia, ora o filme noir, ora o estilo do western, ora o melodrama e até o romance medieval. Todas narrativas já repetidas e familiares na ficção espanhola, seja pela tradição das histórias seja pelo conteúdo cultural espanhol difundido pela sociedade, mesmo com suas peculiaridades regionais ${ }^{38}$.

O cinema metafórico, que teve seus expoentes mais respeitados com Carlos Saura e, na nova geração, com Victor Erice e Jaime Chávarri, manteve-se durante um certo tempo, no final dos anos 70 , cruzando sua narrativa com alguns gêneros. A comédia esperpêntico-coral Las truchas (1977) de García Sánchez - vista como a última saída popular encontrada para manter a tradição metafórica - discute a vida de uma sociedade de pescadores relacionando-a com uma sociedade em decomposição diante do olhar das classes trabalhadoras.

Em 1978, Arriba Hazaña de José Maria Gutierrez usa a vida de um estudante de colégio interno como ambiente da luta pelo poder, estabelecendo um paralelo com a Espanha da transição por intermédio das manobras dos representantes que controlam

\footnotetext{
37 Idem, p. 296.

${ }^{38}$ Idem. p. 297.
} 
a escola. No mesmo ano, Los restos Del naufrágio de Ricardo Franco faz uma parábola sobre a incipiente consciência diante do "desencanto" com a transição democrática na pele de um jovem de 28 anos que ingressa num asilo e torna-se amigo de um ancião com o qual compartilha reflexões capazes de fazê-lo fugir de uma realidade que rejeita ${ }^{39}$.

Em 1979, com Mamá cumple años e, em 1981, com Dulce horas - não só porque não foram filmes bem sucedidos -, Carlos Saura acaba como que por assinar 0 esgotamento dessa linguagem que só viria a mostrar-se residualmente com filmes que recorreriam à ficção histórica, como Maravillas (1980) e Feroz (1984) de Manolo Gutiérrez Aragon, Tiempo de silencio (1986) de Vicente Aranda ou Mambrú se fue a la guerra, também de 1986, de Fernando Fernán-Gómez. Os tempos já se mostravam outros, tanto para o público como para os cineastas. Segue-se no período uma série de filmes históricos que buscavam resgatar um passado que fora renegado pelo franquismo.

Porém, incapazes ou pouco interessados em realizar um cinema históricoanalítico, a maior parte dos cineastas que se ocupou dessa abordagem tendeu para 0 espaço microscópico onde a memória pessoal e familiar se impõe como interpretação global. Para garantir público, os recursos foram depositados em tramas voltadas a sagas familiares, adaptações literárias ou biografias com tonalidades centristas ou reformistas, afastando qualquer possibilidade de revanchismo. São vários os exemplos. Somente a título de ilustração encontram-se El desencanto (1976) e Las cosas Del querer (1989) de Jaime Chávarri, El processo de Burgos (1979) de Imanol Uribe, Pim, pam, pum ... fuego!(1975) de Pedro Olea, La colmena (1982) de Mario Camus, Lorca, muerte de un poeta (1988) de J. A. Bardem, Amantes (1991) de Vicente Aranda, dentre outros $^{40}$.

Acredito que deva parecer claro que esta trajetória de linguagens revele os múltiplos recursos de liberação dos territórios antes proibidos no período franquista. Simultaneamente a um resgate, o período também demonstra um certo prazer - ainda que reservado - em dizer o que se sentia. As discussões veladas sobre a situação política e suas conseqüências nas relações pessoais estão presentes, e o clima de vontades libertárias aparece a todo momento, porém ainda sob a sombra dos hábitos repressivos.

Nesse sentido, a abordagem sexual foi outro campo muito reivindicado no pósfranquismo. Se antes o tabu do sexo imperava nas películas e nas discussões em

\footnotetext{
${ }^{39}$ MONTERDE, 1993, p. 150-152.
} 
geral, agora se procurava recuperar o tempo perdido. De um lado, havia os exageros de cineastas dispostos a explicitar o sexo exibicionista e vulgar. De outro, a exploração do erotismo - ainda que em cenas também explícitas - não se reduzia ao espetáculo vazio de imagens excitantes. Propunha-se a refletir os próprios mecanismos dos comportamentos sexuais e suas implicações com o período da repressão franquista que privilegiava sua perseguição sobre a homossexualidade, transexualidade, incesto, fetichismos e perversões ${ }^{41}$. Portanto, o que se vê nos trabalhos de Almodóvar no período que vai até Matador (1985-86), ou mesmo La ley del deseo (1986), se insere no mesmo conjunto temático de outros autores, ainda que este possua sua própria especificidade narrativa.

Assim, as temáticas recaem sobre esta mescla envolvendo política, sexualidade, comportamentos e relações sociais. São inúmeros os exemplos que poderiam ser citados. Como apontarei alguns mais adiante, neste momento prefiro restringir-me a observar a questão da própria sexualidade tratada no campo artístico na Espanha. Ela se revela na pintura de Velásquez, de Rubens, de Miró e de Picasso. Está no teatro, no cinema dramático, na paródia, na comédia. Talvez pela enorme repressão que a religião - ao lado da política - sempre exerceu sobre os espanhóis, haja na arte este contraponto que responde sutilmente como reação a tantas privações. Mesmo no cinema metafórico e em outras linhas estéticas isto aparece de maneira velada.

$\mathrm{Na}$ pintura espanhola - tradicionalmente famosa e representativa em toda Europa - este aspecto se revela de maneira impressionante só vindo a reforçar a afirmação. Em Velásquez - por exemplo -, sobretudo nos temas mitológicos, a relação aberta entre sagrado e profano se consuma numa forma de movimento de corpos e expressões faciais que denuncia a sensualidade reprimida religiosa e socialmente. Tão efetiva que chegou até o século $X X$ no espaço metropolitano refletida nos comportamentos das pessoas que lutaram por suas liberdades individuais. Velásquez faz mais do que romper as regras e liberar o desejo. Ele traz o homem simples e comum para se relacionar no mesmo nível com os deuses. As obras: Los borrachos ou El triunfo de Baco, La fragua de Vulcano, Marte e Mercurio y Argos revelam uma luminosidade, um cromatismo único para a época, que ressaltam nessa humanização de deuses e homens os desejos e suas inspirações.

Em outras palavras, quero dizer que a sensualidade faz parte do dia-a-dia da cultura espanhola muito mais do que se observa objetivamente. É parte integrante das

\footnotetext{
${ }^{40}$ Idem, p. 153-160.
} 
relações e isso se torna público nas imagens, no estereótipo da virilidade masculina, no tom de voz, nas danças flamencas, nas touradas. Os filmes do pós-franquismo não fizeram nada mais do que colocar de vez esse sentimento nas telas, nas ruas. Um fator que contribuiu de sobremaneira para que os espanhóis começassem a se reconhecer neles.

Acredito que, não por acaso, um último quadro histórico que perpassa vários desses ambientes e conjunturas deva ser destacado nesse contexto devido à sua potencialidade inovadora no período que deu vazão também para o aspecto da sensualidade. Certamente pode não resumir a época, mas foi o terreno propício para que se desenvolvesse uma cultura própria desse tempo de liberdades e sonhos. Nele desembocaram os desencantos da situação política apontada anteriormente, entretanto com o reverso de seu comportamento na esfera cultural. Envoltos em seu espírito, se inauguraram novos olhares sobre a vida, favorecendo o surgimento de cineastas como Pedro Almodóvar.

Me refiro aqui à Movida madrileña. Um conjunto de atividades culturais simultâneas, basicamente regidas pelo campo musical, mas com suas vertentes em outras áreas artísticas. Iniciou-se por volta de 1976 com grupos jovens em diversos pontos de Madrid e desdobrou suas influências para o teatro, os quadrinhos, o cinema, a fotografia e a moda; reavaliando e criando comportamentos, novas idéias e imagens. Não se constituiu propriamente num movimento, segundo a concepção clássica e convencionalmente atribuída pelas artes ou pela política. Talvez sua própria ordem seria negar esta ordem classificatória.

Os próprios membros remanescentes, que participaram na época de toda aquela efervescência cultural, ou rejeitam esta idéia ou, quando a visualizam nestes termos, já apontam para seu término por volta de 1983. Período em que os meios de comunicação de massa e entretenimento já haviam se apoderado de suas práticas e transformado a Movida em atração e espetáculo. Enquanto existiu - apesar de sua eficácia inovadora - não teve um alcance generalizado sobre todas as camadas sociais. Era a expressão de um dado grupo de artistas - grande, mas fechado - que buscava viver e curtir a liberdade que acabava de ser recuperada no país, demonstrando-a nos comportamentos e na arte.

O ano de 1980 vivia a plena busca pela democratização política. Mas, para a grande maioria que não estava na militância, também chegava a reverberação da liberdade no nível comportamental. Assim, as manifestações culturais que começaram

\footnotetext{
${ }^{41}$ Idem, p. 163-165.
} 
a ocorrer por toda Madrid incidiam diretamente sobre as novas idéias e em sua absorção por parte de um público disposto a viver livre e a fazer tudo aquilo que lhe desse vontade.

Sobretudo os grupos musicais - que se multiplicavam nos bares e galpões imprimiam um brilho especial à cidade, e Madrid, em pouco tempo, se transformou no modelo mundial de novidade, liberdade e festa. Uma cidade que não dormia, que permitia a todos viverem imediatamente seus desejos. Não havia tempo a perder e tudo estava liberado: drogas, sexo, amor, arte, sonhos. A vida era movimento e a Espanha já estivera parada em demasia. Era chegada a hora de compensar os anos de marasmo. Essa era a tônica e foi nesse ambiente que se desenvolveu a Movida madrileña.

Até aquele momento as fronteiras entre política e cultura estavam muito ligadas. Impedida de dizer diretamente o que via em virtude da repressão franquista, a expressão política encontrava na música, no cinema, no teatro ou na literatura sua forma de manifestação. Com o processo democrático, estas esferas se separam. E aqueles desiludidos com a militância confluíram com uma geração que cresceu amparada pelo desenvolvimento econômico, na abertura e modernização de costumes em meio ao desemprego e ao jogo partidário pelo poder.

Isso gerou uma juventude que de certa forma rejeitava o modelo tradicional, criando uma maneira particular - para muitos críticos, alienada - de viver seus valores, de fazer sua própria arte e de criar significados para comportamentos cotidianos, educação e cultura. Uma cultura jovem sem a mesma referência e formação acadêmica da anterior ${ }^{42}$.

A cultura juvenil se constituiu num espaço de uma subcultura porque representava uma articulação diferenciada dentro da cultura dominante - tanto para os progressistas como para os conservadores -, gerando um lugar de negociação para as forças que pretendiam um controle ideológico. Para a Movida, este espaço era de contínua explosão criativa e comportamental. Ou seja, um território simbólico onde se compartilhavam produtos de consenso, como os meios de comunicação, valores familiares e escolares, arte em geral, independente das classes sociais. Era uma metáfora de mudança cultural, longe - porque abominava - do controle de qualquer instrumentalização institucional ou ideológica.

Nascida no universo cultural underground da cidade, a Movida madrileña logo

\footnotetext{
${ }^{42}$ FOUCE, Héctor. La cultura juvenil como fenómeno dialógico: reflexiones em torno a la Movida madrileña. Universidad Complutense de Madrid, CIC- Cuadernos de Información y Comunicación, Madrid, ISSN 1135-7991, $\mathrm{n}^{\circ}$ 5, p. 267, 2000.
} 
foi cooptada pelos meios de comunicação como expressão lúdica de mudança política:

Irrompeu espetacularmente como imagem de desordem semântica, bloqueio de sistemas de representação para terminar estabelecendo um novo cenário de convenções. O princípio dos anos 80 é especialmente interessante porque, desaparecida a ditadura, se dá uma situação de luta para estabelecer um novo discurso dominante ${ }^{43}$.

No entanto, a Movida não partiu para o discurso de oposição. Ao contrário, aceitou o discurso de normalidade institucional. Separou-se dele, paradoxalmente, querendo ignorá-lo e ao mesmo tempo se relacionando com ele. Era, no entanto, um conjunto de acontecimentos específicos referentes às necessidades e interesses localizados. Negava as diretrizes de controle e lógicas de uma "naturalização" dos modelos culturais e comportamentais, mas por outro lado utilizava-se delas próprias para gerar e difundir sua novidade. Sobre a articulação de uma cultura focalizada na experiência e no estético, a Movida se constituiu num fenômeno geracional que dentro de sua subcultura criou um conjunto de novos significados que possibilitaram dialogar com outras subculturas, às vezes para incorporá-las, outras para rejeitá-las.

Impossível não visualizar o cinema de Almodóvar dentro deste painel. Sobretudo sua primeira fase, que vai de Pepi, Luci, Bom y otras chicas Del montón (1980) até Qué he hecho yo para merecer esto? (1984). Todos os elementos da Movida se encontram nessas películas até quando esta já havia perdido sua originalidade, não existindo mais como manifestação inovadora e se transformando num instrumento de propaganda para políticos, mídia e empresas de turismo. Ali estavam os ingredientes que sustentavam um espírito do "viver intensamente" a tradição e as ferramentas para quebrá-la, ironizar o ridículo da política, da hipocrisia familiar, das paixões sem limite de papéis sociais, sexo ou idade, além dos fetiches sexuais, da música e dos comportamentos liberalizantes. E os ambientes e as personagens das películas de Almodóvar continham esse panorama.

Ainda assim, apesar de parecer universal, tanto era localizada que no mesmo ano em que foi lançado Pepi, Luci, Bom y otra chicas del mónton, por Pedro Almodóvar, outro diretor, Fernando Trueba, apontava um caminho diferente que saía da lógica daquela festa que parecia infinita. Ópera prima (1980), filme de grande sucesso, mostra a relativa unanimidade da Movida no cinema ou na cultura daquele período. O espírito de liberdade, contudo, era o fator comum dessas produções. Nesse sentido, ele as mantinha em sintonia naquele momento em que Madrid era a capital da manifestação desse valor comportamental. Trueba lembra:

\footnotetext{
${ }^{43}$ FOUCE, 2000, p. 268.
} 
Pero es que esa historia no iba mucho conmigo. En los ochenta había una movida real, la de un país que estaba cambiando su história, su orientación, sus costumbres. Y otra movida oficializada que parecía estar sólo en determinados sitios. Yo nunca fui moderno, sólo fui joven, así que esos lugares emblemáticos, el Vía láctea, el Sol, los locales de Malasaña [pontos de encontro, bares mais conhecidos da "Movida"] no me interesaban. ${ }^{44}$

Com Almodóvar ocorria o contrário. Muito conhecido no meio underground por sua própria imagem particularmente polêmica, tempestivamente engraçada e também por fazer filmes em $8 \mathrm{~mm}$ para exibição entre amigos, o recém-diretor já havia traçado uma pequena trajetória que incluía a participação em tudo que se produzia dentro da Movida. Participou como ator de teatro com "Los goliardos", grupo que the permitiu conhecer uma de suas grandes musas: Carmen Maura. Gravou um disco e cantava em bares com o amigo Fabio MacNamara. Escreveu como colaborador para fotonovelas e nas revistas underground La luna, Star e El víbora - esta última responsável pela encomenda de uma história que viria a se transformar no seu primeiro longa-metragem.

Apenas com esse panorama já é possível perceber que o diretor encarnava boa parte do que a própria Movida madrileña engendrava historicamente ou discursava. Ele não só reproduzia em seus trabalhos as idéias e o espírito daquele momento, como também era um de seus criativos protagonistas. Vivia mergulhado naquela lógica de ações que celebravam o encontro da cultura tradicional com a cultura moderna, ironizando ambas de forma inusitada.

Vinte e cinco anos passados, as várias reflexões de muitos de seus agentes e analistas não dão conta de fechar um quadro homogêneo do que se viveu:

Como es posible que la movida se eclipsase tan ignominiosamente en la segunda mitad de los ochenta? Se podría afirmar que murió de éxito: el cogeel-dinero-y-corre se impuso como modelo ético. Las multinacionales impusieron su poderío y se llevaron las flores de la independencia: lo que eran músicas marginales fueron grandes lanzamientos.Los grupos cambiaban los clubes por los grandes recintos, generalmente con dinero de las instituciones. Tan fatales fueron tropiezos como el cierre de Rock Ola [nome do bar, ícone da Movida em Madrid] en 1985: aunque detestado por la infame calidad de sus bebidas y otros pequeños detalles, servía como punto de encuentro; a partir de ese momento, las tribos se dispersaron. Desaparecieron sin despertar alarma revistas y programas de televisión. El sentimiento colectivo se desintegró en mil aventuras particulares. El triunfo del individualismo y el todo-vale dejó a la movida huérfana de paladines. Latía un difuso remordimiento, una urgencia por pasar página [deixar para atrás]. Ese lavarse las manos permitió que la iniciativa pasara a los enemigos, que efectuaron una demonización efectiva. Bien entrados los años noventa, la movida resucitó como nostalgia boba, simplificada hasta la caricatura [...]. ${ }^{45}$

Mal interpretada, segundo pontos de vista que a colocaram como a passagem de uma moda, de políticos de esquerda que a utilizaram a seu favor, ou de direita que a

\footnotetext{
44 RIVERA DE LA CRUZ, Marta. Así nacieron dos 'Oscars'. EI País, Madrid, 17 set. 2000, Cine 4, p.28.

${ }^{45}$ MARINQUE, Diego A., La Movida 25 años después. El País semanal, Madrid, nº 1492, 01. mai. 2005. p.48
} 
renegam como um acontecimento de envergadura cultural, a "Movida madrileña" entrou para a história mesmo com seu curto tempo de sobrevivência. O reconhecimento de seus efeitos sobre a Espanha e as novas gerações é inevitável e indiscutível. Configurou-se como síntese do espírito político de uma época, ainda que não possuísse tal pretensão.

Inaugurou uma nova forma de expressão cultural em tudo o que havia de mais no país, influenciando os processos de linguagem artístico-social no cotidiano e sobre o que surgiu posteriormente. O cinema pôde difundi-la e ao mesmo tempo ser o reflexo de sua prática e se constituir como seu registro. Foi além disso. Demonstrou ser o marco que ilustra claramente o porquê da forma inaugural da produção de Pedro Almodóvar, e este, o resultado da tradução dos novos códigos então emergentes, ao mesmo tempo sintonizador e renovador de linguagens existentes dentro e fora do cinema produzido naquele momento.

\subsection{Artífices de um novo panorama cinematográfico - perfis}

Vários diretores nascidos entre os anos 40 e 50 - portanto pertencentes à mesma geração de Almodóvar - viveram as mesmas mudanças no país. Porém, Almodóvar desenvolveu uma cinematografia distinta desses cineastas. O painel histórico apresentado anteriormente anunciou uma trajetória indicativa que proporciona algumas pistas para a compreensão deste fato. Todavia, ainda não se explicita nele as especificidades contextuais que motivaram cada cineasta a construir sua obra particular, sobretudo a partir de meados dos anos 70 , quando as mudanças da sociedade pareciam inesgotáveis. Desse modo, no intuito de compreender a diversidade criativa daquele momento, o foco dessa análise estará direcionado para a investigação dos fatores que determinaram as diferentes produções. Buscará esclarecer por que Almodóvar se projetou além dos outros e se há algum diálogo fílmico entre eles.

No decorrer da discussão anterior, apontei em algumas passagens as semelhanças estéticas, temáticas ou discursivas entre sua obra e o contexto históricosocial vigente. Agora, pretendo aproximá-lo mais diretamente dos cineastas no intuito de evidenciar particularidades e similaridades. Para esclarecer tais indagações, selecionei alguns cineastas que me pareceram mais pertinentes no sentido de estabelecer um diálogo com os trabalhos do diretor, com sua trajetória e com o contexto social apontado. Quero dizer: tanto para situar a produção cinematográfica simultaneamente ao que ocorria quando de suas produções, como para evidenciar o 
caráter de destaque que os cineastas obtiveram por seus trabalhos e suas influências mútuas. Dialogam nesse aspecto o contexto histórico que apresentava o que poderia ser captado e o estilo - ou "pactos" - que se estabelecia entre os círculos de amizades e iniciativas estilísticas que criaram.

Contidos nesses parâmetros, preferi traçar paralelos que os identificassem em suas singularidades, afinidades e diferenças com Almodóvar por intermédio da trajetória escolar, da classe social e no âmbito profissional, tanto no desenvolvimento concreto da execução dos filmes e projetos, como de suas temáticas. A data de nascimento dos diretores, tida como ponto de referência inicial, é significativa, pois a partir dela torna-se possível visualizar os diferentes caminhos trilhados por pessoas que viveram um mesmo período histórico, porém em classes e perspectivas sociais diferentes.

Em seus trajetos pessoais e sociais verificam-se as origens, as consciências de mundo e as necessidades de relatá-lo de modos bem específico, traduzindo parte de suas heranças de classe social e dos grupos político-artísticos dentro dos quais desenvolviam sua sociabilidade. Ao mesmo tempo, só o fato de viverem uma mesma época e terem - de certa forma - convivido entre si ou, ao menos visto os filmes por eles produzidos, já desperta algumas afinidades de estilo e temáticas que são compartilhadas. São diversas nuances narrativas. E, em cada preocupação, a defesa de pontos de vista.

$\mathrm{Na}$ seleção dos diretores, preferi eleger aqueles que passaram diretamente pelos anos da Movida e estabeleceram com seus trabalhos alguma relação com Almodóvar - mesmo aqueles que já estrearam seus primeiros longas-metragens anteriormente a esse período - e separá-los em três grupos. Os diretores de Madrid: Fernando Colomo, Fernando Trueba, Manolo Gutiérrez Aragón e, um pouco antes deles - mas dialogando com temáticas similares a Almodóvar -, Eloy de la Iglesia. Aqueles que trabalharam um cinema metafórico anterior ao contexto da "nova comédia espanhola", mas que passaram por toda a transição democrática, pela Movida e sua posteridade desenvolvendo trabalhos que refletiam estas mudanças: Victor Erice e Jaime Chávarri.

E, por último, diretores de Barcelona: Bigas Luna e Ventura Pons que, além de herdarem alguns efeitos da Escuela de Barcelona - marcada inicialmente pelo experimentalismo e cosmopolitismo de um grupo de diretores catalães -, ganharam grande respeitabilidade do público - sobretudo da Catalunha - por razões que mesclam competência cinematográfica e um regionalismo que questiona uma possível 
"cultura hispânica". Mas também por suas aproximações com o modo de filmar e com as temáticas de Pedro Almodóvar. Apesar de parecerem muito semelhantes ao diretor, suas escolhas narrativas indicam caminhos bem distintos, porém o diálogo entre eles é bastante recorrente em razão da utilização que fazem de suas fontes, provocadoras nas histórias e na relação com o público.

A formação universitária ligada ao cinema é o primeiro dado notório a todos eles. Um fator expressivo, especialmente ao se considerar uma época em que a economia espanhola era de total dependência do restante da Europa e de que estudar em uma universidade nos anos 60 e 70 representava um privilégio para poucos. Este fato conduz naturalmente à conclusão de que estes cineastas não eram procedentes das classes sociais populares. Viviam na capital Madrid ou em Barcelona desde a infância e possuíam, por sua vez, uma cultura urbana desenvolvida com uma leitura social fortemente condicionada pelos círculos sociais que conviviam naquele universo cosmopolita. Basta olhar panoramicamente o perfil acadêmico de cada um até a estréia de seus primeiros longas-metragens para se deduzir a afirmação.

Fernando Colomo nasceu em Madrid em fevereiro de 1946. Aos 16 anos fez seu primeiro curta-metragem em formato de $8 \mathrm{~mm}$, intitulado Sssoufl. Arquiteto formado pela Escola de Arquitetura, não conseguindo vaga para o curso de direção em cinema, passou para a especialidade de decoração [cenografia] na Escola Oficial de Cinematografia e já iniciou seus trabalhos no cinema independente.

Fernando Rodríguez Trueba ${ }^{46}$ é oriundo da Faculdade de Ciências da Informação - lembrando que a escola de Cinema havia sido fechada por Franco nos anos 70 -, onde se matriculou para estudar som e imagem. Trabalhou como jornalista, foi crítico de cinema entre 1974 e 1979 para La Guia Del Ócio de Madrid e depois para o jornal diário El País. Deixou a faculdade e produziu vários curtas-metragens em $8 \mathrm{~mm}$ antes de estrear seu primeiro trabalho, sempre ao lado do amigo Fernando Colomo. Nasceu em 1955, numa família numerosa e trocou seus desejos de infância de tornarse pintor - era grande admirador de Picasso - para trabalhar com o cinema. Foi organizador da programação do extinto "Cinestudio Griffith" de Madrid e em 1981 fundou a revista Casablanca, que durou pouco mais de dois anos. Durante sua etapa de crítico e estudante fez alguns curtas entre 8 e $16 \mathrm{~mm}$, obtendo resultados diversos. Nesse período formou o grupo "Del Yucatán", na verdade uma brincadeira de amigos que se reuníam numa cafeteria com o mesmo nome. Entre eles se encontravam Óscar Ladoire e Carlos Boyero ("estrelas" do curta Oscar y Carlos). Alguns desses trabalhos 
nem foram terminados ou montados corretamente, mas, no final, Trueba obteve um bom resultado como En legítima defensa, produção que lhe garantiu reconhecimento para - junto com Colomo auxiliando-o como produtor - conseguir produzir e terminar Ópera Prima (1980), seu primeiro longa-metragem.

Manolo Gutiérrez Aragón ${ }^{\mathbf{4 7}}$ nasceu em Torrelavega (Santander). na Cantabria, região situada ao norte da Espanha ao lado do País Vasco, em 1942. Estudou Filosofía e Letras em Madrid e graduou-se como realizador em 1970 na Escuela Oficial de Cinematografía (EOC) de Madrid, que ainda estava em funcionamento. Quando estudante realizou seu primeiro curta-metragem de 11 minutos, El cordobés, em 1969, produzido pela faculdade. Seguiram-se Hamsel y Gretel, El último día de la humanidad e, em 1970, Cátedras ambulantes. Somente em 1973 estreou seu longa-metragem de 88 minutos Habla mudita ${ }^{48}$, produzido pela "Elías Querejeta P.C. 1 Filmverlag der autorem", propriedade deste produtor que projetou muitos cineastas naquela década e na seguinte.

Eloy Germán de la Iglesia ${ }^{49}$ nasceu em Zarauz, Guipúzcoa, em $1^{\circ}$ de janeiro de 1944 e faleceu em 23 de março de 2006. Ainda que nascido em Zarauz foi educado em Madrid, onde estudou Filosofía e Letras até o terceiro ano, época em que decidiu se dedicar ao cinema, ao teatro e à televisão. Aos 20 anos de idade já havia escrito, dirigido ou produzido quase cinqüenta títulos para a televisão, como La doncella del mar, Los tres pelos del Diablo e El Mago de Oz, textos que formaram seu primeiro longa-metragem Fantasia (1966). Tentou ingressar na "Escuela Oficial de Cinematografia", mas não foi aceito por não possuir a idade mínima exigida para o curso. Estudou cinema em Paris, no IDHEC. Antes de estrear seu longa-metragem Fantasia, trabalhou como roteirista de TV e fez alguns trabalhos em 8 mm.

Nascido en Carranza (País Vasco) em 1940, Víctor Erice já era formado em direito e ciências econômicas e políticas quando decidiu se dedicar totalmente ao cinema $^{50}$. Ingressou na Escola de Cinema de Madrid em 1963 para cursar a especialidade de direção, realizando seus primeiros projetos cinematográficos. Iniciou seu trabalho como crítico em publicações muito respeitadas na época como Cuadernos de Arte y pensamiento e Nuestro cine. No mesmo período já produziu seus primeiros curtas-metragens: En la Terraza (1961), Páginas de un Diario (1962) e Los días

\footnotetext{
46 Disponível em: <http: // www.clubcultura.com/clubcine/clubcineastas/trueba/index.htm>. Acesso em 03.03. 2006.

${ }^{47}$ Disponível em: <http:// www.galeon.com/carpleg/gutierrezbio.htm> acesso em 03. 03. 2006.

${ }^{48}$ Prêmio da Crítica no Festival de Berlim em 1974 e candidato ao Oscar

${ }^{49}$ Disponível em: <http:// <www.culturalianet.com/art/ver.php?art=22527> acesso em 03. 03. 2006.

${ }^{50}$ Disponível em: <http:// <www. elpais.es/publicidad/2003/cine/PAGINAS/40_erice.htm> acesso em 04. 03.2006.
} 
Perdidos (1963). Desse período de formação também está seu trabalho como roteirista no filme de Antonio Eceiza, El próximo Otoño (1963). Nessa época, Erice dirigiu também outro curta-metragem, intitulado Entre Vías (1966), e colaborou em Oscuros sueños de Agosto (1967), dirigido por Miguel Picazo. ${ }^{51}$ No final da década de sessenta, levou para as telas seu primeiro trabalho, Los desafíos (1969), um episódio de um longa-metragem composto por três histórias; dentre as quais uma era sua, outra era dirigida por José Luis Egea, e outra por Claudio Guerín, todos abordando as relações humanas determinadas pelo poder.

Jaime Chavárri Del Moro ${ }^{52}$ nasceu em 1943. Formado em direito, fez dois cursos na Escola Oficial de Cinema, período em que passou a ser crítico da revista Film Ideal e começou a produzir em $8 \mathrm{~mm}$ seus primeiros curtas-metragens, como Otoño salvaje (1964) e Sansón y Dalila (1965). Estes filmes abriram caminho para dois longas-metragens ainda amadores, Run, Blancanieves, run (1967-1968) e Ginebra en los infiernos (1968- 1970). Depois da realização de três curtas em 35 mm, Estado de sítio (1971), Permanencia del arabesco (1971) e Señales en la ventana (1973); e do episódio "La danza", dentro de uma produção coletiva Pastel de sangre (1971), fez seu primeiro longa-metragem profissional, Los viajes escolares (1974).

José Juan Bigas Luna ${ }^{53}$ nasceu em Barcelona em 1946. Iniciou sua carreira profissional dentro do mundo do desenho criando, com Carlos Riart, o "Estudio Gris", em $1969^{54}$, depois de uma formação inicial em diferentes campos como a arquitetura, o desenho e a fotografia. Empreendeu sua carreira cinematográfica com um primeiro longa-metragem intitulado Tatuaje, primera aventura de Pepe Carvalho (1976), um filme policial baseado no romance de Vázquez Montalbán. Porém, sua personalidade e discurso começam mesmo a aparecer em Bilbao (1978) e Caniche (1979), filmes de baixo orçamento que revelam suas intenções como artista.

Ventura Pons ${ }^{55}$ nasceu em 25 de julho de 1945 na cidade de Barcelona. Nos anos setenta já era um reconhecido diretor de teatro catalão e, em 1977, surpreendeu a todos com Ocaña, retrat intermitent, sua primeira película. Manejando sua câmera para falar de um artista popular no intuito de revelar nele um artista total, Pons quebrou as barreiras analíticas - em geral elaboradas pelo meio acadêmico - que ignoram a integralidade entre o perfil pessoal, social e a ausência de limites da arte e do artista.

\footnotetext{
${ }^{51}$ Disponível em: <http:// <www. encadenados.org/n33/el_valor_del_cine.htm> acesso em 04. 03.2006

${ }^{52}$ Disponível em: <http: // <www.elpais.es/publicidad/203/cine/PAGINAS/30_chavarri.htm> acesso em 05.03. 2006.

${ }^{53}$ Disponível em: <http: // <www.clubcultura.com/clubcine/clubcineastas/bigas/bi-info/bio.pdf> acesso em 06.03. 2006.

${ }^{54}$ Disponível em: <http: // <www.galeria-metropolitana.com/artists/blum.index.html> acesso em 06. 03.2006.
} 
Diretor, roteirista, e produtor de cinema, com seu primeiro filme - nas palavras de Jordi Balló: "provavelmente a película mais rentável do cinema catalão" -, Pons iniciou sua carreira cinematográfica com sucesso. Este primeiro trabalho foi selecionado oficialmente pelo Festival de Cannes de 1978.

Pedro Almodóvar Caballero tem uma data de nascimento controversa em sua biografia. Algumas apontam setembro de 1949 e outras, de 1951, ambas em Calzada de Calatrava, província de Ciudad Real, Espanha. Sigo aqui a referência da página oficial na internet de sua produtora "El Deseo"56 e a biografia da Filmoteca Canaria ${ }^{57 .}$ 1951. Praticamente, em todas as biografias encontradas, a descrição é a mesma. Aos oito anos muda-se com a família para Cáceres, onde estudou em colégios católicos de salesianos e de franciscanos.

Fascinado por filmes que via desde a infância e decidido a ser cineasta, com 16 anos partiu sozinho de Cáceres com pouco dinheiro e passou a viver em Madrid. A vida difícil na metrópole levou-o a trabalhar em vários empregos para se manter. Viveu em Ibiza, um ano em Londres, voltou a Madrid e, após passar num concurso público na Companhia Estatal Telefonica, trabalhou como auxiliar administrativo, período que produziu vários curtas-metragens em $8 \mathrm{~mm}$ até lançar - após um ano e meio com várias dificuldades de rodagem - seu primeiro longa-metragem. Toda sua formação foi autodidata, lendo romances, obras sobre cinema, assistindo a filmes, fazendo contatos com várias pessoas ligadas ao campo cinematográfico ou artístico. Continuou trabalhando na Telefonica até adquirir independência financeira para viver de seus filmes.

Percebe-se de antemão nessas rápidas biografias introdutórias que há uma evidente diferença entre a trajetória destes cineastas e a de Almodóvar. Os únicos Luna e Pons - que não começaram suas carreiras cinematográficas muito jovens já possuíam ligação estável com o ramo das artes. Luna nas artes plásticas e Pons nas artes cênicas. Gutiérrez Aragón estreou seu primeiro longa com 31 anos de idade, porém já possuía uma formação universitária anterior ao cinema e possibilidades para ampliar suas intenções numa carreira. Ainda que tradicionalmente todos os diretores tenham começado com curtas-metragens, não deixa de ser admirável o fato de todos possuírem condições para realizar seus projetos, sejam elas devido a seu poder aquisitivo, ou a vínculos com o meio cinematográfico, televisivo ou jornalístico.

Mesmo com pouco orçamento e amparados uns aos outros em ajudas que iam

\footnotetext{
${ }^{55}$ Disponível em: <http: // <www.venturapons.com/biografia.html> acesso em 07. 03. 2006.

${ }^{56}$ Disponível em: <http: //<www.Egeda.es/eldeseo> acesso em 05. 02. 2006.

${ }^{57}$ Cuadernos de Filmoteca Canaria - Pedro Almodóvar . Las Palmas de Gran Canaria, 40º.cuaderno, 2003 , p. 7.
} 
desde a profissional até a mais íntima como emprestar a residência de amigos para filmagens, não há dúvida de que a possibilidade de sair da área cinematográfica por questões financeiras estava descartada. Bigas Luna e Ventura Pons apenas ramificaram suas atividades artísticas, por isso começaram a filmar após os 30 anos. Todos os outros estrearam seus primeiros longas-metragens possuindo até 25 anos de idade. Almodóvar estreou quando tinha 29 anos.

Convém lembrar que a vivência cinematográfica já se conta no próprio espaço universitário, com pessoas envolvidas profissionalmente de várias maneiras vinculadas ao ato de fazer cinema. Portanto, não foram apenas os curtas-metragens que introduziram esses diretores no campo cinematográfico. Inclui-se também, nesse contexto, o fato de muitos já trabalharem como críticos em revistas especializadas. Isso não só aguçava seus olhares, unindo formação acadêmica com observação fílmica, como também ampliava e fortalecia o contato cotidiano com criadores na área. Essa prática os obrigava a exercitar a escrita, o que acabou favorecendo em suas produtoras ou redes de TV desempenharem papéis de roteiristas, diretores ou, eventualmente, atores.

Fernando Colomo é um exemplo de tal procedimento. Desde que começou a trabalhar com cinema, sempre exerceu a função de roteirista e diretor, ajudando vários diretores iniciantes e veteranos. A elaboração do texto do filme De fresa, limón y menta (1977), de Miguel Angel Diez - por exemplo -, teve sua colaboração, além de produzir desde 1980 filmes de novos diretores, como foi o caso de Fernando Trueba com Opera Prima. O processo de ajuda mútua também reflete a precariedade da própria estrutura cinematográfica nacional, que acabou obrigando seus criadores a buscar alternativas para realizar seus trabalhos. O que talvez facilitasse as produções era o fato de todos os envolvidos nesse campo já se conhecerem e garantirem acordos de confiança. Não havia "estranhos" nesse universo. Mesmo os novatos, já pertenciam, de certa forma, a este círculo social.

Nesses parâmetros, Pedro Almodóvar destoava deste universo. Ainda que já tivesse começado seu contatos com vários destes cineastas e mantivesse boas relações de simpatia com todos, seu espaço como diretor dentro dessa esfera ainda não existia até os anos 80. Nada sério se esperava de um "chico" que fazia filmes rudimentares e pornôs. E sobretudo de alguém que não vinha dos mesmos ambientes habituais da vida cinematográfica. Logo, as dificuldades enfrentadas e as estratégias que o diretor precisou desenvolver para entrar nesse meio e começar a ocupar o seu lugar passaram necessariamente por um grande jogo com regras pré-estabelecidas. 
Elas exigiam dele o aumento de boas relações sociais, interesse integral nos assuntos da área junto às pessoas mais indicadas ligadas ao cinema e busca por aprender voluntariamente o ofício, não só de diretor, mas de todos os outros elementos que compõem a fatura de uma rodagem cinematográfica.

Isso não significa que outros diretores não tenham passado por este "ritual". A diferença clara está nas portas de acesso e no tratamento dado aos que se propuseram a ingressar nesse terreno. A condição de classe conta não apenas pelo dinheiro disponível que viabiliza, mas pela facilidade de circulação nos mesmos ambientes onde os vários envolvidos no setor cinematográfico poderiam freqüentar. Como apontado há pouco, já transitar na universidade entre aqueles que possuem acesso aos que estão produzindo - bem ou mal - na área cinematográfica abre possibilidades que não se restringem apenas à apresentação. Os vários ramos de trabalho no cinema se tornam mais disponíveis e cambiáveis entre si. Uma vez dentro deste campo, mais se ampliam as possibilidades de permanecer nele - claro, desde que cumprindo as exigências apontadas em torno da classe social e do meio profissional.

Todavia, por mais que pareçam suficientes, estes são alguns dos fatores básicos, mas não dominantes, para se manter dentro do universo cinematográfico. Há de certa forma uma chave mais importante que condiciona essa carreira. E ela é determinada pelo sucesso. Não é preciso que este seja contínuo e crescente, mas para que haja novas produções é necessário um trabalho bem-sucedido, com seus resultados bem aplicados em projetos futuros. Para que isso venha a ocorrer, público, crítica e investidores (produtores, distribuidores e exibidores) caminham juntos, configurando-se num bloco receptor extremamente severo para o êxito de um filme. Nem sempre eles estão em acordo, mas é de sua conjugação - mesmo às vezes destoante - que se elabora a existência profissional de cada diretor. 


\section{ESCALADAS POR AUTONOMIA}

A trajetória e o avanço dos cineastas dependem e revelam-se de acordo com o complexo fluxo oscilatório e imprevisível de cada novo trabalho que lançam nas salas de cinema. O que se verifica na reação do público é somente a conseqüência também parte constitutiva da confecção do sucesso - de um processo que envolveu diversos setores. Estes já estão implicados desde a elaboração oficial do roteiro a ser filmado, passando pelos produtores, pelo processo de direção, cenários e todo o aparato técnico de rodagem da película, até chegarem nos interesses de distribuidores em mercados regionais, nacionais e internacionais.

O salto das produções de curtas-metragens para o mercado de longas ou a mudança para o universo cinematográfico daqueles que antes exerciam outras funções artísticas não representa apenas uma nova etapa. Ele traz uma experiência inédita para o cineasta que doravante pode buscar de maneira mais eficaz sua liberdade criativa e registrar sua mensagem. Firma o início de uma grande jornada de incertezas e de empreendimentos especiais e únicos para cada um dos diretores.

\subsection{Depois do primeiro longa}

Fernando Colomo, depois de dirigir e produzir Mañana llega el presente (1973), começou a edificar sua fama com En un Paris imaginário (1974) ${ }^{58}$, Usted va a ser mamá, e principalmente Pomporrutas imperiales $(1976)^{59}$. No entanto, foi seu primeiro longa-metragem Tigres de papel (1977), com Miguel Arribas, Carmen Maura, Pedro díaz Del Corral e Emma Cohen, que Ihe proporcionou visibilidade, significando uma grande revelação na época. Seguiu-se a partir daí seu reconhecimento público. Tanto este filme como Qué hace una chica como tú en un sitio como éste ? (1978), se converteram no modelo do que viria a ser denominado pela crítica ou pelos historiadores do cinema de "comédia madrileña", dentro do que se considerou a "nova comédia espanhola", mesmo - como já observado aqui - sob as restrições e insatisfações de Colomo.

Com Trueba ocorreu algo similar. Seu êxito comercial e de crítica, especialmente em Chicago e na Mostra de Veneza com o prêmio de melhor ator para Óscar Ladoire, veio com seu primeiro longa-metragem Opera prima (1980). Reconhecido por muitos como o filme inaugural da chamada "Comédia madrileña",

\footnotetext{
${ }^{58}$ Premiado em 1975 no "III Certamen de Cortometrajes de Huesca”.

${ }^{59}$ Premiado no "Festival de Huesca” e pelo “Círculo de escritores cinematográficos”.
} 
somado posteriormente aos seus outros filmes juntamente com os de Colomo, ele viu seu sucesso direcionar-se para um caminho que não o agradava e nem fazia parte de suas intenções mais gerais. Este quadro é ilustrativo das relações impostas pelo campo cinematográfico, atrelado à mídia. Mesmo entre aqueles mais legitimados pelo meio no qual já estão teoricamente aceitos, existe constantemente a necessidade de prontidão diante de atitudes que obedecem orientações de outros campos como os intelectuais, a imprensa ou os setores financeiros interessados em rotular sob seus critérios os trabalhos de diretores. Estes podem - na medida de suas avaliações ou projetos - criar maneiras próprias de interpretação e denominação, chegando às vezes a dinamizar, distorcer ou até destruir uma obra.

Em entrevista para a revista online Plus em 27 de janeiro de 2003, ao responder sobre o que pensava da comédia espanhola atual diante da "comédia madrileña", sobretudo porque produziu muitos trabalhos no gênero, Colomo radicalizou um pouco mais o discurso que já havia declarado em outras ocasiões:

Nunca existió. Fue una etiqueta inventada por los críticos. Al principio se llamó la "nueva comedia costumbrista madrileña" y luego cayó lo de "nueva y costumbrista". No entiendo por qué por la misma razón no decían que Woody Allen hacía comedia neoyorkina o Eric Rohmer, comedia parisina

A exemplo de Colomo, Trueba também não concorda com essa etiqueta para seu filme de estréia. Sua justificativa explica-se pela própria apresentação da narrativa e cenários onde ocorre a ação dramática. Na verdade, segundo ele, a película se aproximava mais de Billy Wilder e Charles Mingus - se observado pela inspiração de diálogos, personagens e seus lugares sociais - do que da vida madrilenha:

La historia que cuenta la película podría haber pasado en cualquier lugar del mundo. De hecho, Madrid aparece muy poco. Es una película de personajes y de diálogos, pero no de paisajes ${ }^{60}$

Apesar dos rótulos inadequados que receberam, tanto Trueba como Colomo são os cineastas desta análise que mais trabalharam com comédias. Contudo, realmente elas não se restringiram apenas a Madrid, fato que já ocorre com a grande maioria das películas de Almodóvar. Colomo e Trueba foram os cineastas que mais experimentaram diferentes registros, tanto em filmes como em suporte. Talvez só percam para Bigas Luna. Este que, após iniciar sua trajetória em cinema, abandonou suas atividades anteriores ligadas às artes plásticas. O diretor, entretanto, após produzir o curta-metragem Collar de moscas (2001), recuperou seu interesse pela experimentação de vanguarda e pequenos formatos audiovisuais, descobrindo uma vocação didática de investigação no cinema digital por meio do projeto "Taller Bigas

${ }^{60}$ RIVERA, 17. set. 2000, p. 28. 
Luna", que fundou com Catalina Pons em 1999.

Luna desenvolveu uma trajetória intrigante. Saiu do campo pictórico e lançouse no campo cinematográfico discutindo comportamentos, neuroses e fantasias em torno da sexualidade e das tradições hispânicas. Também filmou fora do país - como Trueba e Colomo -, voltou à Espanha e retomou a pintura. Mais recentemente, uniu projetos diversos que mesclam as diferentes linguagens visuais sobre o que há de mais atual no universo da tecnologia digital e visual.

Em 1980, Bigas Luna havia se mudado para Los Angeles. Lá escreveu o roteiro de Renacer (1981), um duro relato sobre o mundo das seitas religiosas. De sua longa estadia nos Estados Unidos nasceram os filmes policiais Lola (1986) e Angustia $(1987)^{61}$, com ótima aceitação por parte da crítica. Anos mais tarde, o diretor voltou à Espanha e passou a morar em Tarragona, na intenção de dedicar-se novamente à pintura. No entanto, recebeu um convite do produtor Andrés Vicente Gómez - o mesmo produtor de Almodóvar em Matador - para fazer a versão cinematográfica de Las edades de Lulú (1990) ${ }^{62}$, baseada na novela de Almudena Grandes. Com este produtor, veio a trilogia Jamón, jamón $(1992)^{63}$, Huevos de oro $(1993)^{64}$, e La teta y la luna $(1994)^{65}$.

Três anos depois, retornou com Bambola (1996), que causou autêntico escândalo no Festival de Veneza, obtendo uma boa aceitação comercial na Itália. Volta no próximo ano com um novo trabalho, La camarera del Titanic $(1997)^{66}$, aplaudido e respeitado pela crítica internacional. Após dois anos Bigas Luna estreou um novo filme, Volaverunt (1999), interpretado pela consagrada atriz espanhola Aitana SánchezGijón $^{67}$. Já no século XXI, levou às telas uma adaptação baseada no romance de Manuel Vicent, Son de Mar (2001). Película interpretada por Jordi Mollà, Eduard Fernández e Leonor Watling, tendo a colaboração de Rafael Azcona no roteiro.

A experiência das oficinas o fez adentrar no mundo das "novas tecnologias"68

\footnotetext{
${ }^{61}$ Ganhador do Golden Raven no Festival Internacional de Cinema Fantástico de Bruxelas.

${ }^{62}$ Indicado para os prêmios Goya de melhor roteiro adaptado.

${ }^{63}$ Ganhador do Leão de Prata no Festival de Veneza.

${ }^{64}$ Prêmio do júri no Festival Internacional de San Sebastián.

${ }^{65}$ Prêmio Leão de Ouro no Festival de Veneza.

${ }^{66}$ Com este trabalho ganhou a Pirâmide de Ouro e o prêmio de melhor diretor no Festival Internacional do Cairo e um Goya como melhor roteiro adaptado.

${ }^{67}$ Prêmio de melhor interpretação feminina no Festival de Cinema de San Sebastián.

${ }^{68}$ Apesar de não se constituir como tema desta discussão, achei pertinente chamar a atenção para o termo, pois este tem se configurado de maneira bem controversa, tratado equivocadamente como algo fora da produção humana. Na análise do filósofo Pierre Lévy a atividade multiforme de grupos humanos, um devir coletivo, se vê ofuscada cada vez mais em torno destes objetos materiais que hoje são identificados grosseiramente sob esta denominação. Isto acaba por impedir a discussão do uso tecnológico como processo resultante das necessidades e fluxos de relações humanas ainda que estejam irregularmente espalhadas na disparidade social. Em sua expansão, estes instrumentos revelam elementos que interferem nas novas formas de comunicação, como a produção de uma inteligência coletiva
} 
e junto a Catalina Pons fundou em 2002 a PLATFORM BL, dedicada à criação e realização de filmes de novo formato e ao desenvolvimento de projetos multimídia. Em 2003 foi convidado pela Fundación Ciudad de Las Artes Escénicas de Valencia para realizar o encerramento da II Bienal de Valência. Representou "Las comédias bárbaras", montagem cênico-teatral na qual colocou seu universo pessoal e um olhar multidisciplinar à obra de Valle-Inclán, incorporando suas indagações em artes plásticas, cinemas e novos formatos audiovisuais.

Em janeiro de 2004 inaugurou a exposição "Origenes", na galeria Senda, em Barcelona, exposição formada por onze pinturas de grande formato em imagem digital e 12 video-criações. Depois seguiu desenvolvendo sua obra pictórica e cinematográfica, considerando-se cada vez mais um artista multidisciplinar. Em fevereiro de 2005 apresentou a vídeo-instalação "Gaudir Nouvelle" no museu Moritz. Em março de 2005, no Festival de Mar Del Plata, organizou uma retrospectiva e, em maio, uma outra na American Cinemathique de Los Angeles. Em junho preparou uma exposição em Nova York, na galeria Bifforms, sobre o projeto "microcosmos" e planejava rodar o filme Yo soy la Jumi.

Não tão dotado desse ecletismo visual, Colomo manteve-se no suporte dramatúrgico e cinematográfico realizando obras em diferentes gêneros. Seu terceiro longa, La mano negra $(1980)^{69}$, foi um filme noir. Depois fez Estoy en crisis $(1982)^{70} \mathrm{e}$ La línea del cielo (1983) ${ }^{71}$, esta última rodada em Nova York com baixíssimo orçamento - duas comédias. Em 1985, estrelado por Harvey Keitel, Klaus Kinski e Miguel Bosé, Colomo deu um salto de qualidade em sua filmografia com El caballero del dragón (1985), filme rodado no verão de 1985 e que teve o maior orçamento da história do cinema espanhol ao menos até o ano de 2003. Uma magnetizante ficção científica ambientada na época medieval, de grande sucesso de bilheteria e quase nenhum retorno de crítica - positivo.

Em 1987 estreou La vida alegre, uma história que levou o diretor novamente às suas origens da "comedia madrileña", obtendo grande êxito de público" ${ }^{72}$ No ano seguinte estreou Miss Caribe, protagonizada por Ana Belén, e no mesmo ano filmou outra comédia, Bajarse al moro (1988), baseada na obra teatral homônima de José

\footnotetext{
e a interpretação de seus usos. Isto para as artes e para o cinema tem sido alvo de recentes e polêmicas discussões em torno do uso do suporte e do exercício da linguagem, sobretudo cinematográfica. Ver: LÉVY, Pierre. Cibercultura, São Paulo: Editora 34, 5ª reimpressão, 2005, capítulos 1 e 9.

${ }^{69}$ Prêmio de melhor filme no Mystfest da Itália; selecionado para os festivais de Montreal e Filmex de Los Angeles em 1980; prêmio de Gran Giallo na cidade italiana de Católica - julho de 1981.

${ }^{70}$ Selecionada para o Festival de Veneza de 1982.

${ }^{71}$ Selecionada para o Festival de Cinema de Nova York de 1984.

72 Prêmio Goya de melhor atriz para Verónica Forqué.
} 
Luis Alonso de Santos, com Verónica Forqué, Antonio Banderas, Juan Echanove, Atiana Sánchez-Gijón, Chus Lampreave e Miguel Rellán.

Na década de noventa dirigiu para a TVE as séries Chicas de hoy en día (1990) e Famosos y familia (1999), além de iniciar e dirigir os primeiros capítulos de Ay, Señor, Señor (1994) e Dime que me quieres (2000), ambas para a rede Antena 3. No teatro colaborou com o grupo La Cubana, realizando um filme que se integra ao espetáculo Cegada de amor (1994), e dirigiu Anabel Alonso na obra de Darío Fo, Un día cualquiera.

Ainda no cinema retomou o campo da comédia con Rosa Rosae (1993), uma história sobre o enfrentamento de duas mulheres, interpretadas por Ana Belén e María Barranco. Continuando na comédia, dirigiu um ano mais tarde Alegre ma non troppo (1994), protagonizada por Penélope Cruz, uma história sobre as relações entre membros da Jovem Orquestra Nacional da Espanha (JONDE). Nesta produção contou também com a participação de Oscar Ladoire, Pere Ponce, e Rosa María Sarda. ${ }^{73}$

Em 1994 atuou como ator, em Todo es mentira de Alvaro Fernandez, estrelado por jovens atores espanhóis na época (Penélope Cruz, Coque Malla e Ariadna Gil). Seu próximo longa foi novamente uma comédia co-produzida pela Espanha, França e Reino Unido, intitulada El efecto mariposa (1995), que conta a história de uma mulher casada com um ator inglês dez anos mais velho, protagonizada por María Barranco, Coque Malla e Rosa María Sardá. Mais um grande êxito de bilheteria e desta vez com ótimos comentários da crítica. A continuação em setembro de 1995 se incorporou ao programa do Canal Plus "Lo + plus", onde dirigiu La consulta de la doctora Delgado. Posteriormente dirigiu Eso (1997) para a rede Antena 3 TV ${ }^{74}$.

Manteve-se no terreno da comédia, dirigindo Los años bárbaros (1998) e Cuarteto de la Habana (1998). Em 2001 produziu Sagitário, um drama sobre a relação entre dois amigos maduros - uma pintora e um ator - e seus desejos sobre um jovem entregador de refeições. Em 2002 apresentou Al sur de Granada (2002), filme que conta a vida do escritor inglês Gerald Brenan durante sua estadia num pequeno pueblo da Alpujarra, na região de Granada. Em 2004 dirigiu uma das 32 pequenas histórias de 3 minutos da produção coletiva do filme Hay motivo?, todas com temas que denunciam algum aspecto da realidade política espanhola deteriorada de 2000 a 2004 . No mesmo ano trabalhou como ator em Cosas que hacen que la vida valga la pena e em 2006 escreveu e dirigiu El próximo oriente, a história de Caín, um açougueiro que vive entre

\footnotetext{
${ }^{73}$ Trabalho ganhador do prêmio de melhor filme no Festival de Cinema de Paris e três prêmios em julho de 1994 no Festival francês de “Arcachón” (Grande Prêmio 'Makila de Oro', Prêmio de Público e melhor roteiro).

${ }^{74}$ Por este trabalho obteve o prêmio de melhor telefilme internacional no Festival de Munique.
} 
imigrantes no bairro madrilenho de Lavapiés entre complexos pessoais e uma situação adversa ligada ao irmão que ele, por desventura, decide assumir para si.

Trueba também percorreu vários gêneros até chegar ao que parece ser o que mais lhe agrada - o documentário. Os ótimos resultados financeiros e de crítica obtidos por seu primeiro longa-metragem possibilitaram-lhe e a Ladoire fundar sua primeira produtora, a Ópera Films. Depois sozinho, em 1984, inaugurou a Fernando Trueba P.C.. Com mais autonomia e já interessado em mudar de registro, rodou um documentário sobre a vida de um boêmio maldito, Chicho Sánchez Ferlosio, Mientras el cuerpo aguante (1982). Filme elogiado por um setor da crítica e incompreendido por outro, pelas mesmas razões. Em 1983 voltou ao estilo dos diretores Lubitsh e Wilder com Sal Gorda, reaproximando-se do público que o havia conhecido por sua comédia.

Seu maior êxito neste gênero veio em 1985 com a adaptação para o cinema de John Ray Chapman, Sé infiel y no mires con quién. É a época em que inicia um trabalho estável com o produtor Andrés Vicente Gómez, com quem um pouco mais tarde - também em 1985 - tentará uma nova incursão narrativa e estilística, focando sua história nos anos 30 e 40 em El año de las luces - com a colaboração de Rafael Azcona -, num roteiro inspirado em anedotas de Manuel Huete. Depois de aceitações pouco entusiastas de seus trabalhos anteriores, este filme colocou novamente Trueba em destaque, motivando-o a investir em projetos mais ambiciosos ${ }^{75}$.

Desde 1981, o diretor alimentava o desejo de filmar um romance de Christoper Frank, mas, possivelmente por valores morais ou pelos padrões sociais espanhóis, guardou este projeto durante toda a década de 80. Somente em 1989 realiza El sueño Del mono loco, um thriller psicológico ${ }^{76}$. Até este filme, trabalhou para a televisão com "La mujer de tu vida" (1988-1989 e 1991), com histórias disparatadas que conquistaram uma boa audiência junto ao público espanhol.

El sueño del mono loco foi uma ambiciosa produção rodada em inglês com locações em Paris e atores internacionais (Jeff Goldblum, caracterizado como um ideal alter-ego de Trueba), que resultou numa película atípica até então - para alguém habituado a filmar comédias -, tanto na filmografia de Trueba como na espanhola. E apesar da boa aceitação pela crítica, o filme - que recebeu cinco prêmios Goya - não obteve boa recepção junto ao público.

Esgotado pela produção e pelos acontecimentos da má recepção, Trueba mudou novamente de registro e foi produtor da série de televisão "Magos de la tierra",

\footnotetext{
${ }^{75}$ Prêmio Urso de Prata no Festival de Berlim em 1986.

${ }^{76}$ O filme estreou em Salamanca em dezembro de 1989, e em março de 1990 obteve seis prêmios Goya da academia Espanhola: melhor filme, diretor, roteiro adaptado, produção, fotografia e montagem.
} 
um documentário sobre pintores e escultores do terceiro mundo. Ainda em 1990, devido à grande admiração que possuía por Eric Rohmer, decidiu traduzir e dirigir no teatro sua única peça, "Trio em mi bemol", para o Centro Dramático Nacional. Assim, em dezembro de 1990 estreou como diretor teatral e lá se encontrou com Geraldo Vera como cenógrafo e com Silvia Munt, protagonista da obra junto a Santiago Ramos. Todos eles haviam trabalhado antes com Trueba em Sé infiel y no mires con quién e em El año de las luces.

Com eles, voltou ao cinema com Rafael Azcona, num filme sobre a Espanha indefinida dos anos trinta, e ao tema da iniciação sexual, combinação que já lhe havia rendido ótimos resultados anteriormente e com a qual reafirma sua arte de direção em Belle Époque (1992) [ no Brasil lançado sob o título de Sedução]. Mais uma bem acabada comédia de sucesso internacional. ${ }^{77}$ Com este trabalho, Trueba entrava de maneira sólida no panorama comercial espanhol e profissional de todo o mundo. Em 1993 produziu para a televisão o programa "El peor programa de la semana", com Gran Wyoming como apresentador. Apesar de original para o gênero na televisão espanhola, sua transmissão foi encerrada.

Voltou-se então para seu projeto americano: rodar nos Estados Unidos uma comédia totalmente espanhola nos moldes dos grandes estúdios, com atores e atrizes do "star system" (Melanie Griffith, Danny Aiello, Daryl Hannah, El Wallach). Rodada em Miami, Two much (1995) foi a oitava produção de sua carreira e uma das mais caras do cinema espanhol. Com roteiro de seu irmão David, Trueba estabeleceu um total domínio da produção deste trabalho antes e depois de sua realização, com uma estrutura inédita no mercado espanhol. A resposta do público foi impressionante, seu sucesso ultrapassou fronteiras, tendo boa aceitação em toda a Europa.

La niña de tus ojos (1998) ${ }^{78}$ é também um filme de grandes dimensões que acompanha as pretensões do diretor em filmar fora da Espanha em padrões internacionais hollywoodianos. Rodado em Praga com altos orçamentos, novamente ambientado nos anos trinta - agora na Alemanha nazista -, o filme também foi sucesso de bilheteria. Curiosamente, a película - também uma comédia, porém com vários tons dramáticos - faz uma sátira das limitações orçamentárias e do perfil da equipe artística espanhola que não se enquadra no modelo padronizado de atores e atrizes internacionais. Em 1999 lançou o romance "Quatro amigos", cuja história trancorrida nos anos 20 , sobre a relação de amizade desses jovens numa época de sonhos e

\footnotetext{
${ }_{78}^{77}$ Nove prêmios Goya em 1992; Oscar de melhor filme estrangeiro em 1993.

${ }^{78}$ O filme recebeu na $13^{\mathrm{a}}$ edição dos prêmios Goya, de janeiro de 1999, sete premiações: melhor filme, melhor interpretação feminina, ator revelação, direção de produção, direção artística, figurinos e maquiagem.
} 
esperanças.

Calle 54 (2000), apresentada no Festival de Veneza, representa um aparente salto de contexto na obra de Trueba, mas não em sua vida: o jazz latino. Seu fascínio por este estilo já vinha desde os anos oitenta, mas naquele momento não tinha condições de correr o risco de assumir um musical com suas músicas favoritas. Agora já possuía tal segurança - tanto intelectual como econômica - e liberdade para realizá$10^{79}$. Sob o efeito do filme, Trueba também produziu o aclamado cd "Lagrimas negras", reunião do piano de Valdes com o cantor cigano Diego "El Cigala", que funde as canções latino-americanas com o canto flamenco. Depois desse filme, continuou envolvido com os cubanos em projetos posteriores com os cubanos no universo fonográfico, mostrando mais uma de suas pretensões e ramificações artísticas.

O drama El embrujo de Shanghai (2002) foi uma adaptação da novela homônima de Juan Marsé. Neste filme, o diretor buscou a imagem de Shanghai como se fosse um filme dublado hollywoodiano. Nele, adolescentes numa Barcelona de 1948 projetam impressões sobre aventuras dos maquis espanhóis (guerilheiros antifranquistas da pós-guerra civil espanhola). Nesse imaginário, um desses heróis míticos embarcaria para Shanghai, cidade que só conheciam por revistas em quadrinhos. Em 2003, seu irmão David dirige em sua produtora Soldados de Salamina, uma história que discute a solidão por intermédio de uma escritora que, ao buscar a recomposição da história de um soldado na guerra civil, encontra a explicação para sua própria vida.

Em 2004, Trueba esteve no Brasil, na cidade de Salvador, na Bahia, local onde filmou El milagro de Candeal, abordando os aspectos musicais e sociais do Candeal, pequeno bairro localizado na periferia da capital baiana. Nesta obra o diretor procurou registrar o trabalho do músico Carlinhos Brown e da entidade que fundou, a "Associação Pracatum Ação Social", responsável por ministrar aulas de música para os jovens do Candeal Pequeno e trazer melhorias nos aspectos de moradia e de saneamento básico na região. O interesse maior do diretor foi mostrar como que por meio da música a comunidade tenta resolver seus problemas e alimentar com isso a alegria de viver. O filme contou com a participação do pianista cubano Bebo Valdés, pai do pianista Chucho Valdés, também presente em Calle 54 e uma das grandes personalidades da música cubana. Carlinhos Brown também está presente com sua performance no carnaval de Salvador. ${ }^{80}$

\footnotetext{
${ }^{79}$ O filme obteve o prêmio Goya 2001 de melhor som e também foi candidato ao melhor documentário nos prêmios de cinema Europeu de 2001, além de converter-se no melhor álbum de jazz nos prêmios da Música 2001.

${ }^{80} \mathrm{O}$ filme ganhou o prêmio Goya nas categorias de melhor filme espanhol e melhor música para Zambie Mameto.
} 
Constata-se nessa trajetória de Trueba mudanças que indicam uma busca própria de registros que pudessem nortear o que mais o identificasse em caminhos bem trilhados. Começou com curtas, a exemplo dos demais cineastas, amparado desde o início por um círculo de pessoas ligadas ao cinema, desde a formação universitária em som e imagem. Seu trabalho como crítico de cinema, jornalista, e a ajuda constante de Colomo - já um diretor reconhecido - em seu primeiro longametragem ampliaram seus contatos. Ópera prima, apesar de ter atores e atrizes desconhecidos, já contava na equipe com profissionais respeitados no mercado e material técnico de primeira linha ${ }^{81}$.

Era previsível que o produto de seu olhar tivesse conformação e repercussão de público em geral diferente de Almodóvar. Sem duvidar de seu talento - sem o qual não teria êxito posteriormente -, é fato que diante da crítica e do mercado cinematográfico esse panorama soava muito mais favorável à sua legitimação e continuidade no cinema do que a Pedro Almodóvar. Mesmo com desafios e dificuldades distintos, ambos avançaram em seus projetos. Das diferenças, essa talvez seja a melhor reflexão.

Manolo Gutiérrez Aragón mostrou sua grande força narrativa com Habla mudita (1973), história que confronta um intelectual e uma pequena camponesa, numa ação dramática que revela mentalidades e universos diferentes, abarcando interrogações sobre a cultura. Foi roteirista de obras significativas, especialmente Furtivos (1975), dirigido por J. L. Borau, e Las truchas (1977) de José Luis García Sánchez. Mesmo ano em que dirigiu Camada negra, filme simples e esquemático que coloca em cena uma iniciação ao fascismo.

Sonámbulos (1977) integra o imaginário na construção de personagens e relatos, articulando uma ousada estrutura metafórica e uma declaração anticonformista sobre o mundo político das esquerdas. El corazón del bosque (1978) trata da história de um maquis tardio antifranquista dentro de uma exuberante natureza, recordando a sua primeira película. Apesar de estrear em Habla mudita com sucesso, segundo muitos críticos foram Camada negra (1977), Sonámbulos (1977) e El corazón del bosque (1978) que converteram o cineasta no melhor realizador de sua geração. Obras onde se mescla com habilidade o político e o experimentalismo dentro de complexas estruturas cujas raízes se encontram nos contos infantis ${ }^{82}$ e que refletem a transição, desde os últimos anos de Franco até a aprovação da constituição. Em 1979 dirige a

\footnotetext{
${ }^{81}$ RIVERA, 17. set. 2000, p. 28.

${ }^{82}$ Disponível:<http://galeon.com/cantabriag/Biografias/CarpG/GutAragon/GAragon.htm\#Demonios\%20en\%20el\%2 0jardín> acesso em 05. 04. 2006.
} 
versão teatral de Peter Weiss sobre "O processo", de Franz Kafka.

Maravillas (1980) inscreve-se nas descobertas da adolescência num contexto judaico (normalmente rejeitado na Espanha), com conotações mágicas. Em 1982 escreve e dirige "Morirás de otra cosa", para o Centro Dramático Nacional, com estréia no Teatro María Guerrero, de Madrid.

Em 1983 filmou Demonios en el jardín, crônica de uma educação sentimental sob o regime franquista nos anos 50 . E na tentativa de ampliar comercialmente seus trabalhos realizou Feroz (1984), uma versão de sua primeira película que, mesmo sendo selecionada para o Festival de Cannes na sessão "un certain regard", acabou convertendo-se num fracasso de bilheteria ${ }^{83}$.

Ainda no anseio de ampliar público, o diretor segue na mesma linha tanto em La noche más hermosa $(1984)^{84}$, como em La mitad del cielo $(1986)^{85}$ e Malaventura (1988) este também um filme mal-sucedido. Logo após este trabalho, se propõe pela primeira vez levar ao cinema "El Quijote" de Cervantes, projeto que concretizou em 1991, dirigindo para a televisão El Quijote, série televisiva que obtém o maior sucesso de audiência para uma série na Espanha. Este trabalho lhe garantiu prêmios no Festival de Cannes, "Prêmio Eurovisioni", e recebeu excelentes resultados em diversas TVs no mundo. Em julho de 1993 foi eleito presidente da Sociedade Geral de Autores e Editores - SGAE -, ficando na presidência até o ano de 2001, quando foi nomeado presidente da Fundação Autor. Desde 2000 é também presidente da Federación Europea de Realizadores Audiovisuales (FERA).

Com El rey del río (1995) viajou ao Festival de Berlim e, em 1997, realizou Cosas que dejé en La Habana ${ }^{86}$. Em 1998 dirigiu com tenacidade "El Rey de Harlem" e "Don Perlimplín”, óperas baseadas em textos de Federico García Lorca, representadas no Festival de Teatro de Granada, na Feira de Veneza e no Teatro de la Zarzuela de Madrid. Em 2000 foi também eleito o Torrelaveguense llustre do ano. Em junho de 2001 recebeu a medalha Blanquerna da Facultad de Ciencias de Comunicación Blanquerna de la Universidad Ramon Llull de Barcelona. No mesmo ano foi eleito acadêmico da Academia de Bellas Artes de San Fernando e lançou Visionários ${ }^{87}$, filme que trata da história de jovens que dizem ter visto a aparição da virgem Maria e das

\footnotetext{
${ }^{83}$ Disponível em:<http://<www.galeon.com/carpleg/gutierrezbio.htm> acesso em 03. 04. 2006

${ }^{84}$ selecionado para os festivais de Montreal, Miami, Chicago, San Sebastián, e para a Quinzena de Realizadores, de Cannes.

${ }^{85}$ Grande Prêmio Concha de Oro no Festival de San Sebastián.

${ }^{86}$ Prêmio la Espiga de Plata na Seminci de Valladolid, em 1997, e Villa de Madrid, em sua edição especial de 1998 dedicada à Iberoamérica, como melhor filme.
} 
repercussões sobre a população, após o anúncio da previsão de uma terrível guerra $^{88}$. O crítico de cinema César Rosino Mata afirma sobre Gutiérrez Aragón:

[...] se trata de uno de los mejores directores del cine español de todas las épocas. Siempre tiene cosas que decir y, en todos los casos, de forma original con respecto a todos los demás y con respecto de él mismo. Ninguna de sus películas se parecen entre sí ni temática ni morfológicamente. Ello es fruto de su inteligencia, de su sensibilidad y de su coherencia con una línea que no ha cambiado. Para entender su cine, es necesario conocer su personalidad. Intelectual de los pies a la cabeza, profundo lector de todo lo publicado y mejor escritor (sus originales ideas así lo demuestran) que cineasta, si ello es posible. Amable, irónico, tranquilo (salvo cuando rueda), abierto.89

O crítico Miguel Marías faz algumas ressalvas que não o consagram de forma tão global. Para ele, o melhor da produção do diretor está nos anos 80, a qual ele denomina de sua primeira etapa e reconhece que este dado é um sintoma desfavorável para um artista:

En la segunda etapa, que va desde El Rey del Río (1994) hasta El caballero Don Quijote (2002), sólo realiza cuatro películas, disminución de ritmo que cabe en alguna medida imputar a su condición de presidente de la SGAE, su colaboración en guiones ajenos y en algunas actividades docentes, aparte de las posibles mayores dificultades de producción que haya podido encontrar. Sin que pueda decirse que exista una clara ruptura entre esas dos fases o etapas que, arbitrariamente, doy por cerradas, sí podría detectarse una cierta diferencia: la primera resulta claramente más atractiva, era más impetuosa y esperanzada, pese a arrancar en los últimos años de la dictadura, quizá por el entusiasmo propio de la juventud y del que poco a poco va dominando el arte que practica. La segunda, y he de decirlo porque así lo siento, tiene algo de viaje de vuelta, no sólo por la mayor distancia temporal entre películas, sino por su ritmo mismo y su carácter, escasamente afirmativo y, al mismo tiempo, poco interrogador. [...] A ningún cineasta que aspire a seguir en activo le hace nada feliz que le digan que su mejor película es una que data de hace 24 años (o más, como le ocurre a alguno); todos quieren creer en su propio perfeccionamiento, y no sólo en el progreso en general, y pretenden preferir la última que han hecho. A ninguno le puede alegrar sospechar o advertir que tiene menos público, que no conecta del todo con los espectadores más jóvenes - casi los únicos que quedan -, que ya no se cuenta con él o no se le contabiliza entre los que de verdad importan en el cine de su país. "90

As duas críticas discutem aspectos relevantes da obra do cineasta. No entanto, a segunda dá um caráter mais específico à sua trajetória, localizando historicamente seu caminho criativo e pessoal, o que sugere uma atenção mais detalhada sobre o desenvolvimento dos fatos. Desde os anos 90 e em suas últimas produções, El caballero don Quijote (2002), La vida que te espera (2004), Una rosa de Francia (2005) e Todos estamos invitados (2006), Manolo Guitiérrez Aragón demonstra

\footnotetext{
${ }^{87}$ Disponível em:<http://www.clubcultura.com/clubcine/clubcineastas/gutierrezaragon/cantabro1.htm> acesso em 03. 04. 2006.

${ }^{88}$ Filme selecionado para competir no $49^{\circ}$ Festival Internacional de Cine de San Sebastián.

${ }^{89}$ Disponível em: <http://galeon.com/cantabria-g/Biografias/CarpG/GutAragon/GAragon.htm\# Demonios\%20 en\% 20el \% 20 jardínhttp://> acesso em 05. 04. 2006.

${ }^{90}$ Disponível em: <http:// www.rtve.es/rne/r3//pr/7vicios/testim/art_mm_01.htm>acesso em 06. 04. 206.
} 
um percurso de trabalhos oscilantes que somam em toda sua trajetória 23 produções como diretor e 32 como roteirista. Sua constante mudança de produtores - tendo se fixado um pouco mais com Luis Megino na primeira etapa - interferiu no seu processo criativo e em seus projetos, talvez mais ousados.

A segunda etapa, mais irregular, parece ter ocorrido muito em decorrência da rotatividade de produtores, que em comum só tiveram a pouca disposição para arriscar experimentações no mercado da imagem. Possivelmente, isso tenha afetado o diretor que demonstrava propensão a incursões mais ousadas. Como nos outros diretores, as alternativas criadas: o teatro, a TV e a universidade como espaço de manutenção no campo e negociação, devido ao lugar historicamente construído, também funcionaram como alternativa para que continuasse a desenvolver seu trabalho.

\subsection{Primeiro balanço comparativo}

Nesse panorama dos quatro diretores, o que fica mais evidente é a maleabilidade com que transitam sobre o universo profissional da imagem e a busca por experiências novas a cada avanço no trabalho. Nas oscilações, voltam aos gêneros que lhes garantem maior segurança econômica ou desenvolvem atividades fora do cinema - como na televisão e na universidade - sempre ligadas à imagem. Aproveitam - logicamente - o prestígio de seus nomes para aceitar convites ou solicitar participações. Acredito que, não por acaso, foram os diretores que não viram fronteiras tanto territoriais ou de linguagem para buscar formas de expressão e se levantar diante das adversidades. Demonstraram autonomia, não só criativa como também econômica. Colomo é co-fundador da produtora La Salamandra, depois Wanda Vision S. A., e Trueba é proprietário da Trueba P.C..

Entre as 25 produtoras de maior arrecadação em 2002 a de Colomo estava em $14^{\circ}$ lugar, atrás da El Deseo de Almodóvar, que se localizava em $9^{\circ}{ }^{91}$ - ano da estréia de Hable con ella. Em 2006, Colomo não aparece nesse bloco e a produtora de Trueba figura em $24^{\circ}$ lugar (com aproximadamente 1 milhão e 250 mil euros arrecadados), atrás da $4^{\mathrm{a}}$ posição de El Deseo (que arrecadou aproximadamente 10 milhões e 900 mil euros até finais de novembro) ${ }^{92}$. A título comparativo, Volver entrou na Espanha como a segunda película de maior arrecadação na estréia, em março de 2006, com aproximadamente 10 milhões de euros, atrás de Alatriste, que rendeu

\footnotetext{
${ }_{91}^{91}$ MINISTÉRIO DE CULTURA (España). Filmoteca española: el cine y el video en datos y cifras: 2002.

${ }^{92}$ MINISTÉRIO DE CULTURA (España). Filmoteca española: el cine y el video en datos y cifras: 2006.
} 
aproximadamente 16 milhões de euros em sua estréia em setembro de $2006^{93}$.

Considerando aqui também a política das cotas, que foi diminuindo gradualmente sua participação nas produções até desaparecer a partir do ano de $2001^{94}$, pode-se compreender o constante trânsito que os autores fazem entre TV, cinema e outras alternativas criativas para garantir projetos e ganhos financeiros. Cruzando os interesses entre mercado e criação, revela-se uma tensão contínua só resolvida com novas narrativas encontradas pelos criadores para responder às suas buscas pessoais, à exceção talvez de Guitérrez Aragón. Não por acaso, para cada grande sucesso, existe a ocorrência de um grande investimento numa nova história, gênero ou então territórios estrangeiros. $E$ diante de um retorno insuficiente ou de um fracasso, buscas de parcerias, trabalhos de co-produção e a volta aos seus estilos mais reconhecidos.

Com Almodóvar esse movimento acabou não ocorrendo. A partir do momento em que criou sua produtora com Agustín, a linha estética que já produzia antes se fortaleceu. Centrou-se em temáticas sempre de mesma afinidade e, somente de modo gradual, no decorrer de sua obra, paradoxalmente manteve-as modificando a forma de abordá-las, interpretando a tradição e a cultura espanholas, ainda que de maneira pouco convencional ou familiar. Assim, uma visão mais clássica que vislumbrasse refletir sobre a cultura ou os valores e heranças históricos - que tanto preocupavam os setores das classes médias ou abastadas -, como aparece em Bigas Luna, não fazia parte de sua reflexão.

Nada de músicos eruditos ou tradicionais como os protagonistas sempre presentes nos filmes de Trueba, nem grupos de classe média vivendo buscas de resgate afetivo ou histórico como em Colomo, mesmo em comédias similares às de Almodóvar. Muito menos películas compondo uma rede de balanço histórico político da época da transição e sua posteridade de difícil convívio social. Centrando-se na temática do desejo, pôde abstrair diretamente estes "compromissos", falando deles sempre a seu modo quando julgasse conveniente.

O cineasta percebeu cedo que os acordos para novas produções - em tese feitos entre os órgãos financiadores do governo ou entre redes de televisão tornavam-se praticamente impossíveis para ele. Quem iria financiar alguém que no seu histórico possuía películas sob o título de: La caída de Sodoma (1974), Sexo va, sexo

\footnotetext{
${ }^{93}$ MINISTÉRIO DE CULTURA (España). Filmoteca española: largometrajes españoles com mayor recaudación: 2006.

94 SUNDAHL, Ingo Michael von. El sector cinematográfico barcelonés. Tese (doutorado) Universitat de Barcelona, Barcelona, 2005. p. 14-15.
} 
viene (1977), Folle ... folle ... fóllome ... Tim (1978) e Salomé (1978), casualmente um nome religioso, mas todas com inspiração pornográfica ? E, como se não bastasse a resistência, também se espalhavam os comentários dos filmes - que a maioria havia assistido - sobre personagens como freiras drogadas, lésbicas que namoravam em relações sadomasoquistas, adolescentes prostitutos e drogados, terroristas homossexuais, toureiros psicopatas, além de transexuais e toda uma corte marginal. Não; era muita coisa bizarra vinda de uma cabeça que poderia perverter a sociedade. Seria perigoso arriscar.

Se de um lado havia o risco das idéias políticas comunistas ou anarquistas que ainda assustavam as classes mais conservadoras do país, de outro havia uma certa onda comportamental aparentemente despolitizada, mas disposta a também romper com costumes e abrir-se para novos que a partir da transição começavam a se espalhar entre a juventude. Boa parte da narrativa dos primeiros trabalhos de Almodóvar resulta do período de sua "formação" na "Movida madrileña", uma explosão cultural e comportamental que refletia a libertação de todos os desejos reprimidos durante tantos anos de ditadura após a morte de Francisco Franco.

Um período que - se entre os espanhóis adultos já acendia uma enorme chama de utopias - para a juventude a repercussão se revelava numa efervescência criativa incontrolável, onde tudo era permitido. Assim, segundo os grupos culturais hegemônicos - e incluo aqui tanto os de inspiração conservadora como revolucionária -, até se admitia que suas obras atingissem uma certa parte de jovens, mas não a maioria da sociedade.

Hoje - diante do cineasta consagrado e com suas histórias mais brandas - fica difícil imaginar que suas cinco primeiras películas só foram possíveis devido a muita paciência e a um grande jogo de boas relações até que ele pudesse criar sua própria produtora. Em 1980 Almodóvar estreou Pepi, Luci, Bom y otras chicas del montón, seu primeiro longa-metragem, contando com um orçamento de meio milhão de pesetas (aproximadamente 3 mil euros) arrecadado de doações oriundas dos bons contatos sociais que ele e seus amigos possuíam. Provavelmente envoltas pelo próprio espírito democrático de solidariedade e investimento nos sonhos que permeavam as ações e anseios do período, todas as pessoas fizeram um trabalho voluntário para o diretor, inclusive atores e atrizes. Não são poucas as vezes que ele reconhece publicamente o impulso que recebeu. Em mais de uma ocasião Almodóvar já se mostrou grato àquele momento único: 
maneras, a veces con mil pesetas para comprar rollos, préstandose a poner careto o cediéndome su casa. Si no hubiera sido por ellas, tal vez hoy no sería Almodóvar, sino simplemente pedro almodóvar caballero. (Festival de San Sebastián, setembro de 1993). ${ }^{95}$

Em pouco tempo o filme se converteu em película de culto, mesmo com todas as suas deficiências técnicas e narrativas. A espontaneidade e o senso irônico e criativo do filme tomaram a todos de surpresa, além de incorporar suas características rudimentares como elemento dramático da vida underground que - como um estilo de vida - se expandia por Madrid. Naquele filme verificava-se muito do que era a dinâmica da "Movida madrileña" que reinava nas ruas da capital.

No entanto, foi em Laberinto de pasiones (1982) que esta celebração de Madrid como a "cidade mais divertida do mundo" se faz claramente e de forma intencional pelo diretor. Mais elaborado - técnica e narrativamente -, Laberinto de pasiones já coloca Almodóvar como referência do cinema espanhol, apesar das divergências entre os críticos. Todavia - mesmo com o sucesso -, Almodóvar continuava trabalhando na Telefonica e precisou de mais dois anos para produzí-lo. Não havia nenhum produtor disposto a bancar seu novo trabalho. Afortunadamente, foi o cine Alphaville - onde seu primeiro filme ficou cinco anos sendo exibido nas sessões noturnas - quem decidiu produzir seu segundo longa-metragem.

Laberinto de pasiones era o enaltecimento mais aberto e fiel do que se vivia naqueles dias, demonstrando o espírito da Movida. Rodado em condições muito melhores que o anterior, ainda assim se desenvolveu precariamente. Com um orçamento de 20 milhões de pesetas (aproximadamente 12 mil euros), não houve como realizar um filme em circunstâncias muito diferentes do primeiro. Porém, há que se relativizar um pouco seu caráter underground. Suas proporções eram maiores: uma média de 40 cenários diferentes, muita ação e muitos personagens, além disso, para esse trabalho já pôde contratar um diretor de fotografia. Em contraposição, as dificuldades ainda permaneciam. Foi o próprio Almodóvar quem pintou o cenário do dormitório de Sexília. ${ }^{96}$

No ano seguinte - 1983 - estréia Entre tinieblas, tratando o tema da religião de maneira kitsch e em alguns momentos surreal, em torno da vida de freiras num convento em decadência. Esta película foi produzida por Luis Calvo, um empresário muito conhecido na Espanha por construir sua fortuna com o petróleo e negócios imobiliários. Naquela época ele vivia com Cristina S. Pascual, e esta ameaçava abandoná-lo. Muito apaixonado, se dispôs a fazer qualquer coisa para não perdê-la.

\footnotetext{
${ }^{95}$ STRAUSS, Frédéric. Conversaciones con Pedro Almodóvar. Madrid: Akal, 2001, p. 21.
} 
Ela, então, pediu para que ele fundasse uma produtora para financiar filmes onde pudesse exercer sua profissão de atriz. Pedro Almodóvar conta:

[...] así que Luis Calvo fundó Produciones Tesauro y preguntó a Cristina S. Pascual con quién quería trabajar. Ella respondió: 'con Berlanga, Zulueta y Almodóvar'. Luis Calvo me llamó por teléfono para saber si tenía algún guión listo [pronto] para rodar y yo fui muy directo conél: le pregunté si Cristina S. Pascual tenía que ser la actriz principal de la película. 'Por supuesto que no', me dijo. Pero su manera de decirlo, comprendí que significaba 'por supuesto que sí'. Le dio la misma respuesta a Berlanga, que escribió un papel secundario para ella, pero nunca llegó a rodar la película, ni tanpoco Zulueta. Yo, por mi parte, intenté abordar este encargo de una manera positiva y explotar todas las posibilidades que me ofrecía. Así que escribí una historia con un papel femenino que podría haber sido el sueño de cualquier actriz. El concepto de la película de encargo se convertió en un estilo de película. Imaginé una historia en la cual la heroína era una mujer que volvía locos a todos los hombres y locas todas las mujeres; una mujer que cantaba, se emborrachaba [se embriagava]; se drogaba, atravesaba periodos de abstinencia y tenía experiencias alucinantes que no podrían vivirse normalmente en menos de cien años. Estoy hablando de lo que me habría gustado hacer, pues como Cristina S. Pascual no pudo convertir ese sueño en realidad, me vi obligado a rescribir el guión y a limitar mis ambiciones $[\ldots]^{77}$

Vê-se, portanto, que qualquer oportunidade que favorecesse a Almodóvar avançar em seus projetos não era recusada. Ele adequa interesses e se adapta às circunstâncias. Se antes era esse período quando não podia recusar nada, pois estava empenhado em expandir seus investimentos que mal haviam começado, em outros momentos isso se dá no campo internacional e na diversidade de países por onde faz conhecidos e aceitos seus trabalhos. Evidente, depois de consolidar sua produtora e sua marca cinematográfica situações como essas não devam ocorrer. Entretanto, o jogo com as produtoras internacionais continua e as lógicas de "trocas" de interesses nos trabalhos se faz sob outros patamares.

$\mathrm{Na}$ época de Entre tinieblas, apesar de já possuir um considerável número de admiradores, isso ainda não the dava a segurança nem a tranqüilidade para recusar propostas. Seu reconhecimento perante a crítica especializada - por exemplo - só chegaria com a película seguinte, Qué he hecho yo para merecer esto? (1984), também produzida pela Tesauro. Uma história sobre as condições e perspectivas de vida de uma dona de casa de um conjunto habitacional da periferia de Madrid, brilhantemente protagonizada por Carmen Maura.

Matador (1985-1986), co-escrita com Jesús Ferrero, se constituiu numa fábula sobre a morte, o sexo e a culpa, metaforicamente desenhada em torno da vida de toureiros, com seus "bailados" e rituais. Com este filme a dificuldade para encontrar produtores já se demonstrou maior. A produção acabou ficando a cargo de Vicente

\footnotetext{
${ }^{96}$ Idem, p. 32.

${ }^{97}$ Ibid, p. 42.
} 
Gómez, Cia. Iberoamericana de TV S.A. Para conseguir financiamento, Almodóvar precisou confeccionar um extenso dossiê e enviá-lo para aprovação no Ministério da Cultura e um outro com pedido de ajuda para a televisão, vendendo os direitos de exibição.

Foi concomitantemente a estas dificuldades burocráticas - que deixavam claro para ele a falta de colaboração e interesse por seus trabalhos ${ }^{98}$ - que o diretor assumiu para si a intenção de eleger o desejo como temática central de suas películas. Sua constatação de aumento das dificuldades para trilhar seu próprio caminho estava definida não só pelo desinteresse cada vez mais intenso dos produtores. Objetivamente, o diretor observava que havia buscas de resultados bem diferenciadas entre ele e seus agentes. $E$ a ele incomodava bastante a sensação de que a todo momento estes grupos tentavam determinar a forma de sua narrativa fílmica.

Some-se a esse quadro a própria origem daquele cineasta que sempre causava polêmica. Não por acaso, rotulado pela imprensa de enfant terrible (menino travesso). A resistência diante de alguém que vinha de regiões carentes da Espanha e não tinha formação técnico-acadêmica para desempenhar a função de um bom artista e comunicador na esfera cinematográfica associava-se a seus trabalhos pré e iniciais na tela grande, opondo-o a outros cineastas com a formação e o nível social exigidos.

O fato de possuir uma origem humilde, de não ter passado pela vida acadêmica para ser cineasta e de ter sido funcionário público parece ser um dado que irá marcá-lo de modo estrutural para o resto de sua vida. Não encontrei nenhuma biografia ou entrevista sobre ele que não resgatasse em algum momento esses aspectos como relevantes, ora como fator de mérito ora como elemento de distinção, demarcador de limites de território - que de uma certa forma o diretor transpôs. A formação autodidata e não acadêmica ecoa de maneira bem singular em cada cultura. Para os norte-americanos, ser um self made man (um homem que se fez por si mesmo) é motivo de orgulho, coragem, destreza. Aos espanhóis, este modelo soa como um certo tipo de incapacidade. Dentro desta cultura, valoriza-se a trajetória intelectual, a formação erudita tradicional, elementos que não apareciam nos personagens e temáticas dos primeiros filmes de Almodóvar, e muito menos nele.

Colomo e Trueba, por exemplo, demonstram o contrário. Poderiam adaptar sua linguagem e histórias apenas com ajustes, para outros formatos. Suas comédias e o tom irônico que usavam, falavam - ou poderiam falar - numa sintonia que não iria surpreender o público, segundo os interesses de integrantes dos conglomerados da

\footnotetext{
${ }^{98}$ STRAUSS, 2001, p. 64.
} 
comunicação de massa aliados aos valores conservadores de uma classe social tradicionalista da sociedade espanhola. A linguagem e a proposta de Almodóvar não só eram outra, como traziam socialmente imagens e idéias que não se adaptavam aos padrões gerais de recepção, mesmo diante de cineastas também inovadores.

Portanto, desde o início de sua carreira cinematográfica o diretor não teve muitas alternativas no plano oficial. Para filmar La ley del deseo já não havia conseguido produtores. A "Lei Pilar Miró" - que acabou ajudando-o a abrir sua produtora - foi o instrumento pelo qual ele conquistou a liberdade para filmar o que quisesse. Porém, La ley del deseo só foi realizada porque Almodóvar recorreu a um comitê de leitura catalã e, junto ao então diretor do Instituto del Cine, Fernando Méndez Leite, conseguiu que fosse concedido o dinheiro para a rodagem. Nem o ministério ajudou, nem a televisão se interessou por comprar os direitos de transmissão daquele filme. Segundo a avaliação do próprio diretor, isso se deveu a uma censura econômica e moral latente no país, em decorrência do conteúdo polêmico de sua película. O trabalho sequer recebeu um prêmio na Espanha. ${ }^{99}$

Curioso e contraditório, pois foi justamente um organismo público que concedeu o financiamento. Bem, talvez não tão contraditório, considerando a existência contínua de conflitos políticos e culturais existentes entre a Catalunha e Madrid - 0 poder central do país. Um jogo democratizante e politicamente provocador pode sutilmente ter ocorrido naquele momento revelando diferentes interesses. Um contraponto que significou um afrontamento à vontade dos produtores ou das redes televisivas, que de sua parte já teriam encerrado a carreira do diretor há muito tempo.

Conjuntura bem diferenciada para diretores que circulavam nesse campo artístico de uma maneira mais confortável e com crédito de confiança significativo pelo fato de pertencerem social ou economicamente a grupos vinculados a círculos midiáticos ou intelectuais supostamente hegemônicos. Situação que trazia certas garantias morais ou estabilidade ideológica aos interesses - ainda que descentralizados - de manutenção do desenvolvimento criativo de autores no cinema espanhol e da qual Almodóvar destoava por buscar filmar somente o que queria.

\subsection{Filmar somente o que se deseja}

Provavelmente este seja o sonho não apenas dos cineastas, mas de qualquer artista ou profissional que desenvolve atividades na área de criação e busca apresentar livremente seus novos trabalhos. Porém, numa sociedade dominada pela lógica do

\footnotetext{
${ }^{99}$ STRAUSS, 2001, p. 64.
} 
capital, onde aquele que detém os meios de produção é quem inexoravelmente controla e - em geral - determina o processo criativo e seus resultados, possuir o próprio negócio adquire um significado bastante expressivo. Representa a independência, uma das chaves mais lógicas para realizar este desejo de liberdade. E para os que não possuem tal recurso ?

Os autores já examinados na análise deste trabalho indicaram alguns caminhos e também alguns problemas. Não abrir mão da própria mensagem e poder desenvolvê-la até transformar-se num produto final denota prezar algo muito valioso, suscetível a mais imprevistos do que um sucesso ou fracasso de bilheteria. São defesas de pontos de vista, de crenças, de valores, são novas adversidades. A cada trabalho realizado, uma conquista.

Ventura Pons se assemelha ideológica-economicamente a Pedro Almodóvar. Filma apenas o que deseja e sabe que, se dependesse dos produtores, também não teria avançado em seu trabalho, embora esteja numa situação mais favorável - ao menos com vantagens no mercado interno - que lhe garante uma produção contínua. Primeiro porque já era um diretor respeitado e conhecido quando entrou para o cinema. Produziu 14 de seus 17 longas-metragens na Els Films de la Rambla, S.A., companhia cinematográfica fundada em 1985 e da qual é proprietário. Além disso, o fator regional de só realizar películas faladas em catalão, mas distribuí-las para o restante da Espanha também em castelhano, contribui para estabelecer um público estável que, diante dessa prática, se sente contemplado culturalmente.

Claro, há uma qualidade bem acabada em seus trabalhos. As histórias são bastante instigantes, críticas e bem-humoradas. Mas o fato de utilizar um recurso que responde a convicções pessoais, que o faz optar por filmes falados na língua da cultura em que foi socializado e que permanece viva em sua cidade, fortalece sensivelmente a movimentação de seus negócios.

Com boa parte de sua produção composta de comédias, o diretor segue seu trabalho. Num misto de reflexões existenciais que ironizam a dureza das relações construídas na sociedade e as possibilidades geradas por elas próprias, Pons não alçou grandes vôos para além da Espanha - ou talvez para além da Catalunha. Porém, sua obra já se fez bem conhecida em vários países. Além da participação da produtora, também foi vice-presidente da Academia de las Artes y Ciencias Cinematográficas de España, conselheiro da SGAE (Sociedade Geral de Autores e Editores), da qual Gutiérrez Aragón participou até 2001, e patrono da Fundación Autor.

Dentre os reconhecimentos por seu trabalho -, que perfazem um pouco a 
dimensão de sua importância não só no campo da cinematografia espanhola encontram-se o "Prêmio Nacional de Cine de la Generalitat de Cataluña", prêmio Ciudad de Huesca, medalha de Ouro ao Mérito en las Bellas Artes e o Prêmio Ondas $^{100}$, que anualmente desde 1954 se concede a profissionais e programas de rádio e televisão de todo mundo patrocinados pela Rádio Barcelona e pela Sociedade Española de Radiodifusión (SER).

Homenageado nos festivais de Bogotá, Tessalônica, Belgrado, Dijon e Luxemburgo, além da retrospectiva de sua filmografia em Londres, no l'ICA (Institute of Contemporary Arts), e na Argentina, Pons também se apresentou no Lincoln Center de Nova York, nos festivais de cinema de Varsóvia, Valdívia, Estambul, American Cinematheque de Los Angeles, nas Cinematecas de Israel; Jerusalém, Haifa e TelAviv. Sua obra está em programas dos melhores festivais internacionais. Em 2001, 0 BA II Festival de Cine Independiente de Buenos Aires fez uma retrospectiva de seus trabalhos e Pons participou de uma entrevista onde pôde apresentar várias concepções sobre seu trabalho. O documentário Ocaña continua sendo seu trabalho de referência. Com ele o diretor descobriu o que basicamente queria fazer. De um exercício com uma câmera, resgatou as inspirações de outros cineastas e definiu sua trajetória.

Naquele momento (1977-78) refletia: tinha uma bolsa de estudos, estudara documentários britânicos do final dos anos 50, um cinema livre feito por uma geração que deu nomes como Lindsay Anderson, John Fletcher, Caroll Righs ou Tony Richarson. Cineastas com uma trajetória artística semelhante à dele, que passaram pelo teatro, pelo documentário e logo ao cinema de ficção em longa-metragem. Pons então disse a si mesmo:

Yo tenía una cierta experiencia en teatro y pensé: en lugar de irte a una escuela, por qué no ves que te pasa a ti con una cámara. Entonces me dije: voy a hacer una película documentalista.

Fez um exercício que saiu do seu agrado. Mostrou ao distribuidor e, quando viu, seu filme estava na seleção oficial de Cannes e depois sendo exibido pelo mundo. Analisa que se ainda hoje o filme perdura é devido à conservação de seu forte conteúdo. Sobretudo porque ficou como um testemunho dos anos vividos quando a Espanha se libertou da ditadura de Franco.

A retrospectiva de seu cinema na Argentina foi simultânea a outra em Londres. Só então pôde perceber o destaque de seu trabalho além das fronteiras da Espanha e a importância de um certo artesanato cinematográfico em que o controle do ofício torna-se essencial. Este período de homenagens coincidiu com seu estado pessoal

${ }^{100}$ Disponível em: http://<www.premiosondas.com/historia/index.html>acesso em 08. 04. 2006. 
voltado para falar de diversos assuntos, em especial aprofundar questões sobre o minimalismo que o encantavam na época. Dessa inspiração surgiram Puta miseria (1989), Caricias (1997) y Morir (o no) (1999). Acerca deste tema, explica:

A mí me gustan mucho las estructuras especiales y sobre todo el contar el mínimo momento de personajes: que los agarras, y que no sabes de donde vienen ni adonde van, pero que explicas ese pequeño momento [...]

Em sua adaptação de El perquè de tot plegat (El porqué de las cosas) (1994), Pons explicou sua relação com Quim Monzó e os esforços de adaptação de seus contos para a linguagem cinematográfica. Amor idiota (2004), uma comédia romântica com Cayetana Guillén-Cuervo y Santi Millán, demonstra bastante a forma como o diretor prefere abordar o amor. Para ele, este sentimento é um mistério imprevisível, por isso as histórias que mais o atraem são as de desamor, como Annie Hall (1977) [no Brasil, sob o título: Noivo neurótico, noiva nervosa], de Woody Allen. Em fevereiro de 2006, produziu Animales heridos, uma comédia distribuída pela Filmax Group ${ }^{101}$, e no final do ano sua produtora Els Films de La Rambla, S.A. já anunciava a estréia de La vida abismal para início de 2007, com roteiro do diretor baseado no romance de Ferran Torrent "La vida em el abismo", com elenco de atores valencianos e co-produção da Televisión Española e da Televisió De Catalunya, e distribuição do grupo Filmax, presente entre as maiores distribuidoras catalãs até $2000 .^{102}$

Seus filmes seguem uma linha estética que destaca as buscas pelo sentido das relações. Ironicamente, quase fazendo o mundo real desaparecer para dar lugar puramente aos sentimentos. Apesar de seu grande sucesso na Espanha, ele reconhece os limites impostos a seu cinema pelo mercado internacional. Na entrevista concedida no festival na Argentina em 2001, adotou uma posição esperada e quase óbvia para todos os cineastas que participam do mercado cinematográfico como ele, diante das grandes distribuidoras.

Aponta as dificuldades encontradas para a circulação de seus filmes frente ao controle dos norte-americanos e sua luta pela sobrevivência de um cinema próprio e livre como referência de que é possível desenvolver um trabalho autônomo. A boa recepção de seus filmes na Argentina demonstrou as chances de interesse - face aos que controlam o mercado de cinema em Buenos Aires - para a ampliação de suas fronteiras, mas reconhece que é um avanço desigual. Assim, dentro dos aspectos econômicos que sabe administrar bem, seus projetos e suas imagens prosseguem.

\footnotetext{
${ }^{101}$ Disponível em: http://<http://es.movies.yahoo.com/a/animales-heridos/index-160937.html> acesso em 08. 04. 2006

${ }^{102}$ Disponível em: http://www.venturapons.com/eindex.html> acesso em 08. 04. 2006.
} 
Suas últimas articulações com redes televisivas na Espanha demonstram seguir os passos de outros cineastas e um novo processo de negociações dentro da indústria cultural que garante sua produção, ao mesmo tempo em que vai formulando novas relações culturais com o mercado de bens simbólicos. Até a produção destes filmes, continua em situação confortável para desenvolver suas temáticas. É o que anseia.

Diante desse panorama, seriam portanto as temáticas os grandes empecilhos para se avançar num mercado mais amplo? A trajetória de Eloy de La Iglesia fornece um outro viés para a questão. Assim como Pedro Almodóvar e Ventura Pons, não abriu mão de filmar e dizer o que realmente queria. Suas dificuldades residiram nos aspectos políticos e comportamentais. Quando rodou Algo amargo en la boca (1969), teve problemas com a censura franquista, devido à sua militância política no Partido Comunista da Espanha. Forte elemento que acompanhou boa parte de sua trajetória, sobretudo pelo caráter profundamente provocador de seu cinema repleto de cunho existencial e de denúncia social.

Seu sucesso comercial veio com Techo de cristal (1971); feito após Cuadrilátero (1970). Aproximou-se depois do cinema de terror, desprezando os maneirismos e academicismos estilísticos e estruturais com La semana del asesino (1972), Nadie oyó gritar (1973) e Una gota de sangre para morir amando (1973), ficção científica parente de Laranja mecânica de Stanley Kubrick, conhecida na Espanha como La mandarina mecánica e Juegos de amor prohibido (1975), história em torno das humilhações que um professor exerce sobre um casal de alunos.

Posteriormente abordou a problemática sexual e homossexual em filmes como La otra alcoba (1976) e La criatura (1977), filme que trata da história de uma mulher que mantém relações zoofílicas, traduzindo uma denúncia sobre a frustração sexual, 0 fracasso do matrimônio e da família tradicional. Seguiu com a temática homossexual já mostrando atração pela linha daquele que os espanhóis chamam de cine "Quinqui"103, em Los placeres ocultos (1977), El sacerdote (1978) e El diputado (1979), considerado um de seus melhores trabalhos, onde mostra a pressão sofrida por um deputado comunista durante a transição espanhola, por parte da extrema direita, pelo fato ser

\footnotetext{
${ }^{103}$ Na Espanha o "Cine quinqui” é um gênero popularmente conhecido como um cinema que narra a vida e a aventura de delinqüentes famosos (em geral jovens) graças a seus delitos cometidos. Tornou-se muito popular no país no final dos anos setenta e em princípios dos oitenta, alcançando seu maior prestígio com centenas de películas e sagas lendárias. É muito comum que se encontre nesses trabalhos um delinqüente na vida real que se converte em um ator que interpreta a si mesmo (correspondência clara ao que se experimentou no Brasil com Pixote, a lei do mais fraco (1980) de Hector Babenco) ou a outro delinqüente (que conhece ou conheceu) causando assim, um efeito de grande realismo à história e obtendo-se uma representação fiel da realidade. Muitas destas películas costumam ser biográficas centrando-se na vida de um determinado delinqüente, seu ambiente social e suas façanhas. Em geral, o formato desse cinema configura o mundo das drogas. Disponível em: <http://es.wikipedia.org/wiki/Cine_quinqui> acesso em 05. 03. 2006.
} 
homossexual. Miedo a salir de noche (1979) reflete uma época marcada pela insegurança do cidadão, difundindo um modelo de filme que acabou convertendo-se numa lenda urbana sobre uma violenta gangue de delinqüentes.

Nos anos 80 estendeu estes temas para o universo da marginalidade, da delinqüência juvenil e das drogas. A esta época pertencem Navajeros (1980), Colegas (1982) - para muitos sua melhor obra - El pico (1983) e El pico II (1984), filmes de autênticos êxitos de bilheteria e que despertaram um mal-estar entre os críticos pelo grau de dureza e pelo realismo das imagens, vistos como desnecessários.

Em 1985 o diretor se afastou da temática homossexual para dirigir Otra vuelta de tuerca, adaptação do romance de fantasmas de Henry James. Voltou ao tema da delinqüência das ruas com uma comédia, La estanquera de Vallecas ${ }^{104}$, adaptação da obra teatral homônima de José Luis Alonso de Santos (1987). Apesar da ótima aceitação de público, Eloy de la Iglesia logo depois entrou numa escassez criativa, resultado de sua dependência às drogas - começou a consumir heroína em 1983 cuja desintoxicação só veio a ocorrer em 1992.

Em 1996, o Festival Internacional de cine Donostia-San Sebastián dedicou a ele uma homenagem e uma retrospectiva. Desde então, estava recuperando seu prestígio e seu reconhecimento, contexto que reacendeu o desejo por voltar a dirigir. Assim, depois de 16 anos estreou um novo e último filme: Los novios búlgaros (2003), uma adaptação cinematográfica do romance homônimo escrito por Eduardo Mendicutti. Uma história de amor homossexual cuja carga social recai sobre o ambiente do mundo da imigração. Antes havia dirigido Calígula (2001) de Albert Camus para a televisão.

Com uma obra muito pessoal, dissidente, transgressora, provocadora e cheia de força, muitos apontam seu cinema como excessivo ${ }^{105}$. Porém, ele reflete nada mais do que a realidade de um momento - ao menos de uma determinada classe social, a notar-se: bem expressiva socialmente -, revelada em crônicas e memórias do submundo dentro do qual Eloy de la Iglesia misturou o que via e o que vivia pessoalmente: a luta anti-franquista, o desencanto da ditadura, sua homossexualidade, a droga, a vida do subúrbio. Seus trabalhos resumem num mesmo conteúdo o exorcismo de uma época e a luta pela liberdade radical, fatores que ele encarnava em sua própria vida.

Mesmo circunscrita à Espanha, sua obra não deixa de evidenciar os caminhos de luta de muitos outros cineastas em outros países. Percebe-se que a resistência a determinadas temáticas não veio, portanto, com o cinema de Almodóvar. Ele mesmo,

${ }^{104}$ Disponível em: <http://es.wikipedia.org/wiki/La estanquera de Vallecas> acesso em 25. 05.2006 
próximo e inspirado em alguns aspectos das imagens deste cineasta. Sem uma produtora própria, Eloy da la Iglesia demonstrou sua grande disposição em manter-se fiel às suas visões.

Sua linguagem, além de popular, também atendia a intenções políticas respaldadas pelos setores progressistas que se viam contemplados dentro de seu papel histórico de resistência democrática. Possivelmente, unindo-se este fato a uma trajetória artística de formação acadêmica e boa produção televisiva, o diretor pôde garantir a manutenção de seu trabalho, só afetado por seus problemas pessoais de saúde. Sua aguçada dimensão político-ideológica afasta sua obra da de Almodóvar, mas seus personagens refletem perfis que aludem aos inícios da carreira do diretor.

Este caminho semi-autônomo também foi o que trilhou Victor Erice, que teve a publicidade amparando seu trabalho no lugar da TV. Seu segundo longa-metragem, El espíritu de la colmena (1973), aborda a relação entre duas meninas e seu pai. Recorrendo ao impacto da tradição cinematográfica americana, tenta explorar o universo psicológico que vive a Espanha dos anos quarenta. Com ele, Erice obtém pela primeira vez para uma produção espanhola - a Concha de Ouro do Festival de Cinema de San Sebastián, além de conquistar um grande êxito tanto de público como de crítica.

Os próximos dez anos do diretor foram consagrados ao mundo da publicidade, até que em 1983 voltou ao cinema com El Sur, um de seus mais bem sucedidos trabalhos. A película, baseada em uma história de Adelaida García Morales, narra as difíceis relações entre uma filha e seu pai. Com estes personagens, o filme nos oferece uma visão pessoal sobre a passagem da infância à vida adulta. Inicialmente concebido para ser uma série para a TVE em três episódios, o filme só se realizou em suas duas terceiras partes devido à mudança de direção na TV durante a rodagem. Apesar disso - segundo muitos críticos - permanece como a obra inacabada mais bela do cinema espanhol.

Depois deste trabalho, o diretor voltou novamente ao campo da publicidade e somente na década de noventa rodou El sol del membrillo (1992), uma comovente história baseada na vida do pintor Antonio López. Nela analisa o processo de criação artística e faz um exercício de reflexão sobre a fronteira entre a pintura e o cinema. Um trabalho muito bem recebido no Festival de Cannes.

No final de 2001 Erice publicou o roteiro La promesa de Shanghai (Editorial Plaza y Janés). Um projeto que desejava realizar há muito tempo, resultante da

\footnotetext{
${ }^{105}$ Disponível em: <http:// www.el-mundo.es/magazine/m78/textos/eloy1.html> acesso em 25. 05.2006
} 
convergência de duas referências iniciais: o filme de Josef von Sternberg El embrujo de Shanghai (1941) e o romance homônimo escrito por Juan Marsé em 1993 - filmado posteriormente por Fernando Trueba. O roteiro é uma recriação do pós-guerra barcelonês, que dá vida aos personagens literários de Marsé. A ação se passa entre 1947 e 1952 e a trama é contada em primeira pessoa por Dani, um adolescente que se recorda do pai, um militar morto no campo de batalha.

Com um respeito inabalável diante da crítica espanhola, o diretor mantém-se alheio ao mercado cinematográfico, quase dizendo oficialmente que o cinema é apenas um complemento opcional em sua vida. Na prática pode-se obter claramente com seu exemplo a distinção entre o ofício de fazer cinema, como um meio de sobrevivência, e $o$ ato de filmar. Assim, mesmo exercendo bem esta atividade, Erice não desenvolveu nenhuma dependência ou relação fixa com esse mercado.

Trilhou um caminho que o manteve desatado dos interesses temáticos mercadológicos, por isso, com um tipo particular de liberdade para desenvolver seu próprio tempo de criação e seu estilo produtivo - mesmo com películas muito semelhantes. Claro, ele também acabou respondendo a grupos sociais que viram em seu cinema abordagens condizentes com suas próprias necessidades de reflexão. Elas saem de um padrão de classe social específica e discorrem sobre suas preocupações, das quais outros cineastas também se ocuparam de uma maneira menos metafórica, contudo, também dialogando com ele.

Este é o caso de Jaime Chávarri, que faz seu primeiro longa-metragem profissional Los viajes escolares (1974), filme premiado no Festival de Valladolid e protagonizado por Lucía Bosé, que mostra o retrato bastante pessoal de uma família. Uma produção que ficou durante vários anos proibida pela censura só podendo estrear anos mais tarde, tendo sua exibição permitida apenas em festivais internacionais.

Seu filme seguinte, El desencanto (1976), faz uma revisão do franquismo por intermédio de várias entrevistas com membros da família Panero. Um trabalho que the garantiu reconhecimento e respeito por parte da crítica espanhola num período em que se abriam os horizontes para a discussão democrática e para o olhar histórico. Mesmo não sendo de total inovação, a película respondia em muito a um momento privilegiado de abertura política na Espanha, associado a vários acontecimentos que se sucediam, como reconhece Chávarri:

Hay precedentes de El Desencanto en los documentales de Basilio Martín Patino que son importantísimos. El Desencanto llegó en un momento en el que el público sentía una gran curiosidad por el nuevo cine que estaba surgiendo. Su narrativa formal tenía tanto de documental como de melodrama. De toda 
No ano seguinte estreou $A$ un dios desconocido (1977), filme sobre um artista em busca da própria identidade homossexual e relações com a obra de García Lorca. Para realizar a película, Chávarri leu tudo o que encontrou sobre o poeta, atraindo-se mais pelo tempo em que este viveu em Nova York. Informações que mais utilizou no filme, mesmo não constando do roteiro. Premiado no Festival de San Sebastián, Chávarri declarou em uma de suas entrevistas sobre a película que ouvir de familiares e estudiosos do poeta que sua obra refletia o melhor do espírito lorquiano já havia compensado seu trabalho. Aparece novamente aqui uma relação - mesmo que indireta - entre Chávarri e famílias que tradicionalmente tiveram sua participação na história política da Espanha. Setores médios ou elitizados da sociedade, contemporizados e registrados na história e na cinematografia do país. Atos que sintonizam o diretor a grupos sociais bem posicionados da cultura hispânica.

Em 1979 realizou dois episódios em filmes coletivos, Cuentos eróticos (1979) e Cuentos para una escapada (1979), e um longa-metragem Dedicatoria (1980), que toca no delicado tema do incesto - filme indicado para o Festival de Cannes. Nos primeiros anos da década de oitenta começou a dirigir filmes mais comerciais, como Bearn o la sala de muñecas (1983), premiado pelo júri no Festival de Montreal; Las bicicletas son para el verano (1983), baseado na peça teatral de Fernando Fernán-Gómez, sobre o cotidiano de uma família e suas relações com empregados e vizinhos no verão de 1936 na eclosão da guerra civil. Alguns anos mais tarde realizou Las cosas del querer (1989), indicado para melhor roteiro no prêmio Goya; Tierno verano de lujurias $y$ azoteas (1993), Las cosas del querer - 2a parte (1994) e Gran Slalom (1996). Seu trabalho seguinte foi uma co-produção hispano-argentina, Sus ojos se cerraron y el mundo sigue andando (1997) $)^{107}$.

No ano de 2000 Chávarri estreou a comédia Besos para todos, indicada para seis prêmios Goya, entre eles o de melhor diretor. Uma história que trata da vontade de viver com otimismo, mesmo num período tão duro como foi a última década do franquismo. Depois deste filme, dirigiu a peça teatral Todo en el jardín, de Edward Albee. Em 2004 dirigiu El año del diluvio, história de uma madre superiora, Sor Consuelo, que num forte verão decide transformar o decadente hospital do "pueblo", onde vive e que pertence à sua ordem religiosa, em um rico e moderno asilo para idosos. Na busca por financiamento, conhece Augusto Aixelá e, durante os seguidos

\footnotetext{
${ }^{106}$ Disponível em: http://<www.elmundo.es-encuentros digitales - 23. 04. 2004> acesso em 28. 05. 2006

107 Indicada para seis prêmios da Asociación de la Crítica Argentina.
} 
encontros que desenvolvem para realizar os trâmites econômicos do investimento, acabam gerando uma grande paixão proibida. Em Chávarri, como em alguns outros destes diretores, vemos que o tabu sexual é um tema recorrente misturado aos limites da hierarquia moral.

Seu próximo projeto foi uma película chamada Camarón (2005), que narra a história de uma importante figura do flamenco moderno - o lendário cantor Camarón de la Islã - numa estrutura narrativa que recorre à vida do artista, intercalando-se à sua obra. Para isso, Chávarri selecionou uma parte representativa dos tipos de flamenco cantados por Camarón, sobretudo suas canções mais populares. O roteiro, criado por Álvaro del Amo, se desenvolve em torno das relações que Camarón de la Isla estabeleceu com pessoas como: sua mulher La Chispa e os violonistas Paco de Lucía, Tomatito e Paco Cepero.

A linha documental, como em Trueba em seus trabalhos mais recentes e em certa tendência com Erice, ainda que possua uma narrativa ficcional e La Iglesia também ficcional, mas com o registro marginal, permeia o trabalho de Chávarri. Revela sua preocupação - assim como os cineastas citados - sob um recorte que situa determinadas classes sociais pertencentes a um campo específico que entende como mais envolvidas direta e politicamente no processo histórico espanhol. Seus personagens aparecem, ora na política, ora na arte, ora na intelectualidade, sempre envolvidos em questões históricas.

\subsection{Segundo balanço comparativo}

Já com sua produtora a partir da La ley del deseo, portanto podendo desenvolver as histórias que realmente quer contar, vivendo exclusivamente do cinema, aparecem aqui mais alguns aspectos semelhantes e divergentes de Almodóvar com estes diretores. A primeira situação evidente aparece nos personagens. Eles não são semelhantes. Em nenhuma das fases do diretor, perfis como os destes cineastas são protagonistas ou relevantes em suas histórias. Mesmo quando ascendem de classe social, como em Mujeres al borde de un ataque de nervios ou La flor de secreto, Todo sobre mi madre e Hable con ella, não são os agentes históricos que surgem como geradores das tramas. Eles nem são os estabelecidos, nem os definidamente à margem da sociedade. Refletem personagens destinados a dialogar com temáticas próprias do autor em um novo espaço de questões ligadas às relações com origem nos pueblos, dos artistas em crise, pessoas solitárias, dos desajustados socialmente, mas todos com possibilidades de transformação. 
O quadro desses cineastas denota que todos caminharam para boas colocações artísticas e sociais, com diversos trânsitos produtivos compostos de currículos que os legitimam como presenças de renome na produção cinematográfica espanhola. Inevitavelmente, estes são alguns dos muitos testamentos que intrigam observadores. Suas indagações procuram entender qual o perfil das peculiaridades de Almodóvar que o fizeram projetar-se no campo internacional em relação a estes e outros diretores também destacados como demonstrou esse panorama.

Se para Almodóvar a autonomia veio com La ley del deseo, sua carreira mundial só começou a deslanchar oficialmente - ao menos em Hollywood - em 1987, com o sucesso de Mujeres al borde de un ataque de nervios. Um filme no estilo das "altas comédias norte-americanas", com uma história de costumes que transita entre amores e traições de mulheres mal-amadas por homens insensíveis. Apesar de inúmeros prêmios internacionais, o filme não rendeu o Oscar tão almejado por Almodóvar, mas o projetou para o mundo como um reconhecido cineasta espanhol e grande revelação - claro, com todas as diferenças de estilo e criação - depois de Carlos Saura e Luis Buñuel. O filme marca o momento de projeção internacional na carreira do diretor: bateu recordes de bilheteria na Espanha e em vários países, abriu portas para co-produções, prêmios em festivais, convites para dirigir filmes nos Estados Unidos e simpatia de atores e atrizes famosos, muitos desejosos de compor com ele um futuro elenco.

Já no final da década de 80 lançou Átame (1989), outro campeão de bilheteria, que no entanto obteve recepção bem distinta. Nos Estados Unidos, por exemplo, foi duramente criticado como escandaloso, pornográfico e censurado para menores de 17 anos. O filme conta a história de Ricky, um rapaz recém-saído de uma clínica para doentes mentais que, obcecado por uma famosa atriz de filmes de segunda categoria, a seqüestra e a mantém prisioneira para demonstrar seu puro amor e desposá-la.

Sua próxima película foi Tacones lejanos (1991). Uma história que versa sobre as relações viscerais entre mãe e filha. Obteve sucesso em toda Europa, mas na Espanha a crítica viu este e seu anterior como trabalhos cambiantes e imprecisos. Kika (1993), uma crítica à mídia sensasionalista- elaborada esteticamente em ritmo aleatório, seja pela narrativa, pela caracterização das personagens ou pela indefinição completa de gênero narrativo -, só viria a reforçar estas más impressões. A crítica espanhola sequer classificou o filme dentro de um gênero cinematográfico. Mesmo diante da grande rentabilidade de bilheteria, para muitos críticos este filme denunciava a decadência do autor. 
Sua película seguinte, La flor de mi secreto (1995), conta a história de Leo Macías, uma escritora (de pseudônimo Amanda Gris) - derrotada pelo desamor e desprezo do marido - que escreve romances "açucarados", conhecidos na Espanha como "novela rosa". Novo sucesso, este filme recuperou a credibilidade de Almodóvar junto à crítica, garantiu seu público e criou perspectivas para futuras histórias. A partir daí, Almodóvar começou um alinhamento cada vez mais forte com o melodrama, gênero que apurou a cada novo trabalho.

As próximas películas foram gradualmente mais bem-sucedidas. Carne trémula (1997), adaptação de parte do romance policial de Ruth Rendel, trata das relações de Victor e dos rumos de sua vida após seu envolvimento acidental num conflito com armas entre policiais $^{108}$. Todo sobre mi madre (1999) - seu grande sucesso mundial dispensa comentários. Recebeu 13 indicações só aos prêmios Goya. Conquistou dezenas de prêmios em festivais, inclusive o Oscar de melhor filme de língua não inglesa. Em torno da vida de Manuela, que perde seu filho num atropelamento na saída de um teatro, o filme vai traçando as inúmeras razões de busca de sentido para as relações, suas identidades e explicações históricas para os relacionamentos, sobretudo no universo feminino.

Em Hable con ella (2002) a centralidade feminina cede lugar aos sentimentos mais profundos experimentados pelo universo masculino e sua cumplicidade. Mais dezenas de prêmios dentro e fora da Espanha e novamente um Oscar em Hollywood, agora pelo melhor roteiro. Esta enorme exposição, tanto dos filmes como do próprio diretor, consolidou Almodóvar com um dos cineastas mais emblemáticos e respeitados dentro e fora da Espanha.

E foi dentro desse clima de vitória e quase legitimidade suprema que em 2003 lançou-se La mala educación, filme que abriu em 2004 o $57^{\circ}$ Festival de Cannes, estrelado por Gael García Bernal - no mesmo festival também protagonizando Diário de motocicleta de Walter Salles. Glamour, aplausos, porém com menor repercussão. A

\footnotetext{
108 Duas indicações aos Prêmios EFA para Melhor filme e melhor Ator (Javier Bardem), quatro indicações ao prêmio Manak Brohters melhor fotografia (Estônia), melhor interpretação masculina protagonista (Javier Bardem), melhor interpretação feminina coadjuvante (Angela Molina) melhor interpretação masculina coadjuvante (José Sancho), prêmio de melhor ator secundário para José Sancho da Academia de las Artes y la Ciencias Cinematográficas de España - Goya, prêmio de melhor atriz coadjuvante para Pilar Bardem da Unión de Actores, Fotogramas de Plata: prêmio de melhor interpretação feminina espanhola para Angela Molina e prêmio de melhor interpretação masculina para Javier Bardem, prêmios El Mundo del Pais Vasco para melhor banda Sonora Original para Alberto Iglesias e prêmio de melhor ator coadjuvante para Alex Ângulo, prêmios Ondas 1998: Premio Cinemanía, prêmio Nastro D'Argento Italiana 1998 de melhor atriz protagonista para Francesca Neri e de melhor filme (crítica), indicação de filme de língua não inglesa da British Academy Film Awards (BAFTA). Abril 1999, melhor filme na A.C.E. Asociación de Cronistas de Espetáculos de Nueva York, revista TIME: inclusão na lista dos dez melhores filmes de 1998, prêmios Función Privada - Universidad de cine de Buenos Aires. Julio 1999 como melhor película estrangeira de língua espanhola.
} 
enorme expectativa cobrava um filme de maior impacto, coisa que não ocorreu. Não só porque o filme tinha incursões narrativas que não se resolveram bem dentro da história. Isto deveria ser previsível. Após seguidas aclamações, qualquer novo lançamento dificilmente significa a somatória e a adição de mais sucesso.

Com uma trama repleta de elipses ${ }^{109}$ imprecisas, o filme trata de uma semibiografia do diretor na imagem de um personagem que carrega em sua história pessoal a herança da infância no colégio interno católico com abusos sexuais exercidos por parte do clero e seus desdobramentos na vida adulta sobre sua personalidade e individualidade, além da relação de sobreposições de identidades que só uma segunda apreciação torna a película mais compreensível e interessante. A narrativa melodramática subordina-se a uma trama noir policial que não resolve totalmente sua lógica. Mais uma vez, um mal-estar e críticas ao desequilíbrio narrativo e ao "estrelismo" de Almodóvar.

Por fim, preparado desde maio de 2005, rodado entre julho e outubro de 2005 e lançado na Espanha em março de 2006, chegou aos cinemas Volver, o último filme do cineasta até o momento deste trabalho, novamente iniciando sua escalada junto ao público e aos festivais que o legitimam ou o destroem. Começou bem. Ganhou o prêmio de melhor roteiro e melhor elenco coletivo feminino no $59^{\circ}$ Festival de Cannes, demonstrando que seu nome também significa a busca por um "volver" a grandes premiações. Centrado na vida de três gerações de mulheres de uma mesma família, o filme discute como estas sobrevivem a todas as provações da vida, inclusive da morte, em vários aspectos, tanto físicos como metafóricos.

É um filme que discute a cultura da morte, sobretudo da terra natal de Almodóvar em La Mancha ${ }^{110}$. Procura visualizar como os mortos continuam presentes na vida dos vivos com ritos e recordações que fazem com que eles nunca morram. Volver procura destruir certos paradigmas tradicionais do país, ao mesmo tempo em que aponta suas contradições e revela a novidade de uma Espanha viva.

Colocando estes trabalhos de Almodóvar como referência direta ao seu processo de ascensão diante dos perfis profissionais destes cineastas, pode-se constatar alguns pontos que explicam seu caminho particular. As resistências ao seu

\footnotetext{
${ }^{109}$ Fala-se de elipse cada vez que uma narrativa omite certos acontecimentos pertencentes à história contada, "saltando" assim de um acontecimento a outro, exigindo do espectador que ele preencha mentalmente o intervalo entre os dois e restitua os elos que faltam. AUMONT, J. e MARIE, M. Dicionário teórico e crítico de cinema. Campinas, São Paulo: Papirus, 2003. p. 96-97.

${ }^{110}$ Em vários momentos de sua carreira Almodóvar cita a cultura de La Mancha como uma cultura da morte, marcada nos vestuários, nos valores, nas relações e sempre diz que seus filmes buscam uma certa forma de exorcismo desta marca. Neste filme, mais do que exorcizar, o autor coloca-se diante dela para dialogar e mostrar a
} 
cinema, seja pela temática ou pela origem não acadêmica, por parte da mídia e da intelectualidade, acabaram forçando o diretor e seu irmão Agustín a buscar maneiras de ampliar seus filmes para fora da Espanha. Situação bem diferente dos diretores citados aqui, articulados com os setores midiáticos, com o mercado nacional cinematográfico ou com classes sociais que apareciam refletidas em seus trabalhos. Mesmo aqueles que saíram do país, buscando de certa maneira universalizar suas temáticas, acabaram focando seus trabalhos novamente no plano nacional.

O processo de autonomia deste diretor se deu em circunstâncias distintas. Mesmo contando com os festivais e distribuidores, enquanto os outros diretores se direcionaram para imagens alinhadas a um diálogo maior com a própria Espanha e seus dilemas nacionais, Almodóvar "negociou" sua própria imagem interna de uma maneira que quebrava certos estereótipos e atraía o olhar estrangeiro. Ainda que tenha carnavalizado muitas das imagens tradicionais, ele abriu as portas para visualizar o que havia de novidade comportamental, que pôde ser exportada, e difundiu aquilo que já está disseminado nas imagens coletivas propagadas sobre a Espanha.

Sua articulação entre mercado interno e externo que lhe garantiu mais liberdade de criação. Assim, críticas muito negativas a alguns de seus trabalhos puderam ser compensadas financeiramente e artisticamente em territórios com outros olhares culturais. Sua circulação como membro respeitado na cinematografia do país nunca deixou de ser tensa. O que mudou foi o jogo das trocas simbólicas. Falando da tradição de maneira irônica, questionou no país os valores vigentes com aqueles que surgiam na transição democrática. Colocou a Espanha novamente no mercado internacional, abrindo caminho para novas produções, cineastas e acordos.

Não buscando tomar para si temáticas ou universos sociais que não lhe pertenciam - segundo setores "formadores de opinião" -, Almodóvar estabeleceu-se em círculos e abordagens que lhe agradavam e que atraíam públicos já identificados com seu estilo. Seu registro, suas personagens e temas permaneceram os mesmos. Porém, cada vez mais refinados e aprimorados tecnicamente, assim como aconteceu com as imagens, os cenários e os diálogos mais lapidados. Ao atingir cada vez mais um público afeiçoado a reflexões, ora melodramáticas, ora puramente irônicas sobre relações estruturadas na excentricidade, tradição ou inovação, garantiu sua presença única, com uma marca de autenticidade que aparece dentro e fora de seus filmes.

Outros cineastas também seguem em geral fiéis a suas linhas temáticas. A peculiaridade de Almodóvar está em seu jogo de ironias dentro e fora de seus filmes, 
fazendo-se também um personagem do universo de suas histórias. Ou são as polêmicas ou são as posturas de impacto. Elas estão nas narrativas fílmicas, mas também nas entrevistas do diretor, na exposição de seus projetos ou de sua vida pessoal, na sua reação diante da recepção de seus trabalhos - principalmente na Espanha. Em seu país, é previsível que os efeitos de seus filmes sejam maiores devido às referências e compreensões culturais que aparecem mais explícitas aos espanhóis. Ali, Almodóvar prefere provocar mais. Não pelo gosto gratuito de polemizar, mas pela necessidade de criar um diálogo mais forte com os condicionamentos, valores arraigados e perspectivas sociais de uma Espanha em permanentes conflitos regionais - culturais e políticos - mesmo quando em seu trabalhos se busca a redenção e a harmonia.

Para realizar estas intenções e enfrentar também este embate, o diretor não se apóia apenas nos filmes. Ao misturar sua personalidade ao jogo de imagens que produz dentro e fora das telas, ele apresenta sua disposição para arriscar mercados, mas estrutura-se numa equipe de confiança, da qual não abre mão. Quase num trabalho familiar, o diretor construiu uma articulação favorável a ele que amplia sua produção sem precisar sair da Espanha e sem mudar sua narrativa, diferente de outros cineastas apresentados neste capítulo. Este amparo afetivo-estrutural vinculado à dinâmica da criação e da figura do autor diante dos vários grupos sociais dá movimento ao processo de sua recepção artística. Assim, Pedro Almodóvar se mantém até agora na esfera cinematográfica e estabelece diálogo com seus agentes sociais, firmando acordos, ora tácitos ora explícitos, sem abalar as bases seguras que elaborou com sua equipe, com seu irmão e seu mercado. Sua autenticidade reside no conjunto dessas relações sociais.

Ele desenvolve um hábil jogo criativo para garantir sua produção, em outras palavras, dizer o que deseja. Não foge daquilo que seu público admirador espera. Segue sua estética, seus personagens e seus temas com questões polêmicas e sentimentos exacerbados e em meio a eles conta suas novas histórias. Não se trata portanto de fixar um estilo. Como resultado da forma que aprendeu, sabe e quer filmar, consciente e inconscientemente Almodóvar já o possui.

O que existe também nesse processo é um jogo de fidelidade e cumplicidade que autor e público solicitam mutuamente. E isto não se faz apenas no nível pessoal: filme-espectador. Ele acontece na própria estrutura geral desenvolvida por este cineasta em nome de sua autonomia e no discurso pela ausência de regras - ao menos 
morais -, condição essencial para este possa refletir, gerar suas histórias e poder contá-las livremente.

A mesma fórmula ocorre com os distribuidores e produtores internacionais que já fizeram algumas co-produções com o diretor. Franceses, italianos, norte-americanos; eles já criaram um perfil de recepção em torno do "produto" que vão divulgar e que motivarão seus países a "consumir". Elabora-se uma espécie de pré-embalagem com as instruções sugeridas. Obviamente espera-se a surpresa, mas esta já deve fazer parte dos códigos dados a seus receptores. Assim, Almodóvar segue sua autonomia, mas negociando sua continuidade de participação no campo cinematográfico. Um jogo sincero, criativo, livre, disciplinado, todavia, nem por isso isento de acordos. Se hoje ele pode circular tranqüilo pelos festivais e com seu irmão estabelecer bons acertos para novos projetos - em geral fora da Espanha -, isso se deu por sua própria trajetória. Esteve à margem de todo o contexto artístico oficial num duplo sentido, tanto social como artisticamente, e foi ali que aprendeu como se incluir no universo do cinema segundo seus interesses, mas isso já faz muito tempo. 


\section{COLEGAS, CONTEMPORÂNEOS E DISTINTOS}

Quando se compara um conjunto de obras artísticas de vários autores num mesmo período histórico parece óbvio observar que nelas haja diferenças e particularidades. A diversidade muitas vezes é tão grande que espanta constatar a riqueza criativa dotada no ser humano para expressar sua visão de mundo e seus anseios. Também esses mesmos períodos produzem perspectivas semelhantes, seja pela conjuntura vivenciada ou pela singularidade com que se elabora cada registro da construção social.

O que talvez não pareça óbvio neste exercício de levantamento comparativo de tantos trabalhos é perceber nele a importante relação de complementaridade que se estabelece. Da composição dos diversos olhares cria-se um diálogo social que forma o universo multifacetado de uma época. $\mathrm{E}$ das diferentes dimensões de cada autor este grande quadro acaba por espelhar a originalidade daqueles que a registram, não raramente, transcendendo tanto os condicionamentos do meio social no qual se inserem - considerando-se inclusive suas linguagens cotidianas e artísticas - como também o momento histórico vivido.

Assim, nesses mesmos termos pode-se compreender como no cinema os inúmeros criadores dialogam - ou não - e se notabilizam em seus trabalhos. Falar em Cinema Espanhol e mais especificamente em sua produção contemporânea implica entrar nesse mosaico de peculiaridades. Um panorama recente que não revela um quadro homogêneo e nem converge para uma leitura - talvez esperada - coesa de uma cultura tão diversa como a hispânica, que, se transformando após o longo período de regime ditatorial, não resume em si todo o espírito do que se produziu culturalmente no país antes e depois da morte de Franco.

\subsection{Criação e diversidade}

O recorte do contexto social do cinema abordado aqui é o do pós-franquismo. Período de - como visto no capítulo anterior - uma efervescente produção cinematográfica e da criação de estilos que continuam exercendo suas influências no cinema espanhol contemporâneo. Sem a pretensão de fazer uma síntese dos mais importantes - o que certamente incorreria em lamentáveis enganos -, a análise continuará firmada nos diretores já apresentados, cujos trabalhos e trajetórias pessoais julgo expressivos para demonstrar algumas linhas narrativas e seu fluxo de mensagens específicas que mais se aproximam ou mais se distanciam daquelas realizadas por 
Pedro Almodóvar. Como representam com ele uma geração cronologicamente próxima, sendo testemunha e herdeira do espírito da transição democrática, quero demonstrar as diferentes formas de leitura ou de captação que inspiraram as várias películas durante e depois daquele período.

Eloy de la Iglesia numa linha de preocupações de denúncia social e política, e Victor Erice, com um cinema político e social intimista e metafórico, iniciaram suas carreiras nos anos 60. Por serem precursores do que viria a ocorrer na cinematografia espanhola dos anos 80 e por também produzirem naquele período, foram incorporados nessa discussão. Os outros cineastas escolhidos estrearam seus longas-metragens no final dos anos 70 ou início dos 80. Jaime Chávarri participa ainda do cinema metafórico, mas se destaca no decorrer de seu trabalho pela narrativa cômica e dramática, destoando de Erice - que possui uma trajetória singular.

Manolo Gutiérrez Aragón notabiliza um conjunto de discussões políticas e reflexões filosóficas acerca das relações entre natureza, história e relações humanas que localizam no início de suas obras um caratér bem distinto das preocupações de Almodóvar numa mesma época. Fernando Colomo e Fernando Trueba sinalizam a imagem da caracterizada "Comédia madrileña" que num primeiro momento se aproxima muito dos primeiros filmes de Almodóvar. Bigas Luna e Ventura Pons fazem parte de um cinema barcelonês que destaca a vida urbana e personagens autênticos. Em Luna são excêntricos e em Pons um pouco destoantes da média cotidiana, ambos com narrativas contundentes que também dialogam de maneira muito próxima com Almodóvar.

Os trabalhos e perfis destes profissionais demonstram os reflexos das rápidas mudanças e heranças de um passado próximo. Um contexto que ao mesmo tempo cultivava o florescimento de um cinema espanhol produto da dinâmica de novos sonhos e das contradições vividas no país. Em suas trajetórias, estes cineastas puderam tanto dialogar entre si, com suas imagens, narrativas, abordagens temáticas e ideologias, como servir de instrumento indicador para o vasto conjunto de buscas e questionamentos pessoais e sociais desde então ocorridos.

Outros diretores tão expressivos como: Vicente Aranda, herdeiro da chamada "Escuela de Barcelona"111, Francisco Regueiro e sobretudo Carlos Saura, referências

\footnotetext{
${ }^{111}$ Escola de cinema surgida no período dos conflitos e manifestações registrados em Madrid e Barcelona no início do 1969, que levaram o governo franquista a declarar o Estado de emergência (referência apresentada no início do filme Carne tremula, na cena do nascimento de Victor). Distante da cosmovisão da Escuela de Madrid, a Escuela de Barcelona defendia o cooperativismo, promovia a experimentação formal e encenava situações regionalistas. Influenciados e fascinados pela Nouvelle Vague francesa, seus integrantes pretendiam compôr uma escola marginal e periférica. Para isso, trataram de conseguir uma organização independente ainda que - segundo o professor
} 
que marcam o conhecido "Nuevo Cine Español"112 dos anos 60, e mesmo Pedro Olea nascido na década de 30 como Saura -, que faz parte do "cinema da democracia", possuem uma formação marcada por um outro contexto social e político. Também Pilar Miró, que teve destacada participação no cinema, principalmente no campo da política pelos cargos que exerceu, dando grande contribuição ao audiovisual no país, dentre outros, não faz parte desta análise. Preferi optar por incluí-los como parte de uma geração anterior marcada pelo enfrentamento político direto. Como a partir dos anos 70 define-se um outro o panorama na Espanha, esses autores acabaram não constando do grupo que integrará esta discussão.

Todos continuaram a produzir películas durante as décadas de 80, 90 e alguns em princípios deste século e falam de temas pertinentes aos cineastas da geração surgida junto a Almodóvar. Porém, a tônica narrativa de suas obras recai mais sobre discursos políticos com tons de resistência que refletem predominantemente a luta contra a ditadura. Circunscrevem olhares que trazem consigo registros sociais - não menos importantes - em sintonia diferenciada da linguagem de sua geração posterior voltada a temas cotidianos, ainda que muitos também se remetam àquele período em decorrência da própria transição que se fazia além da política. Como esta seleção atendeu diretamente à necessidade de diálogo com o período e o cinema de Almodóvar, direcionada muito mais no sentido de uma contemporaneidade narrativa e não de um traçado evolutivo e histórico dentro da cinematografia espanhola, seus trabalhos não foram incluídos.

Ao aproximar e relacionar as práticas criadoras e as trajetórias dos diretores selecionados, pretendo tornar mais clara a observação das especificidades de cada um perante o autor em foco. Este exercício vislumbra evidenciar sua distinção em vez de idealizá-la como expressão única de novidade ou originalidade de uma época. Afinal, em seu conjunto as produções cinematográficas de um período histórico acabam valendo mais no seu estrato cultural - por representarem a busca por novos caminhos criadores e sua multiplicidade expressiva - do que ressaltar a projeção de um artista.

Nesse sentido, a escolha por tomar como ponto de referência películas de cineastas que estrearam seus longas-metragens num período próximo - ou do mesmo

pesquisador de história do cinema José Maria Caparrós - nunca recusassem a proteção dos órgãos oficiais. Dada sua escassa projeção comercial, considerando-se o poder de alcance de uma produção quase caseira, a escola acabou por sugerir apenas algumas inovações técnico-formais, ainda que reconhecidamente seus membros possuíssem uma vasta bagagem cultural e conhecimentos cinematográficos sólidos.

Disponível em: <http://www.mailxmail.com/curso/vida/historiacineespanol/capitulo9.htm>. Acesso em: 30. 12. 2006.

112 Termo utilizado para denominar os cineastas que a partir de 1962 se formaram na Escuela Oficial de Cine, de Madrid, em sua grande maioria integrantes da esquerda política contrários à ditadura franquista. 
ano - da estréia de Pepi, Luci, Bom y otras chicas del montón (1980) de Pedro Almodóvar tem como objetivo localizar marcos criativos de trajetórias cinematográficas. E creio que a comparação entre os filmes e cineastas identificará a singularidade dos caminhos tomados até seus trabalhos mais recentes. Decantando impressões e distinções circunscritas nas esferas estética, histórica e social transcorridas durante quase três décadas sobre suas obras será possível assinalar parâmetros de percepção. Nas sutis diferenças e semelhanças de suas abordagens, as tonalidades próprias das obras e do perfil de Almodóvar nesse diálogo estilístico com alguns de seus colegas de criação aparecerão com mais nitidez.

Sem dúvida, o panorama da teia de relações entre política, economia e sociedade ocorrido historicamente delineia suas influências no amplo quadro das representações culturais - em especial, cinematográficas - produzidas no país. Na Espanha há uma tradição histórica que une intimamente sua vida política à cultura. $\mathrm{E}$ isso não foi diferente com o que ocorreu nesses últimos trinta anos no cinema. Seus reflexos, tanto na produção artística como na forma de recepção e manifestação do público e dos intelectuais espanhóis, são patentes. Uma trajetória calcada em imagens - muitas vezes - viscerais que respondem ao modo como se desenvolveu a vida social no país, ao tratamento dado a seus cidadãos por parte das autoridades e às conseqüências sociais correspondentes a um longo processo de lutas entre classes e governo, registrado pelas criações do vários artistas, em especial: os cineastas.

\subsection{Quase um jogo de espelhos - semelhanças e distinções}

Pedro Almodóvar é um cineasta do presente. E situar esta afirmação dentro do discurso de seus filmes significa muito mais do que constatar o que registra. Seu sentido é duplo. Ele não apenas filma o presente. O que lhe interessa é o presente: 0 que vive sua sociedade atual e o seu próprio em particular. Nele narra como seu contexto se sustenta, se transforma e favorece a utilização dos valores até então construídos. Evidente, esse não é o foco central de sua obra. Mas se configura num dado que contribui para localizar funcionalmente seu território de trânsito a fim de buscar elementos e traçar horizontes que o inspiram no desenvolvimento de seu trabalho.

Outro aspecto a ser observado em sua cinematografia - para efeito desta comparação com os cineastas selecionados neste capítulo - é sua forma específica de ironizar os temas que aborda. Almodóvar reafirma em sua linguagem o humor herdado dos espanhóis - uma arma criada contra aquilo que os faz sofrer ou os preocupa como, 
por exemplo, encarar a morte ${ }^{113}$. O acionamento do recurso irônico em várias de suas situações conflitivas busca traduzi-las a fim de iluminar caminhos para enfrentá-las e compreendê-las.

No conjunto da arte espanhola isso está presente de maneira diversa. Basta verificar as pinturas de Goya, de Velasquez, as pinturas e esculturas de Picasso; no teatro, as peças medievais de Lope de Rueda, as renascentistas de Lope de Vega, as barrocas de Rojas Zorrilla ou, contemporaneamente, Valle-Inclán e, na literatura, "Dom Quixote" de Miguel de Cervantes. Enfim, a incorporação da ironia no jogo das relações configura-se num fator disseminado como parte de um exercício habitual que na Espanha se reproduz também no cinema.

Em Almodóvar, a continuidade narrativa desse aspecto - ligada à construção plural da cultura no país - se estabeleceu simultaneamente a uma inversão da ordem dos valores instituídos e da linguagem formal de exposição cinematográfica. $\mathrm{Na}$ interpretação de Almodóvar nenhuma regra é seguida rigidamente. Ao menos até Kika o diretor costumou misturar num mesmo filme tragédia, comicidade, drama e outros gêneros que considerou adequados para contar suas histórias. Diluía todos esses elementos em torno do fator dominante da trama sem se ater a um gênero narrativo em especial.

Posteriormente, a cada novo trabalho esse aspecto foi suavizado e os filmes ganharam contornos mais definidos ligados ao melodrama. O que permaneceu foi 0 destaque para o conteúdo polêmico e irônico peculiar a seu estilo nas abordagens. Basta lembrar em Hable con ella (2001) o tratamento dado ao assunto da gravidez de Alicia, que - em coma - é violada por Benigno, o enfermeiro apaixonado que cuidava de sua saúde - o próprio nome encerra uma ironia. Nessa análise, quase todos os cineastas selecionados empregam a ironia como recurso de linguagem - em maior ou menor grau - com diferentes tonalidades em suas películas. Discernir suas especificidades significa compreender mais detalhadamente raízes e variantes da produção artística na Espanha e suas relações com o cineasta em questão.

O âmbito propriamente econômico dos cineastas também é relevante para a discussão. Num universo onde talento e condições de realização de projetos caminham juntos, as circunstâncias que alimentam a existência do trabalho de um artista são diversas. No caso especial do cinema, produção ou modelo de produção industrial e mercado se encontram vinculados quase de uma maneira intrínseca ao desenvolvimento artístico e representam um ofício financeiramente caro. Neles, as

\footnotetext{
${ }^{113}$ Comentário de Pedro Almodóvar acerca de sua película Qué he hecho yo para merecer esto?, em que afirma ter
} 
várias esferas que envolvem motivação, criação e produção de um filme se conjugam. Portanto, muito daquilo que se apresenta nas telas é resultado de um longo processo de negociações econômicas e conquistas pessoais que visam a proteger e a valorizar pontos de vista ou convicções dos criadores.

São várias as formas de se garantir estas intenções. Para os cineastas em geral, possuir a própria produtora no campo cinematográfico é sinônimo de uma maior autonomia para assegurar projetos e definir tendências autorais, sobretudo nos países onde o cinema não se consolidou como indústria. Como foi apontado pelo perfil de cada diretor, pode-se observar que o fato de possuírem suas próprias produtoras possibilitou a Colomo, Trueba, Luna, Ponz e Almodóvar uma liberdade maior de criação, razão pela qual sustentam com mais firmeza e tranqüilidade suas propostas temáticas. Entretanto, os que não possuem uma produtora criam seus caminhos para a realização de seus projetos. Assim, possuir dinheiro para novas produções corresponde diretamente ao jogo de manutenção de posições e linhas narrativas ou à mobilidade para mudar seus cursos.

Desse modo, ironia - como expressão cultural - e recursos econômicos como liberdade de criação - serão os elementos norteadores deste exercício comparativo nas obras dos diretores aqui selecionados. Colocando como balizas a narrativa temporal enfocada pelos cineastas (abordagem temática, estilo e gêneros) e as condições materiais dentro das quais se produzem os filmes, destacarei o caráter peculiar das obras, posicionando-as como chaves de diálogo com Almodóvar, considerando-se o contexto histórico e cultural já exposto. Ao compreender suas leituras cinematográficas nesses parâmetros, mais do que verificar as diferenças ou semelhanças estéticas (universos, personagens e linguagem cinematográfica) desses cineastas, será possível discernir a importância de seus papéis criativos dentro do cinema contemporâneo.

\subsection{O diálogo entre as diversas ironias e linguagens}

Do mesmo modo, os meios de comunicação, como a TV, a publicidade, o cinema, os quadrinhos, fotografia e vídeo, além de se constituírem como autoreferências de seu universo de preocupações, relações e origem, também ilustram a vida moderna e colocam-se como instrumentos interlocutores que interagem e interferem na vida das personagens ${ }^{114}$. Há um diálogo indireto com eles envolvendo as 
atividades cotidianas que fascinam o diretor, como a publicidade sempre presente ao menos em uma cena da maioria de suas películas. Sem conduzir à critica acerca de juízos de valor sobre controle social ou questões recorrentes como a baixa qualidade de produtos dos bens simbólicos, suas imagens recaem entretanto sobre a utilização desses recursos como parte da espetacularização da vida ${ }^{115}$, dentre as quais - tão mal-visto pela crítica - Kika é um dos exemplos mais acabados.

Não são todos os cineastas deste grupo de análise que trabalham com a ironia ou a manuseia com muito sucesso. Assim como existem diferentes maneiras de tratála, também as suas intensidades e elaborações de maior alcance dependem do grau narrativo e da quantidade de elementos necessários para constituir cada tema. Quanto mais abrangente for o conhecimento da realidade sobre a qual o cineasta fará sua história, maior será sua habilidade para dosar adequadamente os assuntos tratados em suas obras e com eles poder incluir as situações irônicas que tocarão de modo profundo ou superficial a percepção do espectador. Aos que optaram pela comédia ou pelo puro sarcasmo, tudo fica mais fácil de se desenvolver. A outros, esta opção ou torna-se impossível ou mais árdua. Para Victor Erice e Manolo Gutiérrez Aragón a primeira alternativa indubitavelmente revela-se em seus trabalhos.

Erice desenvolve um cinema intimista com tramas quase lineares, exigindo uma observação intensa que desperte a percepção dos detalhes e ações mínimas de cada personagem para, neles, dar lógica ao público sobre seu sentido narrativo. Não há espaço para grandes surpresas, mesmo nos diálogos, umas das condições básicas para a ironia.

Gutiérrez Aragón optou por várias narrativas, mas em todas conduz seu trabalho elegendo o drama como condutor da história. Seus momentos de discussão política e relações sociais demonstram a opção pela crítica séria e comprometida com uma sociedade menos estranhada - no sentido marxista do termo. Para isso, mobiliza personagens destinados à definição clara de perfil mais sóbrio, sem dubiedade de personalidade - o que daria margem para jogos irônicos. Assim, estes dois diretores cedem seus espaços para que os outros demonstrem a diversidade de armações possíveis que construíram, voltadas para provocar o riso ou a indignação de seus espectadores.

Começando pelo conjunto de trabalhos de Fernando Colomo, verifica-se sua preferência quase total de produção no terreno da comédia. Sua prática inicial mais descomprometida politicamente se transforma profundamente com o tempo. No seu

${ }^{115}$ Ibid. 
amadurecimento, preocupa-se com questões históricas e associa sua narrativa ao encontro ou choque entre culturas, sempre num tom irônico especial que busca uma leitura do passado espanhol, relacionando-o com o presente. Os fatores sociais que utiliza nos seus primeiros longas-metragens possuem todas as marcas da "terceira via", contudo já sinalizam uma nova comédia firmada no processo das mudanças de comportamento - sobretudo entre os jovens - dentro do que viria a se consolidar nos anos 80 como a Movida madrileña. Sua prática lembra a narrativa de Almodóvar, mas sem a mordacidade que este emprega ao tratar personagens e seus comportamentos pessoais.

O clima social de Qué hace una chica como tú en sitio como éste? (1978) e de Pepi Luci, Bom y otras chicas del montón (1980), de Pedro Almodóvar, ilustra este panorama com motivos que aparecerão em várias outras películas da época revelando o ambiente da "Movida": diversão, juventude, alheamento aos problemas sociais. Mesmo apresentando imagens envolvendo delinqüência juvenil, a difícil situação da moradia em Madrid e o machismo, neste filme de Colomo há uma perspectiva de distanciamento frente às questões sociais. O que predomina é o tom da festa e da música.

Toda película é pontuada por um grupo musical que literalmente toca uma mesma melodia pop com o título do filme, animando um público jovem de atitudes "eletrizadas" que destoam do ritmo tocado pela banda. Nessa platéia - ainda nem estreante no cinema comercial - encontra-se Pedro Almodóvar em duas participações como figurante. Uma imagem que denota laços de proximidade entre círculos sociais de artistas e os vários câmbios existentes entre os grupos culturais do período.

Os contornos do peso de uma sociedade machista com alternativas precárias de prazer feminino são demarcados de modo a se compreender as atitudes de Rosa, tanto no assassinato do ex-marido que a violenta, como na sua tolerância diante do rapaz da banda pop - por quem está apaixonada - quando este saqueia seu salão de beleza. Nas cenas prevalece a relevância da satisfação de desejos imediatos e comportamentos dominados pela virilidade. Ali, se aventa o contexto da "Movida" contraposto ao comportamento tradicional conservador do papel masculino que perpassa gerações.

A "transição democrática" se faz presente, citada de maneira indireta englobando a novidade e suas contradições. Ao mesmo tempo em que os problemas sociais mais abrangentes são apenas ilustrados e as personagens passam ao largo deles, há na construção da imagem do vocalista um tratamento específico. Ele é 
apresentado como reflexo de uma juventude sem perspectivas, desocupada e voltada para as necessidades do seu presente: dinheiro, sexo, música.

$\mathrm{Na}$ alternativa dada por Almodóvar em Pepi Luci, Bom y otras chicas del montón (1980) em cenas semelhantes (filme também protagonizado por Carmen Maura no papel de Pepi), nota-se a ironia conferida à sociedade dominada pela figura masculina. No estupro, a mulher não se torna vítima. Ao contrário, a personagem Pepi usufrui seu momento e se satisfaz. Depois, utiliza o acontecimento para chantagear o policial (Félix Rotaeta) e ainda se vinga roubando sua esposa Luci (Eva Siva), para que esta se envolva numa relação afetivo-masoquista com Bom (Olvido Gara, mais conhecido como "Alaska"). A ironia ganha contornos a rompimento a hábitos tradicionais, com situações próximas ao inverossímil, banalizando a herança cultural da dominação masculina. Nela, as mulheres - além de serem as protagonistas - ditam todo o ritmo da ação dramática.

Colomo ridiculariza o homem, mas não apresenta um novo modelo masculino juvenil, nem uma mulher. O rapaz por quem Rosa se apaixona é tão autoritário quanto o ex-marido que ela mata. O ajuste de contas de Colomo não liberta a mulher, nem sugere que aquela nova geração carrega, nos comportamentos, valores diferentes de sua anterior. Os caminhos da ironia entre os autores seguem estratégias funcionais diferentes para atender suas narrativas.

No plano fílmico, Colomo opta por colocá-la no centro para estruturar sua comédia sem acentuar o lugar dos papéis sociais ou questionar os valores vigentes. Age no sentido de mostrar costumes triviais num cotidiano previsível e convencional. Não há novidade. O importante é observar que rir do dia-a-dia é reconhecer sua insensatez. Almodóvar vê a ironia como recurso desestabilizador da ordem institucional para manejar papéis sociais - como o papel da mulher -, sejam eles dramáticos ou cômicos, e apresentar agentes sociais dotados de novas atitudes.

Entre estes dois filmes há uma diferença de três anos. Isso talvez interfira na forma de olhar, ainda mais se for considerado que entre 1975 e 1985 o período de mudanças foi muito rápido em várias esferas sociais. Mas creio que não se trata tão somente de falar de transformações bruscas. Estes olhares representam heranças culturais bem diferenciadas. Colomo vem de uma formação universitária e, portanto para o período -, de uma classe social privilegiada, com valores tradicionais mais arraigados. Seu cinema se desenvolve desde sua adolescência e sua construção de linguagem com a câmera também resulta de uma tradição acadêmica no ato de filmar.

Almodóvar vem de uma formação familiar de estrutura rural, mas preocupado 
em romper com suas determinações. Surge com a Movida e de sua própria dinâmica em grupos musicais e teatrais. Vinha do underground e estava, de certo modo, envolvido com o que havia de mais inovador naquele momento, ainda que marginal. Começou com seus curtas-metragens em $8 \mathrm{~mm}$ já adulto, impulsionado a dizer de uma só vez toda sua mensagem e, no início, sem o traquejo necessário de uma linguagem cinematográfica. Fato que, no entanto, contribuiu para caracterizar sua espontaneidade e delinear suas mensagens.

O que interessava a Colomo - ao menos até meados dos anos 80 - era fazer filmes de costumes. Depois, gradualmente diminuiu o tom marginal de seus filmes. Mesmo como um cineasta já estabelecido e reconhecido nesse período, Colomo persistiu nessa linha com suas comédias até 1987. La línea Del cielo (1983) e La vida alegre (1987) ainda mostram estas preocupações fazendo uma paráfrase amável sobre a vida no socialismo triunfante ${ }^{116}$. Com incursões em vários campos narrativos, até no gênero da ficção científica, Colomo fixou-se numa região intermediária. Misturou o passado histórico e a comédia romântica sem muitas tonalidades de ousadia, talvez motivado pela busca de garantia de equilíbrio comercial.

Em seus trabalhos posteriores, como em El cuarteto de La Habana (1998), os elementos irônicos permanecem fortes. Sua comédia se refina com personagens de classe média. Mesmo em crise, todos encontram saídas otimistas para seus dilemas. Os valores morais não conseguem se sobrepor aos sentimentos. Os abalos diante dos valores matrimoniais são os mais ironizados. O universo musical ainda permeia a narrativa como herança da "Movida", dando-Ihe maior mobilidade para se relacionar com seus personagens e construir diálogos inteligentes, sem pretensões de abarcar uma totalidade analítica da realidade que envolve.

Sem desmerecer seu trabalho ou tornar obrigatória alguma crítica, percebe-se - por exemplo - que em nenhum momento o fato de estarem em Cuba - sobretudo em Havana - suscita qualquer discussão política ou ideológica. Colomo opta pelo caminho de seu universo de classe numa análise social ou histórica sem afrontamentos. Obviamente a classe social a qual pertence passa por conflitos mais profundos do que aqueles vividos pelos personagens desse filme. Contudo, ao deixar de lado tensões sociais - que talvez lhe custassem um ônus perigoso para seus investimentos sobram os anseios sentimentais para serem resolvidos e isso ele sabe desenvolver bem-humoradamente com maestria. Um final feliz sempre nos espera.

Com Trueba ocorre algo semelhante, porém sua preocupação histórico-crítica

${ }^{116}$ MONTERDE, 1993, p. 139. 
se faz clara, diferenciando-o de Colomo e também de Almodóvar no decorrer de sua trajetória. Em seu primeiro longa-metragem, Opera Prima - lançado no mesmo ano em que Pedro Almodóvar estréia Pepi, Luci, Bom y otras chicas Del montón -, o que se demonstra é seu foco de preocupações voltado às relações afetivas. Na cinematografia espanhola, o que se via na comédia de Colomo ditava os tons do que poderia ocorrer futuramente.

Com Trueba e Almodóvar a novidade se consolidava. Não era só o enfoque de mostrar a vida metropolitana e suas personagens cotidianas que imprimia singularidade aos filmes. Nem o encontro com os sentimentos, o dia-a-dia alienado das grandes questões sociais, como se nada mais - além dos problemas pessoais - estivesse ocorrendo. Foi a incorporação da lógica das relações capitalistas modernas - em todas as suas esferas - aos elementos mais corriqueiros do cotidiano visto nas ações das personagens o dado novo revelador da dinâmica social. O que começou a aparecer nos planos e cenários foi uma Espanha moderna disposta e radiante por entrar nesse novo território.

Claro, a forma de abordagem dos temas, o comportamento das personagens, sobretudo em Pepi, Luci, Bom y otras chicas del montón e Laberinto de pasiones, era ainda mais contundente e inusitada do que as de Opera prima. Entretanto, todas continham uma movimentação de cena no espaço dramático que identificava quase automaticamente o público àquilo que via na tela. Era o que mais importava, além do riso e das surpresas que causavam. $O$ fato de se localizar dentro das imagens criava no público um diálogo maior com o filme do que o convencional. Era uma nova Espanha que se mostrava e na qual o espectador se dava conta de estar inserido. $O$ metrô Ópera, as praças, as marcas dos produtos espalhadas pelas ruas. Tudo era muito familiar ao que se mostrava nas telas do cinema e naquela nova realidade de Madrid.

Um clima muito semelhante já havia ocorrido em 1951 no excelente Esa pareja feliz de Juan Antonio Bardem. Ali se vê o encanto com a metrópole, o sonho pelo glamour e pela vida urbana aparentemente fácil. No entanto, mostram-se também seus dilemas para enfim evidenciar suas contradições e desilusões. Ideologicamente, numa grande sátira à política de ajuda dos Estados Unidos ao desenvolvimento da Europa pós-guerra - que na verdade nunca chegou à Espanha -, com o sonho de entrada na modernidade exemplar norte-americana, também era o que se via ironicamente em Bienvenido Mister Marshall (1952) de Bardem e Luis García Berlanga. Anseios de incorporação ao mundo desenvolvido que não se realizaram. 
Com os filmes de Trueba e Almodóvar ocorre o contrário. Não só é possível se alinhar ao que existe de mais atual nas sociedades contemporâneas bem-sucedidas, como já se vive dentro delas - muitos já usufruindo - em suas possibilidades. Em ambos os trabalhos festeja-se a incorporação dos valores e objetos de consumo norteamericanos como elementos que, de um lado, igualam toda a juventude num plano consumidor universal e, de outro, a incluem na mesma esfera de preocupações e vida social da sociedade em mudança, mesmo que inconsciente. Este era o ambiente social pelo qual passava Madrid e o país, uma sociedade em transformação.

Vê-se, portanto, que havia desejos muito semelhantes refletidos em inúmeras produções culturais que transcendiam aparentemente classes sociais ou normas. Porém, a dinâmica das narrativas não deixa margem a dúvidas. As personagens denunciam as relações dos diretores e as classes sociais com as quais conviviam ou pertenciam. Assim, por mais que pareçam universais, as construções dramáticas sarcásticas respondem a códigos já introjetados dentro dos grupos que as recebem. Por isso, as cenas utilizadas por Trueba e Almodóvar dizem mais respeito aos grupos pelos quais se autodenominam mediadores e interlocutores informados do que à tradução de suas visões sobre a sociedade espanhola e sua cultura.

A ironia existente nas comédias e romances de Trueba contribui para um resgate histórico sempre colocando em primeiro plano a discussão dos sentimentos e afetos. A personagem feminina é dotada de poder na ação dramática e as ironias demonstram a contradição das relações sociais e políticas num jogo de forças que não dá controle definitivo para nenhum dos sexos. Com esse recurso, o diretor definiu sua narrativa e concentrou energias em eixos específicos, ligados tanto temática como mercadologicamente. Buscou um refinamento ao estilo das altas comédias norteamericanas que perfilam integrantes das classes médias e seus dilemas. Influência que reconhece ter recebido principalmente de Billy Wilder, mas que também reflete seu próprio contexto pessoal e social.

Um estilo que já estava presente no seu primeiro filme e que também viria a ocorrer na trajetória de Almodóvar com Mujeres al borde de un ataque de nervios - não por acaso um grande sucesso nos Estados Unidos. As cenas de poder machista passam ao largo no cinema de Trueba. Em Belle époque (1992), o soldado Fernando, após desertar do levante antimonárquico nos anos 30, chega a uma cidade e se envolve com todas as filhas de um anarquista e uma cantora de ópera. O que permanece em pauta é o jogo da sedução sem as marcas da cultura sob dominação masculina ou da família castradora, aliás, modelos ridicularizados durante toda história, 
juntos à moral católica.

As questões políticas que apresenta ganham relevância, porém são tratadas no passado e atuam somente como panorama temático, recurso que utiliza em outras de suas películas de época. Todos os personagens - inclusive os protagonistas - passam por elas, mas não são seus agentes diretos. O diretor joga luz sobre os acontecimentos prosaicos, tornandos-os relevantes, e subordina os fatos históricos a suas ilustrações. Trueba não pretende traduzir um momento histórico para dar sentido a ele no presente que vivemos, como ocorre com outros autores. Ao contrário, demonstra querer sair dele. Numa de suas entrevistas, indica esta sua intenção ao responder sobre a razão de fazer vários filmes de época:

Quizás es porque no me gusta mucho el tiempo en que vivimos. Me levanto por la mañana, voy a rodar y digo: "¿cuál es la escena que voy a rodar hoy? Es un tío hablando por un celular o un tío sentado delante de su computadora o uno que toma un taxi". Y digo, qué feo, ¿no? En cambio levantarte e ir a un plato, tener un mundo desaparecido ahí que de repente vuelve a la vida porque tu estás rodándolo, pues es mucho más bonito como estímulo para hacer cosas. Dejé un poco de lado el presente. ${ }^{117}$

Apesar desse aparente alheamento, o que aparece nas obras dialoga com o presente em outros aspectos. Nelas se discute numa crítica bem-humorada à sociedade espanhola, seu valores e estruturas. Com La niña de tus ojos (1998) - uma rodagem feita em Praga num estúdio de cinema que se assemelhava aos estúdios alemães já desaparecidos - o exercício crítico se processa sobre as várias ironias possíveis numa mesma história: a impotência da cinematografia espanhola, a insensatez, fanatismo e estupidez nazistas, a condição do artista frente a ditaduras, referindo-se também ao franquismo. Brinca com os estereótipos espanhóis e parodia duplamente o cinema e sua cultura ao filmar a história de uma equipe de cinema que filma na Alemanha uma película em espanhol e em alemão.

As diferenças culturais, sociais e políticas se cruzam ininterruptamente. Este Trueba mais maduro reflete no próprio ato de filmar suas buscas pessoais e sua sociedade. Seu traçado irônico tem um destino comprometido com uma história que faça compreender sentidos para as relações. Esta é a ferramenta que utiliza para abrir caminho no contexto que apresenta. Seu crescimento se deu na direção de interligar nexos que iluminem um presente que se transforma, por isso a grande presença da história. Não para justificar os fatos gerais, mas para tornar mais plausíveis os sentimentos. Aspecto que se evidenciará nos documentários, seus últimos trabalhos.

Enquanto para Almodóvar a ironia segue para desconstrução da regra, para

${ }^{117}$ Disponível em: http://www.terra.es/cine/actualidad/articulo.cfm?ID=906. Acesso em: 03. 01. 2007. 
este cineasta ela tem uma função instrumental de diálogo com as relações. Não por acaso ele recorra tanto à temporalidade. Ela serve de elo entre o passado e o presente como ferramenta de atualização e memória cultural. Ele apenas brinca com a ordem estabelecida. O passado para Almodóvar só o preocupa em sua fase mais recente. Mas, diferente de Trueba, não precisa ser vivido novamente, ou seja, filmado. Quando ressuscita, revela-se como o próprio presente. Ele está dentro das relações do dia-adia, por isso seu questionamento caminhou para o rompimento, única alternativa para continuar a gerar a história. No presente, ele explica as bases dos comportamentos de seus personagens.

Nos dois autores encontram-se perguntas semelhantes. Elas giram ao redor da busca por sentidos, culturais e afetivos, para as relações sociais. Porém, a forma de fazer com que esses elementos dialoguem - provocada pela ironia - encontra diferentes regências. Em Almodóvar, o confronto. Em Trueba, as afinidades sociais.

Bigas Luna talvez dentre todos os diretores aqui apresentados seja o que mais faz referência à cultura espanhola, à sua arte, e as ironiza como um todo. Não só porque possui um histórico ligado às artes plásticas - uma das grandes marcas acadêmicas da Espanha no mundo moderno -, mas também porque representa uma trajetória circular que busca conciliar sua necessidade de novas linguagens e sua formação intelectual. Nos registros de suas histórias, desde Bilbao - quando inicia uma linguagem contundente acerca das relações entre amor e sexo -, o cineasta percorre caminhos que mesclam a tradição espanhola com sua herança sobre as relações no mundo contemporâneo. Em determinados momentos de seus trabalhos, sua ironia assemelha-se muito à narrativa de Almodóvar. Entretanto, a forma com que carrega os tons de contraste de suas abordagens sobre os temas ligados à cultura os distingue sensivelmente.

Próximo a Ventura Pons, Luna utiliza os regionalismos, seus símbolos e significados, para deles extrair as conseqüências mais viscerais de relações - em geral exageradas - sobre os sentimentos, a sexualidade e a multifacetada produção cultural espanhola. Ao mesmo tempo em que acentua as diferenças, mostra como o peso das instituições - em geral família, Igreja católica e Estado - que, buscando alinhar o país numa única identidade, só acabaram por reproduzir seus aspectos mais repressivos ligados ao moralismo, à culpa e aos tabus afetivos. Para concretizar esses elementos em imagem, a todo momento recorre à própria criação da arte e da tradição cultural do país e não poupa sua crítica à hipocrisia das atitudes.

Se em Bilbao (1978) a ironia é construída de maneira séria e mordaz ligada à 
morbidez, já que o objeto de culto é o mesmo a ser exterminado, em Jamón, jamón (1992) o dilaceramento tende para o cômico e para o surrealismo. Na cena em que o jovem rico José Luís e o aspirante a toureiro Raul lutam agredindo-se com grandes pernas de jamón [um tipo de presunto defumado muito popular em toda Espanha] em nome do amor pela mesma mulher, Luna fixa momentos onde tragédia e comédia fundem-se aos sentimentos e comportamentos, transformando-se numa mesma tradição cultural. Ali as imagens revelam-se polissêmicas.

O jamón não é só um alimento básico presente no cotidiano espanhol que se costuma pendurar em grandes peças de carne nos tetos dos restaurantes e bares, acabando por criar um cenário e um aroma extremamente exótico aos olhos estrangeiros. Uma imagem realmente surreal. Ele está presente na linguagem rotineira como: "chica ou chico jamones" [garota ou rapaz atraentes, desejáveis e apreciáveis, como um jamón, ou seja, também para serem comidos num sentido metafórico de satisfação de necessidades tanto sentimentais como físicas]; "te mato con un jamón" [novamente numa metáfora, agora para medir forças]. Aproxima o homem da sensação de seu domínio da natureza: animal abatido, transformação da carne para alimentação.

Na cena, o diretor inclui o jamón como instrumento de ampliação do ódio que os dois protagonistas sentem um pelo outro, num jogo de forças masculino em que este pedaço de carne transforma-se simbolicamente no poder do falo. Numa sociedade onde já havia despontado publicamente a ambigüidade sexual ou a suavidade das relações vistas nos primeiros filmes de Almodóvar e Trueba, esta cena ironiza o exagero das conquistas e a forma descabida de provar sentimentos, associados a atitudes irracionais que, no entanto, permanecem nas relações.

A construção da cena reproduzindo a pintura Goyesca, principalmente o quadro "luta com clavas" (óleo de 1820-23), não deixa dúvidas às associações. O que vem somente a fortalecer o tom crítico referente àquela cultura visceral. No quadro de Goya, dois homens lutam com longas clavas e flutuam no ar. Seus corpos começam a partir dos joelhos. Suas pernas atraem toda a atenção da obra. Há um grande peixe ao fundo, que parece ser o motivo da briga. A referência do filme à obra é imediata. Mas não só sobre esta obra. O capricho $42{ }^{118}$ de Franscico de Goya intitulado "tu que no puedes" (1797-8) também ilustra uma luta por concorrência entre dois homens, numa cena irônica e grotesca. Ambos carregam jumentos nas costas e olham-se como se

\footnotetext{
${ }^{118}$ Segundo a própria formulação de Goya, este termo designaria observação e invenção. Uma diversão, um jogo imaginativo, artístico, uma descoberta ou revelação do desconhecido. Observações que indicariam formas de explorar sobre o que se ignora ou oculta. Invenções que iriam além do campo pictórico e suas regras. A lucidez goyesca. LOPERA, José Alvarez et alli. História geral da arte - Pintura IV, Madrid: Ediciones del Prado, p. 41, ago. 1996.
} 
dissessem a frase que se encontra na parte inferior da imagem. Surrealismo, grotesco, passional-irracional, estas são as sensações passadas na cena de Luna e que sintetizam todos elementos para a recepção do espectador. Um regionalismo que parece universal, mas que busca na verdade questionar e incomodar sua própria cultura nas suas esferas sensuais, afetivas, machistas, artísticas - basta observar a síntese a que a cena faz alusão: é o pintor Goya, um contestador da sociedade, que media a ação dramática.

Há um questionamento similar em Qué he hecho yo para merecer esto? (1984) de Pedro Almodóvar, quando Glória mata o marido com um pedaço de jamón. Neste filme, a luta é travada entre um homem e uma mulher. Anuncia-se na cena que o eixo do domínio social começa a mudar de gênero. Em Jamón, jamón está em jogo a força masculina ligada ao poder e à sexualidade. Em Almodóvar também. Ambos ironizam estes comportamentos apoiados num símbolo de grande expressão popular na Espanha. Mas a densidade com que Luna aplica "seu jamón" à cena define claramente uma concepção proveniente de aparatos artísticos da vida acadêmica que Almodóvar não possuía.

Assim, enquanto o primeiro atua com ferramentas intelectuais e artísticas, atingindo intencional e decididamente seu público em suas esferas mais arraigadas, 0 segundo utiliza sua intuição e a polêmica resolvendo a cena numa situação cômica. Também obtém excelentes resultados - haja vista as críticas louváveis que recebeu da intelectualidade com este filme - porém faltavam-lhe, até aquele momento, bases mais sólidas de visão sobre a amplitude de valores que começava a tocar.

Jamón, Jamón trata de uma competição exclusivamente masculina. Possui até uma certa dança corporal sensualizada. Seus movimentos beiram a animalidade, externam ironicamente o que imaginam ter de mais poderoso com os pedaços fálicos de carne crua nas mãos. Os desejos de morte alheia se misturam ao desejo sexual que possuem pela mulher amada. Neles se revela o peso da tradição - que em Bigas Luna se reverte na degeneração -, seja da vida metropolitana, seja pelo machismo ou pela posse. A universalidade desta cultura também é posta em xeque.

É importante lembrar que Bigas Luna é um barcelonês e que, portanto, possui nas entrelinhas de suas temáticas também o questionamento sobre unidade e separatismo, questão muito presente no dia-a-dia da Catalunha diante do discurso sobre a "nação espanhola". Discussões presentes em outras de suas películas, ora sobre os caminhos da comédia, ora do drama e melodrama. Nelas o diretor utiliza-se da ironia para tornar suportável e aliviar o público do peso de suas apreciações - para 
sorte do espectador - sobre a reflexão que faz da cultura produzida na Espanha. Imagens fortes com uma densidade única no cinema do país.

Ventura Pons, outro barcelonês que hoje possui uma carreira consolidada, busca em sua concepção técnica diante dos atores, unida à forma como pretende chegar à sua linguagem estética, um trabalho que leve o espectador a refletir sobre os sentimentos. Para isso, articula uma forte preocupação com a totalidade estética que permeia todos os âmbitos da produção até compor todas as nuances da história que pretende contar.

Sempre em tramas que envolvem drama e comédia - ora separadas, ora juntas numa mesma história - mediadas por várias ironias, Pons desencadeia uma série de sensações que levam a pensar sobre questões ligadas à existência. Nesse jogo constante mesclando gêneros, ele negocia consigo mesmo a construção plástica de sua estética fílmica e a direção de atores e atrizes definindo sua marca, formando uma estrutura narrativa absolutamente informal e própria. O resultado é um trabalho equilibrado, sem excessos de qualquer categoria - ao contrário, lapidar. Uma referência que Almodóvar veio buscar, sobretudo a partir dos anos 90, quando amenizou o tom de suas cores nos cenários e acentuou a intimidade das personagens.

Pons reconhece que, mais do que ser cineasta, é um diretor de atores. Não lhe importa tanto o que ocorra nas movimentações e desenvolvimento dentro das cenas. Para ele, o importante é extrair dos atores uma expressão que consiga imprimir sobre a recepção do espectador uma imagem convincente. Suas concepções sobre sua obra se misturam muito ao que sente e pratica na vida. Os mais de 25 anos de cinema levados com um grande humor - aparecem nos filmes carregados também de uma peculiar ironia. Seus filmes seguem uma economia de cenários e ambientes que deixam o espaço direcionado quase que totalmente à ação dos personagens. Assim, o que pesa mais na ação dramática, literalmente, é a interpretação. Toda presença do diretor latente encontra-se presente em suas obras. Os diálogos ligados a questões sentimentais ou existenciais fluem num jogo irônico constante. São comédias que se assemelham às de Woody Allen, mas sem a carga de argumentos e informações que este exibe.

Em El per qué de tot plegat e mesmo no drama Amic, amat, são discutidas as questões essenciais de cada tema explorando-se seus vários prismas. O cotidiano das ruas parece quase irreal. Não existem cartazes, marcas de produtos ou qualquer coisa que indique espaço ou uma temporalidade determinados. Resta ao espectador se ater à história contada pelas personagens. A todo momento surgem questionamentos e 
surpresas em torno de temas versando sobre sexualidade, amor, solidão, fidelidade, comunicação e valores. Sua ironia aparece na contradição de discursos diante da prática. Como toda a estética está voltada para os atores, as falas e atitudes das personagens se sobressaem e o contraste das ironias ganha maiores proporções.

Em Amic, amat um professor universitário homossexual apaixona-se por um estudante inescrupuloso que se prostitui. A todo momento conhecimento intelectual e afetos são contrapontos. El per qué de tot plegat se passa com 15 pequenos episódios. Em um deles um casal de namorados promete sinceridade total um ao outro e, na primeira saída para jantar, os dois se separam por uma discussão banal sobre gostos de comida e maneiras de se vestir. Como deveriam ser sinceros, o rapaz diz tudo o que pensa sobre a comida japonesa que a namorada propõe - e adora - e depois fala de seu corte de cabelo. Isto é o bastante para quebrarem o pacto e se agredirem com socos. Pons deixa claro em seus filmes que trata da vida da classe média sem explorar conflitos de classe ou o aparecimento de outros grupos sociais - salvo poucas exceções, como em La Rossa del bar (1986) e Puta misèria! (1989). Seus temas são sempre cotidianos, a cidade e os cenários de um equilíbrio estético e de uma limpeza e harmonia visual impecáveis. O conjunto dos elementos é organizado de modo compactuado para que não apareça em cena nada mais que o ser humano.

Nas películas não se confrontam ou se ridicularizam os valores construídos como o faz Almodóvar. Os acontecimentos partem de seus protagonistas e desenvolvem-se ao redor de seus significados. Aí se explica a discussão de um diretor de atores. Sua preocupação não vai além do que qualquer ser humano - como também um personagem - possa sentir. Nos filmes de Pons, as cenas não são inventadas, nem seus dilemas. Todos já estão dados pela vida. O diretor parece se ocupar apenas em deixá-los se manifestar. A ausência da ênfase na classe social, de problemas diários da cidade e da sociedade contribuem para que o espectador se concentre somente nas personagens a que assiste.

São as pessoas em suas individualidades que importam e a ironia alimenta sua dinâmica. Isso já aparece em Ocaña, seu primeiro filme, um documentário também repleto de ironias na figura da própria personagem real, o jovem pintor e transformista andaluz. Não por acaso Pons afirma que não separa a obra da vida. É fiel ao seu discurso. Comove pela ousadia em afrontar-se e afrontar temas e sentimentos gerados pelo ser humano. Por isso, sua ironia é muitas vezes mordaz e visceral. Passa pelo âmbito da comédia sem divertir banalmente; sempre abre espaço para uma reflexão. E sua entrada no drama faz do recurso irônico um instrumento dilacerador, pois não 
aponta saída para a contradição e seus desfechos - antes de caminharem para 0 trágico -, deixa como questão a incerteza.

Já a obra de Eloy de la Iglesia possui muitas afinidades com a de Almodóvar quanto aos aspectos temáticos. Olhar sensível e solidário sobre os "excluídos" da sociedade, linguagem ousada, afrontamentos comportamentais, destaque para personagens homossexuais. Entretanto, esta fidelidade entre os autores se traduz distintamente na estética e na forma de abordagem dos temas. La Iglesia não só opta como também acentua a discussão do conflito de classes sociais e, quando faz sua abordagem sobre a homossexualidade, dá a ela um caráter militante. Geralmente tratadas de maneira dramática, estas abordagens tomam rumos diferenciados em algumas de suas obras. Nelas estão presentes uma ironia muito semelhante à de Almodóvar, carregadas de comicidade.

La estanquera de Vallecas é bom exemplo dessa abordagem; uma comédia de costumes cotidianos rodada no bairro madrilenho de Vallecas - tradicionalmente operário -, onde seus moradores têm sua rotina alterada por ocasião de um assalto a uma tabacaria (estanquera). No filme, dois assaltantes entram no estabelecimento e tomam como reféns a senhora proprietária e sua sobrinha. Travam as portas, rendem as mulheres e pedem um resgate. Fora da loja, os moradores do bairro se aglomeram primeiramente por curiosidade e estranheza por verem a loja fechada.

Rapidamente se constata o impasse, e a situação particular passa a ser um grande acontecimento público. Manifestações em razão de diversos problemas, conflitos com a polícia que busca dispersar a multidão já formada e quase nenhum interesse pelo fato original que causou o tumulto. Dentro da loja, inicia-se uma relação de simpatias entre os aprisionados que se atam e desatam sucessivas vezes. Misturase a isso um breve romance entre os protagonistas, que aos poucos vão demonstrando suas perspectivas, medos e sonhos, num clima de tensão entre a caótica situação externa e as afinidades pessoais internas desencadeadas na estanquera.

A ação dramática construída pelo diretor centraliza-se numa demonstração de identificação e simpatia com as classes populares marcada pela comédia e pelo ambiente familiar. O diretor trabalha com inúmeros desdobramentos do mesmo tema e, para cada um deles, constata-se nas cenas gradientes sarcásticos que se ampliam na medida em que suas esferas sociais se sucedem. Ao mesmo tempo, para cada abordagem o cineasta questiona suas condições com desfechos cômicos que armam e desarmam condicionamentos sobre os assuntos apresentados. É o que ocorre com o tema central do poder. Nas relações pessoais ele aparece no papel desempenhado 
entre homens e mulheres dentro da estanquera, assim como na relação bandido e vítima - um jogo claramente de classes sociais -, e da fusão das duas situações os afetos que também se subordinam a estas relações de poder, libertando-se eventualmente.

Até as diferenças e necessidades entre faixas etárias são trabalhadas. Tia e sobrinha externam suas carências e particularidades próprias às suas idades verificadas nos comportamentos oriundos de suas formações e valores de suas épocas. Os afetos misturam-se às carências e desigualdades sociais, que por sua vez se abrem para a denúncia das inúmeras desigualdades na figura dos dois assaltantes. Os momentos de harmonia entre algozes e reféns se fazem repleto de situações que evidenciam suas faces humanizadas, desvencilhadas do peso da desigualdade classista ao mesmo tempo revelada em toda narrativa.

No ambiente externo o conflito desenvolve-se entre moradores e polícia. A discussão do espaço e administração públicos ganha as dimensões inerentes a eles: poder do Estado, segurança pública, autoridade e autoritarismo, poder da população. Como o filme também apresenta a perda de controle da situação e por sua vez da autoridade, também eclodem todos os outros problemas os quais vivem os moradores das periferias. As ironias que mediam os diálogos relativizam papéis e reivindicam ao mesmo tempo em que se cumpram suas funções. É o cidadão que aparece em vários de seus aspectos. Vê-se portanto que a escolha desse recurso adquire um papel político direto.

Portanto, ao optar pela comédia, Eloy de la Iglesia não abandona seu caminho militante. Ele explora novas possibilidades para reforçar sua mensagem. Em outros filmes, seu discurso recorre apenas ao drama. Em El diputado, há uma construção dura e carregada de imagens fortes que denunciam não só o processo da transição, mas também toda a hipocrisia existente no jogo político e na instrumentalização das classes sociais. Ali a ironia possui um peso dramático tão denso que quase desaparece da percepção do espectador. Nesse contexto, o diretor explora suas novas possibilidades para acentuar os contrastes e despertar no observador dimensões mais contundentes sobre as imagens que projeta. Dessa forma, utiliza-se deste elemento narrativo para dele extrair novas funções, além daquela tradicional vinculada à comédia.

Em La estanquera de Vallecas encontra-se um diretor preocupado com as questões da dialética da história, imbuído de uma linguagem popular para estas discussões. Com habilidade para manusear vários elementos sociais dramáticos, La Iglesia otimiza recursos irônicos mostrando - nessa história - as possibilidades de 
manter-se fiel às suas convicções ideológicas. Um processo de amadurecimento pessoal revelador da versatilidade tanto do autor como das possibilidades que as linguagens utilizadas na arte de contar histórias podem conter. Nessas duas histórias, e também em outras que realizou, ele transforma a ironia numa ferramenta que impulsiona e define o conflito de classe, para depois evidenciar e valorizar os agentes sociais que compõem as personagens protagonistas da trama - em geral representantes das contradições econômico-políticas da sociedade.

Jaime Chávarri também possui uma preocupação política. Porém, diferente de Eloy de La Iglesia, procura discuti-la por intermédio da revisão histórica espanhola a partir de personagens membros de classes sociais tradicionais ou médias. Os trabalhos que seguem até finais dos anos noventa e seus posteriores não fogem de temáticas recorrentes a seus anteriores que vinculam aos afetos o documentário, a sexualidade e a famílias. Praticamente todos revelam de maneira positiva ou negativa, com suas diversas variantes - sejam elas de cunho histórico ou de grupos sociais - tais aspectos.

A história do filme Las cosas del querer (1989) remonta o final da guerra civil espanhola ao início da ditadura franquista, personificada no filme pela imagem da polícia. Discute o preconceito contra a homossexualidade e a arte que expressa livremente os sentimentos, além do poder da aristocracia. Sustentada por um triângulo amoroso de artistas repleto de amizade e de conflitos, a ação dramática - composta de músicas e imagens que ilustram uma Espanha muito atrelada às tradições em confronto com as novidades, seja de comportamento ou de idéias - desenvolve-se entre a forte amizade que une os três personagens, a perseguição de Mario - o ator e cantor homossexual -, sobretudo por membros da aristocracia e a busca da mãe de Pepita atriz e cantora - para separá-la do namorado pianista.

Diferente de La Iglesia, que foca no contexto, e de Pons, que vincula personagem aos elementos estéticos, nessa película Chávarri centra a linguagem irônica nas personagens. Mario concentra toda a crítica ao modelo social vigente. Não só por ser homossexual, mas também pelo seu perfil contestador e por revelar as contradições daquela sociedade. Com bom equilíbrio entre drama e comédia, torna-se possível desenvolver mais situações em que a ironia apareça de maneira clara. Aqui, Chávarri acaba por acrescentar nessa linguagem o elemento histórico como resultado dela. Será um membro da aristocracia que se apaixonará por Mario. Assim, os conflitos sociais não isentam a elite de seu envolvimento com as camadas ou grupos sociais que teoricamente rejeitam. Mais além, sua aproximação é tanta que torna a relação irracional e, não vendo seus desejos satisfeitos, encarregam-se de destruí-los. 
Ainda sob a recorrência histórica, a comédia Besos para todos (2000) segue no mesmo sentido. Passa-se em Cádiz, em 1965, em torno de três estudantes de medicina de família burguesa que são obrigados a viver num chalé no intuito de terminar seus estudos. Porém, os projetos são alterados pela tentação dos jovens, que se sentem atraídos pela gente que freqüenta um cabaré próximo a suas residências. A convivência entre eles os faz reverem suas vidas, perspectivas e seus papéis, levando-os a tomar consciência do significado de suas liberdades pessoais.

Essa memória feliz de uma juventude perdida modifica intencionalmente 0 retrato de circunstâncias históricas tão lamentáveis para a Espanha, apresentando-as de maneira amável. Até personagens-símbolo das forças franquistas recebem um tratamento mais irônico do que crítico, quase simpático, fazendo com que o público os reconheça mais como seres humanos vulneráveis do que como a incorporação impessoal da ditadura: o padre é uma mistura de conservadorismo e capacidade de compreensão dos desejos juvenis. O sinistro policial tem coração sensível. O governador civil, sutilmente paródico, revela um ar contemplativo que parece compreender as inevitáveis mudanças políticas, mas está mais preocupado com a reforma das lanternas do carro do sobrinho do que em cumprir a repressiva legislação franquista.

Apesar deste enfoque distante de algum desejo testemunhal, Chávarri não entra na armadilha de uma falsificação histórica ou de um adocicamento das lembranças. Mantém-se simultaneamente longe do sarcasmo revanchista e da amnésia social $^{119}$ Mas, de qualquer forma todo o filme não deixa de ser uma ironia sobre a própria memória das classes burguesas que, apesar de certas privações, têm outras histórias para contar - como esta, por exemplo - sobre os tempos em que a Espanha estaria caminhando para os últimos tempos da ditadura, e certas pessoas - que usufruíram de privilégios - nem haviam percebido que ela ocorrera de fato.

Com estes teores, Chávarri perfila os aspectos sociais da resistência à ditadura ou ao tardo-franquismo, postos diante de uma crônica nostálgica sobre paixões ou da rebeldia da primeira juventude. Também a estética contribui para um jogo irônico, não com a exigência de Ventura Pons, mas com elementos que contribuem significativamente para um resultado apreciável sob os pontos de vista artístico e político. A riqueza de cromatismo e de luminosidade das paisagens da película faz um contraste estético com o ambiente sócio-político obscuro a que estão circunscritos os jovens diante dos interiores dos espaços burocráticos que simbolizam a ditadura.

119 Disponível em: <http://www.lenguaensecundaria.com/resenas/besos.html>. Acesso em: 07. 01. 2007. 
Apesar de não haver um desfecho onde a liberdade de todos se realiza, 0 diretor leva o espectador durante a exibição do filme a um tempo quando todos os sonhos e desejos pareciam possíveis. Acredito então que a não-realização das liberdades também constitua uma ironia com aqueles tempos em que, mesmo para os privilegiados, ela era uma ilusão. Nesse sentido, a história atua de maneira decisiva na ação dramática, por isso, também passando a ser incorporada aos novos sentidos que a ironia pode tomar segundo a construção de cada novo diretor.

Em termos globais, talvez compreender o uso irônico como mecanismo corrente na cultura espanhola possa esclarecer alguns mal-entendidos sobre Almodóvar, não só para o espectador, como também o próprio círculo de críticos na Espanha. Ela funciona como um recurso mediador para visualizar as relações e adversidades vividas não apenas durante os inúmeros períodos de tensão social. São vários os prismas que a iluminam. Cineastas consagrados como Berlanga, Bardem, Fernán-Gómez e obviamente Saura e Buñuel, cada um a seu modo, a utilizaram como ferramenta crucial em seus filmes. Ela aparece no confronto dos valores morais e religiosos, na contradição entre tradição e novos comportamentos sociais, no conflito entre as classes sociais e nas relações com o Estado.

Caracteriza-se na linguagem artística espanhola quase como um porta-voz que apresenta o problema da crise ou então a novidade vigente, atuando ao mesmo tempo como um parecer que determina um juízo e como a negação da cena, no intuito de provocar o espectador. Portanto, a discussão do trabalho dos cineastas apresentados aqui - incluindo-se Almodóvar - é a herança bem colocada e traduzida de apresentar maneiras diferentes de uma mesma matriz.

A particularidade narrativa de Almodóvar no ato de ironizar é apenas um de seus múltiplos ângulos, por conseguinte, não a única entre os cineastas. Certamente também original, porém próxima de outras já experimentadas. Sua escolha narrativa cria mediações que acabam por manter a tradição, apesar de imprimir-lhe novos significados e atributos. É elaborada como um recurso que utiliza os elementos da dinâmica de seu presente, recorrendo a estruturas dramáticas tradicionais existentes no esperpento e no melodrama, a estéticas clássicas encontradas no grotesco e a modernas, retiradas do pop, do camp e do kitsch. A seguir definirei sucintamente estes elementos apenas para localizar, nessa discussão, a produção deste cineasta.

O esperpento criado por Ramón María del Valle-Inclán (1866-1936) tem suas raízes difundidas na própria cultura espanhola dentro da literatura, da pintura e do teatro, adaptando-se já por esse pressuposto à idéia de mescla cultural apresentada 
nas obras de Almodóvar. Nasce de várias contaminações expressivas até tomar forma como gênero resultado de híbrido cultural. Relaciona-se com um conceito de realismo exasperado que abandona a fidelidade à realidade e a substitui por uma distorção com imagens especulativas sobre esse real. A distorção altera os signos típicos da cultura local e inventa outros, claro, utiliza-se deles mesmos para mostrar outra perspectiva. Nesse terreno o autor beberá da fonte do grotesco, que altera as relações com o mundo para ressaltar seu lado mais trágico. Porém, no esperpento, evidenciadas as tragédias, estas são transformadas em fantasias carnavalizadas, direcionando-se para a ironia.

La ley de la distorción esperpéntica utliza el linguage de la ironía en sus múltiples matices y en sus inumerables posibilidades de distorción de los significados; por esta razón, no adopta en nuestro director las distintas reglas y modalidades que presentaba el mundo creativo de Valle-Inclán o Buñuel. Es necesario recordar que la ley irónica de los personajes del dramaturgo gallego o del director aragonés se teñía de lacerante sarcasmo y conseguía los tonos de sátira con el fin de desenmascarar las hipocresías y las ambigüedades de la España de su época. La ironía de Almodóvar tiene que ver con lo grotesco, pero no adopta nunca los tonos cáusticos de la sátira social, ya que en sus películas nunca se aprecia una severa condena moral hacia las diferentes conductas, sino que su juego de deformación esperpéntica presenta rasgos peculiares gracias a su deformante ironía, inmune a la condena moral y capaz en cualquier caso de desvelar aspectos ocultos de la realidad. ${ }^{120}$

Seguindo na discussão do grotesco contido nas obras do autor, vale lembrar que este já existe na memória coletiva espanhola nas suas várias manifestações artísticas, o que o faz tradicional. A própria palavra se refere ao mundo do carnaval como um qualificativo empregado para a encenação dos personagens fantasiados e para o espírito da festa. Nele se encontram a inversão de papéis sociais, a paródia, a caricatura, as brincadeiras picarescas - que mergulham no ridículo -, as piadas chulas e outras obscenidades. Junte-se a isso o hibridismo da relação cidade-campo ${ }^{121}$, onde a ação das personagens aparece marcada pela influência das duas fontes culturais; e veremos que esses elementos aparecem com todas as suas tonalidades nos cenários e no perfil das personagens nos filmes de Almodóvar. Ainda que tenha suavizado sua estética nos trabalhos mais recentes, estes elementos permanecem na estrutura narrativa.

Como resultado do encontro desses gêneros, ainda se inclui numa leitura modernizada o melodrama cinematográfico. O melodrama é um termo de história do

${ }^{120}$ FORGIONE, Anna Pasqualina. Pedro Almodóvar y el esperpento: hacia una nueva retórica e la imagen. In ZURIÁN, Fran A. e VARELA, Carmen Vázquez. Almodóvar: el cine como pasión. Cuenca: Ediciones de la Universidad de Castilla-La Mancha, 2005. p.208-209.

${ }^{121}$ FAUCONNIER, David. Lo grotesco en el cine de Almodóvar. In ZURIÁN, Fran A. e VARELA, Carmen Vázquez. Almodóvar: el cine como pasión. Cuenca: Ediciones de la Universidad de Castilla-La Mancha, 2005. p.196-197. 
teatro que designa em sua origem um drama falado e cantado que, no final do século XVIII, tornou-se distinto da ópera. Como gênero resultante da vida moderna em constante transformação, ele acabou por conter em sua dinâmica um traço bem peculiar de reestruturar-se constantemente, razão pela qual o faz permanecer e ter sobrevivido aos diversos momentos históricos de preferência de público.

Seus traços mais constantes são uma ação intensa fundada em acontecimentos violentos, uma estrutura simples opondo sempre personagens essencialmente bons a outros essencialmente maus, uma intriga com muitos saltos, em geral fundadas em confusão de identidade, e um estilo grandiloqüente que beira o limite da paródia ${ }^{122}$. Com repertório sempre renovado, com novos temas e linguagens por seus novos criadores, estes o mantém atualizado com uma narrativa que atrai o espectador. $O$ advento cinematográfico inaugura uma nova etapa em seu processo de reciclagem.

Em suas origens no cinema, o melodrama não possuía a conformação e nem mesmo esta denominação. Na verdade, isso só viria a ocorrer nos anos 70 . Antes, sua noção esteve totalmente ausente das produções. Não havia em si um termo que o definisse claramente. Nos Estados Unidos, até os anos 20, designava toda trama criminal com muitas proezas físicas. De 1938 a 1955, referia-se a filmes de ação e suspense, o que depois veio a se chamar de filme noir ou cinema negro. Em outros contextos também foi utilizado para definir os filmes catástrofes, de guerra e até os de terror. ${ }^{123}$

Aproximando-se mais da atualidade, ele se aplica aos dramas familiares ou românticos com relatos ligados à sexualidade e ao desejo, porém, como carrega ainda muitos elementos do que o originaram no cinema, seu termo acaba por se diluir e perder força e significado mais profundo, pois enfim, em seu nascimento, já havia um caráter híbrido que, com a sua ampliação, só poderia adquirir essas configurações. ${ }^{124}$ Almodóvar utiliza-se dele, mas também o recicla. Faz inversões nos papéis das mulheres e dos vilões e desenvolve desfechos diferenciados dos moldes clássicos e mesmo dos atuais que os inspiraram, por exemplo, filmes de Douglas Sirkis ou de Rainer Werner Fassbinder.

O pop está, sobretudo, nos primeiros filmes de Almodóvar, com a influência direta de Andy Warhol e de John Watters. O diretor absorve alguns de seus postulados, mas difere do caráter experimental destes. No lugar da crítica à cultura do

\footnotetext{
${ }^{122}$ AUMONT e MARIE, 2003. p.184-185.

${ }^{123}$ RUBIO, Pablo Pérez. El cine melodramático. Barcelona: ediciones Paidós Ibérica S.A., 2004. p. 23-24.

${ }^{124}$ Idem, p. 26-27.
} 
consumo e da standartização dos artistas, que logo se tornou ela mesma padrão, Almodóvar opta pelo ecletismo, misturando gêneros e a cultura moderna dos objetos aos elementos tradicionais da cultura espanhola.

Watters aproxima los motivos pop al espectador mediocre. Eso le brinda la oportunidad a Almodóvar de establecer uma interacción entre la característica expresión de la estética pop y los motivos tomados de los géneros stándar de la producción actual: la comedia, el melodrama, el suspense. ${ }^{125}$

A sensibilidade Camp dialoga com o pop em alguns aspectos. Ela foi a resposta estratégica de dotar de novos significados a velhas formas. Almodóvar realiza um exercício similar quando recoloca resíduos históricos em relações contemporâneas. Com seus amigos, toma a vanguarda no seu processo de reapropriação paródica de elementos centrais para a iconografia tradicional, dotando de novo significado o legado icônico difundido pelo discurso ideológico franquista, subvertendo os códigos que pretendiam reforçar o nacionalismo. Sem se fazer um político tradicional, Almodóvar via a necessidade de uma nova expressão, afinal a ordem social havia mudado. ${ }^{126}$

Por consiguiente, es precisamente a través de la frivolidad de su cine como Almodóvar subvierte el discurso político y social hegemónico. La valorización de superficies y texturas, el sentido del humor y la crítica puesta en cuestión de la sagrada seriedad que dominó la mayoría del arte español de orientación política de izquierda de los años sesenta y setenta sitúan los films de Almodóvar dentro da sensibilidad estética del camp. [....] Susan Sontag enfatiza el exceso como la característica más sobresaliente de la sensibilidad camp. El objeto camp por naturaleza es aquel que se ha atrevido a representar lo irrepresentable fracasando en su intento. Sin embargo, Sontag ve en este fracaso una cualidad enoblecedora, cierta tierna y encantadora ingenuidad. En última instancia, sería precisamente este fracaso lo que valora el contemplador del objeto camp. [...] Sontag subraya [sublinha] la artificialidad del camp, su gusto por lo no natural, esto es, la apreciación de lo artificial que lleva implícita la percepción del mundo como fenómeno estético. [...] La implicación social más obvia de camp es su poder de disolución de la moral social: neutraliza la indignación moral, propone lo lúdico. Pero, más allá de esta cualidad neutralizadora de la moral social convencional - de ahí su utilidad como escudo protector para cierto sector de la comunidad homosexual - para Sontag el camp es, en última instancia, apolítico, dada su preocupación por la textura, el artificio y la estilización. Al contrario de Sontag, para la cual en camp es una sensibilidad inefable y en cierto sentido ahistórica, Mark Booth lo sitúa de una manera muy precisa dentro de la historia de la autorrepresentación de ciertos grupos emergentes. Para Booth, el camp es una sensiblidad y una clase de comportamiento. En general, se origina entre individuos de la clase media que asperjan al estatus de Dany y que no se indentifican con los valores que rechazan por convencionales. Por ello, se puede decir que los elementos fundamentales del camp son la parodia y la ironía. ${ }^{127}$

Vejo que os dois autores complementam, com seus argumentos, um mesmo contexto vivido pelos espanhóis naquele momento em que surgiu o cinema de Almodóvar. Este não pertencia especificamente à classe média, mas vinculava-se a

\footnotetext{
${ }^{125}$ MARKUS, Sasa. La poética de Pedro Almodóvar. Barcelona: Littera. 2001. p. 39.

${ }^{126}$ YARZA, Alejandro. Un caníbal en Madrid - la sensibilidad camp y el reciclage de la historia en el cine de Pedro Almodóvar. Madrid: Ediciones Libertarias. 1999. p. 17-18.

${ }^{127}$ Idem. p. 18-19.
} 
seus membros. Grupos que rejeitavam uma certa ordem política, mas almejavam inaugurar uma nova posição em que pudessem desfrutar livres com suas atitudes e idéias. Para Andrew Ross, o camp foi a estratégia mediante a qual os intelectuais dos anos sessenta puderam agregar-se à estética pop dos resíduos de objetos da sociedade de consumo, sem perder os privilégios que a elite cultural detinha e dos quais o pop mais puro havia fugido ${ }^{\mathbf{1 2 8}}$. Almodóvar e seus amigos seguiram nessa lógica de usufruto.

Por último, o kitsch, que muitos chamam, grosso modo, de mau gosto, lixo cultural, artificialíssimo e outros de arte popular. Seu léxico tradicional, que provém do século XVIII, faz referência à tarefa artesanal de produzir móveis novos como móveis velhos. Em suma, seria falsificar. Seriam determinados objetos artísticos cuja pretensão de realçar a sensibilidade e o bom gosto terminava por revelar o contrário. A grande necessidade de objetos supostamente artísticos fomentada pela sociedade de consumo se proliferou com o advento do cinema e dos meios de comunicação em geral $^{129}$. Não por acaso, além de Almodóvar carregar suas imagens com elementos com características artificiais, há a inclusão constante da publicidade nas cenas de seus filmes, fortalecendo o incentivo para mais consumo e mais produtos kitsch. Foi este fenômeno cultural que o diretor presenciou socialmente quando estreou no cinema e que permanece ainda presente em suas imagens.

Com esses artefatos conjugados, ele inclui seus temas peculiares, muitas vezes ironizando a própria ironia das visões e dos comportamentos praticados em territórios espanhóis ou então diante de algum artista reconhecido como intocável para esse exercício. Foram atitudes como estas que já causaram notórias indignações ou perplexidade de vários analistas de seu país, favoravelmente abrindo possibilidades para novas expressões artísticas. Gerando ou não polêmicas, Almodóvar dialoga inevitavelmente com todos estes cineastas, ainda que - como foi visto - estes possuam suas características próprias para utilizar tal artifício. Os hábitos definitivamente pesam sobre os comportamentos e influenciam as culturas de cada sociedade. No entanto, incidem e se traduzem singularmente em cada artista. Alguns foram vistos aqui e Almodóvar figura entre eles.

\subsection{Os diretores lutam - a manutenção da difícil autonomia}

A trajetória das produções desses cineastas indicou diferentes ritmos de trabalho, tempos curtos ou longos entre a realização de um filme e outro, periodicidade 
de lançamentos ou inconstância, atividades fora do cinema e co-produções. Dentro de suas particularidades pode-se verificar que a busca pela autonomia, seja para garantir uma linguagem seja para se manter nesse mercado, segue uma árdua batalha de negociações e trânsito dentro da complexa estrutura cinematográfica. A discussão a seguir apresentará um breve panorama apontando a posição destes cineastas frente as suas atividades: suas posturas diante do mercado internacional e a geração de alternativas para continuar a desenvolvê-las. Com esses perfis, pretendo mostrar como os diretores buscam soluções para desenvolver seus projetos, num país onde - dentre outros cineastas - Pedro Almodóvar também produz e passa pelos mesmos dilemas.

Fernando Colomo é lúcido em relação à concorrência de seu cinema com Hollywood e não tem pretensões de trabalhar com norte-americanos - apesar de já ter filmado em Nova York - por razões muito próximas aos argumentos de Pedro Almodóvar: perda de autonomia estilística, estética, temática e autoral. Nem pretende concorrer com este modelo de cinema. Para ele, a garantia de um fluxo mais corrente de produções no país pode acontecer com o empenho das autoridades públicas em cumprir na Espanha suas leis ligadas às cotas de exibições européias ${ }^{130}$. Assim, a competição com Hollywood se resolveria de forma diferente e menos desigual. Com a ampliação do público, todos poderiam produzir mais.

O forte apelo da publicidade para os filmes norte-americanos é um outro fator de concorrência desleal que o diretor não ignora. Um instrumento de divulgação que amplia a atração do público e desvaloriza o cinema espanhol. A promoção das produções na Espanha recebe um amparo bastante desproporcional nesse aspecto e, obviamente, diante de uma sociedade de consumo, isso dá frutos imediatos. Colomo argumenta:

El cine cada vez se parece más a la comida rápida: se ve una película y luego se olvida [esquece]. El cine español que funciona es gracias al boca a boca, aunque a veces no hay tiempo suficiente para que esta se pueda producir $^{131}$.

Diante destes desafios ainda incontornáveis, Colomo acredita que seja um diretor rentável para os produtores espanhóis, mesmo porque é produtor e co-produtor da maioria de seus próprios filmes - sua produtora foi fundada em 1992. Do ano de 2002 até agora, esta esteve duas vezes entre as 25 produtoras de maior arrecadação na Espanha. Uma cifra preocupante ainda que consiga, com os resultados das arrecadações, administrar novos projetos. Não por acaso, as relações do diretor com o

\footnotetext{
${ }^{129}$ POLIMENI, Carlos. Pedro Almodóvar y el Kitsch español. Madrid: campo de Ideas. 2004. p. 15-16.

130 Cotas de proteção à exibição de películas - muito semelhantes ao modelo espanhol - estipulando a obrigatoriedade de produções européias nas salas de cinema proporcional aos filmes, sobretudo, norte-americanos.

${ }^{131}$ Disponível em: <http://www.elmundo.es-encuentros digitales>. Acesso em: 23. 04. 2006.
} 
mercado audiovisual espanhol devam ser continuamente amistosas. Como no cinema espanhol há muitas pequenas produtoras e as subvenções estatais ficam cada vez menores, a luta continua frente às majoritárias norte-americanas. O diretor traça sua metáfora: "De todas formas, es la lucha de David contra Golias". E com poucos horizontes para terminar tão cedo.

Almodóvar transita numa lógica próxima à de Colomo, porém ousa mais diante dessa concorrência. Banca e lança seus filmes em território norte-americano, arriscando-se ao crivo da censura - que já o afrontou ao menos em dois de seus trabalhos. Ao ganhar a simpatia de personalidades do mundo cinematográfico hollywoodiano e fonográfico, ampliou a divulgação de seus filmes e de sua própria imagem. Com os prêmios que já recebeu e com sua mudança de linguagem, mais tênue, também garantiu um espaço onde existe uma relação de boa vizinhança e rentabilidade. Sua produtora mantém-se desde 2002 - mesmo com as oscilações entre as 25 de maior arrecadação na Espanha.

Em relação ao mercado internacional - diante deles - Fernando Trueba lançouse um pouco mais. Diferente de Almodóvar, Colomo, Ventura Pons e próximo a Bigas Luna, filmou nos Estados Unidos e em outros países, fez produções caras, ganhou um Oscar como melhor filme de língua não inglesa com Belle Époque (1992), mas também seguiu seu caminho sem cair nas diretrizes das produtoras norte-americanas. Certamente - de todos os cineastas selecionados para esta análise - foi o diretor que mais experimentou diferentes investimentos para concretizar seus projetos.

Como Colomo, também produziu para a TV e incentivou produções de novos criadores. Realizando películas caras fora da Espanha com sucessos consecutivos nos anos 90, o diretor pôde adentrar num campo que parece delinear um viés mais atrativo para ele, alinhando suas buscas no campo da música e da história: o documentário. No ano de 2000, com Calle 54, Trueba fez um trabalho que discutia as relações culturais do jazz latino e as influências espanholas unindo artistas de Cuba, do Brasil e de outros países. Depois de realizar uma ficção, El embrujo de Shangai (2002), voltou ao documentário no filme El milagro Del Candeal (2004), onde apresentou o encontro de Cuba e Brasil por intermédio de alguns de artistas mediados pela discussão sobre a "Ong Pracatum" do brasileiro Carlinhos Brown.

Pelas suas experiências com o cinema norte-americano, Trueba emite algumas opiniões que, apesar da boa circulação que desenvolveu entre seu produtores, deixam evidentes suas restrições e "limitações" criativas apresentadas pela própria estrutura 
que o envolve ${ }^{132}$ :

El cine americano que durante años era un modelo para el cine mundial, hoy en día ha caído en manos de los ejecutivos, de los efectos especiales, de las fórmulas, y entonces ya no hay películas maravillosas del cine americano de aquella época, ya nadie hace Wagonmaster de John Ford, ni The Apartment de Billy Wilder. Ahora es todo el rato explosiones, persecuciones y tiros. A mí me encanta un película buena de tiros, pero mientras que cuente una historia. Creo que el cine americano está muy perdido, aunque hay algunas buenas películas.

Sem a preocupação com o mercado internacional de distribuição nas mãos dos Estados Unidos, com empresários que divulgam o que Ihes convém - sua película La niña de tus ojos (1998) até hoje não teve nenhum distribuidor -, como sinalizada por Colomo, o diretor conclui: "[ ...] No me preocupa mucho, ellos se lo pierden."

Sua primeira experiência hispanoamericana, Two Much (1995) - um filme rodado com estrelas hollywoodianas -, Ihe traz lembranças contraditórias. Uma das mais difíceis, apesar de ser uma comédia. Ainda assim, guarda também boas recordações e um grande aprendizado, por exemplo:

No creo que vuelva a rodar una película con estrellas, no me interesa la estrella como personaje para trabajar con ella. Uno hace películas con actores, con gente normal. Es la metáfora del viaje.

Já realizou com o irmão David vários trabalhos em parceria, seja em roteiros ou produção. David já dirigiu 4 filmes em sua produtora. No ano de 2006 Trueba estava com projetos para cinco filmes, sendo três de ficção, um de animação e um documentário, feitos em cinco idiomas e sete países em sua maior parte desenvolvidos em co-produções internacionais. Notícias que demonstram uma grande versatilidade e disposição para continuar a desenvolver o que gosta e arriscar novas linguagens. ${ }^{133}$

O conjunto cinematográfico se compõe de um thriller romântico rodado em inglês, com Penélope Cruz no elenco, em co-produção da produtora francesa de Luc Besson, EuropaCorp, e roteiro de um jovem escritor norte-americano, Rylend Grant. Pela primeira vez em sua carreira, um trabalho no gênero de animação com desenhos de Javier Mariscal, numa história para adultos "Chico y Rita", com ação desenvolvida na Cuba de finais dos anos 40, ao ritmo de jazz com a participação e música do pianista cubano Bebo Valdés (que participa de Calle 54), com co-produção inglesa.

Um outro trabalho diz respeito a um roteiro escrito a quatro mãos com o francês Jean-Claude Carrière para "El artista y la modelo", história passada na França ocupada de 1943. Também constam a adaptação do diretor de "El baile de la Victoria" para o cinema, baseado no romance do chileno Antonio Skármeta, com produção do

132 MARTOS, Bárbara. Disponível em: <http://www.terra.es/cine/actualidad/articulo.cfm?ID=906>. Acesso em: 03. 01. 2007. 
italiano Vittorio Cecchi Gori, e um documentário musical sobre a recriação da história real de Tenorio Junior, pianista brasileiro que morreu sob a repressão de militares argentinos no final dos anos 70.

Com esta extensa citação de nomes e projetos procurei ilustrar a capacidade de articulações possíveis do diretor que revelam trâmites de grande versatilidade econômica e cultural, resultados das inúmeras experiências colhidas ao longo dos anos e que resumem vários dos traços de suas afinidades. Muitas possibilidades de realização que nem sempre se concretizam totalmente, mas que definem formas de garantir o movimento de uma autonomia, na verdade, de preferência pessoal, pois, como visto, esta "autonomia" depende do estabelecimento de uma grande rede de relações empresariais e artísticas.

A vinculação do exercício cinematográfico a outros formatos também aparece como alternativa mais prática para Manolo Gutiérrez Aragón. Sua associação com as redes de televisão parece, dentre estes, como mais estreita. Além de ter dirigido a série de 5 episódios de $D$. Quixote, também participou da equipe que elaborou a série de 5 documentários Memória recobrada, pela TV La2, onde, por meio de diferentes relatos em várias regiões da Espanha sobre a Guerra Civil, o pós-guerra e o franquismo, procura-se em cada capítulo expôr o que se viveu, sempre com a apresentação de algum personagem conhecido na esfera cultural do país. ${ }^{134}$

Já nos passos artísticos do inquieto Bigas Luna - dados pela sua formação no desenho, pintura, arquitetura e que mais recentemente buscam a linguagem digital e a experimentação -, verificam-se rumos que sempre seguem numa vanguarda que dialoga de maneira alternativa com o circuito tradicional do mercado cinematográfico, com várias experimentações. Uma prática não tão inédita para os diretores catalães. Vale lembrar que o perfil da "Escuela de Barcelona", da qual Lunas e Pons receberam influência, buscava uma linha de cinema independente e experimental. Portanto, referência que conferiu bases para estes cineastas. Essa tendência conduz o diretor cada vez mais por formas diversificadas de produção, tanto pelo meio profissional que já o circunda como pelos novos projetos que desenvolve.

Possivelmente ele caminhou no sentido - em tese - mais próximo de completar suas perspectivas pessoais, pois vem englobando no conjunto de seus projetos as várias dimensões das ferramentas que adquiriu no decorrer de sua vida profissional. Ao

133 Disponível em: <http://www.clubcultura.com/noticias/leer.php?not_id=4477 - 05. 07. 2006>. Acesso em: 04.01.2007.

${ }^{134}$ Disponível em: <http://www.televisiondigital.electronicafacil.net/programaciontv/Article604.html>. Acesso em: 08. 01. 2007. 
calibrar seu discurso estético com as exigências de público e de crítica e ampliar suas possibilidades criativas, garantiu respeitabilidade em seu trabalho, colocando-se num lugar especial que, após tantos anos, o impede de se apresentar somente como cineasta.

Depois de vários anos sem realizar um filme, em virtude da grande atividade em suas oficinas de cinema digital, os "TBL-Talleres Bigas Luna", o diretor estreou em 2006 um novo filme, Yo soy la Juani, uma experiência que lhe trouxe novas e várias idéias. Sobre as oficinas, avalia:

[...] han sido una experiencia muy enriquecedora con los que he podido enseñar lo que yo sé e investigar con las nuevas tecnologías. Estamos viviendo un momento de transición muy interesante en el mundo de la imagen, los analfabetos del siglo XX eran los que no sabían escribir, los del siglo XXI serán los que no sepan hacer películas. He hecho un montaje sobre las "Comedias Bárbaras" de Valle Inclán con el que he podido experimentar con la unión de cine, video, teatro, comida, música, y que es por donde veo el futuro de nuestro trabajo. He realizado varias exposiciones de mis pinturas digitales y video arte, y una video instalación de tres pantallas con Jean Nouvel para el museo Moritz. ${ }^{135}$.

O filme Yo soy La Juani se constitui na verdade num grande projeto de várias

dimensões. Nas declarações do diretor, notam-se os possíveis caminhos que lança à arte de filmar aos seus recursos e que suscitam novas alternativas originadas dentro da própria atividade:

[...] la primera es el ejercicio de pasar de una persona a crear un personaje y convertir ese personaje en nuevo símbolo de nuestra cultura. Un personaje que existe en nuestra sociedad y que es para mi la nueva mujer española del siglo XXI. Descubrir una nueva actriz. Sublimar lo nuestro, hacer una película con una historia entrañable sensual y potente, que sea innovadora, popular, y contemporánea. (...) De la edad que necesitaba a Juani, sobre los 18 años no encontramos con Consol Tura directora del casting, actrices que dieran el perfil deseado del personaje. Con mis alumnos del TBL Taller Bigas Luna, empezamos ha hacer trabajos de campo sobre el mundo de la periferia, investigábamos el mundo de las Juanis y allí empezaron a salir documentos magníficos con muchas de ellas. Decidimos que lo mejor era buscarlas en su ambiente, discotecas, centros comerciales. Hemos visto a casi tres mil niñas, ha sido una experiencia muy enriquecedora y un documento sociológico impresionante. Tardamos ocho meses, éramos un equipo de siete personas. La selección final de las tres mil fue de treinta, de esas pasamos a cinco y de éstas salió Juani, Verónica Echegui, que fue la numero 651 del casting realizado en el Fnac del centro comercial Plaza Norte de Madrid, es San Sebastián de los Reyes.Con todo el material que tenemos de los casting me estoy planteando hacer una película documento, ha estado lleno de anécdotas $\mathrm{y}$ un retrato de la realidad social muy interesante[...]. ${ }^{136}$

Descobrir novos talentos faz parte de um hábito cultivado pelo diretor que, durante todos seus anos de cinema, acabou lançando Penélope Cruz, Francesca Neri, Jordi Mollá e Javier Bardem. Sempre no intuito de conceder oportunidade a artistas

${ }^{135}$ Entrevista: Bigas Luna. Cinestel. Barcelona, 2006. Disponível em: <http://www.cinestel.com/41701/1901.html>. Acesso em: 08 jan. 2007.

${ }^{136}$ Idem. 
novos que demonstram interesse no ramo, Luna estende este incentivo para toda a produção cinematográfica. Já incorporou em sua equipe os melhores alunos das oficinas de cinema digital que desenvolve desde o ano de 2002. Mas, aos que imaginam por isso que ele acredita numa vida eterna para o modelo tradicional de cinema em decorrência de sua própria prática no mundo digital, reflete:

Desde el punto de vista creativo estamos en un momento extraordinario, hoy cualquier persona puede hacer una película y mandarla al otro lado del planeta para que en pocos segundos alguien la vea, esto es casi un milagro, estas son las buenas noticias, por otro lado esto está generando unos cambios en la forma de hacer, de ver y de difundir nuestro trabajo impresionante, y que muchos aún hoy están intentando comprender y asimilar. Todo está cambiando y tenemos que entenderlo. 'Yo Soy La Juani' es un proyecto que pretende estar al lado de todo lo que esta ocurriendo y utilizarlo tanto para la creación como para al difusión del proyecto. Antes una película solo se veía en las salas de cine y en la televisión, más pequeñita, y con algunos cortes. Hoy son las salas, las televisiones, los video clubs, internet, la telefonía móvil, y desgraciadamente también en los top manta [vendedores ambulantes]. La paradoja es que si tu película no está ahí es que no funciona, la gente que va al cine tienen de 13 a 18 en un $80 \%$ y hoy puedes ver una película en tu casa con más calidad de imagen y sonido que en algunas salas, de manera que hoy todo esto hay que entenderlo, asimilarlo, saber donde estamos, lo que tenemos que hacer, para quien lo hacemos y como queremos que lo vean. Los códigos y sistemas anteriores no sirven. Las cosas están cambiando. Erika dice que no va al cine porque prefiere ver las películas en el sofá de su casa, la chica del video club al pedirle unas películas de Renoir que no tenía, me dice que lo mejor es buscarlas en internet ... [...] las salas de cine prevalecerán porque son el elemento promocional más grande que existe para lanzar una película, si una película no va a las salas no crea estado de opinión, ni crítica elaborada. Las películas que van a las salas son las que luego se ven mas por la televisión y de las que se habla más. Lo que ocurre es que hoy hay que pensar en nuevas formas de diseñar y dotar técnicamente las salas, que el público lo que vea o sienta en una sala no pueda sentirlo en su casa, ahí está una de las claves. Y también en las televisiones, internet, DVD , y la telefonía móvil. Cada vez creo más en las formulas de distribución simultanea en todos los formatos posibles. La experiencia de Soderbergh con Bubble es premonitoria como la que ya hizo Jane Deknatell para HBO en LA en el año 1982. Pero en cualquier caso el gran futuro del cine esta en internet con la descarga directa de pago. ${ }^{137}$

Sem pessimismo, nas atitudes de Bigas Luna, constata-se que a linha de trabalho e a forma de administrar a tecnologia não apenas abrem novos olhares sobre as linguagens, como também incrementam a relação com novas histórias, personagens e maneiras de se organizar fontes de informação para refletir e criar sobre elas. Sua postura também amplia alternativas de mercado e, conseqüentemente, novos rumos para seu cinema e o papel deste na sociedade contemporânea.

Ventura Pons, como já visto, inicia sua vida cinematográfica amparado pelo reconhecimento que já possuía no meio teatral. Assim, pôde desenvolver-se no cinema de maneira mais fluida que Almodóvar diante do establishment cultural espanhol, em especial o catalão. Conhecendo de antemão as regras do campo artístico, ele teve possibilidades de avançar em seus projetos, firmar suas preferências de estilo e 
experimentar novas incursões na linguagem cênica com maior mobilidade. A legitimidade no campo artístico, anterior ao cinema, Ihe rendeu bons dividendos mesmo este se configurando num novo território. Segundo ele, o teatro deu a ele o conhecimento do mundo autoral e lhe mostrou os pré-requisitos necessários para se fazer um filme criterioso: uma boa história, um bom elenco e uma boa narrativa. Em sua compreensão estes são pilares inseparáveis, sem os quais não há filme:

[...] Uno se expresa a través de los actores, ellos te crean unos personajes y tienes que saber su técnica, tienes que saberlos manejar para conducirlos hacia el concepto de tu puesta en escena. Esto, sin saber bien como trabajar la técnica de los actores, es imposible. El teatro me ha dado el conocimiento del mundo actoral. ${ }^{138}$

A forma de filmar, colocando a primazia de foco no ator, atribui a Ventura Pons uma singularidade. Ela evidencia uma narrativa concentrada no texto, no sentimento e na imagem. Com isso, constitui um grupo de espectadores identificados com sua narrativa. Segundo ele, a representação convincente sobre a personagem, ao mesmo tempo reconhecida como tal diante do público, deve fazer parte de qualquer atividade no exercício profissional do ator. Por isso, para ele não há distinção entre o ator de cinema e o de teatro:

[...] Yo no distingo entre actor de cine y de teatro. Un actor incorpora un personaje y para teatro hay una técnica, para cine hay otra y para TV hay otra. Lo que un director debe saber es cómo explicarle al actor exactamente lo que quiere y conducirlo hacia el concepto de la película ${ }^{139}$.

O fato de ser produtor e diretor de seus filmes - a exemplo de muitos outros torna Pons autogestionário, significando para ele um mecanismo de maior liberdade criativa, que o permite realizar aquilo que realmente tem vontade:

Mi cine no se entendería si yo no fuera mi productor. Porque que coño de productor tradicional va a entrar en una película como esta (Morir o no) donde todos se mueren o la anterior sobre un profesor que se está muriendo (Amic, amat, 1998) y que pide la eutanasia y está enamorado de un chaval que quiere que sea su heredero? Los productores no apuestan por este tipo de historias, como, duras, y al público le gustan. ${ }^{140}$

Esta também foi a alternativa de Almodóvar e de outros cineastas, dentro e fora da Espanha, que possuem suas próprias produtoras, tanto em razão da defesa de propostas narrativas como para garantir a concentração de recursos. Atitudes à primeira vista defensivas, à primeira vista, mas que justificam olhares que compreendem o mercado cinematográfico com algo instável, sobretudo quando se subordinam novas produções aos critérios de grandes estúdios ou produtores.

\footnotetext{
${ }^{137}$ Idem.

${ }^{138}$ Disponível em: <http://www.canalok.com/cine/venturapons.htm>. Acesso em: 30. 05. 2006.

${ }^{139}$ Idem.

${ }^{140}$ Idem.
} 
As expectativas diante da expansão de mercados frente à linguagem esperada pelos produtores e à que os diretores ou autores trazem são amplas, curiosas e imprevistas. Muitos comparam o estilo de Pons ao de Woody Allen, cineasta consagrado que parecia legitimado pela indústria cinematográfica norte-americana, ou seja, que teria livre acesso para financiamento de novos trabalhos.

No entanto, para produzir Match point (2005), Allen precisou buscar capital de produtores ingleses, pois não despertou o interesse dos estúdios para suas novas produções nos Estados Unidos. Ou seja, não basta estar incluído numa linguagem "universalizada", segundo padrões norte-americanos, para sustentar linhas autorais e histórias. Os detentores do capital financeiro cinematográfico seguem outros mecanismos e ambições para ampliar mercado, os quais não passam necessariamente por espectadores simpáticos às novidades deste perfil de autores.

No caso de Almodóvar, a negociação de co-produções evita um total controle sobre suas películas e simultaneamente garante sua divulgação. Por isso consegue exibir seus filmes em diversos países e mercados cinematográficos e se manter independente de produtores estrangeiros, ainda que não livre de alguma interferência. Kika (1993), La flor de mi secreto (1995), Carne trêmula (1997) e Todo sobre mi madre (1999) tiveram co-produção francesa com o objetivo de agilizar a distribuição das cópias. Porém, ocorreram discretas intervenções visando a adaptar - segundo os produtores - a compreensão cultural do público ao estilo do filme, como ocorreu em Kika, que Almodóvar - em razão da estrutura fragmentada de montagem da história havia originalmente intitulado Collage ${ }^{141}$. Dessa forma - à parte suas boas películas -, as várias estratégias e negociações que o diretor encontra para evidenciar suas produções, ecoam, em geral, de maneira relativamente mais ampla do que as escolhas de Ventura Pons.

Trabalhando no ritmo de um filme por ano - o que está longe de se constituir como modelo industrial -, Ventura Pons busca na literatura catalã o material para alimentar seu trabalho, como em Amic/Amat. Além disso, costuma rodar seus filmes em catalão e quase sempre traduzi-los para serem distribuídos por toda Espanha e em diversos países. Atitudes estas que - conscientes ou não - agradam e ampliam uma considerável simpatia de catalães mais puristas e que, de certa forma, Ihe garantem uma legitimidade mais extensa dentro da Espanha do que fora dela.

Para se manter no jogo de expansão cinematográfica, a obra de Almodóvar segue um caminho que se processa no campo de temáticas afetivas, com imagens que

${ }^{141}$ TORREIRO, M. Las críticas a 'Kika' no me afectan. Espetáculos, EI País, Madrid, 03. nov. 1993. 
mesclam regionalismo com vida metropolitana. A partir delas provoca uma instigante atração no público que busca uma alteridade cultural, porém a assiste integrado a elementos ou preocupações sociais contemporâneos dentro de sentimentos que lhes são familiares. Uma fórmula que integra seu estilo, associando-o a decupagens ${ }^{142}$ correntes e clássicas e a formas narrativas de sentimentos já assimiladas pelo espectador, proporcionadas pela própria difusão de seus filmes por distribuidores norteamericanos e europeus.

Para Pons - que possui sua própria produtora -, a combinação entre produtor e diretor é a base da liberdade e da independência de seu trabalho. Com ela tem condições, inclusive, de investir em projetos para financiar novos cineastas e criadores. Obviamente, segundo a capacidade que sua empresa comporta. Limite dado por qualquer outra produtora, mesmo que vise a fomentar a produção de futuros talentos e a aquecer o mercado da produção nacional. El Deseo de Almodóvar, uma das 25 produtoras mais rentáveis na Espanha nas últimas décadas, ainda que partilhando dessa prática, também aponta suas condições. A equipe interrompeu - ao menos até a data do final desta pesquisa - por tempo indeterminado o recebimento de novos roteiros e projetos em razão do excesso de propostas enviadas.

No caso de Victor Erice, ao pender para o terreno da publicidade, ele especificou uma alternativa de dar continuidade ao manuseio das imagens sem se dedicar exclusivamente ao grande complexo da indústria do cinema. Deixou claras sua narrativa e sua mensagem no conjunto de filmes que produziu, conformando sua assinatura. Sua imagem tranqüila e seu projeto autônomo, ao que parece, significaram exatamente fazer os trabalhos que considerou necessários e manter sua sobrevivência num terreno que não o afastasse das imagens e que ao mesmo tempo lhe garantisse retorno financeiro. Porém, ao que tudo indica, o fato de haver uma censura dissimulada nas mãos de produtores e do próprio Estado, que se apóia e se aliança com eles nos discursos sobre freqüência de público como condição de êxito e de qualidade - por isso, quantidade - das películas, acabou desmotivando o diretor para prosseguir com novos trabalhos. Erice afirma:

Es el famoso Veredicto del Público, al que se suele recurrir en nombre de una razón suprema: la Razón del Contribuyente. Lo apuntaba con ironía Rafael Sánchez Ferlosio en un artículo titulado "Cultura, ¿para qué?" Veredicto del Público pero, ¿de qué público? ¿Del que frecuenta día y noche los espacios de televisión de mayor audiencia? ¿Es que acaso el Público no es precisamente una fabricación previa y permanente desde las alturas, una falsificación de lo que hubiera de gente común y corriente en este mundo? La educación, sobre todo bajo el imperio del audiovisual, a la que un niño se halla condenado desde

142 Forma de executar cortes na imagem da ação dramática, numa seqüência que provoca efeitos estéticos e resultados narrativos eficazes com sentido lógico para a estrutura da história contada. 
que abre los ojos, fabrica eso que llamamos tan inocentemente Público, sus gustos, sus necesidades y hasta sus emociones. Es evidente que así, con tan uniformador y potente foco de educación, la demanda de banalidades desde abajo, desde el consumidor, cada día se identifica más con la administración de banalidades desde arriba, desde los medios y los órganos de poder, tanto industriales como culturales. La noción de Público - unida a su demanda de entretenimiento - que se utiliza desde las altas instancias ha hecho recordar a más de uno estos versos: "Porque como las paga el vulgo, es justo/ hablarle en necio para darle gusto" que Lope de Vega escribió a modo de cínica justificación de no pocos aspectos reaccionarios de su teatro. A los versos de Lope habría que contraponer la sabia fábula de don Tomás de Iriarte a propósito de la protesta del burro a su desconsiderado amo, que le echaba de comer paja a todas horas, repitiéndole siempre lo mismo: 'Toma, puesto que con esto estás contento." Hasta que un día el burro se hartó y le dijo: “Tomo lo que me quieras dar. Pero amo injusto, crees que sólo de la paja gusto, dame grano y verás si me lo como." Claro que es posible que, a estas alturas, ya no queden burros que distingan el grano de la paja y todos se traguen agradecidos lo que les echen. Pero no hay que ser pesimistas dogmáticos, que todavía hay por ahí uno que otro burro no virtual, que sabe distinguir. ${ }^{143}$

Assim, para Victor Erice, o que mais incomoda é ver o cinema transformado num simples negócio e não num instrumento poético ou reflexivo. O comércio sempre esteve presente no cinema, mas o mercado o tornou simplesmente uma fonte de renda:

\begin{abstract}
En los primeros tiempos del cinematógrafo, la creación - entre los cineastas primitivos abundaban los creadores, verdaderos artistas que no tenían conciencia de serlo, y eso era lo bueno - se comercializaba de una forma digamos natural. Para entendernos, la obra nacía como una criatura más o menos libre, como por descuido, y luego se entregaba al mundo. Ahora, sin embargo, la inmensa mayoría de las películas tienen que nacer ya vendidas. El mercado es quien dicta absolutamente la ley, quien decide lo que debe existir y lo que no. La máxima que en su día vocearon los productores norteamericanos - 'una buena película es aquélla que gana dinero y una mala aquélla que lo pierde' - ha sido aceptada prácticamente por el mundo entero, de tal modo que, a propósito de una película que está en cartelera, la cualidad suprema que la publicidad maneja son las entradas vendidas, el dinero recaudado; cifras y más cifras - que, en ocasiones, no corresponden exactamente a la realidad - que se exhiben para hacer que el espectador considere ese producto como algo necesario, de visión obligada. La auténtica sacralidad no está ahora en la bondad de la obra sino en el mercado, en su capacidad para mover dinero. ${ }^{144}$
\end{abstract}

Com sua maneira calma de falar e de colocar suas idéias, Erice imprime efetivamente uma crítica aguda de descontentamento sobre um grupo empresarial poderoso que impede a manifestação livre e mais ampla de novos autores ou de outros talentosos atuantes, que vêem suas inspirações se desvanecerem ao sabor desse modelo de mercado. No "Primeiro Congresso de Cinema Europeu", realizado em Barcelona no ano de 2005, ele não só apontou este aspecto como reforçou sua total descrença na possibilidade de um cinema europeu criativo e eficaz enquanto prevalecerem estas regras. Talvez seu poder de síntese tenha se contentado

\footnotetext{
${ }^{143}$ CAMPAÑA, Mario. Memória y sueño: entrevista con Victor Erice. La Jornada Semanal. Ciudad de México, 6 fev. 2000. Disponível em: <http://www.jornada.unam.mx/2000/02/06/sem-erice.html>. Acesso em: 06 jan.2007. ${ }^{144}$ Idem.
} 
realmente com três películas realizadas, um limite que suportou também para este tipo de relações mercadológicas e que ele preferiu ironizar, assumindo de vez na publicidade o papel das imagens transformadas em meros produtos.

Almodóvar estendeu-se para registros que, enfim, também configuram sua assinatura, porém de maneira mais diversa. Não seguiu ou constituiu uma linha ideológica. Em suas várias fases criativas, mesmo sem perder o eixo de seu tema principal - o desejo -, deixa e constrói imagens muitas vezes se contrapondo sensivelmente a anteriores. Uma das razões se deve a seu amadurecimento pessoal. Outra, foi o que aprendeu nesse mercado concorrencial - apontado por Victor Erice -, dosando e utilizando a seu favor cada uma das ferramentas de seu discurso que, mais recentemente, parecem surtir maior efeito do que nas épocas quando insistiu em atitudes mais radicais em suas imagens. A cautela substituiu a ousadia numa forma de agradecimento ao sucesso, este que por sua vez só é mantido pela ponderação ou por certas tolerâncias. Talvez o cineasta tenha se inspirado mais na serenidade de Erice do que em sua radicalidade.

Eloy de La Iglesia, que sempre manteve uma postura política militante e definida de esquerda, também pôde desempenhar bem sua trajetória. Não fossem seus próprios problemas de saúde - que o afastaram do campo audiovisual durante vários anos- teria desenvolvido mais seu trânsito entre a TV e o cinema - como fez assim que se recuperou. Sua enorme preocupação com os problemas nacionais ligados à desigualdade social e à liberdade política e individual sugeriu poucas relações com mercados internacionais - duas co-produções com o México e uma com a França ainda que o alcance de suas obras ultrapassasse as fronteiras da Espanha. No entanto, seu grande prestígio na TV como diretor e roteirista dariam a ele um respaldo satisfatório para realizar novas películas, como foi o caso de seu último trabalho, Los novios Búlgaros (2003), que teve a participação da TVE S.A., Vía Digital e EITB, além de duas produtoras.

Com Jaime Chávarri, respeitado por uma obra prolífica e pessoal nas artes audiovisuais dentro do panorama audiovisual espanhol, verifica-se uma posição política mais direta diante do quadro nacional do que os outros diretores. Sólido em suas posições relativas à política cinematográfica do país, entende que - diante da crítica que fazem sobre a excessiva dependência dos cineastas às subvenções - as novas alternativas para um desenvolvimento comprometido com a cultura do país devem passar por um viés amplo de discussões que tenha no centro a pauta dos valores públicos no âmbito do Estado: 
Las subvenciones son necesarias en situaciones de competencia desigual. Por supuesto, esta discusión es inútil si no se considera el cine un bien cultural. Las alternativas en Europa solamente han funcionado en Francia, a base de controlar la importación de películas americanas ${ }^{145}$.

Quando olha para a produção espanhola, não the parece que o exercício político para novos projetos entre jovens produtores seja uma prática constante e resulta um tanto impossível adivinhar seus contatos políticos. Num contexto como este, as negociações tornam-se imprescindíveis, porém não percebe que o exercício político seja um instrumento importante incluído na pauta entre os novos criadores. Situação preocupante, pois obviamente enfraquece a organização desses profissionais. E, para crescer, não se pode tratar tal prática sob a ótica da aversão ou do distanciamento. A própria definição do termo "produção independente" é bastante questionável quando não se inclui junto a ela os trâmites do manuseio político:

Independientes ¿de qué o de quién? Producir en este país tiene bastante mérito y prácticamente todos los productores que no están adscritos a grandes grupos mediáticos son independientes. Pero como esos grupos mediáticos también participan en películas de otros, la situación podría definirse como bastante ambigua ${ }^{146}$.

À parte o complicado jogo de estratégias para produzir e permanecer no mercado cinematográfico, para o diretor - muito mais do qualquer teoria ou aprendizagem oficial - o mais importante é contar histórias, filmar, começar com curtas, ter a experiência com a câmera. Uma concepção que desfaz mitos construídos em torno da universidade e que remete à experiência vivida por Almodóvar, que, diferente de Chávarri e de todos os outros cineastas apresentados aqui, não passou pela vida acadêmica cinematográfica.

Quanto à esfera da execução das produções dos cineastas analisados, ocorre entre eles um constante compartilhamento profissional amistoso. Apesar de trabalharem com equipes quase fixas, sempre fiéis e cúmplices de suas funções técnicas entre si, nota-se pelos próprios créditos das películas que em mais de uma ocasião estes cineastas trabalharam juntos e que os membros de suas equipes transitam por várias produtoras. Atores e atrizes não se prendem a nenhum diretor como artistas exclusivos como faz crer a ação da mídia, autora de inúmeros chavões.

"Las chicas de Almodóvar"147 [meninas de Almodóvar] é um desses termos de excelência forjados pela imprensa e designa - ainda hoje - atrizes que foram "descobertas" ou então trabalham preferencialmente com o diretor, dentre as quais

\footnotetext{
${ }^{145}$ Disponível em: <http://www.w3.elmundo.es/encuentros/invitados/2004/04/1054/>. Acesso em: 05. 01. 2007.

${ }^{146}$ Idem.
} 
Carmen Maura foi a mais proclamada. O próprio Almodóvar em ocasiões oportunas já negou esta formulação. Porém, este - assim como outros "rótulos" - acaba se mostrando incontrolável e estigmatiza todos os envolvidos com o cineasta.

Economicamente, o fato de a maioria destes diretores produzirem filmes incentivando iniciantes, além de tornar mais ampla suas participações no mercado para ramificar atividades, também aumenta a visibilidade de seus nomes e produtoras. Amplia a oportunidade e a quantidade de novos diretores, expandindo a própria produção nacional. Uma busca simultânea por sobrevivência, ampliação de idéias e público que não visa a uma concorrência cerrada entre eles e nem a uma cobrança exclusiva do Estado - ainda que este deva garantir subvenções para a produção ou deixar claro seu papel de apoio considerando-se que também possui seus interesses.

Almodóvar, por exemplo, produziu até o ano de 2005 nove películas de novos cineastas, algumas delas fora da Espanha, como La niña santa (2004), de nacionalidade argentina. Esse movimento produtivo consolida papéis profissionais e delineia uma respeitabilidade que legitima projetos e trabalhos em andamento, criando inclusive possibilidades de novos diálogos com setores ligados a leis e subvenções estatais. Estende também as fronteiras mercadológicas de vários setores ligados ao cinema, não somente dos cineastas.

Enfim, diante desse panorama, creio que o lugar político e econômico desses cineastas e de suas produções tenha ficado mais claro. Alguns circulando igualmente entre os diversos meios audiovisuais, outros ligados diretamente só ao cinema. Alguns mais próximos de exercícios políticos com o Estado, outros aparentemente alheios, porém, num país onde se conta com subvenções, sabe-se que é impossível manter-se afastado desse diálogo. Resta conhecer agora, nesse exercício comparativo entre eles, como desenvolvem suas temáticas, personagens e linguagens para aproximá-las às realizadas por Pedro Almodóvar.

Acredito que já foi possível constatar, até agora, que as formas utilizadas pelo diretor para desenvolver-se e manter-se profissionalmente não são de exclusividade sua. A prática dos outros cineastas é muito similar. Alguns se ramificam em territórios mais ousados da linguagem visual, outros se articulam com agentes interessados em parcerias interdisciplinares. Estariam eles também sintonizados quantos aos temas e abordagens? A discussão comparativa dessa geração de cineastas começa a fechar seu ciclo.

${ }^{147}$ La Vanguardia, Barcelona, 27 ago. 1989, p. 49; STRAUSS, Frederic. La conquista de Europa. El Pais, Madrid, 17 out. 1993. En portada, p. 31; HARGUINDEY, Angel S.. Las chicas de Pedro. Avui, Barcelona, 28 mar. 1999. En portada, p. 28-36; FRANCIA, Juan I.. Pedro Almodóvar. La Vangardia, Barcelona, 30 jan. 2000, p. 31. 


\section{TEMÁTICAS E PERSONAGENS - VERSÕES DE UMA GERAÇÃO}

Essa geração de cineastas, nascida na ditadura e que viveu sua juventude dentro do processo histórico compreendido entre o tardo-franquismo e a consolidação da democracia, carregou consigo experiências singulares permeadas pela vivência em diferentes famílias, escolas, círculos de amigos e espaços culturais. Estas determinações moldaram seus olhares e se traduziram em filmes com diversos enfoques temáticos. Assim, ao verificar suas formas de construção e abordagem, é necessário considerar que estas obras são estruturadas por tais bases sociais e não apenas pela aparente liberdade de escolhas narrativas e pelas personagens.

Há inevitavelmente um recorte de classe social e conseqüentemente cultural que além de sustentar, permeia todo o conteúdo dos trabalhos - que deve ser considerado. Os cursos nas universidades, a motivação para discutir e participar da política, o contato com as práticas culturais, tanto aquelas já instituídas - as aceitas e as recusadas - como as inovadoras ou opcionalmente vividas à margem dos círculos oficiais. Estes são alguns dos vários ingredientes que contribuíram e continuam a exercer influência sobre a percepção e as atitudes destes autores empenhados em apresentar à sociedade suas mensagens nas leituras cinematográficas. Porém, não se trata de mostrar aqui um panorama de temáticas.

No capítulo anterior, a comparação entre as ironias elaboradas pelos cineastas em seus filmes foi apresentada com o objetivo de destacar como esta maneira de expressão está presente de modo significativo nos conteúdos de vários ramos da arte na produção cultural da Espanha, portanto não se configurando numa particularidade de Almodóvar. Sua elaboração se singulariza pela sua forma de articular e elaborar sua percepção sobre aspectos de sua sociedade, mas não é única e nem isenta das influências destes e de outros autores - espanhóis e estrangeiros. Não é uma saída por si só inovadora, mas parte de um conjunto de elementos já disseminados na cultura do país, por sua vez, também entre os cineastas de sua geração.

Agora, incorporando estas condições citadas, nesse próximo passo da análise pretendo investigar as demais linguagens e personagens que os cineastas aqui selecionados utilizam para operar suas temáticas e, a partir delas, verificar quais possuem vínculo direto com os trabalhos de Pedro Almodóvar. Como apontei há pouco, do mesmo modo que o uso da ironia não é seu mérito exclusivo, também existem abordagens em seus filmes que aparecem nas obras desses autores, como: personagens ou atitudes não convencionais, sexualidade e homossexualismo, quebras 
de valores morais e paixões excêntricas. Com maior ou menor intensidade de risco para a recepção do mercado - público, produtores, distribuidores e críticos -, eles traçam os contornos do que observam, seja os sentimentos latentes que manifestam em potencial suas necessidades ou as relações sociais que vêm se processando na sociedade.

Baseado nesse conjunto de pressupostos, buscarei completar este mosaico de manifestações que ilustra o contrastante universo da produção cinematográfica contemporânea na Espanha e no qual Pedro Almodóvar se inclui - em suas semelhanças e peculiaridades. Novamente, assim como nem todos os cineastas adotavam a ironia como ferramenta usual para seus procedimentos expositivos - e por isso não entraram na discussão - neste capítulo alguns também não constarão como objeto comparativo porque tratam de temáticas distantes daquelas eleitas por Almodóvar. Outros cineastas, cujos trabalhos possuem poucas referências aos dele, serão pouco confrontados.

\subsection{Estilos e temáticas - quando rir conta mais}

As escolhas narrativas dos autores indicam suas preferências estéticas e os caminhos pelos quais conseguem maior desenvoltura para contar suas histórias. $\mathrm{O}$ que se designa "estilo próprio" só começa a se desenvolver na medida em que cada um incorpora as regras existentes e as ajusta ao seu ritmo e preferência pessoais. Às vezes são tantas as propostas similares de cada artista ligadas a concepções e a maneiras de filmar, motivadas pelas capacidades de inovação técnico-estilísticas ou por ideologias de cunho artístico e político, que estas acabam se constituindo num movimento. O Neo-realismo na Itália ou a Nouvelle Vague na França ilustram exemplarmente este aspecto. Em outras ocasiões, cada diretor segue sua linha particular. Inspira-se em todo esse leque de alternativas e constrói sua própria leitura.

O que ocorre no cinema da Espanha a partir dos anos 70 e 80 do século XX é uma eclosão de vários estilos, dos quais os diretores discutidos aqui são representantes expressivos. Um momento que significou um salto de qualidade para toda a cinematografia do país. Mas, diferente de épocas anteriores, estes cineastas não constituíram nenhum movimento ou nenhuma linha estética coesa entre si que os pudesse identificar como grupo. Ainda que a grande imprensa buscasse forjar coesão sob alguns aspectos.

E acredito que realmente não constituíram, em decorrência das próprias circunstâncias sociais e políticas ocorridas no país e mo mundo naquele período. Os 
acontecimentos advindos desde a crise do petróleo, todo o processo que culminou com o fim da guerra fria, os avanços tecnológicos e a reestruturação econômica provocaram mudanças radicais na esfera da produção e consumo mundiais, ecoando inevitavelmente sobre a cultura. Este conjunto de fatores gerou um novo perfil de cidadãos mais individualizados e repercutiu sobre a criação dos cineastas. Suas obras podem ser compreendidas como um reflexo da consolidação de um modelo de sociedade individualista, calcada na idéia da novidade - ilusoriamente - única.

Ainda que o espírito político vigente na Espanha fosse outro, as relações que se processavam cotidianamente absorviam esse novo modelo individual, fomentando um novo comportamento. Não muito diferente de outros lugares. No Brasil, por exemplo, isso também se ampliou. E os anos 80 igualmente foram marcados por mudanças políticas e uma explosão criativa que não gerou movimentos culturais específicos como em outras décadas, sobretudo no cinema. Muito menos França ou Itália tiveram novidades que resultassem numa nova proposta estética cinematográfica. Portanto, sob a dimensão coletiva esse panorama sugere isoladas visões e perspectivas de cinema. Por outro lado, a aproximação de seus resultados traz informações importantes, tanto para a compreensão da dinâmica cultural do país e de seus diretores como sobre os efeitos constitutivos de discussões acerca da mudança de olhar que refletem e propõem.

Nesse quadro, Pedro Almodóvar cria individualmente uma fatura que afirma e contrapõe sua geração. Afirma, ao alinhar-se com as comédias, com a ousadia de temas existente no período de sua estréia, prosseguindo toda a década de 80 beneficiando-se do prestígio contraditório e polêmico gerado por películas que dividiram radicalmente as opiniões. Contrapõe, pela forma como abordou seus temas e por neles não recorrer diretamente à política - algo esperado dos cineastas pelo meio artístico e intelectual - e ainda por assumir uma postura de deboche que demonstrava agredir valores culturais arraigados no país. Não fez uma reflexão sobre eles, filosoficamente como Buñuel - sobretudo em torno da religião - ou moralmente com Saura acerca da família. Seu cinema não tinha essas proporções e nem o diretor, dimensão pessoal para isso. Somente no decorrer de sua carreira - com a maturidade - este perfil se transforma e as questões que estruturam e intervêm nas relações começam a preocupá-lo. No entanto, mesmo mais sério, é possível detectar fragmentos - de maneira menos contundente - dos aspectos iniciais de sua carreira nas películas que produziu a partir dos anos 90. As trajetórias de seus contemporâneos quase determinam o mesmo caminho percorrido. Mantiveram seus 
estilos, expandiram suas temáticas e seus mercados.

Começando pelo conjunto de cineastas cujos trabalhos são preponderantes no gênero da comédia, pode-se traçar os perfis de Fernando Colomo, Fernando Trueba e Ventura Pons como os mais característicos de irreverências que permanecem até suas últimas realizações. Os três cineastas centram suas narrativas em histórias de estilo sofisticado, em que a preocupação com figurinos e fotografia aparece de maneira bem acabada, com equilíbrio de cores e cenários econômicos, sem muito rebuscamento. Apesar de suas películas em geral privilegiarem personagens de classe média - em geral pessoas ligadas à música - com histórias girando em torno de problemas de relacionamento, sobre amor-desamor, ciúme, traições e de não colocarem peso político em primeiro plano, ocorrem nuances importantes entre eles.

Colomo carrega simpatia por grupos populares de Madrid como aparece em La vida alegre (1987), sobre a história de uma médica que entra em contato com a vida marginal a partir de seus pacientes num hospital de doenças sexualmente transmissíveis. Seu filme El próximo oriente (2006) volta ao bairro de Lavapiés, que já havia sido cenário de Bajarse al moro (1988), para falar da imigração, do multiculturalismo, do choque entre culturas e das relações familiares.

No entanto, é no universo da vida pequeno-burguesa - da qual faz parte - que encontrará as fontes das tramas onde se vê mais tranqüilo e com liberdade para poder satirizar seu universo, como em El cuarteto de la Habana (1998), ao discutir padrões familiares, seus tabus amorosos e seus constantes problemas econômicos. Mesmo quando se remete a filmes de época - Los años bárbaros (1998) - encontram-se ali todos os códigos dessa classe como protagonista e de seus conflitos. De antemão, diante da apresentação de alguns dos temas que aborda, denota-se que existe uma habilidade prontamente disponível do autor para transformar a comédia num veículo capaz de discutir assuntos sérios e conflitivos, sem perder seu espírito crítico.

Já em seu segundo trabalho, Qué hace una chica como tú en un sitio como éste? (1978), temas similares e grupos sociais médios estão dados ainda que misturados a outras classes, com predomínio de uma juventude integrada na vida social do país. Este, entretanto, mesmo fornecendo as linhas gerais que percorrem a obra do diretor, não possui o refinamento e o traquejo com a câmera que passará a conquistar nos próximos trabalhos. Paira no ambiente desta produção uma atmosfera amadorística de improviso. Embora fosse a segunda película do diretor, em vários momentos as imagens parecem feitas de uma maneira mais inexperiente do que as apresentadas em Pepi, Luci, Bom y otras chicas dél montón, a primeira de Almodóvar 
Em compensação, e para efeito de análise estética e histórica, ambas refletem uma construção de imagens que indica linhas estéticas coletivas da época que demonstram os primeiros esboços pela busca de uma linguagem própria admitindo "liberdades" narrativas. Não se enquadram devidamente na estrutura clássica cinematográfica e arriscam experimentações como a linguagem de quadrinhos em Pepi, Luci, Bom y otras chicas del montón e a diluição dos gêneros thriller, comédia, drama numa única fórmula em Qué hace una chica como tú en un sítio como éste ? Neste filme, as cenas abertas - como sem a intervenção do diretor - vistas nos shows parecem colocadas somente a cargo dos figurantes. Um fator que aparecerá também de modo mais sutil numa câmera que percorre praças e cenários absolutamente naturais - quero dizer, não construídos em estúdios -, captando simplesmente o cotidiano urbano em Opera prima de Fernando Trueba.

Esse filme de Colomo também indica sua relação familiar com a cidade, que se repetirá nos posteriores. Não há estranhamento; como o que se passa nos dois primeiros filmes de Almodóvar em que há um fascínio pelo brilho da vida urbana que aguça sua observação, fazendo-o manusear a câmera para o registro de constantes novidades. Sua Madrid era a cidade da festa interminável. Um ritmo que ele vivia na Movida madrileña, o lugar de realização dos sonhos que carregou - ainda adolescente - desde sua mudança de uma cidade provinciana para a metrópole.

Na voz da personagem título de seu livro "Patty Piphusa" - alter-ego do autor se define sua concepção e a forma de relacionamento com a vida, morando em Madrid. As diferenças entre os dois diretores são claras. Para Colomo, que nasceu e viveu em Madrid numa família bem situada economicamente, a cidade não seria percebida da mesma forma. Suas histórias convergem para a vida dos que vivem na cidade fazendo dela seus espaços privados. Ela possui uma funcionalidade que serve à convivência do habitual, não da descoberta. Para Pedro Almodóvar, era o campo das explorações, o lugar gerador de idéias e percepções ainda inéditas pelos cineastas tradicionalmente urbanos.

Ainda que isso se modifique em seus trabalhos futuros, como em Mujeres al borde de um ataque de nervios (1988) e Kika (1993), onde a vida na cidade segue gradualmente do transtorno para uma tortura, recaindo principalmente sobre as mulheres ${ }^{148}$, há um vínculo forte de cumplicidade que atrai e impede o diretor de desencantar-se totalmente com sua dinâmica. Patty Diphusa ${ }^{149}$ descreve quais eram

\footnotetext{
${ }^{148}$ STRAUSS, 2001, p. 86.

${ }^{149}$ ALMODÓVAR, Pedro. Patty diphusa y otros textos. $3^{\text {a }}$ ed., Barcelona, Editoral Anagrama, 1995. capítulo: Vir a Madrid.
} 
seus sonhos antes e depois de sua chegada a Madrid. Comparando as declarações a estes filmes, aparece a visão do autor sobre o que se perdeu e o que ainda permanece em sua leitura sobre a vida metropolitana.

Em Colomo, as questões políticas e históricas não se sobrepõem às da vida pessoal, inclusive os conflitos culturais. Em Los anõs bárbaros (1998), os protagonistas não abrem mão de viverem sua juventude, mesmo diante das ofensivas do regime franquista nos anos 40. Al sur de Granada (2002) conta a vida do escritor inglês Gerald Brenan durante sua estadia num pequeno "pueblo" da Alpujarra, na região de Granada, onde se refugiou com a intenção de realizar o sonho de ser escritor. Lá se defronta com a diversidade cultural desencadeada com as repercussões de sua chegada e com o conhecimento do amor. Segundo Colomo, nessa película pode-se encontrar algumas referências do estilo de Alegre ma non troppo (1994), história romântica contada a partir de Pablo, um homossexual, sobre músicos da Orquestra Jovem Nacional, que o diretor entende ser sua primeira incursão buscando explorar os sentimentos.

Os temas do encontro ou choque entre culturas, como visto, o atraem. Barjarse al moro (1988) fala de "Chusa", uma "sacoleira" que vende mercadorias na escala Espanha/ Marrocos, em Mis Caribe (1988) Alejandra recebe de herança um barcorestaurante - que na verdade era um bordel - e o transforma numa escola, causando reações adversas. O filme La línea del cielo (1983) apresenta Gustavo, um fotógrafo famoso que em Nova York enfrenta dificuldades para progredir por possuir um escasso domínio do idioma inglês. Situações inusitadas, desafios de personagens jovens da classe média, enredos realçando as relações amorosas estruturados predominantemente pela comédia - 14 entre 17 produções -, dosando valores individuais ao contexto social contrastante do mundo contemporâneo. Fernando Colomo trilhou caminhos sutis entre um gênero atrativo e uma crítica social branda porém sensível - para fixar sua marca.

Fernando Trueba segue passos próximos a Fernando Colomo. O fato de que desde o início de sua carreira tenha recebido apoio do diretor é apenas um detalhe diante das atividades que já desenvolveram juntos e que os fazem trocar contínuas idéias acerca de seus projetos. Ainda que não tenham formado nenhuma sociedade cada um possui sua produtora -, os grupos de trabalho, amigos em comum e festivais os mantêm em sintonia constante. Trueba desenvolveu seu trabalho praticamente no terreno da comédia e do documentário, todos estes em geral com personagens ou temáticas referentes à música.

Já em seu primeiro trabalho, Ópera prima (1980), que conta a história de um 
rapaz divorciado de 25 anos de idade que, ao passear amargurado pelas ruas de Madrid, passa na Plaza de Ópera, reencontra e se apaixona por sua prima de 18 anos, percebe-se seu diálogo com o perfil de pesonagens ligados ao gosto musical. Ele é jornalista e ela, estudante de violoncelo. Um roteiro de comédia romântica simples, porém repleto de elementos inovadores na linguagem, nas imagens que se apresenta da vida urbana. O protagonista, mesmo relutando contra seus sentimentos, sem querer ouvir os conselhos dos amigos, envolve-se cada vez mais com ela e acaba por descobrí-la como o grande amor de sua vida.

O recorte de classe de Trueba neste filme o distingue facilmente de Almodóvar e mostrará sua continuidade no restante de sua obra. Seu universo parte da classe média e se estabelece nela, quase que a naturalizando como hegemônica na sociedade, sem enfatizar na história sua problemática. Diferente de outros autores voltados a localizar a contradição social por esse caminho, ao diretor só interessava naquele momento contar uma história de amor e suas personagens pertenciam ao universo que conhecia.

Em Opera Prima, Marisa Paredes faz uma participação interpretando uma atriz famosa, com diálogos hilariantes sobre sexualidade. Se a seqüência fosse abstraída do filme e isolada, não seria possível identificar de quem seria sua autoria, de Almodóvar, Trueba ou de algum de seus contemporâneos. Novamente, é possível perceber que as narrações eram próximas e seguiam num mesmo estilo. Na dinâmica total das histórias e na evolução das personagens, porém, as diferenças se faziam sentir, e mais, visualizar.

Com Almodóvar, seus protagonistas eram grupos mais à margem da sociedade. Não os excluídos econômica e socialmente, mas aqueles que viviam fora dos grupos sociais e culturais legitimados socialmente, com propostas culturais inovadoras e em geral alternativas. Seus membros da classe média só aparecerão futuramente em Matador (1985-86) e em La ley Del deseo (1986) e vistos em seus aspectos de desajuste social. Ainda assim, só surgem porque o diretor começa a mudar seus círculos de amizade. As cenas se circunscrevem integralmente na paisagem da vida urbana de uma Madrid central, impelida pela vida em apartamentos, parques e restaurantes, mas com reduzidas cenas externas que descrevem um cotidiano que poderia ocorrer em qualquer outra metrópole.

Almodóvar leva para a tela em Pepi, Luci, Bom y otras chicas del montón apartamentos e bairros populares e transforma Madrid numa cidade-personagem. São inúmeras as passagens pela paisagem urbana dialogando com as tramas. Festas 
noturnas de amigos em quintais de casas de periferia, personagens punks, drogados, psicóticos, exóticos e também ambientes sociais médios onde se encontram jovens que, aparentemente, não fazem nada de suas vidas além de circular pela cidade e buscar distração para preencher o tempo. Reflexo do desemprego? Não, não existe a preocupação em discutir esta problemática como ocorrerá, por exemplo, em Eloy de La Iglesia. Tanto para Almodóvar como para Trueba - ainda que estivessem em espaços sociais diferentes - partilhava-se do mesmo espírito da vida, centrada no presente sem muita reflexão de seus problemas e de suas causas conjunturais.

Trueba avançou rápido no mercado cinematográfico não só pelo amparo da mídia e da crítica - que conhecia bem, pois havia trabalhado durante um tempo considerável na imprensa como crítico de cinema - mas também por sua amizade com Colomo e outros cineastas. Montar sua produtora logo depois do sucesso de Opera prima possibilitou a ele, em 1982, produzir dois filmes. Trabalhos que acabaram norteando suas maiores preferências: Mientras el cuerpo ardiente - um documentário e Sal gorda - uma comédia, ambos ligados a temas musicais.

Também influenciado pela alta comédia norte-americana, sobretudo pelas películas de Blake Edwards e Billy Wilder - seu cineasta favorito -, Trueba acentua 0 enfoque histórico visto em alguns trabalhos de Colomo. Quando opta por falar de política, escolhe um tempo diferente do de sua juventude, prefere conferir densidade e chamar a atenção do público mais para a gênese do autoritarismo do que para sua contemporaneidade. Um aspecto sintomático não só encontrado em sua obra, como também em Chávarri e Colomo. Todos sabemos que os setores médios em época de ditadura se encontram bem divididos sob a orientação do medo, ora político ora econômico. Nesses momentos, famílias se rompem, qualquer opinião gera polêmica e instaura-se uma censura velada nos lares. Pelo enfoque que estes autores dão à família - ou à ausência delas - em seus filmes, se podem notar os efeitos tácitos destes fatores.

Fernando Trueba faz uma leitura sensível e bem humorada do cotidiano da guerra civil espanhola e do período franquista. Em todos, a ação dramática centra-se em relações amorosas de liberação afetiva desenfreada como em El año de las luces (1986) ambientado nos anos 40, sobre um adolescente e seu irmão pequeno que acabam parando no setor feminino de um sanatório, e em Belle Époque (1992), vivida nos anos 30, numa história de um jovem desertor que se envolve com quatro irmãs, os desenlaces são os mesmos. Paixões e dramas pessoais em comédias que aplicam dão um tom lírico aos sentimentos. As personagens destacadas mantêm relações de 
igualdade no espaço público. Porém o homem acaba até sendo um objeto nas mãos femininas no espaço privado, como se vê em Belle Époque nas quatro irmãs: uma viúva, uma lésbica, outra noiva e outra virgem. Todas atraídas pelo mesmo soldado desertor. Nessas histórias, a negação do autoritarismo se revela na própria atitude das pessoas comuns, que se insubordinam às regras impostas socialmente ao liberarem e praticarem suas vontades.

Com La niña de tus ojos (1998) e El embrujo de Shangai (2002), ambos vividos nos anos 40, também se verifica o tom cômico, porém com um acento maior para o drama. Na verdade, um gradiente que se fortalece de uma produção para a outra. Ainda em La niña de tus ojos a comédia está bem presente e isso se dispersa em El embrujo de Shangai. Porém, em todos o que se sobressai é a possibilidades de experimentar a liberdade dentro de um regime político fechado. Ele é quase esquecido na ação dramática das persoangens para que estas possam realizar os sonhos.

Seus três documentários indicam um norte de interesse ramificado do diretor em sua produção para além do cinema, em setores que fortaleceram cada vez mais seus laços com a música. Os anos de trabalho como jornalista deixaram sua herança nessa forma de expressar novas obras do diretor. Mientras el cuerpo ardiente (1982) faz um levantamento sobre o cantor, compositor e filósofo Chico Sánchez Felósio, Calle 54 (2000) versa sobre o jazz latino e El milagro de Candeal (2004) possui o mote principal sobre a viagem de Bebo Valdes - que participa de Calle 54 - à Bahia, na busca de sua ancestralidade africana e em seu encontro com o bairro do Candeal. No filme, o músico logo toma como personagens principais: o próprio Candeal e Carlinhos Brown, compositor, cantor e fundador da ONG musical "Pracatum", que acabou projetando sua experiência do bairro para o mundo. O filme possui várias músicas ligadas às religiões afro-brasileiras que Carlinhos Brown teve total liberdade para compor.

O diretor se encantou com a musicalidade existente no bairro vendo crianças e jovens com diferentes estilos musicais. Porém, sua busca acabou versando muito mais por registrar todo o complexo organizacional criado. A partir da música procurou demonstrar como se processaram suas repercussões na vida social do bairro, a ausência da criminalidade, o processo educacional e cultural florescente em cada rua, em cada espaço público conquistado e a recuperação da dignidade de seus moradores. Trueba fez um musical social. Uma continuação de uma trajetória que começou a perseguir unindo preferências e habilidades as quais sistematizou e que começaram a refletir mais claramente seus objetivos pessoais e interesses sociais 
como cineasta.

Para esse filme traçou as experiências históricas da escravidão, dos conflitos, das lutas, das esperanças e dos resultados positivos dessa empreitada que ainda não se consumou. Em suas declarações sobre este trabalho, disse que viu no Candeal o aspecto do belo que emerge dentro da pobreza quando se luta humanamente contra ela. A beleza criada no rosto e no comportamento das crianças pelas ruas, banhandose nas fontes ou tocando tambores, para ele, demonstra que elas parecem muito mais felizes do que qualquer criança da urbanização européia, cercadas por uma hiperproteção física, mas sem o afeto e a vida da comunidade.

Um olhar inspirado, certamente externo a problemas estruturais brasileiros e voltado a carências de uma outra cultura, mas que enfim cria mecanismos de diálogo que são universais. Um olhar cuja intenção visa a despertar sentimentos de solidariedade. Ele próprio reconhece que não faz um cinema realista, mas utópico. Acredita num cinema que ensine como as coisas podem ser melhores. Conteúdos temáticos que aparecem tanto em seus filmes de época como nas comédias urbanas. Inclusive Two much (1996), cuja história fala de um pintor falido e de sua pretendente rica, possui esses aspectos. Busca sempre caminhos convergentes.

Com seus documentários ligados à música, Trueba acabou alinhando sua temática e reestruturando seu estilo, pois, apesar de circular pela comédia, saltou para linhas narrativas que, ao identificarem mais seu trabalho, provocaram uma remodelação com seu próprio passado. Seus personagens raramente saem do meio artístico: editores, cantores, músicos, pintores. Nos "personagens" da vida real encontrou novas possibilidades de narrá-los. Enquanto Almodóvar seguiu para 0 intimismo, mesmo mantendo-se num universo próprio de personagens e temáticas, Trueba buscou o espaço contrário e direcionou sua câmera, posicionando-a diante de protagonistas da vida real.

Este também é o enfoque que Ventura Pons dá para o início de sua carreira, com Ocaña - retrat intermitent (1978). Um filme que delineia todo seu perfil, ou seja, sua forma de filmar, seu estilo e seu modo de abordagem temática:

Ocaña es un conmovedor testamento de una época de agitación cultural y provocación sexual que tuvo lugar en España inmediatamente después de la muerte de Franco. $Y$ en su retrato de un hombre gay que reivindica su masculinidad incluso cuando se viste de mujer (el desnudo de Ocaña en un Festival organizado por el partido comunista), la película anticipa los futuros debates sobre la identidad gay y la construcción de las distintas identidades sexuales que no se desarrollaron hasta mucho tiempo más tarde. Al mismo tiempo que una paradoja de la hispanidad y los tópicos hispánicos (las imitaciones que Ocaña hace de las cantantes folklóricas), Ocaña es también un temprano ejemplo del amor que el autor siente por al narrativa y la técnica minimalistas.El trabajo cinematográfico de Pons se sitúa en los primeros años 
alocados y hedonistas de la nueva democracia. Ambos directores han explorado los hábitos sexuales y sociales de la burguesía catalana, la cultura y el folklore de la región, gastronomía, deseo, celos y obsesión. A diferencia de Bigas Luna y muchos otros directores de la Escuela de Barcelona, como Aranda y Gonzalo Suárez, que escogieron trabajar en castellano, Pons ha sido siempre fiel al entorno catalán, estableciéndose en la ciudad cuyo paisaje, cultura, lengua y energía han sido el sello distintivo de toda su obra. ${ }^{150}$

No processo criativo do filme, o diretor buscava um tema e acabou descobrindo esse personagem, e, a partir dele, desenvolveu as idéias para realizar a película. Um retrato que ele faria de si mesmo para a câmera, interrompido pela memória, por intermédio do travestismo: o teatro na rua, a Espanha obscura dos guetos e da abertura política. A reconstrução da memória - o filme foi rodado em 15 dias - e todas as circunstâncias do próprio protagonista inspiraram em Pons uma beleza e um tom literário que o motivaram para uma filmagem que fosse capaz de captar tais aspectos.

Com esse trabalho, o diretor busca retratar José Pérez Ocaña não somente como um pintor andaluz marginal, um cantor, um clown, um ator de rua, ou um transformista, mas também como um personagem destes universos que 0 personalizaram na Rambla e na Plaza Real de Barcelona do final dos anos setenta. Tal como seu nome indica, o cineasta nos apresenta um mosaico com depoimentos sobre lembranças do artista andaluz, imagens de algumas atuações, várias de suas pinturas e, fundamentalmente, a captura de um caráter integral, capaz de fazer valer suas idéias diante da câmera de um diretor que estava apenas iniciando sua carreira no cinema. Pons reflete sobre a força e a atualidade de seu filme sempre que é exibido:

Primero porque el personaje es maravilloso. Segundo porque el concepto de la película se aguanta muy bien. Y por último, porque ha quedado como si fuera el testimonio de unos años que vivimos cuando nos liberamos de la dictadura (de Franco). Cuando el dictador se murió en la cama. Cuando la gente quería tener una gran libertad. La película es como un fiel reflejo de esos años en que creímos que nos íbamos a comer el mundo y que viviríamos una libertad mucho más maravillosa de la que vivimos. Vivir vivimos en libertad, pero creímos que la cosa sería un festín, y sin pagar, y no ha sido así. ${ }^{151}$

A película fornece também um dado precioso, tanto histórica como sociologicamente. Em nenhum momento dos comentários do filme - e mesmo nos trechos selecionados acima - associa-se a descrição dos fatos do período e as atitudes do personagem ao que ocorria em Madrid, sobre a Movida madrileña. O quadro é o mesmo, o comportamento de Ocaña sintetiza ações que ocorriam pela cidade, se passavam também em Madrid e possivelmente em outras regiões. Contudo, aparece como manifestação isolada, como resultante de fatos localizados. Isso é importante,

\footnotetext{
${ }^{150}$ Disponível em: <http://www.venturapons.com/filmografia/morironop.html>. Acesso em: 11. 01. 2007.

${ }^{151}$ Disponível em: <http://www.canalok.com/cine/venturapons.htm>. Acesso em: 20. 04. 2007.
} 
pois externa a simultaneidade de acontecimentos, a falsa universalidade de movimentos sociais únicos para cada época e a possibilidade múltipla de iniciativas comportamentais diante das mudanças nas estruturas sócio-políticas que ocorrem em algum país, como o que se deu na Espanha.

A preocupação com o detalhamento do perfil da personagem, com suas buscas existenciais e o universo que o cerca, conforma-se, portanto, num registro de contraponto para uma época em sua diversidade. Define também um dos fortes elementos estilísticos do diretor que - como já visto -, por ter sua origem no teatro, acaba por acentuar em seus trabalhos o caráter personalizado dos protagonistas das histórias contadas.

Outra questão relevante para observar o estilo e as abordagens desse cineasta vincula-se ao entorno que filma. Se Madrid é a grande paixão de Pedro Almodóvar, Barcelona também tem seu admirador máximo: Ventura Pons. Desde seu primeiro longa-metragem, Ocaña - retrat intermitent, a cidade ocupa lugar de excelência, como se fosse uma celebridade incansavelmente homenageada. Praticamente todas as locações de seus filmes se passam lá. Até Manjar de amor (2001) rodado em San Francisco, tem as cenas de férias do protagonista Paul e de sua mãe passadas em Barcelona. Isso, que parece um dado aleatório, na verdade carrega um peso ideológico e político extremamente importante para a Catalunha.

Acaba por se configurar num reforço à idéia de unidade dos habitantes dessa região, como um reconhecimento da Catalunha e sua capital. Por esta observação, pode-se medir a importância que Pons adquiriu na Espanha. Um valor regionalizado que se expandiu para o país, mas que por essa característica particular mantém uma relação íntima entre diretor e público.

Numa construção estética que limpa a forma da imagem - somente com cenários essenciais para a cena - e carrega no conteúdo das interpretações, dando densidade às seqüências, o diretor desenvolve sua narrativa permeada de reflexões acerca dos sentimentos humanos, em torno da solidão, da diversidade e da importância da arte. Seus assuntos explicitam a crise. Com exceção de dois documentários e quatro dramas, os outros filmes de Ventura Pons são marcados por um cinema que transita entre a tragicomédia e a comédia. Assim, seus desfechos nem sempre são com finais felizes. Sua preocupação maior está em provocar reflexões sobre valores e relações sociais.

Sua trilogia minimalista composta por El perqué de tot plegat (1994), Carícies (1997) e Morir (o no) (1999), todas as películas formando um conjunto de pequenas 
histórias, talvez resuma objetivamente seus interesses e suas mensagens sobre suas temáticas. A circularidade que os sentimentos humanos produzem no processo da vida e suas implicações temporais e espaciais permeiam as narrativas. Suas inúmeras citações ou até histórias análogas a textos teatrais clássicos, como Aquesta nit o mai [Esta noite ou nunca mais] (1992), uma paródia de "Sonhos de uma noite de verão" de William Shakespeare e referências a filmes consagrados, só reforçam essas intenções ao fornecer um teor mais legítimo a reflexões anteriores na arte e a seus trabalhos. Nessa trilogia pode-se constatar como estabelece seu conceito minimalista tanto na construção estética como na estrutura dramática e no perfil das personagens.

El perquè de tot plegat (El porqué de las cosas) é a adaptação de um conjunto de contos de Qim Monzó. Nesse filme, Pons tentou frisar um tom minimalista sobre as relações humanas situadas entre a vontade e a dúvida. A adaptação era uma mistura de estruturas narrativas: contos com diálogo tradicional, outros conduzidos pela voz em off, e dois como monólogo para a câmera. Com o recurso de uma estrutura de pequenas histórias, o autor pôde passar de um tratamento romântico para um outro mais denso ou, ao contrário, fazer coisas frias, entrar numa comédia, refletir com uma frase. E, nesse grande jogo, buscar um estilo.

Em Morir (o no)(1999) a história negativa é apresentada em preto e branco e a positiva em colorido. Seu referencial minimalista, com personagens muito próximos da vida ou da morte, perpassa várias de suas obras. Armado em sete cenas que confluem para uma mesma história, com personagens que vão se relacionando, o filme é uma fábula sobre a segunda oportunidade que somente a vida pode proporcionar. $\mathrm{Na}$ primeira parte da história todos os personagens morrem, mas logo em seguida sobrevivem obtendo uma segunda chance para viverem experiências de maneira diferente. Segundo o diretor, o jogo narrativo inventado por ele visa a que o tema seja o conceito da representação. Sua estética torna concretas as intenções:

[...] La vida puede darte una segunda oportunidad. El juego narrativo que me he inventado es que el tema sea el concepto de la puesta en escena. La puesta en escena, el concepto, es la segunda oportunidad. Mientras mueren la cosa es en blanco y negro y cuando viven ya es en color. Mientras mueren la cámara es una cosa absolutamente participativa y un elemento más de la acción; cuando viven la cámara es descriptiva, es una cámara contemplativa. Mientras mueren todo es angustia, drama, nerviosismo, cuando viven es como una fábula[... $]^{152}$

Apesar de considerar Woody Allen uma de suas grandes referências - e de não se aborrecer quando comparado a ele -, reconhece que não é apenas ele que o motiva: "Es uno de los grandes, pero no el único". Com estilo ousado, filmes com

152 Disponível em: <http://Www.canalok.com/cine/venturapons.htm>. Acesso em: 30. 05. 2006. 
diálogos diretos e excelentes tramas que colocam sempre suas personagens diante de dilemas sociais ou então levam todos a expôr suas individualidades, Ventura Pons notabiliza seu trabalho pela energia com que dinamiza suas histórias, tornando sempre atuais qualquer uma das abordagens já filmadas.

Com seus trabalhos, esse grupo de cineastas situa o público em universos que inspiram a compreensão dos sentimentos e das relações, mediadas pela busca do diálogo ou pela dificuldade em desenvolvê-los. Nos filmes em que se aborda o passado e o presente espanhóis percebe-se os impasses enfrentados pelo próprio mundo em mudança e por uma sociedade cada vez mais afrontada com novidades as quais aprende a tolerar ainda que velhos contra-sensos das relações persistam. A leitura pela via do humor - mesmo que nem sempre resolvida com saídas felizes - favorece olhares animadores para o espectador. O drama abre diferentes caminhos.

\subsection{Estilos e temáticas - sofrer não basta}

A construção de histórias norteadas pelo drama traz à memória imagens tristes de sofrimento e de dificuldade de saída para problemas que parecem sempre intransponíveis. As tramas dramáticas, no entanto, vêm geralmente carregadas de grandes causas que atraem o público e este se vê na posição de opinar moralmente sobre seus desdobramentos, julgando se foram compatíveis ou não com seus valores. Os dramas variam conforme a classe social, mas podem também ser narrados sob valores gerais da sociedade moderna e suas tradições. Em geral, é difícil encontrar este gênero em seu estado puro. Normalmente misturam-se comédia, suspense e outras narrativas para contá-lo. Há zonas intermediárias em que se percebe o contínuo diálogo entre eles. O termo conhecido como tragicomédia realiza um pouco esta fusão, mas na totalidade da história a intenção dramática é a que possui maior destaque.

Um dos diretores, que melhor representa este exercício variável entre gêneros e que atinge os variados campos da sensibilidade com essas tragicomédias na Espanha, é Bigas Luna. Sua trilogia mordaz em torno da simbologia machista espanhola centrada na sexualidade expressa magistralmente este jogo que oscila entre a sátira e a tragédia. Jamón, jamón (1992) fala do amor de dois rapazes por uma moça filha de uma prostituta; Huevos de oro (1993) apresenta a história de Benito e sua ganância após se casar com uma milionária, e La teta y la luna (1994) o dilema de Tete, que vê sua mãe amamentando o irmão mais novo e, tomado de ciúmes, pede à Lua uma teta só para ele. 
Nas três histórias perfilam-se os vários ícones de poder masculino, seu controle, e, simultaneamente a eles, a crítica ao modelo do macho ibérico que já havia em Valle-Inclán e que Bigas Luna reforça aumentando um certo ódio que se mistura a elementos que o comovem. A cena dos rapazes lutando em Jamón, jamón é típica dessa fusão de sentimentos. Eles lutam bestialmente, demonstram sua força, porém se aprsentam abandonados e carentes. É como o menino olhando para sua mãe em $L a$ teta y la luna, ou Benito, que, em Huevos de oro, sustenta a filosofia de "los dos" e deseja possuir tudo duplamente, já que é dotado de "dois ovos". Pedro Almodóvar busca da mesma fonte de Valle-Inclán esta aversão ao mito do macho e radicaliza mais que Luna sua imagem masculina, transformando-a em travestis, em homens frágeis diante das mulheres. Até conversar com elas deve ser aprendido. Elas assumem o lugar do toureiro, símbolo de masculinidade.

Mas Luna faz em seu conjunto de trabalhos uma crítica mais aguçada a toda sexualidade espanhola. Recalcada pela moral, pelos padrões católicos, sem tocar, no entanto, diretamente na instituição. Tudo está diluído nas psicoses, nas liberações dos desejos, como em Bambola (1996) quando uma jovem camponesa italiana desperta a paixão de todos os homens, inclusive irmãos e seu pai; ou Angustia (1987), um filme de terror em que algumas adolescentes decidem matar pessoas numa sala de cinema. Bilbao (1978) talvez seja o exemplo mais dilacerante ao descrever uma história de amor e de possessão. No filme, Leo é um psicopata que alimenta uma progressiva fascinação por Bilbao, uma bailarina de striptease que, para sobreviver, também se prostitui. Leo segue Bilbao todo tempo, estuda seus movimentos e termina por raptá-la, como se tratasse de um objeto a mais para completar sua coleção erótica.

Narrado basicamente em off na voz do protagonista, Bilbao se realiza como um pornô rude, porém numa história que perfila uma personagem que fragmenta sua vida, transformando-a numa mescla de fantasia e realidade permeadas por desejos não realizados. Na verdade, Bilbao descreve a frustração da pornografia ${ }^{153}$. Num contínuo jogo de dominação, a narrativa caminha para um desfecho de posse total da musa pelo protagonista, que a extermina com uma morte trágica, reforçando sua frustração e simbolicamente revelando os limites da desilusão pornográfica. O ambiente hostil da cidade só reforça a sensação constante de desejos não realizados.

Las edades de Lulu (1990) reproduz de maneira mais expressiva e até desprezível essa vida urbana, com total ausência de glamour. A própria estética do filme não apresenta imagens que tornem os acontecimentos atrativos. Aspecto oposto

\footnotetext{
${ }^{153}$ HOPEWELL, 1989, p. 290.
} 
ao de Almodóvar que, em Laberinto de pasiones e outros filmes rodados em Madrid e até mesmo Barcelona, como Todo sobre mi madre, sintetiza a metrópole com requinte e admiração. Porém, quando decide provocar o riso, Bigas Luna também o faz de maneira brilhante. Para isso, elege como tema ironizar a cultura hispânica ou seus regionalismos. Na seqüência em que Javier Bardem treina para toureiro em Jamón, Jamón, sua nudez noturna num curral com o amigo sintetiza elementos e situações que associam o ridículo à provocação. O resultado acaba se transformando numa das melhores cenas cômicas do filme.

O recorte realista é marca necessária na cinematografia de Luna. Em algumas películas chega a ser de uma crueza difícil de apreciar, só compreendida por fazer parte da estética que intenciona realçar a ação dramática. Seu drama de época Volaverúnt (1998) possui o requinte da nobreza, mas não poupa o universo das mesquinharias, da crítica ao poder e da vaidade. Em alguns filmes faz do contra-senso, de valores e práticas que visualiza no país, um jogo hilário repleto de humor. No entanto, o que permanece na estrutura narrativa de Luna é a impossibilidade da redenção. Opção contrária da busca de Almodóvar que, em seu discurso, inclui praticamente em todos os trabalhos - conteúdos que conduzem a uma saída compensatória. Em qualquer um dos casos, Luna não isenta a Espanha de sua crítica. Para ele, o que se vive precisa ser visto com seus significados desvelados.

Seu trabalho de 2006, Soy la Juani - após vários anos sem filmar -, segue uma linha de cunho quase documental, sem perder de vista seus aspectos anteriores. O cinesta comenta:

Juani es hija del brutalismo ibérico por un lado, y el glamour de la periferia por otro, es una niña que con unos pendientes de plástico, su top y su mirada es capaz de comerse el mundo.Es una chica que con su osito de peluche, su chaquetita rosa y su mini, es hoy más atractiva que una señora con su bolsito repleto de marcas y su abrigo de visón." ${ }^{154}$

"Quiero mostrar a la Juani como un nuevo icono ibérico. Como una chica de la periferia, una joven liberada y muy moderna, que no es víctima del machito ibérico. Este tipo de chicas contemporáneas apenas se ven hoy día, porque en la tele sólo salen chicas operadas y rellenas de silicona. En cambio, las juanis proceden de unas periferias que antes albergaban a gente un tanto deprimida y que vivía de las influencias de las modas procedentes del centro urbano. Hoy ocurre lo contrario. Son los jóvenes de la periferia quienes crean unas modas que son asumidas por los del centro. ${ }^{155}$

Como ocurría en Jamón Jamón, deseo mostrar unos personajes dentro de una tradición de cine realista, convirtiéndolos en pequeños héroes de nuestra cotidianidad. El mundo de estos adolescentes de la periferia tiene dos versiones: la de las pastillas y las drogas. Pero también la de una gente que, en el 80 por ciento, es muy trabajadora. Y víctima del mundo del consumo, como lo somos todos. No pueden comprarse una casa, pero sí un automóvil. El coche hace las funciones de casa, es su gran símbolo. Allí viven, follan,

154 Disponível em: <http://www.cinestel.com/41701/1901.html?*session*id*key*=*session*id*val*>. Acesso em: 15. 03.2006

${ }^{155}$ MOJICA, Luís Bonet. La Vanguardia, Barcelona, 13 fev. 2006. 
escuchan música ... a del siglo XXI LO JUANI, Adjetivo: Cualquier elemento que sirva marcar por donde pisas, marcar metas propias, marcar estilo y marcar tu reglas. ${ }^{156}$

O que Bigas Luna continua mostrando com este filme é a seqüência - sem alegoria - de sua visão de um tipo de Espanha e de pessoas que são criadas em seus consecutivos processos de mudanças. Seu estilo voltado a uma orientação documentária, neste filme, não perde o viés de apontar o perfil de seu país e suas contradições, ora sobre a violência, sobre a arte e as várias raízes culturais. Sempre retratos difíceis - por isso dramáticos -, mas também risíveis. Juani traz essa fusão de impressões num momento em que estar incluído na moda e no consumo, em que lutar por ideais ou viver diferentes valores tornaram-se uma batalha interminável frente às inseguranças econômicas e sociais, sem nenhuma certeza de sucesso. O mundo idealizado da festa e da juventude dos anos 80 de Almodóvar, Trueba e Colomo tornou-se um passado remoto.

Contudo, isto não significa afirmar que estes diretores fugiram à realidade. Em seus filmes havia um tipo de juventude que representava uma parcela da sociedade daquele momento e da qual eram próximos e possuíam afinidade. Outros diretores tinham referências distintas e buscavam diferentes perfis, como é o caso de Eloy de la Iglesia. No mesmo ano em que Almodóvar e Trueba celebravam em suas estréias uma linguagem descontraída e debochada da vida urbana, com personagens jovens e festivos, Eloy de la Iglesia apresentava Navajeros, filme ambientado no ano de 1980 num momento social de difícil acesso ao trabalho, dentro de uma Espanha que contava com mais de um milhão e meio de desempregados. Gangues de periferia, caminho marginal para sobrevivência. Este é o quadro de sua juventude. Navajeros marca oficialmente a estréia do diretor no Cine Quinqui.

Baseado em fatos reais - com personagens fictícios -, o filme conta a história de Jaro, um jovem delinqüente procedente comum de bairros marginais da periferia de Madrid, filho de uma prostituta. Para sobreviver, Jaro e sua gangue fazem roubos por toda cidade conseguindo assim dinheiro de uma maneira fácil e rápida. Com referências à Laranja mecânica numa cena de luta no parque El retiro - onde um grupo briga com outro que se ocupa de espancar mendigos -, o diretor circunscreve a delinqüência juvenil de uma maneira que até infantiliza a abordagem de Colomo em Qué hace una chica como tu en un sitio como este.

$\mathrm{Na}$ história, por possuir apenas quinze anos, cada vez que é capturado pela

${ }^{156}$ Disponível em: <http://www.e-barcelona.org/modules.php?op=modload\&name=News\&file=article\&sid=7355>. Acesso em: 01. 03. 2006. 
polícia, Jaro é levado a um reformatório de onde sempre escapa. Em meio a essa trama, uma prostituta mais velha se apaixona por ele e o protege em sua casa. Porém, ele se confessa apaixonado por uma garota mais jovem do que ela. Em mais uma de suas prisões, a prostituta descobre que a namorada de Jaro está grávida e, quando este sai da cadeia, ela acolhe ambos em seu apartamento. A convivência entre eles torna-se insuportável e, entre delitos, brigas e drogas, Jaro morre baleado no mesmo dia em que nasce seu filho ${ }^{157}$.

Como se pode notar, o poanorama social apresentado não vislumbra nenhum brilho pelo fato de se viver em Madrid, sobretudo nos bairros populares. Esses diferentes aspectos de abordagem da vida marginal revelam variantes de um quadro repleto de tonalidades que enfim se complementam. As formas de viver, voluntária ou involuntariamente à margem da sociedade, dão os contornos gerais de um universo social pulsante, porém em La Iglesia os limites e contradições da vida urbana não deixam muitas alternativas para suas personagens. Em Almodóvar os desfechos constantemente se abrem para alguma forma de esperança.

Suas atitudes subvertem a moral vigente, mas não no estilo de Almodóvar, que ora ironiza comportamentos como em Pepi, Luci, bom y otras chicas Del montón e Laberinto de pasiones, ora entra na intimidade de maneira mais explícita como em Qué he hecho yo para merecer esto?, Mujeres al borde de un ataque de nervios, Tacones lejanos, Kika ou Hable con ella. A crítica à moral em La Iglesia incide e se relaciona a título de denúncia social, preocupação bem remota nos trabalhos de Almodóvar, que prefere seguir na linha de reconhecer o problema, mas de encará-lo satiricamente e às vezes até de forma amável.

Nessa lógica, com Colegas, o diretor retrata seus temas polêmicos habituais em torno do desemprego, drogas, delinqüência, homossexualidade e, neste filme, o tráfico de bebês. A história versa ao redor de Antonio e Rosário, um casal de irmãos que vive na periferia de Madrid junto com José, amigo de Antonio e namorado de Rosário. De origem humilde, desempregados, todos se encontram sempre envolvidos com as drogas. A situação se agrava quando Rosário engravida. O casal decide então fazer um aborto e pede a ajuda de Antonio. Sem dinheiro, começam uma série de desventuras para consegui-lo. Aconselhados por um amigo, Antonio e José decidem prostituir-se em uma sauna, mas, ainda assim, não conseguem o dinheiro suficiente. Entram em contato com um traficante de drogas que thes propõe um trabalho aparentemente fácil e que ambos aceitam, mas isso irá complicar ainda mais suas

${ }^{157}$ Disponível em: <http://www.es.wikipedia.org/wiki/Navajeros>. Acesso em: 13. 02.2006. 
vidas. $^{158}$

La estanquera de Vallecas (1987) é a única comédia do diretor. Aqui vale uma obervação para mostrar a habilidade do diretor - que só trabalha com dramas - em falar de problemas sociais variando seus recursos narrativos. Ali estão claras suas preocupações, circunscritas entre a crítica social frente aos descasos do governo e o despreparo da polícia sem a pretensão, no entanto, de fazer uma análise detalhada do contexto. Firmam-se afetos contrapostos à denominação do "ser marginal" e das necessidades do ser humano. Sucesso de bilheteria, a obra apresenta um universo próprio retratando de maneira sensível a vida corriqueira e monótona de bairros de periferia de uma metrópole sem glamour, onde qualquer novidade transforma-se num evento. O tom da denúncia social sai do drama - tradicionalmente escolhido para descrever problemas de desigualdade - e fixa-se no cômico, sem perder seu caráter crítico.

Amante do discurso direto e da estética naturalista, Eloy de la Iglesia colocou como protagonistas de seus trabalhos meninos de rua selecionados das periferias e na fronteira da mesma delinqüência em castings nada acadêmicos. O cineasta mantevese, até o final de sua vida, vinculado aos grupos sociais marginais. Seu último filme trata, dentre outros assuntos, da migração, um fenômeno caro à Europa com proporções a cada dia mais preocupantes em todo continente. Em seus filmes a juventude se perde socialmente e com isso não constrói valores humanitários. A droga não é uma festa como em Pepi, Luci, Bom y otras chicas del montón e Carne trémula, ou comum como em Qué he hecho yo para merecer esto ?, e Entre tinieblas, de Almodóvar.

Sua paisagem cotidiana é de dilaceramento e denúncia frente às dificuldades de sobrevivência entre as diferentes classes sociais na metrópole que, além de dicotômicas, não se encontram. Não há exercício de mobilidade social como Almodóvar, que transferiu suas personagens para os setores médios em decorrência do próprio processo que seguiu sua vida. Em entrevista para este trabalho, Núria Vidal comenta este dado de uma maneira simples e objetiva:

Seu cinema mudou porque sua vida mudou. Antes filmava os pobres, porque era pobre, hoje filma a classe média, os intelectuais, porque está rodeado deles. ${ }^{159}$

Eloy de la Iglesia, diferente, já vinha de círculos médios da sociedade. Sua formação em filosofia e as ídeias oriundas de tantos autores humanistas nortearam

\footnotetext{
${ }^{158}$ Disponível em: < http://www.es.wikipedia.org/wiki/Colegas>. Acesso em: 22. 04. 2006.
} 
suas escolhas para outros grupos sociais. Essa necessidade ou facilidade de diálogo com os grupos desfavorecidos ou discriminados socialmente justifica-se em boa parte por sua formação acadêmica e pelas próprias posições políticas e pessoais de um diretor preocupado em traduzí-las em imagens. Participação no Partido Comunista, homossexualidade assumida publicamente sob críticas em uma época muito mais repressiva que a atual, dependência química durante longo período. Elementos suficientes para entender seu cinema e suas posturas.

No filme El diputado (1978) todos esses elementos estão configurados e descrevem os contínuos conflitos de membros das várias classes sociais, suas posturas e conseqüências políticas num período da transição espanhola em que participantes da ultra-direita afrontam-se com a esquerda emergente. O protagonista é um deputado homossexual casado de grande projeção, membro de um partido de esquerda, acadêmico respeitado. Ainda que tente evitar sua atração por rapazes, acaba se envolvendo com um garoto de programa, numa relação que se transforma em namoro.

Devido ao grau - teoricamente influenciado pelas idéias marxistas de liberdade e de igualdade - de maturidade nas relações afetivas, a esposa do deputado descobre seu caso secreto e também se envolve afetivamente com ele. Manifestações políticas em praça pública, passeios, perseguição da direita, crescimento de consciência de classe do rapaz pobre, repressão sobre ele e sucesso do deputado. Um quadro sombrio que denuncia não somente o contexto político de uma época, mas também a hipocrisia das classes sociais, sobretudo das dirigentes. Nesse filme, as drogas aparecem como parte do cotidiano das personagens e não como fator de conflito.

O mundo das drogas terá espaço amplo de discussão, juntamente com o conflito político-territorial no norte da Espanha em inícios dos anos oitenta, em El pico $^{160 .}$. Nele, Eloy de la Iglesia refletiu com realismo e com inúmeros detalhes todo o processo do vício sobre um dependente químico desde a preparação de doses de heroína, seus efeitos a curto e longo prazo, a síndrome de abstinência até a morte por overdose. Seguramente, o fato de o próprio diretor ter vivenciado esta condição de dependência química por vários anos acabou por imprimir no filme a veracidade das imagens e a abordagem do tema.

$\mathrm{Na}$ história, dois amigos - Paco e Urko - vivem em Bilbao e juntos se envolvem com a heroína. Para conseguir suas doses diárias, roubam, mentem e

\footnotetext{
159 VIDAL, Núria. Depoimento sobre Pedro Almodóvar [13 jul. 2005]. Entrevistador: Gilmar Santana. Barcelona: Universidade de Barcelona, 2005. Minidv (70 min), estéreo. Entrevista concedida para este trabalho.

${ }^{160}$ Disponível em: <http://www.es.wikipedia.org/wiki/ El pico>. Acesso em: 15. 04. 2006.
} 
chegam a matar o traficante que lhes passa a droga. Insinua-se também que existe entre eles alguma relação amorosa. Além dessa situação, acrescente-se o lugar social onde estão circunscritos. Paco é filho do comandante Torrecuadrada, pertencente à Guarda Civil, e Urko, filho de um político separatista da esquerda mais radical.

Observa-se, portanto, nessas películas quais os temas, espaços e agentes sociais que Eloy de la Iglesia procura preferencialmente abarcar e relacionar, dosando na mesma medida afeto, prazer, conflito social e político, intrinsecamente articulados de maneira direta na narrativa. Com o processo de conflitos dentro do jogo político na busca pela democratização espanhola durante e depois da transição, o diretor desacreditou do comunismo - do qual era militante convicto - e desapegou-se dos dogmatismos ideológicos. Assim, simultaneamente à evidente crítica social, não se percebe em boa parte dos trabalhos - sobretudo nos últimos - nenhum caminho de cunho ideológico, nem saídas imediatas. As histórias ocorrem sem desfechos conclusivos socialmente. Prevalece a imagem da realidade e algo ainda por fazer.

Célebre por retratar a marginalidade e o mundo das drogas que nos anos $80 \mathrm{se}$ vivia em diversas cidades espanholas, em suas boas e más películas existe sempre um compromisso com a realidade imediata, grande honestidade. A crítica reconhece que, excetuando os discutíveis méritos estéticos, seu cinema conserva um grande valor documental, configurando-se como fiel reflexo do tempo em que se viveu especialmente a marginalidade espanhola de finais dos anos setenta e princípios dos oitenta. Além disso, o conjunto de suas obras revela a forte marca de sua personalidade e ousadia. Sem possuir uma produtora, passar por problemas pessoais que o afastaram por um período considerável da vida cinematográfica, este cineasta manteve-se fiel às suas temáticas e convicções, deixando sua marca distinta na cinematografia contemporânea.

A produção do cinema de Jaime Chávarri é marcada pela preocupação histórica e com a família. Tanto seus dramas como suas poucas comédias e seus dois documentários versam em geral ao redor desses temas, dentro dos quais ele estabelece suas variantes. Entender o presente aos olhos do passado parece para ele uma questão essencial e com a qual o cinema tem um compromisso decisivo. Seu primeiro longa-metragem, Los viajes escolares (1974) ${ }^{161}$, já percorre essa busca. Conta a história de Óscar, um rapaz imaturo de 24 anos que, após terminar parte de seus estudos universitários e voltar para casa em férias, se demonstra incapaz de enfrentar sozinho a volta ao lar. Depois de convencer Carlos - seu professor de 
matemática - a acompanhá-lo e já com a família, inicia um comportamento cada vez mais desequilibrado e irracional, enquanto sua mãe e parentes projetam nele a figura paterna ausente.

Seu fracasso comercial se deu muito em razão das críticas que atrasaram dois anos sua estréia.Tanto que a compensação para o diretor só veio a ocorrer com a película seguinte, El desencanto (1976), que documentalmente não fazia nada mais do que desenvolver vários dos argumentos esboçados no filme anterior. A diferença agora se encontrava na estrutura narrativa documental-melodramática que provoca maior atração por seguir a via do sentimento e do caráter de veracidade dos títulos documentais.

A sensação de realismo existente nas películas de Chávarri se justifica em grande parte não apenas porque ele busca resgatar fatos verídicos, personagens reais que - em geral - são homenageados e eternizados em suas imagens, mas por uma narrativa visceral que se aproxima de um cotidiano impregnado de paixões que muitas vezes levam à irracionalidade. E estas podem chegar a desfechos encantadores ou trágicos. A referência de personagens que já existiram realmente gera um efeito social de legitimidade e possibilidade comparativa com a própria vida muito mais acelerado do que em Almodóvar.

Nas histórias de Almodóvar, a visceralidade dos sentimentos aparece em sua primeira fase nas formas inverossímeis e em suas últimas películas é transportada para o plano de efeitos social-psicológicos sobre os indivíduos. Seu trabalho - que depois de La flor de mi secreto (1995) caminhou para o intimismo - não perdeu esse caráter de situações fora da normalidade, seja pelas seqüências dos filmes ou pelo perfil de determinados personagens. O que mudou foi o apelo à reflexão do espectador, agora recorrendo a regiões do imaginário e da percepção social ao inusitado. Com a cena posta, não há como refletir outra coisa senão os momentos às vezes absurdos, às vezes impensados. Como estão geralmente amparados pelo discurso melodramático ou pela comédia, isso se acentua e garante-se a atenção, pois são gêneros já assimilados e apreciados pelo público.

Com Chávarri esta narrativa também ocorre, mas sob a recorrência realista e histórica. A comédia Besos para todos (2000) segue nesse sentido, mesmo se tratando de uma ficção. Já a história de Camarón (2005), seu mais recente trabalho até esta pesquisa, sobre o cantor flamenco Camarón de la Isla, contou com a aprovação da família do artista e teve a assessoria dos músicos Paco de Lucía y Tomatito. A

\footnotetext{
${ }^{161}$ Disponível em:< http://www.seminci.com/plantillasphp/catalogo.php?id_pelicula=707>. Acesso em: 23.04.
} 
intenção do cineasta nesse filme de ficção - baseado num personagem real - foi a de que este refletisse a emoção inexplicável que Camarón provocava sobre os sentimentos do público quando cantava. Doze anos após sua morte, ele continua atual. Com a permissão de La Chispa, viúva do artista, Jaime Chávarri criou uma biografia ficcional sobre o cantor.

Apesar de recorrer a filmes com temáticas ligadas à consciência social, ainda que sem a densidade crítica de Eloy de La Iglesia e Bigas Luna, para Chávarri não é preponderante que se façam trabalhos visando especificamente a este foco. Partidário da idéia de que todas as abordagens possuem seus méritos, o diretor divide as opiniões gerais da crítica espanhola, não muito simpatizante de tal visão. Diante de Almodóvar, por exemplo, por mais que sejam feitos trabalhos de qualidade, como o foram Todo sobre mi madre e Hable con ella, na Espanha, ainda se instaura ao redor deste diretor uma certa aura de ressentimento, principalmente em razão da aparente ausência da temática política em seus trabalhos. Digo aparente, pois ela existe, mas de maneira não convencional.

A crítica ortodoxa não tinha e não tem demasiado carinho por ele em razão de suas abordagens. E nós nos identificamos com seus personagens, com a linguagem, com as músicas. Pedro fala da cotidianidade e nela está a droga, a homossexualidade. Isso faz parte da cultura espanhola de maneira mais explícita ou oculta e Pedro falava na transição, quando tudo estava em ritmo de liberdade.[...] Em 'Pepi, Luci ...' já estava lá todo o Almodóvar. Mesmo mal feito. E "Pepi, Luci ..." tinha um frescor, que divertia, era essa a liberdade. Permitia barbaridades estupendas, conflitos com as autoridades. ${ }^{162}$

O diretor está longe do sentido clássico de falar sobre política, sobretudo diante da forma abordada pelos diretores mais respeitados do cinema espanhol. Observada sob esse ponto de vista, a crítica ortodoxa se justifica, afinal possui propriedade analítica para isso, tanto para os pressupostos condizentes aos fatores que compõem esse aspecto como o conhecimento específico de interpretação fílmica:

Para ele não interessa o político. Mas é até melhor que não fale de política porque não sabe. Os outros cineastas consagrados fizeram política. Almodóvar nunca entrou nesse tema. Sempre esteve no seu mundo e no intimismo. A esquerda não o perdoa por não ter tomado posição frente ao sistema ditatorial de Franco e dizer que sua vingança a Franco é não falar de política, é uma falta de compromisso, como Pilatos. Para os comprometidos isso soa como covardia, uma desculpa. Claro, ele é criador e faz o que the dá vontade. ${ }^{163}$

2006.

${ }^{162}$ VIDAL, Núria. Depoimento sobre Pedro Almodóvar [13 jul. 2005]. Entrevistador: Gilmar Santana. Barcelona: Universidade de Barcelona, 2005. Minidv (70 min), estéreo. Entrevista concedida para este trabalho.

163 CAPARRÓS, José Maria. Depoimento sobre Pedro Almodóvar [08 jul. 2005]. Entrevistador: Gilmar Santana. Barcelona: Universidade de Barcelona, 2005. Minidv (70 min), estéreo. Entrevista concedida para este trabalho. 
Porém, o campo político é mais extenso. A própria discussão sobre seus filmes e a ausência de consenso nas opiniões é um saudável dado político e se desdobra não só para os filmes ou para a figura de Almodóvar. Para as temáticas que o drama suscita - segundo os autores apresentados -, realmente o aspecto político tem força narrativa e talvez nisso também Almodóvar tenha seguido por uma outra forma expositiva que diluiu sua percepção tradicional. Para estes cineastas - pelo contrário não só a política, como também a arte e os desequilíbrios sociais foram alvos de seus dramas. Densas e envolventes, são histórias que resgatam e comparam os processos de tensa convivência social nesses anos de liberdade democrática, edificando a firmeza com que cada um elabora sua mensagem.

\subsection{Uma exceção valiosa e necessária - o drama num impasse}

Por seguir um caminho narrativo muito próprio, destoando dos cineastas apresentados aqui, Victor Erice desloca o eixo dessa reflexão. Sua linguagem praticamente não dialoga com Almodóvar. Começou seu trabalho muito antes dele e, se não fosse pelo universo cinematográfico, talvez continuassem pertencendo a círculos sociais completamente distintos. Erice foi incluído nesse debate porque, cronologicamente fazendo parte dessa geração de cineastas apresentados, aparece como seu contraponto marcando uma grande singularidade. Com isso, fornece outros referenciais do que se produziu na época da popularização de tantos cineastas - como Almodóvar - e demonstra que a diversidade criativa torna possível a convivência e a geração de estilos originais simultaneamente.

Victor Erice realizou poucos filmes em sua carreira - dois no período de ascensão e sucesso de Almodóvar -, tornou-se uma das referências mais cultuadas na cinematografia espanhola desde o tardo franquismo. Não se encaixa em nenhuma classificação perpetrada pelos analistas. Seguiu seu cinema único e solitário preocupado apenas em dizer sua mensagem de maneira marcante, atitude que o perpetuou como paradigma criativo.

Dotado de contemporaneidade narrativa ao se utilizar de um cinema metafórico, simultaneamente recorrendo a fatores residuais da tradição e do imaginário social com fragmentos das influências da sociedade moderna, Erice distingue-se pela forma como apresenta suas imagens. Nelas estão as marcas exclusivas e explícitas de uma pessoalidade introspectiva, poucos diálogos, imagens com poucos movimentos de câmera e tramas que - girando em torno da família no processo de desenvolvimento das gerações - revelam os traços dos conflitos que os espanhóis carregam, mas que também poderiam servir para qualquer pessoa de outro país ou cultura. 
El espírito de la colmena aparece como o referencial mais emblemático para ilustrar os contornos apontados. Seus outros filmes contêm a mesma estrutura narrativa e temática com personagens muito próximas a este trabalho. A história ocorre num pequeno pueblo de Castilla La Mancha há muito tempo - por volta dos anos 40. Num domingo, duas meninas, Isabel de oito e Ana de seis anos, assitem ao o filme $O$ Doutor Frankenstein. A menor começa a perguntar à maior várias informações sobre o monstro. E elas acreditam que este viva numa casa abandonada próxima ao pueblo. Um dia Ana desaparece de sua casa. Enquanto todo o pueblo a busca, ela consegue ver o monstro refletido pela correnteza do rio sob a luz da lua, e desde então segue invocando-o.

Metaforicamente, o filme conta a travessia do duro período do pós-guerra espanhol a partir do episódio da chegada do cinema a um perdido pueblo castelhano onde, naquele período, este veículo de imagens possuía um grande poder sobre o imaginário popular. Sob o ponto de vista de duas meninas que, fascinadas pelo filme de terror, acreditam ver pistas do monstro cinematográfico no pueblo concomitante ao pai que trata de iniciá-las à vida, mesclam-se fantasia e realidade, estabelecendo um marco em que medo e repressão estão latentes.

Expressivo, sobretudo num período quando todas as contradições do regime franquista vieram à tona, torna-se curioso como depois de dez anos - em plena "Movida madrileña" -, em El Sur (1983) e depois no roteiro de La promessa de Shangai (2001), permanece a mesma temática. Talvez El sur até passe pelo conflito dessa "adolescência" de rituais de passagem de uma Espanha que amadurece politicamente ou de uma juventude que se conflita com os pais na figura da filha e da sua relação com seu pai. No entanto, o fato é que o foco de Erice claramente não transitou por essas novidades juvenis. Permaneceram para o diretor as várias heranças de um passado marcado pela repressão política e pela estrutura tradicional do país, colocando uma condição irrefutável da qual todos os espanhóis não têm como escapar ou revidar. Suas chances de saída se esvaem mesmo com as mudanças sociais e políticas, talvez ilusórias, e por isso quase que cinicamente lembradas nas películas de forma metafórica dentro do microcosmo familiar. Com esse jogo que parece elementar, o cineasta projeta suas reflexões sobre a condição humana.

Não é um cinema fácil. Tudo é denso, inclusive a estética fotográfica carrega um tipo de luz que pesa no olhar como que arrastando o espectador para o interior de si mesmo. Silencioso, detalhista, o filme sustenta um clima narrativo em que o público se mantém em constante estado de expectativa ainda que intuindo não haver nenhuma 
surpresa. Difícil e fácil de comparar. Não há afinidades com o cinema de Almodóvar, tão cheio de cor e movimento. O jogo de produzido feito pelo diretor de fotografia Luis Cuadrado é o da contemplação, quase como a admirar uma pintura. Texturas em tom de mel vinculando a imagem à profissão do pai que é apicultor, formas de colméias nos vidros da casa onde moram. Tudo visa à observação lenta do detalhe.

Erice faz questão de relembrar o passado com uma propriedade que faz jus à sua formação em economia, política e direito, anteriores ao cinema. Nos anos 80, mesmo renegando objetivamente intenções históricas, Almodóvar também o recontava. Porém, de uma maneira na qual que as metáforas não tocassem no problema das marcas ditatoriais espalhadas sobre os inúmeros comportamentos e valores cotidianos, objetivamente por um aparato de referências bem distintas de Erice. Embora indiretamente e sem intenção tenha elaborado imagens nesse sentido. O jogo de luz e sombra e a presença clara do conservadorismo da Igreja Católica de Entre tinieblas, a presença da Opus Dei no papel da atriz Julieta Serrano em Matador e mesmo os valores da moral cristã espalhados na maioria dos filmes traduzem as heranças históricas.

O legado social franquista da vida nos conjuntos habitacionais populares de Qué he echo yo para merecer esto? e da referência ao medo e à alienação política em Carne trémula. Ou também os comportamentos masculinos sempre dominadores e afrontados pelas mulheres em quase todos os trabalhos, questionados de maneira contundente e delicada em La flor de mi secreto, Carne trémula, Todo sobre mi madre e Hable con ella são exemplos da leitura de um passado que se faz presente.

Mas, cinematograficamente, os únicos fatores que os fazem dialogar é a insistência e a fidelidade aos temas que caracterizam suas obras. A marca intimista de Erice, voltada para os sentimentos diante das influências e circunstâncias históricas, ecoa nas obras de um Almodóvar mais maduro, que também reflete sobre as interferências sociais incidindo no desejo, seu principal objeto de abordagem. A cada trabalho percebe-se um Almodóvar mais reflexivo. Das imagens da Movida restam vagas lembranças somente para aquele espectador muito atento.

A forma de reflexão que aparece em Erice é o elemento mais incômodo. Enquanto o que incomoda em Almodóvar são suas polêmicas, como em Átame e em tantos outros de seus filmes, em Erice - com tão poucos filmes, praticamente um trabalho por década - sua introspecção de sentimentos, num ritmo lento - às vezes maçante - que parece não apresentar nenhuma novidade na próxima seqüência, sinaliza as relações. O oposto das películas de Almodóvar que constantemente 
produzem uma surpresa, um novo enlace ou desenlace da trama. Intrigante em Erice é perceber que nessa constante sensação de mesmice cria-se uma tensão, como um certo temor de que algo está para acontecer. Mantém-se em suspenso as sensações dentro desses aparentes "vazios".

Seus filmes carregam seu ethos pessoal. Victor Erice é um homem circunspecto, taciturno - quase sombrio -, reflexivo, fala baixo, devagar, tem gestos lentos, olhar contemplativo, pouco se expõe. Almodóvar é ágil, falante, trabalha sua imagem, é perspicaz em seus pronunciamentos em periódicas aparições na mídia. Essas dimensões incidem sobre a forma dos trabalhos e também em como os administram, além de construírem suas imagens públicas. Quando há ironia nos trabalhos de Victor Erice esta surge muito sutilmente em suas metáforas sem, no entanto, seguir a intenção de provocar o riso do espectador. Um caminho inverso ao de Almodóvar, que busca consecutivas associações - de preferência ligadas aos hábitos mais corriqueiros dos espanhóis - que divertem o público.

\subsection{Diálogos quase harmônicos}

Este último exame comparativo, que finalizará o capítulo, consiste em aproximar as temáticas mais recorrentes abordadas nos filmes de Pedro Almodóvar com as desenvolvidas pelos cineastas desta análise. Cada uma delas aparece de maneira singular nas abordagens. Contudo, também traduzem intenções comuns que tornam suas obras favoráveis a uma discussão capaz de revelar, em seus cruzamentos, as razões que notabilizam as escolhas dos autores e tornam possível discernir os parâmetros sob os quais o diretor em foco se distingue ou se identifica com eles. Com os resultados, acredito poder evidenciar que na construção de histórias com imagens tão distintas certos enfoques de Almodóvar o singularizam, mas por outro lado o incluem no quadro de seus contemporâneos por contribuir para mais uma leitura de seu contexto.

As temáticas mais recorrentes entre estes cineastas versam sobre: família, relações amorosas, solidão e, a unânime entre todos, a sexualidade. Dentro deste último aspecto, cabe incluir o homossexualismo, tema presente nas obras de quatro dos diretores que compõem esta investigação. Há também uma quase total ausência importante para ser registrada: a religião, ou mais propriamente a Igreja Católica - esta que, quando lembrada, aparece caricata ou punitiva.

Os temas em geral encontram-se entrelaçados e os relacionamentos se explicam por suas oposições ou associações. Portanto, ainda que estes estejam em 
destaque por tópicos, todos os outros fatores que implicarem no seu desenvolvimento dialogam sobre suas narrativas. A família ganha destaque em Jaime Chávarri e Victor Erice como elemento de conservação de tradições ou de reflexão sobre o passado. Não por acaso películas históricas como Los viajes escolares (1973), El desencanto (1976), Bearn (1983), Las bicicletas son para el verano (1984) e as mais recentes Beso para todos (2000) e Camarón (2005) de Chávarri, em seus diferentes gêneros, giram em torno da resolução de problemas para reconstituir ou manter a ordem da família.

Los viajes escolares (1973), com total ausência de pudor, descreve a vida de uma família reclusa no campo e suas influências desequilibradoras sobre um jovem débil num universo de atrações e projeções lançadas sobre ele. Uma narrativa firmada em discursos então em voga, que colocavam a família como espaço de excelência do poder, sintonizados com teorias psicológicas que a vinculavam à esquizofrenia ${ }^{164}$. Desdobramento que poderia ser aplicado facilmente a outras instituições às quais estava vinculada por valores morais e políticos, associando-a simbolicamente ao mesmo sentido de poder. A influência de sua formação em direito voltada à ordem social - mesmo crítica e histórica em Chávarri - acabou se revelando em sua lógica cinematográfica.

Victor Erice busca os caminhos da intimidade psicológica, das palavras não ditas, dos sentimentos imaginados. Suas metáforas claras sobre os efeitos do regime franquista nas relações pessoais não deixam espaço para outro que não seja a família, um receptáculo condensador dos conflitos sociais vividos. Em El sur (1983) toda relação de uma filha com seu pai descreve os vários processos de maturação pelos quais uma mulher passa diante dos afetos que nutre por alguém que ama, ao mesmo tempo em que narra os conflitos de um homem adulto em crise com sua própria consciência. Bigas Luna transforma a família no universo da carência, sobretudo afetiva. Ela não serve de amparo, pois ou está desestruturada ou em vias de desaparecimento. Tudo move sua construção, dinheiro, sexo, traição, marginalidade, menos os afetos - a não ser os reprimidos.

A família em Pedro Almodóvar possui versões diferentes, conforme seu processo de maturidade, tanto cinematográfica como pessoal. Como Luna, é o sinônimo do desmantelamento desde seu primeiro filme comercial até Todo sobre mi madre (1999). Nesse filme o autor começa uma busca para tentar entendê-la no tempo; após perder o filho num acidente, Manuela volta a Barcelona em busca do exmarido e começa um processo de compreensão de sua vida. Em Hable con ella (2002)

${ }^{164}$ MONTERDE, 1993, p. 48-49. 
vai aos sentimentos que possam gerá-la. Em La mala educación (2004) as explicações estão na história, e em Volver (2006) nas raízes da vida no pueblo.

De qualquer forma, a família não está organizada da forma tradicional. Nem para reproduzir-se nem para alimentar os papéis sociais. Seus relatos passados se remetem à fragmentação e seu presente é uma circunstância que ainda está por se completar. A única família - não menos por isso conflituosa - mais harmônica era a de La ley del deseo (1986), que possuía todos seus membros vivendo juntos com papéis tradicionais invertidos: irmão gay, irmã transexual e uma filha de uma amiga que decidiu abandoná-la e viajar pelo mundo. Ou seja, a família é uma escolha em todos os sentidos e não uma imposição hereditária, e quando segue este modelo é um fardo castrador como em Matador (1985-1986). Enfim, em todos estes diretores a família aparece como um problema para ser compreendido, tolerado ou banido.

Com as relações amorosas misturam-se as discussões acerca das carências de afeto, sentimentos exacerbados que levam ora para a dificuldade em transmiti-los ora em relações nas quais o amor é liberado com as atitudes isentas de moral. As tramas centrais de Fernando Colomo giram em torno de casais separados ou em vias de separação, como Tigres de papel (1977), Qué hace una chica como tú en un sítio como éste? (1978), Estoy en crisis (1982), El efecto mariposa (1995) e numa mesclas de união e separação com troca de casais como em El cuarteto de la Habana (1998). Sagitário (2001) - um drama - discute as carências individuais e a projeção de desejos. Colomo situa nesses filmes suas saídas com desfechos felizes. Os conflitos apresentados subordinam as atitudes passionais trágicas a ações onde o prazer vem revestido de ponderação. São saídas possíveis, não mágicas. O diretor busca apenas mostrar a insensatez de certos atos.

Já nos filmes de Ventura Pons este aspecto ganha contornos mais filosóficos. Tanto nos dramas como nas comédias as reflexões buscam um sentido para as ações tomadas pelas personagens. Em sua trilogia minimalista, no drama Amic, amat (1998) sempre as situações são deixadas em aberto para a conclusão do espectador. O que parece, no entanto, algo sombrio, demonstra-se corriqueiro. Qualquer situação, seja entre as três amigas que fazem um jogo para capturar o mesmo homem em Que t'hi jugues Mari Pili ? (1990), ou em Carícies (1997), onde as pessoas não conseguem se comunicar, nem se acariciar, ou mesmo em Animales heridos (2006), sobre um marido infiel, sua amante jornalista e sua esposa fútil, em todos a afetividade prevalece sobre as diferenças, sejam elas temperamentais, de classe, culturais ou de orientação sexual. 
Quase num mesmo sentido caminha Eloy de la Iglesia, porém, como em seu recorte fílmico, a questão política e de classe social fornece as balizas por onde percorre a trama. Desse modo, os sentimentos amorosos também recebem a carga da estrutura social e o desenvolvimento da ação dramática adquire formas mais duras. Os amores são marcados pelas condições de vida dos protagonistas e pelos dilemas que estas determinam. Tanto os membros das classes populares como os das mais favorecidas sofrem as conseqüências amplas de suas atitudes como em Colegas (1982), Los placeres ocultos ou El diputado (1979). Para La Iglesia não há possibilidade de realização total do amor se as condições materiais humanas, incluindo-se as regras criadas pela própria sociedade, não se transformarem e libertarem as pessoas de suas amarras.

Fernando Trueba não teve a paciência histórica de Eloy de la Iglesia. Ele mesmo se encarregou de fazer sua revolução e não esperar que a sociedade a realizasse. E já que ainda não é possível vivê-la no plano real, ao menos no plano fílmico indicou suas alternativas. A todo momento, quando relaciona a história e os sentimentos como em El año de las luces (1986), Belle époque (1992) ou em La niña de tus ojos (1998), suas tramas amorosas não obedecem leis políticas, regras morais ou instituições punitivas. O sentimento ultrapassa todos os limites, sempre descrito como algo natural. Não há crises, dúvidas, apenas certezas a serem atingidas. Nas tramas contemporâneas a regra é a mesma. O amor está disponível para ser vivido.

Bigas Luna trabalha os sentimentos amorosos de maneira mais delicada. Os dramas pessoais, as influências sociais, culturais e psicológicas pesam a todo momento na atitude de suas personagens. Os valores são afrontados, causando efeitos polêmicos como em Bambola (1996), mas os sentimentos não deixam de ser experimentados. $\mathrm{E}$ isso em geral causa reações bem adversas no espectador. Para evidenciar a contradição o autor não poupa elementos e, sobretudo nos seus dramas, como em Las edades de Lulu (1990), todo o processo de amores bem e mal-sucedidos é apresentado na trajetória de vida da protagonista. Em compensação, nas histórias como La camarera del Titanic (1997) ou na tragicomédia Jamón, jamón (1990), a relação intrínseca entre sensualidade e amor envolve o público num belo jogo de sedução de imagens.

Diante destes cineastas e desta temática, Almodóvar investe com intensidade compondo uma somatória que se assemelha à linha de Trueba, imprimindo mais contraste na personalidade das personagens, dando a elas mais ousadia e atitudes mais viscerais; à de Luna, sobre suas referências culturais - embora sem a mesma 
profundidade dos referenciais artísticos -; e à de Pons, nas preocupações existenciais de seus últimos trabalhos, principalmente desde La flor de mi secreto (1995). Todas as histórias são necessariamente movidas a grandes paixões incontroláveis, mas, diferente de Trueba, onde a ausência de regras direciona as personagens para relações harmônicas, com Almodóvar desencadeiam-se atitudes tensas em constantes desfechos inesperados.

Não muito diferentes são as atitudes de Pons diante do tema da solidão. Sobre ela o diretor desenvolve um sombrio panorama, resultado das relações impessoais que permeiam o mundo contemporâneo. Algumas das histórias de El perqué de tot plegat (1994) discutem isso na falta de comunicação, na espera, na dúvida, dentro da reflexão das personagens sobre suas condições. Pensamento que facilmente se desdobra para o dia-a-dia do espectador. Amic, amat acentua o "estar solitário" na pele de todas as personagens. É uma condição e não uma natureza. Nos finais, como contraponto, deixa idéias em aberto sobre a necessidade de não se viver sozinho.

Luna remete esse aspecto ao limite de sua potencialidade, para chegar à imagem do desequilíbrio psicológico. Bilbao (1978) é o exemplo claro - associando várias carências - de que, para ele, o processo de grande individualização da vida social leva a problemas pessoais. Em Jaime Chávari o ato de fazer-se só se justifica como em toda sua obra - pelo processo histórico. Em A un dios desconocido (1977), isso ocorre em razão de um passado mal resolvido. O protagonista tenta compreender para si sua situação, buscando reconstituir lembranças que expliquem seu momento. Desde a vizinhança até a amiga de juventude, todos não entendem sua forma de vida solitária. Nesses dois autores, portanto, a solidão é prejudicial e desoladora.

Este - diferente dos outros autores - é um dos temas de excelência em Almodóvar. A começar por suas personagens femininas. Todas as protagonistas são solitárias e, na quase totalidade das obras, as personagens que orbitam ao redor delas também são. Nesse terreno - ao menos na Espanha - não há diretores que se equiparam a ele. $O$ envolvimento com o assunto da solidão acompanha sua própria trajetória, desde menino em Calzada de Calatrava e Cáceres. A vida das pessoas no pueblo, as mulheres solitárias que observava, o fato de possuir gostos muito diferentes dos habituais para sua idade e classe social em Cáceres, na infância e adolescência, e por isso ser incompreendido pelos colegas de escola. Viver sozinho em Madrid. Foram várias experiências que influenciaram sua visão e o levaram a construir seu próprio universo cinematográfico.

Até a fama contribuiu para aguçar sua parcela solitária. O próprio Almodóvar 
avalia que as conseqüências do sucesso possuem o poder de isolar as pessoas e que isto o afetou profundamente ${ }^{165}$. Suas personagens acabam por refletir a forma como ele próprio encara e administra estas situações, sobretudo a partir de La flor de mi secreto (1995), quando suas histórias se voltam mais para o drama e diminuem o tom cômico. Nos filmes, não há julgamento de valor como nos outros diretores. Não há o que questionar. Para ele, é uma condição dada, um estado natural, um sentimento diferente de estar acompanhado ou de garantir a descendência genética. Entretanto, apesar destas deduções, cada personagem de suas películas busca um caminho para realizar seus desejos, mesmo que estes sejam às vezes insólitos.

Oportunamente, falar do desejo significa abrir um vasto leque de opções objetivas e subjetivas que poderiam englobar abordagens dimensionadas desde os instintos até a racionalização das formas de produzi-lo e de experimentá-lo. No caso do cinema - levando em conta seus desdobramentos mais diretos nos filmes apresentados por estes cineastas - a sexualidade aparece como o principal objeto para discutir este aspecto humano que une impulso e sentimento. Nas elaborações destes artistas, as vias de discussão e possibilidade para vivê-la atingem um grau de multiplicidade tão amplo que olhar apenas para os filmes de Pedro Almodóvar representaria abandonar sua própria raiz cultural e o sentido de sua produção no país.

Como já observei anteriormente, a sensualidade está disseminada na vida dos espanhóis, portanto, a sexualidade como parte desse conjunto que envolve desejo e regras sociais faz parte do jogo de coexistência entre o proibido e o permitido, mas, acima de tudo, entre o desejado e o liberado, ou seja, a consumação dos diversos patamares da ação sexual ausentes de limites e leis morais. O que mais se percebe nos filmes é a necessidade de realizar o prazer. E desde a projeção até as atitudes físicas conforma-se num mesmo plano a busca por uma liberdade antes cerceada, uma mescla totalizadora de afrontamentos diante das repressivas decisões de consenso social que nesse caminho encontram a forma de realização integral.

Algumas esferas institucionais influenciaram diretamente a forma de realização dessas películas. Seja por necessidade de apontá-las ou bani-las do universo das imagens - quando são ignoradas totalmente dos filmes - elas perpassam as entrelinhas das narrativas destes diretores e encontram-se muitas vezes aliadas. É o caso por excelência da Igreja Católica. Seu papel repressivo na esfera social e familiar, conduzindo a moral e as atitudes de seus integrantes, já foi objeto de inúmeros filmes de cineastas consagrados na Espanha. Luis Buñuel certamente é a principal referência

${ }^{165}$ FERNÁNDEZ-SANTOS, Elsa. La fama me ha hecho polvo. El País, Madrid., 15 mar. 2002. Cine. p. 2. 
que coloca a presença desta instituição como controladora da vida social por meio de seus valores. Extraña pasión ou Él (1952), Viridiana (1961) e mesmo Via láctea (1968), segundo o diretor, mais uma incursão sobre o fanatismo do que uma crítica antireligiosa e católica ${ }^{166}$, são exemplos máximos desse aspecto.

Essa aversão ou completa reprovação tem suas razões na própria história da Espanha, que sempre possuiu um clero mais conservador e centralizador de poder, aliado ao poder político do rei e depois ao general Franco durante toda a ditadura. Por mais que tivessem uma postura apolítica, o fato de verem seus filmes censurados por questões morais ou de serem criticados por suas discussões, dava aos diretores uma carga de indignação expressiva. Associando estes eventos à opção ideológica ou ao menos às influências das idéias de liberdade - para eles criativa - vindas da esquerda, das quais ou participavam ou eram simpáticos, pode-se compreender suas posturas e a necessidade de inserir a discussão sobre a sexualidade nas temáticas.

Assim, frente à quase ausência direta da imagem da Igreja como componente participante da trama, ainda constam apenas alguns filmes. De Ventura Pons, $E$ vicarlo de Olot (1986) comédia passada num vilarejo que devido a um congresso para discutir limites de atitudes sexuais tem início uma grande polêmica entre os moradores sobre o direito de suas escolhas. De Fernando Trueba, em Belle Époque (1992), na figura secundária de um padre renegado que vive num vilarejo usufruindo da vida leiga e amigo do velho anarquista, pai das quatro filhas protagonistas da história. De Jaime Chávarri, El año del diluvio (2004), sobre a paixão entre a madre superiora Sor Consuelo e Augusto que the dará ajuda financeira para construir um hospital. E, de Eloy de la Iglesia, El sacerdote (1978), filme sobre um padre e seus conflitos morais.

Ainda assim, vale considerar que os efeitos morais religiosos aparecem em traços de alguns personagens e sempre de maneira negativa. É compreensível; assim como ocorre com Pedro Almodóvar. Entre tinieblas (1983) é um trabalho especificamente sobre a igreja rodado num convento de freiras excêntricas, mas a presença moral da instituição percorre vários de seus filmes, na personagem Berta, integrante da Opus Dei em Matador (1985-1986), ou em Átame (1989), na imagem da virgem Maria e de Jesus Cristo no alto da cama quando o casal se ama refletindo-se em vários espelhos no teto. $O$ teor irônico ou provocador sempre permanece.

A igreja de Almodóvar não é a de Barcelona do período das grandes manifestações classistas operárias que a cada levante queimavam uma capela ou uma catedral. Ela é apenas um espaço da devoção, não importa a quem. Sua trajetória de

${ }^{166}$ BUÑUEL, L. Meu último suspiro. Rio de Janeiro: Nova Fronteira, 1982. p. 344-347. 
difíceis anos vividos em colégios religiosos, além de ter contribuído para seu ateísmo, acabou por libertá-lo parcialmente dos valores moralistas. E ele se livrou do mais importante: o controle eclesial e a culpa. Com sua ausência, pôde fazer filmes sem o julgamento moral. Se em Tacones lejanos (1991) ainda há um certo castigo nas ações, o que se constata nas atitudes do protagonista de Hable con ella (2002), e nos assassinatos de La mala educación (2004) e Volver (2006) já é um processo em que se revelam mais fortes os sentimentos, livres de regras.

No geral, a construção da sexualidade em Jaime Chávarri está ligada à tradição como controle ou liberação de desejos, como em La intrusa (1990) e Besos para todos (2000). Aos grupos que estão fora desta esfera estão as relações de personagens que se projetam em seus mitos, como Sus ojos se cerraron y el mundo sigue andando (1997), na luta pelo direito à diferença, como em Las cosas del querer (1989). Suas abordagens sobre sexo perderam força nos filmes com o decorrer dos anos. Chávarri entende que ele em si é - como todos os temas - um pouco limitado. Durante um tempo interessou-se em abordá-lo, mas não foi o que mais o atraiu nos trabalhos mais recentes.

O foco de Ventura Pons privilegia a liberdade sexual, abrangendo sob este aspecto o direito de escolha do que fazer e com quais parceiros, podendo ser bissexualismo em La rossa del bar (1986), homossexualismo em Rosita, please (1993), Amic, amat (1998) e Manjar de amor (2001), três amigas para um mesmo homem como Que t'hi jugues Mari Pili? (1990), um travestismo social - ou inúmeras trocas de papéis sociais e sexuais - em Aquesta nit o mai (1992), filmes que resumem diversidade, liberdade feminina, em formas que naturalizam o sexo sem rituais, medos ou vergonhas. Mesmo a traição é tratada sem culpas.

Pons preserva a fruição dos sentimentos. Tudo é apresentado num tom de franqueza e fina ironia sem grandes exposições físicas ou apelativas. Claro, há exceções; em uma das pequenas histórias de El perqué de tot plegat (1994), um casal pratica sexo oral e a única frase que a parceira pronuncia - quando fala - é sobre o quanto gosta do órgão sexual do parceiro. Isto se tornará tão insuportável para ele que ambos acabam numa cena de ciúme - dele contra seu órgão sexual - que culmina numa briga. A situação é tão nonsense que nem a nudez do casal passa a ter importância. O sexo aparece como mais um elemento cotidiano - e muito praticado.

Nos filmes de Fernando Trueba a sexualidade vem sempre como resultado da paixão, num processo que indica as iniciações sexuais, a pureza dos relacionamentos impulsivos e francos. Como em Pons, em Trueba há uma ausência de julgamento 
moral sobre as relações. Isso aparece da melhor forma do diretor, de maneira bem humorada, em Belle Époque (1992), irmãs com diferentes perfis, pai anarquista, sexo como prática natural. As surpresas decorrem de situações que passam longe da moral sexual. O que conta é a liberação dos desejos. O ato sexual está no nível da contemplação. Desde sua estréia é sobre esta regência que seguem seus filmes. Sem limites para o desejo. O envolvimento da personagem interpretada por Penélope Cruz com o prisioneiro imigrante, versus o oficial nazista, dá o tom de seu olhar sobre relações, história, poder e sexualidade. O sexo acompanha os sentimentos e estes estão em primeiro plano.

Como já apresentado, Eloy de la Iglesia vincula o sexo e as relações afetivas à liberação das regras políticas e sociais. Neles estão fundados os tabus e as privações que se subordinam à moral burguesa e religiosa. Não por acaso, quando as personagens se liberam deles, suas relações íntimas fluem naturalmente. O sexo é para ele o espaço da liberdade geral. Iglesia rompe nesse momento com limites de idade, gênero, classe e opções ideológicas. Los placeres ocultos (1977) e El diputado (1979) ilustram tais aspectos com uma veracidade ímpar. Num sentido oposto, o sexo funciona também como denúncia social sobre os desequilíbrios emocionais que a desigualdade social provoca nas relações, como em Navajeros (1980), ou da repressão social e da falência das instituições, como La criatura (1977). Em seus filmes, a sexualidade é mostrada sem muitos retoques, porém há momentos de singeleza nos gestos e doses poéticas.

O mesmo não pode ser dito de várias películas de Bigas Luna. Para discutir as neuroses e o abandono social, ele não poupa cenas duras, cruas esteticamente, sem glamour e sem delicadeza. O sexo na cidade é tratado de maneira fria, atendendo a desejos reprimidos, como em Bilbao (1978) ou Las edades de Lulu (1990), denunciando também a marginalidade, em tons diferenciados de Eloy de la Iglesia mais carregados esteticamente. Neles se misturam psicoses, sadismo, paixões incontroláveis e violentas como em Lola (1985), ou então toca em tabus como o incesto, em Bambola (1996). As relações vinculando poder e sexo também são abordadas, misturando processos históricos, arte e vaidade em Volaverúnt (1998).

Mas, para quem imagina que a sexualidade para Luna é apenas o terreno do "desabafo" dos complexos e privações sociais, ele responde com o universo da sedução, como em La camarera del Titanic (1997), e diverte seu público com cenas hilárias e eróticas na sua trilogia Jamón, jamón (1992), Huevos de oro (1993) e La teta y la luna (1994), claro, sem esquecer de tocar em valores culturais que vão desde a 
poesia até o modelo do machismo mediterrâneo e as conseqüentes carências afetivas.

Valores que também Fernando Colomo aponta quando apresenta o machismo em Qué hace una chica como tú en un sitio como éste? (1978). Porém, o que importa mais a Colomo é relativizar a sexualidade e realçar a liberação das paixões, como em El efecto mariposa (1995) ou mesmo em El cuarteto de la Habana (1998), quebrar tabus. Também sua discussão sobre a infidelidade não parte para o drama tradicional em Estoy en crisis (1982), em que o marido infiel diz viver em crise, mas só mergulha numa verdadeira quando é abandonado pela esposa. Como Colomo opta pela comédia para discutir estes problemas, as ações sexuais caminham muito mais para a concretização tranqüila dos desejos do que para os conflitos sociais que possam existir no cumprimento tradicional de papéis.

Pedro Almodóvar possui momentos diferenciados em sua obra para tratar da sexualidade. Até La ley del deseo (1986) figuram relações sexuais possessivas, obsessivas tanto no campo da comédia como no drama. Nesse conjunto estão personagens psicopatas, sadomasoquistas, travestis, transformistas, gays e estupradores. O que conta é a realização desenfreada da vontade sexual sem limite e sem respeito ao outro para que os desejos se satisfaçam. Sexo, festa e liberação das taras significam quase a mesma coisa. Mujeres al borde de un ataque de nervios (1987) é uma grande exceção. Ali todos os desejos estão reprimidos, salvo Carlos (personagem de Antonio Banderas), que se atira nos braços de Candela (Maria Barranco) enquanto sua noiva dorme após ter tomado, por engano, um gazpacho com sonífero. Embora não haja sexo, toda a discussão gira em torno de relações afetivas e sexuais frustradas.

Em seguida, continua com situações onde o sexo é muito presente, com cenas de sexo em meio a paixões avassaladoras até Kika (1993). Após este filme, suas obras deixam a sexualidade num segundo plano e as seqüências cedem espaço para as reflexões em torno da afetividade. As cenas de sexo e sua discussão não desaparecem por completo. Agora se subordinam à compreensão dos valores que cercam sentimentos de aproximação amorosa entre as pessoas, cada vez mais em tom familiar ou de resgate pessoal de afetos. Após a perda da mãe, em setembro de $1999^{167}$, o diretor demonstra uma vida mais reservada, com menos amigos e festas, refletida também nas histórias. Nota-se, portanto, um processo que segue momentos vividos, não um projeto acerca de discussões sobre temas ou valores. O autor filma suas buscas presentes.

${ }^{167}$ TOLEDO. Adiós a una madre. La Vanguardia, Barcelona. 12. 09. 1999. / Strauss. 2001, p. 178-179. 
Esta temática é abrangente. Possui vários subtemas compostos de seu desdobramento. A homossexualidade é apenas um deles, mas aparece como um ponto significativo no período da transição. Emerge na Espanha democrática não mais como um fenômeno ou desvio social, mas sim como um fato cotidiano. Deixa de ser algo oculto, de guetos, ilegal. E torna-se pública não apenas porque todos aqueles que tiveram suas liberdades cerceadas puderam finalmente emancipá-las.

No início do século XX na Espanha a homossexualidade era considerada um delito. O artigo 616 do código penal de 1928 penalizava como atentado ao pudor os atos sexuais cometidos por pessoas do mesmo sexo, vistos como escandalosos. Após a Guerra Civil, a ditadura de Franco não se pronuncia contra a homossexualidade mas a persegue duramente. É o que se vê em Las cosas del querer (1989) de Jaime Chávarri. Em julho de 1954 foi incluída uma emenda na "Ley de vagos y maleantes" que considerava qualquer homossexual como delinqüente. A lei castigava severamente estes comportamentos e causou uma absurda onda homofóbica no país em nome da estabilização social.

Em agosto de 1970 foi aprovada a "Ley de peligrosidad y rehabilitación social", que considerava a homossexualidade um problema mental, que deveria ser tratado, para que o "doente" pudesse voltar a ser normal na sociedade. Mas a emenda da outra lei ainda tinha seus ecos e entre 1975 e 1979 calcula-se que 181 pessoas foram processadas, porém, mas como eram consideradas doentes pela lei, não podiam mais ser condenadas. Esta última lei tinha um duplo objetivo: de um lado ser um aviso para outros homossexuais e, de outro, realizar um estudo científico sobre o "problema". Somente a partir de 1978, após os debates entre o PSOE e a UCD sobre a constituição, o caráter criminal das leis foi abolido. ${ }^{168}$

Portanto, é como resultado deste contexto que a abordagem cinematográfica pode ser considerada relevante como registro e manifestação artística. Mas, ainda que a liberdade estivesse "decretada", isto não quer dizer que havia aceitação da diversidade. A resistência vinha, talvez, não só pelo modelo de masculinidade mediterrâneo arraigado na formação cultural do país, resultante de imagens do homem forte e dominador e de regras político-católicas. Existe uma diversidade de orientação sexual dentro do próprio - genericamente falando - "grupo" sob classificação homossexual. A forma de vivê-la e de se apresentar para a sociedade possui uma pluralidade de alternativas que suscita leituras diversas que refletem também o próprio contexto.

${ }^{168}$ GARCÍA, Victor Hernández i M. A., Revista Lambda, nº 53, primavera 2005, any XXVII. p. 11-12. 
Às vezes escandalizadas, como em Ocaña (1978) de Ventura Pons, ou em Pepi, Luci, bom y otras chicas del montón (1980), Laberinto de pasiones (1982) e La mala educación (2004) - como lembranças de um passado remoto - de Pedro Almodóvar. Filmes que diante da conjuntura da época não poderiam deixar de surtir os efeitos que causaram. Ora resignadas, como $A$ un dios desconocido de Jaime Chávarri e El diputado (1979) de Eloy de la Iglesia. E em tempos de democracia, a naturalidade de Alegre ma non troppo (1994) de Fernando Colomo, Las cosas del querer - 2 (1995) - uma possibilidade de viver o direito à diferença em outro país - de Jaime Chávarri, Los novios búlgaros (2003) de Eloy de la Iglesia, a bissexualidade de La rossa del bar (1986), a ironia com um homossexualismo resultante de um elixir mágico de Rosita, please (1993), os dramas da solidão e da meia idade em Amic, amat (1998) ou da descoberta pessoal-sexual da juventude nesses tempos livres em Manjar de amor (2001) de Ventura Pons.

Mesmo circunscritos ao meio social e às suas condições históricas, estes filmes apresentam um panorama geral e sensível das possibilidades e formas de vida da homossexualidade durante estes últimos 30 anos na Espanha. $O$ peso religioso aparece pouco e as dificuldades se estabelecem mais nas esferas política e individual. Há uma certa moral que percorre os trabalhos, mas esta não impede que realizem suas vontades.

Almodóvar percorre suas buscas nesse sentido, de modo um pouco distinto. A moral não existe. Em seu lugar são colocados os desejos e as formas de sua realização. A homossexualidade já aparece desde seu primeiro longa-metragem comercial como algo natural e rotineiro na vida das personagens. Não há afrontamentos que indiquem algum discurso ou militância em nome dos direitos, como aparece em Eloy de la Iglesia e Jaime Chávarri.

Almodóvar aborda, mas não faz um "cinema homossexual". Suas histórias utilizam gradientes que vão do perfil masculino ao feminino - ou vice-versa - no sentido de se traduzirem como elementos que explicitem sentimentos. O que menos importa é o sexo no aspecto biológico ou a orientação sexual como problema de discriminação e de conflito social. Essas ações dramáticas não existem em suas películas. Estão desvinculadas de qualquer condição social como determinante das relações. Sua busca visa a ultrapassar os limites dos papéis sociais para que, anulando ou destruindo-os por intermédio da ironia, se possa enxergar e revelar a humanidade que enfim iguala todas as necessidades.

Almodóvar utiliza a noção do carnavalesco, do dúbio, da paixão que se 
sobrepõe à razão, transformando suas personagens apenas em porta-vozes do desejo, este sim - para ele - o verdadeiro agente das ações. Retiram-se do primeiro plano da narrativa os aspectos pertinentes à classe social, suas implicações e desdobramentos, com a exceção parcial de Qué he hecho yo para merecer esto?. Em entrevista para este trabalho, José Enrique Monterde sublinha esta ruptura entre personagem e história:

[...] Os personagens de Almodóvar não existem por si mesmos. Em Todo sobre mi madre, há muitos elementos melodramáticos que sustentam a história, não os personagens. Hable con ella tem elementos mais estilizados $[\ldots]^{169}$.

Por isso, enquanto La Iglesia opta por integrar a realidade no perfil da personagem, Almodóvar leva isso para o plano da forma, da história exterior a ele. Exercita assim uma variação de planos de possibilidades, como a desvinculação da personagem de uma classe social e seus impedimentos de realização pessoal ou ao papel sexual como pressuposto de satisfação e prazer. Em nenhum momento percebese em suas histórias situações onde alguém sofra por sua orientação ou condição de classe. Nas histórias de la Iglesia, esses elementos incidem a todo momento sobre as cenas dos envolvidos na ação dramática.

Mesmo com estes aspectos, nota-se que Eloy de la Iglesia inspirou parte dos trabalhos de Pedro Almodóvar. Seu mundo cinematográfico se move numa órbita próxima da sua. Entretanto, o cinema de la Iglesia possui mais pontos comuns com o de Pier Paolo Pasolini (que sonda o mundo do sub-proletariado e do lumpensinato) e com o de Rainer Werner Fassbinder ao aplicar uma violência social essencial no conteúdo e na forma. ${ }^{170}$

Chávarri também aborda temas recorrentes a Almodóvar, porém busca dois elementos inexistentes - ao menos intencionalmente - nos filmes do diretor: a referência conteudista ao passado ditatorial, suas conseqüências sobre a vida social dos espanhóis e o cunho documental. Mais uma vez se percebe o afastamento das questões sociais associadas ao instrumental histórico-sociológico das abordagens. Um fator inaceitável para muitos que vêem nessa prática um sinal persistente não apenas de alheamento à vida e ao processo de desenvolvimento da sociedade espanhola, mas também de um certo ofuscamento da realidade. Essa crítica à artificialidade das histórias e personagens de Almodóvar é fato comum, reconhecido e observado no interior dos círculos intelectuais, e gerador de polêmicas:

\footnotetext{
169. MONTERDE, José Enrique. Depoimento sobre Pedro Almodóvar [21 jun. 2005]. Entrevistador: Gilmar Santana. Barcelona: Universitat de Barcelona, 2005. Minidv (60 min), mono. Entrevista concedida para este trabalho.

${ }^{170}$ Disponível em: <http://es.wikipedia.org/wiki/Eloy de la Iglesia. Acesso em 20. 03. 2006.
} 
- A saída de Almodóvar é sempre artificial, mesmo nas cenas mais pretensamente realistas. Ele faz um jogo de forças de efeito que não se ligam com a realidade social“"171

" - Ele faz um cinema de referências, não lhe retiro o mérito por isso, pois afinal, aprendeu a fazer cinema" ${ }^{\prime 172}$

" - Almodóvar pensa mais na forma que no conteúdo. Sua formalidade é única, quem vê seus filmes a identifica claramente: as cores, o kitsch. Possui uma consistência visual tão grande que os puristas não vêem suas películas como sérias. Elas saem um pouco do acadêmico e isso acaba sendo um prejuízo para Almodóvar. Fala muito do grotesco e do esperpento, mas isso é uma parte muito superficial da narração. Seus personagens são extremos e suas situações inverossímeis. Mas quem fica apenas nas formas grotescas, não aprofunda a crítica social, permanece na superfície ${ }^{173}$.

E, quando colocadas ao lado de filmes como os de Chávarri, o choque dessas visões se torna não só evidente, como comprovável, ainda que apresente sua crítica social voltada para um outro plano que questiona hábitos arraigados ou correntes no senso comum. Mesmo a ironia, presente de maneira muito semelhante em ambos, difere quando se incluem os fatores da herança histórica e do conflito social. Diferenças também encontradas entre Chávarri e Eloy de la Iglesia nesse sentido, quando incluem a discussão sobre as classes sociais. No primeiro, elas se circunscrevem num tipo específico de "excluídos", mais próximos às personagens de Almodóvar, no segundo, são revelados pela marginalidade. No entanto, a participação desse elemento social na narrativa como determinante das ações direciona a trama para caminhos que não se encontram com as histórias de Almodóvar, mesmo quanto todas falam de afetos e de realização de sentimentos.

O que parece mais evidente em Almodóvar - e esta comparação com alguns cineastas mostrou - é constatar sua contínua capacidade de reciclagem no sentido de selecionar do antigo, do clássico e do contemporâneo traços e valores que possam ser traduzidos como material para seus filmes, numa nova mensagem. Uma equiparação que analogamente se estende para temas e estilos dos diretores que the são contemporâneos.

Nada escapa ao olhar do diretor. Ainda que em muitos cineastas não haja diálogo narrativo, percebe-se nas películas de Almodóvar marcas ou mesmo referência a vários deles. É como se por uma sugestão inconsciente, a cada momento, algum dado disponível de cada diretor pudesse ser guardado para uma nova composição. Ou seja, tudo é material para uma criação ou reinterpretação. Ele não faz uma paródia,

\footnotetext{
${ }^{171}$ MONTERDE, José Enrique. Depoimento sobre Pedro Almodóvar [21 jun. 2005]. Entrevistador: Gilmar Santana. Barcelona: Universitat de Barcelona, 2005. Minidv (60 min), mono. Entrevista concedida para este trabalho.

172 CAPARRÓS, José Maria. Depoimento sobre Pedro Almodóvar [08 jul. 2005]. Entrevistador: Gilmar Santana. Barcelona: Universitat de Barcelona, 2005. Minidv (60 min), mono. Entrevista concedida para este trabalho.

${ }^{173}$ ZURIAN, Fran A. Depoimento sobre Pedro Almodóvar [09 ago. 2005]. Entrevistador: Gilmar Santana. Madrid, 2005. Minidv (60 min), mono. Entrevista concedida para este trabalho.
} 
mas também se utiliza dela. As referências, homenagens a diretores consagrados, seus contemporâneos, amigos mais próximos ou distantes, algo sempre acaba por integrar-se no painel de seu presente e de suas películas. Núria Vidal confirma esta observação:

Nós tivemos uma grande cumplicidade, hoje não mais. Tanto fomos próximos que inclusive em 'Tacones ...' há uma personagem que é secretaria de Marisa Paredes que é de origem mexicana e é catalã, essa sou eu, isso foi chupado de mim, por que Almodóvar coopta tudo ao seu redor. Tudo é material para seus trabalhos. ${ }^{174}$

Nesse sentido, entendo que o diretor consegue ir um pouco mais além do que uma collage ${ }^{175}$, segundo a análise de Antonio Holguín, que vê nos trabalhos de Almodóvar - ao menos até onde pesquisou com Todo sobre mi madre - uma união entre a idéia de um quebra-cabeça e da collage, uma totalidade coerente a serviço de uma idéia. Um estilo resultante de dois mundos: o genuinamente espanhol e o pop norte-americano, que geram uma série de constantes que se repetem e lhe dão originalidade - a exemplo de tantos outros artistas - sob a marca de sua personalidade criadora $^{176}$.

Vejo que seu processamento de informações vai desde associar ou citar linhas estilísticas e autores até incluir na narrativa de suas histórias uma pessoa especial que observou nas ruas ou um fato absurdo que pôde inventar enquanto estava na suíte de um hotel. Não é só a capacidade de dar a cada uma dessas idéias novos significados que o torna especial. Dificilmente encontramos em uma imagem ou cena que mostram suas referências algo que não inclua sua trajetória pessoal.

Como também se viu, a abordagem homossexual é objeto comum entre os cineastas espanhóis. Dentre os analisados aqui, por exemplo, a maioria já discutiu essa temática. Portanto, nesse sentido o diretor não traz uma novidade. O que incomoda tantos críticos, claramente é que em sua descontextualização social e abstração de valores morais abre-se o espaço para viver uma afetividade na qual esse aspecto se torna irrelevante. Numa sociedade que mesmo possuindo esta prática no cotidiano - num ritmo crescente de manifestações favoráveis - haja resistências oriundas de padrões comportamentais hipoteticamente consolidados. Dispôr a homossexualidade sem repressão significa, para grupos conservadores, difundir o caos e não a liberdade humana ou o reconhecimento sincero dos sentimentos. Enquanto

\footnotetext{
${ }^{174}$ VIDAL, Nuria. Depoimento sobre Pedro Almodóvar [13 jul. 2005]. Entrevistador: Gilmar Santana. Barcelona: Universitat de Barcelona, 2005. Minidv (70 min), mono. Entrevista concedida para este trabalho.

${ }^{175}$ Palavra francesa que designa uma técnica que une na pintura elementos de origem distinta colados num papel sugerindo um todo homogêneo.

${ }^{176}$ HOLGUín, Antonio. Pedro Almodóvar. 2. ed. Madrid: Cátedra, 1999. p.62-123.
} 
outros autores mostravam as conseqüências sociais deste "desvio", isso poderia ser assimilado. Mas da forma como Almodóvar indica, isso passa a ser perigoso. Porém para ele -, inevitável.

Se o diretor assumisse um papel de processador das imagens de seu tempo, seria uma síntese de seu tempo e de seus colegas de criação. Mas nem se pretende a isso e nem é o que faz. Sua particularidade narrativa e escolhas temáticas notabilizamse por permitir ser de seu tempo de uma maneira bem peculiar e instigante: observar 0 ignorado e supervalorizá-lo. No fundo, ao revelar as inúmeras buscas que faz de si mesmo e de seu universo: amigos, festas, seu oficio, seu passado, suas mulheres, seus homens ou a projeção deles, o diretor faz emergir um complexo universo de desejos dessas personagens, de seu contexto e não de suas ações. Fantasias, frustrações e esperanças, dentro das possibilidades do elemento do desejo, são reveladas a cada uma de suas manifestações em cena. Por ser universal, a possibilidade de identificação com algum de seus aspectos torna-se bastante previsível.

Esses elementos arremessam a imagem dos filmes e do próprio Almodóvar para um plano universal atraindo, para si a simpatia de admiradores, sejam eles espectadores, produtores internacionais ou teóricos. Os constantes desvios das regras sociais, algumas já assimiladas pelas relações atuais e outras ainda hoje excêntricas em vários aspectos, indicam uma das razões que o mantenham sempre em foco. 0 desejo é incontrolável e cria novas necessidades. O diretor o segue e nele se descobre ou produz polêmicas.

Pelo perfil dos cineastas analisados, pôde-se perceber que cada um possui seu brilho próprio, suas ousadias e originalidades que garantem em grande medida sua contribuição na filmografia espanhola ou mundial. Também são ou foram destacados ganhadores de prêmios importantes, marcando com notoriedade seus nomes no cinema espanhol. Por que então Almodóvar se projeta em mais de duas décadas no cinema mundial sem precisar sair do país para dirigir filmes? $\mathrm{O}$ desenvolvimento das comparações demonstrou que ele não produz "o melhor" do cinema espanhol, mas um nível de qualidade que dialoga em inúmeros sentidos com o de seus colegas de trabalho e com o mundo.

Talvez a imagem que construiu sobre si mesmo, ajudado pelo seu produtor, 0 irmão Agustín - que leva suas produções para diversos festivais e mostras -, 0 mantenha em evidência. Mas isso também não explica tanta projeção, afinal outros diretores também executam essa tarefa. A crítica favorável ou contrária a seu trabalho 
é um fator que contribui para destacá-lo. Estes fatos alimentam mitos e podem continuar reproduzindo seu sucesso. Como e quantos foram construídos? O que movem? Qual o processo histórico que o levou a isto? Basta seu caráter polêmico para sobreviver ao quase "selvagem" mercado do cinema? O próximo capítulo ajudará nessa reflexão.

Assim, completa-se esta análise comparativa sobre alguns cineastas que, cronologicamente próximos a Almodóvar, construíram o contexto de um novo cinema espanhol. Em seu conjunto - se não dialogando com ele - demonstraram a pluralidade de alternativas e visões projetadas concomitantemente ao processo de mudanças ou, muito mais, de sonhos que almejaram um devir melhor. Um processo que provocou o diálogo de uma Espanha mais integrada aos fluxos de relações mundiais e o despontar de novos cineastas no cinema atual, além de Pedro Almodóvar e destes analisados aqui. 


\section{DESCONSTRUINDO E RECONSTRUINDO PEDRO - O ENTORNO}

Ele é famoso pelas histórias que conta. Em virtude de seu caráter polêmico que não deixa margem para meio termo - e de suas narrativas provenientes das experiências privadas que teve pela vida - sobretudo as sexuais - acabou adorado e abominado por muitos. Entra em crise criativa. Personagens que havia criado começam a procurá-lo na intenção de ajudá-lo a compreender sua própria trajetória. Desce de elevador até as profundezas do inferno - seu inconsciente - na intenção de resgatar a namorada que o demônio havia roubado. Lá encontra mais alguns de seus personagens. Prossegue seu martírio, pois o mito construído sobre ele - ou que ele mesmo esculpiu de si - não o deixa em paz. Questiona-o misturando realidade e imaginação e suas personagens tentam reconciliá-lo com as pessoas do mundo real que as inspiraram. A partir desse momento, ele mesmo percebe que apenas se sente bem quando é o mediador que harmoniza sua criação e suas fontes.

Não ... não falo de Pedro Almodóvar, nem de mais uma de suas histórias excêntricas. Trata-se de uma breve passagem pela trama aparentemente insólita de Woody Allen, misturando mais uma história de seu ego e alter-ego com um pouco da sua própria vida: Desconstruindo Harry (1997). O jogo metafórico presente neste filme - quase autobiográfico do diretor - reflete uma das possíveis situações que ocorrem em torno de inúmeras pessoas que conquistam sucesso. Em diversos casos, muitos até permitem certas construções de suas imagens. Em outros, perdem o controle.

No campo cinematográfico, são vários os exemplos de livros destinados a alimentar ou a desconstruir mitos edificados em torno de pessoas que se tornaram ilustres, como James Dean ou Marlon Brando. Ou então, escritos por seus próprios parentes, como os publicados sobre Charles Chaplin, Klaus Kinski, Bette Davis, Judy Garland, entre outros. Talvez nem imaginem estes "apocalípticos" que, na busca por destruir um modelo de mito, revelando informações desconhecidas, estejam - na verdade - criando outros ou reproduzindo os já existentes.

\subsection{Uma biografia de imagens}

A vida e a imagem dos cineastas são inevitavelmente suscetíveis ao fenômeno da mitificação. Numa indústria como a do cinema na qual produzir ícones para a sociedade equivale a ampliação de investimentos, qualquer dado que contribua para fortalecer estas intenções será aceito e incorporado como parte do complexo gerador de celebridades. Por isso, são vários os agentes sociais que se aliam à sua dinâmica. Determinados ramos da imprensa - por exemplo - ocupam-se de vender informações 
lucrativas. Algumas contribuem para a notoriedade de um diretor, outras, para depreciá-lo. Nos dois casos, divulgam seu trabalho e instigam a curiosidade do público. Em geral, os cineastas que já entraram para o círculo dos mais respeitados ou considerados "gênios" são os mais visados. No produto de seus trabalhos revelam-se os traços e perspectivas de suas próprias vidas. Fato que não passa despercebido por esse entorno de setores que se encarregam de tecer determinadas leituras de suas obras e, com isso, confeccionar projeções. E foi exatamente com elas que muitos também se transformaram em mitos.

São inúmeros os filmes no cinema que convertem a referência mítica de alguém ou de fatos em um bom roteiro. Divinizar, exorcizar ou desmitificar uma personalidade, uma época, um acontecimento, para extrair deles uma nova perspectiva de vida. Um recomeço ou talvez um olhar mais humano sobre o mito que - com suas fraquezas e virtudes -, enfim, inicie novos processos de mitificação. Rebecca - a mulher inesquecível (1940); Cidadão Kane (1941); Crepúsculo dos deuses (1950); A malvada (1950); Belíssima (1951); Glória feita de sangue (1957); Teorema (1968); Sonata de outono (1978); Gandhi (1982); Malcolm X (1992); Diário de motocicleta (2003); Adeus, Lênin! (2003); Capote (2005); entre tantos outros. Perde-se na história do cinema o elenco de filmes acerca desse tema que encanta cineastas e espectadores, provavelmente em razão da enorme gama de assuntos que é capaz de gerar. Inclusive, de alimentar a própria imagem deste veículo de comunicação.

Não somente porque o mito suscita os diferentes aspectos da construção ou da desconstrução de pessoas ou momentos e ações históricas que - por seus atributos marcantes - "conquistaram" coletivamente um papel social idealizado. Ele possui um papel social decisivo, sobretudo nessa sociedade moderna motivada pelo efêmero. Sob o referencial do mito pode-se refletir a própria vida, repensá-la, seguir ou fugir de modelos de conduta e refazer a dimensão do universo que costumamos vislumbrar. Sua força é tão grande que, mesmo neste mundo secularizado, ele sobrevive e desenvolve novas imagens com valores que lhe garantem sua manutenção. Impulsionado pelo cinema, sua força só tende a se multiplicar.

As próprias funções do mito se confundem contemporaneamente com a prática cinematográfica. Uma ferramenta resultante da contínua inter-relação entre tecnologia e criações artísticas que, manuseada habilmente por diretores e suas equipes, desenvolveu - em pouco mais de um século - sua mitologia particular. Apropriando-se das formas tradicionais de arte e reinterpretando relações e valores cotidianos - que porventura procedessem dessa referência - o cinema gerou um universo próprio. Além 
de sua linguagem, fabricou um tipo de projeção imaginária com um poder de alcance tão grande que só mesmo a equiparação ao mito poderia mantê-lo.

Com seu evento, não foram somente as histórias contadas nos filmes as criadoras mitológicas - em muitas delas o mito é a própria fonte do teor dos roteiros como Vertigo (1958) de Alfred Hitchcock - que transporta para o século XX sua leitura de Orfeu. O cinema pôde alastrar esses significados simbólicos também em torno de seus atores, atrizes, diretores, enfim, daqueles membros destacados nesse ofício. Este capítulo pretende discutir o processo de construção de uma celebridade artística a partir de sua trajetória. Esta que numa primeira impressão demonstra ser um mérito pessoal, mas que na observação dos desdobramentos profissionais revela uma rede mais complexa e repleta de fatores sociais que projetam alguém para a fama e talvez para o mito.

Na sociedade contemporânea, em que fama, competição e poder caminham juntos, mostrando-se ampliados no campo artístico em razão das circunstâncias de difusão e circulação de bens simbólicos, a contribuição dos elementos mitológicos e dos seus efeitos transfigura-se, pois é moldada no sentido de atender à consolidação destes valores. Para aqueles que circulam fora deste eixo de interesses e que também conquistam seu espaço de reconhecimento, permanece a questão de saber como eles são envolvidos por esses fatores, como se relacionam e usufruem deles. Como Pedro Almodóvar se inclui nesse cenário?

Negociação, genialidade, méritos próprios, heroísmo, auto-promoção, associação a outras personalidades que também tiveram referenciais mitológicos em sua trajetória. São diversas as formas acionadas para chegar a esse resultado. Um processo contínuo envolvendo a pessoa celebrada e todos aqueles que orbitam em seu universo de ocupações e contribuem para desenvolver sua imagem. O próprio exercício desta pesquisa contribui inevitavelmente para sua expansão. A manutenção pública do nome de uma pessoa que se destaca socialmente recorre assim a funções mitológicas para fazê-lo sobreviver. Este é o caso de Pedro Almodóvar - dentre outros - que, num misto entre personalidade, criatividade, convicções e negociações com o universo cinematográfico, continua atraindo o interesse do espectador, do mercado e dos analistas, tanto artísticos como acadêmicos.

Nas formulações de Joseph Campbell ${ }^{177}$ existem quatro funções do mito tradicional oriundas do desdobramento intrínseco da necessidade humana para dar sentido, ordem e harmonia ao universo. De acordo com a experiência do homem, a

${ }^{177}$ CAMPBELL, J. Isto és tu. São Paulo: Landy livaria, editora e distribuidora LTDA,2002, p. 29-34. 
formulação do mito busca estabelecer uma ordem que simultaneamente tanto forneça lógica ao ambiente físico e mental, como também ao social existente e percebido ao seu redor.

Segundo o autor, a primeira função é buscar o alinhamento das pré-condições de existência do universo ao entendimento humano, juntamente com a função religiosa da mitologia que representa a revelação do mistério do ser ou da existência. A segunda, busca dar uma imagem consistente de ordem do universo, haja vista que o "ser" já se identifica dentro de um espaço como interventor no mundo por meio da constituição de uma sociedade. Ele está e se vê numa ordem cósmica. A terceira função traz por meio da ordem moral e simbólica veiculada pela cultura uma validade de relações que justificam uma ordem cósmica. Por isso, se explica o objetivo de moldar a pessoa à lógica de um grupo social específico.

A última função conduz o indivíduo - por intermédio das várias crises de sua existência - a compreender o desdobramento da vida com integridade. O processo se iniciou na primeira função, passou pelas seguintes e finalmente chegou à visão do todo, transcendendo o próprio indivíduo. Essas funções, além de fornecerem a noção de cosmos, regulam e harmonizam sentimentos, ações, dão referências de comportamento e oficializam o papel da sociedade e de seus grupos sociais.

$\mathrm{Na}$ elaboração de Karen Armstrong ${ }^{178}$ mantém-se a idéia da busca do ser humano para dar sentido à sua experiência cotidiana, fator que o torna peculiar diante de outros animais. Contudo, ele não somente busca atribuir sentido como também imprimir significado e valor às coisas vividas, utilizando-se para isso de sua mente e imaginação. Recursos que a autora destaca como os mesmos utilizados pela ciência ao defender e justificar sua produção de conhecimento em nome de uma razão autônoma e que trata, em geral, o pensamento mitológico como irracional, incorrendo num grande equívoco.

Muito próxima à Campbell, a definição de Armstrong sobre o mito aponta cinco aspectos que julga importantes para sua compreensão, ampliando a construída pelo autor. No primeiro aspecto explica o mistério do ser como procedente da experiência dos seres primitivos diante da morte e seu conseqüente medo de extinção, razão pela qual se entende a busca de sentido das coisas e as associações à religião. Para que isso se consolide, o segundo ponto se constitui na ritualização de todas as coisas envolvidas no processo da articulação de significados.

Esse exercício contínuo se concretizará no mito. Quanto mais forte, mais ele se

${ }^{178}$ ARMSTRONG, Karen. Breve História do mito. São Paulo: Cia das letras, 2005, p. 7-9. 
relaciona com o extremo motivando o ser humano a ir além de sua experiência, ir ao encontro do desconhecido, num lugar onde ainda não existem palavras, o terceiro aspecto. Quarto, "o mito não é uma história que nos contam por contar. Ele nos mostra como devemos nos comportar (...) por fim, toda mitologia fala de outro plano que existe paralelamente ao nosso mundo e em certo sentido o ampara. ${ }^{179}$ Uma experiência transcendente que faz o ser humano sair de si próprio, ao mesmo tempo em que se encontra internamente ou ao menos se explica.

Assim, os mitos dão forma e explicam aquilo que antes ele percebia apenas intuitivamente. A referência da imitação de deuses em sua vida serve como parâmetro para que também ele mesmo experimente a divindade. Portanto, a criação mítica se desenvolveu para auxiliar o ser humano a enfrentar suas dificuldades mais problemáticas e realizar sua verdadeira orientação.

Ainda que os relatos mitológicos não tenham ocorrido realmente, eles nos ajudam a explicar nossas atitudes atuais, costumes, nosso ambiente, e nos motivam a explorar novas possibilidades na vida. Por isso o mito passa a ser verdadeiro. Não por ser factual, mas eficaz. Enfim, funciona como um guia que nos diz o que fazer para vivermos de maneira mais completa. Dessa forma, se as condições da realidade mudam, ele também será contado de maneira diferente, podendo, então, alimentar novas perspectivas de mundo. ${ }^{180}$ Assim, diante do objeto desta pesquisa, cabe indagar: que ambiente social e cultural deu origem à imagem do autor ? Em que contribuiu para sua obra ? Como o espaço físico contribuiu para sua elaboração artística e visão de mundo ? Ele contribuiu para qual necessidade de equilíbrio ou entendimento de sua sociedade ? Se impôs porque se fez sozinho?

\subsection{Adeus, Movida? - Referências e projeções mitológicas}

A construção humana diante dos fatos ocorridos é seletiva e obedece a regras culturais inconscientes de projeção e apropriação. Assim, a forma de narrá-los os transforma em objetos moldáveis que destacam alguns de seus aspectos, conservando-os, e abandona outros ou então os esquece. Isso não significa dizer que presenciamos uma série de mentiras. Certamente, no plano histórico a busca pela apuração de informações - ainda com o risco de muitos deslizes - se utilize de ferramentas e de critérios mais esclarecedores. Entretanto, frente aos dividendos valorativos da estrutura social, estes fatos devem ser compreendidos no conjunto de relações que os alimentam e que os mantêm vivos.

${ }^{179}$ Idem, p. 9-10. 
Nesses termos, entender acontecimentos e personalidades que hoje possuem algum caráter excepcional também significa interpretar como foram construídas as formas de suas imagens e o grau de relevância que adquiriram suas trajetórias a ponto de servirem de referência à ordem ou lógica de relações vigentes dadas as dimensões ampliadas que conquistaram. Cada concepção se vincula a contextos históricos e lugares específicos que favorecem seu florescimento, e a criação de Pedro Almodóvar não se esquiva disso.

Estas observações constituem os pressupostos que estruturam constantemente a noção de ordem e desordem na sociedade servindo como elementos articuladores de novas lógicas e suas permanências. Portanto, creio que essas definições devam levar a uma estruturação de um painel sobre o legado contextual. No caso de Almodóvar, cabe situar a "Movida madrileña" como palco do nascimento de sua obra para tornar compreensível a criação de seus efeitos mitológicos que não só repercutiram na obra, como contribuíram - numa estreita proximidade - com 0 processo de ascensão vivido pelo diretor.

Uma relação intrínseca que gerou associações e projeções amparadas em fatores de cunho mitológico e hoje firmadas como fatos, diante da própria legitimação de seus agentes. Referências que animam o cinema espanhol contemporâneo e olham para aquele período como uma fusão entre fonte criativa e inspiração diante da abertura da Espanha para um novo rumo histórico e para o mundo. Que sustentam dentro de inúmeras controvérsias a imagem de Almodóvar como um cineasta lutador, que mostrou sua genialidade a custo de esforços pessoais e honrou com isso o nome e a imagem de seu país.

Mesmo que provavelmente essa última ação nem tenha passado pelos pensamentos do diretor, esta apropriação de atitudes traduzida pelos críticos espanhóis como nacional - no mesmo plano em que o classificam de diretor polêmico - Ihe serve como instrumento para seu destaque no cenário cinematográfico internacional, garantindo a ele a continuidade de sua produção e visibilidade no universo artístico. Isso foi possível porque a construção social feita sobre este autor coincide com valores ancorados num conjunto de mitos que dialogam ao redor de seu perfil.

As funções mitológicas apontadas há pouco, aparecem e se cruzam na medida em que se reproduzem referências de situações, leituras similares dos acontecimentos e são traçados parâmetros - nem sempre tão explícitos - ligados a momentos

${ }^{180}$ Idem, p. 10-15. 
históricos e suas personalidades correspondentes. Num momento em que simultaneamente ocorreram a Movida madrileña, o cinema do período da transição democrática, a própria transição política e a emergência de Pedro Almodóvar, estas funções convergiram e deram corpo a uma realidade pulsante.

Em especial, ao redor desse diretor criou-se uma movimentação tão intensa, buscando interpretar os motivos de seu sucesso frente à sua origem humilde, que sua história - constantemente recontada - misturou-se cada vez mais à sua própria produção fílmica, à Movida e à sua circulação que, a cada passagem em novas fronteiras, trataram de reforçar sua imagem e sua fama. Um fator que intriga críticos, estudiosos, admiradores e contestadores de sua obra. Pois, sempre que ocorrem novos comentários, tecem-se mais especulações e descobertas sobre sua capacidade de incomodar, reciclar linguagens ou fazer com que as pessoas reflitam sobre as abordagens que elabora sobre sentimentos ligados ao desejo. Com o amadurecimento do diretor e de seu cinema, também as críticas pareceram mais cautelosas. Seria o fortalecimento das referências mitológicas?

A necessidade de uma ordem simbólica que justifique o papel de Almodóvar para o cinema, para o público e para novos cineastas dialoga com mito. Afinal, serve de modelo para que muitos se motivem na produção cinematográfica, reforça a idéia da garra, da persistência e das convicções próprias diante das dificuldades. Valores bem utilizados numa sociedade calcada na competitividade e na potencialidade do indivíduo. A cada discussão travada sobre um novo filme ou alguma atitude do diretor que atraia o interesse de "amigos" e "inimigos" nas esferas da crítica e do mercado de cinema, abrem-se novos flancos de debate sobre seus perfis pessoais e sua trajetória. Novamente se toca em suas raízes e quase sempre se acrescenta mais um detalhe inusitado ou desconhecido, ampliando sua imagem.

Observando atentamente o contexto de transição política na Espanha e a Movida madrileña que nasceu culturalmente nesse mesmo quadro histórico, percebese nos dois acontecimentos vários fatores indissociáveis ao surgimento e sucesso do cinema de Pedro Almodóvar nos anos 80. Suas duas primeiras películas - por exemplo - foram resultado direto do comportamento cultural e político daquele período. Certamente, não existiriam, não seriam realizadas da forma como foram, passariam despercebidas ou ao menos teriam uma repercussão infinitamente menor se a reação social no país diante do fim da ditadura tivesse ocorrido num clima diferente do que ocorreu. As condições sociais de leitura da realidade de recepção das histórias contadas nas películas também teriam chaves de compreensão que não sintonizariam 
o espectador àquele universo de personagens e de ironias sociais.

Mas o que ocorreu - muito pelo contrário - foi um encontro de novidades. As películas de Almodóvar e de outros cineastas do período divertiam por mostrarem a vida da democracia e o fim da censura. Do mesmo modo que se iniciara uma reflexão por parte de alguns diretores sobre o passado franquista, também se ria de suas heranças ou então ignorava-se sua obscuridade. Tudo começava a ser um passado próximo que - num primeiro momento - muitos queriam esquecer para viver o clima da festa libertária. O cinema - mais do que porta-voz daqueles anos - era quem trazia e exportava as novidades, pois introduzia nas narrativas e cenários a vida moderna, mas também mostrava para fora do país a tradução de uma nova Espanha, além da tradicional visão folclórica sempre invocada.

Os críticos estrangeiros surpreenderam-se com imagens de uma Espanha que ria $^{181}$. Os espectadores se divertiam com as caricaturas daquele presente - de um país ansioso por ser moderno - onde a ousadia dos comportamentos íntimos e sociais exóticos misturava-se aos hábitos que se remetiam ironicamente ao passado tradicional espanhol que aparecia nos primeiros trabalhos de Almodóvar. A reação contrária dos que se escandalizava revelava os padrões sociais de grupos preocupados em resistir às mudanças do país ou então aos setores estéticos com um rigor de análise para o qual Almodóvar ainda não possuía estatura.

Via-se nos filmes - não apenas nos de Almodóvar - auto-retratos que misturavam um tempo presente em que liberdade, esperanças e sonhos correspondiam a blocos de vontade coletiva que não eram coesos e se contrastavam a outros moderados ou conservadores. Como visto no capítulo anterior, os filmes eram um reflexo das sociabilidades cotidianas. As cenas carregadas com várias nuances de ousadia, contrastando sexualidade, marginalidade, drogas, novos valores, condições de vida urbana ou revisando um passado tão recente, imprimiam energia revigorada a um cinema que durante décadas ficara restrito à exibição na Espanha - com raras exceções - e sua criação sob o controle da censura do Estado.

Mesmo cineastas já consagrados como Carlos Saura ${ }^{182}$ e Luís Garcia Berlanga $^{\mathbf{1 8 3}}$ - respeitados mestres da cinematografia espanhola - produziram trabalhos expressivos, refletindo aquele novo momento. Um período de verdadeiro boom criativo que - em termos gerais - tomou a via da comédia com alguns tons dramáticos,

\footnotetext{
${ }^{181}$ GARCÍA de León, M.A. e MALDONATO, T. Pedro Almodóvar, la outra España Cañí (sociologia y crítica cinematográfica), Madrid: B. A. M.,.1989. p. 207-209.

${ }^{182}$ Ver: Los ojos vendados, Bodas de sangre e Deprissa, deprissa.

${ }^{183}$ Ver: La escopeta nacional, Patrimônio nacional.
} 
voltando-se para temas cotidianos. No final da década de 70 e início de 80, filmes sobre o desencanto diante de um futuro esperançoso aparecem como perspectiva dramática. Porém são as comédias do período reformista nos anos 80 que predominam, atendo-se também aos reflexos da crise, para depois se converterem em comédias de costumes que exaltam a "Movida", tendo Pedro Almodóvar como um dos principais expoentes ${ }^{184}$.

Os filmes lançados durante a Movida acionavam diversos mecanismos de percepção sobre um momento que exigia inúmeras explicações e que os próprios cineastas buscavam esclarecer não apenas para a sociedade, mas também para si próprios. Incidiam sobre comportamentos, sobre as várias lacunas históricas deixadas pela repressão vivida no país e sobre os novos ares democráticos. Autores como Vicente Aranda ${ }^{185}$, Bigas Luna ${ }^{186}$, Jaime Chavárri ${ }^{187}$, Fernando Trueba $^{188}$ e Fernando Colomo $^{189}$, contemporâneos de Almodóvar, produziram películas que também trouxeram olhares inovadores ao então cinema dominado por lógicas morais e políticas conservadoras ou medíocres que permeavam toda a produção cinematográfica sob a égide da censura do período franquista.

O momento foi tão fértil que mesmo temas não polêmicos envolvendo costumes cotidianos repercutiam também como incômodos, pois "esbarravam" em outros mais amplos ligados a tradições, condicionamentos sociais, valores morais e sobretudo religiosos. Relações entre sexos, obsessões, sexualidade, a reposição do lugar do privado e sua discussão pública diante do núcleo tradicional da família, o desencanto com as novidades políticas e econômicas, o resgate de valores frente ao período ditatorial e suas conseqüências socias. Esses eram alguns dos temas levantados pelos diretores que - mesmo atendendo e refletindo apenas suas necessidades expressivas - vislumbravam a celebração em nome da liberdade criadora e o questionamento de seu processo histórico.

A reação social aos filmes foi muito diversa. la desde aqueles que desejavam proibir as películas - impossível em pleno período de liberdades e manifestações democráticas - pois viam nas imagens depreciações da cultura espanhola, até os que reconheciam nelas o reflexo do "desbunde" geral, da explosão criativa e alienada de uma juventude apenas deslumbrada com os novos comportamentos. Estavam na pauta

\footnotetext{
${ }^{184}$ MONTERDE, 1993. p. 169-171.

${ }^{185}$ Ver: Cambio de sexo

186 Ver: Bilbao, Renacer

187 Ver: El desencanto, Bearn, Las bicicletas son para el verano.

188 Ver: Opera prima.

${ }^{189}$ Ver: Qué hace una chica como tú en un sítio como éste?
} 
do dia, nas conversas dos bairros, restaurantes, bares, escolas, universidades e jornais.

Foi dentro desse contexto que Almodóvar tornou-se singular. Comparado a qualquer película daqueles anos sua audácia e originalidade se destacavam. Nelas se identificam claramente as expressões da mudança cinematográfica e de movimentos artísticos que ocorriam no período. Em 2003 o diário espanhol "El país" comprou e editou em DVD toda a obra de Pedro Almodóvar em forma de fascículos semanais para ser vendida nas bancas de jornal da Espanha. No lançamento do primeiro filme, Pepi Luci, Bom y otras chicas del montón, o escritor e crítico de cinema do jornal, Diego Galán, dá um depoimento significativo sobre o surgimento do cineasta naquele quadro histórico.

Galán afirma que o tom corrosivo e descontraído que se vê na película dificilmente aconteceria hoje dentro desta prática do "politicamente correto" que se alastrou pelo mundo. O atrevimento das cenas inusitadas que quebravam tabus demonstra uma coragem única para aquele periódo. O escritor lembra que a Espanha ainda não estava tão democratizada para receber filmes com aquela carga liberalizante. Eram fortes as suspeitas sobre a insatisfação de grupos ultraconservadores que receavam qualquer mudança. No próprio filme há referências a isso na pele do policial, personagem interpretado por Félix Rotaeta. Rumores comprovados em 23 de fevereiro de 1981 quando um tenente coronel fracassou ao tentar um golpe militar invadindo o palácio de "Las cortes"190.

Naqueles filmes de Almodóvar, aquilo que antes aparecia em guetos ou lugares reservados se apresentava - a partir de então - nas ruas, numa nova e divertida prática de vida pública como espetáculo para ser observado. Para os que preferiam o envolvimento direto, a Movida estava disponível e aberta nos bares, nas calçadas e praças repletas de pessoas dispostas a curtir a vida e aproveitar o tempo perdido da época da repressão. Para os mais recatados havia a opção de conhecê-la sob o olhar de diretores como Almodóvar. E para os que queriam se espelhar entre e a realidade e os sonhos, o trânsito entre rua e cinema se apresentava livre e quase indissolúvel.

Era também um período de discussões estéticas no plano cultural e político com artistas de várias vertentes, muitos dos quais acabaram se constituindo como parte do entorno de Almodóvar, compondo sua iconografia. Sobretudo no campo da pintura, os debates ocorridos desde dos anos 70 ocupavam-se em discutir um projeto

${ }^{190}$ HOPEWELL, 1989, p. 13. 
político de homologação da arte na Espanha para o plano internacional. Basicamente, havia duas facções: uma, partidária da pintura de realismo social de crítica política grupo conhecido como os Nuevos Comportamientos artísticos - e outra que reivindicava a autonomia da arte, sendo refratária a uma arte política - os chamados de Nueva Figuración Madrileña - defendendo uma pintura abertamente narrativa. Recuperava-se o tradicional conflito entre compromisso e autonomia da arte. ${ }^{191}$

Os artistas próximos a Almodóvar faziam parte deste segundo grupo. Dentre eles, Pérez Villalta e Costus, pintores que tiveram como ponto de encontro com o cineasta a estética Camp; uma proposta que vinculava a identidade gay e relações com o kitsch, considerada também o marco de confluência dos estratos elitistas e populares. Elementos que já faziam parte do conteúdo do espírito pop. Sob este substrato, Almodóvar depositou outros elementos relacionados com a arte de ação num contexto vanguardista. Foi dentro desse contexto e com essas pessoas que também nasceu a revista La luna de Madrid, esteticamente próxima ao fanzine, e de conteúdo, ao magazine.

A gênese da revista continha a proposta de diluir hierarquias tanto na forma de linguagem como na produção. Em todo esse movimento de atividades a participação de Almodóvar - não apenas na multidisciplinar La Luna - foi marcante. ${ }^{192}$ Portanto, houve um encontro de interesses e identificações de pessoas e grupos que sustentavam as mesmas concepções. Práticas e idéias que influenciaram a obra do diretor e que também eram resultado de sua leitura, encontrando-se com sua formação, suas concepções e anseios profissionais. Produtos culturais originais que mostraram novas idéias de ordem e criação social que, por serem bem divulgados por eles, acabaram conquistando crescentes adesões.

Assim, tanto a figura de Almodóvar como a imagem da Movida deixaram suas marcas de novo modelo comportamental, servindo como construção mitológica segundo as funções já apresentadas. Seus símbolos e seus discursos convergiam para representações que motivavam ultrapassar não apenas o medo herdado dos inúmeros modos de relações trazidas do passado, mas justificavam idéias que levavam à compreensão do novo processo que se vivia, revestido - por isso - numa louvação contínua dessas atitudes em vários setores nela envolvidos.

As irmãs Lola e Marta Moriarty, proprietárias de galerias de arte desde os anos 80 - locais onde promoviam exposições de artistas emergentes e aglutinavam em seus

191 ORTEGA, Juan Pablo Wert. Almodóvar en La Luna, in ZURIAN, Fran A. e VARETA, Carmen Vázquez. Almodóvar: el cine como pasión. Cuenca, Ediciones de la Universidad de Castilla-La Mancha, 2005. p. 471-472.

${ }^{192}$ Idem, p. 473-474. 
espaços continuamente músicos, escritores e cineastas -, depois de 25 anos da Movida recordam a grande agitação cultural da época e revelam sinteticamente seu espírito para os envolvidos no processo. Na ocasião, chegavam a Madrid vários jornalistas estrangeiros para saber o que estava ocorrendo e, em uma de suas entrevistas, um deles perguntou a elas:

Bueno, y después de la movida ... ¿qué hay?" Lola lo tuvo claro: La gloria ${ }^{193}$

Essa irreverência e ironia faziam parte da dinâmica de seus integrantes alastrando sua ressonância internacional, reforçada em cada produção cultural lançada:

En Laberinto de pasiones, Almodóvar hizo que uno de sus personajes extranjeros [Riza Niro] afirmara, como algo bien sabido que Madrid era 'la ciudad más divertida del mundo'. Al poco, eso se pensaba realmente en todo Occidente. Puede que ni la muerte de Franco ni la transición convocaran en España a tantos periodistas [joranlistas], equipos de televisón, cazadores de tendencias $^{194}$.

Eram comportamentos, invenções musicais, moda, contato com as múltiplas linguagens de arte que não necessariamente estivessem eclodindo para o sucesso. A ausência de regras e a reciclagem cultural dos grupos envolvidos naquele processo se confrontavam e apareciam como nova regra. Percebe-se pelo próprio discurso posterior que a imagem da liberdade de seus participantes e analistas continua:

Eran, para entendernos, los modernos. Les distinguían sus modos gay o, por lo menos, su ambigüedad sexual. Culturalmente ávidos, estaban al tanto de modas imitables de Londres o Nueva York. Se comunicaban con el mundo del cine - Almodóvar - y del arte: Todos se fotografiaron con Warhol en su visita a Madrid, aunque Andy no les inmortalizó (sí lo hizo con Miguel Bosé, quien pasó por caja). Los modernos cumplieron los anhelos, los propósitos del hipotético manifiesto de La Movida: la interacción entre las artes (o, por lo menos entre artistas de diferentes disciplinas), la exigencia de cosmopolitismo, la violación de tabués sexuales, el desprecio de la santurronería progre [gíria irônica semelhante ao que se chamaria no Brasil 'moderninhos progressistas']. Les perdía claro, su elitismo. En lo musical, se vieron desbordados por la ascensión de los grupos pop, hijos de la new wave británica [...] lo extraordinario fue la proliferación de propuestas. Iniciativas que saltaban a la arena cuando todavía no había mercado, ni, por supuesto, subvenciones. El contagio fue inmediato: surgieron movidas en Vigo, en Barcelona, en San Sebastián, en Sevilla, en Valencia ... sin manual de instrucciones se tradujeron y adaptaron los modelos del tecno, el rockabilly, el after-punk, el rock gótico, el funk-pop, el reggae [...] tras ese aprendizaje, los más listos despegaban hacia expresiones personales. Un dibujante galego, Victor Coyote, inventaba el rock latino 15 años antes de que fuera rentable ${ }^{195}$

Ou seja, não era apenas um movimento de "bricolages" ou de paródias. Sua busca por inovação chegou a antecipar tendências, a criar e influenciar mercados musicais, editoriais e cinematográficos. O filme Café da manhã em Plutão (2005), não

\footnotetext{
${ }^{193}$ MANRIQUE, 01 mai. 2005, p. 58.

${ }^{194}$ Idem, p. 46.

${ }^{195}$ Idem, p. 46-47.
} 
só por se passar e tratar de uma época próxima à da Movida - porém na Irlanda e Inglaterra -, possui quase os mesmos elementos pictóricos e narrativos dos filmes de Almodóvar ou de Colomo. Até seu protagonista surge como uma simbiose de Fábio McNamara de Laberintos de pasiones (1982), do travesti La Agrado de Todo sobre mi madre (1999), interpetado pela atriz Antonia San Juan, e Juan/ Zahara de La mala educación (2003), interpretados por Gael García Bernal. Os reflexos daquele período ecoaram na cinematografia internacional.

Quando a Movida se consagrou, cada grupo a seu modo procurou demonstrar sua participação e muitos recontam a história a partir de ângulos que justificam ou fortalecem seus interesses. Foi o caso dos integrantes da esquerda política que afirmam serem eles os financiadores daquele movimento, fator rechaçado por seus participantes como Alaska (Olvido Gara), que apresenta um depoimento significativo. Ela, que sente pavor diante das armadilhas da nostalgia, explica sua particular ambivalência:

Nacho [Canut, seu companheiro de boêmia] és más militante del olvido [adepto do esquecimento], hasta le divierte que se difundam tópicos [cliclês] y mentiras. A mi me sale la vena de historiadora [eu, ao contrário, fico provocada pelo meu jeito de historiadora] y entro al trapo ${ }^{196}$ siempre! [e não deixo passar uma]. Oigo alguna barbaridad y no puedo reprimirme: 'Un momento, eso no fue así. Y me tiro media hora explicando que Madrid realmente no se llenó [não se encheu] de punkis y new romantics cuando Tierno Galván era alcalde [Henrique Tierno Galván, prefeito socialista de Madrid na época de existência da Movida] ${ }^{197}$

Esta afirmação de Alaska, cantora e atriz que interpreta a personagem "Bom" em Pepi, Luci, Bom y otras chicas Del montón, assinala como o processo político não caminhou tão em paralelo ao movimento da Movida madrileña - como uma certa militância pretendeu fazer acreditar - e que esta não foi acionada pela esquerda no poder que, aliás, nem sempre esteve ao lado desses grupos e nem foi fundadora do movimento:

Es el gran baldón [a grande ofensa] de la movida: su supuesto origen municipal (y socialista). Para los que vivieron aquella época, un disparate: no hube respaldo oficial en 1980, quando eclosionaran los primeros grupos; ni tampoco en 1981, año de reflujo tras las decepcionantes ventas de las bandas; ni en 1982, quando el bache [o rombo] se resolvió con los sellos indepiendentes. Gran parte da esquierda contemplaba com desconfianza aquel despuntar, assumiendo el tosco análisis de columnistas miopes que favorecían la 'autenticidad' vallecana de Ramoncín [Valleca é um bairro da periferia de

\footnotetext{
196

"Entrar al trapo", expressão de origem taurina. Os bons touros para "las corridas", aqueles verdadeiramente bravos, com a ferocidade que devem ter, reagem atacando com força quando o toureiro lhes coloca na frente a "muleta" e/ou a "capa". Trapo (pano, tecido) é um nome genérico para a muleta ou a capa. "Entrar al trapo", significa metaforicamente, reagir sem parar para pensar, se manifestar sem refletir antes, cair na provocação de alguém, falar abertamente sem roupagens, sem as devidas precauções para falar apenas o politicamente correto. Às vezes leva uma conotação (não neste caso de Alaska) de cair no engano, na armadilha, de alguém que puxou o assunto, que "jogou o verde", ou alguma pessoa que provocou uma outra com algo que a motivasse manifestar aquilo que não revelaria (ou não revelaria daquela forma) se não tivesse sido incitada.

${ }^{197}$ MANRIQUE, 01. mai. 2005. p. 46.
} 
Madrid, urbanizado no período de Franco de onde saiu Ramoncín, cantor e compositor de protesto] sobre la frivolidad [vulgaridade] de los Pegamóides [banda pop], donde coincidieron la hija de un exilado - Alaska - con un Canut y un Berlanga ( $y$ con hijos de famílias menos significadas; aquello fue una conspiración interclasista). Nada de 'movida promovida', como insinuaria una canción posterior. El verdadero catalizador fue a la mayoría de edad de una generación que, com aliento de muchos adultos, deseaba disfrutar de las liberdades democráticas. Más que una quinta despolitizada eran tan optimistas que no podían concebir un retorno al franquismo (...). ${ }^{198}$

Nas artes de produção mais rápida houve um florescimento de talentos. A fotografia contou com cronistas da revista "La realidad" como Miguel Trillo, Alberto García-Alix, Pablo Pérez-Mínguez, e a fotógrafa e pintora Ouka Leele. No campo da moda, os especialistas se sentiram atraídos por aquele universo de criaturas chamativas. Antonio Alvarado, desenhista de moda, chegou a fazer desfile com atrizes no bar "Rock Ola". Siguifrido Martín Begué, pintor e arquiteto, amigo de Almodóvar na época, lembra:

[...] entonces, cada uno iba de lo que quería. De punk o de mod. Y si te apetecía de facha, pues de facha. Cualquier cosa para luchar contra 'la grisez' [o cinza, a tristeza] de la época. ${ }^{199}$

Não por acaso, a existência de tanto colorido e da predominância de cores quentes como o vermelho e o laranja nos filmes de Almodóvar. Um recurso explicado pelo diretor para fazer frente ao uso constante da cor preta nos vestidos das mulheres que via em sua infância até os oito anos em sua cidade natal, na região de La Mancha. Mas que se verifica também na vida metropolitana de uma Madrid dominada pela exigência do recato e da discrição oriunda do moralismo católico, muito presente no período. Vale lembrar que a hierarquia eclesial não só havia apoiado a ditadura franquista como era sua aliada.

Em sua homenagem, a Movida também deixou agradecimento. Pedro Almodóvar realizou Entre tinieblas (1983), um filme que o próprio título já ironiza o comportamento e a referência ao período medieval: "Entre sombras" - que chegou ao Brasil, por uma questão publicitária sob o título: Maus hábitos. Na película, suas freiras receberam belas guirlandas de flores coloridas - confeccionadas com papel crepom sobre as cabeças com seus hábitos pretos para a comemoração do aniversário da madre superiora (Julieta Serrano), num salão saturado de brilho, plumas, papel celofane, folhas de papel laminado imitando folhas de árvore e fundo azul celeste. Um ambiente especialmente decorado para a apresentação do show de Yolanda (Cristina Sánchez Pascual), uma cantora de cabaré, grande paixão erótica da aniversariante. Uma hilária seqüência kitsch que une sagrado e profano, paixões, projeções e desejos.

${ }^{198}$ Ibid., p. 46. 
A manifestação "carnavalizada" de vestuário, mal vista pelos conservadores que eram muitos -, negava padrões de comportamento, inclusive daqueles vividos no pueblo. Ou seus prolongamentos, considerando-se a presença da moral eclesial nas leis do país e dos hábitos trazidos por pessoas que migraram das províncias para as capitais desde os anos 50 devido às sucessivas crises e isolamentos econômicos. Porém, seus descendentes, nascidos nos anos 60, formavam uma geração essencialmente urbana. Resultante de um boom demográfico, sem a experiência da guerra e do rural, havia uma juventude que carregava apenas as imagens idealizadas do campo e a vivência do meio urbano. Estes jovens produziam e projetavam suas vidas sob referenciais cosmopolitas e identificavam-se muito mais com a vida moderna transmitida pelo cinema de Hollywood do que com o cinema realista do "cinema de qualidade" promovido pela Ley Pilar Miró ${ }^{200}$.

Assim, a geração que assistiu aos primeiros filmes de Almodóvar já estava sintonizada com seu discurso. Porém, nesse panorama, que parecia de destruição de valores, os trabalhos do diretor não promoveram uma negação da cultura espanhola, mas sim uma condensação dessas duas realidades. Ele ironizou os estereótipos tradicionais e apresentou a versão de modernidade espanhola então vigente. Novos espaços urbanos, a aproximação do punk e do underground à realidade das classes trabalhadoras e da periferia de Madrid são revelados em suas duas primeiras películas. O questionamento de suas imagens desarticula a construção antiquada do espanhol que o franquismo havia elaborado. Depois, subverte a religião em Entre tinieblas (1983), a família em Qué he hecho yo para merecer esto? (1984), a sensualidade e o macho mediterrâneo em Matador (1985-1986) e apresenta um modo de homossexualidade ainda inédito em La ley del deseo (1986) ${ }^{201}$. Esses quadros, apresentam a leitura de uma nova Espanha.

Pintores como Guillermo Pérez-Villalta, El Hortelano, Siguifrido Martín-Begué, Dis Berlin, Ceesepe, oriundo dos quadrinhos, na revista "Madriz" (esta, realmente com financiamento municipal), fizeram várias atividades conjuntas como exposições e um curta-metragem de televisão. O mural pintado por Villalta - até hoje mantido no paseo Imperial em Madrid - em seu apartamento, lugar de reunião destes artistas, Ouka Leele e tantos outros que encontravam ali um ponto de encontro, foi elaborado para adornar uma parede do apartamento da personagem Sexilia (Cecília Roth) em

\footnotetext{
${ }^{199}$ Idem, p. 55.

200 LOEW, Camila e LUNA, Antonio. De la M30 a Hollywood Boulevard, in ZURIAN, Fran A. e VARETA, Carmen Vázquez. Almodóvar: el cine como pasión. Cuenca, Ediciones de la Universidad de Castilla-La Mancha, 2005. p. 410-412.

${ }^{201}$ Ibid, p. 410 e 414.
} 
Laberinto de pasiones (1982). Toda criação gráfica, incluindo os cartazes e as pontuações da linguagem em quadrinhos de Pepi, Luci, bom y otras chicas del montón foram elaborados por Ceesepe. Portanto, quando se fala que Almodóvar resumiu em seus trabalhos uma considerável fração do espírito da "Movida", não existe exagero. Em seus primeiros filmes estão concentradas várias das expressões artísticas inovadoras do período.

Fundaram-se companhias independentes de discos como a "DRO y Gasa, revistas como Madrid me mata, El víbora (na qual colaborou Almodóvar) e diversos fanzines, além de uma rede de cumplicidades entre amigos que garantiam a presença das produções na Radio 3 e em espaços da TVE com os programas Caja de ritmos e La edad de oro ${ }^{202}$.

No auge de seu sucesso, não havia quem ousasse ser contra a "Movida madrileña". A única ocasião para atacá-la veio em 1983 na TVE quando um grupo de garotas Punk de Bilbao, "Las Vulpess" fez uma adaptação de uma música de Yggy Pop em Caja de ritmos e, por ser mal transcrita pela rede ABC causou um escândalo político. As eleições estavam próximas e para garantir imagens moralmente favoráveis a votos, o programa foi cancelado e seu diretor, Carlos Tena, processado. Alguns anos depois, Paloma Chamorro passou por um problema semelhante, quando foi acusada de fazer ofensas à religião em seu programa "La edad de oro".

À exceção destes incidentes - que não necessariamente faziam afrontamentos diretos ao conjunto do que se produziu na Movida -, só muito tempo depois, em 1991, quando o partido Popular - de ideologia conservadora - já havia assumido o governo na cidade de Madrid, José María Alvarez del Manzano, então prefeito, levantou rancores contra a Movida numa entrevista ao jornal La Vanguardia:

No hay que enterrarla porque se ha evanescido, ni siquiera tiene cuerpo para enterrar. Era algo etéreo, un solo poso. Yo no recuerdo un solo libro, un solo cuadro, un solo disco, nada, de la movida no ha quedado nada ${ }^{203}$

Esse rechaço sustenta uma carga dúbia, pois as citações quase que afirmam uma presença histórica efetiva, o que contribui de certa forma para animar os brios de seus participantes, ressuscitar lembranças e fatos. Mesmo em seus aspectos desafortunados, como a morte pela Aids, pelas drogas ou em acidentes automobilísticos envolvendo muitos de seus paticipantes, nota-se a mistura entre alegria e tristeza, dor e prazer. Seu espírito se mantém:

Por encima de todo, la movida obedecía al hedonismo.Para los mayores de aquella tropa urgía gozar todo lo que la dictadura había prohibido. Para los

${ }^{202}$ MANRIQUE, 01. mai. 2005, p.48.

${ }^{203}$ Idem, p. 46. 
demás, no particularmente traumatizados por el franquismo, se trataba del derecho natural a hacer con sus vidas y con sus cuerpos lo que deciedieran. Sin embargo, la muerte estuvo presente desde los inicios [...] cuesta hoy hacer un listado que distinga entre muertes naturales, muertes accidentales y muertes debidas a una acelerada forma de vivir. Las sobredosis o el sida [aids] acarrean un estigma que incomoda a amigos y familiares; se prefiere cualquier subterfúgio. Los eufemismos y las mentiras son una defensa contra las moralejas [moral da história] fáciles: las muertes más llamativas provocan recriminaciones automáticas contra el carpe diem del movimiento. Incluso parte de la izquierda ha tirado con bala, aquejada de lejanos resquemores [ressentida pela consciência de suas falhas] por haber perdido a su parroquia juvenil $y$, quizá, por no haber disfrutado de la fiesta ${ }^{204}$.

Fatos e suas leituras posteriores. Vozes que carregam a herança irônica e irreverente do movimento. Em cada um, elementos que atirbuem à "Movida" uma aura de encantamento que hoje nutre a idéia dos discursos propagados entre a conjugação dos valores de liberdade e a necessidade de criação. E que deram o tom para uma geração de artistas cujos remanescentes continuam atuando ativamente na esfera cultural do país passadas quase três décadas de seu surgimento. Mesmo nos mais recentes filmes de Almodóvar pode-se verificar as nuances daqueles comportamentos e posturas. Sem dúvida, o cinema foi um dos principais colaboradores para dialogar com aqueles anseios e experiências registrando as diversas projeções sociais. As novas películas atendiam, e revelavam de maneira eficaz, as reivindicações, atitudes e questionamentos de uma época preciosa de transformação. Como já apontado, ir ao cinema significava compactuar com aquelas atitudes, com as mudanças.

Coincidiram num mesmo ponto daquele momento a necessidade de mudanças generalizadas na sociedade e a busca dos cineastas por registrar sua história. $\mathrm{O}$ cinema funcionava simultaneamente como um porta-voz mais rápido e abrangente para difundir o que se vivia no período e como instrumento de reflexão que explicava a herança do passado e suas seqüelas no presente. Além disso, aproximava várias gerações - sobretudo as mais jovens - a um contexto que alinhava a vida urbana do país a outras experiências do mundo num diálogo que incluía novos comportamentos, valores, objetos, consumo e, principalmente, ausência de fronteiras para experimentálos. Como veículo de massa, o cinema contribuiu também de maneira mais eficaz e veloz para divulgar e construir um determinado tipo de imagem da Movida e de seus protagonistas para além das fronteiras de Madrid e da Espanha.

O filme de Pedro Almodóvar Laberinto de pasiones (1982) figura como um dos registros mais emblemáticos nesse aspecto, ao refletir a época em sua multiplicidade de valores, atividades artísticas, comportamentos e "personagens" festivas ou exóticas que circulavam por Madrid no período:

${ }^{204}$ Ibidem, p. 48. 
La materizalización de semejantes criaturas, la tentadora posibilidad de cambiar de identidad sin traumas constituían inimaginables provocaciones en el panorama cultural de 1982 [...] la critica, o esa gran parte de la critica que sentenció Pepi, Luci, bom como una aberración sin possibilidad de descendencia, recibió con cuchillos afilados [facas afiadas] su segun largometraje 205

O jornalista Diego A. Manrique, recorda com alegria seu lançamento:

Laberinto de pasiones pasó en sesión de gala por el Festival de San Sebastián, para consternación de lehendakari y demás autoridades presentes. Un grito colectivo de horror brotó en el teatro Victoria Eugenia cuando la portera del local de ensayos Tablada 25 pierde materia fecal ante la sofisticada Toraya. Una vez concluido el pase, visto que allí no abundarían las palmaditas, el equipo y los simpatizantes nos extraviamos por las discotecas donostiarras [da cidade de San Sebatián]. Es posible que algunos termináramos bañandonos desnudos en plena playa de La Concha, medio protegidos por la oscuridad. No podría jurarlo: los años 80 fueron así de vertigionosos. ${ }^{206}$

Decantando os limites e as boas lembranças entre realidade e sonho, verificase que o campo cinematográfico espanhol se encarregou de reproduzir com a "Movida" a permanência de seus cineastas e expandir seus filmes além de seus territórios. Ainda que deficiente em vários aspectos técnicos e com dificuldades econômicas, na medida em que alcançava outros países, este veículo dava ao mundo as informações de seu momento. E os poucos incentivos aliados à grande vontade de produzir, atraiam todos aqueles sintonizados nesse espírito, exportando assim a Movida madrileña.

Não é novidade no mundo contemporâneo a "exportação cultural" por via cinematográfica. Característico por disseminar suas imagens e valores do país, o cinema norte-americano em pouco mais de três décadas tornou-se o modelo clássico que influenciou e seduziu, com sua visão de mundo e comportamentos - além de impor um padrão de qualidade técnica e tecnológica na produção cinematográfica - , milhares de pessoas e atraiu ou indignou cineastas no mundo inteiro com seu estilo estandartizado. Levou aos lugares mais distantes referências de seu padrão de vida e moda, sua forma de contar histórias sobre o passado, presente ou futuro, com valores próprios de sua cultura e ideologias predominantes, praticamente excluindo outras formas de interpretar a vida.

Dizer, portanto, que um cinema como o espanhol - em particular o surgido no período de transição política - conquistou seu espaço de difusão frente a uma potência cinematográfica norte-americana não corresponde a incluí-lo no mercado concorrente de filmes num mesmo patamar ou muito abaixo dele, mas sim reconhecer sua potencialidade temática na época. Fato que atraiu tantas pessoas para ver de perto o que era aquela tal Movida apresentada em algumas películas.

\footnotetext{
${ }^{205}$ MANRIQUE, Diego A. Laberinto de pasiones. El país, Madrid, 11. dez. 2004.

${ }^{206}$ Idem.
} 
O cinema ainda é um dos principais representantes de difusão do processo cultural, tecnológico e social de uma sociedade. Traduzir a cultura que se origina dele significa reconhecer etapas de relações e conflitos. Foi o que se passou na Espanha em meio à Movida e que se demonstrou em seus registros, mesmo não sendo a principal marca do período, esta pertencente - sem equivalência - à música. Não só por ser mais fácil de produzir e difundir, mas também pela acessibilidade de público e pela formação de compositores e cantores. A banda de rock Radio futura é um bom exemplo daquela produção:

\begin{abstract}
Constituye el paradigma de la prodigiosa maduración del movimiento. Al nacer, em 1979, habían pasado más tiempo en universidades o en galerías de arte que en locales de ensayo. Su LP de 1980, "Música moderna", quería venderse como pop adolescente, pero estaba confeccionado con las enseñanzas del Pop art. Aunque "enamorado de la moda juvenil" o "Divina" adquirieron categoría de himnos, el proyecto se estrelló y "Radio Futura" se recompuso en rock. Tras tres años de miseria se impusieron como banda de ideas, cuyos discos y entrevistas reflexionaban sobre la cultura popular en España, la urgencia de recuperar tradiciones urbanas, la conveniencia de establecer un diálogo con América, nuestro lugar en el mundo. El grupo de Enrique Sierra y los hermanos Auserón [eles compõem junto com Javier Pérez Grueso, a banda de rock que toca com Riza Niro (Imanol Arias) filho do imperador da Pérsia, personagem no filme Laberinto de Pasiones (1982)] también fue un ejemplar en establecer lazos con artistas gráficos, escritores, videorrealizadores, el mundo universitário. La movida tuvo su manifestación más visible en la música, pero también iluminó otras áreas de la creación. Eso sí, con desigual impacto. ${ }^{207}$
\end{abstract}

Há inúmeras razões para reconhecer a Movida madrileña como fonte de referência e modelo criativos. Ela representou a afirmação de novos olhares sobre a realidade traduzidos na invenção de estilos na moda, na música, no desenho, nas artes plásticas, na imprensa, na fotografia, no mercado editorial de livros e revistas, na liberação de comportamentos e no cinema como porta-voz desse complexo cultural. Relacionava-se com o período democrático naquelas esferas onde antes tudo era proibido. Buscava a liberação dos desejos pessoais, antes cerceados e vigiados nos âmbitos públicos e privados.

Não por acaso esse fenômeno partiu e incidiu sobre a juventude que buscava viver intensamente a liberdade proporcionada. Parte expressiva da população na época já vinha gerando suas mudanças quando o regime franquista mostrava sinais de degeneração no final dos anos 70. A Movida só veio refletir no campo cultural os efeitos da busca pela normalização política e sua separação definitiva de esferas dentro da estrutura social.

Em torno dessa celebração pela liberdade irrestrita - vista segundo grupos conservadores como um momento de "caos social" -, grupos dominantes na área da

${ }^{207}$ Ibidem, p. 47-48. 
indústria cultural despertaram seu interesse mercantil. Buscaram trazer novamente à sociedade a sensação de harmonia e de ordem social, cooptando o movimento para transformá-lo em algo que pudesse ser "digerido" por todos ou pensando em termos capitalistas: consumido. A partir de então a própria "Movida" serviu de novo modelo de comportamento numa mescla de novas tendências que, após alguns anos, já haviam se tornado a regra geral. Não por acaso, o desencanto com o processo também coincide com o desfecho da luta político-democrática e aparece no filme Qué he hecho yo para merecer esto?(1984). Ali, Pedro Almodóvar reconhece que a "festa" já havia acabado.

Acabou oficialmente, mas seus traços mitológicos se reproduziram no presente sob vários aspectos. Cabe avançar um pouco mais na reflexão que fazem de sua dinâmica, a fim de esclarecer suas repercussões. Héctor Fouce ${ }^{208}$ sustenta que este movimento negociava as regras e linguagens do discurso dominante para dentro dele construir as suas peculiares. Negociando uma leitura das relações vigentes, criou-se uma subcultura diante de uma cultura hegemônica de democracia que havia se imposto após o fim da ditadura.

O discurso de normalidade institucional havia substituído o da ditadura e definiu mais seu campo de atuação, separando assim a cultura da política. A queda pelo interesse político fez emergir o interesse pela festa, pela novidade, pela cultura livre da política, sobretudo no campo estético. Mais do que criar sua peculiaridade, a Movida ressuscitou hábitos que haviam sido proibidos durante várias décadas, como sair à noite e circular pelas ruas de bar em bar até o amanhecer, uma característica da vida urbana espanhola hoje cotidiana. O próprio significado da palavra "movida" na língua espanhola traduz literalmente sua dinâmica: movimento, circulação, agitar, agitação. Estar na "Movida" era estar na boemia, ter o conhecimento de que se produzia o melhor, o bom, o que realmente interessava. ${ }^{209}$ Mais do que liberar a circulação sobretudo para a juventude - a Movida colocava publicamente o que já vinha se produzindo culturalmente de maneira velada nos espaços clandestinos ou guetos.

Não por acaso a manifestação aberta dos comportamentos e da diversidade sexual - em particular, dos grupos gays - ocorreu de maneira tão intensa. As fotografias dos jovens de grupos musicais da época, as cenas dos filmes de Almodóvar e de outros cineastas evidenciam este aspecto. Como apresentado no capítulo anterior, a grande repressão exercida contra os homossexuais na ditadura cerceava qualquer atitude "suspeita" fora dos padrões. Com a democracia, manifestar-se em público numa

${ }^{208}$ FOUCE, 2000, p. 269-276. 
condição homossexual assumida significava uma vitória e um enfrentamento em vários aspectos, seja moral, tradicional ou político. Funcionava como ato de demarcação de espaço e era um momento de reelaboração de conceitos. E os produtos da Movida contribuíam para sua disseminação.

A partir dos materiais da cultura dominante, inclusive daqueles veiculados pela mídia, a "Movida" construiu sua própria experiência cultural, dando a ela novos significados, muitas vezes de forma não intencional - apesar de demonstrar o contrário para a sociedade -, subvertendo as tradições. Diante de uma cultura internacional decadente e carente de novidades, assim como o próprio contexto espanhol - em especial a cidade de Madrid -, a "Movida" chegava com todos os ingredientes necessários para causar impacto aos olhos atentos para a novidade, onde quer que estivessem.

A música, fortemente influenciada pelo punk, sobretudo pela estética e muito menos pelas letras, transmitia um tom diferente quando produzida para a juventude até então. Com letras simples, sem virtuosismo, cada show demonstrava que as coisas podiam mudar a qualquer momento e realmente era isso que estava acontecendo. A reinvenção dos códigos criou uma nova realidade. Nos próprios shows havia uma destruição da hierarquia verbal da linguagem, ofensas, palavras coloquiais ou chulas, tudo era incorporado como parte do familiar e desejável naquela estética que invertia valores e imagens, típica do movimento punk.

Estes discursos e comportamentos foram caracterizando os membros da "Movida". A capacidade textual e discursiva de seus grupos atribuiu a ela um caráter eficaz no nível entendido aqui como "subcultural", sempre aberto a mudanças, mas também convincente, produzido pela própria estrutura semântica que garantia as modulações e transformações freqüentes. Esta mobilidade permitia que a "Movida" refinasse a noção de temporalidade. Ao ocupar a noite como tempo de ação, ela inventou uma nova Madrid com dinâmica própria e um espírito criativo que necessariamente se nutria do público para sua existência.

Almodóvar faz no início de Carne tremula (1997) uma referência precisa dessa mudança que carregou consigo a liberdade conquistada, olhando para o período histórico anterior em que até a circulação pública noturna era controlada pelo regime totalitário. No filme, utiliza o mesmo espaço público das ruas para anunciar o nascimento de crianças. No início, desertas numa noite de Natal sob "estado de emergência", e, no final da película, também numa noite - já na democracia - repleta

${ }^{209}$ GARCIA DE LEÓN, e MALDONATO, 1989. p. 128. 
de transeuntes. Compara, assim, os diferentes períodos num claro louvor à liberdade de ir e vir, quase um rito que exorciza a repressão.

Ao abrir essa prática, a Movida provocou uma ruptura com o tempo habitual e com cada uma das lógicas e práticas que a ele se subordinassem. Na vida noturna cada um poderia se transformar no personagem que quisesse e exercer sua vontade pessoal atuando como lhe conviesse. Na verdade, este é um comportamento individual típico e comum das metrópoles ou capitais de países no mundo. No entanto, para um país recém-saído da ditadura, o gosto por esta atitude adquiria um sabor mais substancial, temperado de autonomia e, simultaneamente, de novidade. O resgate de atitudes públicas que proporcionavam prazer não era algo corriqueiro. Havia se transformado numa atitude política sem os ranços partidários que atraem seu sentido. As pessoas se identificavam num universo o qual podiam se apropriar e modificá-lo a qualquer momento.

A noite evocava um tempo mítico, sem limites, sem horas racionalizadas, sem obrigações de atividades a serem cumpridas, práticas estas que comumente constróem sua linearidade. Almodóvar avalia este tempo vivido em entrevista concedida ao jornal El periódico:

\begin{abstract}
- Recuerde La Movida.
Desapareció justo en el momento en que se empenzó a hablar de ella. A partir de 83 aquello no era lo que era.

- Y Tierno Galván ? [prefeito de Madrid no período].

Tuvo su importancia, lo mismo que tiene importancia ahora haber destruido la vida nocturna madrileña, que era una de las bases estratégicas de lo que era La Movida. Desde arriba, desde la admnistración se ha tratado de convertir a Madrid en una ciudad como cualquier otra europea en el peor de los sentidos. Si había algo caracteristico de Madrid era su vida nocturna. La cultura de Madrid se desarollaba por la noche. Ahora está matada y bien matada. Madrid de pronto se despertó, perdió el miedo a la policía, como todos los españoles. Todo lo que nació de un modo espontáneo, fue aprovechado por el ayuntamiento y por el propio Partido Socialista, del mismo modo que luego ha sido denostado por el actual ayuntamiento. ${ }^{210}$
\end{abstract}

A vida noturna acarretava uma ruptura com o cotidiano, resgatando - como por memória histórica coletiva - experiências temporais diferenciadas. Como as vividas em outras épocas, já na Antigüidade, cujos registros das palavras comprovam suas evidências de terem sido experimentadas. Entre os gregos havia nomenclaturas distintas para determinar a temporalidade. Para o tempo linear, havia Kronos, para os momentos intensos e infinitos, existia Kairós ${ }^{211}$. Henri Lefebvre também sublinha esta divisão do tempo construída entre o linear - controlado, ordenado - e o cíclico, em que não se detém sua forma.

${ }^{210}$ LA TORRE, Iosu de. Entrevista com Pedro Almodóvar. El periódico. Madrid, 7 nov. 1993. La gente, p.11-12.

${ }^{211}$ Lipsitz, G. 1995, p. 195. 
A festa carrega consigo todos os elementos que evidenciam a realização do tempo cíclico, do Kairós: liberação e busca pela satisfação de desejos, regras flexíveis, intensidade da experiência do momento como forma de prolongá-lo ou de anular seu percurso para torná-lo imaginariamente eterno. Ambos movimentam-se numa mesma rotação, sendo o linear dependente do cíclico. Porém, dentro de um mundo onde o controle e a racionalização dominam, o linear tende a prevalecer. ${ }^{212} \mathrm{O}$ contexto da Movida rejeitou - em seu tempo particular da festa - tal determinação. Em nome da necessidade e da satisfação de desejos - possíveis num tempo cujas regras lineares foram negadas -, impôs um outro ritmo social que decorria de seus comportamentos e práticas.

Assim, pôde expressar um momento geral de exceção institucional e de concessão de desejos que abriram caminho para articular novos valores. Não foi um momento de crise, de anulação ou de suspensão de atitudes. Ao contrário, colocou-se em prática toda vontade organizada - ou não - de uma geração que fez a própria criação ser o mote principal de suas práticas.

A Movida se instalou num momento perpétuo frente a um passado que não merecia ser recordado e a um futuro sem garantia de chegada. Uma referência repetida nos discursos de Almodóvar quando lhe acusavam de não falar de política, mas que também consta das declarações de Trueba - que, intencionalmente, sequer pertenceu à "Movida" - quando de suas estréias no cinema:

Trueba:

Es que a mí todo aquello no me interesaba [...] yo no quería rodar la generación de los padres, porque pertenecían a una España del pasado. El franquismo que yo había vivido me parecía algo tan feo, tan reciente, que no quería retratarlo. Porque en la España de Franco lo peor era la mediocridad, el silencio. No, yo no quería ni tocar todo aquello ${ }^{213}$

Almodóvar:

Mis películas están siempre hechas como si Franco no hubiese existido ${ }^{214}$

Posição depois revista pelo diretor quando fala sobre Carne Tremula:

Las cosas cambian con el tiempo [...] Hace veinte años, mi venganza contra Franco consistía en no reconocer su existencia, su memoria, en hacer peliculas como si él no hubiera pisado la tierra jamás. Ahora creo que no es bueno olvidar aquella época y que conviene recordar que, al fin y al cabo, no está tan lejos. Me gustan los dos nacimientos de la película, el primero en una ciudad abatida por el miedo, y el segundo en la misma ciudad, pero llena de gente, de alegría, sin miedo. Y este elemento optimista, en una historia que tiene un claro perfume a tragedia, me produce el efecto de un soplo de aire fresco y liberador. ${ }^{215}$

\footnotetext{
${ }^{212}$ LEFEBVRE, Henri. Critique a la vie quotidiéne. Paris: Livro II, 1968, p. 103-110.

${ }^{213}$ RIVERA, 17. set. 2000, p. 30

${ }^{214}$ Idem, p. 30.

${ }^{215}$ Strauss, 2001, p. 154.
} 
O diálogo estabelecido entre as palavras com seus códigos de subversão não só atingiu seus interlocutores como também as palavras dos atores sociais de um modo específico que seguia em paralelo com a história de uma cultura juvenil dentro da Espanha. Por isso, o que se via na influência do punk espanhol não tinha nada a ver com o punk surgido nas ruas de Londres. Na Espanha foram gêneros musicais redefinidos, ainda que passassem por circunstâncias parecidas como a alienação ou o desemprego. Ao se comparar o contexto histórico de ambos os países, essas diferenças se tornam mais evidentes. Enquanto a Inglaterra entrava no violento regime de Margaret Thatcher, a Espanha vivia o momento inverso.

O processo cultural da Movida provocou um encontro de diversos estratos sociais, de diferentes discursos e vozes que denotam distintas consciências e visões de mundo antes separadas pela classe social ou pela época. Porém, não teve um cunho político classista, como alguns querem acreditar. Não rompeu estruturas políticas, nem econômicas, pois não tinha estes propósitos. Funcionava como uma instância a-classista no espaço e no momento a que se pretendia: expressão individual, arte, criação em geral, comportamentos. Poderia ter se aproximado destas outras esferas? Não. Como já apresentado, era o que rechaçavam pelos interesses controladores e partidários. Nela, seus membros optaram pela negação. Talvez, naquele momento, a única forma de criar algo novo na esfera cultural. Também foi política, mas não no sentido estrutural, espaço no qual os militantes - inclusive de esquerda - também rejeitavam seus membros. Tornaram-se universos estranhados. $\mathrm{O}$ diálogo da Movida era permeado pela ironia, pela paródia e pela mescla de linguagens sociais ou pelo hibridismo conformado no encontro entre o moderno e o tradicional.

O próprio disco que Almodóvar gravou com Fábio MacNamara sob pretexto de constar em Laberinto de pasiones (1982) contém todos os elementos que vão do punk ao pop, com letras que refletem as subculturas dos grupos gays, prostitutas, drogados e punks que constituíam parte da Movida. Uma apresentação de um mosaico que poderia ser trágico - como apresenta Eloy de La Iglesia -, mas que Almodóvar apenas pretendia fazer rir ou ele mesmo rir de tudo aquilo. As estruturas musicais compunham grande parte do que significava aquele pastiche. Apresentava-se um tipo de paródia disposta a destruir toda e qualquer cultura que aparecesse pela frente, glorificando as culturas marginais e negando a cultura estabelecida.

Uma prática aparentemente original e inerente à Movida que, no entanto, resulta de práticas já enraizadas há tempos no cotidiano da cultura popular. Atualizada e incorporada pelo discurso de negação na cultura da Movida, ela se renovou por 
intermédio da rejeição a qualquer forma construída em nome da unidade de participação política ou de hegemonias discursivas da cultura dominante. Nos filmes também houve um resgate de tradições narrativas e hábitos populares que apareciam em imagens que mantinham heranças culturais do passado difundidas sob a nova roupagem trazida pelas circunstâncias exclusivas do presente.

Suspendendo o tempo, esquecia-se o passado - repressivo do período franquista - e negava-se o futuro. Sobrava para a Movida o presente como algo para ser vivido intensamente, fato que causou a ira dos setores progressistas que a rotularam de pós-moderna e descomprometida com o processo histórico. Por ironia, eram os mesmos representantes dos setores que depois a colocaram na mídia e a utilizaram para seus discursos políticos, transformando-a em objeto de exportação. Héctor Fouce conclui que:

Observar un fenónemo subcultural como la movida a través de una perspectiva dialógica nos permite entender con mayor claridad el proceso de sustituición de los referentes de una cultura por otros, es este un proceso que nunca se completa, pues toda nueva cultura conserva estratos de las anteriores, con las que ha tenido que interaccionar. Este proceso nos es siempre evidente, por ello es necesario rastrearlo a través de los textos. En las producciones de la movida vemos como se genera la nueva cultura juvenil incorporando elementos de otros marcos culturales; en ello radica su importancia. Por mucho que se postule como cultura de la modernidad urbana, los textos de la movida incorporan otras voces que la singularizan. Su modernidad radica en su capacidad de construir textos que contienen voces de otros tiempos y otros ambitos. ${ }^{216}$

Diante desse breve panorama sobre a Movida madrileña, creio que se torna mais claro o caminho trilhado por Pedro Almodóvar e a íntima relação dos vários aspectos daquele movimento com sua linguagem cinematográfica. Observando a trajetória da Movida torna-se possível perceber como seus elementos foram absorvidos e traduzidos pelo diretor em suas imagens. Ocorre entre eles quase uma simbiose, afinal Almodóvar não só contribuiu para sua constituição, como também foi um de seus expoentes mais significativos, e ela, por sua vez, alimentou suas idéias.

Seu ativo envolvimento em várias das atividades criativas ocorridas durante aqueles anos lhe garantiu um legado de informações que rendem dividendos em todos seus trabalhos produzidos posteriormente, dando a impressão de algo inesgotável - da mesma forma como se apresentava a Movida ou se demonstrava ser seu espírito. A afirmação, no capítulo 3, de que ele é um cineasta do presente encontra-se agora com a lógica da própria Movida. Nela buscava-se o presente como algo eterno, repleto de fatos a serem registrados, explicados e vividos - de preferência com muito prazer com intensidade. Isto é o que se vê ainda no diretor maduro que filma seu momento. 
Contudo, mesmo que de maneira mais ocasional, se percebe em suas atitudes e nas últimas películas os elementos remanescentes daquele momento cultural tão singular da história espanhola.

Há em seus filmes um certo deslumbre por uma época que passou e da qual ele não só se sente protagonista como também realmente contribuiu para a fundação de um novo olhar sobre a sociedade espanhola - ou ao menos sobre a vida urbana e sua mobilidade:

[...] hay cosas que haces en un momento de tu vida y ya no vuelves a hacer, cosas de esas que, desde fuera, se pudieron ver con locuras, pero que para mí no lo eran, y ésa es la base de mi equilibrio: haberlas hecho me dejó muy relajado, mi quitó fantasmas. El final de setenta, el principio de los ochenta ... años, efectivamente irrepetibles, para Madrid y para el país, una situación única que vino condicionada por la muerte del dictador, algo irrepetible en si mismo. Por otra parte, las ciudades tienen ciclos más altos y más bajos, en Madrid, se fueron sumando una serie de capacidades creadoras y una postura especial para lo frívolo, para lo superficial, pero también para la alegría de vivir, que surgió no sólo como resultado del momento, era algo que ya estaba ahí. Para mí y para mucha gente, los años de 1978 a 1983 fueron de verdadero esplendor. Si Madrid atravessara ahora otra época de gloria sería diferente, porque además se incorporarían personas más jóvenes, que viven una situación muy distinta a la de entonces. Nada indica que vaya a ocurrir algo parecido, entre otras cosas porque esos momentos siempre vienen provocados por los más jóvenes, y me da la impresión de que ya no existe ese tipo de inquietud, la vida y el futuro para el que se preparan tampoco es el nuestro. La verdad es que nosotros no pensábamos en el futuro. No soy un nostálgico, aunque me acuerdo mucho de esos años, sobre todo porque nos divertíamos mucho más que ahora. ${ }^{217}$

$\mathrm{Na}$ expansão de seu trabalho pelo mundo - diante de espectadores com recepções distintas em razão das múltiplas culturas - permanece a preocupação de transmitir às pessoas suas mensagens relativas à liberdade, à solidão e aos afetos. Elementos presentes na leitura que fazia da "Movida" presentes no seu primeiro longametragem, nas películas seguintes e em sua última produção. O discurso e o sentimento da pessoa "Pedro Almodóvar" podem não ser nostálgicos, entretanto paira em seu trabalho um misto de nostalgia, desencanto e, ao mesmo tempo, inconformismo e esperança diante dos bons tempos passados. Em Volver (2006) suas homenagens a alguns de seus filmes percorrem toda a narrativa. A realidade adversa burlou os sonhos e todos seus criadores - inclusive ele - se acomodaram por caminhos distintos. Mesmo maduro, o diretor ainda parece não querer apagar aquela chama que mantinha a Movida como sua fonte de alegria.

Por mais contraditória que pareça, sua negação com a história não é imparcial. Ele negava e ainda mantém um certo distanciamento sobre a relação com o período franquista e suas seqüelas, mas sua história pessoal faz um constante ir e vir da

\footnotetext{
${ }^{216}$ FOUCE, 2000, p. 276.
} 
cultura e referências ao passado tradicional espanhol - tanto camponês como urbano em suas relações de diálogo e choque com o moderno. Perfila-se ainda em seu trabalho uma certa saudade daquela Movida, misturada à maturidade de alguém que usufruiu bem - o necessário - de uma época.

Passados os anos, ele entende e aceita os processos vividos mesmo que não o agradem totalmente. Entretanto, o mito da Movida o acompanha e se perpetua a cada nova personagem. Como o Harry de Woody Allen, suas personagens dialogam com ele na figura de Agrado em Todo sobre mi madre, da toureira Lydia - antes do coma - em Hable con ella, Angel e Paquito em La mala educación e Augustina em Volver. Uma história, muitas vidas, muitos olhares, num único cineasta. Um mito que os sustenta.

\subsection{A cidade que nasceu da Movida - um diálogo físico com o mito}

Pedro Almodóvar não abre mão da liberdade conquistada e experimentada na Movida. Isso aparece em suas películas como elemento de luta constante para mantêla mesmo como lembrança. A cidade - em especial, Madrid - que apresenta é outro componente imprescindível para compreender seu trabalho. Ela dialoga na história como mais uma das personagens e interage nas relações. É a própria vida pública que alimentou a Movida. Na análise de Jean-Claude Seguin ${ }^{218}$, Almodóvar criou sua própria geografia de Madrid, fazendo caber em seus filmes tanto o rural como o urbano, 0 campo e a cidade, o vertical e o horizontal, numa constante relação dialética que confronta suas diferenças, as faz conviver e gerar uma síntese, nem sempre harmoniosa.

A construção de suas imagens sobre Madrid difere de décadas anteriores ao surgimento de seus filmes. Antes os cineastas apresentavam a cidade sob o ponto de vista negativo. A visão conservadora apontava o espaço urbano como o lugar da perdição. Almodóvar rompe com essa leitura tradicional e coloca Madrid não apenas como cenário e pano de fundo das relações. Sua cidade interage na narrativa e possui uma função dramática na trama das personagens, acompanhando a trajetória do próprio diretor.

Segundo o autor, a cada filme ele atualiza sua Madrid e coloca suas personagens em locais estratégicos que dão sentido às narrativas: classes burguesas,

\footnotetext{
${ }^{217}$ LINDO, Elvira. Entrevista com Pedro Almodóvar. Babelia, El País, Madrid, 26. set. 1992, p. 6.

${ }^{218}$ SEGUIN, Jean-Claude. El espacio-cuerpo em el cine: Pedro Almodóvar o la modificación. In ZURIÁN, F.A e VARELA, C. V. Almodóvar: el cine como pasión.Cuenca: Ediciones de Universidad de Castilla-La Mancha, 2005, p. 229-242.
} 
periferia, bairros em destruição como em Carne tremula. Ela apresenta o contraste do consumo vertical por intermédio das "Galerias Preciados" como modelo de compras do passado e o prédio da "Fnac" no presente, no filme La flor de mi secreto. Em Carne tremula a cidade se historiciza. No início, vazia, devido ao "estado de emergência". No final, repleta de gente, com a população ocupando-a após a democracia. A cidade do passado contrasta com a Madrid moderna.

$\mathrm{Na}$ relação entre ruptura e descontinuidade, o centro perde seu brilho, passando a ser o lugar da tensão entre o centro e o periférico, modernidade e destruição do antigo, passado e futuro. Configura-se numa urbe de constante mudança sem possibilidade de estabilização. A cada filme os olhares sobre a cidade se atenuam. Da Madrid agitada de Pepi, Luci, bom y otras chicas del montón, verifica-se a sofisticação de Todo sobre mi madre, onde o todo urbano perde suas dimensões espetaculares sobrando apenas fragmentos da Madrid sensual e vibrante.

A cidade de Almodóvar agora é um conjunto de zonas justapostas, um espaço da transição e contínua desestabilidade. As personagens estão em íntima relação com ela, mas não conseguem fundir-se a Madrid. A tentativa de integrá-las não ocorre. Em Mujeres al borde de un ataque de nervios se elabora o corpo-cidade, um espaço de germinação. A personagem Candela funciona como elemento de integração de vários fatores, suas roupas misturam moderno com mal-gosto, apaixona-se por um terrorista árabe, encarna esse contínuo fluir de relações. O corpo-cidade está submetido a suas funções biológicas essenciais: a ingestão (Candela), a integração (Pepa/ Marisa) e a expulsão (Paulina/ Iván).

Em Mujeres al borde de un ataque de nervios o autor propõe uma visão de um corpo desde seu interior como centro simbólico e abstrato da cidade. Em Qué he hecho yo para merecer esto ? suas personagens sequer pretendem se integrar à vida urbana central madrilenha e o desejo de volta ao pueblo é uma constante. Este desempenha o papel de abastecedor das energias perdidas na cidade, é o incorruptível, lugar onde o ser humano encontra sua essência extraviada.

No entanto, o espaço rural não possui a capacidade de arrastar de vez suas personagens para si. É o urbano o lugar de suas vivências, como se vê em La flor de mi secreto, em La mala educación e em Volver, este porém vinculando campo-cidade de maneira maternal. Uma relação já apresentada sob outro aspecto em Todo sobre mi madre, onde Madrid e Barcelona são ligadas por um túnel, completando-se como um organismo, um parto estético que as faz possuir uma complementaridade vital. Elaborações metafóricas que buscam garantir a cumplicidade - elemento bastante 
recorrente em sua obra - entre os membros envolvidos na ação dramática em todos os sentidos, inclusive com o ambiente que os cerca. Fato só possível de concretização se forem pactuadas e oficializadas as relações entre personagem e cidade.

A fragilidade e o desequilíbrio da cidade representam um mesmo elemento essencial na obra de Almodôvar, atualizados num constante exercício de juízo e de questionamento. A cidade mítica é buscada repetidas vezes pelo inconsciente das personagens e nunca é encontrada. Torna-se um corpo inconcluso que recorre ao espaço campestre como se buscasse um sopro vital. Evidentemente, uma necessidade do próprio diretor em socorrer-se às suas origens para tentar explicar para si seu momento e suas insatisfações. Origens que ora recorrem ao rural de sua infância, ora à Madrid mágica que conheceu quando chegou adolescente na cidade. Sua construção do rústico, da terra, do campo, constitui uma forma de marginalidade. Mesmo os edifícios novos de suas películas não escondem o descampado, a relação periferiarural-urbano. Um sistema narrativo que num contínuo ir e vir distancia-se da cidade para voltar ao pueblo, como faz a personagem Leo em La flor de mi secreto, "para recuperar seu sentido da vida e encontrar-se a si mesma" ${ }^{219}$, porém que também a faz concluir que o rural não constituirá a solução para sua vida, por isso seu retorno à cidade.

Almodóvar elabora uma Madrid muito particular, com elementos que diferem de outros cineastas também apaixonados por suas cidades. Federico Fellini demonstra sua paixão por Roma construindo uma cidade como palco de excelência do processo entre tradicional e moderno. Ela se torna atemporal. Seus enquadramentos buscam um cenário de admiração que presencia acontecimentos pitorescos, homenagens e a apropriação pública como espaço de circulação. Nela está o circo, a rua, o salão de festas burguês e seus respectivos personagens: o clown, a prostituta, os executivos, as crianças, a família italiana.

Woody Allen apresenta Manhattan como monumental. Tudo é favorável no espaço para que suas histórias se desenvolvam: o anonimato das pessoas nas ruas, a cortesia de praxe com a vizinhança, o passeio com animais nas calçadas, o fluxo do trânsito dando ritmo à cidade, os arrabaldes. Ali se encontram apenas os personagens da classe média e suas crises: os jornalistas, escritores, psicólogos, diretores, artistas plásticos, designers e intelectuais. No entanto, reconhece no início de seu filme homônimo - na voz do personagem Isaac Davis - que Nova York é a metáfora da decadência da cultura contemporânea, porém era e seria sempre sua cidade. Em

${ }^{219}$ Strauss, 2001, p. 182. 
ambos a metrópole permanece como espaço claramente físico propício às relações humanas.

Nos dois diretores, a cidade, apesar de encantadora, funciona como um belo cenário para abrigar suas histórias e ampliar a ação dramática, permanecendo como elemento estético e estático na narrativa. Almodóvar faz com Madrid algo mais visceral. Dialoga com a cidade como se esta fosse uma pessoa por quem alimenta relações de amor e ódio. De seu encanto nas duas primeiras películas e sua noite que vai envolvendo todos os espaços privados de Entre tinieblas, a transforma em perigosa e de difícil relacionamento em Matador e na lei Del deseo ou mesmo em Átame!. Em Qué he hecho yo para merecer esto? algo na cidade já desagrada o diretor. A falta dos valores da vida do pueblo na cidade aparece nas palavras de Chus Lampreave que levará seu neto para sua terra natal no final da película. Em Mujeres al borde de um ataque de nervios e em Kika, a cidade torna-se incontrolável e alucinante, frenética.

Em todo caso, há, ao menos até Mujeres al borde de un ataque de nervios, uma cidade que aparece para Almodóvar como espaço de desfrute e de luta. Sua predisposição em mudar, conhecer e fazer o novo funciona como mola propulsora de sua adaptação e movimentação dentro desse cenário. Aquele impulso de inconformismo que ele carregava desde menino e que o fez chegar até Madrid tão jovem vai-se revelando numa personagem que ele precisa domar, mas ao mesmo tempo se relacionar e aceitar suas condições.

A cada trabalho, Madrid se converte numa outra personagem. No filme Átame!, o próprio autor reconhece viver com a cidade uma relação de amor em constante conflito:

En esta ocasión ya no es el sitio ideal sino una ciudad decrépita e infernal. Yo con Madrid tengo una relación amorosa maldita. Imagínate que estás enamorado de un yonqui y que sabes que tienes muy pocas esperanzas, pero tú le quieres y le ves destruirse y le quieres y le ves cercano al desastre y le sigues queriendo. Yo tengo esa relación con Madrid, una ciudad que cada vez es más dura y más inhabitable, pero que sigue siendo mi ciudad. ${ }^{220}$

Algo que soa à declaração de Woody Allen em Manhattan (1979). Em Kika, a personagem Andréa Caracortada (Victoria Abril), representa essa ruptura que ainda busca - como um último suspiro - a movimentação tresloucada da Movida, porém se defronta com algo que já não possui mais o mesmo espaço de convivência. Há na trajetória da película uma despedida oficial do diretor para aquelas formas de vida e para aquele período.

[...] Las ciudades grandes se han convertido em sitios invivibles. No sé como hemos llegado a construir espacios tan en contra de nuestras propias

${ }^{220}$ LLOPIS, Silvia. Entrevista com Pedro Almodóvar. Cambio 16, Madrid, n n 941, 11. dez. 1989 , p. 174. 
Em Carne tremula vê-se a cidade antiga sendo destruída e, em seu lugar, impôr-se uma outra, moderna, com as arrojadas torres Kio - portas da Europa próximas a Plaza de Castilha, no alto da longa e larga avenida "la Castellana" em Madrid. A casa do personagem Victor e seu bairro La Ventilla, em destruição, presenciam uma cidade nova que avança sobre eles impetuosamente.

Em Carne tremula e em Todo sobre mi madre e Hable con ella o autor entra em contato com a geografia-corpo. Ali, da mesma maneira com que as personagens se relacionam, também há uma relação intensa em que a palpitação da cidade encontra paralelo com a do coração, com o sangue. Os longos travellings, além de descreverem espaços percorridos, apontam as separações e os novos laços de vida. Almodóvar aproxima cada vez mais seu discurso às suas preocupações mais profundas acerca do sentido da vida.

Ao abordar nos três filmes as discussões sobre vida e morte - e acrescento aqui também La flor de mi secreto -, o diretor revela uma das grandes incógnitas que o preocupam em seu presente. Por isso, o que se vê nelas é a busca de sentido ou a explicação para si dessa relação que, quando debatida, traz ao pensamento a reflexão sobre a existência e, em contrapartida, sobre o lugar que o ser humano ocupa. Ou seja, um espaço que não é somente físico e impessoal, mas pulsante e interativo com ele.

Em seus pronunciamentos, essa relação "humanizada" com a cidade aparece repetidas vezes. Na estréia de Carne tremula a vinculação entre gente e espaço físico se traduz claramente:

Yo soy muy de Madrid y me encanta que la ciudad sienta que ha llegado un estreno al que tiene que ir. Me gusta esa identificación con mi gente, pero cada vez son más los que quieren ir, incluso muchos los que no suelen ir al cine. [...] Madrid es mi pueblo, forma parte de mi vida y el hecho de que las calles que tú sueles transitar se vuelvan locas ese día por una película tuya me produce un sentimiento muy personal y muy íntimo. Ahí es donde tengo que certificar el nacimiento de mi película. Estoy contento de que esta vez le hayamos podido prestar más atención a Madrid. Yo por mí estrenaría aquí y en ningún sitio más. Porque los estrenos deben ser únicos $[\ldots]^{222}$.

Mas, anteriormente, em La flor de mi secreto, os sinais de um certo desapontamento com a cidade e a relação conflituosa no sentido já construído aqui: desavenças, insatisfações e insegurança no espaço público também estavam presentes. Nas próprias cenas há maior valorização de ambientes interiores em detrimento dos exteriores.

\footnotetext{
${ }^{221}$ JALONCH, C. Entrevista com Pedro Almodóvar. La Vanguardia Magazine, Barcelona, 18. jul. 1993, p. 19.

${ }^{222}$ ALMODÓVAR, P. Testimonio. La Esfera, Madrid,. 11. out. 1997.
} 
Passados alguns anos, o ritmo de vida da cidade havia se acelerado. A fama conquistada já não permitia que Almodóvar andasse tranqüilamente pelas ruas de Madrid. Cada vez mais ele sentia sua privacidade diminuindo. Indisposto com Madrid quase em processo depressivo -, ele decide mudar de ares em seu trabalho, mas, principalmente, essa necessidade aparece no plano pessoal.

Enfim, todas as suas películas respondem ao momento em que ele está. Esta situação está clara a partir de 'Mujeres ... ' é o reflexo de seu momento de solidão, lamentos, medos. Não saía de casa porque todo mundo o conhecia, sentíasse violado pela sociedade. Ele só veio a perder o medo em Todo sobre mi madre, tanto que o rodou em Barcelona. Madrid nos anos 70 e início dos 80 era uma cidade maravilhosa, depois ficou agressiva, perigosa. Isso repercurtiu em Almodóvar. Imagino que foi por isso a vontade de sair e se firmar em outro lugar e vir a Barcelona, isso fez muito bem a ele e lhe abriu um horizonte muito grande. Foi uma nova etapa. ${ }^{223}$

Transferir-se com sua equipe para Barcelona com o objetivo de realizar Todo sobre mi madre se constituiu num salto de qualidade em sua carreira. E, como já observado por Seguín, o túnel que leva o espectador direto de Madrid para o alto do Tibidabo, numa belíssima panorâmica de uma Barcelona noturna, funciona como um parto. O filme não só liberou o cineasta para uma nova paisagem, com novos olhares, como inaugurou ali o renascimento de sua criação. Nos depoimentos do diretor, ao iniciar as filmagens, novamente pode-se notar sua relação corpo-cidade, geografia como corpo, e incluo: erotismo-cidade. Ela aparece em seu discurso tão metafórico quanto direto acerca do poder sedutor cosmopolita:

Pedro Almodóvar, que rodará esta semana en Madrid, confesó su pequeña traición ayer durante la presentación del rodaje, y descobrió su nuevo secreto, una admiración renovada por Barcelona, donde comenzará a rodar el próximo lunes: 'He descubierto un decorado natural fastuoso, donde conviven todas las etnias y la gente se sienta tranquilamente en la calle y se pone a dormir. Me siento traicionando a Madrid y venerando a Barcelona,224.

"Por primera vez Pedro Almodóvar abandonará Madrid para rodar parte de la película en Barcelona y el 28 de septiembre todo el equipo estará trabajando en la Ciudad Condal. 'Barcelona es una de las infidelidades de esta película. He descubierto un decorado natural fastuoso y un ritmo que tiene la ciudad diferente al nuestro (por Madrid). No tiene nada que ver con el catalanismo ni eso que quiere Pujol que doblemos las películas al catalán. Barcelona es mi amante, me siento traicionar a Madrid y venerar de rodillas [de joelhos] a Barcelona,225.

Às vésperas da estréia de Todo sobre mi madre na Espanha, a mudança de cidade e a paixão por outra ainda percorriam os noticiários como forma de atração de público, unindo a fama do diretor, sua história e o cenário de Barcelona:

Gaudí fascina Almodóvar: el director usa la Sagrada família con a escenari de 'Todo sobre mi madre'. 'Aquesta ciutat m'ha ofert una estètica diferent de Madrid', diu Almodóvar. La seducció que Barcelona ha exercit en el director

\footnotetext{
${ }^{223}$ VIDAL, Nuria. Depoimento sobre Pedro Almodóvar [13 jul. 2005]. Entrevistador: Gilmar Santana. Barcelona: Universitat de Barcelona, 2005. Minidv (70 min), mono. Entrevista concedida para este trabalho.

${ }^{224}$ PIÑA, Begoña. La Vanguardia, Barcelona, 24. set. 1998.

${ }^{225}$ MARTIN-LUNAS, Milagros. EI Mundo, Madrid, 24. set. 1998.
} 
manxec generarà per a la ciutat excel.lents dividends en tots els aspectes. [...] 'Per al seu últim melodrama, el cineasta espanyol més universal s'ha deixat fascinar per Barcelona. 'Tota la ciutat - afirma - és un magnífic decorat que ofereix infinites possibilitats ${ }^{226}$.

Sua relação instável com a cidade ora o apaixona ora o esgota. Os constantes trajetos cidade-campo, ampliados de La flor de mi secreto para Hable con ella, vão descrevendo uma busca pelo campo e pequenas cidades como espaço periférico incorruptível, dotado de fonte de vida, realizador da ressurreição da memória. A volta do personagem Marco à cidade, e seu encontro com Alicia no final da película, consolida essa contribuição do campo que novamente iniciará um novo ciclo de vida.

O filme La mala educación está pontuado quase geometricamente com este traçado narrativo que busca peças para completar o sentido, tanto da trama apresentada, como da vida das personagens. Volver - seu último trabalho até esta pesquisa - encontra-se de vez com o pueblo e com as origens do diretor, consumando sua busca por entender e se relacionar com a sua própria trajetória e restabelecer com estes espaços seus laços de afetividade.

Não há grandes surpresas nessa estrutura e lógica narrativas. Evidentemente, estas ficam por conta das histórias que se encarregarão de instigar o espectador a pensar nos sentimentos que preocupam o diretor. O conjunto narrativo do diretor sobre este aspecto consiste em colocar, de um lado, a cidade-transformação-novidade, relacionando-a em contraste com a cidade-conservadorismo-tradicional, de outro, a cidade-sentimento-desejo na projeção da cidade-conflito-mito. Com esses elementos, a cidade possui vida própria, adquire um status quo independente como se fosse um ser humano. E isso só se torna possível porque a forma como ela é apresentada pelo diretor manifesta sua vida pulsante, com todos os protagonistas possíveis habitando-a e sua própria trajetória:

La ciudad almodovariana nunca pierde há huellas [as marcas] de su origen, y como la interacción entre la ciudad y los personajes es una constante de sus películas, y Madrid es un gran urbe pero compuesta em gran medida por gente que procede de pueblos, de otras partes del país, ese carácter 'publerino' de su gente no puede sino teñir a la ciudad entera. Así, en la gran ciudad los personajes se cruzan, encuentran, reconocen y reúnen como si de un pueblo se tratara ...227

Em Mujeres al borde de un ataque de nervios (1987), Pepa acaba tornando-se amiga do motorista de táxi por encontrá-lo coincidentemente três vezes quando precisa de um serviço. Ao mesmo tempo em que há uma necessidade em mostrar a cidade

\footnotetext{
${ }^{226}$ RUBIO, Teresa. El Periodico, Madrid, 14. mar. 1999.

${ }^{227}$ LOEW, Camila e LUNA, Antonio. De la M30 a Hollywood Boulevard, in ZURIAN, Fran A. e VARETA, Carmen Vázquez. Almodóvar: el cine como pasión. Cuenca: Ediciones de la Universidad de Castilla-La Mancha, 2005, p. 414.
} 
real com locações em cenários reais, interiores de ônibus ${ }^{228}$ que favorecem a visualização da cidade e seus monumentos, também verifica-se sua dinâmica: as pessoas, o processo urbano em movimento, como um organismo. E com estes mesmos instrumentos o diretor a eterniza, seja pelo registro de sua película, seja pelo modo como escolheu filmar os espaços: ângulo, movimento, luz, enquadramento.

Nesses termos, é possível retornar à discussão do mito e verificar como a cidade apropriada por Almodóvar tornou-se um mecanismo capaz de contribuir para alimentar o mito da metrópole em festa ou em crise, porém magistral e sempre aberta à busca pela completude. Uma grande mãe disposta a se reconciliar com seus filhos e, ao mesmo tempo, um filho que busca o colo materno. Ela é o recurso da ordem cosmológica que explica o movimento de seus integrantes, ora contribuindo para modificá-la ora para questioná-la.

Movimentando-se e dialogando com ela, seus personagens estão continuamente intranqüilos, nada os satisfaz. Circulam de um canto a outro para encontrar uma explicação para seus lugares sociais e psicológicos. E, dentro deste constante conflito, só a cidade permanece soberana. Ela direciona a lógica dos limites e satisfaz os desejos, alimentando aqueles que precisam se saciar em seus dotes apesar de não serem todos os contemplados.

Assim, a metrópole madrilenha e sua "Movida" se constituíram num mesmo elemento mitológico que motivou, inspirou e acionou a criação de Almodóvar. Um momento favorável à integração e à emancipação de personalidades que emergiam na cena cultural do país, muito mais dispostas a liberar suas vontades e a usufruir da cidade do que em contestar ou construir politicamente uma nova história. A Madrid dos três primeiros longas-metragens de Almodóvar é o espaço das oportunidades daquele rapaz que saiu de Cáceres disposto a realizar seus sonhos e naqueles momentos era 0 que ocorria. Não só o conjunto de personagens que povoam os filmes revelam uma cidade com mais prismas do que se imaginava, eles sintetizam aquele seu momento vivido, um universo de amigos, de experiências, de contínuas novidades e amores. As coisas acontecem porque Madrid propicia para que se concretizem. Há entre o diretor e ela uma relação de confiança mútua. Este é o jovem diretor em plena cidade fazendo ao seu redor o que ele também fazia.

O que se vê nos filmes do diretor até em Qué he hecho yo para merecer esto? é um traço das outras movimentações em campo no período. E foi este ambiente social e artístico com seu momento de encantamento e posterior desencanto que também

${ }^{228}$ ALLISON, Mark. Un laberinto español. Madrid: Ocho y medio, 2003, p. 156. 
amadureceu o diretor e o fez trilhar novas histórias. O término da "Movida" foi também o encerramento de um modelo de cidade e o início para exercitar uma nova relação com ela. Creio que seja por isso que apareçam explicitamente cenas referentes ao pueblo e às origens humildes de Almodóvar somente em Qué he hecho yo para merecer esto?. E ali algumas reflexões sobre a validade da vida na metrópole.

Para outros diretores, que também passaram pelo período da "Movida" e rapidamente se desapegaram de Madrid, abriram-se as fronteiras para o mundo, como Colomo ou Trueba. Para Almodóvar, que optou por "ficar", foram suas miradas que adquiriram novas percepções e também novos caminhos buscando explicar o sentido das muitas relações criadas ao seu redor - ou até onde alcançou sua sensibilidade na vivência que adquiriu dentro da dinâmica social metropolitana.

A cadência cosmopolita e sua profusão de valores originaram as histórias - do que hoje se pode chamar - almodovarianas, com suas personagens solitárias, mulheres sempre reagindo a um universo masculino que lhes priva de realizar seus desejos. Ou, então, de homens cuja cumplicidade denuncia o valor das amizades profundas e suas carências afetivas. Uma leitura de um diretor que buscou na cidade e em seus habitantes sua realização e encontrou também as contradições. Suas películas resultam da fusão entre as imagens que guardou de sua infância, as experiências da vida que desenvolveu na metrópole e suas projeções pessoais.

A Movida deu aos "seres" da cidade sua concepção de realização da desordem e de uma nova ordem. A frase, tão propagada no período, inclusive transformada em nome de uma de suas revistas mais conhecidas: Madrid me mata, revela os vários sentidos de prazer, vida, temor e morte da mesma cidade que, como uma esfinge, poderia devorar seus habitantes, mas que na "Movida" poderia também ser devorada. Foi a Madrid da transição política e sua "Movida", ocupadas em livrar-se de todas as amarras do passado que transformaram para Almodóvar uma cidade já luminosa e sedutora - quando de sua chegada aos 16 anos - em um símbolo metafórico dotado de poder transcendental capaz de justificar os novos modos de vida e a busca pela harmonia social em suas películas.

Madrid, como palco vivo da Movida, não só permitiu sentido aos inúmeros acontecimentos do período. Também alimentou o imaginário e a ritualização das diversas manifestações artísticas difundidos internacionalmente por um cinema que buscava se expandir e se consolidar - apesar de ter-se constituído apenas como indústria incipiente. O próprio contexto econômico do setor cinematográfico daquele período também refletia essa busca por novos horizontes conquistados, enfim, pela 
proliferação de várias produtoras - quando a Movida

já havia se esgotado - dentre elas El deseo, de Agustín e Pedro Almodóvar.

O processo da articulação de significados dos discursos permitiu a formação dos mitos de Madrid e da Movida" como fontes de experiências intensas que motivaram a ampliação de contínuas novidades onde antes preponderava uma cultura do medo. Esse poder discursivo - seja em filmes, fotografias, pinturas, músicas, livros, revistas ou artigos - formulou uma nova imagem da cidade. Uma prática que vem confirmar a definição de Roland Barthes ${ }^{229}$ do mito como uma fala. Fala que, por sua propriedade de disseminação, possui em seu discurso um poder legitimador capaz de mitificar qualquer coisa, pois sua capacidade de significação alcança e transcende limites impostos, instituindo novas regras de compreensão e valor. Foi esta eficácia da mensagem construída pelos tantos agentes sociais - dentre eles Almodóvar - que delegou, tanto a Madrid como a seus acontecimentos, valores simbólicos que alimentaram os novos comportamentos e visões, consolidando-os.

Pertencente a um sistema de comunicação munido de um conjunto de significados e não apenas de uma idéia ou um conceito, o mito depende da história como fator determinante para transformar o real em discurso, cabendo somente a ela manter sua linguagem viva ou morta. Como este não pode surgir da natureza das coisas, sua forma e acepção só possuem sentido na fala escolhida historicamente por meio da mensagem elaborada e determinada por seus agentes. Assim, na medida em que o discurso da "Movida" ganhou maior eficácia, mais ele serviu como modelo de comportamento viável e palpável, aberto para contínuas adesões.

Dessa maneira, houve um efeito favorável na ação - mesmo de curto prazo das formas estabelecidas por uma movimentação de várias atitudes simultâneas pessoais e culturais, numa cidade que permitia sua prática física e socialmente. Fundiram-se quase num mesmo ato criador: espaço, apropriação e dinâmica social. Os participantes da "Movida" deram forma e sentido ao que antes era apenas desejo. Pode-se perceber nesses termos que - com todos os méritos reconhecidamente atribuídos a Almodóvar -, além de haver uma fusão entre criação e vivência direta do diretor com todo esse universo que o lançou, sua projeção só foi possível por esta determinação histórica e cultural.

As construções mitológicas sobre a cidade e a Movida permitiram o avanço das ações criativas. O reconhecimento do valor de Almodóvar deve-se muito a essa capacidade de captar, traduzir e fazer ecoar com tanta reverberação - em sua síntese

${ }^{229}$ BARTHES, Roland. Mitologias. 5a ed. São Paulo: Difel, São Paulo, 1982, p. 131-132. 
cinematográfica - o que se produziu nesse sentido. Foi o que lhe garantiu sua fama mundial. Historicamente motivado pela busca em desarticular a ordem social e instituir uma outra, o diretor reproduziu ao mesmo tempo o mito de uma Madrid gloriosa e de uma juventude que viveu uma liberdade específica para sua história. Uma experiência peculiar com a cidade vivida por ele e não a equivalência geral de um mito absorvido por todos.

Em seus filmes constam os olhares sobre sua própria trajetória: amigos, dificuldades, anseios e o meio urbano que o cativa. Em meio a personagens exóticos, à margem da sociedade, passando pelos polêmicos e depois sentimentais, ele constrói seu universo e nele edifica pessoalmente sua cidade, sua composição social e suas possibilidades afetivas. Esta é sua Madrid. A Movida contribuiu para oficializar sua paixão por ela. Isso alimenta seu desejo de continuar interpretando sua imagem, porém, a cada filme sob aspectos mais amadurecidos. Cada etapa da vida nos proporciona criar novos mitos, afinal são sempre novas experiências e novas apropriações da cidade e, para Almodóvar, também do cinema.

Os participantes da Movida tinham consciência de que estavam modificando suas buscas e envelhecendo para aquele universo quase no mesmo momento em que esta saiu do alcance de suas mãos e se transformou em mera mercadoria. A consciência do diretor que fez parte daquele círculo de artistas, pertencentes a uma determinada "elite underground urbana" -, chamada na Espanha de cutre ${ }^{\mathbf{2 3 0}}$ [de mau gosto, tacanha, fora dos padrões] - que depois se legitimou culturalmente, também já havia mudado. Contudo, os valores míticos que ele mesmo elaborou e que contribuíram para transformar sua experiência em cinema ainda percorrem de maneira remota seus trabalhos. Seu amadurecimento trouxe novas preocupações à sua obra, mas na maioria das abordagens apenas aprofundou questões que desde o início já estavam potencialmente dispostas, como a solidão. Em mais de uma oportunidade Almodóvar se pronunciou a respeito deste fato em sua vida. O que ele carrega para si daquele tempo em sua imagem ? Recebeu algum legado?

${ }^{230}$ GARCIA DE LEÓN e MALDONATO, 1989. p. 56-57. 


\section{DESCONSTRUINDO E RECONSTRUINDO PEDRO - MITO E HUMANO}

Como visto no capítulo anterior, o conjunto de acontecimentos sociais ocorridos em meados da década de 70 e 80, possibilitou, na esfera cultural, o surgimento de um cinema inovador e irreverente desenvolvido por Almodóvar. Nele, havia dimensões que contemplavam propostas de grupos artísticos que buscavam novos diálogos com o público e o mercado, ao mesmo tempo em que rompiam com um modelo tradicional de política e instauravam seu estilo "descomprometido". Com eles, inauguravam-se novas formas de exercê-la. Envolvidos pelo clima da Movida, paralelamente a uma ação agressiva de mercado que aliava arte e economia, estes agentes sociais - muitos amigos do cineasta - ganhavam mais vigor vendo seus trabalhos projetados em suas imagens.

A mudança cinematográfica que sintetizava tais manifestações nos filmes de Almodóvar veio carregada de uma só vez de muitos elementos que rompiam, questionavam ou atualizavam as tradições de uma Espanha muito atrelada a valores morais do período franquista. Mesmo imbuída de um discurso de rechaço àquele passado tão próximo e desejosa por constituir uma nova nação, a realidade interna de tantas disparidades regionais e conjunturais ainda inviabilizava o desejo de entrar na então contemporaneidade européia. E a liberdade comunicativa de Almodóvar não era e nem se pretendia didática.

Assim, quando ainda hoje se detectam nos seus primeiros filmes diálogos e comportamentos ousados, talvez seja necessário projetar um pouco a imaginação para compreender o que isto representou em seu conjunto para aquele período histórico. Abordagens que naturalizavam temáticas como: sexualidade, homo e bissexualidade, consumo de drogas, modos de vida alternativos - às vezes bizarros - eram tratadas no limite entre a normalidade e a excentricidade sob tom irônico, afrontando o contexto de uma Espanha que apenas dialogava timidamente com o mundo e com as novidades que chegavam do exterior.

\subsection{Da Movida para a maturidade - nasce um gênio ?}

O forte impacto dos filmes sobre o público espanhol habituado a uma rígida moral católica, ao mesmo tempo em que escandalizava, fazia delirar a platéia diversa. Para os que buscavam a inovação ela havia chegado - descomprometida politicamente e muito mais divertida do que poderiam imaginar. Para conservadores e moderados 0 que se via era a deturpação geral dos valores e mudanças que não chegavam às ruas 
e aos lares gradualmente como planejavam. Esta talvez seja a principal diferença entre Almodóvar e Trueba quando do lançamento de suas películas no ano de 1980.

Em Trueba são apresentados os mesmos elementos da novidade dos cotidianos e do consumo na cidade como em Almodóvar. Porém, seus personagens circunscrevem-se a espaços onde se movimentam membros da classe média e de uma pequena elite intelectual. Em Almodóvar, vários personagens pertencentes aos setores marginais da classe média, popular e da elite da sociedade relacionam-se naturalmente, integrando-se como efetivos participantes da vida cotidiana entre as pessoas comuns.

Bares noturnos repletos, vida sexual aberta publicamente, milhares de festas e inumeráveis grupos musicais. Era um ciclo incontrolável. A Movida madrileña se alastrava desenfreadamente na vida pública espanhola e Almodóvar lia seus passos, tornando-se um de seus principais representantes ao transportá-la para o cinema. E imagens reveladoras não faltavam. No apartamento de "Bom", em Pepi, Luci, Bom y otras chicas del montón, a grande quantidade de garrafas vazias de coca-cola amontoadas no chão da sala ilustra - cômica e metaforicamente - esta entrada exagerada dos espanhóis no consumo e na massificação mundiais, que mergulhava todos no universo da repetição de produtos como em uma instalação de algum artista plástico, numa cenografia remetida diretamente às reproduções das latas de sopa Campbel ou das fotos de Marilyn Monroe de Andy Warhol.

Concursos noturnos de erecciones generales [ereções gerais] em festa de amigos na periferia, num direto trocadilho irônico referente às campanhas da esquerda por elecciones generales [eleições gerais], relações eróticas sadomasoquistas entre mulheres. Situações nada convencionais convivendo com modelos tradicionais de sociedade. Os dois filmes posteriores não fogem à linha excêntrica: um príncipe bissexual, um terrorista apaixonado por ele com olfato canino, uma atriz obcecada por sexo, um pai que transa com a filha em Laberinto de pasiones (1982), um convento com uma freira escritora de livros eróticos, outra lésbica e consumidora de drogas, uma outra que trata de um tigre como um filho em Entre tinieblas (1983). Esta era a tônica: onde estivessem aprisionados, os desejos deveriam ser liberados e satisfeitos incondicionalmente - ainda que não pertencessem ao senso comum.

Não se propunham relações afetivas fixas ou que levassem à estabilidade institucional. Mesmo na última cena de Laberinto de pasiones, quando Sexilia e Riza Niro embarcam juntos num avião, não se sabe se o casamento será consumado juridicamente. Apenas em Qué he hecho yo para merecer esto? (1984) começa um 
ciclo diferenciado, apesar da continuidade de elementos como as drogas e de hábitos sexuais fora das regras permitidas oficialmente. Agora no universo familiar da periferia madrinhela, no bairro de Concepción, as práticas excêntricas se travestem no cotidiano com remédios que viciam, produtos de limpeza tóxicos, no uso da sexualidade por dinheiro ou na satisfação momentânea recalcada buscando suprir a escassez sexual do matrimônio. Ali se decreta: a festa da Movida acabou e os desejos ainda não foram todos realizados.

Este filme fecha um ciclo e indica de uma forma marcante a transição do diretor para um novo processo criativo. Esta é a que denomino como sua primeira fase: a absorção reinterpretada da cultura estrangeira que entrava diretamente no país e incidia sobre a juventude, o deslumbramento com o mundo do consumo e novos movimentos culturais, o rompimento com alguns tabus religiosos e comportamentais. Naquele momento ocorria uma releitura da cultura nacional diluída em todo esse movimento que unia e ironizava passado, tradição e presente.

Já em 1984, o contexto toma outro eixo. A Movida é cooptada pela indústria de entretenimento e por interesses políticos, perdendo sua originalidade. Deixa de ser atraente para seus protagonistas, tanto por sua instrumentalização quanto pelas próprias mudanças de perspectiva de seus fundadores. Não por romantismo ou por serem incorruptíveis. Os próprios membros de La Luna - revista que aglutinava boa parte dos mentores criativos da Movida, todos amigos, parceiros ou conhecidos de Almodóvar - afirmavam que aquela vanguarda era mercado, portanto, necessitava de divulgação.

Não por acaso, a principal crítica que faziam direcionava-se à imprensa e à publicidade. Em suas concepções, estas exerciam um papel fundamental em difundir as obras, no entanto não depositavam nenhum valor ao que estava ocorrendo naquele momento. A grande auto-promoção de Almodóvar - tanto de sua imagem como se seus filmes - denunciava indireta e diretamente esta precariedade do aparato publicitário carente de uma mentalidade industrial para trabalhar a esfera da cultura. ${ }^{231}$

Nesse processo, Almodóvar abondona aos poucos o mundo adolescente e inclui a família, o dia-a-dia monótono, e fala - por intermédio da "personagem" Madrid das conseqüências da ditadura vistas nas imagens e na vida de moradores dos conjuntos habitacionais populares periféricos da cidade. Essa quarta película marca uma transição pessoal, reconhecendo o final da Movida e a busca por novas abordagens.

${ }^{231}$ ORTEGA, 2005, p. 475-476. 
Já conhecido nacionalmente desde seu filme de estréia - um sucesso transformado em cult movie que permaneceu durante quatro anos em cartaz nas sessões noturnas das salas de exibição Alphaville em Madrid -, Almodóvar fixara com três obras sua imagem de diretor marginal, polêmico, kitsch, irônico e recordista de bilheteria. Somente a partir daí seu trabalho começa a ser notado pela crítica espanhola sob os argumentos de possuir qualidade narrativa e contextualização das classes sociais - inclusive relativa à sua própria origem humilde e às referências históricas franquistas. A imagem construída até aquele momento, do cineasta de origem rural, autodidata, ex-auxiliar administrativo da Companhia Telefônica, tomava novos rumos. Com este filme, ela se transforma e também sua postura. No discurso de estréia em Barcelona, nada de Movida ou festa:

[...] no se trata, en efecto, de una comedia. Como hacía Charlot, me gusta provocar risas y lágrimas. Durante la película creo que el espectador se va a reír, pero lo que al final prevalece es la parte patética de la historia. En este sentido debo también decir que se trata de una de mis películas com más contenido crítico y social. Una película de izquierda, sin ser tradicional, y feminista, sin el falso feminismo que significa presentar la mujer como una víctima permanente y un modelo de virtudes [...] he querido mostrar este tipo de familias proletarias donde cada uno de los miembros tiene su autonomía, y las únicas reglas morales son la lucha por la supervivencia. También he querido retratar la vida de barrios como el de la Concepción, edificado por José Banús cuando Franco quería demostrar que el proletariado español difrutaba de confort, mientras que en realidad se estaban construyendo verdaderos infiernos ${ }^{232}$.

São pronunciamentos como este, em relação a outros de total deboche ou ousadia, que começam a reproduzir a construção social - pela crítica - de uma genialidade de Almodóvar, num emaranhado de visões e opiniões diversas transitando entre perplexidade, admiração, inveja, indignação, repulsa e atração.

Nesses termos, seguirei no sentido de traçar os vários elementos que esclareçam as razões desse relacionamento, aparentemente tão passional, mas que, contudo, compôs um caminho gradual de sua imagem artística. Uma trajetória mediada por discursos do próprio diretor e de seus entrevistadores, portanto nem sempre convergentes. Pronunciamentos que continuam a se desenvolver, num processo que coloca a imprensa e a mídia em geral como agentes decisivos para a elaboração de uma celebridade. Em cada detalhe das inúmeras declarações, paulatinamente se alimenta e garante-se consistência à imagem deste cineasta num plano internacional ligado aos círculos sociais cinematográficos. Constituídas de atributos consagradores ou depreciativos, as visões sobre o diretor tornaram cada vez mais inseparáveis seu caráter polêmico pessoal e autoral.

Assim, do mesmo modo que a Movida e Madrid aparecem como ingredientes

${ }^{232}$ ROVIRA, Bru. Entrevista com Pedro Almodóvar. La Vanguardia, Barcelona, 27 out. 1984. 
essenciais para o surgimento do cineasta Pedro Almodóvar, o cinema consta nos discursos como algo intrínseco - quase genético ou profético - a ele. Uma lapidação aleatória executada por várias mãos nem sempre voltadas para os mesmos objetivos, mas cujos resultados acabam por difundir a imagem pública do diretor e beneficiar as diversas partes dos conglomerados envolvidos: redes de rádio e televisão, jornais, revistas, festivais e distribuidoras. As vantagens para ambos permutam-se como audiência, aumento das vendas nas bancas de jornais e maior bilheteria. Mídia e Pedro Almodóvar encontram-se fatalmente vinculados pelas próprias determinações que os movimentam. Numa relação nem sempre harmoniosa - por isso paradoxal -, o diretor e os veículos de comunicação de massa trocam - segundo seus interesses informações que atraiam a atenção do público.

$\mathrm{Na}$ introdução do artigo elaborado em torno da entrevista sobre o lançamento de Qué he hecho yo para merecer esto ?, em 1984 em Madrid, já é possível notar as referências que o estigmatizaram:

Pedro Almodóvar, 34 años, una de las revelaciones de la cultura pop madrileña, director de cine, articulista, novelista y cantante, todo ello de una forma peculiar, personal y polémica. Ésta es la historia de un chico que desde la soledad rural ha llegado a la popularidad de las páginas satinadas de las revistas del corazón, tras pasar siete años de auxiliar administrativo en la Telefónica. ${ }^{233}$

O reforço à sua singularidade artística é o primeiro elemento destacado, juntamente com suas origens rurais e vida pessoal oriunda de classes populares. $\mathrm{O}$ desenvolvimento e o desfecho dos assuntos do artigo demonstram como simples detalhes contribuem para demarcar as bases do que interessa evidenciar publicamente e que abre caminho para constituir - a partir deles - elementos míticos: trabalhador, lutador, criativo, polêmico, origem humilde e rural. As palavras ou frases destacadas (grifo do autor) na entrevista abaixo, buscam ampliar esta observação :

Qué he hecho yo para merecer esto? es el cuarto largometraje, a punto de estrenarse comercialmente en España. Almodóvar ataca de nuevo, y lo hace con un tema que le resulta próximo y familiar en su filmografia: la comedia costumbrista y esperpéntica. (...)

De todas formas, Pepi, Lucy ... era, por así decirlo, una comedia pop, aunque con ciertas diferencias, porque era corrosiva y el pop no lo es, por lo menos en lo cinematográfico. Mi última película es dramática, ni siquiera melodramática, y es mucho menos comedia que Pepi ... y he pasado de todas las referencias del mundo pop de una forma consciente.(...) Almodóvar, al margen de la calidad de sus productos, es un director de cine que consigue algo difícil para el gremio: trabajar de forma continuada y constante. Sin haber estudiado en ninguna escuela de cinematografía, sin haber pertenecido a la crítica ni a ninguna capilla de cinéfilos, consigue filmar al menos por ahora, a un ritmo de una película por año. La solución a este misterio no es otra que el rendimiento en taquila [bilheteria]. Sin embargo, Almodóvar no goza de la estima de buena parte de quienes suelen decidir lo

${ }^{233}$ HARGUINDEY, Ángel S. Entrevista. El pais semanal, Madrid, 30. set. 1984, p. 8. 
que es bueno y malo en el arte cinematográfico.

- Es evidente que yo molesto a mucha gente, no sólo a los críticos. Es evidente porque lo noto. Recibo desde anónimos amenazadores en el contestador telefónico hasta algunas otras cosas, pero estoy ya acostumbrado a eso porque desde pequeño me ocurre de la misma forma. En el pueblo, a los ocho años, no hablaba como hablaban los chicos del pueblo. Recuerdo que en colegio yo ya provocaba en la mayor parte de mis compañeros el mismo rechazo que ahora puedo provocar a la crítica.

Tras aclarar que el pueblo al que se refiere y en el que nació es Calzada de Calatrava (Ciudad Real), la pregunta es obligada. Porqué?

- Yo no era un niño habitual, y por fortuna esto no me ha traumatizado. Me gustaba leer, lo que parecía raro. En el recreo prefería sentarme y hablar de Ava Gardner, por ejemplo, qe, aunque no sabía bien quién era, sí sabía que había tenido 15 maridos, y eso me divertía más que jugar [brincar]

- De qué colegio se trataba?

- De un colegio de franciscanos en Cáceres. Mi família, por cuestiones económicas, se traslada de Ciudad Real a Madrigalejo, en Cáceres, y yo estudio el bachillerato allí, en plan de internato.

- Estudia el bachillerato en Cáceres y se viene a Madrid con toda la familia?

- Cuando cumplí 16 años, al terminar el bachillerato, mi padre decidió que me iba a emplear en una oficina en Madrigalejo y le dije que para nada, que me venía a Madrid a intentar seguir estudiando y trabajar. Me vine a un pequeño apartamento que habían comprado mis padres, con lo que tenía asegurado el techo, y a conocer la ciudad.

Es un relato típicamente cinematográfico. Joven provinciano llega a la gran ciudad con él ánimo de triunfar. Es como una película musical en la que en lugar de Fred Astaire el protagonista se compra una bata guateada [alcochoada] y unas pantuflas y actúa, con previo musical, ante la flor y nata de la modernidad. Cambian los decorados, los estilos, pero la historia es la misma. Incluso, en el caso de Pedro Almodóvar, la vida y el cine coinciden en un final feliz: el joven pueblerino triunfa.

- Cuando llegué me di cuenta de que lo de continuar los estudios iba a ser más difícil. Me fui a la plaza de Santa Ana - hablo del año 1967 - comencé a hacer abalorios, collares y toda la parafernalia hippy, que cubrí escrupulosamente hasta el detalle de irme a Ibiza. Un año después lo superé porque ya me aburría, buscaba algo más sofisticado.

- Y conecta ya con el grupo teatral Los Goliardos ? ${ }^{234}$

- Sí, simultaneamente conecto con los Goliardos y impiezo a trabajar en la Telefónica, porque hice unas oposiciones [provas para concurso] a auxiliar administrativo y me aprobaron. Bueno, la verdad es que la entrada en la Telefónica fue muy aparatosa [exagerada, escandalosa]. Yo llevava el pelo larguísimo [cabelo muito comprido] y para las fotos y lo metí debajo de la camisa. Cuando me aprobaron y fui apresentarme, me desmelené [soltei os cabelos] y al jefe de negociado le dio un ataque y dijo que no admitía a nadie así. Llequé al puesto de trabajo y me di cuenta de que ocurría algo raro porque no me adjudicaron ninguna mesa, sino que me sentaron en una especie de sala de espera. Luego me enteré de que se habían reunido todos los jefes de negociado de la planta para decidir qué hacían conmigo, porque no me podían echar sin haberme dejado trabajar, y el jefe que me había correspondido se negaba a que trabajaba con él. Afortunadamente, hubo un jefe que era algo más moderno y dijo que bueno, que me llevaba con él. A la vez que comenzaba a trabajar en la Telefónica conocí a una serie de personas, como Félix Rotaeta, que me puso en contacto con Los Goliardos cuando el grupo ya estaba un poco de capa caída [em decadência]. Trabajé en algunos montajes, como un Don Juan que no se

${ }^{234}$ O sentido da palavra "goliardos" é interessante, sobretudo se pensado no contexto dos anos 70, quando a Espanha ainda vivia sob o regime franquista. Um termo bastante irreverente e provocador: dado à gula e à vida desordenada; seguidor do vício e do demônio personificado no gigante bíblico Golias. Na Idade Média, também significando clérigo ou estudante vagabundo que levava uma vida irregular, devassa. 
A entrevista começa com uma provocação ao caráter polêmico do diretor, ele "ataca" novamente. Logo após, busca-se direcionar a linha do filme para os interesses dos que já o popularizaram e ele defende sua mudança de narrativa. A crítica direciona-se para a baixa qualidade técnica dos filmes do diretor na época, mas compensa seu perfil pessoal com o discurso moral de trabalhador incansável e seu autodidatismo. Seu conhecimento estético e consciência de sua posição polêmica ainda não são significativos o bastante para justificar seu sucesso, nem seus contatos no meio cinematográfico. Ao contrário, este é atribuído apenas à alta bilheteria dos filmes.

A antipatia da crítica é ressaltada para que não haja dúvidas sobre a diferença entre popularidade e qualidade. Almodóvar rebate mostrando consciência sobre o fato das rejeições intelectuais que possui e recorre ao seu caráter especial que desde a infância justifica suas atitudes - polêmico, excêntrico e estudioso. A auto-construção está em processo. O entrevistador cede, entra no universo do discurso do diretor e compara sua vida à história de um filme, encarregando-se, nesse momento, de confeccionar uma parte de sua mitificação: um rapaz pobre, mas um lutador que triunfa.

O diretor ainda acentua sua trajetória numa mescla de buscas alternativas para sobreviver e tentativa de vencer dentro do que almeja. Não há uma fidelidade específica à Madrid como fonte de sua inspiração, a exemplo do que aparece depois nas declarações sobre as filmagens, como apresentado no capítulo anterior. Novamente acrescentam-se detalhes à imagem de sua excentricidade ao serem descritas as situações sobre sua entrada no teatro e na Telefonica.

A frase inicial que o colocava num lugar de ofensiva resume o tom pelo qual tanto a imprensa tratava o cineasta como este se apresentava publicamente. Uma soma de ironia e agressividade que se transformou num hábito comum. Várias outras manchetes seguiam no mesmo sentido provocativo, enquanto outras o louvavam ao patamar de gênio. Um jogo que na verdade corresponde à própria forma como Almodóvar divulgou sua imagem durante vários anos, e que lhe garantiu seu marketing pessoal:

'La sombra culpable de Corral [quintal] de Calatrava - carta abierta a Pedro Almodóvar' (Cartelera Turia - 12. 11. 1984)

'Un chiquito como yo, que viene de familia humilde' (El pais semanal - 28. 09. 1986).

${ }^{235}$ HARGUINDEY, 30. set. 1984, p. 8-9. 
'Pedro Almodóvar, entre el fervor popular: hago el cine que me sale de las vísceras' (Cartelera Turia - 25. 04. 1988)

'El hombre del año - Pedro Almodóvar, el ingenioso manchego' (Cambio 16, nº 895 - 23. 01. 1989)

' El manchego duro que encanto Hollywood ' [sobre a conquista de mercado com Mujeres al borde de un ataque de nervios nos Estados Unidos e as expectativas do Óscar] (El Periodico - 27. 01. 1989)

El héroe gordito ataca de nuevo: a punto de cumplir los 40 , ha pasado de marginal que curra [trabalha] en la Telefónica a heróe de la mitología nacional. Todos le pretenden y le aplauden. Incluso aquéllos que le negaban el pan y la sal le obsequian ahora com falsas alabanzas que no han hecho mella [não fizeram efeito] ni em su personalidad ni em su obra. El establishment no le ha devorado, aunque admite que algún día puede caer em sus garras ... (El Periodico - 21. 05. 1989).

Mucha Movida - Almodóvar, oh: Es un personaje, ya no hay duda. Y controvertido al máximo por sus maneras. El mundo del cine se pregunta ahora mismo si se trata de un creador extraordinario o si es sólo un aspaviento [exagerado sentimental]. El desenlace no tardará demasiado en llegar (Vision 3 - maig, 1989)

"El mundo de Pedro Almodóvar ya no es un laberinto de pasiones: los protagonistas de la Movida madrileña dicen que 'Pedro ya no vive sus películas' (La Vanguardia - 27. 08. 1989, p. 49)

"Pedro Almodóvar: Estic condemnat a l'escàndol [estou condenado ao escândalo] (Diari de Barcelona - 02. 03. 1992) [sobre um incidente ocorrido num programa de entrevistas do Canal 5 italiano entre o apresentador Maurizio Costanzo e um espectador que abriu um debate paralelo quando Almodóvar discutia seu filme Tacones Lejanos e o livro "Patty Diphusa". Na ocasião, o apresentador do programa afirmou que só a presença do diretor já criava um clima particular para a polêmica, comentário que ele reconheceu verossímil comentando que percebia desde sua infância a polêmica e o grotesco perseguindo-o]

Soy un producto de la democracia (El Periodico - 07. 11. 1993)

Es un genio? O es todo montaje? [antes de estrear Kika, um fracasso diante da crítica nacional] (El pais semanal - 17. 10. 1993)

"Almodóvar arranca tímidos aplausos" [na apresentação do filme La flor de mi secreto, fora da competição no Festival Internacional de Cinema de San Sebastián. E dentro da mesma matéria a chamada de um apontamento de um jornalista sublinha: El genio sigue vivo] (El Periodico - 19. 09. 1995)

Almodóvar redescubre sus orígenes manchegos en su nueva película / De La mancha a las estrellas (El País - 19. 09. 1995) [ sobre o filme La flor de mi secreto]

Almodóvar, em 'La noche temática': El triunfo de un manchego internacional (El País - 24. 03. 2000) $)^{236}$

Este quadro possibilita visualizar algumas construções sociais e artísticas sobre o autor que se relacionam com os trechos da entrevista anterior: as origens rústicas, incluindo a família humilde, impulsividade e intuição, que justificam seus comportamentos polêmicos e sua forma agressiva de comunicação. O pouco tato com o universo cinematográfico evidencia-se na produção ainda mal-acabada do período inicial e no reduzido contato com os círculos envolvidos nesse ramo - como, por exemplo, produtores - devido à sua trajetória fora dos meios clássicos de formação universitária. Este último interpretado pela imprensa como uma característica própria do diretor em não ceder a grupos hegemônicos, mantendo-se popular. Um olhar simplista, mas que revela uma postura sempre notória do diretor em manter - 
realmente - o apoio do público como fonte de seu sucesso. Também se evidencia as dúvidas: se é um cineasta original ou uma construção da moda, que por isso logo desaparecerá.

\subsection{Autodidata e popular - ônus conflitivo}

O autodidatismo do diretor, na verdade, foi involuntário. Primeiro ocorreu por problemas econômicos - não teria dinheiro para pagar uma faculdade - e depois por questões políticas - a Escuela de Cine de Madrid havia sido fechada por Franco. Assim, todo seu processo de aprendizado resultou de suas buscas pessoais, visando conhecer a maior quantidade de filmes a que tivesse acesso, do estabelecimneto de contatos com profissionais do ramo, e da experiência direta em seus próprios trabalhos ao executar os trâmites financeiros e técnicos para realizá-los. Como que diante de uma côrte da realeza, onde a participação só ocorre a convite de um nobre, Almodóvar parecia invadir um espaço de excelência a cada novo trabalho. Ele trazia consigo a popularidade ou, então, a própria presença e a imagem do popular a um universo elitista que não estava habituado, nem queria apreciá-lo daquela forma.

Os clássicos cineastas espanhóis possuem suas próprias leituras sobre grupos populares em suas películas. Em geral estes são associados a imagens folclóricas como Placido (1961), de Berlanga, ou a grandes dramas onde incorporam a imagem de vítimas e a denúncia social, como Muerte de un ciclista (1955), de Bardem, e Los olvidados (1950), de Buñuel, este realizado no México. Talvez Berlanga e Bardem se aproximem um pouco mais de Almodóvar, porém a preocupação social e política os difere - Almodóvar não possui as intenções ideológicas desses diretores - e em geral suas histórias abordam o popular de forma ora romantizada ora caricata. Mesmo Fernán-Gómez, com o brilhante e inovador El extraño viaje (1964), circunscreve sua trama a uma cidadezinha de província.

Em Almodóvar todos estes códigos são revistos e reinterpretados. Não há vítimas no sentido classista. As personagens das classes populares atuam em igual relação de forças, aparecendo como protagonistas das histórias em todo o espaço urbano. Mesmo naquelas que revelam maior posição social e são centrais na ação dramática, verifica-se suas influências humildes como em Mujeres al borde de un ataque de nervios e La flor de mi secreto. Diante disso, a todo momento esta "côrte", formada por intelectuais e grande mídia, o adverte para que não se esqueça de suas origens antes que se veja fascinado pelo brilho de sua fachada.

${ }^{236}$ Grifos do autor 
Este grupo é seleto e reitera sempre sua distinção. Ser manchego será quase uma justificativa para segregar o diretor. Mas ele também transformará esse dado em sua trajetória numa arma de deboche e auto-afirmação para utilizar nos filmes ou nas entrevistas e conquistar mais simpatizantes na medida em que, gradualmente, conquista popularidade. A própria imprensa também retira seus dividendos no intuito de garantir-se popular, abrindo espaço para personalidades nesse perfil. Os atributos se assemelham: gênio manchego, herói, criador extraordinário. As controvérsias aguçam a curiosidade e a imagem de "polêmico" garante audiência: condenado ao escândalo, perseguido pela polêmica e pelo grotesco. Qualquer elemento que caracterize o diretor começa a fazer parte de um espetáculo - em geral, aguardado. Uma pessoa que não nega suas origens, ao contrário as expõe, e - segundo a disseminação de sua imagem - vence em razão delas: redescobre origens manchegas, triunfo de um manchego internacional.

No informativo sobre o programa La noche temática aparecem claramente todos estes elementos, inclusive os interesses - por audiência - dos jornais e suas redes:

F. Morales, Madrid. Pedro Almodóvar está viviendo su gran año. El realizador ha conseguido con Todo sobre mi madre lo que antes algunos le habían negado. Al reconocimiento unánime del público hay que sumarle el de la Academia de las Ciencias y Artes Cinematográficas, que por fin le ortogó el Goya al mejor director y a la mejor película, el del Festival de Cannes y su triunfo en los Globos de Oro. El broche perfecto [chave de ouro] puede llegar la próxima madrugada del domingo al lunes [segunda-feira] con la entrega de los Oscar. Todo estos triunfos le han convertido en el personaje español de actualidad. 'La noche temática', de La 2, quiere sumarse a la cantidad de homenajes que se le han tributado en estas fechas [datas] con un programa especial en el que se hace un repaso de la vida - desde sus orígenes manchegos hasta su triunfo em Hollywood, pasando por sus años como auxiliar administrativo en Telefónica - y obra del cineasta español más universal.[... $]^{237}$

O texto segue explicando como serão divididas as reportagens, fornecendo todo o histórico do cineasta, com um documentário de sua vida pessoal, a relação com a mãe, sua trajetória filmográfica, a exibição de um de seus filmes e sua fase de cantor apresentando músicas que gravou com Fabio MacNamara. Vê-se que a mudança de postura da crítica e da mídia não se restringe apenas às homenagens. Os termos de consagração, devido aos prêmios que proporcionaram visibilidade internacional ao diretor e conseqüentemente à Espanha, aparecem de maneira evidente: cineasta espanhol mais universal, personagem espanhol da atualidade.

O conjunto de atributos não compõe apenas elogios ao diretor. Refletem uma contribuição que beneficiou a própria mídia. Ele expandiu as fronteiras do país com

${ }^{237}$ EI País, Madrid, 24. set. 2000. (grifo do autor) 
suas imagens, flexibilizou mercados na área audiovisual que antes estiveram fechados não só no franquismo, mas na própria democratização, antes por questões essencialmente políticas, depois pela fragilidade econômica da própria indústria cultural espanhola.

Esta própria reportagem se deu às vésperas da entrega do Oscar - que agraciaria o diretor com o prêmio de melhor filme de língua não inglesa com Todo sobre mi madre -, evento que interessa mundialmente às redes de televisão, rádio e não público cinéfilo. Portanto, a preparação desse aparato de homenagens significava chegar na frente de outros jornais e emissoras. Assinala também a concorrência interna desses grupos e a conseqüente garantia de público. O texto chega ao exagero de afirmar que Almodóvar atinge o reconhecimento unânime - uma projeção decorrente do mito que orbita ao redor da indústria hollywodiana - até ser respeitado e premiado pela Academia de cinema espanhola

Revelar suas origens manchegas antes das aclamações - quando sua carreira se expandia - significava demarcação de terreno para the establishment, espaços a não serem invadidos por um diretor "marginal". Com sua fama, esta característica se transformou num símbolo de unificação nacional. A imagem do diretor como representante das classes populares que vence na metrópole e no mundo cinematográfico funcionaria como resgate do orgulho no país se não fosse a própria resistência do diretor aos rótulos ${ }^{238}$.

Um aspecto também discutível, pois em ocasiões oportunas algumas imagens que serviram para sua promoção acabaram permitidas ou incorporadas sob interpretação cômica por ele. Termos como: gordito ou el enfant terrible se difundiram como marcas familiares e íntimas entre diretor e público forjadas pela mídia. Boatos, posturas, descrição física. Nada escapa para este setor ocupado em vestir seu personagem à sua moda a fim de garantir a divulgação de suas notícias ou a audiência. Entre afetos e provocações, os aspectos pessoais observados, descritos e acentuados por seus comentadores ganham força e estabelecem os elos de mediação:

- Tiene una mata de pelo ensortijada y azabache [floresta de cabelo emaranhado, duro e negro] que, de niño, debió de ser la envidia [inveja] de muchas madres primorosas: ahí es nada, tener un hijo con semejante esplendor de rizos [cabelos rebeldes e enrolados] en el cráneo. Debajo de esta exuberancia capilar asoman dos ojos muy vivos y muy negros, una nariz carnosa, los labios gordezuelos. Más abajo encontramos una camisita de estampado moderno y unos pantalones vaqueros [calça jeans] muy discretos. Y si descendemos un poco más, en fin, llegamos en seguida al suelo, porque la estatura de Pedro Almodóvar es más bien breve. Eso sí, todo lo que tiene de bajito lo tiene asimismo de garboso: Almodóvar pícaro, Almodóvar carnal, coqueto [charmoso, galanteador] y sandunguero [gracioso], tan apetecible de

${ }^{238}$ GARCÍA DE LEÓN e MALDONATO, 1989, p. 204. 
abrazar y de sobar [apertar] como un buen oso de peluche [urso de pelúcia] ${ }^{239}$

- Se trata de un señor gordito y elocuente, ingenioso y parlanchín [tagarela], de nariz reluciente, boca contorsionista, ojos vivos, poca frente [testa] y mucho pelo [muito cabelo]. Gasta un aire de moro zumbón [mouro alegre] y zampabollos [comilão] con su pelo rizado [cabelo crespo], y sus rasgos [traços] conservan el sello [marca] infantil.Su aspecto general es una mezcla de osito de peluche [ursinho de pelúcia], cariñosón y suave, y de cantante melódico suramericano. En el ojo más reflexivo anida [habita] una hojarasca sexual [resquício sexual], una frondosa excitação. Predomina en toda la cara una languidez [debilidade] incontrolada y peligrosa, una humedad sentimental y visceral, combinada con rasgos de niño [menino] travieso y convencional con ganas [vontade] de hacer películas traviesas y convencionales, películas llenas [cheias] de purpurina y de espuma, coloreadas como brillantes tebeos [revistas infantis], como muñecos [bonecos] recortables, tintineantes [estridentes] películas con estribillos, nerviosas, desconyuntadas, bien marradas y con una estética a mil años luz de lo que se hace hoy aquí por estos pagos [estas redondezas]. La urdimbre [urdidura] ardiente de esta cara gordezuela lo constituye, lo mismo que la urdimbre de sus filmes $[\ldots]^{240}$

Tanto estes trechos como os citados anteriormente demonstram que mesmo seus simpatizantes articulam discursos situados entre ironias e elogios. Ao que tudo indica, foi a forma utilizada tanto pela imprensa como pela intelectualidade, que permitiu a entrada do diretor de origem popular no restrito círculo das estrelas. Ridicularização e sarcasmo ao acentuar seu físico: gordinho, baixinho, nariz largo, peludo, caricato; mas, por outro lado: charmoso, compenetrado, com estilo próprio, sensual, obstinado, lutador. Percebe-se a constante unificação entre perfil pessoal e profissional, entre autor e obra, a ponto de associar sua composição física exótica como uma justificativa idêntica ao tipo de filme que executa. São os contornos que o público recebe e que se vê induzido a observar na figura de Almodóvar.

Estigmatizando seu perfil, a mídia conseguiu dar forma mais evidnete do cineasta como um produto. Uma prática já tradicional na indústria hollywoodiana do cinema, ocorrida, por exemplo, com Steve Spilberg, que durante um grande período foi visto como diretor adolescente, ou com outras centenas de estrelas cinematográficas sobretudo as falecidas - que rendem milhões de dólares a esse mercado de imagens.

Hoje, o complexo de comunição de massa desenvolve suas estratégias mercadológicas em conjunto. Livros, filmes, revistas, roteiros, roupas, objetos de cena, miniaturas, trilhas musicais: toda essa produção só pode se movimentar tendo a publicidade, a imprensa e a TV aliadas ao cinema. O próprio Almodóvar já descobriu isso há tempos e ramificou sua produção cinematográfica em outros suportes: press books, roteiros dos filmes - em geral com vendas fabulosas que os esgotam rapidamente - e CDs com trilhas sonoras, todos vinculados à sua patente.

\footnotetext{
${ }^{239}$ MONTERO, Rosa. Entrevista com Pedro Almodóvar. EI pais semanal, Madrid, 28. set. 1986.

${ }^{240}$ MARSÉ, Juan. Señoras y señores. El País, Madrid, 30. 08. 1987, p. 24.
} 
Com o aumento da fama, também se ampliam as especulações a respeito do segredo de seu sucesso e as ofensivas. Quando colhia os resultados do primeiro grande sucesso mundial, Mujeres al borde de un ataque de nervios, novamente as perguntas voltavam-se para o âmbito pessoal, incidindo sobre sua forma de ser e de apresentar ao público:

- Dicen que usted es uma mezcla de persona afectuosa y morbosa.

- Morbosa?

- Que tiene unos atractivos atípicos. Que no es una persona convencional. [0 sentido da palavra também corresponde a uma pessoa que causa reações mentais moralmente insanas ou que é resultado delas, explicação mais embaraçosa não dita pelo jornalista].

- No soy una persona convencional y además el hecho de ser muy espontaneo es lo que me hace lo menos convencional del mundo. Todo el mundo tiene su propia moral. Incluso los malos, malos, malos, la tienen también. Nadie puede decir que eso es bueno y esto es malo, porque lo bueno y lo malo no existen. Si algo está malo lo digo claramente pero mi concepto de la moral no es el concepto de la moral tradicional. El ser humano desperdicia casi todo tiempo que tiene preocupado por si uno es homosexual y si entonces esto es bueno o es malo. Eso son bobadas porque los problemas esenciales son otros. $[\ldots]^{241}$

As construções que se efetuam são trabalhadas mutuamente: o entrevistador busca legitimar mais uma imagem sobre o diretor como atípico, exótico e insano. Por sua vez, Almodóvar - mesmo não compreendendo devidamente as insinuações do jornalista - defende-se, elaborando sua própria imagem de cineasta livre das regras sociais, espontâneo e não convencional. Manipula o sentido da palavra morboso, acrescentando seu significado e destruindo a malícia da pergunta, inclusive citando um exemplo sobre a homossexualidade que potencialmente está contida na indagação feita.

Entre os amigos que trabalham com ele, percebe-se pela própria descrição histórica de suas relações que o perfil pessoal do diretor já funcionava como uma marca registrada em sua trajetória em virtude de sua maneira de se apresentar publicamente. Esther García - ao lembrar a época quando o conheceu - sublinha este seu traço particular:

Supe de él [soube dele] en la faculdad. La gente hablaba de un tío listísimo [rapaz obstinado] que andaba por ahí haciendo unos cortos [uns curtas-metragens] tronchantes [engraçadíssimos], pero todo el mundo decía que él era aún más gracioso [que ele era ainda mais engraçado] que sus historias. Desde el principio, más que sus películas, el fenómeno fue el propio Pedro ${ }^{242}$.

Em seu estudo sobre o diretor, María Antonia Garcia de León observa que em outros cineastas nunca os aspectos pertinentes ao fator físico aparecem como

\footnotetext{
${ }^{241}$ MOJICA, Luis B.Entrevista com Pedro Almodóvar. La Vanguardia , Barcelona, 08. mai. 1988. p.12.

242`FERNÁNDEZ, Juan. Entrevista com Esther García. EI Periódico, Madrid, 19. mar. 2000. p. 24.
} 
significativos para suas carreiras. Nem são ressaltados nos noticiários como foco de discussão. Como seu viu, esse fenômeno ocorre sobre a figura de Almodóvar. Para a autora, isso se dá pelas próprias normas sociais que reagem implacavelmente diante de trajetórias "meteóricas" como a dele. Ele próprio faz essa leitura e compreende o comportamento desses profissionais que buscam encontrar maneiras constantes de falar da vida de pessoas famosas. Assim, as saídas estratégicas para enfrentar as ofensivas, em geral respostas bem-humoradas ou então desculpas de enfermidade para causar compaixão, só vieram ampliar o que havia criado anteriormente sobre si mesmo. $^{243}$

Aqui associo uma outra análise da autora que a mim melhor justifica, de uma maneira causal e complementar, este tratamento distintivo diante daqueles que chegam à fama muito rapidamente. Ela recai sobre a classe social. Pedro Almodóvar se distancia bastante da tradição dos diretores espanhóis cuja origem provém de maioria universitária, com vários membros provenientes da elite ou com antecedentes artísticos na família e donos de suas próprias produtoras.

Sua trajetória artística resultante de experiências em diversos ramos de manifestações culturais oriundas do underground, sua ascensão vertiginosa e triunfante de cineasta nacional e internacional também o tornam distinto diante de sua origem popular. Isso não é visto como natural para grupos habituados a legitimar outros perfis, em geral com vinculações sociais muito próximas a eles. O conteúdo dos trabalhos dos cineastas mais consagrados ou conhecidos demonstra as classes a que pertencem e as temáticas que os preocupa. Dos mais politizados ao mais cotidianos firmam-se modelos de personagens e reflexões que ainda contemporaneamente destoam da lógica cinematográfica de Almodóvar ${ }^{244}$.

Num universo cultural já habituado em manusear regras e códigos de classes equivalentes, possuir alguém exterior ao seu círculo de relações significa estabelecer novas regras para incorporar ou não as novidades e, conseqüentemente, a própria pessoa. Não é preciso analisar muito para constatar o que representa um cineasta com o perfil popular de Almodóvar, já definido pelo comportamento como alguém que não abriria mão de sua linguagem e de sua mensagem. O termo cunhado durante muito tempo pela mídia, de enfant terrible ou menino travesso, reflete a dinâmica dessas relações.

O desenvolvimento desse fluxo oscilante contínuo de rejeição, inveja, admiração, reconhecimento e até perplexidade delineou uma luta sem tréguas entre o

${ }^{243}$ GARCIA DE LEÓN,e MALDONATO, 1989. p. 70-71. 
diretor e seu ambiente profissional. Esses comportamentos permeiam as atitudes dos integrantes que compõem o establishment cinematográfico e social, formado por grupos que, ao se auto-denominarem juízes de uma cultura legítima, outorgam-se o direito de qualificar o que é ou não cinema.

No período em que a Espanha - em sua abertura - precisava de uma imagem externa que pudesse mostrar suas mudanças, Almodóvar não era o bom exemplo do que a crítica queria apresentar para o mundo. Entretanto, por mais paradoxal que possa parecer, foi justamente essa imagem que agradou o restante da Europa e outros países, que viam através de Almodóvar uma Espanha despojada e aberta para as mudanças. Passados os anos e dada sua consagração, as ironias e o humor ainda permanecem. Porém, como a Espanha retornou ao cenário cultural mundial do cinema por intermédio de seu trabalho - num patamar só antes conquistado por Luis Buñuel e em menor escala por Carlos Saura - existem e se multiplicam os interesses ao redor de sua imagem.

Com sua prática de aproveitar tudo o que lhe acontece para compor suas histórias, esse aspecto também não foi desperdiçado. Em Tacone lejanos o diretor faz uma primeira incursão irônica à imprensa colocando-a como protagonista em seus personagens. Depois Kika aciona uma onda demolidora contra o sensacionalismo durante toda narrativa, e Hable con ella e Volver desmascaram os programas de entrevistas com suas perguntas e respostas combinadas que constrangem os entrevistados.

Verifica-se, nesse contexo, que nem fama, nem dinheiro. Nada retirará dele sua marca de origem popular e o que ela representa na escala da hierarquia social. Nem o fato de ser melhor tratado pela mídia o impede de exteriorizar suas ironias e críticas. Em resposta ao diretor, o duelo continua. O respeito conquistado pela trajetória de sua obra no país não é forte o suficiente para mudar as posturas que sempre o surpreendem com gracejos. Ora diante de uma imprensa que constrói falsas intimidades entre autor e público, ora nos círculos que possuem poder para legitimar uma forma diferente do que julgam cultura e resistem ao seu perfil, o cineasta continua seu trabalho. Os constrangimentos em aceitar no rol dos eleitos pessoas oriundas das classes populares continuam na reprodução de regras e piadas. Porém, já compreendendo o funcionamento dessas estruturas, Almodóvar também se apropria, quando lhe convém, de aspectos das imagens implantadas sobre ele e rebate o que sente agredi-lo: 
No utilizaré el César contra nadie [ninguém] [...] En España no me hacen falta los premios y no guardo ningún rencor a nadie por no dármelos, y menos a la Academia. El mejor premio que ha recibido mi filme en España han sido los 850 millones [512.048 euros] de pesetas que recaudó" [...] los franceses normalmente son unos hijos de puta, pero una vez que se entregan a tí lo hacen para toda vida ${ }^{245}$ [declarações feitas por Almodóvar numa festa que organizou para comemorar o "César" - o "Oscar" da Academia de cinema francês - por seu filme Tacones lejanos]

Ao que parecia uma manifestação de modéstia e auto-suficiência - não deixando por menos -, a imprensa espanhola rebateu o argumento na mesma matéria, utilizando-se de observações sobre atitudes do diretor e de um outro de seus pronunciamentos:

Relativa humildad - al filo de las 9 de la noche el grupo 'diabéticas aceleradas' subió al escenario de una céntrica discoteca regentada por Alaska para interpretar una de las canciones de Tacones lejanos. Después, una pantalla [tela] reprodujo el momento en el que la Academia francesa entregaba el César a la mejor película extranjera a Tacones lejanos. El director aprovechó esta imagen para aparecer con el César en la mano, un galardón [prêmio] por el que competían Woody Allen, James Ivory y Jacques Annoud. 'No me considero superior a nadie, bueno quizá mejor que Annaud sí, pero tampoco voy a pecar de humildad' ${ }^{246}$.

Mantêm-se o jogo de forças que mistura afetos, defesas de grupos e valorização de méritos. Almodóvar apóia-se no público que dá bilheteria, em sua popularidade. A imprensa, ao "flagrar" sua atitude contraditória, alia-se - discretamente com seu discurso - ao lado das atitudes da Academia de cinema. Porém, em momentos posteriores, até isso Almodóvar acabou substituindo: nas construções elaboradas e incorporadas sobre ele no passado, sobrepôs com mais refinamento: de cineasta polêmico e escandoloso, para criador de argumentos ágeis e geniais, ou seja, de uma inteligência aguçada.

Diante do cineasta maduro, ainda existe uma busca por sustentar nele a imagem anterior e também por provocar no público esse desejo. No entanto, o que resta foi diluído na irreverência sutil do presente e em abordagens e projetos mais pessoais. Existe ainda um certo grupo intelectual simpatizante nostálgico que prefere celebrar o Almodóvar da fase descontraída e outro atento para fazer alguma depreciação de seus trabalhos no sentido de relegar a ele seu lugar de reconhecimento artístico.

Porém, como se movimentam nesse campo outras forças de valores equivalentes, enaltecendo suas realizações mais recentes ou rebatendo as visões negativas, permanece a falta de consenso e as situações desconfortáveis. Fatores que acabam dando mais visibilidade ao diretor, que transita entre as discussões

${ }^{245}$ MONTERO, Manuel. El Periodico, Madrid, 11. mar. 1993. 
representando seu papel de polêmico sério e irônico, imprevisível e implacável. Imagens tão encarnadas em suas atitudes que fica difícil saber onde começa e onde acaba a personalidade pura ${ }^{247}$ e a representação ou marketing pessoal. Em paralelo, a imprensa permanece construindo seus estereótipos e seu jogo de atrações, elaborando a caricatura cômica dos traços físicos e das atitudes do diretor.

Os membros da imprensa demonstram sentir-se confortáveis e livres para dizer o que querem, como se respondessem naturalmente - ainda que nem pronunciados a argumentos provocativos do próprio diretor provenientes do comportamento adotado por ele em seus filmes e diante da mídia. Elabora-se assim um fluxo de invasões de limites num acordo tácito de intimidades - em verdade nunca estabelecido oficialmente - que se transforma num agressivo e bem humorado jogo de forças que acaba revelando traços - nem sempre fiéis - da personalidade e da vida do diretor: sua irreverência, sua disciplina e indisciplina, sua paciência e austeridade, sua relação com a fama, com os amigos, atores e atrizes e, nas entrelinhas, suas origens.

As saídas bem-humoradas de Almodóvar às perguntas embaraçosas de seus entrevistadores, misturando seu perfil de criador, de defensor do ideal do prazer com idéias otimistas e inusitadas, já se transformaram num espetáculo único e esperado. Sem perder de vista o jogo de forças constantemente em campo, é importante observar o misto de admiração, provocação e revelação da vida do diretor que é tecido a cada conversa.

Na entrevista intitulada "Un chiquito como yo", em 1986, após descrever o perfil físico do diretor, a jornalista fala de seu apartamento, comparando-o a um ninho desorganizado onde se amontoam os resíduos cinematográficos de suas películas e um "armazém" de papéis e livros empilhados em estantes modulares:

Pocas veces he visto un entorno doméstico tan indiferente y descuidado. Almodóvar, siempre tan pinturero [elegante] en su vestir, mantiene, sin embargo, en su vivir un despego de nómada [nômade]. $\mathrm{O}$ de progre antiguo [moderninho ultrapassado]. O de maldito marginal.

- Usted suele repetir que es un amante del placer, pero ésta es la casa menos hedonista que conozco; es un entorno que carece por completo de placer.

- Bueno, carece de placer por la decoración. Pero yo he gozado mucho en esta casa, incluso en ese mismo sofá en el que estás sentada. [logo após esta colocação sarcástica, o diretor segue um rumo sério na conversa e delineia sua forma de relação com sua privacidade e amizade, permeada com seu ritmo de trabalho]. Lo que pasa es que realmente no paro aquí, y yo no sé si eso va a ser ya mi vida, y eso me preocupa. Pero la verdad es que no he tenido tiempo.

- No estás usted en casa normalmente.

- No. O sí, estoy mucho; pero la verdad es que cuando estoy en casa, o estoy trabajando, o leyendo, o durmiendo. No recibo en casa, por ejemplo.

\footnotetext{
${ }^{246}$ Idem.

${ }^{247}$ GARCIA DE LEÓN e MALDONATO, 1989, p. 68.
} 
- Y eso?

- Pués no sé, porque soy poco hospitalario. Cuando quiero relacionarme con amigos voy a sus casas o a un lugar público; pero ellos no vienen nunca a mi casa, no me gusta que vengan, y ellos lo saben, de modo que me llaman por teléfono. Y además es que no tengo tiempo. Sobre todo, es que no tengo tiempo. [...] [isso se reforça na medida em que constata seu descaso com sua residência e o que se verá mais adiante quando fala da presença do trabalho em sua vida]

- No soy nada organizado, en realidad. Y lo que ocurre es que ya me he acostumbrado a abstraerme de todo esto y a leer y escribir por encima de este desastre sin enterarme. Es que no tengo tiempo.

Repite y repite Almodóvar su letania sobre la falta de tiempo, una salmodia [ladainha] que es más histérica que quejumbrosa [uma queixa]. O sea, no es que se lamente, sino que lo dice como quien define un hecho consumado: la vida es así para él, un puro vértigo. Una aceleración continua, un trote peleón [ritmo que não se pode dar conta], uma hiperactividad que se manifiesta también en su mod de hablar, a tantas palabras por minuto, que resulta asombroso que le dé tiempo a respirar entre dos sílabas [...]

- El trabajo se ha convertido en mi vida; vivo también otras cosas, vivo todas las parcelas que un ser humano necesita, pero lo cierto es que últimamente estoy más pendiente del trabajo que de otra cosa. Es que se ha creado en mí una especie de segunda naturaleza, en la cual las cosas no sólo son dignas de ser vividas porque las estás registrando. Me estoy especializando en desarrollar todo lo que hay de insuficiente en la vida; te decía antes que la realidad siempre es inferior a los sueños. Pero esto, lejos de amuermarme [longe de aborrecer-me], se convierte en el primer material con que trabajo."248

O jogo de falsas intimidades fabricado entre a imprensa e o diretor permanece de uma forma que ele acaba revelando aspectos de sua vida. Porém, essa elaboração só vem reforçar suas imagens anteriores. A essa época pertence o filme Matador, portanto ainda Almodóvar não era conhecido nos grandes mercados cinematográficos internacionais e até então se firmando entre a crítica interna. Vê-se que, enquanto a jornalista deprecia a organização íntima do cineasta frente à sua imagem de elegante, ele reafirma a construção, mas a justifica de maneira nobre para a sociedade. É a falta de tempo - devido a seu trabalho excessivo e sua criação - que não lhe permite ocupar-se com "coisas" rotineiras. Sua casa também funciona como espaço de trabalho, por isso nem os amigos o visitam.

Assim, ele cria uma imagem pública cada vez mais excêntrica - verdadeira, mas exagerada - de mostrar como se relaciona com a vida. Tanto que até com relação a ela diz ter gerado uma segunda natureza dentro de si que o faz transformar suas observações em arte, antes que Ihe aborreçam. Esses argumentos tornam-se imbatíveis e tudo o que está ao redor justifica essa "grandeza" dos esforços: sua tagarelice, a vida atordoada, a falta de tempo, a casa desorganizada. Viver e registrar tornaram-se mais importantes, pois são seu trabalho. Numa sociedade baseada moralmente nesse ethos, ninguém que o cumpre pode ser derrubado. Ao contrário,

${ }^{248}$ MONTERO, 28. set. 1986. p. 22-23. 
deve servir de exemplo.

Depois de Matador (1985-1986), Almodóvar torna-se campeão de bilheteria na Espanha. Mas os elogios foram em geral centrados na técnica e não na história corrosiva do toureiro e sua relação com a cultura da morte e do machismo difundidas miticamente. Nota-se que enquanto Almodóvar não ganhou público com recordes de bilheteria os críticos se viam mais à vontade para dispor de suas opiniões - em geral depreciativas.

Com o sucesso, isso se modifica e as críticas ficam mais retraídas. Vislumbram-se interesses de mercado que induzem os comentaristas a declarações mais comedidas. Os próprios críticos percebem seu pequeno prestígio e a falta de interesse popular. Articulistas que antes criticavam negativamente Almodovar modificaram suas posições radicalmente. Acima do apoio dos críticos - como ocorria nos trabalhos de Erice ou Gutiérrez Aragón -, o diretor desenvolveu sua carreira à margem da crítica espanhola ${ }^{249}$, e as imagens criadas sobre ele - favoráveis ou não tornaram-se muito menores diante de seus projetos. Não por acaso - em diversas ocasiões - ele declarou que lhe interessava a crítica do público e esta aparecia nas bilheterias. Um retorno praticamente de desprezo à crítica, sugerindo uma total desavença.

Afortunadamente para ele - como não existe unanimidade em nenhuma esfera da sociedade - também no meio acadêmico o diretor possui seus estudiosos e simpatizantes. Na abertura do Primeiro Congresso Internacional "Pedro Almodóvar", realizado na Universidade Castilla-La Mancha, na cidade de Cuenca, no final de novembro de 2003, o vice-reitor e de extensão universitária José Ignacio Albentosa fez uma apresentação que agrupa sinteticamente valores, contribuindo com mais um elemento - agora com a respeitabilidade acadêmica - para legitimar construções míticas e fortalecer o prestígio do autor:

[...] en el año en que celebramos la efeméride del Cuarto Centenário de la primera edición de la obra que tiene por protagonista a nuestro manchego más universal, D. Quijote [note-se: a primeira edição foi lançada em dezembro de 1604 e muitas fontes oficiais datam-na de 1605], sirva esta publicación, que la Universidad de Castilla-La Mancha pone en manos de los amantes y estudiosos del cine contemporáneo español, como testimonio de que la persona y la creación de otro manchego universal, Pedro Almodóvar, despierta un profundo interés en el ámbito académico y en universidades de todo el mundo. ${ }^{250}$

\footnotetext{
${ }^{249}$ Idem, p. 201-203.

250 ALBENTOSA, José Ignacio. Pedro Almodóvar: el cine como pasión, Cuenca: Ediciones de la Universidad de Castilla-La Mancha, 2005. p. 13-14.
} 
Associando-se o aniversário de 400 anos do lançamento do romance Dom Quixote ao congresso sobre Almodóvar, o diretor ganha também um novo status quo e Cervantes se atualiza. A memória reavivada de Quixote no evento unifica as homenagens e ao mesmo tempo fortalece a imagem da região como geradora de personalidades. O ano de 2003 apresentou um Almodóvar premiado e respeitado internacionalmente, distinto das entrevistas anteriores em que estava se afirmando. Mas as divergências continuam. Em diversas delas a ênfase ao fato do diretor ser manchego, por exemplo, não desaparece. Existiria alguma relação? La Mancha impulsionou a carreira do cineasta? Que informações relevantes contêm esse dado?

\subsection{Ter nascido em La Mancha - um acaso sem predestinações}

São várias as especulações que procuram entender a ascensão de Almodóvar desde seu aparecimento no cinema comercial. Não eram poucos os críticos que, celebrantes da metrópole como único modelo de vida contemporânea - aparentemente esvaziada de valores herdados de tradições rurais -, reagiam de maneira negativa à mescla cultural irônica contida nos comportamentos urbanos das personagens dos filmes do diretor. Era nítida a surpresa que demonstravam diante de sua compreensão e capacidade de manusear elementos que traduziam a vida de Madrid:

como este chico manchego, de pueblo, rural, puede 'controlar' tan bien y ser tan 'in' y el más moderno de los modernos de la cultura urbana? ${ }^{251}$

Desde la sociologia se sabe que las élites, cualquiera que sea su esfera de poder (económico, político, cultural, social ...) son eminentemente urbanas. Y, en el caso concreto de los diretores de cine español, el $50 \%$ han nacido en Madrid o Barcelona ${ }^{252}$

Os dados sobre a porcentagem dos cineastas espanhóis, retirados da consulta biográfica de Who is who in Spain, de 1987, e da obra coletiva Cine Español, 18961983, do Ministério de Cultura de 1984, apontavam até estas datas apenas um manchego: Almodóvar ${ }^{253}$. Aqui, aparecem as primeiras insinuações apresentadas em dados e pela crítica de um provável fio condutor interpretativo da ascensão deste cineasta, focado num possível mistério regional de alguém que traz consigo um aparato cultural diferenciado e, por isso, rico em informações. Mas o simples fato da localidade de nascimento, em si, não indica maior ou menor mérito para um artista. Esta informação pode facilmente se transformar numa primeira armadilha mitológica tecida pelos próprios críticos.

As origens sociais de classe possuem um peso muito mais notório e

\footnotetext{
${ }^{251}$ GARCIA DE LEÓN e MALDONATO, 1989, p. 30.

252 Idem, apud. p. 31.

253 Idem, p. 31.
} 
determinante nos resultados do trabalho de qualquer pessoa do que o ambiente geográfico que a rodeia. O espaço só ganha sentido e gera algum efeito sobre os indivíduos quando inserido na lógica das relações socias construídas sobre ele e principalmente dentro de uma trajetória contínua que revela os múltiplos acontecimentos que dialogam com seus limites. No caso de Almodóvar, suas origens não dizem respeito somente ao meio rural onde viveu até seus oito anos de idade. Assim, antes de entrar ingenuamente no jogo de idéias pré-concebidas, creio ser mais prudente fazer um exercício de compreensão das entrelinhas dos discursos. Lugares onde se localizam intenções e se desenvolvem projeções, tanto sociais como pessoais, do autor e dos grupos que o circundam na área profissional que o insere.

A exploração da imagem de ser de La Mancha - e não apenas ter passado o início de sua infância na terra natal - concentrou ao redor do diretor o resgate de mitos já estabelecidos na região encarnados na figura de Miguel de Cervantes Saavedra e permitiu que as comparações se multiplicassem. O título de "el ingenioso manchego", no artigo da revista Cambio 16 e que faz referência direta ao livro "O engenhoso fidalgo D. Quixote de La Mancha" publicado em $1604^{254}$, se encarrega de associar os dois artistas pela chave de leitura da fama mundial :

Desde la época del Ingenioso Hidalgo, ningún manchego había sido tan universal como el autor de Mujeres al borde de un ataque de nervios ${ }^{255}$

E a chamada do El Periodico com dois atributos que realçam duas imagens da mesma personalidade: El héroe gordito ataca de nuevo (o polêmico caricato, com um Sancho Pança) e heróe de la mitología nacional (grifo do autor) não deixam margem de dúvida de que existe uma necessidade provocada pela imprensa de dar visibilidade e notoriedade ao cineasta, forjando aproximações. Uma delas é o fato de ser manchego, como Cervantes. Uma comparação que já se constitui por ela mesma um modo de alimentar ou atualizar mitos. Por analogia, nessa construção o diretor se encaixa no perfil do próprio Dom Quixote. Um personagem que sai de sua terra e encontra, conhece e conquista novos territórios, se defronta com desafios e os vence motivado por sua fabulosa imaginação e ironia diante de seu tempo. Uma projeção bem recorrente que parece ter sido, inclusive, incorporada pelo próprio Almodóvar no decorrer de sua carreira. Porém, fadada ao descrédito em razão da própria trajetória pessoal e produção artística distintas de ambos.

Como já apontado, os mitos não designam somente pessoas. Eles também

\footnotetext{
${ }^{254}$ NERLICH, Michael. In BRICOUT, Bernadette (org.). O olhar de Orfeu. São Paulo: Cia das letras, 2003. p. 123.

${ }^{255}$ BAYÓN, Miguel. El hombre del año - Pedro Almodóvar, el ingenioso manchego. Cambio 16 - especial, $\mathrm{n}^{\circ}$ 895, Madrid, 23. jan. 1989, p. 56.
} 
dizem respeito a fatos históricos, objetos e lugares. Segundo os títulos das entrevistas e artigos, ser manchego implica carregar todos os elementos culturais que a região hipoteticamente - transmite a seus descendentes. La Mancha é um desses espaços propícios à expansão do imaginário. Geográfica e culturalmente discriminada por sua aridez, La Mancha - do árabe "terra seca" -, tradicional região de passagem que na Idade Média servia de caminho para mouros e cristãos em função da guerra ${ }^{256}$, até hoje concentra a imagem de local estéril. Lugar de pouca rentabilidade econômica, território de comportamentos regionais e comunitários, vastos campos que se perdem de vista e que aguçam a imaginação. Bem diferentes e distantes dos espaços adensados urbanos e das relações impessoais modernas das grandes cidades nas zonas centrais.

Almodóvar busca justificar sua inspiração nessa origem mítica ao explicar seu processo criativo. Quando realizou La flor de mi secreto (1995) este aspecto regional se realçou em razão da própria narrativa que levava as personagens ao espaço do campo. No filme, o contraponto da formação familiar é direto, mas possui seus limites no desfecho da história:

[...] después de hacer la película descubrí que yo también pertenecía a aquellas tierras, aunque haya dejado de ir por allí y toda mi vida represente justo lo contrario de lo que debe ser un manchego ortodoxo. Las calles blancas de estos pueblos, las casas encaladas, me conmueven mucho - son las primeras que vi en mi vida, y el campo manchego siempre me ha impresionado, es uma inmensidad de tierra rojiza [avermelhada] y llana [plana] que se une al cielo en el horizonte, sin ninguna línea de ruptura. Por eso son tan imaginativos los artistas de La Mancha, tienen que inventar figuras que pueblen [povoem] este espacio vacío. $[\ldots]^{257}$

O discurso romantizado do diretor já indica sua tendência a mitificar a região. Primeiro reconhece que sua referência é nostálgica e por isso ele não possui o perfil do manchego tradicional, ao contrário, segue o oposto de seu modelo. Depois, remete-se à geografia para justificar a capacidade criativa do artista manchego. Com isso o diretor faz um contínuo movimento de negação e afirmação sobre o que interpreta como pertinente a si próprio.

Aliando-se seu comentário à mídia, cria-se a possibilidade de um grande investimento - mesmo que inconsciente - a favor da difusão de imagens estereotipadas ou idealizadas que favorecem o diálogo com outras produções culturais já existentes e crenças estratificadas. O mito da fonte vital, dos valores ainda não impregnados e corrompidos pelas grandes cidades, se mantém. São para regiões como estas que os moradores cosmopolitas acorrem quando se saturam das

\footnotetext{
${ }^{256}$ GARCIA DE LEÓN e MALDONATO, 1989, p. 30.

257 STRAUSS, 2001. p. 144.
} 
metrópoles. Basta verificar as férias de verão espanholas. Madrid se torna uma cidade semi-deserta e seus habitantes viajam aos pueblos em busca de uma paz mítica que sintetiza estes diversos valores em via de extinção. Uma inspiração justificada por Almodóvar.

Nesse contexto, os personagens históricos de La Mancha também acabam servindo a diversos interesses diante daqueles que se apropriam e instrumentalizam suas imagens. Assim, ao ligarem passado e presente - mesmo demonstrando características díspares - eles são utilizados e comparados a serviço da reprodução de valores que sustentam a lógica de relações de cada sociedade.

Cervantes, por exemplo, tem sua legitimidade dentro do significado cultural de La Mancha porque a registra como elemento chave para o desenvolvimento de sua obra em torno da crítica à Idade Média por meio da cavalaria. Com seu livro mais famoso, inaugurou a partir daquela região - como eixo narrativo - uma nova literatura para a cultura moderna ${ }^{258}$ e difundiu gradativamente a Espanha para o mundo. A história que conta reflete sua trajetória dentro de uma estrutura de escrita inovadora para o período que, ao ironizar a literatura de cavalaria - tão admirada por seus contemporâneos -, inaugura uma literatura inédita até então.

Sua narrativa aventureira encarna numa mesma personagem e em seu acompanhante a possibilidade de ambos exercerem uma atitude realista e imaginária, ridicularizando a nobreza espanhola. Simultaneamente, explora e descobre dentro daquela sociedade a capacidade humana de criar e suportar seu próprio universo. Ainda que para isso se pague o preço da incompreensão social fixada na contradição entre loucura e virtude no caráter do herói. ${ }^{259} \mathrm{Na}$ verdade, Cervantes apresenta na junção de dois personagens complementares - Quixote/Sancho - a contradição da sociedade de seu tempo. Qual dos dois mundos se encanta e se desencanta ?

Não é o caso de Almodóvar. Ao reciclar linguagens, tanto na esfera narrativoliterária do grotesco, esperpêntico e melodrama, como cinematográfica, sob referências a diversos cineastas, ele revê e ironiza comportamentos que revelam vínculos na relação campo-cidade. Com eles, elabora significados de recepção que incidem sobre o sentido moral e dinâmico de seu momento histórico-cultural. No entanto, não cria uma novidade que rompe radicalmente com o passado. Por mais chocantes e divertidas que tenham sido suas primeiras películas, elas já estavam projetadas para um público amplo, aberto e desejoso de ver nas telas certas surpresas que já presenciava nas próprias relações cotidianas. Seus trabalhos fazem uma releitura da

\footnotetext{
${ }^{258}$ NERLICH. In BRICOUT (org.), 2003. p. 132-133.
} 
tradição, não sua negação, nem rompimento com ela.

Sua trajetória cinematográfica revela registros de imagens traduzidas numa relação de experiência urbana que flui no dia-a-dia, não rural. Este, quando surge, reforça as ironias e está disposto num plano complementar da narrativa. Aparece como resíduo cultural presente, mas não determinante. Além disso, não existe afrontamentos diretos que questionem a estrutura do poder, apenas citações que não movem o eixo das ações dramáticas.

Ainda que depois de La flor de mi secreto comece a haver uma recorrência ao pueblo de forma afetiva à relação materna ou a laços de cumplicidade que também remetem ao campo (Hable con ella - 2002), passando por questões auto-biográficas que também fazem referência a pueblos (La mala educación - 2004), culminando com Volver (2006), não existe o tratamento de algum personagem central com perfil cervantino numa ironia que busca revelar contradições das estruturas sociais dominantes ou inventar uma nova linguagem. Ao contrário, por mais que revele elementos contraditórios e extremamente irônicos do quadro social e político, Almodóvar não desenvolve uma crítica da estrutura social de seu tempo, nem inaugura uma nova estética cinematográfica, como fez Cervantes com a literatura.

Todo seu conflito e suas personagens aglutinam-se e desenvolvem sua ações dramáticas em um presente objetivo, cosmopolita, localizado e pessoal dentro de uma narrativa que se utiliza de linguagens das artes plásticas já conhecidas elaboradas no território do kitsch, do camp e da pop art. Seu sistema de decupagem obedece ao padrão clássico com poucas exceções.

Claro, seu caráter autêntico também reside em sua habilidade de recolher todas essas linguagens narrativas e estéticas para contar a sua própria história. Mas isso não traz explicações sólidas para associá-lo a Cervantes simplesmente porque adquiriu fama internacional e por ter nascido na mesma região do escritor. Muito menos que La Mancha deva criar artistas naturalmente. O que vem explicar, então, as contínuas comparações entre dois autores tão diferentes entre si senão os interesses de integrantes de campos culturais ocupados em manter e gerar projeções unificadoras de uma cultura hispânica universal ou de artistas geniais, como ocorreu na pintura ?

Este desejo que parece coletivo define uma parte do jogo de imagens constantemente em trânsito num mercado de bens simbólicos que dialoga com esferas mitológicas existentes na cultura e na política, cristalizando valores disseminados no presente. Associando-o a elementos marcantes do passado no sentido de reconstruir 
uma leitura histórica que justifique a permanência ritualizada de determinados mitos, se elaboram explicações para o presente.

O trabalho "Mitologia da mineiridade", de Maria Arminda do Nascimento $\operatorname{Arruda}^{260},(1990)$, é bastante elucidativo nesse sentido. No momento em que analisa os aspectos da construção mítica de Minas Gerais e o imaginário acerca do mineiro politizado, a autora evidencia a projeção de imagens sobre o próprio lugar e seus processos e atores socias, transformados em mitos unificadores que explicam a manutenção e reprodução de relações de sociabilidade prevalecentes na região.

Sua reflexão demonstra que a idéia de pessoas dotadas de espirito de liberdade está presente na própria historiografia das origens do território de Minas. Nas visões do século XIX, já se encontra na literatura a visão de que naquela província seus habitantes eram pessoas insubordinadas e movidas por um desejo incontido de liberdade. Uma região montanhosa, árida e desenraizadora, cuja lógica econômicoextrativista também contribuía para a não fixação no território, onde até a natureza conspirava contra as autoridades e nem a Igreja cumpria devidamente seus rituais. Um lugar marcado pelo seu caráter individualizante ${ }^{261}$.

O processo separatista que culminou com a Inconfidência era composto por homens instruídos, dotados de razão suprema de sonhos revolucionários e pela figura popular do mártir Tiradentes como herói impulsivo, nacionalista e patriota que não se acovardou diante do despotismo vigente. O movimento funcionou como simbiose entre um Dom Quixote e um Sancho, prevalecendo o pragmatismo do segundo, simbolicamente na exigência da prática política. De símbolo da derrota, o inconfidente morto e o movimento passaram a síntese, não apenas dos ideais revolucionários da época, mas da idéia de coragem e certezas que servem de referência aos cidadãos modernos. Minas Gerais, indomável com suas vantagens econômicas na época do ciclo do ouro, ocupando o centro do país, por ser o foco de tantas preocupações e controle, se transformou na terra onde se deveria garantir a ordem, a liberdade, a tradição e a esperança, como unidade nacional.

Aquele movimento político inaugurou a gênese de um imaginário de autonomia que repercute e se faz reproduzido pela produção cultural de artistas, intelectuais e políticos referente à região, até nossos dias. Para garantir sua permanência, cultiva-se uma tradição inventada por esse processo de releitura da unidade e equilíbrio político. Daí imagens como o "espírito das minas" representando a ponderação e a visão politizada do mineiro. O mito recria a tradição e os agentes envolvidos em sua lógica.

${ }^{260}$ ARRUDA, Maria A. N. Mitologia da mineiridade. SP. Brasiliense, 1990. p. 100. 
Utiliza-se da história, interpretando-a a seu modo para ritualizar cotidianamente grandes e pequenos acontecimentos, diluídos nas convenções, nas atitudes corriqueiras e nos momentos ritualísticos. No caso da Inconfidência Mineira, quando os interesses de grupos da classe dominante passaram a ser de todos, a figura de um participante popular acabou fundindo e unificando realidades e ideais antes distintos. $O$ rito promoveu uma integração ${ }^{262}$.

Diante desta exposição evidencia-se o conjunto de elementos que envolvem, constituem e alimentam a manutenção de um mito. Busquei este paralelo como maneira de ilustrar que em diferentes objetivos sociais e históricos se mantém a mesma estrutura mitológica para nutrir padrões ou ideais de unidade e ordem. Como apresentado no capítulo anterior, é um recurso criado pelo ser humano para sustentar sua necessidade de existência e de equilíbrio cosmológico. No entanto, a partir do momento em as regras estabelecidas são elaboradas segundo valores submetidos ao controle de setores minoritários, por intermédio deles se desenvolverá também a compreensão geral da sociedade a respeito de determinado processo ou personagens históricos.

São estes aspectos que analogamente percebo ocorrerem entre os grupos que se circunscrevem à produção cultural na Espanha diante de personalidades que elegem para articular suas atualizações mitológicas. Em Minas Gerais, as interpretações sobre o conjunto dos acontecimentos culminaram nacionalmente na imagem do mineiro político. No caso específico da figura de uma celebridade como Almodóvar, forjaram-se elementos da obra de Cervantes - sobretudo de fama - para servir de alinhamento à trajetória de uma cultura nacional e ao atendimento de interesses mercadológicos. São os setores envolvidos nessa esfera que elaboram suas próprias leituras e multiplicam as visões consolidando os ídolos atuais. Cristalizam em seus perfis sociais - constantemente reconstruídos pela sociedade que os recebeu as imagens que convém negociar socialmente.

O histórico de Almodóvar é mais do que conhecido na Espanha. Todos os jornais e revistas insistem em recordar suas origens, sua idade - pois a ele incomoda a velhice - e seu processo de ascensão a partir da famosa Companhia Telefonica - uma referência repetida tantas vezes que mais se assemelha a um merchandising. Sua infância e juventude em regiões pobres, seu estudo em colégios católicos. Durante uma época considerável, a enorme exposição de sua vida dava motivos suficientes para reforçar a imagem divulgada de seu egocentrismo e auto-promoção. O oposto do 
que ocorre com sua vida recente, cada vez mais preservada dos holofotes.

Pode-se verificar esse quadro na froma como Almodóvar resguarda sua família das investidas da mídia sensacionalista. Fala de sua solidão, de suas buscas, mas não permite o avanço na privacidade de seu parentes. Entre ele e seus membros familiares há um acordo de recato. Não dão entrevistas gravadas, não se deixam fotografar, não fazem pronunciamentos públicos. Desse modo, essas ações garantem a todos uma vida normal sem os abusos de uma "indústria da fama". Mesmo assim, o exercício de ampliação de fatos, as associações com outros acontecimentos ou pessoas que favoreçam uma publicidade e a alimentação de sua imagem não cessam. Este momento pode ser reinterpretado com novos mitos reciclados dos anteriores: a solidão, a excentricidade madura, um novo marketing pessoal, etc.

A pouca documentação que descreve o perfil e a trajetória de Cervantes já recebeu as aproximações "forçadas" e necessárias - feitas por uma mídia disposta a alinhar fama a uma visão mítico-cultural espanhola universal - para compará-lo a Almodóvar. Chegou a um limite. O diretor - por sua vez - não recorre como antes à figura quixotesca para se afirmar diante de uma intelligentsia que - por não ser hegemônica nem coesa - também já definiu os simpatizantes e antipáticos ao tipo de cinema que ele produz. E depois de uma carreira, agora reconhecida, alguns elementos que antes poderiam dar visibilidade ao diretor foram abandonados pelo pouco alcance que reverberam na imagem do cineasta maduro. Os integrantes da mídia continuam a reelaborar seu perfil buscando fatos que alinhem suas imagens polêmicas do passado com situações mais recentes, afinal, a vida dos famosos movimenta um considerável, mercado de podutos - jornais, revistas - para fãs e inimigos.

Alguns dos últimos fatos que geraram bastante notícia até o encerramento desta pesquisa traçam um perfil que envolve simultaneamente o cineasta e a pessoa Pedro Almodóvar. Em julho de 2001, quando realizou Hable con ella (2002), o grupo Amnistía Animal-Comunidad de Madrid denunciou o diretor e sua equipe à Consejería de Medio Ambiente de la Dirección General de Agricultura de la Comunidad de Madrid por provocarem a morte de quatro touros na Plaza de Aranjuez durante as rodagens da película e mais dois na Plaza de toros de Brihuega, em Guadalajara, que só não foram também denunciados porque lá não existe uma lei de proiba filmar este tipo de cena. Sob o título "6 toros para Almodóvar: una película que nace con polémica"263, o artigo

\footnotetext{
262 Ibidem. 89-101.

${ }^{263}$ NIEVES, Rosa de las. 6 toros para Almodóvar: una película que nace con polémica. Interviú, Madrid, 23. jul.
} 2001. 
mostrava que os touros foram submetidos a um cruel sofrimento antes de morrerem.

Os membros da produtora El Deseo, do diretor, argumentaram que esperaram as datas de treinamento dos novos toureiros para filmar. Juán Antonio Alcóbar Macanero, o comprador dos touros, explicou que todos estavam fora dos "padrões" das touradas, um manco, um quase cego, outro baixo, pois para esses treinos sempre possuem algum defeito. De toda forma seriam sacrificados. Não só sacrificados, como incinerados depois. A produtora havia cumprido com todos os requisistos estabelecidos pela prefeitura de Madrid e recebido autorização após pagar os encargos exigidos pela lei, inclusive obedecendo as regras de segurança e atendimento. Na semana seguinte ao artigo, a discussão tomou dimensões internacionais. A mesma revista publicou outra reportagem acerca do problema sob um título instigante: La faena de Almodóvar ${ }^{264}$. No trecho sobre a mobilização internacional encontram-se passagens importantes para essa discussão:

Pedro Almodóvar siempre es noticia fuera de España. $Y$ los toros también, por ser uma práctica muy criticada. La suma de ambos argumentos puede resultar explosiva. Desde que Interviú desveló el pasado lunes [segunda-feira] la denuncia contra el director manchego por la muerte de varios toros para la filmación de la película Hable con ella, en otros países ha ido creciendo el interés por este asunto. La agencia de noticias estadunidense Reuter difundió unteletipo intitulado "El ganador del Oscar Almodóvar, acusado de crueldad animal". Por su parte AP tituló: "Los activistas de los derechos de los animales, contra el director Pedro Almodóvar". También la Agencia de Prensa Alemana (DPA) se hizo eco de la denuncia, pues, según comentan em su redacción, "Almodóvar siempre es noticia. Y como estamos acostumbrados a que las escenas com animales sean simuladas, y eso lo dejan bien claro los directores de cine em sus créditos, la noticia todavía es mayor". Matilde Cubilo, presidenta de Amnistía animalComunidad de Madrid y denunciante del caso, ha atendido llamadas de diarios extranjeros, alguno británico, y de emisoras como Radio Caracol de Colombia. Cubillo cuenta que en su asociación se sienten desbordados [abarrotados]: "Nuestro correo electrónico está casi bloqueado porque em cinco días hemos recibido un millar de mensajes de personas que quieren apoyar nuestra denuncia. La gran mayoría de ellos son españoles, pero hay muchísimos correos de Fracnia y Portugal". Entre esos correos, destaca el de respuesta de la poderosa organización norteamericana de defensa animal PETA (People for the Ethical Treatment of animals), que ha dicho: "Nos sentimos ultrajados por la muerte de cuatro toros [...] Es espantoso que el director Pedro Almodóvar elija glorificar un deporte (sic) cruel y sangriento como las corridas de toros [...] pedimos a todos los amantes de los animales que no vean esta película.

Abrindo qualquer discussão, a marca de "diretor manchego" já se encontra registrada e intrínseca ao seu título de cineasta, aparecendo em algum momento na matéria. Outra imagem que percorre todo o texto é a de que ele é sempre notícia. Depois, diante da divulgação dos acontecimentos pela própria associação madrilenha,

\footnotetext{
${ }^{264}$ NIEVES, Rosa de las. La faena de Almodóvar. Interviú, Madrid, 30. jul.. 2001. A palavra faena é originária do catalão antigo: trabalho sobrecarregado, afã, agitação. No artigo joga-se com seus vários significados vinculando-os aos diretor: ansioso, rigoroso e trabalhador, perfeccionista, sobrecarga no ofício não apenas no trabalho, mas em conceder explicações - com um fardo já visto antes que se incorpora ao ato de filmar, desgastando mais suas atividades com a equipe, física e psicologicamente.
} 
enviada a várias grupos similares, verifica-se o alcance das informações quando estas se vinculam ao diretor.

Ganham projeção - intencionalmente ou não - a revista que divulgou as notícias, inclusive ressaltada na observação dos próprios editores, a pequena associação de proteção aos animais, todas as outras associações afins e o próprio acusado, que teve o nome de seu filme difundido pelo mundo um ano antes de sua estréia. E respondendo ao temor de um efeito negativo, conclamado pela PETA norteamericana para boicotar o trabalho, quando o filme foi lançado, não só obteve 22 prêmios internacionais, como ganhou o Oscar da academia de Hollywood como melhor roteiro original em 2002, além de receber 10 indicações a prêmios ${ }^{265}$.

Em 2004 lançou La mala educación em Cannes. Coincidentemente, no mesmo período ocorreram as inúmeras denúncias sobre pedofilia e abusos sexuais de padres da Igreja Católica com crianças e adolescentes. Antes da estréia, vários militantes leigos e membros da hierarquia católica conclamaram aos seus fiéis a rejeição ao filme. Em Paris alguns grupos chegaram a fazer protestos nas portas de salas de cinemas. E muitos entenderam que Almodóvar estava se aproveitando da "onda" de escândalos para fazer uma película rentável, interpretando-a como anti-clerical. O diretor se pronunciou em Cannes:

La Iglesia, por lo menos la española, se degrada a sí misma cada vez que sale en los periódicos, es el peor enemigo de sí misma; y a mí lo único que me interesa de esa Iglesia es su forma de idolatría, esa liturgía católica que en España es tan profana, tan pagana. De pequeño no creía en dios, creía en las cerimonias, en la parte decorativa de la religión, y lo que he hecho en la película es prestarle esa liturgía a los personajes. ${ }^{266}$

Em 8 de fevereiro de 2005, mais uma polêmica. Três dos principais jornais espanhóis anunciavam a saída de Pedro e Agustín Almodóvar da Academia del cine Espanhol em virtude de suas desavenças diante do sistema de votação. O filme La mala educación não recebeu nenhum dos quatro prêmios Goya aos quais tinha sido indicado e isso evidenciou para eles as contradições do processo de eleição. Depois de 17 anos de filiação, Agustín como membro da junta diretiva, os irmãos Almodóvar chegaram a uma decisão final de rompimento. Suas críticas se voltaram à falta de informação sobre o número de participantes nas votações e à pouca quantidade dos que votam efetivamente. A estrutura montada em 2002 divide-se em duas rodadas. A primeira, realizada por especialidades. Cada membro elege quatro candidatos da especialidade à qual pertence, exceto os prêmios considerados genéricos - filme, animação, documentário, filme europeu e filme estrangeiro de fala espanhola. $\mathrm{Na}$

${ }^{265}$ Disponível em: <http:// www. egeda.es/eldeseo/premios17.asp> acesso em 15. 01. 2007 
segunda, todos os acadêmicos podem votar em todas as indicações. ${ }^{267}$

No julgamento de Agustín, eles não se sentiram queridos e já há alguns pensavam em dar baixa da Academia:

El sistema de votación actual provoca que sean los gremios de la industria los que se voten entre sí. España tiene una industria muy pequeña, en la además son muy pocos los académicos que ejercen su derecho, y por ello el voto es muy interesado. ${ }^{268}$

O jornal La Vanguardia optou por ironizar os acontecimentos, dizendo que a imagem do cinema espanhol saltou pelos ares e ficou numa situação enquadrada como o título de um filme do protagonista do conflito: Al borde de un ataque de nervios. Logo depois, o enobrecimento antecede o fato com o anúncio: El icono más famoso del cine español, Pedro Almodóvar. A descrição dos desentendimentos inclui obervação sobre um dos motivos ligados ao desprezo conferido à película La mala educación que, diante das quinze indicações de Mar adentro de Alejandro Amenábar, só havia recebido quatro e não ficou com nenhum prêmio.

A comienzos de los años noventa, la academia había dado una bofetada aún mayor a Almodóvar, Átame fue elegida como aspirante a trece Goya y finalmente no le dieron nada. Cero. Pero eran otros tiempos. Aquellos en los que el propio director no se recataba en emitir en publico declaraciones tan poco amorosas como; "A muchos les gustaría que yo siguiera trabajando en la Telefónica ..." Y, además, todavía no le había llegado el reconocimiento mundial - dos oscar incluidos - del que goza en la actualidad. ${ }^{269}$

O jornalista deixa percorrer, nas entrelinhas, os desafetos e o sutil relacionamento envolvendo doses de ciúmes entre cineastas e estes, afrontados pelo jogo de forças da Academia sobre eles. Explicitando mais esse contexto, o jornal catalão El Periódico reservou em sua página intitulada: Cine/ polèmica, a manchete: Els Almodóvar obren un cisma en el cine espanyol focando a mesma discussão dos anteriores. O apontamento do jornalista Rafael Tapounet, apresenta impasses que sempre permeiam o universo cinematográfico:

Almodóvar ${ }^{270}$ és uma referència indispensable del cine que s'ha fet a Espanya em els últims 25 anys,un gegant amb uma gran ombra que há deixat sovint em penombra el treball dels seus contemporanis. Això, de manera inèvitable, genera enveges i recels, i possiblement Afustín Almodóvar té raó quan afirma

\footnotetext{
${ }^{266}$ MORA, Miguel. Almodóvar tiñe de negro La Croisette. El País - La cultura , Madrid, 13. mai. 2004 , p. 39.

${ }^{267}$ Pedro y Agustín Almodóvar dejan la Academia por su sistema de votación. EI País - espetáculos, Madrid - 08. fev. 2005.

${ }^{268}$ Idem.

${ }^{269}$ MUÑOS, Diego. Pedro y Agustín Almodóvar se dan baja de la Academina del cine de España. La Vanguardia Cultura. Barcelona, 08. fev. 2005. p. 41

${ }^{270}$ Almodovar é uma referência indispensável do cinema feito na Espanha nos últimos 24 anos, um gigante com uma sombra que deixou muitas vezes na penumbra seus contemporâneos. Isso, de uma maneira inevitável gera inveja e ressentimentos e, possivelmente Agustín Almodovar tem razão quando afirma que as películas de seu irmão podem ser julgadas a partir destas perdas. E, não obstante, o cineasta manchego deverá dar muitas explicações se não quiser que seu gesto seja interpretado como algo nada além de um arrebato de uma estrela que não sabe perder e com um ego daqui a Melilla, que abrirá mais uma ferida da qual o cinema espanhol tardará em recuperar-se.
} 
que les pel.lícules del seu germà solen ser jutjades des del prejudici. I, no obstant, aquest cop el cineasta manxec haurà de donar moltes explicacions si no vol que el seu gest sigui percebut com alguna cosa més que un rampell d'una estrella amb mal perdre i un ego d'aqui a Melilla, que obre a més uma ferida de la qual el cine espanyol trigarà a recuperar-se. ${ }^{271}$

Nesse parecer manifestam-se três fatores essenciais: a obra de Almodóvar como marco importante para o cinema espanhol, seu brilho que ofusca os trabalhos de outros cineastas da atualidade e - como no artigo anterior - os riscos da vaidade, ao mesmo tempo que necessidade de uma racionalização do problema. Nos três textos evidencia-se o jogo do mercado em negociações e oscilações.

De volta à discussão sobre as origens de La Mancha, verifica-se que estas conduzem a análise para uma outra imagem de maior potencialidade construída coletivamente, claro, com a grande participação de Almodóvar: a polêmica. Ela compõe a produção, as temáticas ligadas à exibição e difusão, formando um conjunto de contínuas tensões. O termo "cineasta manchego" prossegue em todos os artigos reforçando a imagem levantada no início e no decorrer da discussão deste tópico. Porém, começa a passar para um segundo plano e compor apenas um elemento da polêmica, um fator agora mais candente. Ser manchego, diante das situações descritas até aqui e pelas próprias atitudes do diretor e de seu irmão, não determina os rumos dos investimentos, nem as relações que estabelecem com o mercado.

A existência de um forte espírito separatista dentro da Espanha talvez justificasse esta demarcação de sobrenomes e atributos sobre algumas personalidades, mas, como afirmei no início, a condição de classe determina as relações efetivamente. Se não fosse assim, Buñuel seria sempre chamado de diretor aragonês, fato que nunca ocorreu. Ser originário de família humilde numa região carente do país define um quadro mais elucidativo para a compreensão dessas situações. No entanto, também não explica tudo, afinal o diretor e seu irmão romperam com as determinações de classe a que estavam teoricamente destinados.

No aprendizado e cumprimento das regras do campo cinematográfico conquistaram seu espaço como profissionais respeitados, apesar dos inúmeros contratempos. Portanto, o panorama revela-se mais extenso e significativo em outros horizontes a serem investigados e, diante de cada um deles, La Mancha torna-se algo presente apenas nos afetos dos irmãos Almodóvar.

${ }^{271}$ TOPOUNET, Rafael. Els Almodóvar obren un cisma em el cine espanyol. El Periodico, Madrid, 08. fev. 2005. 


\section{AUTÊNTICO E INCOMPREENDIDO}

O final do capítulo anterior demonstra que a polêmica acompanha diversos momentos da vida cinematográfica do cineasta Pedro Almodóvar. Mas em suas lembranças o diretor recorda que desde a infância e A adolescência, antes de chegar a Madrid, ele já enfrentava situações dessa natureza. Em sua memória guardam as inúmeras cenas de perplexidade das pessoas diante de suas atitudes insólitas, em geral todas relacionadas ao cinema. Estas auto-referências chegam a público com um forte caráter de predestinação do diretor que facilmente podem associar todos os seus passos rumo a um único destino que teria sua vida: ser um bem-sucedido diretor de cinema. Sob tal pressuposto, a todo momento o mito da genialidade paira sobre sua trajetória.

Porém - como já discutido - essa narrativa obedece a um modelo de história reinterpretada e ritualizada que atende funções visando o consolidar a condição atual das circunstâncias de uma pessoa ou acontecimento. O que se torna pertinente para essa análise sobre o diretor é perceber nos relatos pessoais e nas imagens das películas que realizou, como a polêmica povoa sua trajetória e se constitui em mais um elemento para sua projeção. Combinada aos outros fatores - vividos, inventados ou ampliados - que desenvolveu em sua vida, ela faz parte de um universo muito particular do cineasta, composto do contraste entre sonhos, realidade e construções pessoais. Em seu conjunto, amparam a continuidade da auto-imagem do diretor, justificando e comprovando seus caminhos.

\section{1 Polêmica e auto-construção}

O histórico reelaborado pelas lembranças de Almodóvar proporciona a visualização dos contornos de suas temáticas, o perfil de suas personagens, assim como a leitura que faz sobre si e a experiência vivida. A infância, até os 8 anos de idade, marcada pela convivência com as mulheres do pueblo, ouvindo as conversas da mãe com suas tias e vizinhas, as vestimentas sombrias, o hábito cultural de cultivar o sofrimento e a morte ${ }^{272}$. são elementos que recentemente emergiram de maneira direta nas reflexões de Volver (2006).

$\mathrm{Na}$ abertura deste filme, esse conjunto de lembranças e significados está totalmente definido e sintetizado nas mulheres que limpam e lavam os túmulos num cemitério. Uma homenagem sensível a tantas daquelas que observou quando menino,

${ }^{272}$ GARCIA DE LEÓN e MALDONATO, 1989. p. 32 
e a cultura da morte que ele transforma em geradora, ou ao menos provocadora da vida - fatos cíclicos da existência. Imagens que - no entanto - já apareciam como temática ou em figurinos dos vários dos trabalhos anteriores. Em Hable con ella (2002), por exemplo, será Benigno quem proporcionará uma nova vida a Alicia e Marco. Ou mesmo em Todo sobre mi madre (1999), no processo que Esteban desencadeia na vida de sua mãe quando morre atropelado. A presença da morte como componente da trama ou como tema central, percorre todos os trabalhos do diretor.

O mesmo acontece com as roupas pretas ou sóbrias contrastando com o colorido excessivo de toda composição imagética, sobretudo o vermelho - este também uma cor emblemática para situações viscerais. Não vejo casualidade nas vestimentas dos punks e roqueiros presentes nos dois primeiros filmes, nos hábitos das freiras e na caracterização de todas as personagens reprimidas que apresenta. Em todos ecoam a herança das referências infantis. Além disso, aquelas centenas de discussões escutadas renderam também para o cineasta um acervo imenso de idéias e recordações favorecendo a criação de filmes e de personagens com tonalidades rurais e, sobretudo dos diálogos entre personagens femininas carregados de cumplicidade e dissimulações diante de um universo dominado por homens, mas que nas películas é subvertido.

Según palabras del director, La mancha es un lugar árido lleno [cheio] de silencios, de palabras que se callan, de puritanismos y convencionalismos, de gente ruda y dura. De ahí que los carnavales se viveran como el único momento de respiro, la catarsis necesaria. Él recuerda cómo su madre y sus amigas se disfrazaban [fantasiavam] y gastaban bromas [brincadeiras], gritaban y reían con un desenfreno que a él le producía un cierto temor; era como ver todos los instintos sueltos por unos días, era la válvula de escape de unas ansias tanto tiempo reprimidas. Almodóvar debió decidir muy pronto que él no quería sentir tal represión toda su vida y que su camino debía ser mucho más contestatario y libre, tal como muestran sus películas, sobre todo las primeras, aún rodadas en un ambiente de miedo y autocensura. Él mismo ha afirmado en varias ocasiones que lo que menos le gustaba del pueblo era precisamente esa atmósfera opresiva y represora en la que no se permitían ni los más mínimos placeres. ${ }^{273}$

Nos filmes estas cenas se transfiguram no oposto, num exercício para exorcizar um modelo de sociedade totalitária, simultaneamente revelando-a. Também se detecta, pelas próprias intenções movidas pelo medo na infância, o desejo incipiente de contestar. Espírito que passa a alimentar, portanto, sua prática a cada um de seus passos futuros. As seqüências de Pepa em Mujeres al borde de un ataque de nervios (1987) evidenciam este contraste entre o vivido e o renegado. Mesmo em Hable con ella (2002), quando a toureira Lydia entra em crise histérica porque encontra uma cobra em sua casa e decide nunca mais voltar à residência, obtêm-se os reflexos dessa 
rejeição aos elementos do passado que se busca ritualisticamente reviver para garantir seu distanciamento.

As tantas personagens escandalosas de outras produções também fazem esse jogo carnavalesco que Almodóvar presenciou várias vezes e que nos filmes são redimidas. Quase um manifesto contra a repressão, um espírito polêmico em essência se anuncia para banir de vez os momentos reprimidos. Não poucas vezes o que se revela é praticamente um ato incondicional de solidariedade às mulheres privadas de seus desejos. Os filmes acabam reproduzindo os vários prismas de um mesmo contexto de sentimentos.

O colorido das imagens e dos figurinos, os inúmeros adornos e a cenografia carregada com formas e cores diametralmente opostas aos vestidos pretos com recorte quase uniforme das mulheres nos pueblos e casas simples e rudes são uma resposta de rechaço condizente àquele estilo enrijecido de sociedade. Uma vida marcada pela vigilância e pelo controle da moral religiosa e masculina sobre o corpo e o comportamento femininos. Cenas que permaneceram registradas na memória do diretor e que são tratadas em seus filmes de maneira a fortalecer personagens femininas, atribuindo a elas o protagonismo da maioria das histórias. ${ }^{274}$

Em sua infância e adolescência na cidade de Cáceres - região de Extremadura -, onde viveu dos 8 aos 16 anos estudando em colégios católicos - salesiano ${ }^{275}$ e franciscano respectivamente ${ }^{276}$-, Pedro já demonstrava mais interesse por inventar histórias do que em jogar futebol com os amigos. Esse aspecto se deu em grande parte pela influência materna. À noite - ainda menino - ele lecionava alfabetização para adultos e sua mãe lia cartas para uma grande vizinhança iletrada, ao estilo da personagem Dora interpretada por Fernanda Montenegro em Central do Brasil (1998). Além de ler, ela interpretava e inventava o conteúdo das cartas, sobretudo porque conhecia seus consulentes e sabia o que gostariam de escutar. Essas cenas encantavam a Pedro e fomentaram seu imaginário fornecendo as chaves de leitura para que ele entendesse a relação entre ficção e realidade. ${ }^{277}$ Uma experiência que o ensinou e o motivou a escrever histórias.

Cáceres, uma cidade pobre também carente de infra-estrutura - no entanto urbanizada - possuía melhores caminhos para algum progresso pessoal, e o melhor -

\footnotetext{
${ }^{273}$ SALGADO, Silvia Comenero. Pedro Almodóvar, Todo sobre mi madre. Barcelona: Paidós, 2001. p. 18.

${ }^{274}$ Idem.

${ }^{275}$ STRAUSS, 2001, p. 46.

${ }^{276}$ HARGUNDEY, 30. set. 1984; breve biografia incluída no Roteiro de La flor de mi secreto, Barcelona: círculo de lectores, 2000.

277 SALGADO, 2001. p. 19
} 
para Pedro : cinco salas de cinema. Ali, sem recursos para estudar gratuitamente em colégio de classe social mais abastada, sua mãe conseguiu para ele uma vaga como bolsista sob a condição de ser seminarista, carreira que, porém, logo mostrou-se inviável a Almodóvar ${ }^{278}$. Estudar em colégios de rígida disciplina e bom nível educacional, freqüentar o cinema e conhecer as várias películas que influenciaram seu olhar e sua forma narrativa cinematográficos constituíram-se no legado que aquela cidade deixou para sua vida.

Além disso, foi nos colégios de Cáceres que experimentou os nada salutares assédios dos padres, como aparece em La mala educación (2003) no personagem que representa sua infância. Estes fatos, somados à austeridade do ensino religioso, levaram Almodóvar a desacreditar na existência de Deus. Situação que acabou trazendo para ele um efeito de liberdade criativa extremamente favorável. Livrando-se da moral cristã baseada na culpa, seu exercício para desenvolver histórias com personagens que respondessem aos seus desejos se emancipou deliberadamente.

Patrimônio histórico da humanidade, Cáceres possui um passado longínquo iniciado como colônia romana, influência do período árabe, depois fortificada com muralhas na Idade Média, arquitetura medieval e sítios arqueológicos do período préhistórico. É também a cidade dos conquistadores das Américas e, aliada ao espírito religioso católico de universalidade cristã, foi palco de festas tradicionais que reproduziam uma cultura católica muito arraigada, conservadora e orgulhosa de seu passado vitorioso.

Esse conjunto de valores e imagens presentes na cidade também marcou decisivamente a visão cosmológica do diretor. Pedro viveu sua infância e adolescência entre as pressões dos maus exemplos dos padres nos colégios, as projeções sagradas dos discursos e comemorações eclesiásticos, as festas populares e os sonhos exibidos pelos filmes, universo que contrastava com as duras condições de vida dos lugares onde morou. Nas entrevistas ele afirma que seu grande prazer era sair das aulas e, no cinema, constatar que os diálogos e as histórias contadas pelos filmes resultavam para ele dividendos muito mais interessantes do que os discursos dos padres. ${ }^{279}$

Naquele universo, repleto de imagens e histórias, tudo era motivo para suas criações. Os cromos com astros hollywodianos que vinham nos tabletes de chocolate $^{280}$ ou os cartazes que anunciavam os filmes ainda por estrear acionavam nele uma gama de idéias mirabolantes. Suas irmãs contam que as histórias inventadas

\footnotetext{
${ }^{278}$ GARCIA DE LEÓN e MALDONATO, 1989. p. 155.

279 ALMODÓVAR, Pedro. Es Almodóvar un genio ? - autobiografía. El país, Madrid, 17. out. 1993, p. 18.

${ }^{280}$ MAHIEU, José A. El único premio posible es el dinero. Fotogramas, nº 1705, Madrid, fev. 1985.
} 
por Almodóvar diante das imagens eram mais empolgantes do que as próprias películas. Várias vezes preferiam ouvir o irmão e não assistir aos filmes, ou então, quando chegavam em casa após uma sessão de cinema, pediam a ele que contasse sua versão, em geral de maneira exagerada e com mais detalhes. Quando lia a revista de cinema Fotogramas, bastava alguém se prestar a servir de público para que ele inventasse suas narrativas ${ }^{281}$. Ao que parece, tudo que passava por ele poderia em tese fomentar sua imaginação.

Informações bem-humoradas e difundidas pelos meios de comunicação de massa como estas compõem exatamente os motivos desabonadores para que o diretor não seja visto amistosamente pela crítica pouco simpática à sua obra e nem por pessoas com uma moral conservadora, ao menos na Espanha. Os fatos denotam sua diferença vivida fora do habitus de classe tradicional dos cineastas e daqueles que fazem parte da mesma lógica social no país.

Não causam portanto surpresa, portanto, determinadas resistências em aceitálo como alguém capaz de dominar todas as regras do ofício, sobretudo porque isso implica também exercitar adequadamente - segundo as normas estabelecidas pelo habitus - os comportamentos e condutas desses diversos grupos que orbitam nessa esfera cultural. Para Almodóvar, que já trazia um histórico pessoal tempestivo e irreverente, porém distinto da compreensão e leitura que esses grupos fazem desses aspectos, as possibilidades de sua inserção no campo cinematográfico se anunciavam pouco promissoras.

Verifica-se como apenas poucos detalhes que ora surgem nas entrevistas e declarações aleatórias contribuem para construir lentamente um perfil sobre 0 imaginário coletivo. Fatos que também atraem os diferentes espectadores animados com histórias que confirmam os caminhos tomados pelas películas do cineasta. E será a junção dessas repercussões diversas, associadas aos fragmentos biográficos identificáveis nas obras, o principal ingrediente criador de uma relação de confiança entre público e cineasta que se desdobra em imagens mitificadas do artista.

A cada detalhe mais se explicam as razões dessa constituição imbricada entre autor e obra. As influências que o conduziram a escrever seguem no mesmo sentido das discussões anteriores, inclusive diante dos grupos que possuem poder legitimador. Pedro assistia a todos os filmes que chegavam aos cinemas da cidade e teve contato com uma literatura aparentemente eclética, proporcionada - desde a infância em Calzada de Calatrava - pelos livros que comprava por encomenda, selecionados dos

${ }^{281}$ BAYÓN, 23. jan. 01. 1989, p. 57. 
catálogos que sua família recebia do magazine El Cortes Inglés. Catálogos com diversos produtos modernos e manequins que contribuíram para que ele desenvolvesse uma percepção estética voltada ao costumes da metrópole - segundo a linha padronizada da loja - e aguçasse seu imaginário sobre Madrid. El cortes inglés ficou tão presente na história do diretor que ganhou uma homenagem numa cena de La flor de mi secreto, visto da janela do quarto de Leo, a escritora interpretada pela atriz Marisa Paredes.

Essas encomendas mantiveram nele um hábito de leitura que ia desde bestsellers como "O advogado do diabo" de Lahos Zilahy ou "Bom dia tristeza" de Françoise Sagan, depois levado ao cinema por Otto Preminger, até "O lobo da estepe" de Hermann Hesse ${ }^{282}$ e livros de Jean Genet e Rimbaud. No entanto, se na esfera intelectual havia uma certa disparidade entre os escritores lidos, causando uma impressão de ecletismo do diretor, no plano narrativo lógica se desconfigurava. Esses autores em geral possuíam afinidades temáticas voltadas a grupos excluídos ou reflexões sobre a vida e seus valores que diziam muito a respeito de situações vividas pelo diretor ainda que este não percebesse o motivo de sua atração por essa literatura. Esse repertório aguçou nele um tipo de espírito que não iria se satisfazer vivendo em Cáceres e em nenhum outro lugar semelhante.

Assim, mesmo com as dificuldades do cotidiano naquela cidade, o conjunto dessas experiências acabou traduzindo ao rapaz Almodóvar melhores perspectivas do que se tivesse permanecido no pueblo de Calzada de Calatrava em Ciudad Real. Viver ali e adquirir as experiências que colheu aumentou seu desejo de mudar-se para Madrid. Assim, nem Calzada de Calatrava e nem Cáceres faziam parte de seus planos futuros. E nem das perspectivas de sua mãe, que sonhava em dar aos filhos uma vida diferente daquela que tivera. Sonhara para Almodóvar um trabalho burocrático e estável. Desejo de toda uma geração que viveu o modelo de produção capitalista do mundo ocidental dos anos 60 aos 80, firmado na idéia de trabalho estável com longa permanência de tempo numa mesma corporação até a aposentadoria. Contudo, isso também ele já havia eliminado de suas perspectivas. Mais do que algo melhor, ele queria ter a possibilidade de viver coisas que aquele universo não propiciava e que dentro do seu imaginário - a cidade grande prometia ${ }^{283}$. Já havia decidido: seu destino era Madrid.

\footnotetext{
282 STRAUSS, 2001, p. 15.

${ }^{283}$ ALMODÓVAR, 1995. p. 106-110.
} 
Ya eras muy maduro a los doce años.

No sé si era maduro, pero ahora me doy cuenta de que las cosas que me interesan hoy ya me interesaban entonces y las descubrí muy pronto yo solo, sin necesidad de una formación específica.

También estabas muy solo.

Solo! Completamente solo! Recuerdo que los diez años les hablé a mis amigos de El manancial de la doncella de Bergman, que me había impresionado mucho. Me miraron con una cara casi de terror y al mismo tiempo de fascinación, porque era algo que les resultaba ajeno [que desconheciam]. Entré en contacto con las cosas que me gustaban en la más absoluta soledad. No empenzé a enterarme de que había gente con mis mismos gustos hasta que llegué a Madrid.

Entonces, hasta ese momento, viviste en una especie de mundo paralelo.

Por supuesto.

Imagino que tus padres estarían preocupados.

Sí, recuerdo de mi madre, plantada en jarras [com as mãos na cintura], mirándome y diciendo totalmente desconcertada: pero, dónde habrá aprendido eso ?

Tuviste que luchar mucho para imponer tu propia personalid?

Los niños desarrollan una fuerza enorme cuando están solos. También pueden desarrollar una tremenda neorosis, pero por suerte no fue mi caso. Seguramente, porque era muy buen espectador de la vida de los demás, un testigo contento, satisfecho de lo que veía, pero un testigo al fin y al cabo; nunca participaba.

Así que tu soledad no tenía ningún asomo de autismo.

No. Por suerte, tenía un carácter bastante fuerte y debo decir que, a menudo [freqüentemente], me divertía mucho mi propia situación. Mi infancia está hecha de monólogos. Muchas veces, la gente me escuchaba muy atentamente. Más tarde, cuando volví a subirme para presentar mis películas, comprendí que la soledad que se siente en el escenario era la misma que la de mi niñez, cuando hablaba de lo que me gustaba. Por eso me siento muy a gusto en la escena y también es, sin duda alguna, lo que explica que haya tenido éxito en el teatro. Nunca me han dado miedo las tablas; me siento como pez en el agua".

Estes relatos traduzem aspectos fáceis de serem modelados em função de uma mitificação: menino humilde incompreendido, cheio de imaginação e que não está num universo adequado ao seu, solitário, gosto pelo ousado, excêntrico e, pela reflexão adulta, persistência nas escolhas e não se sentir isolado, afinal no cinema havia pessoas que pensavam como ele. O produto equacionado desse histórico: um gênio.

Circunstâncias que, ordenadas segundo um olhar posterior, permitem a elaboração quase linear de uma trajetória de vida e só afirmam o momento atual de uma personalidade, como aparece nesta entrevista, quase num jogo de cumplicidade entre jornalista e diretor. Porém, do modo como foram vividas, essas experiências poderiam ser singulares para qualquer outra pessoa. A especificidade de Almodóvar foi sua propensão ao cinema. E esses acontecimentos aguçaram suas aptidões. Sua condição solitária colaborou muito para o desdobramento de suas atitudes e o motivou a buscar formas de equilibrar seus sentimentos e relacionamentos ao seu redor. A solidão proporciona ao ser humano um aumento de seu imaginário, que funciona como uma compensação para a carência de relações sociais concretas. Assistir a filmes e ler 
livros são também essencialmente hábitos solitários. Reflexões que possam conter assuntos sobre a existência - independente da idade - do mesmo modo contribuem para provocar a sensibilidade do ser humano.

Diante de uma dura realidade, um menino sensível e habituado a observar minuciosamente o mundo a seu redor só poderia ver no cinema e na literatura que o identificavam a possibilidade de exercitar seus sonhos. Entrar em contato com as preocupações dos autores era o começo da satisfação de suas dúvidas, ao menos intuitivamente. Outrossim, nas histórias que o atraíram se encontrava a racionalização do repertório de temas que ativavam a curiosidade geral característica do mundo juvenil, ainda mais se fossem seqüências ousadas.

Qual menino de 10 ou 12 anos não ficaria impressionado com $A$ fonte da donzela (1960), uma história ambientada no século XIV em que uma menina é violentada e morta por dois homens e que depois seu pai acaba se vingando-se matando-os junto com um menino que os acompanhava? $\mathrm{E}$ ainda mais quando o desfecho da narrativa desdobra-se para a transformação do local do sacrifício da menina num lugar de culto e peregrinação, pois ali passou a jorrar uma fonte. Culpa, pecado, redenção, fé, milagre, valores morais amplamente presentes em Cáceres e na rotina do então garoto Pedro Almodóvar.

São esses pormenores que, às vezes passando despercebidos, fazem da elaboração de um discurso uma revelação mítica e não um ponto de vista e, dessa forma, reforçam o julgamento de atitudes, tanto do autor como do público em geral. Não poucas vezes, quando seus filmes obtêm recepções diferentes pelos países por que passam, o diretor se diz incompreendido por alguns e compreendido por outros. ${ }^{285}$

Nesses momentos, reflete-se a defesa dessa construção excêntrica que remonta seu passado - numa leitura já reconstruída com experiências do presente para explicar a interpretação adequada de seus filmes somente para pessoas que - em algum lugar - pensam como ele. Desvencilhando-se de sua própria tradução diante do público, cabe somente reconhecer que sua trajetória solitária, aliada aos outros processos que viveu, transformou-se num recurso de expressão artística. Possibilitou ao cineasta entender a vida de uma maneira singular, suportar as adversidades e traduzi-las cinematograficamente em todas as personagens de sua obra ${ }^{286}$.

Segundo alguns analistas, esta solidão também acompanha sua estrutura

\footnotetext{
${ }^{284}$ STRAUSS, 2001, p. 15.

${ }^{285}$ El Periodico - 11. 03. 1993; SARTORI, B. El público español me comprende. El mundo - cinelandia, año II, $\mathrm{n}^{\circ}$ 30, Madrid, 15. jan. 1994; La Vanguardia - 01. 05. 1994; GONZÁLEZ, Enric. Almodóvar cree que Italia es más generosa con su cine que España. El País - espetáculos, Madrid, 06. fev. 2005.

${ }^{286}$ FERNÁNDEZ, 19. mar. 2000.
} 
narrativa, tornando-o isolado perante a produção espanhola, pois não se enquadra em nenhum perfil de escolas ou próximo a outros cineastas no país. Funciona como um aspecto distintivo de personalidade e, ao mesmo tempo, como característica própria de uma genialidade que não se adequa ao mundo "normal". Argumentos que ele não aceita integralmente, pois reconhece que ninguém nasce despido de influências ${ }^{287}$. $E$, notoriamente, ao menos referências a outros cineastas não faltam em seus trabalhos. Por isso, prefiro chamar de autenticidade o que muitos chamam de genialidade. Por que a distinção?

\section{2 Autêntico ou gênio ?}

As breves definições que estabelecerei a seguir possuem apenas um caráter comparativo para evitar pontos de vista do senso comum e favorecer o discernimento de alguns tipos de criação. Evidentemente, as diversas produções não se esgotam em conceitos que limitam artistas e suas obras. Aqui, embora em muitos momentos estes se encontrem e partilhem práticas e visões comuns, acredito que haja peculiaridades em cada um e estas formalizam imagens que permitem delinear as sutilezas do perfil que pretendo esclarecer sobre Pedro Almodóvar.

$\mathrm{O}$ artista autêntico - pensando em tipos ideais, no sentido weberiano - garante sua autoria na obra, mas não a isenta das inúmeras influências que recebeu e recebe. Isso se revela inevitavelmente para um público sintonizado com sua produção cultural quando observa outros criadores. Por exemplo - ainda que com suas diferenças - não há como deixar de perceber a tradição irônica contida nos trabalhos de Berlanga, Fernán-Gomez e Valle-Inclán que perpassam os filmes de Almodóvar. Um dos fatores da legitimidade que marcam um artista nesse perfil consiste no fato de sua persistência em não abrir mão de sua mensagem. Para isso, negocia com seu campo cultural todas as possibilidades que contribuam para manter existindo a linha de suas obras, inclusive moldando linguagens estéticas que as façam compreensíveis para públicos diversificados. Ele conserva suas intenções e as modula continuamente.

O artista gênio - seguindo o modo idealizado - possui algo de incomparável que se perpetua e não precisa deste aparato tensionado de relações no universo de sua atuação. Por isso, vive muitas vezes incompreendido dentro de sua sociedade. Ele é movido por sua intuição e por uma consciência supra - racional. Dotado de uma personalidade divinizada, faz suas obras originais e as mantém independente do julgamento daqueles que o circundam. Segue um caminho que permite sempre à

${ }^{287}$ LINDO, 26. set. 1992. 
inspiração conduzir e realizar nele seus desejos. Ele está acima dos que possam julgálo e isso o reveste de um caráter quase mágico. Pode até não ser descoberto em sua época, mas em algum momento será reconhecido pela posteridade e isso o eternizará.

$\mathrm{Na}$ prática, ambos enfrentam situações próximas e dependem do aval daqueles que fazem parte dos círculos que apreciam e determinam o valor da obra na área em que estão inseridos. No processo histórico, os artistas ou qualquer personalidade ilustre só poderão ser aceitos se passarem necessariamente pelo crivo de alguma sociedade e de seus especialistas. No passado ou no presente, serão os agentes sociais - dispostos em seu contexto de avaliação e verdades ao redor dos trabalhos pertinentes ao meio específico da obra de arte - quem se encarregarão de assegurar a visibilidade e a importância do autor e de legado para o futuro.

Isso pode ser constatado historicamente diante de vários artistas consagrados na atualidade e que entre seus contemporâneos tiveram destinos bastante distintos. $O$ que ocorreu com Mozart - em seu tempo - demonstra significativamente essa afirmação e contribui para compreender as inúmeras circunstâncias sociais que incidem sobre um artista para a expansão de sua obra e de sua imagem. Mozart não era um membro da nobreza. Mesmo convivendo nos palácios e sendo admirado por sua criatividade, viveu numa sociedade que tratava o ofício da música como um trabalho manual, porquanto não reconhecendo em suas realizações a dimensão inovadora e original que continha. A busca do compositor por autonomizá-la não teve espaço histórico-cultural para emancipar-se como ele pretendia, vindo apenas a ocorrer muito posteriormente por análises e caminhos inéditos em sua época. Segundo Norbert Elias, ele permaneceu como um outsider diante do establishment.

Entender historicamente essa afirmação torna-se importante aqui porque ela é esclarecedora também para situações vividas estruturalmente por Almodóvar, ainda que sua inserção no campo artístico tenha sido diferente. Elias explica que, de acordo com a relação outsider-establishment, pessoas pertencentes à posição de outsiders possuem uma necessidade intensa de se fazerem reconhecidas diante deles, pois sentem-se iguais ou superiores ao grupo dos estabelecidos. Ainda que reajam rancorosamente às humilhações a que estão expostas e que reconheçam os defeitos desses grupos, seu desejo é de pertencer a eles. Entretanto, como não conseguem romper a estrutura vigente encontram-se presas e identificadas com as verdades que movem estes grupos e a época. Tal fato se explica devido à duração da relação de poder instituída. padrão de comportamento e sentimento podem exercer uma atração muito 
forte sobre os outsiders [...] A curiosa fixação dos desejos dos outsiders pelo reconhecimento e aceitação do establishment faz com que tal objetivo se transforme no foco de todos os seus atos e desejos, sua fonte de significados. ${ }^{288}$

Percebe-se que a composição e o reconhecimento de alguém notável - e aqui prefiro não fixar nenhum dos termos apresentados: autêntico e gênio, para não impregná-los de sentido - depende de vários fluxos intercambiáveis temporal e socialmente. Outros artistas que estiveram na posição de Mozart viveram situações semelhantes. Mesmo Almodóvar passou e ocasionalmente passa por momentos idênticos, inclusive porque alimentou os mesmos desejos de participar do establishment - ainda que tenha parecido nas entrevistas que o desprezava.

Historicamente, sua vantagem de maior reconhecimento se deu no período em que expandia seu trabalho, pois encontrou um campo cultural em situação suspensa e com regras abertas um tanto fragilizadas em decorrência do inúmeros impactos causados por todas as mudanças da época da transição democrática. Em meio a tantas novidades, esse contexto favoreceu sua projeção. No processo de nova estabilidade, já possuindo registros e condições modificados para a aceitação da produção artística na Espanha democrática este campo pôde criar seu novos mecanismos de triagem. Os fatos ocorridos entre a Academia de cinema espanhola e o diretor demonstram esta afirmação.

Um dos fatores atribuídos às rejeições deve-se também a um mito construído pelo senso comum de que determinados artistas são incompreendidos por apresentarem um comportamento "selvagem" ou ao menos incomum. Novamente Elias contribui para o discernimento dessa questão, afirmando de início que se torna difícil definir na arte entre inovações de sucesso e fracassadas. Isso porque:

[...] as sociedades mais diferenciadas, relativamente desenvolvidas, cultivaram uma alta tolerância quanto aos modos sumamente individualizados de ampliar mais o padrão existente de arte; isto favorece a experimentação e o rompimento de convenções caducas e pode, assim, ajudar a enriquecer os prazeres artísticos proporcionados pela visão e a audição. Sem dúvida, tal não ocorre sem custos ou riscos. Aliás, o rompimento da rotina pode congelar-se em convenção. Porém, em geral, as dificuldades de comunicação que as inovações artísticas implicam são absorvidas com mais facilidade. Pode ser que dêem origem a conflitos; mas há funções sociais (historiadores de arte, jornalistas, críticos, ensaístas) que tentam transpor as lacunas de opiniões contraditórias, atenuar o impacto de ousadias artísticas e facilitar a transição para novas maneiras, pouco familiares, de se ver e ouvir. ${ }^{289}$

As funções sociais a que se refere o autor na verdade cumprem duplos papéis, pois entre os que buscam esclarecer as interpretações, outros não estão muito

\footnotetext{
${ }^{288}$ ELIAS, Norbert. Mozart, sociologia de um gênio. RJ: Jorge Zahar Editor, reimpressão: 1997. p. 39.

${ }^{289}$ Idem, p. 51-52.
} 
interessados nem em compreender, nem em incorporar certas obras no universo oficializado. Algumas das experiências vividas por Almodóvar vistas aqui, comprovam uma dinâmica nesse sentido, muito mais composta de riscos do que de certezas na recepção geral de suas obras pelo establishment. No pensamento de Elias, ainda que muitos escritores se lancem contra o culto idealizador do gênio para torná-lo acessível à humanidade, estes acabam sendo outros adoradores de ídolos. Uma preocupação que permeia também o meio acadêmico, inclusive este trabalho.

No caso de Mozart, o grande conflito era entender como alguém cuja figura humana era tão simples e até vulgar poderia produzir aquele tipo de música quase divina. O autor entende que isto é um reflexo do constante e renovado conflito entre civilizados e sua animalidade, até hoje não resolvido na tradição intelectual européia, que sempre separa o mistério atribuído a um gênio de um lado e sua humanidade comum de outro. Um problema civilizatório não resolvido. ${ }^{290}$

Trata-se de um recurso que contribui para o ato de investigar, mas incorre no erro de manter estanque a totalidade do autor ou de transformar seu talento em algo puramente hereditário, sobretudo suas obras que sobrevivem a gerações posteriores. O que interessa observar não é a pessoa do autor, mas sim o que existe na qualidade de sua obra que a faz permanecer, e estabelecer a conexão das experiências do artista e seu destino na sociedade. Assim como vários artistas ficam obscurecidos ou esquecidos pela história, nem todas as obras dos mais famosos são lembradas. Portanto, genialidade ou autenticidade dependem de aprimoramento e exercício constante, nada inato ${ }^{291}$. Nesse sentido, ainda acredito que a idéia de gênio - mesmo com estas exposições - carregue um estigma que sempre chega a algo inquestionável, e a outra - a de autêntico - ainda não foi tão saturada, por isso mais passível de manusear e exprimir maiores nuanças do perfil do diretor na trajetória de sua obra.

De uma forma inelutável, quando o próprio autor fala de si e seus interlocutores reproduzem suas expressões - como nas entrevistas citadas aqui - há uma dupla elaboração que legitima gradualmente uma imagem cristalizada, a auto-construção e a interpretação dos entrevistadores. Nelas, constantemente formam-se brechas que permitem incluir mais elementos legitimadores em momentos futuros. Um manuseio de cumplicidades. No caso de Almodóvar há um jogo de projeções que não se incorporam definitivamente nele em razão de sua própria personalidade inquieta, mas que ocasionalmente torna-se conveniente para reforçar e trazer de volta narrativas de experiências que foram vividas. Por isso, cada vez que se toca em sua trajetória, 
surgem novas interpretações compostas por um vasto leque de analistas ou comentaristas que acabam por justificar e consolidar seus gestos artísticos.

Em Volver (2006), a vida das personagens é permeada pelo trânsito entre pueblo e cidade. A influência da cultura camponesa do autor revela-se no conjunto dos sentimentos que explicam suas memórias sociais e afetivas, porém a sociabilidade de todas está dentro da lógica cosmopolita de uma Madrid com bairros operários compostos de conjuntos habitacionais, migrantes das várias províncias espanholas e seu ritmo de vida agitado.

Este viés que assume de uma forma sintética as origens do diretor parece definir melhor - inclusive para a aceitação de uma certa intelligentsia cinematográfica espanhola - seu lugar e sua maturidade. Ainda que o contexto de suas produções continue saindo dos padrões de normalidade difundidos pelas regras sociais, ocorre uma negociação menos acirrada do que há vinte anos. E não apenas pelo tempo decorrido, mas também em razão da insistência do cineasta em apresentar sua mensagem de maneira aprimorada.

Sua origem humilde e sua formação cultural autodidata, proveniente da fusão entre uma teoria erudita elementar, sua cultura popular, literatura escrita e cinematográfica eclética e a prática da vida underground dos anos 70 e 80 agressiva a conservadores, definem também um lugar social de classe. Suas personagens de comportamentos excêntricos, que lhe deram a reputação de cineasta marginal no início de sua carreira, complementavam seu próprio perfil irreverente com sua moral e valores - todos expostos: ateu, homossexual, libertário, a-partidário - e reforçaram antipatias e adesões desde que começou a galgar a fama.

Acredito que o período mais caloroso das rejeições e críticas ocorreu entre a primeira - já apresentada - e a segunda fase de seus trabalhos. Esta, que aborda temáticas relativas a classes sociais, toca nas raízes simbólicas da cultura e nos modelos morais disseminados pela Espanha e culmina com a expansão do nome do diretor pelo mundo compreendendo de Qué he hecho yo para merecer esto? (1984) a Mujeres al borde de un ataque de nervios (1987). Porém, é em sua terceira fase, começando em Mujeres al borde de uma ataque de nervios (1987) e terminando em Kika (1993), que ocorrem as principais oscilações que o obrigarão a repensar seu cinema.

Nesse conjunto de filmes, o diretor apresenta situações ligadas às raízes culturais tanto do campo como da cidade, começa a tocar nos conflitos interiores

${ }^{291}$ Ibidem. p. 57-58. 
ligados aos sentimentos e acentua críticas à mídia em Tacone Lejanos (1991) e sobretudo em Kika (1993). A projeção internacional conquistada por Mujeres al borde de uma ataque de nervios (1987) havia dado a Almodóvar uma aura de proteção dentro da Espanha que calou muitos setores e curvar-se diante de sua popularidade estrangeira. Seu próximo trabalho, Átame (1989), causou polêmica pelas cenas ousadas e Tacone Lejanos (1991) foi criticado pelo melodrama cambiante malestruturado. O clima já não estava favorável ao cineasta até que chega Kika (1993) com sua narrativa caleidoscópica. Neste último, após as ofensivas de períodos anteriores, o diretor revidava com suas ironias críticas à publicidade e à TV, revelando indiretamente as ligações nada fáceis entre autor e mídia. Em sua estréia, o diretor reafirmou a imagem de incompreendido, preparando o público para sua novidade: soy un director polémico porque no todo el mundo entiende los mensajes de mi
cine $^{292}$.

Era insuficiente. Kika não foi poupada dos especialistas, ávidos por um desequilíbrio maior do diretor. O fracasso de crítica em kika, quando tudo já parecia estar devidamente acomodado para Almodóvar, evidenciou bem o quadro de constrangimentos e preocupações que envolvem trabalhos artísticos e recepção de público. O filme abriu a chance para a crítica mais tímida - sobretudo a espanhola, que se via um pouco acuada com tantos elogios internacionais ao diretor - de lançar suas insatisfações ao trabalho. Alguns críticos afirmavam que o império de Almodóvar estava começando a ruir. Sem a densidade melodramática de Tacones lejanos, Kika passou a ser o grande bode expiatório do diretor. Utiliza cenas que nos Estados Unidos foram censuradas e projeta uma crítica frágil à televisão. Por outro lado, possui uma linguagem dinâmica e fragmentária que não segue nenhum gênero e funda caminhos inéditos para o estabelecimento de diálogo entre mercado, moda, televisão e publicidade.

A repórter Andréa Caracortada, personagem surreal que parecia oriunda da vida noturna underground chic de qualquer metrópole no mundo com sua roupa emborrachada - se não fosse a câmera filmadora que possui na cabeça -, transita incorporada literalmente na tecnologia hightec em nome do sensacionalismo televisivo. A película dava a entender ao público que tudo dali por diante não teria mais novidades e que a fórmula Movida madrileña - praticamente desaparecida de suas películas com essa história dava seus últimos suspiros e o cineasta já apresentava esgotamento do que teria para dizer ao público.

${ }^{292}$ EI Mundo, año I, nº21 - Cinelandia, Madrid, 30. 10. 1993. p. 3. 
Quatro críticas a este trabalho demonstram já em seus títulos como funciona a mescla de expectativas entre sucesso e fracasso sobre figuras autônomas e polêmicas como Almodóvar, sobretudo na sociedade espanhola:

\section{Kika, uma mistura sem idéias}

O cinema de Pedro Almodóvar ansiosamente impactante e provocador, parece haver tocado seu limite. Durante alguns anos, cada uma de suas (esperadíssimas) películas tiveram uma mudança, um truque, amparando-se sempre nos gêneros que mais dão prazer ao diretor manchego: o melodrama folhetinesco (La ley Del deseo, Tacones lejanos) e a comédia delirante (Laberinto de pasiones) ou de ambiente sofisticado (Mujeres al borde de un ataque de nervios). Com Kika não se sabe ao certo o que Almodóvar quis fazer. É uma collage genérica, de fato, mas os elementos dispersos se acumulam atropeladamente e não se consegue, em nenhum momento, uma fusão fluída e progressiva dos muitos traços temáticos dos personagens que se apresentam. Há no filme um pouco de tudo para satisfazer os seguidores mais fervorosos do diretor [...] mas o conjunto resulta deslavado, com uma história que avança a tropeços, personagens sem verdadeira identidade e relações nunca trabalhadas a fundo [...] Em suma, o máximo estandarte do cinema espanhol dos anos 90 necessita renovar-se já que ficou sem seu famoso galã" ${ }^{293}$ [referindo-se a Antonio Banderas que havia aceitado convite para filmar nos Estados Unidos].

Outro jornal expressivo no país também apontava na mesma data a decadência de Almodóvar:

A Lei do desastre [uma paródia maldosa com o título La ley del deseo]

Kika é uma película de orçamento alto - diante da média espanhola - e parece produzida e elaborada com meticulosidade sem medir gastos, fato que a permite alcançar um look agradável. Sobretudo por causa da capacidade de solução do olhar de Alfredo Mayo na câmara. Mas não é uma boa película. Ou, dizendo de outro modo e endurecendo a frase: é uma má película. O fato de que este jeito anti-cinematográfico contenha uma zona com o verdadeiro cinema - a pitoresca e bem formada Verônica Forqué e a composição que fazem esta atriz e Rossy de Palma os personagens de Kika e sua criada - não eleva a película. Um filme é um todo, e o fato de que uma película medíocre contenha uma cena não medíocre, uma composição verdadeira e algumas ocorrências divertidas não redime sua totalidade. Ao contrário, estas graças e soluções parciais ampliam a insuficiência do conjunto. Não se descobre nada de novo: Almodóvar é um brilhante idealizador, um sagaz promotor, um diretor imaginativo, um engenhoso conversador e um mal escritor de películas [...] o que em 'Mujeres ...' e Átame era um simples, ainda que condenável desequilíbrio entre texto e visualização, em Kika tal desequilíbrio adquire proporções sem salvação, mortais. Uma película de ficção convencional é. antes e sobretudo, uma construção, mas em Kika não há armação alguma: há uma sucessão amorfa de sucessos confusos e de ocorrências sem efeito, quando muito, momentâneos $[\ldots]^{294}$.

No mesmo período, Fernando Baeta advogava em favor do autor, com um alerta: "Almodóvar, tenha cuidado com o porco". Seu artigo compara uma situação histórica da transição espanhola num conflito entre ácratas e comunistas: todas as noites em que eram apagadas se colocavam novamente nos muros duas pichações: "vamos a matar al cerdo de Carrillo"e "cuidado Carrillo, que te quieren matar al cerdo".

\footnotetext{
${ }^{293}$ CASAS, Quim. Una mezcla sin ideas. El Periódico. Madrid, 06. nov. 1993

${ }^{294}$ FERNÁNDEZ-SANTOS, Ángel. La ley del desatre. EI País. Madrid, 06. 11. 1993
} 
Ahora que se acercan Kika, Pedro Almodóvar y toda su parentela yo me acuerdo del cerdo de Carrillo [...] Creo que se quiere sangre de ese gran vendedor de si mismo que es Pedro Almodóvar, con o sin su cerdo, puira sangre de genio. Aqui en España, en el cine español, no se quieren ni cerdos ni genios vitalicios, y es deporte nacional lograr bajar a los infiernos al que antes hemos ocupado a los altares. Conveniente es no olvidar que una cosa es que le digamos que es un genio, y otra muy distinta que él se lo crea y actúe como tal, con o sin su cerdo, sin encomendarse al altisimo. Además, el desado es un provocador [...] es adorado por el francés y admirado, en clase ' $X$ ' [refere-se à classificação usada nos Estados Unidos na época para definir nos cartazes das salas de cinema, os filmes pornográficos, nos quais Almodóvar já tivera essa taxação, inclusive para esse filme] por esos pocos pero interessantes norteamericanos que no se parecen en nada a la mayoria de los norteamericanos. Cuidado Almodóvar que te quieren matar el cerdo ... ${ }^{295}$

O último comentário, quando do lançamento do filme em vídeo, também reforça as posições negativas anteriores:

confirmação da decadência de Almodóvar. Kika foi uma decepção já anunciada por Tacones lejanos e referendada pela posterior La flor de mi secreto, ainda que logicamente tudo é relativo e seus admiradores, suponho que discordem dessas afirmações. Como ocorre com a maioria dos filmes de Almodóvar, Kika é difícil de classificar em um gênero determinado porque costuma misturar notas melodramáticas, suspense, humor, homenagens cinéfilas e a inevitável presença de artistas convidados, os amiguinhos e amiguinhas de plantão, que são alguns da maturidade de seus filmes, já que condicionam sua linha narrativa lógica ${ }^{296}$.

Esse quadro ilustra algumas das expectativas daqueles que observam 0 trabalho e a imagem do diretor de maneira reservada ou recusando-o como cineasta competente. À leitura de sua construção pública irreverente, associa-se um cinema feito para agradar e garantir fãs, feito - pejorativamente - com amigos ressaltando o caráter superficial e mal estruturado da narrativa. O resultado surte num efeito que une artista e obra como medíocres. Posturas diretas assumidos pelo o conjunto dos críticos concentrados na falta de habilidade do diretor para elaborar e consolidar seu roteiro e sua direção. Retiram Almodóvar de seu pedestal e um alerta solicita que o diretor saiba observar mais sua estatura cinematográfica antes que caia em ilusões e decepções.

Em resposta, numa coletiva à imprensa em Barcelona quando do lançamento da película na cidade, Pedro Almodóvar rebateu certas acusações:

Las críticas esta vez no me han afectado, las he olvidado a los cinco minutos [ as que ouvi a cinco minutos, já esqueci]: será que me estoy haciendo mayor? [envelhecendo] (comentou alegre) [...] hay una necessidad de cambio em mi vida, y supongo que también en mi cine. Por eso Kika es como es, un filme deliberadamente no lineal, con algunas zonas oscuras, en el cual hurto información al espectador, que probablemente se quedará con ganas de saber más sobre los personajes. Ése es el reto, si se aceptará o no mi opción. [...] A los críticos de Madrid los conozco a todos, y sé qué hay detrás de cada coma que escriben. Han sido injustos porque han olvidado que la película no soy yo, sino un equipo de gente cuya labor han silenciado. No obstante, no me

\footnotetext{
${ }^{295}$ BAETA, Fernando. Almodóvar, ten ciudado con el cerdo. El mundo, Madrid, 23. 10. 1993

${ }^{296}$ COMAS, Àngels. Kika - confirmanción de la decadencia de Almodóvar. Revista 8 - La Vanguardía. Barcelona, 14. out. 1996.
} 
preocupan porque para mí el primer dato principal es que en el primer fin de semana ha recaudado 100 millones de pesetas [602.409 euros] en toda España. $Y$ eso es un bombazo ${ }^{297}$.

O uso da ironia nas declarações do diretor acaba resultando numa postura de não aceitar críticas, ao que ele logo justifica a incompreensão destes analistas que não percebem sua mudança de perspectivas de vida, narrativas e cinematográficas, que se encontram subentendidas na película. Nesse momento, a citação da equipe o ampara como defesa de um trabalho coletivo e não só de sua autoria, indicando suas intenções gregárias e não personalistas. Um discurso que mistura as várias esferas de sua criação, visando a proteger-se. O apego ao argumento de sucesso de bilheteria assegura-o de sua popularidade para rebater críticas muito ofensivas. Isso aparece em diferentes momentos para se justificar diante de outros setores, além da mídia. Nessa mesma época, rivalizando com a Academía de las Artes y Ciencias cinematográficas de Espana, que a cada ano diminuía as indicações de seus filmes ao prêmio Goya, trata com descaso a atitude de seus membros e mantém seu apego aos resultados de bilheteria:

[...] no le guardo ningún rencor a La Academía del Cine Español, no creo que nadie esté obligado a darme premios. Además, habiendo recaudado con Tacones Lejanos 850 millones de pesetas [512.048 euros] sólo en España, no necesito premios $[\ldots]^{298}$

Seguem na mesma matéria seus comentários acerca da crítica que renegou Kika, as repercussões do filme na França e a forma por onde se estrutura este trabalho tão contestado. Diferente de outros momentos, em que a ironia bastava para responder a seu duelo com o julgamento dos críticos, ele demonstrou também que há limites suportáveis para qualquer artista. No trecho abaixo, suas respostas ao que julgou uma injustiça com seu trabalho e trajetória alinham várias dimensões: sua auto-construção - a idéia do incompreendido - e a posição jornalística que "recortou" os discursos, proporcionando uma nova montagem e um caminho interpretativo que indica os intercâmbios de campos e de interesses:

Almodóvar, que ha confesado que hacer películas es una pasión que ha fagocitado su vida, estrenó en octubre Kika, décima película de su carrera, denostada [detestada] por la crítica pero bien recibida por el publico. Antes de estreno, el 17 de octubre, confesaba en El País: "Kika es mi pelicula menos clasificable, la menos definible". El 1 de noviembre decía en Tiempo: " no estoy preparado para un fracaso y tengo un miedo atroz". El miedo del realizador resultó premonitorio. La crítica vertió mayoritoriamente comentarios negativos sobre el film. Acerca de esto en el número de la revista Fotogramas de diecembre, Almodóvar dice: "no leo todo lo que se publica sobre mi, pero leo mucho y me afecta más de lo que yo quisiera, sobre todo si tiene que ver con personas que me rodean [...] frente a Kika ha existido una unanimidad 
extraordinariamente negativa, por eso utilizo la palabra linchamiento. No quiero caer en el recurso facilón de hablar de la envidia [inveja], ni del ajuste de cuentas, no deseo sentirme víctima".

Por todo ello, la relectura del texto que Pedro Almodóvar escribió sobre Tacones Lejanos en noviembre de 1993 para el número 200 de la revista cinematográfica francesa Première, adquiere mayor significado: "el César y el reconocimiento francés me han servido para compensar la frialdad y la envidia mal contenida de mis colegas españoles. Yo no hago cine para ganar premios. Mi único interés es contar una historia en la que pongo mi vida, intentar que sea transparente y comprendida lo mejor posible. Cuando ésto ocurre es un milagro. Si no, no pasa nada grave. La incomprensión y el fracaso forman parte de la vida y el cine. De todas formas, 'merci beaucoup!'

A su vez Cahier du Cinema dedica la portada de este mês a Almodóvar (también se la había dedicado en julio de 1991), doce páginas y una crítica entusiasta en la que Frédéric Strauss - que publicará en febrero un libro de entrevistas con el director - asevera: "es ésta una película-resumen y evidentemente personal (en beneficio de la emoción única que surge), lo más avanzada a su tiempo que se pueda imaginar". Después, en una entrevista con el critico, Almodóvar dice en respuesta a una pregunta sobre el estimulante juego que Kika propone al espectador si se acepta la lógica del 'puzzle' [quebra-cabeça] y los personajes en caleidoscopio: "lo que más me sorprende es que las gentes especializadas del cine, los críticos, deberían haberlo visto como usted. Pues no, en España ha sido el público el que lo ha comprendido. Pero éste es un terreno que no quiero entrar porque lo que se ha hecho en España conmigo es lo más parecido a un linchamiento".

El 7 de noviembre respondió en el Periódico a la pregunta de si sus películas podian ser consideradas documentos sociológicos de la España de fin de siglo: " en la parcela que me corresponde represento la España que he vivido en este sentido, Kika es muy elocuente del desasosiego que vivimos ahora. Trato de contar la hostilidad en la que vivimos" ${ }^{\prime 299}$

Os vários elementos de relação entre imprensa, crítica e diretor aparecem na própria estrutura do texto apresentado. A autora busca tecer seus comentários simpáticos ao cineasta, no entanto, evidenciando os problemas pelos quais passa com seu filme diante dos agentes sociais que circundam autor e obra. A recepção diferenciada marca um meio termo onde se pode relativizar olhares e imputar valores. Eles podem surgir de diversos ângulos, portanto pareceres negativos de especialistas representam apenas uma visão. Ao mesmo tempo, quando eles se mostram favoráveis, cria-se uma sobrecarga de legitimação ao diretor que o permitem rebater com mais tranqüilidade os argumentos menosprezadores. Sobretudo quando se estava às vésperas do lançamento de um livro sobre sua trajetória e a crítica provinha de um grupo entre os mais respeitados e tradicionais da Europa na área cinematográfica, o Cahiers du cinéma.

Ele articula as várias posturas a seu favor desconstruindo seu próprio discurso de que a crítica não o interessa. Inversamente, nessa matéria evidencia suas preocupações e confronta as opiniões e análises contrárias sobre o mesmo trabalho. Amplia com isso a polêmica, projetando-a internacionalmente ao questionar a capacidade da crítica nacional. Deposita e sabe da importância dos prêmios e críticas, 
pois, além de vinculados, contribuem para a divulgação de seu trabalho. Assim, apesar da afirmação de que só busca se expressar, subjazem seus anseios de suscitar várias indagações sobre seus trabalhos e de provocar controvérsias, pois estas o mantêm em evidência.

Mais uma vez a preocupação com os amigos e pessoas que o cercam surge como elemento importante na vida do diretor aliado à sua interpretação de ser incompreendido. Dentro dessa lógica segue a declaração de que filma seu universo - a Espanha vivida por ele - reforçando um dos argumentos deste trabalho de que Almodóvar é um cineasta do presente e ocupado em revelar os sentimentos e sensações do que vê ao seu redor. Como visto na discussão sobre a cidade, Kika era seu momento de relação com uma Madrid incontrolável e frenética, insegura para um diretor que viveu o oposto - ao menos em seu meio - na Movida.

Apesar da adesão de Cahiers du Cinéma, na figura do então redator chefe adjunto da revista na época, este filme também não obteve fora da Espanha toda a aclamação dos anteriores. Lançado na França com uma promoção excepcional pela produtora Ciby 2000 - co-produtora do filme com El Deseo - em 21 salas de cinema, ocupando páginas inteiras de jornais, revistas, além de entrevistas em redes de TV e rádio, a crítica não mostrou muito entusiasmo. Com a manchete: Kika se estrena em Francia com duras críticas - la prensa dice que Almodóvar se repite ${ }^{300}$, a correspondente de El Periódico em Paris informava que os jornais foram unânimes em afirmar o caráter insólito da película:

\begin{abstract}
El semanario L'Express ve en Kika la expressión de la crisis em que se encuentra sumergido no sólo el cineasta sino toda España [...] otros consideran la película como una obra maestra y todos coinciden en señalar que se trata de un filme "extraño" e "inclasificable" [...] por su parte Almodóvar, para hacerse perdonar, ha medio prometido que su próxima película la rodará en Francia y con actores franceses. Con ello trata de conseguir que les quite la molesta impresión de deja vu de la cinta del director manchego" ${ }^{301}$
\end{abstract}

A próxima produção de Almodóvar foi La flor de mi secreto (1995), totalmente rodada em Madrid. Apesar da promessa não cumprida, este filme garantiu a volta de seu prestígio entre os franceses e que continua a cada estréia de uma nova produção. Diferente destino ocorreu nos Estados Unidos. Kika foi a terceira película a causar escândalo no país - as outras foram exatamente as duas anteriores Átame e Tacones lejanos - e provocou a indignação do cineasta, somando mais um onda polêmica em seu currículo:

\footnotetext{
${ }^{300}$ CAPDEVILA, Montse. Kika se estrena em Francia com duras críticas - la prensa dice que Almodóvar se repite. El Periódico, Paris, 21. jan. 1994.
} 


\section{Pedro Almodóvar contra la censura norteamericana}

Pedro Almodóvar ha hecho público un comunicado dirigido a los 'medios de información americanos' en el que denuncia la censura sobre su película Kika, por parte del órgano censor estadounidense, la MPPA (Motion Pictures of America), que la ha prohibido a los menores de 17 años. Tras señalar que, "vivo y trabajo em España, lo cual significa hacer ambas cosas en liberdad. En este continente no existe la censura, siempre me olvido de ella hasta que alguna de mis películas va estrenarse en Estados Unidos [...] me sorprende que sea una asociación privada la encargada de clasificar las películas y más teniendo en cuenta que se trata de un lobby, es decir, un grupo de empresas con intereses muy concretos, los cuales les involucran en la materia que están clasificando [...] no estoy buscando polémica [...] el valor de una obra no se mide por los centrímetros de piel [pele] que muestren sus intérpretes, ni por la cantidad de gemidos, ni palabras malsonantes que digan. Su valor es algo más profundo. Deben ser el espectador y el tiempo quien lo dictaminen. El resto sólo es miedo, hipocresía y un mal entendido paternalismo. ${ }^{302}$

\section{Pedro Almodóvar pierde su batalla americana}

Los Angeles - "Almodóvar no es un pornógrafo; es una verguenza que equiparen su película con el cine para adultos". Jeff Lipsky, presidente de October films (distribuidora de Kika em Estados Unidos) abandonó ayer [ontem] indignado la Junta de Clasificación y Censura norteamericana. El director español se desahogaba [desabafava] sin tapujos [disfarces] tras el preestreno de la película en Los Angeles: "Sé que si quiero labrarme una carrera en América debería ser más discreto, pero ya me da igual [mas agora, é indiferente] (...) un sector de la prensa norteamericana se há sumado también a la campaña moralizadora. Varios periódicos, entre ellos el New York Times, se han negado a incluir el anuncio de la película por considerarlo obsceno (Victoria Abril luce [ostenta] dos pechos [dois peitos] de postín [de luxo] que sobresalen del traje).[... $]^{303}$

\section{Los menores de edad no prodrán ver Kika em EE.UU.}

Nueva York - Pedro Almodóvar vuelve a ser noticia en los Estados Unidos por culpa de los ratings, las arbitrarias clasificaciones de la MPPA. Kika se estrena esta semana com la clasificación NC-17, que em realidad equivale a la antigua $X$ prohíbe la película a los menores de 17 años, hecho que imposibilita su exhibición em los grandes circuitos estadounidenses. ${ }^{304}$ [...] Lo que más molesta a Almodóvar es que la MPPA es una asociación de carácter privado que depende de las majors de Hollywood y que lógicamente defiende unos intereses específicos. Según una nota difundida por October films, distribuidora en Estados Unidos de kika, la MPPA discrimina claramente a las películas independientes [...] Almodóvar pone como ejemplo a Instinto básico, que considera una película moralmente cuestionable, y sin embargo también mereció únicamente la $\mathrm{R}$, porque "pertenece a uno de los estudios que forman parte de la MPPA, mientras que kika es un filme europeo indefeso, dirigido por un conocido degenerado español" [...] Pedro Almodóvar ha destacado en sus entrevistas con los medios norteamericanos, que estos días realiza en Los Ángeles con motivo del inminiente estreno de kika, el hecho de que la MPPA es una instituición privada que no ha sido elegida por el voto popular. "Como pueden guiar al público los señores de la MPPA, quienes no representan a nadie más que al poder establecido de Hollywood?", se pregunta Almodóvar, que há vuelto a sentirse "insultado, humillado e incomprendido"305

\footnotetext{
${ }^{301}$ Idem.

${ }^{302}$ Pedro Almodóvar contra la censura norteamericana. ABC. 23. 04. 1994.

${ }^{303}$ FRESNEDA, Carlos. Pedro Almodóvar pierde su batalla americana. El Mundo - cultura, Madrid, 30. abr. 1994. p. 67.

${ }^{304}$ Em 1990, Almodóvar já havia enfrentado um mal-estar com a empresa devido à proibição de Átame. Na ocasião, o diretor escreveu uma carta aberta comparando a censura dos Estados Unidos à intransigência de Franco na Espanha. No processo de discussões, o diretor conseguiu modificar a lei que utilizava o X para filmes ditos pornográficos para a lei que amenizava as sanções com o NC-17.

${ }^{305}$ PARRONDO, Jorge. La Vanguardia - espetáculos, Barcelona, 01. mai. 1994. p. 62.
} 
A polêmica causada e a conseqüentemente auto-promoção da imagem do diretor,, parecem ganhar terreno. Mas o que revelaram e passaram para o primeiro plano foi sua inquestionável garra para garantir a livre expressão artística no cinema. A idéia do desejo, que marca sua produtora e suas temáticas, encarna-se literalmente em sua prática pessoal e profissional. Em seu discurso, a Espanha se transforma no país da liberdade, rechaçando seu passado franquista e questionando a hipocrisia do mito norte-americano firmado nessa máxima.

Os dados também explicitam o jogo mercadológico misturado a ideologias e corporativismos que apontam o cinema como um grande universo de interesses. A incompreensão proclamada novamente pelo diretor serve como ferramenta de denúncia e amplia sua autenticidade no sentido discutido nesse capítulo. Isso o faz avançar em suas convicções. E o fato de possuir popularidade internacional favorece seus pronunciamentos. Cada controvérsia movimenta seu nome no circuito cinematográfico e nos setores coligados.

O filme La flor de mi secreto (1995) começou a modificar este quadro e a própria intelectualidade espanhola passou a olhar seus trabalhos de maneira mais séria, ainda que com receios. Coincidência um pouco suspeita, a exemplo de Qué he hecho yo para merecer esto, esta produção também toca nas raízes camponesas do diretor e fala das insatisfações da mãe idosa que não gosta de Madrid e quer voltar ao pueblo. Na outra película, a mesma atriz Chus Lampreave intrepreta a avó que levará o neto para o campo. Entendo como suspeita, porque os setores que não simpatizam com os filmes e as posturas de Almodóvar parecem demonstrar um alívio ao visualizarem que ele sabe seu lugar social e do que falar com mais propriedade.

Diante do mercado internacional, sobretudo o norte-americano, o recado do diretor era outro. Para amenizar os ânimos, quando estava na metade das filmagens, Almodóvar concedeu uma entrevista coletiva onde anunciou que aquela seria uma película sem sexo e sem drogas: una película para todos los públicos, incluido el americano $^{306}$. Preparava seu mercado e seu público, sem deixar de tecer um pequeno comentário sarcástico aos que haviam rejeitado sua produção anterior. Ao que tudo indica, a estratégia foi positiva. No ano de seu lançamento, o filme foi indicado pela Academía de Arte y Ciências Cinematográficas de España para concorrer ao Oscar de Hollywood, com um paradoxo: não obteve nenhum prêmio Goya frente às sete indicações que havia recebido.

${ }^{306}$ MONTERO, 03. mar. 1995. 
O escritor Román Gubern tentou aventar algumas razões que explicassem esse fato. Uma delas seria a inveja e os ciúmes diante de um artista celebrado mundialmente. Negar um prêmio a ele seria uma forma de castigá-lo - como uma correção religiosa que o recordasse de sua condição humana e não divina - ou minimizar seu triunfo, a exemplo da frase: ninguém é profeta em sua terra. Uma segunda razão, mais diplomática, seria exatamente sua projeção internacional que não precisa mais de visibilidade. O recurso dos prêmios poderia ser dado ao novatos ou menos estabelecidos. Com o Oscar a situação mudaria de figura. Como Hollywood premia fundamentalmente filmes que indicam tendências comerciais de indústrias consideradas mais convincentes de acordo com suas necessidades mercantis, o filme de Almodóvar seria interessante para ampliar mercados fora da Espanha. ${ }^{307}$

Acredito que essas duas razões caminham juntas em relação ao diretor e em cada contexto uma ganha mais relevância sobre a outra, porém nunca abandonando o espaço das negociações. A imagem que o próprio Almodóvar construiu sobre si contribui nesse aspecto. Não só por suas polêmicas, mas pela forma como sabe administrar sua atividades dentro e fora do país, sempre dinamizando projetos e estabelecendo acordos independente das políticas culturais internas. Com a recente saída dele e do irmão da Academia de cinema espanhola esse quadro tomou algumas tonalidades mais brandas, mas a lógica continua a mesma. Ele faz o marketing de si mesmo e carrega com ele a imagem da Espanha, ainda que isso desagrade a muitos que prefeririam um perfil mais "enobrecido" como o masculino, burguês Luis Buñuel. Até neste aspecto o diretor utiliza sua irreverência.

A ironia que Almodóvar desenvolve em seus trabalhos - e que provoca tantas reações distintas onde são exibidos - surge num momento de explosão democrática e de liberdade comportamental. Os efeitos daqueles tempos festivos se encontram disseminados por sua obra, caracterizando uma ironia peculiar, considerando que esta já existe na produção geral das artes no país. Sua construção preocupa-se em desprezar a rigidez das relações e viver intensamente um presente rico de novidades. Não se pretende a uma crítica de valores morais ainda que esta apareça nos comportamentos de seus personagens, nem à elite como fizeram Buñuel, Saura e outros cineastas espanhóis. Em uma entrevista quando havia acabado de estrear $L a$ ley del deseo sua intenção era categórica e não se modificou muito no decorrer de sua carreira, mesmo com a mudança de perfil de classe social de suas personagens:

Historias siempre de gente marginal, desclasadíssima, demencial, aunque tratada con un cariño brutal.

${ }^{307}$ GUBERN, Román. El Periódico. Madrid, 31. jan. 1996. 
- no te imaginas describiendo una historia de la jet-set [elite], por ejemplo, de personas en la antitesis de tus personajes acostumbrados?

- Hombre, podría hacer una historia de jet-set, pero no los trataría bien. Los reflejaría si se pariecieran a los de La dolce vita de Fellini, pero nuestra jet-set es la cosa más cutre [tacanha] del mundo. Entonces, ahí me sale mi conciencia social, los trataría con crueldad y no quedaría otro remedio. Los nuestros, esa élite, son seres tan grotescos que me puedo acercar a ellos con humor pero, inevitablemente, mi corazón apoya otras clases sociales [...] no puedo renunciar ni enmascararlo. Todo lo contrario, es un elemento básico, son mis raíces, mi educación. Tampoco caigo [caio] en el alegato [discurso] social, que no lo hago [que não faço], pero soy muy consciente de donde estoy, de donde vengo. Lo mismo aparezco por la tasca [taberna] más inmunda que a una fiesta que dé el rey. Y me siento afortunado por eso, porque puedo ser testigo de casi todo lo que ocurre en el país, de lo más bajo a lo más alto $[\ldots]^{308}$

Esse desprendimento, que lhe parecia tão natural diante das classes, em sua maturidade permanece nos filmes. Os traços daqueles que estão à margem da sociedade perfilam-se de maneira mais sutil do que antes. Não são apenas os marginais socialmente reconhecidos como o ex-detento Victor de Carne tremula (1997) ou o travesti Agrado de Todo sobre mi madre (1999) que revelam as afinidades do diretor. As personagens pertencentes a um perfil de classe média dialogam com seus dilemas relativos a afetos e à morte como fator de mediação de valores. $E$ nestas abordagens estão presentes várias gradações polêmicas envolvendo as diversas possibilidades de compreendê-las. Em Hable con ella (2002) não só as duas mulheres encontram-se num tipo de morte cerebral - das quais uma volta à vida - como a relação de amizade entre os homens culmina num rompimento de morte. Mas o que tensiona a trama é a atitude de Benigno, que acaba por engravidar Alícia que estava em coma.

São os excêntricos que convivem entre os convencionais que ganham projeção. Almodóvar retira-os do tratamento narrativo tradicional sempre enfocando-os como dotados de maldade, psicose - em geral vilões na histórias - e desequilibrados, para situá-los em zonas intermediárias ou na vida cotidiana onde podem desenvolver seus sentimentos e encontrar alternativas de realização. São os inúmeros solitários interpretados sob diversas possibilidades de existência que habitam o imaginário do diretor, com os quais ele se solidariza por encontrar-se sentimentalmente em condição análoga. Essa naturalização de personagens dispostos todos no mesmo plano geralmente é o principal causador das polêmicas. As cenas de sexo - quando acontecem -, nesse contexto, só contribuem para complementar os efeitos das prováveis reações morais já ocorridas nas atitudes das personagens.

O confronto entre as classes sociais na trajetória de sua obra não compactua

\footnotetext{
${ }^{308}$ TORRELLAS, María. Entrevista com Pedro Almodóvar. Lo mismo voy a una tasca que a una fiesta que dé el Rey. Diario de Barcelona, Barce1ona, 1986. p. 16.
} 
com ideologias que atendam os interesses de manutenção ou divisão de classes sociais nos moldes clássicos vinculados a teorias revolucionárias ou conservadoras. No entanto, não deixa de aparecer na trama o lugar das classes e seus papéis. Os valores demonstrados nas obras estão organizados de maneira incômoda no sentido de questionar as normas instituídas. Optando pela ironia, o cineasta descomprometese de uma crítica social tradicional livrando a narrativa do enfrentamento direto sobre as questões de classe e seus conflitos tradicionais.

Os discursos racionalizados nos padrões oficiais de leitura artística, habituais de cineastas ilustrados e apreciados pelo establishment cultural, perdem força diante da ótica do desejo enfocada pelo diretor. De um lado, a ausência de normas sociais se sobrepõe a qualquer outra determinação. Não por acaso suas polêmicas causam malestar para um círculo que partilha dessa crítica. De outro, em vários aspectos das ações dramáticas tudo se naturaliza, abrindo espaço para que os sentimentos ganhem destaque nas cenas, impondo-se diante das estruturas sociais que barram e impõem limites às relações humanas.

Dado que esses aspectos também fazem parte de sua trajetória pessoal, o resultado é um complexo efeito de recepções irregulares, pois sua marca de cineasta que busca continuamente conquistas o torna virtuoso. Mesmo quando Almodóvar não serve de modelo comportamental a ser seguido, o prestígio por suas qualidades como homem digno de suas vitórias supera suas imagens polêmicas. Estes elementos povoam as interpretações. Frente à rejeição encontra-se a fama e o êxito universal do cineasta. Diante desses fatos - como ocorre com outros personagens tornados ilustres -, o respeito por sua obra cresce.

Alguns autores sentenciam que Almodóvar é uma moda. Que seus filmes serão esquecidos com o passar dos anos, principalmente porque não constituiu escola. Outros afirmam que ele continuará sendo incompreendido - sobretudo na Espanha porque suas histórias contêm críticas que surtem mal-estares sobre os espanhóis e estes resistem a olhares destoantes de suas tradições. Diante da ausência de respostas, continuam os confrontos.

\section{3 Fama não basta, talvez tranqüilidade}

A busca pelo êxito difere radicalmente da fama segundo Pedro Almodóvar, para cada um ele reconhece o ônus que pagou. Desde os prazeres aos aborrecimentos. Em algumas das entrevistas apresentadas até aqui, alguns dos fatores que contribuíram para essa escalada já foram sinalizados. Em todo caminho trilhado, o 
diretor reconhece a importância do amparo de amigos e do trabalho em equipe. Não por acaso, quando se preocupa com sua imagem, esta se projeta nos filmes, estes naqueles que o rodeiam e, por sua vez, ele de certa forma trata de protegê-los. Apesar de carregar a marca de uma celebridade que se fez sozinha, suas constantes referências ao grupo que trabalha em sua produtora não deixam dúvida sobre sua cumplicidade e gratidão a todos.

Humildade no reconhecimento da camaradagem, soberba diante das inúmeras ironias da crítica. Estes são alguns dos elementos que se contrastam e aumentam sua fama em meio a inúmeras construções que fazem dele, mas que o próprio Almodóvar também se encarrega de auto-construir às vezes em busca de explicar para si o que falam ou o que não entendem dele. A cada indagação provocativa que recebe e lança uma explicação, logo esta caminha no sentido de tornar-se legendária. Este fenômeno é reconhecido como fama.

E no decorrer de sua carreira verifica-se em suas atitudes um certo desgaste em vê-lo justificando cada concepção de vida que possui, cada valor que carrega. $O$ diretor demonstra um considerável grau de indisposição para se relacionar com a fama - algo que diz não ter desejado 309 - mas que inevitavelmente o persegue a cada filme bem ou malsucedido. Já em 1984 isso o sufocava:

\begin{abstract}
En principio, el éxito es muy agradable, y como a mí me gusta experimentarlo todo, pues me apetecía conocerlo. Me divertían las entrevistas, etcétera, pero no era el mundo del éxito en sí mismo lo que yo anhelaba [almejava], sobre todo porque el éxito en si mismo, si supone lo de Georges Miller, que tiene todo un staff detrás de él, que le protege, que le soluciona las pegas [as dificuldades], que se lo monta por todo lo alto, ese éxito sí me podía interesar, pero como en España eso se traduce en que te invitan a muchas fiestas, en que te hacen muchas entrevistas y en salir en muchas revistas, eso realmente no es lo que yo había soñado, porque además no es nada divertido. En lo que sí coincide este mundo con el que había imaginado es en lo de poder trabajar en un medio como el cine y vivir de ese medio. ${ }^{310}$
\end{abstract}

O encanto e o desencanto com o universo cinematográfico chegaram para o diretor simultaneamente com as normas de qualquer outro tipo de trabalho. Sem essa dinâmica - inerente a quase todos os ramos da arte - o cinema não se sustentaria. Assim, com este fenômeno em sua vida, o cineasta descobriu e aprendeu as várias regras que regem o cotidiano do campo artístico e cinematográfico. Orientações que exigem de seus integrantes atitudes artificiais que pareçam voluntariamente naturais no intuito de garantir espaços, trabalho, contatos, uma certa legitimidade ou ao menos um bom trânsito nesses círculos. O diretor sabe que as festas são importantes pontos de encontro para estabelecer contatos. Sua postura acuada, aos poucos, se revela mais

${ }^{309}$ LA TORRE, 07. NOV. 1993. 
estratégica:

[...] vivir el éxito te obliga a compartir situaciones con tanta gente que no te gusta, que cada vez te separas más del entorno y estás más interesado en demostrar cómo eres tú en realidad. Porque el éxito es un proceso muy esquizofrénico habla de ti, y cuando lo hacen, parece que están hablando de otra persona, pero nunca de ti. Y cuanto más hablan de ti, menos se sientes reflejado, y entonces necesitas de un modo más violento el imponerte, el llamar la atención de que eres tú ${ }^{311}$.

Esta queixa do "não encontro de si mesmo" indica o primeiro sinal da necessidade do diretor em criar uma personagem pública para defender-se. Na prática, isso já havia acontecido desde antes de sua estréia no circuito de cinema oficial e colaborou para expandir sua imagem rapidamente na figura do cineasta polêmico. Sua afirmação de que buscou o êxito e não a fama - circunstâncias para ele bem distintas se processou com esse recurso, tanto no plano nacional como internacional, espontaneidade e representação diluíram-se num mesmo papel:

[...] una cosa es el éxito, otra la fama y otra, manejar a uno y otra. Por ejemplo, a mí el éxito me encanta y es lo que quería conseguir. No podría decir que soy una persona feliz, pero si creo que soy una persona afortunada. $Y$ el éxito me permite hacer lo que quiero. Otra cosa es la fama, pues no necesitas hacer nada para llegar a ser famoso, estamos rodeados de ejemplos de este tipo. Y todo relacionado con la fama me abruma [abate] y no lo llevo bien. En cuanto a las presiones internacionales son, sobre todo, las que vienen del mercado. Pero yo le aseguro que ruedo lo que quiero, que no pienso en ese mercado. Me comunico y eso es lo importante, y si ocurre es porque el público y yo coincidimos. ${ }^{312}$

Na mesma lógica de ser natural, mas de representar socialmente, segue a idéia de fazer somente o que deseja. É um bom discurso e em boa parte acontece, mas já com o reconhecimento alcançado e regras incorporadas se torna impossível. O filme Mujeres al borde de un ataque de nervios (1987) já denuncia a mudança de um estilo de filmar e cenas que demonstram uma negociação de imagens no estilo das altas comédias norte-americanas para um diálogo com um mercado que pudesse ir além do europeu.

Nesse sentido, é sempre importante investigar em que circunstâncias o diretor fala quando diz filmar somente o que tenciona, considerando já se encontrar num ramo que subentende mercado. O ano desta entrevista foi quando produziu Kika (1993) e aquela experiência demonstrou que realizou o que desejava, mas os diferentes públicos tiveram reações distintas. Seu próximo filme foi mais ponderado, mas não fugiu de seu estilo. Portanto, há uma liberdade. Contudo, muito distinta dessa proclamada pela boa retórica do diretor.

\footnotetext{
${ }^{310}$ HARGUINDEY, 30. SET. 1984, p. 11.

${ }^{311}$ MONTERO, 28. set. 1986, p. 23.

312 TORRES, Maruja. Entrevista com Pedro Almodóvar. El País - La cultura , Madrid, 25. set. 1993.
} 
Nesse contexto, as mudanças em sua vida não foram poucas. Incidiram nos seus hábitos de relacionamento com amigos, na esfera profissional e em sua privacidade. Quando passou todo o turbilhão do sucesso de Mujeres al borde de un ataque de nervios e sua grande seqüência de prêmios, entrevistas e frustrações sem o almejado Oscar, ele pôde novamente visualizar sua condição de cineasta famoso:

\begin{abstract}
Creo que la mayor esclavitud [escravidão] del éxito es la imposibilidad de estar solo, porque todo ser humano tiene derecho a engordar, a que le salgan canas [saiam cabelos brancos] , a fracasar ... y a vivir todo eso en solitario; envejecer o sufrir decepciones ante un montón de ojos que te están mirando es una crueldad. Pero tampoco quiero dramatizar pero aunque el éxito sea la norma injustísima en esta sociedad, tiene algo maravilloso: el placer de ver que lo que tú haces comunica con los demás [...] el mero hecho de la comunicación es siempre milagroso y casi te compensa de todo lo demás. Por eso estoy encantado de haberlo conseguido [...] yo soy más exigente que nunca, pero esa es mi propia evolución. Creo que el más crítico con mi obra soy yo mismo y que, a la hora de trabajar, el éxito no me ha afectado especialmente, lo ha acusado más mi vida privada. Sigo haciendo las películas que quiero hacer y habría hecho Átame independiente del éxito de 'Mujeres' [... ${ }^{313}$
\end{abstract}

Portanto, para Pedro, este jogo do êxito, como ele prefere nomear, está circunscrito na esfera do prazer com todas as suas compensações e desgostos dele decorrentes. É o que escolheu, admite. E sabe que diante disso, não pode permanecer ou pretender - como imaginava antes das decepções enfrentadas com alguns trabalhos - unanimidade. Nessa entrevista, mais elementos de sua auto-construção como cineasta aparecem mais forte: a exigência consigo mesmo e sua realização pessoal diante do trabalho, a invasão da privacidade, a reivindicação do direito à solidão.

Esta convivência cinematográfica o fez compreender que a dinâmica das estréias, a boa ou má aceitação do público, os vários setores da mídia que começam a disparar críticas positivas e negativas, as indicações e premiações todos exigem respostas que the assegurem permanência. Ou seja, de tudo, o que enfim deve prevalecer é sua mensagem, seu ato de escrever e dirigir, mas agora mediado pelo complexo do cinema e suas ramificações, por isso sempre movendo relações precavidas para as surpresas.

- De donde nace esa agresividad hacia usted?

- Hombre, pues porque soy una persona muy independiente

- Y la indendencia se paga?

- Pues que sí. Te la hacen pagar los demás. La independencia, que para mí es simplemente mi modo de funcionar, se convierte en una especie de reproche [censura]. Da la impresión de que a veces creas mala conciencia. Desde que empecé a hacer cine estoy acostumbrado a tener fanáticos. Me han adorado y me han odiado, con toda la intensidad de la palabra. Y por dios, qué pesado es ese asunto! Porque yo ahí ni entro ni salgo. Dicen que eso es bueno, porque no dejas indiferente. Pero a mí me parece un peso. Entre otras

\footnotetext{
${ }^{313}$ PONGA, Paula. Entevista com Pedro Almodóvar : Estoy me haciendo mayor. Fotogramas, $\mathrm{n}^{\circ}$ 1760, Madrid, fev. 1990.
} 
cosas porque una pelicula tampoco es tan importante. La cantidad de gente que me ha dicho; 'me he peleado [briguei] con no sé quien para defenderte'. Pues, joder [que saco!], digo, a ver, pues no te pelees por esas cosas, peléate por otras. ${ }^{314}$

Como apontei anteriormente, mesmo quando devolve ou responde as críticas, Almodóvar acrescenta uma imagem ou um olhar sobre si mesmo que deduz e convence aos demais sobre o que pode vir a ser sua índole polêmica. É o caso discutido sobre sua independência. Junto à idéia de quem o adora ou odeia associa-se o conceito da liberdade conformando sua trajetória, justificando outras atitudes. Sua independência individual o permite avançar em projetos que realizem seus sonhos, buscar novidades e também extrair de sua equipe o talento necessário para concretizálos. Mas, como visto, sem antes passar pelas condições do campo cinematográfico, torna-se impossível. Sobretudo nas condições do diretor já estabelecido em 1997, ano da entrevista.

Quando se associa maturidade e fama em sua carreira, as formas discursivas se modificam. Com o sucesso internacional de Todo sobre mi madre no ano de 2000, as posições críticas ocupam novos territórios. A própria imprensa se encarrega de avaliar suas reflexões diante das atitudes que toma nos lugares por onde se pronuncia. Num artigo intitulado "Por vez primera me toman en serio", referindo-se aos vários prêmios conquistados por Todo sobre mi madre e ao Oscar que o diretor ganharia logo em seguida em Los Angeles, percebe-se um texto talhado para equilibrar ansiedade e tranqüilidade, mostrando a postura menos polêmica e mais vivida de um cineasta que conseguiu - pelo seu trabalho - conquistar seu lugar na "corte cinematográfica". Um texto produzido para naturalizar um trajeto movido de forma inconsciente:

\begin{abstract}
Si la madurez era esto, a Pedro Almodóvar el concepto lo tiene confundido, sin saber dónde colocarlo. Por una parte, en los últimos meses su nombre se ha convertido en sinónimo de aplauso unánime al otro lado de cualquier frontera y más allá de cualquier crítico. En eso, la sensación sé es la de haber llegado a un lugar o a un momento nuevo. Pero al mirar las razones que han causado la trasmutación que está viviendo, el cineasta se busca y no se encuentra: su acititud es la misma que en otros tiempos, la pasión por su trabajo no ha variado desde sus comienzos, su dominio del invento tampoco se ha disparado con motivo de su creación más reciente. Pero su cine, de la noche a la mañana, es respetado por aquellos que siempre le miraron con recelo. Ahora, Almodóvar ha de hacer malabarismos para disimular la cara que le sale por dentro: 'Que he hecho yo para merecer , justo ahora, esto?' ${ }^{315}$
\end{abstract}

Mas, como visto até agora, não houve nada de natural no trajeto de Almodóvar até a chegada da consagração com Todo sobre mi madre. Um acontecimento que não o isenta de perder seu reinado se eventualmente fracassar sua próxima produção,

\footnotetext{
${ }^{314}$ IBORRA, Juan Ramón. Entevista com Pedro Almodóvar. El Periódico, Madrid, 26. out. 1997.
} 
como ocorreu com a recepção de La mala educación (2003), fime que abriu oficialmente o festival de Cannes. A interpretação e os efeitos desta fama chegaram a Almodóvar lentamente com conclusões para ele pouco otimistas. E, junto ao cineasta, a mesma imprensa que o acompanha desde o início de sua trajetória continua alimentando os mesmos estigmas manchegos e a ironia, com a diferença de observações em virtude da idade do diretor. Passados mais de 50 anos de idade, ele é alvo de observações sobre condição de maturidade e saúde física, num mesmo tom que recebia os comentários sobre sua energia e seu aspecto polêmico:

Pedro Almodóvar (Calzada de Calatrava, cuidad Real, 1951) saca los trastos de su cartera: vitaminas, ginseng rojo [vermelho], tónico homeopático, unos populares ansiolíticos [calmantes] y un pedrusco más grande que su mano. 'me lo han traído del desierto, para que se lo tire [me trouxeram do deserto - a pedra que tinha nas mãos - para que eu o atire] a los que se metan conmigo', dice riendose. ${ }^{316}$

Nessa entrevista, o diretor havia acabado de lançar Hable con ella (2001) em Madrid e, ao analisar os sucessos, comentou sua impressões sobre a fama:

Nunca he analizado mi vida a partir de los éxitos, siempre la he sentido de un modo más íntimo, más ligada a mi naturaleza. Soy un hombre, el tiempo va pasando y las cosas son cada vez más difíciles. Creo que soy una persona vitalista pero tengo algo muy claro: la fama me ha hecho polvo [me reduziu a pó] . No quiero quejarme del éxito. Pero de la fama sí me quejo. Yo nunca había pensado en ser famoso y, afortunadamente, se respeta mi intimidad, pero no es eso. Soy yo, que quizá no me gusto lo suficiente. No quiero que la gente me vea envejecer, ni engordar. Y es completamente imposible. Además, tengo un acceso muy difícil a la realidad de los demás. La fama te aisla [te isola]. Yo siempre me ha gustado conocer gente, escuchar conversaciones, mezclarme y observar, he bebido de eso, pero ahora me cuesta estar cerca de la realidad. No quiero que suene trágico, aunque de alguna manera lo es. La soledad [a solidão] tiene que ver con todo esto. Yo no quiero parecer una persona dramática, pero hay un fondo muy solitario en mí. De verdad, no me quejo. Todo esto lo elegido yo. Yo me devertí mucho en los ochenta y me divierto mucho menos ahora. Me he cerrado y la situación también me ha cerrado ...

Esta conclusão, praticamente, já está dada pela própria obra do autor. Basta observar que a partir de La flor de mi secreto - já o título do filme uma revelação, ou melhor, uma confissão - se processa o início da introspecção e o exercício reflexivo do cineasta em torno de suas questões existenciais, prosseguindo até a última película lançada nesta data pela El deseo: Volver. Solidão, morte, cumplicidade, amizade, sinceridade e dissimulação. Elementos que articulados e explicados diante da vida garantem para o diretor a reprodução das relações, unidos sob os acordes da solidariedade. Os afetos ganham centralidade em relações - limite que questionam o

\footnotetext{
${ }^{315}$ FERNÁNDEZ, Juan.Entevista com Pedro Almodóvar: Por vez primera me toman en serio. El Periódico, Madrid, 19. mar. 2000.

${ }^{316}$ FERNÁNDEZ-SANTOS, Elsa. 15. mar. 2002.

${ }^{317}$ Idem
} 
tempo e a vida.

E quando a fama aparece, sua imagem se opõe ao brilho buscado na Movida. Aliás, os próprios personagens nos filmes rejeitam a fama. A escritora Leo esconde-se sob o pseudônimo de Amanda Gris em La flor de mi secreto (1995). Victor é um famoso anônimo que tem passagem vitalícia de ônibus porque sua mãe o concebeu, numa noite, dentro de um coletivo, e viaja solitário pelos ônibus de Madrid em Carne trêmula (1997). A toureira Lydia de Hable con ella (2001) detesta falar com a imprensa.

$\mathrm{Na}$ vida real do diretor, algo semelhante se passa. A fama se transformou num fantasma com o qual ele necessariamente precisa conviver. E esta se apropria não somente de sua vida. Ela acabou gerando uma estrutura de divulgação e alimentação tão gigantesca de sua imagem que expande sua presença aos espectadores além do cotidiano dos veículos tradicionais de comunicação de massa. Até 2003, a internet registrava, apenas no buscador Google, 200 menções ao autor, 60 mil referências em chinês e russo, coreano e sérvio, 34 mil em inglês, 21 mil em espanhol, 11 mil em alemão, 7 mil em francês e 6 mil em italiano. Na tabela dos mil melhores filmes da história do cinema da página Theshootpictures constam duas de suas películas, Mujeres al borde de un ataque de nervios e Todo sobre mi madre, junto a 12 de Buñuel, 14 de Fellini, dentre outros.

A Universidade de Berkeley possui um catálogo que até o início de 2003 oferecia a mais completa bibliografia do autor ${ }^{318}$. Um acervo que talvez só perca para o Centro de Documentación Digital Pedro Almodóvar dentro do Instituto de Estudios Avanzados de la Comunicación Audiovisual (ICA) em Cuenca na Universidade CastilaLa Mancha. O centro foi criado em parceria com a produtora El deseo e conta com mais de 20 mil documentos para consultar na página web, dentre artigos, teses e imagens, disponíveis logo após o encerramento do "Primeiro Congresso Pedro Almodóvar" no final do mês de novembro de 2003 na mesma universidade ${ }^{319}$.

Este centro revela um paradoxo com o qual Almodóvar se relaciona e alimenta. Concomitantemente ao fato de sentir-se invandido pessoalmente pela fama, ele trata de administrá-la de fomentá-la, haja vista que o Centro de Documentação Digital Pedro Almodóvar resultou de uma parceria com sua produtora. A própria El deseo possuía um acervo de todas as publicações, inclusive trabalhos acadêmicos, de tudo que puderam colher sobre o diretor. Para um cineasta que discursa não ter esperado tamanha fama, os fatos demonstram que ao menos sabe conviver com ela, apesar de queixar-se de

\footnotetext{
${ }^{318}$ MARTín, Javier. La academia de Hollywood hace universal el cine de un manchego hijo de mulero. El País, Madrid, 20. fev. 2003.

${ }^{319}$ E. S. Expertos internacionales sobre Pedro Almodóvar se reunirán en Cuenca. El País , Madrid, 24. out. 2003.
} 
problemas sobre individualidade. Um valor que - por sua incontinência verbal também acaba tornando público, permitindo mais especulações sobre sua vida.

Somou-se à difusão de sua imagem, uma homenagem promovida pelo New York Film Festival, no Lincoln Center de Nova York, para 1.100 convidados, com o nome "Viva Pedro" no mês de outubro de 2004. Na oportunidade, Almodóvar fez declarações que, mais do que revelar sua identificação com o público, reforçaram a imagem do trabalhador incansável e de eterno buscador de sentido para os valores da vida. Um discurso "politicamente correto" mais do que eficiente para uma platéia cuja cultura possui como pressuposto máximo a ética do trabalho e dos méritos próprios justamente o que sintetiza sua figura.

Claro, um discurso sincero de seu momento pessoal, mas com uma dose estratégica de boa vizinhança para um país onde, possivelmente, entre os membros participantes do evento naquele círculo cinematográfico, também estavam os que já rejeitaram dois de seus trabalhos e polemizaram com mais alguns outros. Mostrando uma atividade ininterrupta, ele mantém a projeção de trabalhador sério e uma forma de amenizar os ânimos frente a suas polêmicas:

Tengo un guión [roteiro] entero para una película muda, en colores y además estoy trabajando en otras cuatro historias, dos relacionadas con mi madre, que es una de mis grandes inspiradoras y otras dos sobre un cineasta con problemas porque se acuesta con una de sus actrizes y sobre la película que ese mismo cineasta ententa rodar [...] Nunca me he intentado escandalizar al público, sino encontrar la reciprocidad con el espectador algo que he sentido siempre en Nueva York ${ }^{320}$.

A última homenagem, que referenda ainda mais a consagração do diretor, ocorreu no primeiro semestre de 2006 em Paris, no Centre George Pompidou, unindo exposições fotográficas, filmes e debates coordenados pelo roteirista, crítico de arte e ex-redator chefe adjunto do Cahiers du Cinéma, Frédéric Strauss, também escritor e editor de livros contendo entrevistas com Almodóvar em vários períodos de sua trajetória. A simpatia dos franceses por Almodóvar vem de longa data. Em 1994, o escritor Félix de Azua, diretor do Instituto Cervantes de Paris já afirmava que o cineasta agradava bastante os espectadores do país porque ele apresenta um outro olhar da Espanha. Não o folclórico, de toureiros e ciganas, mas o travesti, a prostituta e o drogado. ${ }^{321}$ Uma Espanha moderna e aberta ao mundo. Conta-se também o fator cultural que aos franceses interessa: histórias insólitas com humor mordaz, repletas no acervo almodovariano.

\footnotetext{
${ }^{320}$ CELIS, Bárbara. Pedro Almodóvar defiende el artificio en su cine en Nueva York. El país - espetáculos, Nova Cork, 09. out. 2004.

${ }^{321}$ CABEZA, Elisabet. Almodóvar agrada a França perquè ha renovat el clixé folklòric espanyol.. Avui, Paris, 13. fev. 1994.
} 
França e Estados Unidos são dois grandes mercados cinematográficos que apreciam as obras de Pedro Almodóvar e sediam dois dos festivais mais famosos dentro dessa indústria: Cannes e o Oscar. Pelo conjunto de símbolos que há décadas sintetizam e pela visibilidade que produzem, geram uma imagem de universalidade, no entanto limitada a seus mercados. Uma das estratégias de Almodóvar na conquista de desses mercados aparece nesses tipos homenagens, numa espécie de retorno, agradecendo sua contribuição à permanência da indústria cinematográfica e seu mundo.

Mais recentemente a Itália tem se apresentado como mais um novo mercado com interessados nas obras do diretor. Em 2004, La mala educación foi um dos filmes de maior bilheteria no país. Ao receber o prêmio de melhor filme estrangeiro do Sindicato italiano dos jornalistas cinematográficos em cerimônia transmitida pela RAI, por entender que esta é uma película carente de personagens positivos, difícil para o público, Almodóvar afirmou que os italianos são mais generosos com seu cinema do que os espanhóis:

Tengo la impresión de que mi hogar está en Itália, no en España [...] aunque debo decir que, políticamente, me parece que los españoles estamos ahora mucho mejor que los italianos. ${ }^{322}$

A idéia da incompreensão e compreensão persiste a cada tipo de público e, em torno do que se desenvolve, ora com polêmica ora com as especificidades dos temas, gera dividendos ao diretor. Este, por sua vez, não deixa de fazer suas gentilezas políticas e também suas comparações irreverentes para cada país em que se apresenta. Exibir um filme como este no berço do catolicismo, justamente num momento em a Igreja católica enfrentava as denúncias por assédio sexual, reverteu-se numa boa vantagem. Só poderia obter grande bilheteria, talvez não o sucesso. Estratégia ou casualidade, o fato mais importante para ele é ver seu trabalho se disseminar pelos diversos espectadores no mundo.

\section{4 Algumas modulações}

Pedro Almodóvar conhece e manuseia devidamente todas essas regras que o mantêm em evidência. Aprendeu de forma correta como movimentar-se na complicada trama da indústria cinematográfica, mesmo não tendo obtido formalmente nenhuma preparação social para a fama em sua trajetória de vida. Sua condição social inicial não Ihe anunciava que deveria exercer algum tipo de poder.

${ }^{322}$ GONZÁLEZ, Enric. Almodóvar cree que Italia es más generosa con su cine que España. El País - espetáculos, Roma. 06. fev. 2005. 
A atitude de mudança de cidade - em especial, escolher Madrid - o retirou de um espaço social e o colocou em outro sem fornecer integração aos grupos que lhe interessavam. Estes em seus lugares foram pouco flexíveis em aceitá-lo. O diretor não se intimidou. Seu temperamento sociável e mediador possibilitou-lhe conhecer as pessoas adequadas para que pudesse desenvolver seus projetos. Quando se fez conhecido, preparou e delegou ao irmão Agustín a tarefa da continuidade dos "contatos". O aprendizado de conviver com outras classes, depois com o poder, trouxe ao diretor a compreensão para articular-se com as regras específicas da esfera dos envolvidos no cinema, até criar as suas e ter melhores condições de agir nesse campo artístico.

Sua transição do underground para o universo cinematográfico oficial não o desvencilhou da imagem e das marcas de suas origens. Aliás, é com a constante reciclagem delas que desenvolve novas idéias, histórias e alimenta sua imagem. A polêmica ainda que mais branda o mantém gerando dúvidas e diferentes recepções de sua mensagem, seja nos filmes ou em suas entrevistas. Diante das várias interpretações, safou-se de algumas armadilhas em torno da imagem de "estrelas", mas também usufruiu dela naquilo que lhe foi conveniente.

Suas concessões e afrontamentos o permitiram avançar vários limites que lhe haviam imposto a crítica e os produtores. Não por menos todo esse desencadeamento de situações provocou a invasão sobre sua privacidade. Ainda que negando sua formação e destino de classe social, com os contatos e vínculos amistosos que criou no establishment, não fez uma negação tão radical que pudesse apagar as origens que moldaram seu temperamento no decorrer de sua história intelectual, cultural e social. Estes elementos estão marcados nele intrinsecamente. E aparecem em sua obra.

Parte considerável da critica percebe os descompassos de classe entre diretor e os setores intelectuais, bem como sua popularidade ao falar numa linguagem corrente para diversos tipos de público, sobretudo o espanhol. Percebe também sua busca pelo rompimento desta estratificação tão publicamente conservadora que separa intelectuais e espectadores - pensando aqui apenas na esfera cinematográfica. As críticas que recaíam sobre ele e suas atitudes - que fugiam dos comportamentos tradicionais de quem convive com a fama ou foi educado para ocupar lugar de destaque na sociedade - não vinham simplesmente porque sua filmografia não condizia com um gosto apurado culturalmente segundo os integrantes dos campos intelectual e artístico-cinematográfico. Elas também tocam na relevância - sem apologias - que o diretor outorga às classes populares e a grupos marginais. 
Muito desta indignação que sentem os grupos do establishment tradicional e moderno - em geral articulados entre si - para aceitar alguém que não seja originalmente de seus círculos provém em grande parte do receio em permitir a valorização de pessoas que não partilham de seus valores e visão de mundo. Contudo, alguns outros compõem o grupo que apenas analiticamente não aprecia a visão estética e narrativa do diretor. Fazem sua crítica sob seus parâmetros culturais e justificam suas opiniões sob suas preferências e referências acadêmicas, artísticas e cinematográficas clássicas.

Por outro lado, nesse mesmo campo intelectual, Almodóvar aglutina a seu favor um outro grupo voluntariamente afinado a seu trabalho, que faz um contraponto a estes mais resistentes. Seus membros simpatizam e alguns aderem de maneira mais entusiasta à sua lógica fílmica. Participam dessa elite cultural, mas, por referências progressistas ou revolucionárias de autores e cineastas, vislumbram em Almodóvar caminhos abertos para novas linguagens e reflexões. Para eles, o autor representou um avanço de atualização artística, narrativa e social da sociedade espanhola e reflete contemporaneamente em suas temáticas os dilemas sociais e pessoais candentes do dia-a-dia espanhol, que, já integrados ao mundo moderno, enfrentam desafios e dificuldades para serem solucionados.

A eles não importa se o diretor não possui as exigências tradicionais de formação escolar ou um grau de intelectualidade que demonstre sua refinação de gostos culturais e suas possibilidades de ascensão ou manutenção de seu lugar social. A avaliação fazem de sua obra e paralelamente de sua pessoa - porque o autor favorece esse olhar - incide sobre seu poder de diálogo e reconhecem suas limitações e sabem de seus propósitos. E, pelo que se percebe na trajetória do diretor não existe em seu trabalho interesse em romper ou afrontar essa hierarquia.

Sua preocupação com a ascensão econômica, por exemplo, sempre esteve ligada à possibilidade de fazer novas produções e assegurar sua popularidade, não em pertencer aos grupos dos estabelecidos no país. Entretanto, sabe que as boas relações são necessárias para viabilizar novos projetos. Logo, sua posição não é de rompimento, porém nem um pouco de conivência. Tanto que, ao primeiro sinal de controvérsia, ele já aciona seus dispositivos polêmicos. Fatos que causam a indignação ou a diversão de distintos públicos.

Nesses momentos, trava-se uma luta de classe simbólica onde entram os diferentes saberes e a capacidade de ocupar territórios não destinados a pessoas com perfil autodidata como Almodóvar. Os saberes hierarquizados dentro das normas 
estabelecidas pela sociedade decidem e condicionam todos aqueles que pleiteiam algum espaço social ${ }^{323}$. No caso deste diretor, sua própria situação autodidata o transformou em bode expiatório da sociedade que impôs os títulos, e as instituições de saber legítimas.

Afinal, no campo cinematográfico do que chamei de uma certa "corte" anteriormente, busca-se garantir, mesmo com as diferenças estilísticas, um perfil de classe que já prejulgou e definiu sua estética e sua temática. Utilizar os sinais impostos pelos que possuem preparação "adequada" - segundo os critérios desse campo - para manipulá-los e subverter suas diretrizes configura-se num risco para o establishment e para o cineasta. Ele pode assumir ou não a continuidade de seus contemporâneos ou antecessores e seu autodidatismo não proporciona esta segurança. Assim, a um Luis Buñuel, pertencente a campos de excelência que dialogam no universo econômico, político, cultural e intelectual, permite-se, tolera-se ou respeita-se ousadias, críticas e inovações. A um autodidata nas condições de origem de um Almodóvar tudo é perigoso.

Certamente por isso o diretor não obteve a mesma resistência intelectual fora da Espanha, afinal as regras dos campos também variam de um país a outro. Outrossim, dentro da sociedade de origem a conjugação do campo cultural com outros dotados também de autonomia - ou buscando estabelecer-se - gera novas relações. Junte-se a esse contexto o fato da existência dos grupos que pertencem ao campo cultural já autônomo - mas que divergem de suas determinações - e a emergência de novas linguagens como foi inicialmente a Movida e o cinema de Almodóvar. Temos nesse quadro a possibilidade da abertura para novos códigos e registros artísticos.

Entretanto, como o reconhecimento estético e narrativo não se faz fora das intenções artísticas, nem das definições de arte, todas elas pertencentes a um campo aberto de disputas, percebe-se que a "batalha" continua sua marcha. Ou seja, a construção do diretor Pedro Almodóvar ainda se processa dentro dos contextos que criaram, tanto o cineasta, como a figura pública e o homem comum.

Como diante das esferas discutidas existe um contínuo fluxo de incertezas e surpresas, a cada novo passo do cineasta e de todos os setores que são acionados em torno da indústria e do universo cinematográfico, também se modificam os atores sociais que se movimentam nesse cenário. Este campo já teve aqui alguns de seus personagens apresentados: jornalistas, críticos de cinema, escritores, entre outros. Também apareceram rapidamente alguns acadêmicos. Na intelectualidade há um

${ }^{323}$ ORTIZ, Renato (org.). Pierre Bourdieu. Coleção Grandes Cientistas Sociais - nº 39. SP, Ática,1983. p. 111-113. 
grupo expressivo que também observa e dirige seu parecer ao diretor contribuindo para confeccionar sua imagem.

Estes se constituem em algo mais que críticos de arte. Encarregam-se de elaborar e sistematizar conhecimentos, a partir da reflexão sobre as formas de abordagem das temáticas levantadas nos filmes, da transposição da realidade para o cinema, das construções estéticas e seus efeitos sobre a sociedade que as inspira. Nos meios de comunicação e na arte eles atuam de maneira estratégica para legitimar no plano acadêmico as projeções culturais desenvolvidas socialmente. Ao lado deles às vezes eles próprios - estão os críticos em arte e cinema de revistas especializadas e renomadas nacional e internacionalmente que possuem poder de conferir visibilidade ou ofuscamento às personalidades já destacadas na mídia em geral ou no campo das artes. Alguns inclusive já citados até aqui. Seus papéis são imprescindíveis e falam de Pedro Almodóvar. O cerco se fecha e os critérios se fazem mais exigentes. Continuam os paradoxos em torno do cineasta. 


\section{ACADÊMICOS E CRÍTICOS}

Creo que los críticos españoles comenten a veces atrocidades, pero no es elegante hablar mal de los críticos ni atacarlos, aunque ellos a veces te trituran. La crítica está en un lado y los cineastas de otro ${ }^{324}$

Os membros da crítica cinematográfica e acadêmica geralmente são encarados como aqueles responsáveis por destruir ou louvar os trabalhos dos cineastas. Amados e odiados pelos criadores de filmes, seus integrantes constituem parte crucial na difusão, legitimação ou desmantelamento da imagem de um autor. Possuem poder limitado para induzir ou motivar o público ao consumo das películas. Mas, como grupo pertencente a uma certa "nobreza cinematográfica", estes atuam de modo especializado e racionalizado em suas análises, atraindo - além de reduzida parcela dos espectadores - a atenção de uma infinidade de profissionais ligados ao cinema. Podem, inclusive, influenciar prêmios, festivais e contribuir para acelerar o mercado de objetos vinculados aos filmes. Óculos, roupas (de grife ou não), cartazes, cds de trilhas sonoras, roteiros, dvds, miniaturas de personagens, gravuras, atores, atrizes, e tantas outras mercadorias diretamente resultantes dos filmes em exibição ou daqueles que, a cada dia, vão se transformando em clássicos ou em cult-movies. Essas são algumas das influências que indiretamente causam no mercado.

Ou seja, ainda que em pequeno número, constituem um grupo que possui ressonância sobre a opinião pública e isso lhes garante legitimidade do ponto de vista artístico e teórico, além de alimentar segmentos do mercado de bens simbólicos. Diante dos cineastas, nem sempre a relação que estabelecem é harmônica. Maria de Medeiros, diretora portuguesa, em seu documentário Bem me quer... mal me quer (2004), ilustra um pouco este quadro conflituoso e apaixonante entre cineastas e críticos. Universo onde cada análise ou pronunciamento torna-se fator estratégico para a carreira de um diretor. Estes profissionais desenvolvem papéis específicos que determinam o julgamento estético sobre a reputação de obras de arte e seus artistas, fortalecendo linhas, tendências ou formas do mundo da arte.

Quando um filme é exibido pode-se notar o quanto essa relação é simultaneamente rejeitada e desejada, inclusive pelos próprios cineastas, pois sabem da importância de verem seus trabalhos comentados por certos críticos de prestígio. $\mathrm{Na}$ pior das hipóteses, até obter uma crítica negativa ainda os coloca em evidência, pois gera controvérsias, expõe seus trabalhos, seus nomes e gera bilheteria.

Para Pedro Almodóvar - também entrevistado nesta película da cineasta -,

${ }^{324}$ FRANCIA, Juan I. Entrevista com Pedro Almodóvar. La Vanguardia, Barcelona, 30. jan. 2000. p. 29. 
esse ritual já é bem conhecido. A cada novo trabalho as controvérsias se sucedem e, para cada uma, ele sempre encontra saídas que possam lhe render alguma vantagem ou então dar respostas que sustentem sua imagem de diretor respeitado. Entretanto, reconhece que em vários momentos isso desgasta e que a vontade é ignorar de vez essas "personagens". Para ele, fazer isso seria quase como apagar a alma ou retirar o ar que dá vida ao mundo cinematográfico.

\subsection{Detentores de poder simbólico e artístico}

O fracasso de crítica e de público em Kika (1993), quando tudo já parecia estar devidamente acomodado para Almodóvar - como se apresentou no capítulo anterior -, evidenciou bem o quadro de constrangimentos e preocupações que envolvem o desempenho de um criador e sua obra. Deu a chance de a crítica mais tímida sobretudo a espanhola, que se via um pouco acuada com tantos elogios internacionais ao diretor - lançar suas insatisfações ao seu trabalho, dizendo inclusive que seu império estava começando a ruir.

As duas películas posteriores, La flor de mi secreto (1995) e Carne tremula (1997), recuperam sua credibilidade dentro da Espanha. Novamente o reconhecimento pelo trabalho se amplia, propiciando ao diretor mais respaldo financeiro, ampliação de mercados, respeitabilidade artística e uma extensa premiação que lhe garantiu o aval necessário para alçar vôo numa nova produção. Após uma série de acontecimentos já relatados neste trabalho, estes últimos filmes asseguraram uma mudança favorável ao diretor que, em sua maturação, chegou a Todo sobre mi madre (1999).

O filme é um melodrama puríssimo e sensível sobre a história de Manuela, que perde seu filho Esteban, de dezessete anos, num atropelamento. Por haver prometido a ele que contaria tudo sobre sua vida e sobre o pai - que o adolescente não conhecia - assim que voltassem para casa, ela decide cumprir a promessa e ir a Barcelona procurá-lo; e o reencontra, agora convertido em Lola la Piconera. Sucesso absoluto internacionalmente e centenas de prêmios que culminaram com o tão almejado Oscar, que Almodóvar perseguia havia anos, várias situações irão se transformar na vida do espanhol "manchego", agora, oficialmente , cidadão do mundo cinematográfico.

O filme Hable con ella (2001) apresenta um panorama bem diferente para o diretor, tanto em relação ao mercado como diante da crítica e de um público que se amplia. Centrado numa situação limite de duas mulheres que entram em estado de coma e de dois homens por elas apaixonados, o filme discute a dificuldade e a importância do diálogo entre as pessoas. Enquanto a produção anterior focava o 
universo feminino, reforçando o discurso que apresenta Almodóvar como o leitor da alma feminina, este se volta a discutir o universo masculino, sua cumplicidade, mas o faz revelando a sensibilidade do homem, muitas vezes ocultada por padrões sociais. Novamente, sucesso de bilheteria e de crítica e mais prêmios relevantes.

Relação aparentemente legitimada, circulação mundial. Apesar desse panorama tão alentador, isso não significa hegemonia. La mala educación (2003) não chegou à altura de sua propaganda e Volver (2006) recebeu apenas a boa simpatia tanto de público como de crítica. Na Espanha, esta crítica sustenta opiniões diversas e, dentro delas, expectativas e receios. O grande campo de negociação deste "mercado" refinado de idéias acaba se traduzindo em acordos de exibição, novos festivais, aumento, diminuição ou manutenção de espaço e de visibilidade. Nesse aspecto, embora Almodóvar insista muitas vezes em dizer que a ele não interessa a opinião da crítica espanhola - quase sempre destrutiva - sobre seus trabalhos, sua trajetória mostrou que foi preciso também negociar com ela. Afinal, prêmios em festivais ampliam as possibilidades para que seus filmes circulem em outros espaços que não seriam conquistados apenas com boa qualidade cinematográfica.

Também, ver sua cinematografia e seu nome - como cineasta - objetos de análises acadêmicas significa o reconhecimento de sua obra como instrumento de reflexão da vida contemporânea. Pedro Almodóvar e seus filmes estão colocados num mesmo patamar dos trabalhos de outros diretores extremamente respeitados como artistas porque deixaram um legado expressivo nesse aspecto. Assim, seu status quo não se amplia simplesmente pela popularidade, e suas buscas pessoais se traduzem em processos de diálogo com diversos âmbitos sociais.

A elaboração da imagem de um cineasta - como visto até agora - se faz com vários elementos conjugados, envolvendo público, jornais, revistas, entrevistas, artigos, intelectuais, antigos e novos filmes, mostras de diretores ou ciclos temáticos. Com a expansão e poder de alcance do cinema sobre a sociedade mundial, este acabou se transformando também em objeto de análise intelectual, tendo ao redor críticos e revistadas especializadas, além de inúmeros acadêmicos que se ocupam de estudar seus efeitos no campo psicológico, estético, histórico, econômico, sociológico, antropológico, filosófico e artístico. Perde-se de vista a quantidade de teses e de livros escritos sobre um tema tão intrigante para o mundo moderno como é o cinema, não apenas por sua magia de transformar sonhos em realidade - ao menos imagética mas também pelo poder de alcance de sua mensagem sobre as diversas culturas.

Dentro deste aspecto me parece relevante compreender como o meio 
acadêmico contribui para analisar o cinema contemporâneo e, em particular, o cinema produzido por Pedro Almodóvar. Seriam eles - armados com seus instrumentos racionais científicos - os desmitificadores destes novos magos industriais? Ou eles também contribuem para alimentar e até fortalecer certas imagens já consolidadas? Mesmo com suas críticas parciais e também imparciais - positivas e negativas - suas tomadas de posição demarcam trajetos, focos com detalhes mais aguçados do que uma imprensa muitas vezes imediatista.

Fazer a crítica sobre um artista famoso - consagrado pela sociedade - não é tarefa fácil. Significa tocar em diversos planos que partem da própria celebridade, passando pelos círculos que a apóiam ou a amparam, até os que se beneficiam dele não necessariamente apoiando ou gostando. Também participam desse grupo admiradores em geral e personalidades ilustres que representam a nação e que, de alguma forma, precisam dar um relativo apoio e visibilidade a ele, pois sabem que isso representará aumento de divisas em muitos aspectos nas relações internacionais.

Howard Becker ${ }^{325}$ distingue estes setores especializados entre os estéticos e os críticos. Enquanto os primeiros examinam os postulados e os argumentos que as pessoas usam para classificar as atividades em belo, artístico, arte, grande-arte ou não arte, os outros usam este sistema para julgar a obra de arte, estabelecendo assim seu valor. Esse julgamento acaba por determinar a reputação do trabalho artístico e do seu autor. Nesse sentido, a estética aparece como uma atividade e não como uma doutrina. No entanto, suas formulações criam um sistema de convenções que lhes permite agir da mesma forma quando avaliam e elegem o que entendem como arte, conforme seus pressupostos. Essa prática estabelece um padrão que pode preceder ou acompanhar a elaboração de novos artistas, formas e obras.

No mundo das artes, mais complexo, estes profissionais especializados constroem sistemas estéticos dotados de uma coerência lógica que garante uma validade filosófica. A criação desses sistemas pode se transformar numa verdadeira indústria de ordem sociológica, manipulando-se discursos que alimentam a obra e a própria instituição à qual pertencem seus membros. Formulam suas regras de observação e, por intermédio delas, fixam critérios de avaliação. Este exercício reaproxima as atividades dos artistas à tradição da arte, autorizando-os a pedir recursos e vantagens para continuar a desenvolver seus trabalhos, desde que estes se encontrem sintonizados com as regras dos estéticos. Muitas artes podem ser executadas de maneira independente disso, porém uma estética coerente contribui

${ }^{325}$ BECKER, Howard S. Les mondes de L'art. Paris: Flammarion, 1988. p. 147-148. 
para a estabilidade de valores. ${ }^{326}$

Assim, muito além de um exercício filosófico, na formulação estética encontram-se várias opiniões dos participantes que caminham para certo consenso, assegurando a permanência de certas estruturas de cooperação entre eles. Isso favorece uma estabilidade que determina preço de obras, seus papéis comerciais, a reputação do artista e seu prestígio. Sob esse ângulo, o valor estético nasce da convergência dos participantes deste mundo da arte. Mas, como nesse universo são numerosos os estilos e movimentos e o acesso a todos é limitado, os grupos brigam para usufruir de suas vantagens usando razões lógicas em sua defesa. Nesse momento, os debates não apenas buscam defender suas potencialidades e qualidades no plano abstrato, mas também seu lugar na divisão de recursos valiosos. ${ }^{327}$

Os estéticos são voluntariamente moralistas em seu escritos. Partem do princípio de que sua tarefa consiste em encontrar uma receita infalível para fazer a divisão do que não é digno do nome de "arte" e as obras que merecem esse honrado título. ${ }^{328}$

Porém, a realidade é dinâmica e, por isso, também aqueles que possuem legitimidade para ocupar o lugar do julgamento ganham ou perdem posição. Assim, a autoridade para decidir o que é ou não arte estará nas mãos daqueles que se envolvem num mesmo universo e dele se apropriam, respondendo histórica ou socialmente à necessidade que diz respeito a valores de suas classes sociais ou de situações da conjuntura de suas nações. Pensando em termos universais, também nos espaços onde circulam os mesmos grupos em torno de objetos artísticos iguais. É o que também ocorre com o cinema.

Tocar com maior ou menor intensidade e responsabilidade no trabalho e na trajetória de um diretor também implica - nesse contexto - saber do julgamento e comprometer a própria imagem de quem se manifesta a respeito do artista. Ou seja, existem inúmeras questões em jogo e que são movimentadas a cada manifestação acerca da pessoa em foco. Assim, a discussão - e os olhares que serão abordados nesse momento - subentende considerar essas condições. Mesmo não aparecendo diretamente nas opiniões e análises, elas estão inevitavelmente imbricadas nesses pressupostos. Em geral, mesmo para chegar às grandes distribuidoras, torna-se necessário um bom referendo desses grupos. Portanto, mais do que pensar sobre essas opiniões, convém constatá-las.

\footnotetext{
${ }^{326}$ Idem, p. 149-150.

327 Ibidem. p. 151.

${ }^{328}$ Idem. p. 151.
} 


\section{2 Depoimentos - a relevância dos especialistas e intelectuais}

Os depoimentos a seguir, constituem um resumo de entrevistas que realizei com profissionais, cujos nomes se apresentam como representativos na crítica acadêmica e cinematográfica espanhola e européia. Pessoas que já escreveram e escrevem sobre Pedro Almodóvar e que se posicionam francamente tanto sobre suas estratégias de produção como do conteúdo narrativo de seus filmes. Todos demonstrando um alto grau de seriedade, acompanhada de grande simpatia e disposição para dialogar. Adiante apresento as preciosas conversas que desenvolvemos tranqüilamente nos dias quentes do verão mediterrâneo espanhol do ano de 2005. Elas foram dispostas, exatamente na seqüência em que ocorreram.

Jean-Claude Seguin ${ }^{329}$ é professor das Universidades Lumière e Lion 2 na França. Na data desta entrevista, apresentou uma comunicação no Primeiro Congresso de Cinema Europeu realizado no Centro de Cultura Contemporânea de Barcelona realizado entre 30 de maio e 3 de junho de 2005. Preparava o lançamento de um estudo sobre obras de Pedro Almodóvar em forma de ensaio dedicado a encontrar no autor algo que não referendasse apenas o discurso difundido de suas películas como um catálogo kitsch e procedimentos de cores.

Seguin iniciou a entrevista expondo estas considerações: se entrarmos numa leitura diacrônica da obra de Almodóvar, creio que há momentos claros, provavelmente em Kika, onde isso aparece como objeto mais evidente de discussão. É uma película muito importante, ainda que não tão valorizada. Porém muito importante. Ela dá um giro, não sei, talvez seja a que abre para outras coisas do diretor. Agora ele está rodando uma comédia, se chama "Volver", então suponho que terá outro ritmo, outra dimensão. Para mim La mala educación, representa também mudanças bastante profundas.

Vejo que Almodóvar detém de certo modo um movimento que está na maneira de escrever, esse fluxo rápido, que vai se pleiteando e nesta película há muito mais uma preocupação com o tempo, de momentos parados, uma certa atenção mais detida à escritura como no momento em que aparecem singularmente significativos o final da película. A porta se fecha e quase poderíamos simular uma espécie de lápide com o cinza de sua cor, como uma paleta de Almodóvar. Ele não utiliza o branco. Trata mais uma soma de cores. Portanto, poderíamos mostrar melhor como esse diretor se acerca do cinema como a uma tela para pintura.

${ }^{329}$ SEGUIN, Jean-Claude. Depoimento sobre Pedro Almodóvar [30 mai. 2005]. Entrevistador: Gilmar Santana. Barcelona: Primeiro Congresso Internacional de Cinema Europeu, 2005. Minidv (40 min), mono. Entrevista concedida para este trabalho. 
Há uma pertinência do tema da morte em suas películas. Não sei se este é o tema que os franceses mais gostam. Devem haver outros motivos pelos quais o diretor é muito estimado na França. Eu diria que a morte é um marco importante da vida. De certo modo, tudo termina nesse limite. Há uma espécie de determinação, de sinal que construímos a partir deste termo. Não acho errado dizer que a morte, nas películas de Almodóvar tratam tanto da impressão de vida e por outro lado, da trepidação da vida. A vida que percorre os espaços, como os órgãos humanos que correm de um lugar para outro [fala de Todo sobre mi madre]. Não é contraditório ver nas películas sempre - ou quase sempre - a morte presente. De uma maneira ou outra, junto a isso está o desejo, e este ligado ao amor.

Creio que em Almodóvar há cenas de amor mas que não me parecem muito bem rodadas, há sempre muita naturalidade, mas muita tensão. Bem, mas efetivamente a estrutura de cada película tem a ver com o desejo. Cada personagem está em sua função. Eu não limitaria o desejo a uma dimensão unicamente sexual. Para mim o desejo é algo que atravessa a todos nós e nos leva a fazer coisas diversas, não só o encontro ou relações físicas. Ele funciona como expoente de comunicação. O desejo de tentar capturar o público à sua maneira também se inclui na narrativa e na prática do diretor.

Enfim, creio que nas películas de Almodóvar todas as personagens possuem seu próprio desejo. Talvez na mais emblemática, Mujeres al borde de un ataque de nervios, cada mulher tem sua própria recorrência. São ruídos que se cruzam, mas cada uma tem seu jeito próprio de desejar e se constroem partir de seu desejo, assim como as mulheres de Todo sobre mi madre. Estas, seriam talvez as películas que mais mostraram essa questão do desejo em vários aspectos. Não só pela imitação puramente homossexual, que também é importante em Almodóvar e talvez única.

A atração que Almodóvar exerce sobre os franceses é um tema bastante complexo, porque - como se sabe - ele é um diretor de cinema muito criticado na Espanha e desprezado por uma certa crítica - não pelo público - e tem sido aceito, não só na França, mas também em outros países da Europa, assim como nos Estados Unidos. É uma pergunta bastante complexa. Os espanhóis diriam que Almodóvar defende de certo modo, uma Espanha folclórica de pandeiro e superficial. Mas isso não reflete a mesma impressão do que viria a ser para um francês diante da imagem da Espanha.

Eu não estou totalmente de acordo com essa visão sobre ele. Apenas acho que é um diretor que possui, digamos, marcas de estilo reconhecido. Assim como Kubrick 
que tem um estilo que não se vê, se sente. Mesmo quando ele muda totalmente de uma película para outra, todos o reconhecem. Com Almodóvar ocorre algo semelhante. Quando se vêem dois planos do filme já se sabe que o filme é dele. De outro modo, eu creio que ele conectou não para si a imagem da Espanha, de que falamos, mas conectou uma geração - da qual eu pertenço - que sofreu uma série de transformações bastante marcantes, muito fortes nos anos 60 e 70 . Isto está muito presente. Estas experiências estão mais além do que as fronteiras da Espanha. Eu creio que isso poderia conectar o diretor com o público francês.

Mujeres al borde de un ataque de nervios fui uma das películas com mais êxito e de maior bilheteria na França, mas a película de maior evidência foi Tacones lejanos. Se colocou na França em 1991 e 1992, com a nona posição entre as películas mais vistas no país. De qualquer modo, foi determinante ao êxito posterior de Almodóvar entre os franceses. Na França não existiam estudos universitários anteriores a Todo sobre mi madre, por outro lado, o êxito de uma película não está determinado pela crítica. Nós universitários também não temos este poder.

É o público que faz com que a película tenha ou não sucesso. Pelo menos 90\%. Creio que haja uma incidência determinante hoje na academia que se volta a discussões ao redor de Almodóvar. O primeiro congresso que se realizou na Espanha sobre Almodóvar foi realizado em Cuenca. Foi um congresso onde estiveram muitos universitários, estudantes, algo importante, um pouco como aqui [refere-se ao congresso que estava participando]. Lá esteve presente Almodóvar e seu irmão. Todos muito amáveis. Não vou citar nomes porque também estavam amigos meus, mas alguns espanhóis se negaram a ir nesse congresso. Houve um único espanhol representante amigo meu e pouquíssima participação espanhola. Participaram italianos, franceses e representantes de outros países.

Por esses fatos deduzo que o reconhecimento dele aqui na Espanha não existe. Além disso, começa a haver uma espécie de ruptura entre Almodóvar e a crítica. Esta presta mais atenção ao estrangeiro do que dentro da Espanha. Isso ocorre desde a crítica, passando pelos universitários até a academia. Evidentemente Almodóvar é um dos poucos diretores que se fez bem-sucedido durante anos, que não pensa somente em rodar películas. Organiza-se sempre para pensar, rodar e vender. E claro, isso é marketing. Creio que o faz Pedro ser o que é, provém dessa agilidade de saber rapidamente vender não só as películas, mas também sua própria imagem. Ele se midiatizou tanto que agora nem quer ser visto. Mudou, está distante.

Durante muito tempo, nos anos da Movida, cantando com Fabio MacNamara, 
seu modo de vida era outro. Naquele período vendeu seu produto - sua imagem e seus filmes - como outro produto qualquer e isso lhe resultou uma boa popularidade. Talvez esse fato seja também algo que ofende aos intelectuais. La ley del deseo foi o primeiro trabalho na produtora que montou com Agustín, na qual teve a possibilidade não só de fazer o que queria, como também produzir. Já produziu La niña santa e antes, El espinazo del diablo.

São películas que efetivamente ele pretendia também participar, com os direitos de produção com a El deseo. Claro, isto é um caso à parte. Ele é único produtor de cinema que tem uma produtora, ou seja, não existe outro caso dentro da Espanha neste perfil. Não existe neste sistema fora de Hollywood. Por isso ele leva tão sério sua produção. Há outros - como Patino - que também possui sua produtora, mas não é a mesma coisa. Efetivamente Almodóvar segue a linha: pensar, rodar, montar e vender. Esta seria a "factoria almodovariana".

Em seu melodrama não há coisas novas. O único que se pode dizer é que as diz de uma maneira nova. Além disso, eu acredito que Pedro Almodóvar, querendo ou não, pertence a um período da cultura que chamamos de pós-modernidade. De certo modo parece que um dos princípios dela é a reciclagem. Suas películas estão recicladas, reinventadas e redesenhadas. Uma série de películas subordinadas a esse modelo de referência possuem uma importância muito grande dentro de seu cinema. Quando ele faz um melodrama recorre a películas com forte conteúdo melodramático, recuperando uma série de motivos, tipos e arquétipos, mas - e talvez isto é o que faz a corte triturá-lo - mesclando a partir de sua sensibilidade o criador dos anos 70, 80, 90 e 2000.

Imagino que no cinema pós-moderno - ao que o críticos podem me atacar - eu diria que Pedro Almodóvar - não o comparo - está como foi Buñuel para o surrealismo ocorrido no cinema. Há outros diretores surrealistas, mas Buñuel foi e segue sendo o referente cinematográfico do surrealismo. Almodóvar ficará - para bem e para mal como o diretor desta pós-modernidade. Houve um tempo em que a academia rechaçava Almodóvar, depois o aceitou.

Digamos que na Espanha o reconhecimento de Almodóvar surge em sua quarta película, Qué he hecho yo para merecer esto? É a primeira película que a crítica reconheceu como uma obra interessante, porém sem vislumbrá-la como obra-prima. Na França o filme passou desapercebido, inclusive as críticas foram más. Recordo uma de um jornal que dizia no título: que he hecho yo para merecer esto? e colocava abaixo: é nós então? Dizendo que não havíamos merecido como espectadores tal 
película. E curiosamente, esta mesma revista dez anos depois, o pôs nas nuvens.

Assim, vejo que a crítica tem uma função epidérmica e reativa. Eu sou universitário e não funciono ou seja, não creio que um universitário em seu labor científico, possa colocar questões de gosto a não ser que este esteja subordinado ao estudo. Salvando as instâncias peculiares, seria como um médico que, como investigador, está pesquisando sobre algum ramo da medicina, ou outra coisa, olhar um vírus e dizer: - este eu gosto, este eu não gosto. Logo, eu posso estudar o cinema de Almodóvar e poderia não gostar, mas este é outro tema. Posso estudar ou me interessar por estudar as películas de Guerin [fala do cineasta espanhol José Luis Guerin], mas isso não significa que o aprecie.

O meio universitário em geral costuma não confundir - sobretudo no terreno do cinema - estes fatores e isso não se produz na crítica. Eu posso estudar uma película que está sendo exibida por aqui considerada malíssima - isso também um outro tema - mas academicamente esse fato é irrelevante. Não creio na perenidade das coisas. Não creio que uma obra hoje não considerada uma obra-prima, ao longo de cinco anos passe a ser. Há sociedades que percebem em seu momentos as obras. Que redescobrem obras desapreciadas em seu momento, que redescobrem, filmes que foram êxito. Basta fixarmos o caso da França diante de Almodóvar e o êxito da película que na Espanha se chama Los niños del coro (2005), que é um remake dos anos 1940. $\mathrm{Na}$ época foi um grande sucesso. Animado com este histórico, seu diretor atual decidiu fazer um remake que é um plágio - não todo, claro. Mas há momentos em que os diálogos são os mesmos.

Almodóvar soube fazer um cinema de autor e ao mesmo tempo um cinema popular, desinibido, aceito em muitos países. Conto uma experiência - e não vejo nenhum problema em falar, porque o próprio Almodóvar fez comentários favoráveis a respeito - que trata do cinema na internet. Hoje pode-se baixar qualquer película de Almodóvar. Está em diferentes idiomas, alemão, inglês, espanhol, francês, chinês e ele afirma estar muito contente com isso. Para ele esta é a única maneira que os chineses tem - por exemplo - para ver seus filmes, antecedendo aos vídeos piratas. Ainda disse: - pois que sigam, porque no dia em que eu puder estrear uma película no país, eles já entenderão meus diálogos. A pirataria pode ter suas coias boas, não só para o consumidor, mas também para o criador.

Mas efetivamente, para voltar a discussão dos acadêmicos, na Espanha está muito claro que as pessoas se desentendem de Almodóvar. Enquanto que na França, a reação foi um pouco posterior e diferente. Eu diria que em Mujeres ..., despertou um 
interesse. La ley del deseo por exemplo, foi uma película que interessou os mais idosos e os gays. Este porque era em seu momento um filme um pouco mais para um circuito fechado e Mujeres ... foi um trabalho que já passou comercialmente e claro, o caso específico de Tacones lejanos.

José Enrique Monterde ${ }^{330}$ é professor na universidade de Barcelona e crítico cinematográfico. Regularmente escreve como colaborador em várias revistas especializadas em cinema na Espanha. Já escreveu sobre Pedro Almodóvar e nesta entrevista preocupa-se com opiniões extremas positivas e negativas que ofuscam segundo ele - a crítica científica. $O$ início da conversa buscou um discernimento histórico e estilístico do cinema no país.

Comparando diretores expressivos espanhóis podemos dizer que em Buñuel havia uma mescla surrealista entre o hispânico e cosmopolita assim como em Berlanga, sobretudo nos anos 60. Mas citar Almodóvar como surrealista é absurdo. No caso de Berlanga, Bardem, Buñuel, todos possuem uma densidade social grande para entender os anos 50 e 60, mas não estou seguro que Almodóvar tenha essa consistência para entender a sociedade dos anos 80. Buñuel trabalhava com elementos mais abstratos da Espanha, diferente de Berlanga que trabalha com materiais documentais identificados com a cotidianidade.

A saída de Almodóvar é sempre artificial, mesmo nas cenas mais pretensamente realistas. Ele faz um jogo de forças de efeito que não se ligam com a realidade social. Não dialoga com Saura, nem com Bigas Luna. Apesar de que este, assim como Almodóvar, parece estar mais próximo da pós-modernidade. Porém Bigas Luna é um cineasta mais visual e em Almodóvar seu visual é muito mais de acumulação de objetos, o que não me agrada em particular, é muito artificial. No cinema espanhol, Almodóvar ocuparia o lugar central na pós-modernidade cinematográfica. Ele se apropria de referências, tanto na imagem como no som, faz homenagens, produz imagens prévias apropriadas de outras películas, fictismos que não são necessários na história, são mais gracejos para agradar seus seguidores. Faz uma soma de efeitos. Há uma certa falsificação estilística. Atrás deste estilo não há uma cosmo-visão. Há um exagero em Almodóvar que nos anos 90 chega ao seu ponto mais baixo. Porém, a conjugação entre críticas favoráveis, publicidade, o dinheiro francês em produções e críticas do Cahiers du Cinéma, deram um forte incentivo que o ajudou a se levantar, além da boa e aguçada visão comercial de seu irmão que é muito

330 MONTERDE, José Enrique. Depoimento sobre Pedro Almodóvar [21 jun. 2005]. Entrevistador: Gilmar Santana. Barcelona: Universitat de Barcelona, 2005. Minidv (60 min), mono. Entrevista concedida para este trabalho. 
bom para isso.

Almodóvar teve que fazer uma escolha em sua vida: ser popular ou ser importante e creio que optou por ser popular. E estou convencido que com o passar do tempo, em 20 ou 30 anos muita coisa de Almodóvar vai cair no desinteresse. Suas monjas [refere-se ao filme Entre tinieblas] podem ser interessantes num tempo, mas podem ser muito fugazes depois. Por que estes fictismos são como fogos de artifício, se bem que Almodóvar já possua uma filmografia bastante ampla e tenha feito coisas interessantes. Mas não tenho notado tanta evolução. Em Hable con ella está num momento ótimo, mas La mala educación é mal construído.

Os personagens de Almodóvar não existem por si mesmos. Em Todo sobre mi madre há muitos elementos melodramáticos que sustentam a história, não os personagens. Hable con ella tem elementos mais estilizados. Creio que a boa aceitação do mercado mundial está ligada muito à marca Almodóvar e o que o público intelectual vê. A Espanha não é mais o touro e pandeiro. Vejo que a grande virtude da marca Almodóvar é seu exotismo cosmopolita. É claro que Espanha não funciona por isso, mas fora do país, ainda permite conectá-la a uma certa tradição do exótico espanhol.

A idéia do exótico cosmopolita e homenagens cinematográficas permitem a inserção de Almodóvar internacionalmente. Suas raízes exóticas mais ou menos negam o hispânico. Trabalha com materiais de campos muito distintos: cinema, TV, publicidade, artes plásticas, cultura popular, pop, kitsch, e os utiliza bem. Com isso, um dos problemas que provoca seu cinema é a quantidade de pessoas que são seus imitadores. Que tentaram, mas não conseguiram imitá-lo.

Tematicamente, toca em certos tabus, como a homossexualidade. Mas o que nos primeiros filmes representava coisas chocantes, hoje são quase normais. Talvez seu cinema tenha contribuído para isso. Há uma crítica que o referenda demais e outra que não entende por que tanto êxito internacional, mas há aquele discurso de que ninguém é profeta em sua terra. E até, inclusive, essa faceta de incompreendido ele soube explorar de certa forma em sua imagem comercial. Ele sabe ser um elemento de publicidade, de estar na polêmica.

María Antonia Garcia de León ${ }^{331}$ é diretora do curso de Sociologia na Faculdade de Educação da Univerdidad Complutense de Madrid e escreve também sobre cinema. É autora, se não do primeiro, um dos primeiros livros sobre Pedro

${ }^{331}$ GARCÍA de Leon, Maria Antonia. Depoimento sobre Pedro Almodóvar [28 e 29 jun. 2005]. Entrevistador: Gilmar Santana. Madrid: Universidad Complutense de Madrid, 2005. Minidv (60 min), mono. Entrevista concedida para este trabalho. 
Almodóvar, cuja referência de suas passagens já se apresentaram várias vezes neste trabalho. Possui também diversos trabalhos publicados sobre gênero, onde debate o lugar da mulher nas várias esferas sociais. A entrevista foi desenvolvida em dois dias. Uma parte em sua residência em Madrid e outra em seu gabinete na universidade. Iniciamos com assunto da originalidade de Almodóvar:

Almodóvar faz coisas genuinamente espanholas, mas não são piadas, brincadeiras, pois todos países possuem as suas. São coisas que só podem ser entendidas aqui. Tem uma graça enorme, como não entender na Espanha? Sua maneira direta de falar faz com que reconheçamos Almodóvar como um particular universal que tem uma graça que atinge as pessoas. No ano passado, sem ir mais longe, estive em uma conferência na Universidade São Marcos, no Peru em Lima e gente muito jovem, de 18 anos, estudantes de ciências sociais em geral estavam presentes. Pusemos o filme e eles encantaram-se e entenderam tudo, isto é notável, não? Só se passa com os clássicos do cinema, não? Creio que meu trabalho "La outra españa cañi" seja realmente o primeiro trabalho sobre Pedro Almodóvar; é de 89. Sou socióloga, mas também estudei direção de cinema. Porém, como fazer uma película é muito caro e escrever um livro é muito mais barato, optei pela segunda alternativa.

A mim, o primeiro Almodóvar é o que gosto mais. Eu diria que existem quatro Almodóvares. O primeiro vai até a película anterior a Qué he hecho yo para merecer esto? Esse Almodóvar me divertia enormemente, me encantava. Era um contraste enorme com o cinema espanhol dominante na época. O segundo Almodóvar é o de Qué he hecho yo ... para mim - se tenho de maximizar e ficar com uma - é a melhor. Também gostei muito de Mujeres al borde de un ataque de nervios, mas esta é mais minha opinião, não a única. Um terceiro Almodóvar segue desde Mujeres ... bem, esta terceria segue até a quarta, intuitivamente creio que um pouco latente. Talvez se o retomar para estudos, eu trabalharia esta quando me animar, provavelmente faça outro livro.

Este terceiro e quarto Almodóvar me interessam menos, não como sociologia, pois como socióloga sempre os estudos são interessantes e trazem chaves importantes que abrem para a situação espanhola, mas este gosto menos. Da última etapa, o filme que gosto mais é Hable con ella. Parece-me uma película elegante, fina. La mala educación, sendo sincera, me decepcionou muito. É uma publicidade de certa maneira enganosa, pelo seguinte: sou espanhola, mais ou menos da geração de Almodóvar. Vi o cartaz do filme, aquele menino que está fraquinho com a camiseta de esportes. Achei fenomenal, pensei que poderia ser uma película sobre a educação no 
pós-guerra na Espanha e quando assisto ao filme, isso ocupa apenas dez minutos da história.

Todo o restante, apesar de ser uma película sobre homossexualidade, devo respeitar o ele quer fazer claro, mas não era o que eu havia pensado e também, um tema de minorias que se exacerba muito, concretamente a mim - está ótimo pelo seu direito de criador, mas me aborreceria se fosse o tema número um da Espanha ou do mundo. Explico: me chatearia qualquer tema que passasse a ser um todo. Sinto, como vê, sou bastante sincera. Bem, estou bastante propensa a voltar sobre um tema acerca de Almodóvar. Tenho muitas idéias. No ano passado me convidaram para falar em algumas escolas em Boston numa conferência sob o título: Pedro Almodóvar ou a revolução das massas.

Gosto muito do livro que fiz com Tereza Maldonato, pois é muito sério, sem essa coisa das pessoas que dizem da Movida como uma banalidade, não! Não estou de acordo, nem creio que Almodóvar esteja de acordo. Ele trata seus temas de maneira muito séria, é possível ser sério e muito engraçado ao mesmo tempo. Então, este livro necessariamente é muito serio e creio que seja imprescindível, ou que deveria ser, para ver a Movida no contexto da Espanha. Fizemos entrevistas não só com Pedro, mas também com Cassali que era diretora da revista La luna de Madrid e uma pessoa muito importante para esses aspectos, Jaime Chávarri diretor de cinema.

Deliberadamente, eu não iria entrevistar Almodóvar. Eu queria me sentir livre, porque se você vai a uma hemeroteca e verifica o que ele diz, é impressionante. Fala tanto, há uma quantidade enorme de coisas. Quando eu não o conhecia não sabia que Almodóvar entrevistava a si mesmo. Ele diz: que pensas Pedrito de tal cosa? Tudo ele mesmo. Eu não queria este enfoque, então fechei essa possibilidade. Fui motivada ao tema por que sou socióloga e me interessam muito tanto os assuntos espanhóis, como as coisas feitas no cinema.

Bom, termino contando este episódio. Agustín Almodóvar me liga do telefone público da porta de El retiro [um dos principais pórticos de Madrid que fica na entrada do parque El retiro] e me fala sobre o livro que acabava de ser editado. Eu perguntei: que tal?, sim, porque se gostassem, poderiam vir apresentá-lo no lançamento. E ele me disse: ficamos todo o final de semana fechados, não conseguimos parar de ler, ficamos encantados, seu trabalho é muito sério. O lançamento foi muito divertido, num bar muito famoso da Gran via de Madrid, onde esteve Ava Gardner, todo glamour., Enfim, fiz o livro, como se diz aqui: porque meu deu ganas. Mas no sentido, claro, que - como socióloga, Pedro Almodóvar catalisava para mim, temas muito interessantes. 
Hoje Almodóvar continua sua mesma linha, é um efeito de seu inconsciente que lhe dá força para continuar. As heranças de sua infância, estão aí. E se puder continuar refinando ou então classificando e teimando em suas abordagens, prosseguirá. Bem, eu não quero colocar um diagnóstico, pois - não sei quando - estou me preparando, refletindo se voltarei a revisitar Almodóvar e escrever sobre ele. Bem, houve uma continuidade em aspectos coisificados, demasiados utópicos e simplistas. Porém, como disse, eu tenho uma certa distância deste último Almodóvar.

As pessoas no estrangeiro que não o conheceram antes, falam muito, o endeusam. Não é bem isso. Criaram uma espécie de bola de neve, marketing, mercado. Não deve-se esquecer que Pedro Almodóvar abriu um grande império midiático, ele é um homem midiático. Então, talvez eu volte a estudá-lo, pois, como é uma pessoa muito equilibrada, um homem muito inteligente ... Bem, além disso, seu ofício intelectual, como diria Bourdieu - pois sou bourdieana - seu ofício intelectual está contra a dominância, inclusive suspeitando dela. Pode-se falar da dominância Almodovariana: por que ele aprecia tanto o sistema, o establishment? Creio que seja uma boa questão.

\section{9 de junho de 2005.}

Almodóvar está sempre na imprensa espanhola - ao menos em El País, importante diário cultural que leio. Todas as etapas de sua produção são acompanhadas e divulgadas. Desde antes de seu nascimento, durante sua gestação e depois do nascimento. Há sempre uma quantidade enorme de informações. Sua fonte de inspiração é o cotidiano e seu tema forte é a mulher. Ele possui duas irmãs e o irmão que é seu produtor. A irmãs vivem em um bairro popular de Madrid que antes era um pueblo e depois passou a ser um conjunto de habitações constituídas de habitantes de classe popular. Ele diz que quando visita suas irmãs, elas já o recebem contando sobre uma nova vizinha muito simpática, sobre uma cabeleireira, etc.

Ou seja, está todo momento como um antropólogo observando suas irmãs, captando coisas, observando o universo das mulheres [muito do que se vê no filme Volver: a vida das vizinhas, a solidariedade no bairro, a irmã cabeleireira, as mulheres em grupo no pueblo]. O cinema e a literatura, devem encarnar as coisas. Dar substância aos detalhes que estão na vida cotidiana. Efetivamente, ele se nutria muito de sua mãe que já faleceu. Falar de sua mãe é como um código interno da cultura rural medido nele, ou seja, o pueblo fala por intermédio de sua mãe [novamente, convém lembrar a estrutura do filme Volver, calcada em duas personagens centrais representando a maternidade. Carmen Maura encarna a imagem da mãe pueblerina 
que faz a ligação mítica entre campo e cidade e restabelece as relações que haviam se rompido, dando sentido à trajetória de todas as personagens].

Bem, como disse ontem, estou um pouco distante do último Almodóvar. Mas observo que existem algumas questões recorrentes neles. Em Hable con ella e em outros de seus filmes ele vai constantemente ao campo. Como digo em meu livro, ele domina perfeitamente os códigos da cultura urbana e da cultura rural. É um aspecto que outros cineastas não tem. Em geral filmam classes altas, aristocratas, culturas urbanas e não dominam o código rural. Às vezes, claro, Berlanga e outros são genais. Estamos falando de arquétipos, mas como tendência, houve diretores que não souberam tratar o rural e Almodóvar sabe. Ele tem essa dupla riqueza. E é muito verídico, é um bom antropólogo, os outros tratavam personagens, mal caracterizados, como em Jeca Tatu no Brasil, como bobos. Ele não; pois sua mãe é rural. Ele trata bem esse assunto. Com graça, mas bem.

Poderíamos ver em seu melodrama a relação com a classe social ou quem sabe Almodóvar e sua relação com a cultura popular. Outros cineastas tratam a temática de classe, mas de uma forma muito estilizada. O problema, talvez seja a existência de um certo pudor em falar da classe popular. Mas sou ambivalente com esse tema. A mim me parece tudo muito excessivo, isso também é o problema do melodrama. É exagerado. Eu estava um dia conversando com uma senhora numa tinturaria e ela me disse: mas a vida não é assim, como que dizendo que Almodóvar havia exagerado. Sua brutalidade condensada me incomoda.

Quando faz promoção de seus trabalhos e de si mesmo ele já pensa como um criador e um criador publicista. O primeiro Almodóvar me encantou porque quebrava os paradigmas de cinema na Espanha, mas sem o excesso melodramático. O cinema iraniano tem melodrama mas não precisa de todos esses exageros para contar uma história e ainda afronta a estrutura hollywoodiana com boas histórias. Por isso, gosto mais de Hable con ella, Geraldine Chaplin está perfeita em seu papel e Todo sobre mi madre me aborrece, há tantas lágrimas, tantos gritos que me deu um efeito - estou falando pessoalmente, não como crítica - de saturação.

É como na pintura - como você viu, eu pinto - se colocamos muitas cores num quadro, elas se neutralizam. Se num quadro se põe uma pontinha de negro, isso vai ser maravilhoso, assim o ser humano não pode ter tanto estímulo, deve receber apenas um pouco. Agora sobre sua auto-promoção e por sua vez os filmes, vejo que tudo o que Almodóvar toca se converte em publicidade, eu diria que isso é uma natureza dele. Quando estréia um filme de um diretor espanhol, sai uma crítica no 
jornal. Com Almodóvar elevam-no ao céu. Como disse, domingo passado, El País fez uma página inteira sobre Almodóvar com uma foto sua no centro. Quando estréia, sai na primeira página com a manchete: a realidade da estrela Almodóvar.

Apesar disso há muitas críticas. Existe na Espanha uma espécie de inveja doentia, um pouco injusta. Nos prêmios Goya tem havido muitos conflitos, mas em geral ele recebe críticas boas. Os franceses o elegeram uma mascote, uma moda de coisas simpáticas. Claro, não quero tirar seus méritos, mas estamos fazendo algumas análises. Sabemos das pessoas, de suas inteligências e esta alienação da cultura de massa - falando como socióloga - me deixa um pouco nervosa porque fazem dele uma pessoa mascote e se monta todo um império: se vendem roteiros, camisetas, tudo. Almodóvar não é político. Ele faz uma brincadeira ou outra, fala algo curioso, mas é sempre uma anedota apenas. Creio que as coisas que ele disse no primeiro trabalho continuam. Mas claro, essa continuação pode ser positiva ou negativa, só não pode se converter em utópica.

José Maria Caparrós ${ }^{332}$ é professor da Universidade de Barcelona, diretor do Centro de investigações filme-história no parque científico de Barcelona e membro da Academia de las Artes y la Ciencias Cinematográficas de España - Goya. Especialista em cinema, trabalha sobre o tema desde os anos 60 e até a data da entrevista estava em vias de publicar um artigo num livro sob o título "El fenômeno Almodóvar"; com outros autores.

"Ninguém é profeta em sua terra". Almodóvar é uma pessoa consagrada, mas bem diferente de Bardem e Berlanga que se consagraram como anti-franquistas. Depois chegou Saura com um cinema também político, se bem que internacionalmente seja conhecido por seus musicais. E em seguida vem Víctor Erice um mestre cineasta, com somente três películas. Almodóvar surge num momento de mudança, na Movida madrileña, juntamente com Fernando Trueba, que era crítico da revista El país. Representam a transição e recorrem a uma Espanha folclórica, lembrando Florian Rey.

Pois então; surge este homem do mundo marginal, underground, do mundo gay, que cria muitos inimigos, rompendo com todos os padrões culturais espanhóis paradoxalmente recorrendo à toda sua tradição. Uma vez estávamos num congresso convencidos de que Almodóvar não sabia fazer cinema, que era apenas um resultado do underground que fazia filmes em super-8. Suas primeiras películas eram muito malfeitas, porém com bons técnicos e uma boa equipe ele se fez um cineasta sólido. Depois de La flor de mi secreto e Carne tremula ele pôde se revelar um cineasta que 
sabe fazer cinema. Porém, porque não está no elenco dos grandes? Por que não definiu claramente seu tom marginal e porque fez muitos inimigos na Espanha. Eu, por exemplo, não sou simpático a ele, mas reconheço que é um cineasta que tem categoria, apesar de não partilhar de seus ideais.

Mas aqui - mesmo com seu sucesso - ainda possui muita rejeição. A Espanha é um país muito invejoso e ciumento. Outra coisa: Almodóvar saiu do nada, se fez sozinho, um self made man. Este perfil é muito bem visto nos Estados Unidos, mas aqui não. Mesmo sendo muito trabalhador assim como seu irmão, isso cria uma rejeição. Outra discriminação, está no fato de que somos um país muito machista. $\mathrm{E}$ como ele defende o mundo gay, a droga, a prostituição, está defendendo uma série de valores que ofendem a moral social. E como os espanhóis são muito "machos" ... Outra coisa que a mim me cai muito mal: Almodóvar influiu muito no estrangeiro a favor de setores da "máfia rosa" (termo espanhol para designar guetos gays ou que defendem a liberdade comportamental) que também apóia Almodóvar como um defensor da diversidade.

Como os anti-franquistas utilizavam Carlos Saura para "caçar o rei", os setores que defendem a diversidade usam Almodóvar para isso. Ele representa o que foi Picasso e Dali na pintura, aliás mais Dali, por que Picasso era comunista. Almodóvar nunca triunfará e se triunfar será pelo setor que o defende. E se tem bilheteria aqui na Espanha, não é por que gostam de seus filmes, é somente porque todos querem ver sua última obra. Não porque o reconhecem, mas o respeitam. Na última película [refere-se a La mala educación (2003)] - que não foi boa - todos a viram, mesmo que para falar mal.

Almodóvar precisa cuidar de seu egocentrismo. No último filme seu nome aparece com letras imensas no começo e no final. Isso envergonha as pessoas. Ele se sente endeusado. Agora, com o sucesso de Amenábar ele se sentiu extremamente abalado. Isso é típico dos artistas. Os pintores e atores aqui também são muito ciumentos uns com os outros. Almodóvar precisar ser mais humilde. Se na França a leitura de filmes é mais cinéfila e ele brilha, aqui entra a ideologia, a paixão.

Para ele não interessa o político. Mas é até melhor que não fale de política porque não sabe. Os outros cineastas consagrados fizeram política. Almodóvar nunca entrou nesse tema. Sempre esteve no seu mundo e no intimismo. A esquerda não o perdoa por não ter tomado posição frente ao sistema ditatorial de Franco e dizer que sua vingança a Franco é não falar de política, é uma falta de compromisso, como

${ }^{332}$ CAPARRÓS, José Maria. Depoimento sobre Pedro Almodóvar [08 jul. 2005]. Entrevistador: Gilmar Santana. 
Pilatos. Para os comprometidos isso soa como covardia, uma desculpa. Claro, ele é criador e faz o que Ihe dá vontade. Quando morreu o ditador, Saura também não fez mais filmes políticos, queria fazer trabalhos intimistas.

O que interessa hoje a Almodóvar é fazer uma homenagem a à sua mãe, esse é o tema de "Volver": fala agora mais de si mesmo. Todos os autores famosos sempre fazem a mesma película, o mesmo se passa com Almodóvar, com as atrizes de sempre, recuperando inclusive Carmem Maura. Almodóvar une a pós-modernidade com a tradição. Para os intelectualizados isso é bom, mas para o grande público essa dimensão não é percebida, bem ... as películas vendem.

Sobre o fato de hoje produzir filmes para outros diretores, vejo que ele não está preocupado apenas com seu dinheiro. O que ganha não fica só para si, ele incentiva outras pessoas. Com isso ele está desenvolvendo uma indústria, coisa que na Espanha não existe. Aqui sempre foi tudo artesanal, se bem que com as liberdades da república espanhola houve um pequeno nascimento industrial. A guerra civil truncou aquela indústria nascente e a ditadura franquista era um túnel onde se vivia de subvenções, a indústria do cinema sempre foi tutelada pelo Estado e fez com que as pessoas se subordinassem a elas. E essa nova geração caminhou com as próprias pernas e não se interessou pela política. Somente lhes interessam os próprios problemas e daí surge também uma certa independência em relação ao Estado.

Com seu cinema circular e marginal Almodóvar pôde criar sua indústria. Assim como Fernando Colomo e Trueba que criaram suas próprias produtoras. Na economia de mercado em que estamos, Almodóvar pode vender suas películas ao estrangeiro, a cadeias de TV, coisas que não havia no tempo de Franco. Sua censura selecionava inclusive o que saía da Espanha. E hoje estamos dominados pelo capital norteamericano e os filmes de Almodóvar interessam à empresa americana, assim como os de Spike Lee, que é um homem ofensivo, mas dá dinheiro. É o que importa aos Estados Unidos.

Almodóvar sabe vender sua imagem, faz auto-entrevistas para dizer o que quer de si mesmo, faz grandes coletivas com a imprensa. No tempo de Franco não havia coletivas, nem publicidade. Agora, Almodóvar faz as pazes com Carmem Maura diante da imprensa. Sua vida se mescla às suas películas. Por isso é um fenômeno. Qualquer um nas ruas de Nova York o conhece; isso é muito forte!

Suas temáticas tem sido constantemente estudadas. Nos meios acadêmicos, já existem muitos estudos sobre a homossexualidade em seus filmes. Isso já está 
ultrapassado nos personagens de Almodóvar, já está estudado. Ainda não pesquisaram nada para saber o que a gente comum pensa de suas películas. Porque as assistem? Hoje Almodóvar está criando uma fase industrial e não tem cumplicidade com os prêmios dados na Espanha. Não precisa somente deles para se fazer notar. E mesmo o irmão Agustín é muito ético, não teriam porque se beneficiarem das premiações. Agora Almodóvar sabe fazer cinema. Passou de intuitivo a um homem que sabe o que é ser um artista internacional. Aprendeu a manusear a câmara, especificar tempo e duração de seus filmes. É um gênio, tem um estilo; muitas de las chicas [termo dado pela imprensa às atrizes que trabalham sempre com o diretor], também cresceram com ele.

Em suas películas mistura constantemente tanto o cinema negro [cine noir] com o melodrama, é seu estilo. Alguns o comparam com Buñuel, bem ... não vamos confundir as coisas: Buñuel era surrealista, tudo partia do subconsciente freudiano. Trazia todas as tradições espanholas e a tradição da cultura francesa, Garcia Lorca, era um intelectual. Almodóvar é um homem popular, vindo do pueblo, sem cultura, que trabalhava na Telefonica. Não tem uma formação intelectual com Buñuel . as propostas de Buñuel são de um pensador intelectual. As propostas de liberação, de homossexualidade de Almodóvar são de um público popular, das classes populares. Buñuel era da burguesia intelectual - da alta burguesia aragonesa. Ele se relacionava e se debatia com a elite. Almodóvar não, vive em seu mundo de origem, do mundo gay, de quando fazia espetáculos em salas de travestis, de seu mundo marginal. As idéias que propõe são expressões de sua natureza. Buñuel era um filósofo, este é um homem do povo. Sua sexualidade não é freudiana como a de Buñuel, mas de um homem que expressa sua parte animal, sensual, coisa bem diferente de Buñuel que era um cavalheiro espanhol.

Almodóvar é como o povo espanhol. E nessas classes populares ainda dizem que ele é um maricas. Faz um cinema que não tem formação intelectual. O que sente e vive, fala e joga na película. E por possuir uma genialidade incrível sai uma obra artística, mas sem a profundidade de Buñuel. Ele é um menino de recados de Buñuel. Saura poderia fazer referência a Buñuel, era seu discípulo. Não Almodóvar. Ele faz um cinema de referências, não lhe retiro o mérito por isso, pois afinal aprendeu a fazer cinema.

Nuria Vidal ${ }^{333}$ é jornalista, colaboradora eventual da revista cinematográfica Fotogramas e integrante da coordenação do Festival de San Sebastián, o mais 
importante festival de cinema da Espanha. Tem publicado um livro sobre Pedro Almodóvar, sendo também uma das pioneiras no estudo sobre seus filmes. Já foram amigos pessoais, mas por divergências externas a eles, acabaram se distanciando. Algumas passagens desta entrevista foram incluídas em outros capítulos deste trabalho. Preferi mantê-las na intenção de evitar interpretações fragmentadas de seu depoimento:

Me interessei em escrever sobre Almodóvar primeiro porque me divertia muito seu cinema e segundo porque a crítica na Espanha sobre ele era muito negativa. No resto do mundo quase não o conheciam, talvez só Entre tinieblas e Que he echo yo para merecer esto?. Falava da realidade espanhola de uma maneira muita engraçada. Não era um diretor muito considerado. Mas me apetecia. Então recebi uma proposta de Fernando Mendes Leite que era um diretor geral de cinema e que queria fazer uma coleção de cineastas contemporâneos da Espanha. Convidou-me e achei interessante.

A crítica ortodoxa não tinha e não tem demasiado carinho por ele em razão de suas abordagens. E nós nos identificamos com seus personagens, com a linguagem, com as músicas. Pedro fala da cotidianidade e nela está a droga, a homossexualidade. Isso faz parte da cultura espanhola de maneira mais explícita ou oculta e Pedro falava na transição, quando tudo estava em ritmo de liberdade. O que eu queria era fazer uma entrevista e quando se fala de um diretor vivo deve-se realmente conhecer e saber suas opiniões. Assim, passamos muitos dias convivendo juntos e vivi seu cotidiano muito tempo.

Ele havia acabado de fazer La ley Del deseo e iria fazer Tacones lejanos, mas não este que foi exibido. Ele cancelou o projeto e fez Mujeres .... A ideía de Tacones ... era outra. Em Pepi, Luci ... já estava lá todo o Almodóvar. Mesmo mal feito. E Pepi, Luci ... tinha um frescor, que divertia, era essa a liberdade. Permitia barbaridades estupendas, conflitos com as autoridades. Enfim todas as suas películas respondem ao momento em que ele está. Esta situação está clara a partir de Mujeres ... é o reflexo de seu momento de solidão, lamentos, medos. Não saía de casa porque todo mundo o conhecia, sentia-se violado pela sociedade. Ele só veio a perder o medo em Todo sobre mi madre, tanto que o rodou em Barcelona. Madrid nos anos 70 e início dos 80 era uma cidade maravilhosa, depois ficou agressiva, perigosa. Isso repercutiu em Almodóvar.

Imagino que foi por isso a vontade de sair e se firmar em outro lugar e vir a Barcelona, isso fez muito bem a ele e lhe abriu um horizonte muito grande. Foi uma

${ }^{333}$ VIDAL, Nuria. Depoimento sobre Pedro Almodóvar [13 jul. 2005]. Entrevistador: Gilmar Santana. Barcelona: 
nova etapa. Há uma etapa até Mujeres, a primeira. Uma segunda até Todo sobre mi madre e uma terceira que estamos, agora não sei. A primeira vai levar até Mujeres ... ali se acaba a relação com Carmem Maura e é a última produção exclusivamente espanhola. Na próxima já entra o capital estrangeiro francês e italiano. Mujeres ... resume uma época. Em Átame a situação muda, os temas são os mesmos, mas a situação é outra. Todo sobre mi madre inicia um momento diferente estilístico e pessoal de Pedro. Mas não gosto de tudo de Almodóvar. Carne tremula, por exemplo, parece uma película que ele simplesmente quis fazer. Não é seu mundo.

Buñuel é o "fantasma do paraíso" de Almodóvar, mas ele não tem nada a ver com ele. Buñuel tinha outro conceito de mundo. Os temas de Almodóvar são a solidão, as dificuldades em ter um par, a família, a vida urbana. Importa-se muito com a amizade em geral feminina, as mães, as filhas, o mundo pequeno do bairro, do pueblo, sua nova película é um "volver" em todos os níveis. Mas não creio que seja uma estratégia. É uma necessidade dele. A volta de Carmen Maura é um exemplo da maturidade de todos. O tempo supera tudo. Quando se separaram em Mujeres ... , o problema não foi o Oscar. Quando filmaram La Ley del deseo tiveram uma paixão fulminante - mas sem sexo - e Carmen que era a estrela, em Mujeres ..., o centro da película, foi tratada como mais uma dentre todos. Foi uma filmagem difícil cheia de brigas e conflitos. O Oscar apenas culminou o que já vinha se passando.

Nesse sentido tanto Antonio Banderas como Victoria Abril foram mais habilidosos. Antes que chegassem ao conflito, cortaram as relações profissionais. Almodóvar quando filma tira o sangue dos atores, não permite que façam nada além do filme. Claro, tira deles o que possuem de melhor. Ele sabe como fazer. Nós tivemos uma grande cumplicidade, hoje não mais. Tanto fomos próximos que inclusive em Tacones ... há uma personagem que é secretaria de Marisa Paredes que é de origem mexicana e é catalã, essa sou eu, isso foi sugado de mim, por que Almodóvar coopta tudo ao seu redor. Tudo é material para seus trabalhos. Quando o conheci ele era um show man livre, hoje é um show man aprisionado por que hoje é muito conhecido. Faz anos que não passeia tranqüilamente pelas ruas. Mesmo assim mantém sempre seu bom humor. Todas suas coletivas à imprensa sempre são espetaculares.

Sobre sua produção devo ressaltar que seu irmão Agustín é fundamental em todo o desenvolvimento de sua carreira. Um dia estávamos sentados em um banco na rua e ele me mostrou uma maleta preta e me disse: - isso é nosso escritório. E a partir dessa maleta construiu um império. Sabia controlar Pedro quando havia problemas, 
conhece as estratégias de lançamento, enfim, Almodóvar tem a sorte de contar com uma equipe muito boa e ter seu irmão ao lado.

Sobre sua narrativa, vejo que o melodrama estava presentre desde o princípio nos trabalhos de Almodóvar. Mas não um melodrama clássico. Em Laberinto ... já havia. O melodrama forma parte de uma cultura mais popular, uma forma de falar de grandes sentimentos sem grandes palavras. Está em tudo, no cinema, no teatro, na literatura. Há uma outra questão narrativa em seus trabalhos que me incomoda. Em todas as películas de Almodóvar há algo que sobra. É como se tivesse medo de não agradar seu público. Há coisas que não fazem falta, mas estão no filme. Sua vida está em suas películas. A figura da mãe, por exemplo, está presente em muitas, pois sua mãe foi muito importante.

Ele faz um cinema tradicional, mas muito sólido. Não no sentido conservador, mas que está na tradição e é bom cinema, não estas outras coisas que estão por aí. Seu cinema não dialoga com nada, nem com espanhóis, nem com os estrangeiros, nem com os jornalistas, tem uns quatro amigos isso sim. Fala muito com seu irmão e se fia muito dele e é só. Tem uns 3 ou 4 amigos que se fiam dele. Ele não fala com ninguém.

O que mudou da época do livro que escrevi para cá ... Não sei se posso responder claramente. O que se mantém é o próprio Pedro, suas obsessões, sua história. O que muda é que antes falava de gente mais normal, entre aspas e hoje fala de pessoas mais isoladas, mais solitárias. Também sua abordagem sobre as classes mudou. Até meu livro todos os personagens são de classe média baixa e a partir de determinado momento seus personagens são intelectuais, acomodados, ricos, profissionais liberais, cineastas, escritores, atores de teatro.

São pessoas de outra classe social. Isto mudou porque antes ele era pobre e agora não é. Como todo cinema é autobiográfico, falava de pobres porque era a gente que conhecia e fala de ricos por que é a gente que conhece agora. Hoje eu não escreveria um novo livro sobre Almodóvar. Já me propuseram várias vezes, mas disse que não quero. Não, porque creio que um livro de diretor deve dar voz ao diretor e eu neste momento não tenho vontade de falar com Almodóvar, então pergunto, para que?

Fran A. Zúrian ${ }^{334}$ é professor na Universidade de Castilla-La Mancha e coordenador do Fórum Mundial Pedro Almodóvar. Em novembro de 2003 coordenou com Carmen Vázquez Varela o Congresso Internacional "Pedro Almodóvar" na cidade de Cuenca reunindo os principais estudiosos sobre o cinema do diretor: 
Almodóvar pensa mais na forma que no conteúdo. Sua formalidade é única, quem vê seus filmes a identifica claramente: as cores, o kitsch. Possui uma consistência visual tão grande que os puristas não vêem suas películas como sérias. Elas saem um pouco do acadêmico e isso acaba sendo um prejuízo para Almodóvar. Fala muito do grotesco e do esperpento, mas isso é uma parte muito superficial de narração. Seus personagens são extremos e suas situações inverossímeis. Mas quem fica apenas nas formas grotescas, não aprofunda a critica social, permanece na superfície.

O caso de Todo sobre mi madre possui esse tratamento, mas seu efeito é imenso. Trata da maternidade e da paternidade. Os críticos muito intelectuais não sabem reciclar, fazem uma crítica somente de maneira séria, não podem rir. E nós somos capazes de rirmos de nossa situação. Isso não significa que não temos consciência. Tivemos uma ditadura, mas seu cinema não se adaptou à crítica cinematográfica que faziam. Mesmo o Saura dos anos 90 não é o dos 70. A crítica "seria" pensa somente em coisas solenes. É preciso saber transcender a forma, senão fica-se somente na superfície.

As películas de Almodóvar têm vários níveis, um estilo encantador, outro linear (da história) e outro que realmente conta a história. Que fala dos sentimentos. Curiosamente é mais entendido fora do que dentro da Espanha. Pois fora não se fala de pré-julgamentos. O juízo ideológico e a seriedade demasiada, acabam por enfraquecer a análise. Não há por que ser assim. O desejo, o amor e suas categorizações e formas são algumas das barreiras que Almodóvar rompeu com seu cinema. Por exemplo, ele nunca sustentou a bandeira de luta gay. Ele é contra a etiqueta da relação. Para Almodóvar são pessoas que vivem, que amam, que desejam. É isso que a crítica muitas vezes não entende.Em geral há sempre uma manipulação do politicamente correto da relação normal. Isso não existe em Almodóvar.

Ele é um diretor de personagens, mesmo que alguns não agradem. Ele deixa o personagem falar quando está rodando. Respeita a lógica interna dos personagens. Mas a crítica fica sempre presa em ver se eles são maus ou bons moralmente. Ele usa muito os gêneros, mas violentando-os. Faz isso com o melodrama utilizando-o como estrutura narrativa e não como uma dicotomia tão clara como é a forma tradicional. Sempre há um personagem que está inscrito em um gênero em si mesmo. Muitas vezes em suas películas, não há como ver um monolito. Mas o gênero mais presente é o melodrama. Se observarmos, mesmo nas películas douradas americanas não há 
também isso tão fixo.

Em La flor de mi secreto, há um dos grandes personagens melodramáticos de Pedro, o de Marisa Paredes, uma escritora de "novelas rosa" que oculta sua identidade. Ela possui um valor dramático enorme, quase trágico, é uma das personagens mais perfeitas de Pedro, mais melodramáticas. Genericamente em seus filmes há sempre personagens que arrastam em si um gênero, mais do que toda a história. São quase que independentes da estrutura geral.

Almodóvar é um criador, um contador de histórias desde que era pequeno. Ele contava as histórias das películas que chegavam a seu pueblo com base nas fotografias dos cartazes e seus irmãos gostavam mais daquilo que ele inventava do que das próprias películas. Elas fluíam e ele necessitava contá-las. E Almodóvar é uma pessoa que respeita muito as idéias alheias. No congresso nos disse que ficou admirado diante de tantas percepções sobre seu trabalho, coisas que ele não via.

Alguns dizem que seu cinema é pós-moderno. Bem, todo pensamento não tratado com solenidade, capaz de rir tem que ser pós-moderno e é tratado como superficial? Não concordo com isso. Se pensarmos na teoria do gênero, e virmos suas primeiras películas, perceberemos que a pessoa que mais trabalhou sobre isso foi Almodóvar. La ley del deseo, por exemplo, tem o amor com naturalidade. Mas a academia é um pouco clássica e resiste a esta mobilidade. Almodóvar está em seu ponto máximo de criação, isso manifesta que não é tão superficial como dizem.

Apontam que não falou de política, que fez muito pouco pela transição espanhola nesse sentido. Mas sua posição em não falar do franquismo foi política e por outro lado, fez muito pelo gênero. Para ele aquilo não deveria existir. Pepi Luci ... é de um radicalismo imensa no período, contundência política absoluta. Faz crítica ao sistema policial, aos comportamentos, aos valores. Contudo, parece que não tem política e a academia de cinema aqui, não lhe concedeu nenhum Goya. Isso é um prejuízo. Seu contexto hoje trata de temas universais. Pedro tem uma grande consciência da crise do indivíduo, mas também uma preocupação grande com a comunidade, são os vizinhos, a solidariedade. Muito de sua origem de pueblo que ainda o influencia.

Sobre o livro do encontro de Cuenca, bem ... foi um encontro desenvolvido, devido a grande quantidade de coisas já produzidas sobre Almodóvar. Os únicos espanhóis que estavam no congresso trabalham fora da Espanha. Na Espanha se estuda muito pouco sobre a Espanha. O cinema espanhol é mais estudado fora do que 
dentro. A preocupação do encontro era de fazer um balanço e estabelecer em que estado se encontra hoje o estudo sobre Almodóvar. Tivemos uma panorâmica de vários aspectos, um repasse acadêmico. Foi a primaira vez que todos os que o estudam se mostraram, se viram, não foi um encontro de fãs. Veio gente de diversas partes do mundo, gente de Israel, por exemplo.

Daniela Aronica ${ }^{335}$ é italiana. Jornalista e professora da Universitat de Barcelona. Escreveu um livro sobre Pedro Almodóvar e na data desta entrevista residia na cidade de Barcelona: Comecei a estudar a obra de Pedro Almodóvar por pura casualidade. Eu vinha à Espanha para pesquisar sobre o cinema espanhol da época de Franco. Isto foi em 86, mas dois anos antes, em 84, no verão, vim a Salamanca e assisti a uma película de Almodóvar, particularmente Qué he hecho yo para merecer esto?, dentro de uma seleção de filmes que se projetavam para estudos de cursos de verão. Aquela película me surpreendeu pela novidade, no do marco do cinema espanhol, pelo estilo e enfoque dos temas e porque dialogava com algumas películas espanholas que eu já conhecia, tradicionais de Fernán-Gómez e de Marco Ferreri, dos finais dos anos 50 .

Tinha alguma coisa a ver com eles, mas, finalmente, com esse caráter corrosivo, rompedor, que se aplicava ao presente do cinema espanhol da transição, havia apenas alguns casos de novidade. Havia muita provocação em filmes de temática homossexual, por exemplo, Ocaña, retrato intermitente, Cambio de sexo de Aranda. Eram películas que rompiam com certos esquemas do cinema espanhol. Mas, o cinema de então era bastante aborrecido, não conseguia passar da intenção de recuperar a memória histórica. Eram películas que pareciam teses, muito chatas. A novidade de Almodóvar retomava toda a temática do cinema tradicional: a temática religiosa, coisas que eram tópicas, ele trabalhava de maneira distinta.

Permaneci com essa imagem e, à luz dos anos, houve uma ocasião em que voltei à Espanha para estudar com mais tempo o cinema da época de Franco e fiquei com vontade de saber mais sobre esse diretor espanhol. Falei com o diretor da Filmoteca Espanhola, Djalma Prado, responsável pela programação da própria filmoteca, e entrei em contato com Almodóvar. Ele havia acabado de rodar La ley del deseo. Nesse primeiro encontro - já era quase Natal -, em 30 de dezembro, convidoume para encontrar com ele, Carmen Maura e Mendes Leite para uma apresentação privada do filme. Estamos falando de 86. Eu fiquei realmente impressionada, pois se confirmavam todas as impressões que eu tinha. Decidi atualizar-me. 
Vi as películas, recompilei todo o material que pude e comecei a fazer um projeto de investigação. Quando voltei, propus a Fernando Djalma Teo uma monografia sobre Almodóvar para uma coleção de cinema, a única coleção dedicada a diretores de cinema na Itália. Recordo-me que a resposta de Fernando Djalma Teo foi muito curiosa: "bem, este diretor agora está bastante magro. Deixemos ele engordar um pouco." Porque ele era "el gordito". Então se suspendeu o projeto naquele momento. Estamos falando do ano de 87. Enquanto isso, Almodóvar estreava La ley del deseo em Berlim e esta se converte em película de culto. Depois, Mujeres... ganha como melhor roteiro no Festival de Veneza e já conquista todo o êxito de público que o acompanhará posteriormente.

O fenômeno Almodóvar se originou na Itália como resultado de uma relação histórica recente entre a cinematografia italiana e a espanhola. Até então, tínhamos a Espanha como espectadora da Itália. Antes, havia uma relação entre imitados e imitadores. Almodóvar inverte este modelo. Com isso, a Espanha teve condições de recuperar um pouco de crédito. Passaram-se uns anos e a coleção de cinema deixou de ser publicada. Até que, com a ocasião da semana internacional dedicada à Espanha, em Verona, em 94, da qual eu participava, consegui ajuda do governo de Barcelona.

Nessa época tive a oportunidade de encontrar novamente com Fernando e ele me disse que a coleção de cinema seria transformada num editorial independente, formada por um grupo de jovens que apostava num cinema de autor ${ }^{336}$ do cinema contemporâneo e, nessa ocasião, Fernando me disse que Almodóvar já havia engordado, e, portanto, o diretor comporia um dos títulos. $E$ foi assim que, pessoalmente, tive a oportunidade de reunir todo o material que havia colhido. Enquanto isso, se passou na Itália o fenômeno Almodóvar. No começo, completamente despercebido, no Festival de Veneza, com Entre Tinieblas, em 1983. Mesmo a Itália sendo um país muito católico - e a película usando de várias ironias à instituição -, o filme foi exibido num circuito bem fechado e não obteve repercussão.

Não se percebeu a novidade naquele primeiro momento. O contexto sóciopolítico da Itália e da Espanha nos primeiros anos da década de 80 era bem distinto. A

335 ARONICA, Daniela. Depoimento sobre Pedro Almodóvar [12 ago. 2005]. Entrevistador: Gilmar Santana. Barcelona, 2005. Minidv (60 min), mono. Entrevista concedida para este trabalho.

${ }^{336}$ Este termo "cinema de autor" foi cunhado originalmente nos anos 50 pelos editores da revista francesa Cahiers du cinéma e definia um cinema cujas imagens apresentavam claramente as marcas de autoria de um cineasta em seus filmes: roteiro, direção, proposta estética e produção, revelando sua autonomia. Pedro Almodóvar estaria - a princípio - dentro destas condições, por isso o interesse do grupo italiano em questão. Sobre esta discussão ver: BERNARDET, Jean-Claude. O autor no cinema. SP: Brasiliense, 1994, neste livro o autor discute a construção e significado dessa concepção e estabelece, inclusive, suas relações com o processo cinematográfico brasileiro. 
Itália vivia os difíceis anos de uma política em conflito e de ataques terroristas. A Espanha vivia a euforia da transição da chamada Movida. Os países viviam momentos opostos. Com Entre tinieblas, a produção e a distribuição quiseram jogar ao público um titulo muito discreto: Face do pecado, um título buñeliano, que pretendia a todo custo estabelecer esse paralelismo para um público que não via muito a películas espanholas. O único diretor espanhol conhecido, salvo Saura, era Buñuel. A única forma que encontraram para atrair o público, depois do Festival de Veneza com um dos primeiros de Almodóvar, foi com um titulo buñeliano.

Não serviu muito porque a película mereceu uma outra resenha para olhos mais atentos. Apenas saltou num momento do que foi o marco do festival de Veneza. $E$ talvez devamos esperar pelo sucesso de La ley del deseo no festival de Berlim, quando já se começa a criar um público em potencial, mas não era grande ainda. Mas, quando Mujeres... estréia no festival de Veneza o quadro se transforma. O filme foi saudado com dez minutos de aplausos e ganhou como melhor roteiro. Absolutamente toda a imprensa começa a interessar-se por esse diretor. Já se sabia dele do festival de Berlim; de sua fama rompedora e moderna, com tão pouco pudor, das inversões sexuais ou, inclusive, da política, que também não falta.

De repente eclode a idéia do cinema almodovariano. Em pouco tempo, foram exibidas até seis películas do cineasta de uma só vez. De uma maneira confusa, os filmes chegaram às telas da Itália em ordem aleatória. Na França, ocorreu algo no mesmo estilo [no Brasil também]. Depois, Mujeres..., Átame, Tacones lejanos - filme que já estava pré-vendido - foram saindo em ordem cronológica e os outros foram se recuperando. O último foi Laberinto de pasiones. O que aconteceu com Almodóvar foi uma exceção. Nunca havia acontecido de seis películas de um mesmo diretor estrear ao mesmo tempo. Foi um caso único na história. Não havia no país o costume de se fazer fila para ir ao cinema, nem reservas com antecedência. Já faz uns 30 anos que se perdeu o costume de ir a salas de cinema e não ver películas na versão original.

Os anos 80 não se constituíram numa etapa feliz para o cinema. Acabaram-se os cineclubes, os debates e as pessoas viviam para a televisão. Chegamos a ter 25 cadeias funcionando de 1978 até meados dos anos 80. Quando ocorreu a escalada das TVs comerciais e públicas, estas tentaram não corromper sua tradição cultural com as comerciais e as pessoas tinham perdido o costume de ir ao cinema. Nas 50 cadeias de TV havia uma grande oferta de produtos contendo filmes clássicos e recentes que foram se recuperando. Dentro desse quadro, de repente, surge um diretor contemporâneo vivo, que provocava filas, foi um impacto impressionante. A 
distribuidora Filmauro se encarregou de fazer o cartaz de Tacones Lejanos, como dos outros seis filmes desconhecidos da filmografia italiana. Salvo as comédias natalinas disparatadas, as comédias de teens ou de guerra de tortas, não havia nada desse tipo na Itália.

Assim, ocorreu com Tacones... uma promoção muito habilidosa. Almodóvar apareceu na TV italiana três dias seguidos em dias de máxima audiência: no Festival de San Remo, num programa de Rafaela Carrá e em Maurício Constanzo Show. Três programas diferentes nas redes privada e pública. Cerca de 30 ou 40 milhões de pessoas chegaram a ver em sua casa a cara do diretor. Assim, estrearam as películas com maior ou menor êxito. Kika - como em todas as partes - teve um sucesso tímido, e Tacones..., o contrário. As outras se mantiveram constantes entre alguns picos, até que chegou Todo sobre mi madre. Esta, apesar de toda a bilheteria que rendeu, eu diria que Hable con ella e La mala educación foram mais significativamente ajudadas pela crítica. Podemos falar um pouco de como a crítica foi acorrendo ao trabalho do diretor e elaborando - ao tentar interpretar - este fenômeno no cinema italiano diante desse novo diretor que pegou a todos totalmente desprevenidos.

Estamos falando da distribuição. Como eu comentava antes, no caso italiano, não é freqüente estrear várias películas ao mesmo tempo, como aconteceu com Almodóvar. Em seu momento, teve um papel destacado, com numerosa cinematografia e até os filmes de Almodóvar alcançaram realmente as salas dos multicines. Até então, na Itália, somente o cinema norte-americano era campeão de bilheteria. Tacones Lejanos permitiu que se discutisse isso. A distribuidora Filmauro o exibiu em muitas salas do país, mas antes havia preparado o público, o que obrigava, de alguma forma, as pessoas a se somarem ao cinema.

Por outro lado, também recordo o papel preparatório do êxito de Almodóvar para o grande público sob seu caráter mítico, a posteori, em torno da Movida. Lembro Manolo Ferreras - um dos corifeus da Movida -, que no ano, aproximadamente de 86, quando não se falava mais nada sobre a Movida na Espanha e que Almodóvar já rodava películas fora daquele mundinho que já não tinha mais nada a ver com ele, a partir de sua quarta película já havia deixado para trás estas experiências. Oficialmente, a Movida foi um dos produtos que tiveram uma das trajetórias mais artificiais depois dos anos 70. Lembro que em 86 o Ministério da Cultura Espanhol Ihe pagou uma viagem, junto a uns 10 ou 15 jornalistas italianos, para que fizessem uma cobertura sobre a rota da Movida.

Foi uma projeção de marketing extraordinária que se associou ao fenômeno da 
Movida, que, insisto, na Itália se conheceu - mal e pouco - muito posteriormente de forma reconstruída, especificamente para que a etiqueta made in spain começasse a vender os anos em que a Espanha - a partir de 82, com a entrada dos socialistas e sua integração na comunidade européia - pudesse demonstrar que havia passado por uma mudança profunda. Isso era importante. Era preciso que o mundo visse suas transformações. O país teve uma efetiva e importante mudança para o futuro europeu, em decorrência da mentalidade de seus movimentos culturais de arte transgressiva dos anos 70. A partir deles, logo criaram um produto útil para exportação.

Este é um terreno importante para o cinema de Almodóvar e, para entender seu êxito, o caso da Itália. Um caso paradigmático porque consta que foi assim em outros países, mas não na França. Todo ano de sol. Este era o lema da Espanha, uma marca diferente aos aborrecidos países europeus, em oposição à Italia, que vivia uma etapa complexa de grandes desencantos e desesperanças depois das lutas estudantis dos anos 60 e 70, as bombas, o terrorismo, os atentados, as ligas maçônicas, ou seja, uma luta entre choques de distintos poderes de direita e de esquerda extraparlamentares, que haviam piorado um pouco o clima no país. Havia, portanto, a necessidade de um desafogamento, de uma saída, de um escape.

Nesse sentido, creio que Almodóvar foi essa nova imagem que encarnou em pouco tempo, e de forma artificial, a Espanha que havia conseguido vencer por si mesma e mostrar isso ao estrangeiro. Creio que ali começaram as dificuldades de interpretação deste diretor; se associou de forma exagerada ou associaram automaticamente seu nome ao novo conceito de moda na Espanha, que encabeçava as últimas tendências. E, claro, foi fácil utilizar de forma superficial a evidente tendência a transgredir que está no filme de Almodóvar. Foi difícil explicar, e aí está o papel da crítica. Desde já, ressalto, que não está à altura da situação porque acabou preferindo os discursos da imprensa de marketing e do Ministério da Cultura Espanhol, que conseguiram divulgar uma imagem diferente da Espanha da época, e, certo, Almodóvar era diferente e atendia a esses interesses.

Apesar disso, Almodóvar é o diretor e produtor de si mesmo. Tentarei matizar um pouco esse aspecto. Quando em 87 funda sua própria produtora, ele joga com uma dupla vertente de diretor de cinema, de autor que busca total liberdade, para expressar desde o produto à idéia de produtor de si mesmo. Ele está totalmente involucrado com seu trabalho. Sabe intuir e usufruir - sobremaneira - de sua capacidade porque tanto ele como Agustín, seu irmão -, que leva os aparatos econômicos - são autoridades em seus respectivos terrenos. Agustín - que é um profissional de química - se colocou 
como produtor de cinema, e Almodóvar é a autoridade absoluta e prefere ser diretor de cinema. Os dois irmãos - com uma grande intuição sobre a Espanha - sabem aproveitar os benefícios que proporcionam aos realizadores, como ocorreu com a Lei Miro, que lhes favoreceu montar sua produtora.

Porém, Almodóvar, nesse sentido, não se limita a isso. Tem a necessidade de vender suas películas, fazendo-se como um desdobramento de diretor, ator-artista e produtor. Por outro lado, delega o papel de produtor a seu irmão, mas os dois estão no mesmo barco. Essa versatilidade se constitui numa das razões que levou, sobretudo, a crítica espanhola e historiadores a só tardiamente reconhecer seus méritos artísticos. Efetivamente, havia, como eu dizia, uma cultura na Itália favorável a Almodóvar.

Por outro, a produção no país prosseguiu fragmentada e escassa desde o ano de 75. Em dez anos, as entradas vendidas passam de 100 a 10, estávamos, portanto, mais ou menos nestas proporções brutais e num processo criativo incapaz de produzir um filme que interpretasse o presente, chegando particularmente ao vazio, ao minimalismo. Por exemplo, são essas as tendências do cinema italiano dos ano 80. Sobrevive um cinema difícil, e a produção destinada ao grande público é homologada e achatada pelo modelo televisivo.

Então, esse era o clima de asfixia que se vivia na Itália no campo cinematográfico. Por isso, o papel da TV é decisivo e engloba o cinevídeo como parte consciente das autoridades que evidentemente encabeçam este tipo de cultura, entre aspas. Claro, essa época foi muito boa para que a Espanha se aliasse a este tipo de cinema capaz de rir de si mesmo, do presente, deixando cair por terra os tabus e, enfim, introduzindo o latino na pós-modernidade. Não só a distribuição italiana soube fazer isso bem. Outros distribuidores também corresponderam, abrindo suas portas para os filmes de Almodóvar.

E o diretor também soube que era preciso usar a cabeça para tornar os mecanismos de marketing e da publicidade a seu favor. É como uma concretização de negócios, sem esnobismo. Ele soube perceber a condição necessária para que seu cinema não se traduzisse em histórias de grupos minoritários para sempre e não fosse somente composto de minorias de Madrid, apenas exibido nos circuitos de Alphaville. Portanto, que deveria passar e aparecer na TV. Eu admiro muito essa decisão de Almodóvar. Isso delineou sobre ele tanto um traço de reconhecimento acadêmico, de críticos e de investigadores, como para ganhar público.

Ele entendeu que, para seguir com seus filmes, sua produtora teria que ganhar com tal repertório. Não vale o discurso - pelo menos para ele - de que: - se quero ser 
livre, prefiro não fazer nada a ter que me obrigar a submeter-me às exigências da produção. Almodóvar se desligou de qualquer tipo de laços. Montando sua produtora, ele percebeu que esta deveria ser rentável e isso implicava passar pela publicidade e pelo marketing. Nesse sentido, midiatizou-se com a TV, concedendo entrevistas. Coloco aqui também o papel decisivo do Cahiers du cinéma. Nesse sentido, digamos que foi sua ponte para alcançar o sucesso. Concedendo entrevistas, fotos de rodagem, imagens bonitas, a revistas na Espanha, por exemplo, garantiu sua legitimidade.

Fotogramas - que possuem uma crítica de recorte acadêmico sério - recebeu com certa displicência, quando não com descarado desprezo, o cinema do primeiro Almodóvar e depois passou a elogiar os filmes que realizou nos últimos anos, abrindo caminho para outras revistas menos elitistas. Ele sabe manejar e falar com o ministério. A longa entrevista publicada pelo ministério, em 1987, concedida a Núria Vidal, demonstra como o diretor sabe mover-se, tanto com as instituições, como com uma certa imprensa na época demasiado elitista e desde já, como sabe, buscar seus distribuidores, começar as co-produções com a França e preparar suas negociações. Todas as suas películas já estão pré-vendidas. Claro, tudo isso significa [para ele pessoal e mercadologicamente] ser livre e seguir fazendo filmes à sua maneira.

Sabemos que não faz só suas próprias películas. Também produz filmes de outros diretores. Creio que Almodóvar cuidou de todos estes aspectos desde o começo. O aspecto da pós-produção aponta um dos grandes problemas ou defeitos do cinema de autor, que está acabando. Aí não falham os norte-americanos, que sabem que a películas não acabam com a última montagem. Há um momento fundamental, este, da pós-produção. Que significa não simplesmente vender a película que se fez, mas também gerar a possibilidade de fazer a seguinte.

Estes fatores não são banalidades e Almodóvar entendeu isso rapidamente, desde quando começou a ter problemas para financiar suas histórias com os produtores diante dos poucos lucros. Nunca gostou de filmar tendo que buscar dinheiro por toda parte, como fez em Pepi, Luci, Bom... ,que Ihe custou dois anos para produção. Enfim, aprendeu sobre a luta e o duro que eram os compromissos que deveria assumir e coisas que precisaria ceder para realizar suas películas. Apostou com atrevimento, fez o possível numa época que acreditava ser possível concretizar seus projetos, e investiu neles. Isso é o que muitos não são capazes de fazer e, que, todavia Ihes custa muito reconhecer no diretor. A lei Miró esteve à sua disposição, mas ele soube aproveitá-la de poucas maneiras e creio que isso foi fundamental no êxito que recebeu em todas as partes. Ou seja, a capacidade de vender seu cinema, de 
acompanhar suas películas e, além do mais, evidentemente, rodeado de artes, de atores cada vez mais conhecidos também ajudou. Mas eu diria que, com uma inteligência considerável, não dando passos maiores do que suas próprias pernas.

Há muitos anos lhe oferecem a possibilidade de rodar nos Estados Unidos, não sei se ele não gosta do inglês, pois não fala e aprendeu pouco e-mail. Ele tem a forma de fazer cinema, como sabem, totalmente uterina, visceral e tem que se fechar com seus atores, com os que o acompanham habitualmente. O sistema dos americanos de fazer filmes não lhe permitiria fazer isso ou, se permitisse, seria uma vez e nunca mais. Ou seja, ele não caiu na armadilha das sereias que cantaram maravilhas para ele. Isso é o que me parece muito importante.

Sobre a crítica italiana: a crítica italiana ficou um pouco surpreendida com esse diretor e com poucas chaves de leitura para entender sua cinematografia. Nesse sentido, creio que - citando eu mesma - por exemplo, esta biografia que fiz dedicada a Almodóvar representou para crítica italiana um pouco a possibilidade de interpretar esse conjunto de forma ordenada, com vínculos estreitos ao contexto de procedência, totalmente desconhecidos do setor publicitário e da moda. Claro, estamos falando de dois planos diferentes, um pela via do grande público, que tentei expor anteriormente e que depende muito da capacidade de Almodóvar estabelecer contatos interessantes, de dosar suas entrevistas, de concedê-las, de entregar presentes em momentos determinados, para chegar a uma revista numa primeira página. Mas este auto-cine é uma imagem inflacionada, concentrado em momentos importantes como os citados em Tacones lejanos. Portanto, por uma parte segue o caminho comercial das películas.

E, agora, tentarei esboçar como foi a aceitação do ponto de vista da crítica. A crítica italiana, como dizia antes, não conhecia o cinema espanhol, apenas algo de Buñuel e Saura. Portanto, não há memória cinematográfica relacionada à Espanha no mundo crítico e acadêmico italiano. Por outro lado, efetivamente a cinematografia espanhola é de grande alcance na América Latina em virtude do idioma e tem muitos costumes evidentemente reconhecidos. Por essa capacidade dos produtores espanhóis de flertarem com as Américas e com seus costumes, suas personagens, histórias e temas, são conhecidos. Mas fora deste circuito a cinematografia espanhola teve pouquíssima projeção, salvo algumas evidências pontuais. Como colocar então Almodóvar? Como eu dizia, a Itália estava complemente distraída com seus problemas, não havia contato com a cultura espanhola, inclusive no meio acadêmico, as análises terminavam com a geração de Saura. Na literatura terminava com a geração de 27 e com o conhecimento de grupos de pintores que todos conhecemos, encabeçados por 
Picasso.

Eu creio que não havia mais conhecimento nem de música, de temas espanhóis, nem se conheciam os boleros, nem as coplas [músicas rimadas, curtas e inventadas na hora de sua apresentação] e, nesse sentido, Almodóvar também veiculou esta outra bagagem da cultura hispano-americana ou latino-americana em geral, como Caetano Veloso. Sua obra também foi um veículo ao grande público para esse tipo de cultura, mas para toda a crítica lhe faltava um marco, um contexto. E o contexto frágil que havia proporcionado o Ministério da Cultura era o de defender a Movida madrileña.

Almodóvar era essa máxima expressão e a encarnação desse fenômeno, tão tipicamente espanhol e contemporâneo que era a Movida madrileña. Mas seus participantes não foram capazes de ir além e Almodóvar não apresentava a transgressão pela transgressão. Sua busca visava exclusivamente o direito de expressar-se totalmente livre, mostrando o mais autêntico de si mesmo, fosse o que fosse, fizesse o que fizesse. Assim, introduz temas que soam provocadores às pessoas, como foi Buñuel, em muitos casos intencionalmente demolidor. Almodóvar acaba por afirmar-se como sendo o que é. Dizendo isso de uma forma um pouco simplista, porém, para este momento, sintética.

Nesse sentido, a crítica não soube fazer outra coisa senão lançar as mesmas interpretações, os mesmos lemas. Ela se aprofundou muito pouco em decorrência da própria falta de informação contextual. Não tinha outras películas, e sobre a questão da Movida só possuía dados muito sintetizados pelos jornalistas de forma muito simplista. Nem sabiam exatamente o que significou a Movida, em onde esta se inscrevia no processo de transição democrática, que para a Espanha havia representado muito. Isso chegou ao estrangeiro de forma muito superficial e visto pelos aspectos mais transgressivos e totalmente fora de contexto, com atraso e de forma desordenada.

Começaram a etiquetar as películas de Almodóvar como expressão da Movida quando esta já não tinha mais nenhum laço com esse fenômeno. Isso serve só para as suas duas primeiras e algumas coisas na terceira. Depois, Almodóvar não faz mais referência a esse momento histórico. Mesmo porque o cinema de Almodóvar está submerso no presente do indicativo. As películas dos 80, como Pepe..., ou em 82, obviamente falavam do que estava acontecendo na Espanha naquele momento, já em 84, depois da vitória socialista e as mudanças do primeiro desenvolvimento numa etapa de desencanto, aparece na quarta película Qué he hecho yo ... Ali já não existe qualquer referência ao mundo anterior da Movida. Bem ao contrário, estes temas que 
haviam sido, digamos, objetos de películas antigas como os turcos dos anos 50, a imigração, o problema da relação campo-cidade. Tanto que a crítica não soube o que fazer com ele.

Creio que, nesse sentido, realmente este livro que lancei - por conter muitas informações sobre a Espanha - deu algumas chaves importantes. Recordando Fernando Djalma Teo, lembro como ocorreram favoravelmente as primeiras provas do livro. Djalma é um marxista de nossa geração e, portanto, desconfiava das intenções do trabalho. Quando me entregou a monografia, um pouco mais arrastado pelos editores do que por sua própria convicção, ele me chamou e me felicitou pelo texto e me disse que finalmente havia entendido para quê servia aquilo.

Este e outros esforços dos demais autores deram seus resultados quando Almodóvar já se consagrou autor de fato. Com estes, ele passou a integrar os catálogos cinematográficos e os programas de disciplinas universitárias de cinema. Começa também a ramificar seu trabalho publicando seus roteiros, um recurso muito inteligente do diretor: sendo seu cinema muito narrativo, entrar no mercado com editorial próprio lhe rendeu grandes vantagens. Além de contar com ajuda estrangeira, mas sempre tratando de controlar as publicações dos roteiros. Eu tinha me disposto a estudar comparativamente os roteiros, com as notas, as apostilas. Consultei a produtora na época que escrevi meu livro para observar um pouco como ele havia evoluído, desde a idéia cinematográfica, o tratamento do roteiro e como havia se modificado, na trajetória e como tudo aquilo havia finalmente se fixado nas películas.

A meta dos roteiros é fundamental para que se reflita academicamente, por exemplo, sobre um diretor de cinema. E o fato de Almodóvar também ter pensado em aproveitar sua capacidade de escrever - uma tarefa conhecida, para tirar este outro filão do mercado dentro da preparação do marketing, é interessante não só porque mantém o interesse vivo do cinema. Não só a crítica, mas o próprio texto pode interessar a muitos e desde cedo isso permitiu que se começasse a estudar seus filmes na universidade e no mundo.

São várias as escolas que o analisam, desde licenciaturas até doutorados dedicados a Almodóvar, muitas dentro do habitual e dentro do que era previsível. Lendo as primeiras resenhas, tanto espanholas como italianas sobre este diretor, vale dizer que, finalmente, graças a Almodóvar, essa veia latina pôde introduzir a pósmodernidade na discussão. O pós-moderno chegou às faculdades de cinema da Itália com ele. Realmente chegamos a tocar no filme de autor, mas ficamos até os anos 70, e com Almodóvar, começamos a transformar o panorama da investigação. Por isso 
começa-se a fazer teses de doutorado.

O público italiano encontra dentro da temática de Almodóvar elementos universais. Creio que nesse sentido este cineasta é muito inteligente e por isso que chega a conseguir essa projeção internacional. Sendo extremamente arraigado à cultura da Espanha, soube extrair o melhor de toda a experiência que pôde viver. Sempre se utilizando da cultura espanhola, sabe tocar algumas cordas universais, como o problema da liberdade, de alguém ser ele mesmo. Eu creio que aí veria, por exemplo, com surpresa, as salas cheias de jovens. Não seria fácil dizer que aqueles que possuem mais de 40 anos gostam de seu cinema, porque de alguma maneira nos identificamos mais ou menos com essas vivências. São as nossas, as compartilhamos de forma muito autobiográfica.

Porém, o público de menos de 25 anos gosta mais dos filmes de Almodóvar. Eu creio que seja o problema da confusão, da identidade, da necessidade de autoafirmação, um problema típico da adolescência. Nesse sentido, os jovens se identificam muito nele. Eu deixaria de falar de público italiano e veria mais um público geral de distintos setores. Evidentemente que a comunidade homossexual, poderia dizer que a liberdade com que tocou certos temas e certas situações e a coerência com que os perseguiu, transforma-se numa bandeira, mas pelo contrário apenas tocou com tranqüilidade em temas que eram tabu.

Se vê esta situação com aqueles que o converteram em um autor de culto, antes de La ley del deseo. E nos adolescentes está isso. Esta intensidade de ser a si mesmo, a dificuldade de identificar-se de forma clara, precisa. Essa mescla de cultura pop e pós-moderna, não só de visual entre gêneros diferentes, mas de culturas distintas, essa capacidade de absorver elementos de culturas mais tradicionais e modernas, tanto espanholas como estrangeiras, Andy Warhol e a cultura pop norte americana, a música, o comics, a fotonovela. Ou seja, gêneros heterogêneos que acabam um pouco na pós-modernidade, na contaminação, na reelaboração de conteúdos distintos, mesmo que não sejam originais. Nessa relação, passam a fazer sentido.

Vemos seu cinema com muito frescor, muito jovem, muito atual e, enfim, hoje, resulta que já passados dos 50 anos, o diretor começa a refletir sobre os grandes temas da vida, da morte, a maternidade, a paternidade. À sua maneira evidentemente com grande coerência, sem chegar a nenhum compromisso - digamos, sem renegar, sua trajetória, se dispôs a buscar esta liberdade, os caminhos de ser ele mesmo, custe o que custar, em qualquer situação. Este foi o êxito de Todo sobre mi 
madre, que conquistou um público que não parecia, entre aspas, almodovariano, por exemplo, de muitíssimas mães que podem se ver em alguns momentos na película.

Realizei muitas conversas em institutos secundários e me disseram que baixa muito a idade do público almodovariano nas academias de cinema. Nas escolas, a película analisada foi justamente Todo sobre mi madre, e é surpreendente ver como os professores e os jovens se projetaram e se identificaram. Foi uma grande surpresa, pois creio que é uma película difícil de manejar, mas todos a assistiram com grande desenvoltura e naturalidade. Acredito que é uma prova a mais que desde o ideológico, já não digo desde o cinematográfico, nem desde o estético, mas do ideológico, o projeto, o caminho que vai seguindo Almodóvar. No estético melhorou muito porque aprendeu a fazer cinema fazendo.

\subsection{Legado acadêmico - contribuições e questionamentos em pauta}

A versatilidade de Almodóvar, tanto para dialogar como para produzir frente ao público, mercado e críticos é o elemento que integra todos os depoimentos. Todas as análises, envolvendo maior ou menor simpatia por sua obra e trajetória, não deixam de demonstrar que seu poder de circulação em variados meios dentro dos setores vinculados ao universo cinematográfico é de longo alcance. Não deixa de ser curioso perceber como na observação muito similar entre estes intelectuais, sobre as estratégias que o diretor desenvolve para se projetar, encontram-se previsões distintas que vislumbram de um lado sua consolidação na cinematografia mundial, enquanto outros prevêem sua derrocada.

Claro, a falta de consenso é saudável para o debate porque evidencia aspectos não percebidos entre um e outro analista. Mas segue um pouco mais além; revelando posições sociais e a dinâmica destes profissionais no exercício comum de papéis que alimentam o campo artístico num contínuo jogo de tensões entre os que buscam conservar e os que buscam transformar regras vigentes. Retomo novamente Howard Becker sobre alguns pontos que levanta porque contribuem para refletir o lugar destes atores sociais no mundo da arte, antes de fazer uma comparação mais detida acerca de suas visões sobre o cineasta. Afinal, estes também encontram-se no processo de manutenção de obras e artistas que participam desse universo. O mundo da arte centra-se sistematicamente na reputação, ocupando-se de analisar a importância dos indíviduos que se lançam a fazer arte. Seus críticos estéticos os observam para julgar 
se podem fazer arte, ou seja, se são capazes e como demonstram isso. ${ }^{337}$

Será de acordo com as posturas que tomam estes críticos que se consegue notar a durabilidade de uma obra. Assim, não basta saber apenas as opiniões divergentes. Deve-se também conhecer quem são esses agentes dentro do painel da crítica especializada sobre o assunto. Basta observar mais diretamente nestas entrevistas. Caparrós, um crítico internacional, ocupado em manter valores morais vinculados à tradição espanhola, e Monterde, voltado ao enfoque histórico e à realidade social, avaliam para o cinema de Pedro Almodóvar um breve encerramento. Em contraposição, Seguin e Aronica vislumbram na estratégia mercadológica do diretor sua continuidade e expansão no cinema mundial. Aronica situa - como Monterde exatamente o processo histórico como resultado do sucesso do diretor, porém dentro da cultura italiana. Percebe-se que os determinismos podem ser facilmente relativizados.

São olhares de dois espanhóis, um francês e uma italiana. Há um jogo de forças expressivo, considerando seus papéis dentro da vida acadêmica e midiática para o cinema e para Almodóvar. A hegemonia dos espanhóis é maior dentro da Espanha. Caparrós representa uma tradição crítica e grupos sociais específicos no país ligados aos valores familiares e à religião católica, além de uma séria preocupação política. Por outro lado, Arônica veicula a postura da mídia italiana, favorável à novidade e aos efeitos internacionais que a obra do diretor pode surtir sobre os espectadores em seus desdobramentos sociais. São duas leituras que aparecem tão convictas e ao mesmo tempo tão arriscadas.

O mundo da arte faz e refaz a todo momento a reputação da obra de arte. A cada processo social alguns autores ganham maior ou menor mérito por suas realizações. O recohecimento aparece em premiações, homenagens e no grau de divulgação das obras. Para que se realize é necessário que sejam traçados parâmetros claros que funcionem como referência geral para obervar a criação artística. Becker apresenta uma teoria da reputação formulada nos seguintes termos:

\begin{abstract}
pessoas que possuam dons especiais criadores de obras excepcionalmente belas e profundas que exprimem as emoções humanas e valores culturais essenciais. A qualidade das obras atesta o dom particular do seu autor e dom pelo qual esse autor já é reconhecido. Como as obras revelam qualidades e méritos de seus autores, é a totalidade da produção de um artista que pode contar para sua reputação. ${ }^{338}$
\end{abstract}

Claro, esta teoria não vale para toda a história, nem para todas as culturas. Ela está focada na personalidade do artista, um elemento historicamente dado desde o

${ }^{337}$ BECKER, 1988. p. 348. 
renascimento quando, na Itália do final do século XV, o artesão deixa de ser anônimo e passa a ser criador. Portanto, é uma teoria temporal que prevalece em sociedades que valorizam o indivíduo em detrimento do coletivo. Como em seu postulado afirma-se a excepcionalidade do artista, sua obra não é casual, portanto será sempre uma expressão de sua competência. Assim, essa convenção permite ao autor legitimar-se. $\mathrm{Na}$ medida em que se conhece o talento de um criador, se presta mais atenção à sua obra. E não só o artista possui reputação. Também se inclui aí sua obra ou um movimento ao qual pertence. Ele pode inclusive escolher o que prefere divulgar. No cinema isso se torna um pouco mais complexo, pois toda obra cinematográfica é pensada em vistas de ser lançada e de possuir o maior alcance possível. ${ }^{339}$

Assim, o conjunto das atividades que produz a obra de arte contribui para fabricar seu lugar público e seu criador. A teoria supõe que aqueles encarregados em definir a reputação das criações devem possuir acesso a todas as obras antes do público para que possam julgar com conhecimento de causa. Mas, com a reprodução industrial do mundo da arte, torna-se impossível para alguém ver tudo e, portanto, o julgamento, as comparações também podem oscilar. O critério do que pode durar precisa necessariamente possuir condições que o definam muito além do que apenas torná-lo difundido. As obras que duram podem ser vistas como as que se impõem por excelência, mas só delegar a estima universal ainda é limitado, sobretudo numa época tão mercadológica como a nossa. Se a arte é um fenômeno social ela responde a diferentes modos de ações coletivas que atuam sobre sua realização e reflete ao mesmo tempo as lógicas de valores e grupos sociais que predominam sobre cada sociedade e época ${ }^{340}$.

Creio que essas afirmações situam de maneira mais fluida a atuação dos intelectuais dedicados aos estudos e à compreensão da obra em seu tempo. Aqui, as diferentes opiniões exprimem como num mesmo universo intlectual, seu agentes atuam de maneira a fortalecer - ainda que inconscientemente - seus grupos e valores. Assim, o olhar estrangeiro de Seguin e Aronica sobre o papel da mídia e dos espanhóis diante de Almodóvar converge com Fran Zurián quando analisam a rejeição obtida no país. Zurián, em especial pelo fato de coordenar um fórum que está em contato com as produções internacionais sobre a obra do diretor, aguça mais sua percepção para estes fatores internos e externos.

Também Caparrós e Núria Vidal observam esse aspecto, porém de maneira

\footnotetext{
${ }^{338}$ Idem, p. 349.

339 Ibid. p. 350-354.

${ }^{340}$ Idem. p. 358-365.
} 
peculiar. Enquanto ele aponta que o autor não assumiu seu tom marginal e mesmo assim conseguiu sucesso, o diretor gerou inimigos que não contavam com suas alternativas de sobrevivência, Vidal entende que sua forma de abordar a vida cotidiana espanhola moderna, evidenciando seus personagens e comportamentos marginais, acabou agredindo a crítica ortodoxa. Seguin acrescenta um dado importante ao sublinhar que o cineasta trata seu trabalho simples como mercadoria em todo seu processo de realização, o que ofende os estéticos que costumam tratar a obra de arte como algo em separado das relações mercadológicas. Porém, para o cinema, um elemento difícil de dissociar, apesar de haver inúmeras análises que o abstraem.

Por outro lado, realmente torna-se relevante esses olhares mais atentos ao aspecto estético das películas porque neles é possível discernir, não apenas intenções estilísticas e temáticas, mas também condição social de classe de cada cineasta. Nesse sentido, Caparrós e Monterde, ao ressaltarem as especificidades de Almódovar e de Buñuel, ainda que Caparrós acentue uma análise de certa maneira discriminatória e também classista, definem com precisão o lugar destes cineastas na cinematografia espanhola.

Núria Vidal, por seu lado, também se mostra original ao afastar o diretor de qualquer escola, movimento ou tendência estética anterior a ele. E María Antonia Garcia de León, sem mitificá-lo, traduz em sua popularidade a chave que o faz dialogar universalmente, mesmo fazendo um cinema genuinamente espanhol. Essas colocações desfazem as más interpretrações e elucidam os contrastes com analistas internacionais que traçam paralelos externos ao contexto da cultura vivida na Espanha e que julgam aparecer nas obras do diretor e de outros cineastas no país. E, como visto - sobretudo pelas declarações de Daniela Aronica -, não são poucas as leituras desfocadas.

As declarações não escondem o caráter incômodo que Almodóvar cria com seu modo de produzir e de fazer propaganda de si mesmo e de seus filmes. A opção pelo popular, observada por Monterde, indica seu viés depreciativo, enquanto que para Aronica é exatamente seu trunfo, caminhando na mesma linha com a postura de Seguin. Sem juízo de valor, María Antonia também atenta para as formas com que o autor transforma tudo em publicidade, suas auto-entrevistas, suas constantes aparições na mídia para promover seus filmes. Ainda que em tom reprovador, Caparrós também observa este lado, mas conclui que é um bom negociante.

Fica presente no meio deste debate o grande dilema entre cinema como arte e como mercadoria. Um exercicío que inclui diretamente criador e obra e, como visto na 
elaboração de Becker, elemento que expõe seus integrantes do mundo da arte. Todos aqui manifestando suas crenças, porém revelando seus lugares sociais. A falta de consistência histórica do diretor para revelar os anos 80, como apresenta Monterde, possui suas razões justificadas. Almodóvar realmente só apresentou o universo que viveu dentro da Movida - apenas uma experiência, dentre outras vividas na transição democrática - e não avançou dentro da totalidade dos acontecimentos da época. Mesmo assim, com sua forma irônica, apontou seu contexto político ainda que superficialmente diante dos fatos. Porém, os aspectos ideológicos e os efeitos sociais surgem de maneira clara.

Frente a esses argumentos Zurián responde ao modo específico de Almodóvar em falar de temas sérios utilizando-se da via cômica, referendado por Garcia de León, Vidal, Aronica, exatamente como seu caráter positivo inovador, ousado e conciliador entre o tradicional e o moderno. A película Qué he hecho yo para merecer esto?, que tanto encanta a vários críticos, como Garcia de León, por revelar uma Espanha pósfranquista cotidiana, segue nesses termos. E, pelo que observei, agrada a muitos por ser compreendida como herdeira do neo-realismo italiano, tão inspirador e revolucionário na cinematografia mundial. Não são poucas as críticas a este filme que trilham para essa leitura.

Minha visão destoa desse olhar cúmplice com aquele movimento. $O$ neorealismo italiano tem suas propostas estéticas politicamente marcadas pela busca de cenários reais, personagens comuns pertencentes às classes populares, pouca utilização dos recursos de estúdios, atores muitas vezes recrutados dos próprios meios onde eram rodadas as películas. Seus criadores opunham-se radicalmente à representação de uma Itália burguesa, prepocupada apenas com problemas sentimentais. Sua fonte de inspiração recai sobre os efeitos da Segunda Guerra Mundial na vida de seus protagonistas e revela o caráter militante, ora na celebração da resistência contra a guerra, ora com oportunistas, ora com os engajados em busca da libertação por uma nova sociedade. ${ }^{341}$

Não é o que se vê, nem nesse filme nem em outros do diretor, ainda que esses elementos sejam lembrados diante das condições de vida das personagens. Os cenários artificiais kitsch, mesmo revelando uma prática comum em Madrid e a trama que em nenhum momento vislumbra a dimensão política neo-realista, separam este movimento das - apenas - citações do diretor. Até mesmo quando o neo-realismo entrou em sua fase emotiva e moralista após os anos 50 - bem diferente da anterior

${ }^{341}$ FABRIS, Mariarosaria. O neo-realismo cinematográfico italiano. SP: Edusp/Fapesp. 1996. p. 38-39. 
que visava fatos de política organizada -, ou em seus remanescentes que mitificaram aquela proposta cinematográfica, reduzida a experiências pessoais como em Mediterrâneo (1991) ${ }^{342}$, não se aproxima deste cinema almodovariano.

Assim, mesmo afirmando ter sofrido influências neo-realistas e gostar desse tipo de cinema, Almodóvar dialoga apenas com referências. E, claro, isso poderia ser um elemento de "Elevação" de seu cinema, mas acredito que seria falsificar demais sua originalidade e talvez desmerecer o caráter especificamente inovador dos dois tipos de cinema. Seria dar mais um aval à critica demasiado consagradora do diretor, ainda que somente tenha associado romanticamente suas preferências e lembranças nas imagens do cineasta.

No mesmo sentido segue a observação do pós-moderno, citada por quase todos os entrevistados neste capítulo, cada qual com suas definições e preferências para aproximar o diretor deste termo tão controverso e mal definido até nossos dias. Sua discussão começa na década de 1980, tornando-se um dos temas centrais para o debate sobre a arte, cinema, cultura e sociedade, em particular nos Estados Unidos e na Europa Ocidental, mas também alastrando-se para países como Brasil e outros da América Latina. Há toda uma retórica negativa que associa o termo com o fim da ideologia e da história, o eclipse do sujeito, o fim da metafísica ocidental, fragmentação e descontinuidade. São várias as teorias que buscam defini-lo.

A posição de Habermas é a da reafirmação do que ele considera o impulso autêntico e consistente da tradição modernista, da qual busca resgatar o poder crítico, utópico e emancipatório que dá continuidade ao projeto iluminista. Para Habermas, a mergência do pós-modernismo, que ele não considera uma fase do modernismo, se associa ao conservadorismo político e cultural, que deve ser atacado por todos aqueles que vêem a modernidade como um projeto vivo e vital, embora ainda incompleto. De outro lado, Lyotard parte da consideração de que o pós-moderno é uma fase do moderno, mas ressalta sua especificidade e valoriza o que ele chama de "condição pós-moderna". Em posição oposta à de Habermas, Lyotard destaca como positivo o declínio das metanarrativas totalizadoras do paradigma ocidental, e o desprestígio das categorias iluministas dominantes da racionalidade e progresso. [...] a intervenção de Fredric Jameson no debate também coloca ênfase na questão do político [...] Jameson caracterizou em mais de um momento, que seu adversário conceitual era o "pluralismo liberal" e o "humanismo" hegemônicos na cademia norte-americana, ou seja, a mistura de liberalismo político, empirismo e positivismo lógico para a qual o pensamento dialético representava uma ameaça. ${ }^{343}$

Sinceramente, não vejo nestas definições nenhuma aproximação com aquelas apresentadas pelos entrevistados e menos ainda de todas estas com o cinema de Almodóvar. Se é para escolher alguma afirmação ainda prefiro a de Núria Vidal que o desvincula de qualquer tendência ou grupo. Apenas incluí a citação acima para mostrar

\footnotetext{
${ }^{342}$ Idem. P. 42-43.

${ }^{343}$ JAMESON, Fredric. Espaço e imagem - teorias do pós-moderno e outros ensaios. RJ: Edit. UFRJ. 2004. p. 7-10.
} 
o quanto é complexa e nebulosa esta discussão e só a incluí como observação porque esta apareceu de maneira intrigante nos discursos, porém, vejo que sem densidade para argumentos mais aprofundados. É um tema que permanece em aberto e creio que, para Almodóvar, tão avesso a rótulos ou a tendências de qualquer gênero, ser pós-moderno só se constituiria numa possibilidade se pudesse também fazer um filme que o negasse. Mas, se entre os teóricos o que se vê são apenas mais desacordos e especulações, torna-se preferível afirmar que é uma discussão improcedente, ao menos para o diretor em pauta.

Das observações restantes, creio que a indagação de María Antonia sobre a relação de fascínio e rechaço que Almodóvar alimenta pelo establishment e a afirmação de vários entrevistados de que seu cinema é tradicional, mas que coloca o desejo e a liberdade acima dos papéis sociais, são os argumentos provocadores que deixam caminhos abertos para discussão. Exatamente o que pretendia este capítulo. Mostrar as diferentes interferências e contribuições destes atores sociais na construção da cinematografia do diretor e a prática de seus papéis numa dinâmica inacaba, em constante processo de elaboração. Rejeições ao autor, mesmo reconhecendo seu brilhantismo, apontamentos de sua falta de visão histórica e sua artificialidade formal, mas a afirmação de seu papel histórico na cinematografia. Cada elemento, indissociável de outro.

As declarações de Daniela Aronica sobre o uso político de Almodóvar como "vitrine" de uma nova Espanha deixam evidente as contradições e os usos favoráveis que cada um em sua esfera buscou para beneficiar-se. Uma inexorável troca de interesses. O "ser moderno" de Almodóvar significou o uso mais flexível póssível da tradição contida em sua cultura, desde o campo-cidade à politica engajada de direita ou esquerda, até a mais descomprometida. Fran Zurian ressalta a importância das personagens em Almodóvar como um dos grandes méritos do diretor em oposição a Monterde. Neles estão a chave para a leitura de um cinema que expressa somente seu mundo e seu momento.

A crítica ao artificialismo e ao exagero de suas imagens reflete os gostos e a formação destes intelectuais. À exceção de Zurián, partidário da diversidade difundida por Almodóvar, percebe-se que o referendo de alguns opta pelos caminhos estéticopolíticos do diretor e suas restrições definem os limites suportáveis fornecidos pela formação de classe que carregam e que determinam seus pareceres. Mais do que isso, que determinam seu lugar como mediadores de obras artísticas e definidores de padrões ou regras do exercício de um bom cinema. 


\section{GAZPACHO NÃO É COCA-COLA}

"Si tuviera que elegir, me gustaría ser uma mezcla de Billy Wilder y Alfred Hitchcock. Pero aún me gustaría más ser el sucesor de Rockefeller"344

O verão da Espanha - um dos mais intensos da Europa mediterrânea - é apaziguado de diversas maneiras entre seus habitantes. A busca por bebidas que refresquem os dias ensolarados é bem diversa e, entre elas, os espanhóis fabricam um refresco aparentemente incomum, porém com um efeito revigorante. Composto por legumes, sal, pão e água, todos triturados, depois coados, transforma-se num tipo de sopa fria com um delicioso sabor e realmente resfrescante, o apreciado gazpacho. Obviamente, diante de outra bebida também insólita e refrigerante da qual até hoje não se sabe a receita - a internacional coca-cola - esta especialidade típica do país passa anônima pelo paladar estrangeiro. Os nativos - que podem experimentar as duas ampliam as oportunidades de escolha e preferências.

Supondo que, da produção caseira de consumo regional, o país decidisse abrir concorrência no mundo entre o seu gazpacho e a coca-cola, o que aconteceria ? Ou se buscasse apoio de seus fabricantes para ampliar seu mercado, dispondo-se a conquistar outros além de suas fronteiras ? Como seria a produção ? Essa pode ser a lógica metafórica do cinema espanhol contemporâneo ao longo dos anos diante do mercado internacional. Apesar das tentativas - como já verificado nos capítulos iniciais deste trabalho - sabe-se das limitações e das suas conseqüências. Em meio a alguns grandes sucessos fora do país e sua abertura mercantil, os cineastas se destacaram e conseguiram garantir os caminhos para uma nova geração de novatos dispostos a ampliar territórios para suas imagens.

Concorrência desleal com os norte-americanos, jogos mercadológicos com diversos continentes além do europeu, subordinações estéticas padronizadas para atingir um público médio mais amplo, diálogo com as Américas. Quantas são as condições impostas para produzir cinema dentro e fora do país? Aos que sobreviveram a esses embates tais alternativas tornaram-se satisfatórias, porém tímidas. Talvez sejam os únicos espaços possíveis até o momento e, nestes, cada cineasta encontra viabilidades para desenvolver seu trabalho. Ao que se insinua como um nacionalismo, acaba por revelar-se como alternativa pela manutenção e busca pelo crescimento autônomo. Pedro Almodóvar não foge à regra. 


\section{1 Uma negociação de economias culturais}

A fidelidade com que Almodóvar traduz seus valores, diluídos em todas suas películas - ainda que os ironizando -, a maneira como projeta importância à vida dos pueblos, das personagens e costumes existentes no país fazem dele um cineasta espanhol. Ainda me parece difícil compreender como absorvido por uma linguagem hoje mais apurada, de alinhamento à decupagem e narrativa de cinema norte-americanohollywoodiano, este cineasta também não tivesse abandonado sua cultura. $A$ análise tem mostrado, ao contrário, que em nenhum momento ele omite na estrutura da trama algo que não se refira a seu país.

Em Mujeres al borde de un ataque de nervios, sua primeira película de projeção internacional, esse aspecto chama muito a atenção e vai se repetindo até as últimas obras. Não só pelo sucesso que the rendeu uma indicação para o Oscar, perdendo para Pelle, o conquistador (1989) de Bille August. Havia naquele trabalho um tom que agradava ao público menos atento à diversidade e mais preparado para um "certo diferente" que na verdade estava disseminado no senso comum e no estereótipo. Porém, observando sua dinâmica dialogar abertamente com uma construção cinematográfica estandartizada, ainda assim o que se vê é um cinema caracteristicamente espanhol.

No terraço do apartamento de Pepa, animais são criados como no campo. Na sala, todos reunidos bebem o gazpacho, enquanto Pepa lista a receita completa sem falar dos calmantes que havia misturado à bebida. Deposita-se no gazpacho um elemento narrativo que concentra, mobiliza o espectador e dinamiza toda a ação dramática subseqüente. É o cotidiano e seus hábitos familiares que ganham força. Visualiza-se nos detalhes da trama, não a propaganda de um produto típico - ao contrário, a bebida é apresentada com ironia - mas a escolha por imagens que traduzam referências nacionais é recorrente voltando-se a um público bastante regional e não mundial.

Paradoxalmente, nesta cena e em outras também paradigmáticas, o que parece vir a ser uma película preparada para exportação revela-se como instrumento de barganha ou de um "cartão de visitas" com citações culturais cuja função se direciona em articular-se com outros elementos narrativos do filme e não com a propaganda da Espanha. São esses pequenos detalhes que contribuem para sinalizar e aproximar o diretor do campo artístico e intelectual no país. A película se reverteu em uma de suas chances para demonstrar habilidade simbólica e poder de manipulação dos significados regionais e nacionais. Em seu conjunto para o mercado, cativou o

\footnotetext{
${ }^{344}$ ALMODÓVAR, Pedro. Almodóvar traspasa fronteras. El Periódico - espetáculos. Madrid, 22. mai. 1988. p. 83.
} 
olhar estrangeiro surpreendido com aquela Espanha apresentada e habituado ao estilo das comédias sofisticadas norte-americanas, das quais obteve inspiração para desenvolver sua narrativa. Essa composição de vantagens quase lhe garantiu um Oscar.

Evidente, o encantamento que teve com a possibilidade de ganhar com aquele trabalho um dos prêmios mais almejados por qualquer cineasta foi imenso e o diretor, ao mesmo tempo em que fazia projetos, não escondia sua ansiedade dois dias antes da cerimônia do Oscar:

Confiesa Pedro que le gustaría hacer en este país la segunda parte de Lo que el viento se llevó y afirma que Mujeres al borde de un ataque de nervios debe ser llevada como musical a Broadway. Se imagina a Jane Fonda, que ya ha dicho que sí, en la versión norte-americana de Mujeres ... ${ }^{345}$

Porque en España ya me han dado el Oscar, pero los que votan son los académicos de Hollywood [...] la competencia es muy dura y me preocupa mucho el ambiente que se ha generado en España [...] me siento como en una pesadilla [...] no sé con qué cara volveré. [...] . ${ }^{346}$

A derrota, entretanto, também Ihe proporcionou algumas lições, o fez refletir caminhos trilhados, pensar novos passos e fazer suas críticas:

- Cómo le ha sentado no ganar el "Oscar", cuando era el nombre más barajado [badalado] para el premio?

- Ya dije que sería maravilloso conseguirlo, pero que en caso de que subiese a recoger el premio, tampoco mi iba a tirar de los [não vou arrancar os cabelos], Lo mejor, y que permanecerá, es que Mujeres al borde de un ataque de nervios me ha introducido en el difícil mercado norteamericano. Los mismos productores me han promocionado [...]

- En España se han unido para apoyarle cuando usted ya había sido reconocido en el extranjero, como las dieciséis nominaciones de cara a los premios "Goya"

- Es verdad, pero la oficialidad ha tenido que rendirse ante el éxito comercial. Ahora hay un cambio de actitud hacia mi cine. Se me reconoce porque no pueden negar la evidencia, cuando antes me consideraban poco más que un dependiente ultramarino [...]

- Ya no pretende escandalizar con sus películas?

- Cuando hice Pepi, Lucy y Bom, y otras chicas del montón quería seguir el estilo de comedia guarra [sacana], de costumbrismo sucio [maus costumes] y agresivo, en la onda del cine de John Waters o Paul Morrisey. Ahora he evolucionado hacia algo más elegante y artificioso. A finales de los setenta, lo de romper era en mi caso visceral, quería divertirme. Aquel cine estaba dominado por la progresía y el desencanto, algo que quizá sigue todavía coleando. Ahora tenemos a la generación más desgraciada en el poder, porque no ha vivido la liberdad sexual. Se casó mal, no ha vivido más que sus frustraciones y no acaba de situarse em la actualidad [...]

- De importantes estudios americanos le han caído suculentas ofertas de trabajo. Está decidido a macharse y centrar allí una nueva etapa?

\footnotetext{
${ }^{345}$ BASTERRA, Francisco G. No sé con que cara volveré. El País, La cultura, Los Ángeles, 29. mar. 1989. p. 31. ${ }^{346}$ Ibid
} 
- No, de momento no medito tal cosa. Las ofertas que me han hecho son muy apetecibles y de productores muy importantes, pero mis próximos planes están en España, donde voy a rodar una película sobre quinquis[... $]^{347}$

Os desdobramentos do sucesso sem Oscar apareceram rapidamente, introduzindo o diretor na constelação hollywoodiana que este atraiu para a sua órbita. A cantora Madonna estava disposta a aprender a língua espanhola para participar do elenco numa futura produção. Cogitou-se euforicamente uma versão norte-americana para o filme, indicando Jane Fonda para protagonizar o papel de Carmen Maura. A multinacional Orion, encarregada de distribuir a película mundialmente, já pensava em levar à fama a próxima produção de Almodóvar, e David Byrne, líder da então banda Talking Heads, iria compor a trilha sonora do filme que se intitularia "Mujer tóxica"348, posteriormente lançado como Átame. De outra parte, grandes companhias como a Disney, Paramount, Warner e Columbia estavam interessadas em fazer a versão de Mujeres al borde de un ataque de nervios com a atriz Kathleen Turner.

Tanto assédio na indústria do cinema explica-se indiscutivelmente pelas cifras bastante atraentes proporcionadas aos cinemas norte-americanos. Alguns meses antes da cerimônia do Oscar, o filme já havia arrecadado nos Estados Unidos aproximadamente três e meio milhões de dólares, desbancando Uma cilada para Roger Rabbit, produzido pelo mega diretor Steven Spilberg. ${ }^{349}$ O sucesso se explica, como já dito, pela fórmula das altas comédias como as de Blake Edwards, Billy Wilder ou Frank Capra, linguagem bem conhecida e muito apreciada pelo público no país e pelas referências sobre a cultura produzida na Espanha que o filme apresenta e várias vezes ironiza. Não podemos esquecer de que a quantidade de imigrantes oriundos de cultura hispânica nos Estados Unidos é bem expresiva. A língua espanhola - um aspecto revelador - constitui-se no segundo idioma mais falado entre seus habitantes depois do inglês. O encontro desses diversos fatores culturais, considerados desde os diferentes povos até a linguagem cinematográfica, proporcionou aquele quadro animador.

A resistência aos convites para rodar em estúdios norte-americanos tinha uma intenção clara de expansão, mas, segundo os planos do irmãos Almodóvar, sob os receios de verem cerceadas suas propostas, como já havia ocorrido na Espanha. Agustín afirmava:

\footnotetext{
${ }^{347}$ FALCON, Pilar. Entrevista coM Pedro Almodóvar. He perdido el Oscar pero mi película es la más taquillera. Tribuna, Madrid, 03. abr. 1989. p. 113-114.

${ }^{348}$ MUÑOZ, Diego. El líder de los Talking Heads compondrá la banda sonora de la próxima película de Pedro Almodóvar. La Vanguardia - espetáculos, Barcelona, 17. abr. 1989. p. 27

${ }^{349}$ MARTÍN, Ana. Almodóvar y su clan se acercan a Hollywood. Cambio 16, no 889, Madrid, 12. dez. 1988. p. 164.
} 
No queremos crecer demasiado. Tan sólo queremos controlar nuestros propios productos manteniendo nuestra personalidad al 100 por ciento, lo que significa cuidar todos los detalles. No queremos ganar cien veces más, sino hacer a gusto todos nuestros proyectos 350

Pedro seguia na mesma linha de raciocínio, discutindo a questão da criação e de seu repertório:

Consideraría un error trasladar mi universo tal cual es, a otro país. Mis películas tienen éxito em extrangero por que están hechas em España, com temas españoles y por personas españolas. Sólo me avendría [viria] rodar fuera em el caso de que se me ocurriera uma idea que sucediera allí. Además, no me gusta gastar mucho dinero em mis películas, porque no me gusta que nadie arriesgue mucho por $\mathrm{mi}^{351}$

A sintonia entre trabalho e projetos futuros não só lhes garantiu uma forma particular de produção como difundiu no meio empresarial uma imagem própria que transmite segurança aos investidores internacionais, como se repetiu e ampliou futuramente, mesmo com os problemas enfrentados nos três filmes seguintes. Na ocasião da festa do Oscar, Agustín Almodóvar explicou que a idéia era levar "talentos" para a Espanha em lugar de transferir Pedro para fora. Fatos semelhantes aos vividos naquela oportunidade se repetiram posteriormente quando Jodie Foster, Suzan Sarandon e Glenn Close - quando da estréia de Tacones Lejanos em Nova York disseram que ficariam encantadas em trabalhar com o diretor ${ }^{352}$.

Estas "estrelas" da grande mídia norte-americana assinalam simbolicamente como uma vitrine - a projeção do autor e da sua imagem diante de uma indústria cultural representativa e tentadora, o que significa dizer: a atenção em incorporá-lo mais eficazmente na máquina produtiva de filmes. Mercados abertos, fama internacional, foram esses os recados claros que passou a receber desde então ${ }^{353}$. Mas, como também já havia deixado explícito seus interesses, todas as promessas hollywoodianas não se cumpriram.

Para os espanhóis, a película que projetou odiretor internacionalmente o diretor e incluiu novamente a Espanha no círculo do mercado cinematográfico como portadora de grandes cineastas significou a disseminação de toda obra de Almodóvar pelo país. No final do ano de 1990 sua produtora vendeu para a Televisão Espanhola todos seus

\footnotetext{
${ }^{350}$ Ibid. p. 167.

${ }^{351}$ Ibid. p. 167.

352 MONTAGUT, Albert. Jodie Foster y Glenn Close quieren trabajar con Almodóvar. El País - espetáculos, Nueva York, 21.dez. 1991.

${ }^{353}$ Antes de seu sucesso nos Estado Unidos, Mujeres al borde de un ataque de nervios já havia rendido a El Deseo 15 indicações e 5 prêmios Goya, da Academia de Ciência e Artes da Espanha, melhor atriz (Carmen Maura) no Festival de Veneza em 1988, prêmio de público no festival de Toronto no mesmo ano, prêmio de melhor filme estrangeiro de 1988 pelo círculo de críticos cinematográficos de New York e inúmeras indicações em outros festivais.
} 
filmes produzidos, estimados em um milhão e duzentos mil euros.

A única exceção foi Mujeres al borde de un ataque de nervios - considerado por muitos críticos no país como a síntese entre modernidade e vanguarda espanhola sem renunciar por isso ao mercado - que tinha seus direitos de exibição nas mãos dos co-produtores, a Lauren Films, só liberados em 1991. Período em que o diretor rodava Tacones lejanos e estabeleceu acordos para produzir a ficção científica "Acción mutante", que seria dirigida por Alex de la Iglesia. A negociação feita com a TVE implicou na aquisição dos direitos de exibição da emissora para todas as películas feitas pelo diretor dali por diante. ${ }^{354}$

A presença impactante de Almodóvar no mercado cinematográfico internacional beneficiou em grande medida os mercados de bens simbólicos na Espanha. Ele não assinala simplesmente sua fama, mas também seu processo de autonomia crescente no campo artístico, cada vez mais distante do campo político, do qual vários cineastas no país dependeram já nos anos democráticos em razão das subvenções estatais. Suas experiências anteriores à fundação da produtora El Deseo haviam demonstrado que nesta esfera - se quisessse avançar - não poderia esperar colaboração nem do campo artístico-econômico de produtores pouco interessados em suas histórias, nem do campo político, que via em seu cinema uma propaganda desabonadora da imagem nacional. Com os prêmios e repercussões que obteve, este quadro certamente se transformou. ${ }^{355}$

$\mathrm{Na}$ medida em que os públicos se diversificaram e se ampliaram, também o sistema dos bens simbólicos se multiplicarou no país e a produtora de Almodóvar é um dos agentes e ao mesmo tempo resultado desse processo. Num mercado com dinâmica própria como o cinema, os vários mecanismos a ele associados - publicidade e imprensa - delegam um valor mercantil otimizado à obra de um artista, contribuindo para a afirmação de sua autonomia como criador, tanto nos momentos de aprovação como naqueles ofensivos. Foi o que ocorreu com este cineasta no plano mundial . ${ }^{356}$

Este panorama - ampliado nas produções posteriores e culminando com Todo sobre mi madre e Hable con ella - ilustra o vasto sistema de articulações que promovem gradualmente o artista dentro do capital cinematográfico e da crítica internacional. Porém, o desencademaneto dessa operação necessariamente deve contar com a figura de alguém que o gerencie e o incremente. A notável percepção e a

\footnotetext{
${ }^{354}$ SANCRISTÓVAL, Piedad. Pedro Almodóvar vende todas sus películas a Televisión Española. El país, televisión/ radio, Madrid, 29. dez. 1990.

${ }^{355}$ BOURDIEU, Pierre. A economia das trocas simbólicas. SP, 5a ed., 2a. reimpressão, Perspectiva, 2004. p. 99102.
} 
agilidade de Agustín Almodóvar para conectar as produções do irmão a todo esse cenário cumpre esta função e é a grande responsável pelo seu reconhecimento mundial, num sistema de trocas que ao mesmo tempo favorece novas produções e referenda a marca do diretor e da sua produtora El Deseo.

Segundo José Luis Alvarez e Silviya Svejenova, ocorre entre Pedro e Agustín uma simbiose em função do mesmo trabalho por intermédio da divisão de tarefas entre o que realiza e o outro que negocia. A simbiose atua para falar de que maneira 0 artista e seu agente, com uma relação estável que envolve profisionalismo e afetividade se engajam numa carreira comum que muitas vezes poderia ser incompatível se levada por uma pessoa apenas. Por meio desta prática, o artista consegue conciliar as tensões entre produtor e diretor. Assim, o trabalho de ambos, unido num mesmo alterego profissional, nutre-se do aspecto pessoal, contribuindo para a auto-realização do artista e da obra, proporcionando o crescimento da criatividade. ${ }^{357}$

Dialogar eficazmente com o mercado internacional de cinema implica saber promover estratégias de expansão e sobrevivência das próprias produções e estas subentendem a harmonia constante entre as atividades do ato de produzir e de negociar. Ou seja, significa desenvolvê-las de maneira compatível com o que está sendo realizado ou como o que já existe técnica e artisticamente nesse campo dentro do mercado, além da inovação. Se quiserem continuar difundindo e garantir fidelidade às suas raízes culturais e à sua simbiose nesse universo, Almodóvar, o irmão e depois sua equipe devem criar formas de alimentar essa sintonia.

Aqui, somam-se a esse contexto os recursos técnicos. Os próprios espectadores já se habituaram a um padrão de qualidade nas produções. Portanto, boas histórias também devem obedecer a estes critérios. Esta também se constituiu numa das razões que fizeram com que a crítica especializada vislumbrasse em Almodóvar um cineasta de filmes com caráter de "cinema de exportação", além de ter levado às telas uma nova imagem sobre a Espanha. Por isso, a cada novo trabalho o diretor aprimorou linguagens, enquadramentos, temas e sua própria originalidade.

No decorrer de suas atividades, a ânsia em tornar seus filmes sintonizados com o "bom cinema", visto como aquele tecnicamente bem feito e, por isso, convencionalmente muito assistido, levou Almodóvar a "refinar" sua equipe com melhores cenógrafos, diretores de arte e de produção, elenco e fotografia, chegando a

\footnotetext{
${ }^{356}$ Ibid. p. 103-104.

${ }^{357}$ ALVAREZ, José luis e SVEJENOVA, Silviya. "Symbiotic carees in movie making: Pedro and Agustín Almodóvar” in PEIPERL, M. et alli.(org.) Career creativity - explorations in the remaking of work. Oxford, 2002. p. $184-185$.
} 
um grupo praticamente fixo. Enfim, os passos necessários para um melhor reconhecimento estavam em histórias originais, mas também numa qualidade de som e de imagem que deveria ser compatível internacionalmente, realçando também a necessidade de um autor que pretendia trazer ao público não apenas uma boa diversão, mas sua competência profissional e artística.

Quando o criador atua nesse contexto, cumprindo as regras do campo, seus horizontes se expandem. Foi o caso de Almodóvar. Seu jogo de imagens, transitando entre uma narrativa comercial e uma Espanha moderna com elementos tradicionais, atraiu tanto a crítica quanto os mercados europeu e norte-americano, num lento processo de comparações e de reconhecimento, com todos os acertos e equívocos que decorrem de análises entusiastas. A crítica estadunidense, por exemplo, chamavao de novo Buñuel ${ }^{358}$ quando da exibição de Mujeres al borde de un ataque de nervios, uma visão desfocada sob vários aspectos, mas, em se tratando de visibilidade mundial mercadológica, gerava seus dividendos.

Com Tacones lejanos já não houve o mesmo entusiasmo entre os críticos norte-americanos. O filme não conseguiu situar-se nem entre os cinco candidatos a melhor filme de língua não inglesa na candidatura ao Oscar. A resposta de Almodóvar a tal quadro é familiar: "La compreensión de mi cine por el público americano es limitada". Apesar disso, o filme havia arrecadado mais de um milhão de dólares em sete semanas. ${ }^{359}$ Fato muito distinto do que houve na França, onde, após uma massiva campanha publicitária e sua exibição, a película seduziu a crítica a ponto de alguns profissionais qualificarem o diretor como "El Woody Allen Del sud". Os críticos de Paris comentaram:

Um melodrama brillant en què Almodóvar há reunit tots els gèneres cinematogràfics: la comèdia, la tragèdia, el cine negre i el drama psicològic ${ }^{360}$

Para eles, Almodóvar fazia parte do grupo de autores de vanguarda e de realizadores da nova geração. Percebe-se que a atração da crítica divulga o filme de uma forma que causa interesse para vários tipos de público, apreciadores de diferentes gêneros. Comentários como este atraem um mercado consumidor bem amplo. Com aquela película ele assinava sua maturidade e a fase dos "quarenta" marcava uma nova etapa em sua carreira.

Una película on hi ha menys bogeria desenfrenada, encara que el

\footnotetext{
${ }^{358}$ NARVAÉS, Raquel. El héroe gordito ataca de nuevo. El Periodico - el tema de la semana, Madrid, 21. mai. 1989.

${ }^{359}$ Redacción. Almodóvar perdió su segunda opción al Oscar pero no el favor de la taquilla. La Vanguardia, Barcelona, 21. fev. 1991.

360 Redacción. Pels francesos, Almodóvar és “el Woody Allen” del sud. Diari de Barcelona, Barcelona 18. jan.
} 1992. 
realitzad desplegi tresors de fantasia i humor en els diàlegs i en les imatges [...] sobre aquest melodrama de sèrie $B$ que abraça tots els gèneres, Almodóvar,l'enfant terrible del cine espanyol, firma una pel.lícula devertida, càustica, commovedora, que passa sense transició de fer riure a ser un drama' diu la critica.'Almodóvar s'ha convertit en una mena de Woody Allen del sud, que substitueix l'anàlisi per la sexualitat, el diàleg pel frenesí', escriu el crític Daniel Toscan. Tant Allen com Almodóvar, tenen en comú "el mateix sentit de la ironia, el mateix amor per les dones, que són l'únic tema de les seves pel.lícules'. 'Lliscant per la comèdia desenfrenada fins a arribar a un to més dramàtic, el cineasta més delirant de Madrid prossegueix a la seva manera l'exploració de totes les ambigïtats de la vida, de la realitat, i léspectacle, dels corrents misteriosos que es diuen sexe, desig, por o amor', diu el setmaneri Le Point. Al seu torn, el crític del rotatiu Le Figaro considera que Almodóvar creu que s'ho pot permetre tot, i no s'equivoca'. La crítica ha elogiat també el talent de victoria Abril, Marisa Paredes i Miguel Bosé. ${ }^{361}$

A apresentação do filme na Itália não foi diferente e demonstrou sua grande popularidade. Almodóvar participou de coletivas com a imprensa, visitou pontos turísticos da cidade de Roma e pôde constatar que os cartazes de seus filmes estavam nas salas de cinema há mais tempo do que outros filmes europeus. Seu livro "Pathy Diphusa e outras histórias" estava há duas semanas entre os mais vendidos nas livrarias. Foi nessa estadia na cidade que ocorreu a polêmica com um espectador ao participar do programa "Maurizio Costanzo show", do canal 5. Costanzo comentou que a simples presença de Almodóvar havia criado um clima favorável e particular para estas manifestações teatrais.

A partir desses exemplos é possível obter uma breve dimensão do jogo de articulações necessárias para se manter dentro do universo cinematográfico. Um jogo nem sempre bem sucedido em todos os lugares, mas que, na medida em que atinge 0 maior número de espectadores, também alcança culturas diferentes que treinam suas percepções e gostos de maneira diversa, acabando por receberem o trabalho distintamente. Assim, pode-se observar que há uma dinâmica constante que envolve divulgação, pareceres e qualidade técnica/ narrativa, num fluxo contínuo que sustenta a indústria do cinema e seus criadores.

Este espaço de negociação fez com que Almodóvar se projetasse: sua estratégia de imagem pública, suas obras ou posições polêmicas, a superexposição de seu histórico pessoal humilde, seu autodidatismo. Ele mesmo cooptou-os ao seu marketing pessoal, elemento que contribuiu para a promoção e a manutenção de seu nome no cinema. Até seu senso de humor, já conhecido do público nas películas, também o torna notório pessoalmente nos círculos cinematográficos e na mídia - que utiliza essa característica como chamariz quase folclórico. Quando da entrega do Globo de Ouro em Mujeres al borde de un ataque de nervios, a atriz Sigourney Weaver se aproximou dele dizendo que tinha assistido várias vezes a seu filme e Pedro 
respondeu: - "Sigourney te adoro, eres más grande que los gorillas" [refererindo-se ao filme A montanha dos gorilas, cuja atriz era protagonista]. A intérprete o olhou desconcertada e logo riu. No entanto, ficou sem saber se aquilo era um insulto ou um elogio. ${ }^{362}$

A busca por um público cada vez amplo não significa apenas maior popularidade. Corresponde também à própria sobrevivência do autor frente a seus admiradores. Nem sempre a dosagem de todos os elementos cinematográficos atende a todos os espectadores. E é nessa instabilidade que o diretor alimenta sua mensagem, modelando linguagens. Tanto um público menos exigente intelectualmente como um outro mais seleto levam Almodóvar a restabelecer constantemente novas formas de diálogo. Almodóvar mantém seu estilo, mas o faz sintonizado e aberto com o que o rodeia, disposto a negociar.

Esse mercado de cinema se revela diretamente numa relação entre autorpúblico, e num lugar de excelência, repleto de competitividade entre colegas de trabalho. Hoje, Almodóvar já não é a única referência espanhola em Hollywood e em outros mercados cinematográficos também expressivos: o fenômeno Alejandro Amenábar, que com seu quarto filme Mar adentro (2004) ${ }^{363}$ recebeu diversos prêmios, deixou o cineasta incomodado. Prêmios expressivos para um espaço curto de tempo na carreira, incluindo Amenábar como grande integrante da cinematografia espanhola da geração atual. O diretor, de origem chilena, entrou no mercado internacional com toda linguagem hollywoodiana, o que favoreceu sua projeção.

Possuir outros competidores e não ser a única referência no país - quando se está usufruindo de fama - provoca alguns desconfortos para qualquer personalidade pública que pretende ampliar seus projetos. Essa esfera envolve muito mais do que gentilezas. Poder, dinheiro, reconhecimento, concessões e investimentos são apenas alguns dos fatores que integram a difícil trama de viver e executar filmes na vida de famosos, que convivem constantemente com o risco.

Cada um, enfim, possui suas estratégias e seu modo específico de filmar e de inserir-se no mercado internacional. A equipe de Almodóvar o acompanha fielmente

\footnotetext{
${ }^{362}$ Nota de artigo in El tema de la semana, El periódico, Madrid. 21. mai. 1989.

${ }^{363}$ Amenábar recebeu o Leão de Prata - prêmio especial do júri, prêmio Yong cinema e prêmio cinemania de acontecimento cinematográfico do ano no Festival Internacional de Veneza em 2004, três indicações (incluindo melhor filme e roteiro) e prêmio de melhor diretor e melhor ator (Javier Bardem) do European Film Awards de 2004, duas indicações na Critic choice Awards em 2005, prêmio de melhor filme na National Board of Review, USA - 2005, Globo de Ouro de melhor filme estrangeiro e indicação de melhor ator - Hollywood Foreign Press Associacion, quinze indicações nos prêmios Goya (Espanha), duas indicações para o Oscar e Oscar de melhor filme de língua não inglesa, além do prêmio Fotogramas (revista especializada em cinema na Espanha) como melhor filme espanhol - 2004.
} 
numa estrutura semelhante a uma família. Ali desenvolve um modelo que define alguns dos traços que privilegia em seus filmes, ancorados na amizade e num trabalho intenso. Nesse ritmo também evidencia uma estratégia que demonstra por que fixou suas raízes de produção na Espanha e não se mudou para os estúdios norteamericanos. Isso apesar das inúmeras vezes em que afirmou que filmaria nos Estados Unidos e noutras em que refletiu suas desvantagens.

Em entrevista acerca desse assunto, concedida no programa Jonathan Ross Presents, da cadeia britânica Canal 4, dedicado integralmente ao diretor manchego em finais de março de 1991, esta postura estava clara:

No pienso en trabajar em los grandes estudios de Hollywood. Lo he hablado con otros directores amigos míos y sé que es uma clase de producción peligrosa para mi. No creo además que tuviera éxito de este sistema. ${ }^{364}$

A declaração deixa clara a intenção de manter as mesmas narrativas e estratégias de mercado. Na entrevista, Pedro até admitiu que, apesar disso, estaria se preparando para trabalhar fora, fato que acabou não ocorrendo. Quatro anos depois, com a discussão sobre a disputa do Oscar, a situação recebe outros contornos e reforça as pretensões mercadológicas do diretor e de suas parcerias nos Estados Unidos que correm em paralelo aos grandes estúdios. Quando o filme La flor de mi secreto saiu indicado pela Academia de Cine Española - sob poucos aplausos - para representar a Espanha na competição do Oscar, a película já havia atingido quatrocentos e dez milhões de pesetas (249 mil euros), vista por mais de 750 mil espectadores no país. A disposição de Almodóvar em divulgar seus filmes estava mais forte do que a premiação:

[...] En esta ocasión me lo voy a tomar con más tranquilidad. Si hay que ir a Hollywood diez veces, pues voy. Estoy dispuesto a entrar en juego. De momento tenemos la referencia de que en Nueva York ha gustado, así me lo demostró la gente y la Prensa de allí. De manera que la promoción, en principio, está asegurada [...] me sentiré, lógicamente contentísimo, pero a quien más le interesa es a la distribuidora norteamericana, porque así se asegura la distribución mundial [...] ahora la estrategia es de la productora norteamericana. Por mi parte, iré en enero para el estreno en Los Ángeles y luego para hacer la promoción necesaria: entrevistas en las que estaré muy simpático y cosas así. [...] ${ }^{365}$

Estes caminhos compostos de pequenos detalhes configurando articulações integradas demonstram as preocupações do diretor em dialogar devidamente num território onde as inúmeras possibilidades sedutoras devem ser observadas com cautela. Tudo deve ser planejado, inclusive a preparação de sua misé en scène. $\mathrm{Na}$

\footnotetext{
${ }^{364}$ GUITART, Manuel. Almodóvar rechaza ofertas para dirigir em hollywood. El Periódico, Londres, 01. abr. 1991.
} 
entrevista, quando lançou La flor de mi secreto em Nova York, novamente as perguntas sobre rodar um filme com os norte-americanos revelam os constantes assédios e o conhecimento dos receios do cineasta frente aos vários convites:

- Quais são seus receios em torno da sociedade americana?

- Continuam os mesmos. Ainda que minhas películas tenham êxito, isso não quer dizer nada. Este país está cada vez pior, mais intolerante, cada vez mais fechado em si mesmo. Aqui é muito fácil ser irreverente: tudo o que não seja matar-se a tiros escandaliza.

- Continuam chovendo ofertas para rodar na América?

- Ontem, sem ir mais longe. Quase todos os meses me chamam para tentar me convencer. 'To Wong fu' a história de três 'drag queens' que se lançam à conquista da América, me ofereceram para dirigir faz tempo. O que acontece é que o roteiro não me convenceu. Continuo com medo desta aventura, penso muito, ainda que na verdade comece me atentar, necessito mais do que nunca de certas mudanças. Se tudo se encaixar, pode ser que eu acabe dando um pulo para cá em três anos. Será um roteiro meu que já ambientei na América. Quero encontrar alguém que me ajude a adaptá-lo. Mas não estou disposto a renunciar ao controle final. Existem muitos exemplos de diretores europeus que patinam quando caem nas garras desta indústria. ${ }^{366}$

Nada se consumou desse projeto. Mesmo depois, em 1999, quando Almodóvar declarou que rodaria em inglês em Hollywood uma adaptação cinematográfica da novela de Pete Dexter "The paperboy" que seria produzida pelo realizador holandês Jan De Bont, pela United Artist e roteirizada pelo próprio autor ${ }^{367}$, a filmagem não aconteceu. No lançamento do filme Todo sobre mi madre para a crítica novaiorquina ainda, chegou a declarar no mesmo tom estratégico que reforça as afirmações anteriores:

Es posible que lleve al cine la novela "The paper Boy", pero no es seguro. En todo caso, no trabajará en Hollywood. "Soy un artesano y en Hollywood, el director no es ni uno más, sino uno menos" ${ }^{368}$

Apesar de conhecido por ser falante, são nas menores frases do diretor que se revelam suas faces e formas que unificam criatividade e produção. Ele assume que desenvolve um artesanato de imagens e novamente a presença não-dita do irmão surge em potencial no discurso do diretor. Mujeres al borde de um ataque de nervios envolveu o diretor numa aura de cineasta de sucesso que lhe possibilitou dar-se ao luxo de cogitar produções em qualquer parte do mundo. A fama sobre seu talento criativo indicava rentabilidade financeira e artística para um público diverso, portanto, um artista atraente para grandes produtores.

Este filme possibilitou a ele um leque de relações e um alcance jamais encontrado pelo cinema espanhol. Aproveitando a imagem da "marca Almodóvar", no

365 ARENAS, José. Almodóvar:'si hay que ir a Hollywood diez veces, voy porque estoy dispuesto a entrar en el juego'. ABC - espetáculos. Madrid, 01 nov. 1995.

${ }^{366}$ Tradução livre do autor.

${ }^{367}$ La Vanguardia - 39, 20. ago. 1999

${ }^{368}$ XAXÀS, Xavier Mas de. Almodóvar abre Nueva York. La Vanguardia, Nueva York.. 27. set. 1999. 
final de 1990 sua produtora vendeu os direitos de exibição de todas as películas produzidas até então para a rede estatal de televisão espanhola num contrato que envolveu um acordo de colaboração para novas produções ${ }^{369}$. Mesmo com ataques ou com desprezo de uma parte da crítica dentro do país, o diretor mantém credibilidade no exterior. Quando fez Tacones lejanos, por exemplo, antes mesmo de ser concluído, a El Deseo já havia vendido os direitos de exibição do filme para distribuidores italianos que eram responsáveis por todo mercado europeu e os norte-americanos também buscavam participar. ${ }^{370}$

Diante das inúmeras negociações nesse teor, tornam-se curiosos os pronunciamentos do diretor sobre permanecer ou sair do país. Essas atitudes soam mais como um termômetro medidor de popularidades e de insatisfações, tanto do diretor como do público, do que uma vontade objetiva. Elas contrastam com as formas de mercado que exercita - para ele, aliás - muito mais rentáveis, como se vê, pelos trâmites que realiza. Na prática da produtora as estratégias são diversificadas, respeitando lógicas que partem diretamente da maneira como os irmãos Almodóvar administram seu trabalho, inviabilizando a saída da estrutura que organizaram para uma da grande indústria. Talvez seja mais um outro marketing pessoal. Fazer-se importante, querido, mostrar que seus projetos são desejados e que seu mercado está aberto e favorável, e que, portanto, permanecer na Espanha é um ato de fidelidade e de consideração com os espanhóis.

Juntos, Pedro e seu produtor, o irmão Agustín Almodóvar, tornaram a El Deseo uma das produtoras de cinema mais rentáveis da Espanha nos últimos vinte anos. Contudo, ao contrário do que possa parecer, a tentação por grandes bilheterias não suplantou o desejo do cineasta em produzir filmes que intimidassem sua necessidade criativa. Ele poderia manter a linha de comédias ligeiras, ou leves, de Mujeres al borde de un ataque de nervios, que tornou o diretor conhecido internacionalmente e que the garantiu uma boa fortuna. Porém, quando apresentou a próxima produção, Átame - um melodrama duro como ele próprio sabia -, obteve uma renda muito menor que o anterior. Com isso, acabou demonstrando que suas intenções não se submetiam simplesmente a altos dividendos monetários. Para o diretor, o que contava era garantir sua criatividade.

Consciente de seu papel e de seu lugar como cineasta reconhecido por seu trabalho, diversas vezes criticado como personalista e pretenso superstar, o autor mantém nesse sentido grande sensatez e humildade dentro do brilho conquistado.

${ }^{369}$ SANCRISTÓVAL, 29. dez. 1990 
Mesmo que sejam sedutoras as propostas de realização de mega produções nos Estados Unidos, tanto ele como Agustín sabem o que implica "negociar" diretamente com os grandes investidores dos estúdios da indústria cinematográfica norteamericana.

A experiência de proibições de cenas e de exibições de filmes como Átame, julgado pornográfico, tachado com um "X" nos cartazes pela censura dos Estados Unidos e alguns outros incidentes do gênero, como em Kika ${ }^{371}$, imposições de estrutura e remodelação de filmagens, até enquadramentos ditados pelos estúdios, já foram sintomas suficientes para que o diretor percebesse o que poderia e o que não poderia desenvolver criativamente naquele território.

Portanto, continuar suas atividades na Espanha tem sido uma atitude bem clara e seu objetivo demonstra o interesse por ramificar sua atividade a partir de seu próprio patrimônio cinematográfico. Foi dentro deste espírito que já se produziram em El Deseo: Acción mutante de Alex de la Iglesia (1992), El espinazo del diabo (2001), dirigido por Gulhermo del Toro, Mi vida sin mi (2002) da diretora Isabel Coixet e o filme argentino La niña santa de Lucrecia Martel, lançado em 2004.

Ao vincularem carreira e criatividade num núcleo que envolve afeto e carinho, os irmãos Almodóvar conduzem o trabalho fortalecendo os laços e suas fraquezas individuais, legitimando a auto-confiança. O ato de criar é uma atividade social. Quando alguém talentoso se encontra com alguém que defende seu trabalho, não se fala nem de cooperação ou de arte como negócio, mas de relações multifacetadas resultantes desta vinculação. ${ }^{372} \mathrm{E}$ esta relação não só se estabelece entre eles como também se desdobra para o restante da equipe. Num jogo contínuo de cumplicidades, se constrói uma base de produção de lógica familiar que referenda as próprias temáticas e personagens vistas nas películas.

\subsection{Um trabalho familiar - intensas relações entrelaçadas}

A imagem de trabalhador intensivo - uma constatação concreta - garante a Almodóvar não só respeitabilidade no seu exercício de diretor e no universo profissional que o circunda. Ela conserva para ele as portas abertas para futuros projetos, sua circulação no mercado cinematográfico, além de traçar um estilo próprio de trabalho em equipe que impõe um ritmo exaustivo a todos. Não são poucos os que já trabalharam com ele que afirmam seu enorme grau de exigência. Nas rodagens de

\footnotetext{
${ }^{370}$ MONTERO, Manuel. Las cuentas del mago Almodóvar. EI Periódico - espetáculos, Madrid. 30. jun. 1991.

${ }^{371}$ O filme "Kika" foi classificado com NC-17 pela Motion Pictures of America, a mesma equivalência do "X" que proibiu “Átame” para os menores de 17 anos nos Estados Unidos.
} 
Kika, em 1993, a atriz Verónica Forqué comenta:

Es duro trabajar com Pedro, siempre lo ha sido. Aunque ahora le veo más relajado y más fácil de tratar que la primera vez que trabajé con él [...] aunque es muy exigente, es el que más valora tu trabajo. Sí no le gustas te lo dice, y si le haces gracias se troncha de la risa ${ }^{373}$.

Amiga e diretora de produção de Almodóvar, Esther García entrou para sua equipe em Matador. Conhecida pelo mau humor e pela rigidez de seu ritmo, já trabalhou com os melhores cineastas espanhóis e admira a dedicação do diretor:

Todo mundo sabe que él es muy creativo, pero desconocen que trabaja como un negro, que cuando te entrega un guión [roteiro] está cuidadísimo porque ya hecho 20 versiones y es capaz de repetir una toma [uma tomada, cena] 30 veces sin rendirse jamás [...] con 'Mujeres' tuvimos que vender el 25 por ciento antes de acabarla porque si no, no llegábamos [chegávamos ao fim]. Ahora disponemos de más medios y puede ser más exigente, pero no es una persona en absoluto caprichosa, lo que pide es justo y nosotros procuramos que no encuentre trabas [impedimentos] para desarrollar su creatividad ${ }^{374}$

$\mathrm{Na}$ equipe, Esther tem a missão de transformar em realidade os sonhos do diretor fazendo as contas, convertendo-as em orçamento e dizendo o que pode ou não ser feito:

Y no es fácil, porque Pedro no acepta un no como respuesta si no lo tiene claro. Cuida los detalles de sus películas hasta la extenuación. No hay una sola lámpara, una cortina de sus paredes que no hayan sido supervisados por él. Es tremendamente exigente. Lo controla todo en sus películas, no se decide por la tela de un sofá hasta ver todos los catálogos [...] Buscar localizaciones con él es divertidíssimo [...] es como ir de excursión con un amigo con quien te ríes todo el rato [momento] [...] cuando tiene que enseñarnos el monstruo de la película, las primeras pruebas, sufre muchíssimo, se come las uñas hasta conocer la reacción de su gente y ver qué cara ponemos [...] ha tenido momentos más duros y bajos que ahora [refere-se às duas películas anteriores] Durante los últimos años le he visto demasiado presionado por todo lo que le estaba ocurriendo, cansado, agotado. Creo que ha superado todo eso y ahora le veo tan contento como al principio, con el humor menos acido. Lo encuentro ligero de equipage [pronto para outra] ${ }^{375}$.

Almodóvar projetou sua carreira em suas excentricidades, para além de seu perfil como indivíduo dentro da criação industrial. ${ }^{376}$ As declarações Esther García apontam alguns de seus aspectos. O ritmo exaustivo de trabalho reflete a própria imagem pública que o diretor criou sobre si. Este hábito frenético criativo que idealiza cenários ou figurinos de uma forma única e não mede esforços para concretizá-los também faz parte dessa composição. São inúmeros os exemplos de seu minucioso exercício virtuosístico. Quando filmava La flor de mi secreto, Almodóvar queria que o avental de Chus Lampreave - que interpretava a mãe da escritora Leo - fosse

\footnotetext{
${ }^{372}$ ALVAREZ, e SVEJENOVA, 2002. p. 185.

${ }^{373}$ El Periódico - 01. jul. 1993.

374 JALONCH, 18. jul. 1993, p. 24

${ }^{375}$ FERNANDÉZ, 19. mar. 2000, p. 24-25.

${ }^{376}$ ALVAREZ, José luis e SVEJENOVA, Silviya, 2002, p. 185.
} 
confeccionado à base de tecidos remendados. Como a equipe não conseguiu algo do tipo que ele havia imaginado, o diretor entrou em contato com sua prima do pueblo e a encarregou de conseguir o tal avental. A solução foi realmente encontrada naquela região onde muitas mulheres usam este tipo de utensílio. Ele explicava:

No es que haga un primer plano de esse delantal, pero necesitaba que estuviera hecho a base de telas usadas, que tuviera el vivo de una tela, el fondo de otra, los parches [pedaços de remendo] y los bolsillos de otra ${ }^{377}$.

Nesse comentário também se encontram referências de sua herança interiorana, elemento que dialoga com as condições sociais e com os hábitos antigos arraigados ainda no país. Apenas detalhes. Porém, carregados de significado na composição geral da imagem.Também Pepe Salcedo, montador de todos os filmes do diretor desde Pepi, Luci, Bom y otras chicas del montón, compartilha das idéias de Esther García sobre seu humor e sua rigidez no trabalho:

La sala de edición donde trabaja sólo necesitaría un reclinatorio para terminar de parecer un confesionario, pues el espíritu que han respirado estas paredes durante infinidad de noches de cortar y pegar planos es el de las grandes declaraciones íntimas. Desde que Pedro Almodóvar empenzó a hacer largometrajes, siempre, tarde o temprano, ha terminado pasando por el 'ave maría purísima' de Pepe, dato que ortoga a Salcedo un conocimiento de causa sobre el personaje del que presume. Salcedo se considera una de las pocas personas que al director puede decirle lo que piensa en la cara sin temor a su reacción, lo que explica su análisis tan despiadado [dura]: 'Ha cambiado, antes era más divertido y cercano [próximo]. Hasta Mujeres al borde de un ataque de nervios, yo me lo pasé de lujo trabajando [passei exageradamente trabalhando ao extremo] con él. A partir de ahí empecé a verlo más ansioso por su cine, demasiado angustiado por que todo no estuviera perfecto. Yo me quedo con el primer Pedro. Le sentía más, le veía más humano, me reía más con él" [Salcedo no entanto pondera e reflete a postura de Almodóvar depois da última película Todo sobre mi madre] Creo que ha pasado una época mala, cuando La flor de mi secreto y Carne Trémula, en la que yo temí que se agotaba, que enloquecía, que ya no veía más. Ahora ha vuelto a la chispa [voltou à tona, reacendeu], de nuevo le veo reírse como antes' ${ }^{378}$ [Todo sobre mi madre já havia começado a trilhar sua longa estrada de celebrações e prêmios, dentre eles o de melhor diretor de Cannes em 1999 e nessa entrevista a equipe estava apenas a alguns dias da festa do Oscar; almejada e depois celebrada por Almodóvar por sua conquista do prêmio como melhor filme de língua não inglesa, além de outros que se seguiram em outros países. Até aquele momento, Salcedo já havia ganhado o prêmio Goya de melhor montagem].

Outras atrizes como Candela Peña e Antonia San Juan, que trabalharam em

Todo sobre mi madre, falam de seu controle, numa mescla de admiração e de exaustão:

Él es el centro, el princípio y el final de sus rodajes. Todo pasa por Pedro, todo lo controla Pedro, desde el grosor de las sayas [formato das saias no corpo] de cada actriz, al diseño y último detalle. Transmite la sensación de saber de todo o de tener autoridad para opinar de todo[Candela Peña]

Tiene muy claro lo que quiere y lo que necesita sacar de cada actriz y de cada

${ }^{377}$ GARCíA, Rocio. De dónde ha salido el mandil que usa Chus Lampreave en 'La flor de mi secreto’? El País de Las Tentaciones, Madrid, 22. 09. 1995.

${ }^{378}$ Idem.p. 25 
personaje ${ }^{379}$ [Antonia San Juan].

Este tom também se faz presente na fala de atrizes, como Rossy de Palma ao fazer Kika:

da gusto llegar a casa cansada sabiendo que él está contento ${ }^{380}$.

Sua secretária ou, como prefere ser chamada: sua assistente pessoal, Lola García, irmã de Esther, alimenta pelo diretor uma amizade e grande respeito, tanto pela forma como o diretor se apresenta no trabalho, como também nas relações pessoais - nas quais demonstra grande intimidade:

Pedro pasa muchas horas de la semana solo y es muy celoso de su mundo privado. Esa manía ha hecho de él casi un ermitaño. Es el peor anfitrión que conozco, pero no porque no le guste la gente, que le encanta, sino porque no está acostumbrado a que anden muchas personas metiéndose en su territorio. No sale de él lo de invitar a gente a su casa, ni sabe comportarse cuando tiene visita, aunque le encanta ir de visita a las de los demás [...] nunca me he quejado de Pedro. Al contrario me siento una privilegiada [...] Pedro es muy intenso y muy exigente. Para lo bueno y para lo malo. Sabe estimular a la gente que tiene a su lado, es muy generoso, lo da todo, pero a la vez exige mucho. Tiene un carácter muy fuerte y si tiene que decirte algo no se lo calla, te lo suelta a la cara. Eso facilita el trabajo ${ }^{381}$

Imanol Arias, que havia trabalhado com Almodóvar em Laberinto de pasiones e voltou em La flor de mi secreto, observa ainda mais a mudança de temperamento:

[...] en Laberinto de pasiones, Almodóvar era un gran provocador, con una vitalidad que superaba todos los condicionamientos y que ahora 13 años después es un ser adorable, simpático y más tranquilo [calmo] que yo" ${ }^{\text {"382. }}$.

A atriz Victoria Abril faz um comentário sintético e esclarecedor do que sentiu quando trabalhou com o diretor:

una de las actrices que más sabe de Pedro Amodóvar es Victoria Abril, y ayer descobrió como nadie lo ha hecho nunca la relación que el manchego mantiene con sus actores. 'Pedro nos destruye y luego nos construye'. Le salió natural, aunque esas frases se preparan unos cuantos meses. Almodóvar tiene fama de sacarle todo el jugo [suco, substância] a los actores, pero luego les da una mano de cariño reparador. ${ }^{383}$

A jornalista e organizadora do Festival de San Sebastián, Núria Vidal - uma das pioneiras a escrever um livro sobre Pedro Almodóvar -, observa os focos de tensão desses contatos detectando as movimentações que ocorrem com o elenco e com o diretor. Evidencia, nesse cenário, o fluxo de relações e a manutenção das simpatias:

Os temas de Almodóvar são a solidão, as dificuldades em ter um companheiro (a), a família, a vida urbana. Importa-se muito com a amizade, em geral feminina, as mães, as filhas, o mundo pequeno do bairro, do pueblo. Sua nova

\footnotetext{
${ }^{379}$ Idem.p. 26

380 JALONCH, 18. jul. 1993. p. 25

381 Idem.p. 27.

${ }^{382}$ COSTA, J.J. Sánchez. El Periódico, Madrid, 19. set. 1995.

${ }^{383}$ MONTERO, 11. mar. 1993.
} 
película é um "volver" em todos os níveis. Mas não creio que seja uma estratégia. É uma necessidade dele. A volta de Carmen Maura é um exemplo da maturidade de todos. O tempo supera tudo. Quando se separaram em 'Mujeres ...' , o problema não foi o Oscar. Quando filmaram La Ley del Deseo tiveram uma paixão fulminante, mas sem sexo. E Carmen, que era a estrela em 'Mujeres ...', era o centro da película, mas foi tratada como mais uma dentre todos. Foi uma filmagem difícil cheia de brigas e conflitos. O Oscar apenas culminou com o que já vinha se passando. Nesse sentido, tanto Antonio Banderas como Victoria Abril foram mais inteligentes. Antes que chegassem ao conflito, cortaram as relações profissionais. Almodóvar, quando filma, tira o sangue dos atores, não permite que façam nada além do filme. Claro, tira deles o que possuem de melhor. Ele sabe como fazer. ${ }^{384}$

Algo que Núria reconhece não apenas no que ele faz com a equipe, mas também em como administra sua própria vida e a mistura em seu ofício, tanto no ato da produção como no produto final. Esse depoimento, associado aos anteriores, não só reafirma as excentricidades pessoais e profissionais do cineasta como também sua necessidade de partilhar afetivamente seu trabalho de maneira austera com aqueles que o rodeiam. O próprio diretor reafirma em sua postura as características dessa disposição para chegar onde deseja:

[...] desde que vine a Madrid sabía que queria ser director de cine, tenía uma disciplina espartana; para llegar a eso debía renunciar a miles de cosas, eso ha dominado incluso en los momentos de mayor desmadre [desespero] [...] ${ }^{385}$.

Bem esclarecido; Aqueles que quiserem trabalhar com Pedro Almodóvar já devem saber de antemão o que os espera: muito trabalho e disciplina. Uma completa contradição quando observamos a descrição da forma como ele organiza sua vida pessoal. Mas na esfera do trabalho - em princípio apenas ligado ao espaço público do diretor - esses hábitos não se misturam. Por outro lado, nas relações pessoais os limites entre público e privado se diluem. Como foi visto, todos os relatos apresentados demonstram espontaneamente por ele uma forte relação de amizade e de admiração. Os membros de sua equipe, os atores e atrizes, todos o tratam pelo primeiro nome, hábito que dilui certas formalidades existentes na cultura espanhola, traduzindo um grau de proximidade que, inclusive, dá vazão para expressar a forma como vislumbram as relações de trabalho e de amizade com o diretor.

Uma afetividade que os fazem se preocupar com seu humor - ao que tudo indica o medidor de seu estado de espírito e de suas condições físicas - e que os anima para continuar trabalhando com ele ou ao menos alimentar o espírito de companheirismo. Mesmo reconhecendo sua austeridade na produtora El Deseo, todos acabam se convencendo de que ela é necessária.

\footnotetext{
384 . VIDAL, Nuria. Depoimento sobre Pedro Almodóvar [13 jul. 2005]. Entrevistador: Gilmar Santana. Barcelona: Universitat de Barcelona, 2005. Minidv (70 min), mono. Entrevista concedida para este trabalho

${ }^{385}$ LINDO, 26. set. 1992.
} 
A meu ver, o poder de convencimento que Almodóvar possui sobre a equipe e a necessidade de administrar o trabalho dessa forma encontram duas matrizes vivenciadas pelo diretor que, se não determinantes, ao menos são condicionantes de um modo de aprendizado pela vida em comunidade.

A primeira é ligada à dureza do padrão de vida no pueblo onde viveu até os oito anos de idade, com um pai que transportava e distribuía vinho em armazéns, e com mulheres cujas conversas, permeadas por muito trabalho, deram ao menino Pedro uma referência de valorização das pessoas a partir de sua utilidade e esforço. Uma cultura própria da vida rural em que a ajuda mútua e as contínuas tarefas físicas são condições essenciais para a manutenção da sobrevivência, colocando o trabalho como o centro e o prazer da vida. Sobretudo em relação às mulheres, cujo papel consiste em manter o bom funcionamento da casa e a reprodução da família.

Reinterpretados, esses são os elementos cruciais que movimentam toda a estrutura de seus filmes, indo desde as personagens, cenas, temáticas até a condução dos conteúdos e dos desfechos narrativos. Em todos, estas experiências encontram-se diluídas e recuperam a memória passada e presente do diretor, objetivando em imagens o diálogo entre seu inconsciente e seu imaginário. Associam-se a eles o histórico pessoal da organização escolar e da vida econômica que interferiram nas escolhas e de preferências peculiares do diretor. Como conseqüência, a paixão pelo trabalho e a necessidade de controle sobre o processo criativo caminham juntas, pois somente o talento é insuficiente para uma trajetória artística. Trabalhar por amor personifica-se numa fórmula excitante que satisfaz um desafio pessoal de êxito. A paixão é complementada pelo auto-controle do trabalho e propicia desenvolver a demanda por uma auto-performance criativa do artista. ${ }^{386}$

A segunda matriz provém dos colégios católicos, cujo ethos religioso prima pela disciplina e pela rigidez em nome da busca pela perfeição da alma. Deles, Pedro não herdou a crença religiosa, mas a exigência educacional escolar dos padres acabou incidindo e sendo traduzida de maneira muito particular no comportamento que exerce em sua vida profissional. Dentro do mundo, o diretor pratica um hábito de monastério bem próximo ao conceito do que Max Weber denomina de "ascetismo laico". Um trabalho exaustivo privado dos prazeres terrenos numa busca contínua de se aproximar do divino - em Almodóvar, o artístico. Um paradoxo curioso diante de uma produção voltada para a liberação dos desejos mundanos e espirituais. Com Almodóvar, estes desejos devem obedecer uma disciplina austera. Ele próprio reconhece que administra

${ }^{386}$ ALVAREZ, e SVEJENOVA, 2002. p. 187-188. 
[...] Cada vez me interesa más hacer cine y cada vez es más esencial para mí seguir haciendo películas. Nada más que me libero de una me meto en otra. Es pesado porque haciendo una al año casi no te puedes permitir tener ningún tipo de vida, es difícil hacer lo que la gente normal, leer los periódicos [jornais], salir de copas [ir a bares], ver a los amigos, la televisión, leer libros ... Es una especie de sacerdocio; pero como es elegido [como escolhi], de momento no me pesa. ${ }^{387}$

Pode não pesar a ele, mas os relatos mostram que, ao arrastar sua equipe para suas vontades, colhe-se um desgaste espantoso de todos os profissionais.

Ha dicho Victoria Abril que a Pedro hay que echarle comida aparte [garantir energia a mais] porque siempre pide más de lo que uno le da.

- Yo siempre pido más y creo que hay que hacerlo, tanto en la película como en tu vida. Después, la realidad ya se encarga de darte lo que te mereces o lo que no te mereces, de ser unas veces generosa contigo y otras no tanto, pero por pedir ... Siempre hay que pedir más! $!^{388}$

Porém, os que imaginam que essas declarações constrangem o diretor, se enganam. Sua forma de retirar o que pode dos atores e atrizes é bem famosa e, para ele, estas são as regras do jogo, e a exigência se deve ao seu próprio processo evolutivo dentro do cinema:

desde luego, soy muy exhaustivo y reconozco que les exprimo mucho, pero eso ya está en las reglas del juego y, afortunadamente, ellos vienen con una disposición muy generosa, se ponen en mis manos ... Victoria, por ejemplo, lo ha pasado mal durante el rodaje, pero una vez que ha visto los resultados no se arrepiende, repetiría la experiencia todas las veces que fueran necesarias ... lo que ocurre es que, cuando mi relación con los actores sufre de algun 'accidente' o distanciamiento personal, empienzan las críticas por todo lo que me han dado ... y no sólo en el caso de Carmen. Ella no me lo criticó imediatamente después de hacer 'La ley ...' y se había entregado tanto como em 'Mujeres ...'. Cuando hay problemas personales, empieza una versión mezquina del pasado común, pero en el momento en que les estoy exprimiendo, nadie se queja porque son las reglas del juego. Yo no les exprimo más que a mí mismo y, en cualquier caso, la vida de un rodaje no se parece nunca a la vida real; la paisón que desarrollamos en rodaje,no tiene nada que ver después con las relaciones personales, porque sino cuando ruedo, les toco cosas muy profundas, a veces sin pedirles permiso, porque me interesa que estén desnudos y no lo sepan [e não saibam], pero creo que siempre respetándoles. Es una experiencia muy vibrante [...]"3389

Diante de tamanha exigência, não resta outra alternativa ao diretor senão conduzir todas as etapas do trabalho até chegar aos objetivos concebidos em todo seu processo de criação. Este conjunto de atividades centrado em suas mãos amplia 0 grau de responsabilidade do diretor perante suas obras e sua produtora. Não apenas porque escreve e dirige suas películas. A ligação que possui com Agustín também o leva a participar - mesmo que indiretamente - da produção, pois seu irmão, mais do que administrar, o mantém a par de todo o processo da execução do filme. Assim, em

\footnotetext{
${ }^{387}$ La Vanguardia, Barcelona, 25. out. 1991. p. 47.

388 JALONCH, 18. jul. 1993. p. 17.

${ }^{389}$ PONGA, Paula, fev. 1990, p. 33.
} 
função das inúmeras condições materiais para elaborar uma película e pelo modo como as conduz, inevitavelmente Almodóvar se vê inundado de atividades.

\section{30 autêntico se constrói socialmente}

A versatilidade do diretor é sua imagem vendida. Está em sua biografia tão difundida pelos meios de comunicação e pelos intelectuais e em sua prática cotidiana no trabalho. Nela combinam-se o artista criativo e o homem de negócios. O fato de centralizar tudo, em decorrência das próprias condições precárias de trabalho iniciais e também pelo seu ímpeto criador, propiciou o avanço de uma companhia independente, reduzindo as influências externas. Portanto, maior liberdade criativa e mais resultados. Nesse sentido, não só constrói um perfil de cineasta dissidente como também uma forma produtiva. Seus trabalhos excêntricos dialogam com uma técnica tradicional que é a negociação. Unindo-as, reinventa as próprias estruturas, imprimindo sua visão não convencional, a serviço de um modelo padronizado. ${ }^{390}$

Pedro Almodóvar está entre os poucos bem-sucedidos dessa mentalidade e dessa escolha que fez pelo underground. O artista pode optar em seguir as convenções profissionais ou em romper com elas e tornar-se um dissidente, entretanto, para isso, precisa da colaboração de uma rede na qual está envolvido. Diante das resistências que recebeu dos modelos tradicionais, ele concentrou todas as suas energias em seus objetivos, criando sua própria estratégia de expansão, e atua agora dessa maneira. Com isso, mostra uma face humana dessa indústria em que é possível romper com a burocracia - ou ao menos com boa parte dela -, afirmar-se e fazer-se ouvido. Esse processo gerou seu rompimento com o círculo tradicional artístico espanhol e criou diversas reações enciumadas, pois se fez ouvir dentro e fora do país, e mais, se sustentou. Tanto que na Espanha, somente com Todo sobre mi madre, obteve o reconhecimento da Academia Espanhola de Cinema. ${ }^{391}$

Assim, mesmo constituindo uma empresa rentável com profissionais de alta confiança, competência e autonomia, todos reconhecem que vão para suas mãos todas as grandes decisões e todos os novos caminhos ${ }^{392}$. Foi a observação desse contexto que motivou Frédéric Strauss a chamar de "mundo Almodóvar"393 o conjunto de atividades iniciado com sua produtora El Deseo desde seu primeiro lançamento, com La ley del Deseo. As declarações indicam que Almodóvar tratou de garantir uma

\footnotetext{
${ }^{390}$ ALVAREZ, e SVEJENOVA, 2002. p. 189 e 192.

${ }^{391}$ Idem. p. 188. O filme obteve 2. 590. 237 espectadores na Espanha e arrecadou 9. 962. 047, 60 Euros em 1999; fonte: MINISTÉRIO DE CULTURA (España). Filmoteca española: base de datos de películas: 1999.

${ }^{392}$ GARCIA, Rocío, 22. set. 1995. p. 21.

${ }^{393}$ STRAUSS, 2001, p. 63.
} 
estrutura quase familiar entre todos seus envolvidos, não apenas porque há relações de parentesco de alguns integrantes. A maioria da equipe já trabalha com o diretor há mais de 20 anos. Seguindo essas condições - de aceitação de condutas de trabalho, de cumplicidade e de ações cotidianas subordinadas a seu modelo de produção dissidente -, pode-se compreender melhor por que, em sua produtora, o diretor faz 0 que lhe dá vontade sem depender de produtores e de financiadores que diriam o que deveria ou não entrar em suas histórias.

Entendendo a obra de arte como atividade social, a estrutura do entrelaçamento entre criatividade e negócio gera uma dualidade que potencializa, mas também limita, o trabalho artístico. No acomodamento desse exercício, qualquer influência do artista depende de sua entrada em um grupo com graus de influência e níveis de rede social. E cada pequena rede situa-se numa mais complexa. O artista se alimenta do mundo artístico, imprime uma imagem estética e acaba influenciando projetos. Isso propicia um fluxo que gera oportunidades de acordos e de novos trabalhos, posicionando o conjunto das atividades num mercado específico. A carreira do cineasta sustenta-se por esse "namoro" entre arte, técnica e mercado. Tal contexto o leva a conviver e a administrar produção independente, contratos, conexões em festivais, mostras, Hollywood, Cannes, etc. ${ }^{394}$

Ele precisa de um suporte estrutural para produzir sua arte e seus projetos. Em geral, a estrutura existente bloqueia suas idéias inovadoras. Em muitas carreiras pode fomentar, mas tabém pode diminuir o grau de criação do autor em sua obra. Almodóvar lembra que, anteriormente a El Deseo, sua relação com os produtores não era boa. As arrecadações de bilheteria em suas películas nunca ultrapassavam os gastos, e sua impressão era de que sempre ele queria realizar um filme, e os produtores, outro. Isso criava constantes tensões. Não só se tratava de impressão, mas de um fato mensurável diante da discussão apontada até o momento.

De todas as formas de negociação possíveis e de oportunidades de investimento em seus projetos que aparecem os irmãos Almodóvar buscaram usufrir. Em 1983, entrou em vigor na Espanha a lei de Pilar Miró - que carrega o nome da autora -, em virtude da qual se organizou um sistema de subvenções baseado no modelo francês que antecipava o valor dos ingressos. A lei contribuiu para que Pedro e Agustín criassem sua própria produtora, facilitando também a todos os diretores espanhóis o acesso a produções ${ }^{395}$. Com ela, tanto Almodóvar como outros cineastas inclusive os analisados no capítulo 3 deste trabalho - foram beneficiados.

${ }^{394}$ ALVAREZ, e SVEJENOVA, 2002. p. 189-190. 
A posse de sua produtora eliminou o controle anterior que ocorria sobre a criação do diretor, propiciando sua liberdade para inventar histórias a seu modo e para investir nos mercados que lhe conviessem. Apesar da opinião da crítica contribuir positiva ou negativamente para suscitar o interesse de distribuidores estrangeiros, 0 público continua sendo o principal termômetro para o diretor. Não só porque lhe garante bilheteria, mas porque indica o grau de sua popularidade. Os dois depoimentos abaixo fazem o contraponto de suas buscas:

[...] soy probablemente el director español más libre, lo cual me hace más responsable, porque soy absolutamente dueño de lo que hago.[um tanto exagero do diretor, afinal Fernando Colomo, FernandoTrueba e Ventura Pons já possuíam essa autonomia no mesmo período desta entrevista. O que os diferencia é a relação estabelecida com o mercado internacional, nesse ponto indiscutivelmente bem mais amplo para Almodóvar]

Sentirse el más libre significa que se asfixia dentro del cine español?

Quiere decir que he conseguido ser dueño absoluto de mi trayetoria. El cine español no se me ha quedado pequeño [não ficou pequeno para mim], pero lo que yo busco es la novedad, probar registros y géneros diferentes [...] ${ }^{396}$

[...] cuando me refiero a que una película no tenga éxito, no pienso ni siquiera en que salga mal, sino en que funcione mal comercialmente, aunque sea [ainda que seja] lo que yo he querido hacer. Me da tanto miedo que pueda romperse esse milagroso cordón umbilical que me comunica con el público, que para evitarlo daría no sólo los premios pasados, sino también los futuros. Pero he de pensar que si un día se pierda esa sintonía, forma parte de la carrera de un director, a todos les ha pasado alguna vez. ${ }^{397}$

Estas frases vislumbram não só um diretor responsável e comprometido com a liberdade de criação e com a apreciação de seu público, mas também revelam uma imagem quase auto-suficiente de alguém que se fez sozinho. Como venho demonstrando até aqui, há uma complexa articulação de partes ativas nesse sistema que garante a produção do diretor e a sua visibilidade. Sobretudo a produtora El Deseo e o irmão constituem-se na principal plataforma desse sucesso, agentes que nem sequer são citados ao menos nestas entrevistas. Nelas se constata a corporificação de um herói disposto a fazer contínuos sacrifícios para que as platéias continuem satisfeitas e, certamente, aplaudindo suas obras.

Nessa narrativa, seu trabalho personifica-se em algo inesgotável, reforçando sua imagem de lutador e de merecedor de suas conquistas. Um incansável cavaleiro na batalha por agradar os espectadores. Isso justifica suas exigências, não apenas com sua equipe, mas também consigo mesmo. Uma relação que torna também 0 próprio público mais impiedoso, desejando ver sempre algo estupendo. No Festival Internacional de San Sebastián, em 1995, quando lançou La flor de mi secreto, sua reação aos tímidos aplausos revelou esse aspecto eloqüente de seu perfil, registrado

\footnotetext{
${ }^{395}$ STRAUSS, 2001. p. 64.

${ }^{396}$ MUÑOZ, 17. set. 1995.

397 JALONCH, 18. jul. 1993. p. 17.
} 
por um comentarista do evento:

\section{'Almodóvar arranca tímidos aplausos'}

Uno de los acontecimientos más esperados en esta edición del festival de San Sebastián era la presentación, fuera de concurso, del último filme de Pedro Almodóvar La flor de mi secreto [...] el público acogió con tímidos aplausos el final. Esa falta de entusiasmo parece obedecer a un motivo: a Almodóvar se le exige mucho, quizá demasiado ${ }^{398}$.

No mesmo artigo, como que numa compensação para o desapontamento do cineasta e do público, o jornalista afirma numa nota que reforça as imagens mitificadoras construídas:

El genio de Almodóvar sigue vivo.

Una afirmación tajante [contundente] a las pocas horas de haber abandonado la sala con cierto aspecto de decepción. La causa de esa aparente falta de coherencia está en el techo tan alto que se ha colocado este cineasta. Prescidiendo de emblemáticos títulos anteriores a 1988, el autor de filmes tan originales y redondos como Mujeres al borde de un ataque de nervios o Tacones lejanos lo tiene muy difícil para superarse. Con Kika no es que se equivocara, es que no tuvo tanto éxito. En este caso, está por ver la resonancia comercial de esta desesperada historia de pasión no correspondida [...] ${ }^{399}$.

Almodóvar provavelmente interpretou, na reação do público ao seu filme, o mesmo sentimento que construiu para a história de sua protagonista Leo. Sua relação de paixão com os espectadores se dá no mesmo nível. E essa busca incansável elaborada publicamente o faz permanecer em constante ato criativo, pensando em novos projetos. Ele acaba cumprindo um duplo acordo tácito: manter a imagem trabalhador, irônico - e gerar novas histórias que o agradem, mas que atraiam seu público.

Auxiliado por um diálogo contínuo de uma imprensa que segue seus passos e que alimenta essa imagem de trabalhador inveterado, ele garante também sua promoção internacional. Um dos aspectos que sustentam o mito do homem insatisfeito que deseja sempre o melhor em função do espectador. As estratégias são várias. Quando o cineasta apenas pensa em fazer algo novo, já começa a "manufatura" de sua película. Tudo se anuncia muito tempo antes e cria uma grande expectativa entre adeptos e não adeptos de suas narrativas.

Às ideías de trabalhador incansável e insatisfeito se associam especulações sobre suas ambições e o incômodo coletivo que causa por parecer não parar nunca:

- $\quad$ No tiene usted ganas de tomarse unas vacaciones [tirar umas férias] ?

- Pues sabe usted que no? A mí me mosquea [desconcerta] no tener ganas. En mi imaginación no hay lugar para tener proyectos eso es una especie de pobreza. Lo mismo que al final de Que he hecho yo para merecer esto?, cuando el personaje de Carmen Maura se queda sola en la casa, entra y lo encuentra todo limpíssimo, abre la ventana para tirarse porque no tiene nada

\footnotetext{
${ }^{398}$ COSTA, 19. set. 1995.

${ }^{399}$ Idem.
} 
que hacer. Y lo peor es que no ha tenido tiempo para tener ni un sueño, ni un proyecto ..., pues estoy un poco así yo. Me encuentro como bobo.

- Quizás es que ya ha cumplido el sueño de su vida ... ser rico, famoso, ir a Hollywood ...

- No, el sueño que mi vida era hacer películas y ahora tengo más ganas que nunca de hacerlas. No me he quedado satisfecho, estoy en los comienzos de eso de hacer cine. La verdad es que ahora que he descansado como dos días desde que acabé con Átame lo único que me interesa es hacer otra película. Eso anula todo lo demás, no sé si es bueno o malo.

- Se ha hecho rico?

- Yo de vez en cuando le pregunto a Tinín: 'Somos ricos, Tinín?' Y él me dice: 'sí, somos muy ricos, Pedro'. Debemos ser muy ricos. No lo sé. El que lleva las cuentas es él. Al princípio me dijo ...'bueno, planteáte tu vida ... si quieres vivir como los ricos'. Le dije que no. Yo quiero vivir como siempre, comprarme videos, libros y discos ... no va a haber ningún cambio em mi vida. Eso me desconcierta tambén. Creo que estoy en el punto más alto de mi pasión irracional y a veces destructiva porque todas las pasiones lo son, por el cine. ${ }^{400}$

Ou por marketing pessoal - e profissonal - ou por incontinência verbal do

diretor, o fato é que seus filmes começam a existir muito tempo antes de estrearem na tela grande e nem sempre se realizam. Coletivas, entrevistas esparsas em rádio, redes de TV. A cada lançamento ele próprio anuncia seus novos projetos ou algum roteiro que vem esboçando. A imprensa encarrega-se de instigar as novidades e de fomentar a imagem do eterno trabalhador.

'Almodóvar no cierra en vacaciones [não entra de férias]' Si Pedro Almodóvar no es un cineasta convencional, mucho menos es un turista al uso [convencional]. Su paso por Mallorca no responde a un deseo gregario de unirse a la troupe de famosos que han pasado y pasan por la isla, sino a un intento de refugiarse en el único hotel no playero de Palma para dar cuenta de un guión [roteiro] cinematográfico que escribe al alimón [conjuntamente] con Agustín Villaronga. La presencia del director de cine no ha pasado desapercibida aunque él asegura que es un escritor y 'no una pin up'. 'La verdad es que no voy nunca de vacaciones, así que no soy un buen turista', dice el director, que nunca había estado en Mallorca a pesar de que una de sus 'chicas' es Rossy de Palma, una actriz que tomó prestado el nombre de la ciudad donde nació [Palma de Mallorca]. [...] Almodóvar no sabe estar sin hacer nada. 'Tendría que encontrar un hobby, algo en que entretenerme cuando no trabajo, pero la verdad es que no he desarrollado ninguna afición'. En los años que lleva de frenética actividad no ha tenido vacaciones. 'Quizá lo que considero descanso es estar un poco más relajado y poder tomar notas. Siempre voy con un cuaderno', asegura. [...] De momento, Pedro Almodóvar está a la espera de empezar el rodaje de Carne tremula, que le mantendrá ocupado los próximos meses. Esta película será fuerte. 'Y pensar que me había moderado mucho. La flor de mi secreto casi era apta para todos los públicos. Ésta tiene mucho sexo. Será porque está en verano', agrega ${ }^{401}$.

A idéia de que sua criação é incontrolável e imprevisível, como no final desta entrevista, agrega-se ao fato de seu histórico apresentar, desde a infância, o hábito de escrever e de ler muito, de observar muito. Essas práticas não dão espaço para descansos convencionais. O que se acentua a cada momento é que realmente ele não

\footnotetext{
${ }^{400}$ LLOPIS, 11. dez. 1989. p. 172.

${ }^{401}$ ALCAZÁR, Mariángel - enviada especial.. El Periódico del Verano, Palma, 20. ago. 1996.
} 
é alguém tão normal. Como se não bastasse trabalhar, pode-se notar nos comentários da jornalista a adjetivação do ritmo que leva: frenética atividade. Raros são estes comentários estar ausentes. Muito mais do que informar ou reproduzir a imagem do diretor, eles alimentam uma indústria cultural baseada em novidades. Não importa muito se elas se realizarão. O que conta nessa imprensa em busca da exclusividade do produto é manter o espectador-consumidor sempre pleno de informações.

A leitura comportamental de um artista acelerado, que parece falar sem deixar tempo para respirar, que possui olhar compenetrado - atento e eterno observador - e tantas outras descrições de suas atitudes e atividades - compõem a visão pública sobre o autor. Uma narrativa que trata de adaptar sua biografia e de criar sentido a seus atos presentes. Uma construção que paradoxalmente aproxima e distancia na medida em que se tece o perfil de um cineasta espanhol internacional. O faz próximo, permitindo descobrir - segundo a mídia - sua intimidade, e distante porque possui características e modo de vida tão singulares, cheios de excentricidades que só é possivel concebê-lo como um gênio.

$\mathrm{Na}$ descrição que faz de seu processo criativo o próprio diretor trata de contribuir para estas idéias de ser dotado naturalmente de uma mente em incontrolável ebulição. E este comportamento acaba justificando a descrição jornalística de seu modo de falar e de seu temperamento impulsivo e exigente:

A mí me sucede algo que es topiquíssimo, pero te aseguro que yo lo vivo así; y es que hay veces que acabo de escribir las primeras líneas de una sinopsis y luego me voy a la cama, y entonces la historia sola empienza a desarrollarse, pero de una manera casi monstruosa, ramificándose caóticamente y de un modo muy fuerte, muy fuerte, muy fuerte. $Y$ me impide dormir. $Y$ en más de una ocasión he tenido que levantarme y parsarlo todo a máquina para liberarme de ello, porque me sentía igualigaligual que si hubiera desembarcado un alien, un monstro encima de mi cabeza, y tú ya no eres el creador de eso, sino que te ha cogido como vehículo para que esa historia salga.

- Y esa tremenda imaginación que usted tiene, ha sido siempre tan fértil? No ha tenido ningún momento de bajón, ningún instante de crisis, esas etapas en las que uno cree que ya no se le va a ocurrir nada?

Si hay una única cualidad que me reconozco, y eso sí, desde pequeño, es que siempre he tenido una gran imaginación. Esto me lo demuestro cada día. Y a veces sí he tenido miedo de decir: Y si esto se me va en algún momento? Y esa possibilidad me da terror. Pero siempre he tenido imaginación; por eso he sido siempre una persona muy provocadora y muy polémica, porque todo lo que he hecho ha sido imaginativo, pero casi siempre ha estado mal hecho, o casi nunca a estado hecho convencional y correctamente, porque me he lanzado impulsado exclusivamente por las ideas y por la imaginación. Y esto es peligroso, porque la imaginación no basta: las cosas hay que hacerlas. Yo siempre he sentido esta preocupación porque nunca he tenido los conocimientos suficientes para hacer las cosas que he hecho. [...] Pero siempre he tenido claro que un chiquito como yo, que venía de familia humilde, etcéteraetcéteraetcétera, no iba a esperar una situación fantástica y maravillosa donde se iba a encontrar con todo, sino que yo tenía que robar esa oportunidad e imponerla [...]"

${ }^{402}$ MONTERO, 28. set. 1986. 
A maneira como o diretor constrói sua criação dota suas histórias de uma autonomia especial, como se estas fossem entidades que o transformam num mero porta-voz da vontade de um outro ser. Porém, basta retirar os exageros e a grande capacidade metafórica e narrativa do diretor e compará-la com depoimentos de outros artistas quando estão em processo de criação para constatar que não existem diferenças tão significativas entre eles. O que mais se detecta - segundo as próprias definições que o cineasta elabora sobre si mesmo - é seu caráter pessoal e suas atitudes sociais afirmativas de sua genialidade.

Porém, quando o discurso parece convencer o espectador de seu perfil divino, Almodóvar salta para o outro extremo, trazendo o mundo real para a concretização de seus sonhos, transformando-se em mais um cidadão comum, como qualquer um de seus espectadores. Nesse momento, reconhece a consciência a respeito de sua origem de classe social, reflete as condições necessárias para realizar seus projetos e sobre seu lugar diante das elites intelectuais - sobretudo cinematográficas - que o observam. Este trânsito entre a imagem do próximo e do distante sem, contudo, fixarse em nenhuma delas, garante, por isso - como já afirmei anteriormente - traços que evidenciam sua autencidade e não sua genialidade.

Sua autencidade, ou o aqui e o agora original de uma obra de arte como discute Walter Benjamin sobre os critérios para sua autenticidade ${ }^{403}$, se desdobra no conjunto intrínseco que o autor construiu sobre si englobando sua imagem, seu trabalho e sua obra. Em todas as atitudes, os processos de produção e o produto final se misturam. Transitam e aparecem com mais ou menos evidência em um deles ou em todos simultaneamente. Para isso, contribuem vários mecanismos intra e extra cinematográficos.

Em nenhum momento o autor se contradiz e, quando isso parece ocorrer, isso se incorpora em seu discurso polêmico e irônico que comporta as más interpretações e as decodifica em novas formas criativas. Por isso, quando se fala em algo referente ao universo de Almodóvar, o que se imagina é somente algo idêntico a ele mesmo. Por que a obra reproduzida deste cineasta não se esquiva dele? Porque ela é o próprio autor. Sua história, seu momento e seus dilemas. E quando não a vemos, sejam os filmes anteriores ou algum novo, ele se encarrega de manter presente sua imagem. Sua freqüência na mídia só vem a potencializar sua aura.

Para isso, não bastam discursos contundentes e saídas inteligentes para se relacionar com o universo que alimenta o mundo cinematográfico. Necessariamente é 
no dia-a-dia que ele se arma de uma rígida disciplina e de objetivos claros para mantêla em funcionamento. E isto ocorre desde Pepi, Luci, Bom y otras chicas del montón, contradizendo boa parte do parecer de críticos que viam seu cinema como uma diversão para os amigos, reconhecendo-o como um cineasta sério apenas a partir de Qué he hecho yo para merecer esto? Novamente, imprensa e diretor unem-se para reproduzir sua imagem de sucesso relendo um passado próximo.

A película realmente destoa das três anteriores. Evidencia de modo claro o conjunto de universos populares ao retratar a vida de uma dona-de-casa da periferia de Madrid, sofrendo todo o peso social dos valores e dos comportamentos de uma sociedade pós-ditadura. Ali se encontram a vida nada glamourosa da cidade, seus contrastes e os resquícios de uma estrutura social autoritária representada na figura da personagem masculina e nos anseios de uma mulher disposta a romper com isso, mesmo sendo completamente alienada de sua condição submissa. Seguem-se personagens deslocados socialmente, revelando as inúmeras seqüelas deixadas por uma lógica de governo conservadora e a relativização que o diretor faz das relações familiares, sobretudo quando se faz necessário sobreviver a qualquer custo.

Para a maioria dos críticos, com este trabalho, Almodóvar inaugura uma fase mais séria digna de ser respeitada e analisada, razão pela qual tanto Matador como La ley del Deseo já foram notados e comentados com mais atenção em razão das anteriores. $O$ diretor sabe que aquele trabalho representa uma nova fase, mas a forma das críticas não o agradou, apesar de elogiosas. Em seus argumentos, ser sério foi sempre algo mais profundo do que fazer filmes cômicos ou dramáticos. A resposta mais sensata para estas observações chegou a longo prazo, de uma maneira mais tranquila, possivelmente em decorrência das próprias buscas e da maturidade do diretor:

[...] supongo que es cosa de la edad y del paso del tiempo, pero eso no significa que me vuelva más sério. $Y$ mis otras películas no es que sean menos serias, es que tienen más elementos de humor. ${ }^{404}$

À essa avaliação agregou-se outra mais elaborada e refletida anos depois, que só foi possível num momento de legimitação mundial, sobretudo com a imensa quantidade de prêmios que culminaram com o Oscar. Um troféu não só almejado pelo diretor, como também pelo próprio país em Todo sobre mi madre. O conjunto de aclamações permitiu ao diretor não apenas maior tranquilidade para avaliar sua trajetória, como também não ser necessário justificar-se diante de cada crítica no país.

\footnotetext{
${ }^{403}$ BENJAMIN, Walter. Magia e técnica, arte e política - obras ecolhidas, v. 1, 10 reimpressão. SP, Brasiliense, 1996. p. 167-169.
} 
Mais uma vez coube ao próprio Almodóvar o papel de construir sua imagem e seus objetivos, reelaborando o "corpo" de sua obra desde suas origem e apontando aos críticos a falta de visão anterior, na verdade - para ele -, 20 anos de olhares desfocados. Uma avaliação posterior, que lapida arestas indesejáveis ou oscilações entre uma película e outra, esculpindo ao gosto do presente do diretor um momento de solidez que ordena todos os outros passados. Agora - com a consagração - ele poderia se gabar e responder aos estereótipos que o rotulavam de imaturo rebelde e de polemista gratuito. Falar de sua seriedade era muito mais do que avaliavam. Obviamente, constatou: mais do que nunca, a aura da fama o protegia.

Tengo la sensación de que mi éxito se debe a la acumulación. Si miro la trayectória de los directores europeos más importantes de mi generación y las comparo con la mía y yo no pongo nombres, yo me distingo de ellos en que he seguido una trayectoria totalmente autóctone y personal. El echo de nacer para el cine como un efant terrible [menino travesso, terrível] es bueno para la promoción, pero a la vez es muy delicado, porque se olvidan de ti a las dos películas. No fui yo quien quizo ser un enfant terrible, a mí me etiquetaron así. Por eso creo que esta avalancha de premios responde a que han unido una película a otra, a otra, han visto una trayectoria y se han dicho: oye, que este chico va en serio, que a este chico le preocupa su profesión, que preocupa de ir evolucionando, de ir cambiando, de ir madurando.

- Hoy sí le toman en serio?

- Sí. por primera vez siento que me toman en serio. Por primera vez percibo que la gente, al ir a ver mi película, ha pensado en la película y no en sus prejuicios, han mirado lo que ésta les provoca y se han olvidado de que es Almodóvar quien está detrás. Lo de tener una marca de fábrica previa es muy complicado. Crea muchos prejuicios, la gente no te mira con objetividad. [...]

- Usted se toma en serio?

- Por supuesto, desde que nací. Y más me vale, porque si no ...Pero bueno, me tomo en serio con distancia. Me tomo en serio porque ésta es la única vida que tengo y quiero vivirla a mi modo tanto como pueda. $Y$ éste es el trabajo que tengo, el que he elegido y al cual le doy mucha importancia. Pero esto no quiere decir que no utilice el humor en mi vida y en lo que hago" ${ }^{405}$.

Foram-se os tempos em que, por ocasião da crítica se fazer mais acentuada ao seu modo de filmar e de se comportar, Almodóvar precisava de uma afirmação pública mais eficaz em que se registraram respostas num tom mais contundente como esta:

[...] lo que pasa es que al sacar mis orígenes, porque en esa película hablo un poco de mi familia o, mejor dicho, no de mi familia, sino de la classe social a la que pertenezco, pues a lo mejor el resultado es más visceral y te comunicas de un modo más inmediato [fala de Qué he hecho yo para merecer esto?]. Pero en las demás películas mías hay cosas semejantes. Y en cuanto a la seriedad, tú sabes lo serio que hay que ser para hacer una película como la primera mía, Pepi, Luci, Bom y otras chicas del montón, que tardé año y medio en poder terminarla? Tu sabes lo que es coger [pegar] 40.000 pesetas [241 euros] de aquí y rodar un plano en un fin de semana, y seguir así año y medio, sin desesperar y sin dar terminada la película? la constancia y la seriedad que se necesita para eso son tremendas. Ha sido la película más dura y más difícil de

\footnotetext{
${ }^{404}$ FLORES, Felix. Entrevista com Pedro Almodóvar. La Vanguardia , Barcelona, 25. out. 1991.

${ }^{405}$ FERNANDÉZ, 19. mar. 2000. p. 17.
} 
hacer de todas las mías ${ }^{406}$

Yo soy muy posibilista y actúo com los medios que tengo en las manos. Al princípio, además de la ignorancia, tampoco podía hacer las cosas de otro modo ya que no tenía dinero ${ }^{407}$.

O discurso eficaz melodramático do diretor alterna família, classe e dificuldades, num processo que culminou em vitória, não só da película como também de sua carreira. Portanto, a leitura que fazem de sua trajetória se transforma numa virtude pessoal do diretor e num método de sucesso. Os textos se organizam de um modo que coloca em seus antecedentes toda a forma de trabalhar e de administrar projetos que o levou a uma estabilidade profissional que pudesse conceder-lhe um terreno mais firme. Ele fixa como fio condutor do argumento a seriedade, exatamente o tema escolhido pela jornalista.

Observar bem as perguntas e saber qual seu foco para poder atacar, há tempos tem sido um recurso que favorece a carreira do cineasta. Ele sustenta sua seriedade ou suas preocupações em torno da dimensão econômica, aliada à discussão sobre seu método de trabalho. Nas entrelinhas, descrevem-se suas origens sob a influência cultural de família camponesa pobre e de regiões áridas onde viveu - La Mancha e Extremadura - que Ihe transmitiu a noção de só gastar o possível, de saber se planejar, de ter paciência com a escassêz ou melhor, de suportá-la. Quase se presencia uma lição de vida.

Porém - como apresentado -, Pedro Almodóvar não construiu e não mantém sozinho toda sua "oficina de desejos". Além da equipe alinhada a seu regime e identificada com sua proposta, o irmão desempenha, como numa simbiose, todo o aspecto da negociação que nutre o diretor e, por sua vez, este alimenta Agustín com sua criatividade, motivando-o a expandir seu trabalho, por amor ao irmão. José Luis Alvarez e Silviya Svejenova apresentam quatro proposições que elucidam precisamente seus passos ${ }^{408}$.

$\mathrm{Na}$ primeira refletem que, em geral, quando existem objetivos diferentes entre diretor e produtor, nos trabalhos independentes, ocorrem tensões entre os profissionais. No caso da produtora El Deseo, houve uma combinação de papéis e os dois irmãos absorveram a tensão ao simplificarem a coordenação e ao reduzirem os problemas de agenciamento. A cumplicidade entre eles tirou a ambivalência e inclusive rompeu com a separação entre tecnologia e artista mais domínio de negócios, conseqüentemente, com os perfis de limite profissional. O que tradicionalmente seria

\footnotetext{
${ }^{406}$ MONTERO, 28. set. 1986.

${ }^{407}$ Cartelera Turia, 25. abr. 1988. p. 30.

408 ALVAREZ, e SVEJENOVA. 2002. p. 193-196.
} 
contraditório: artista, só criador, e produtor, só técnico e negociante se quebra na prática de fazer várias atividades aparentemente incompatíveis.

Será sempre dentro deste espírito de possibilidades que os irmãos Almodóvar ampliam seus projetos. No final de 2003 eles se preparavam para entrar no ramo de seriados televisivos com a emissora Telecinco. Nesse campo rentável e perigoso, os dois vinham sondando um diretor jovem, Jorge Torregrosa, para dirigir "Solteros" (em título provisório), algo que misturaria o universo almodovariano com uma história no estilo hollywoodiano da série "Friends".

En 'Solteros' no se espera que abunden transexuales, violadores, vírgenes suicidas ni enfermos mentales. El surrealismo dejará paso a la cotidianeidad más rentable en una historia centrada en las relaciones entre un grupo de vecinos solteros que rondan la treintena [trinta anos] [...] el proyecto, que está en fase de preparación de guiones, forma parte de un acuerdo que la productora del popular cineasta manchego mantiene com Mediapro para el desarrollo de series y documentales. ${ }^{409}$

Na segunda consideração observam que, desde que a produtora foi criada, ela requer diferentes atividades artísticas, mas o diretor não consegue movimentá-la sozinho. Pedro Almodóvar não é um homem de negócios, nem se interessa por isso, mas delega para seu irmão mais novo o gerenciamento da produção executiva do filme. Como ocorre com FernandoTrueba e sua esposa, que faz a produção executiva de suas películas. Modelo também dos irmãos Auguste e Louis Lumière, Paolo e Vittorio Taviani, Joel e Ethan Coen, Bernardo e Giuseppe Bertolucci entre outros. Portanto, uma prática já familiar e bem-sucedida no meio cinematográfico.

O irmão Agustín é quase o alterego de Pedro em seu aspecto de viabilização e de racionalização das obras, tanto antes como depois de realizadas. Em sua declaração de experiências vividas com o diretor, alinha os laços familiares de uma maneira que subordina os vínculos consangüíneos a um companheirismo transcendental:

Mi relación con el cine y con Pedro como director empenzó en 1972, quando llegué a Madrid. Tenía 16 años y venía de provincias, donde había estudiado con los curas [padres] y descubrí un mundo diferente. Era el final de la dictadura y Pedro hacía muchas cosas en aquella vida de Madrid a la que me aventuraba con muchos privilegios, pues Pedro conocía a la gente clave para acceder a los ambientes más interesantes. Mi hermano era a la vez mi protector y mi iniciador. En aquella época se divertía con el cine y la narración cinematográfica haciendo cortometrajes en super 8, le acompañaba a las proyecciones que hacía en cualquier sitio, y tengo la impresión de que hoy en día sigo haciendo lo mismo: acompaño a Pedro donde se proyectan suas películas, simplemente han cambiado los amigos y los lugares, ahora son más distinguidos, también ha cambiado nuestro aspecto, llevamos smoking, pero nuestra motivación y nuestra relación sigue siendo la misma [...] cuando Pedro dirigió su primera película profesional, yo iba de vez en cuando al rodaje, sólo para ver a mi hermano. $\mathrm{Y}$ actualmente sigo haciendo lo mismo, no me

${ }^{409}$ ABC, 03. nov. 2003. 
considero el productor de Pedro, nuestra relación es la de dos hermanos que se ayudan, se protegen mutuamente. Es una relación afectiva, basada en cosas misteriosas, irracionales, referidas a la fraternidad. El día en que se termine de analizar el mapa genético humano, seguramente encontrarán el gen de la fraternidad y descubrirán el secreto de afinidad entre hermanos. ${ }^{410}$

O terceiro aspecto é diretamente uma conclusão lógica do anterior. Para tocar esse tipo de negócio, o artista precisa de uma pessoa de confiança. Almodóvar iniciou seu trabalho artístico com alguém que entendia sua essência, desde o primeiro filme. Agustín fala que precisou tomar uma decisão vital de amor e dedicação no trabalho integral com Pedro. Esta o introduziu no ambiente do cinema num nível instrumental para poder desenvolver sua parte do trabalho e, com isso, suspendeu a tensão ente arte e negócios. Acrescento aqui, que não basta uma confiança pessoal, mas também uma sintonia de identificação com o tipo de trabalho a ser desenvolvido em parceria, pois a realização de um se faz na realização do outro. Assim, concomitantemente ao prazer de um trabalho desenvolvido com o sucesso de um, há um oferecimento ao outro, assim como a responsabilidade pela boa execução e a satisfação dos resultados também são bilaterais.

A última consideração que explica uma carreira simbiótica como a dos irmãos Almodóvar define uma dupla que partilha os diferenciados domínios compatíveis para serem encaminhados por uma pessoa. O próprio Pedro reconheceu publicamente que ser produtor é um bom negócio e, sendo seu irmão, nem sempre é tão fácil. Não por menos a necessidade de um trabalho tão visceral e familiar afasta Pedro Almodóvar dos grandes estúdios dos Estados Unidos que, para funcionarem dentro da enorme dimensão física e organizacional que possuem, precisam ser impessoais. Essa racionalização norte-americana que fragmenta e que atinge todas as esferas, inclusive a da criação, é algo impensável para o diretor.

Assim, quando se constatam seus novos investimentos dentro do ramo, sua expansão e sua recusa aos convites das grandes corporações é em contraposição a esse modelo que proporciona segurança e liberdade ao cineasta que se deve comparar as certezas e as inseguranças. Numa produtora em que até o avental da personagem é decidido pela vontade direta do diretor e na qual todos seguem sua regência, uma forma industrializada quebraria sua estrutura artesanal e familiar que não se situa apenas na sua prática, mas sobretudo em sua lógica criativa e imaginária. É somente o modelo de sua produtora, que reflete o seu estilo e a cultura administrativa criada por seu histórico, que o possibilita desenvolver suas histórias.

Os novos investimentos, ainda que resultem de suas narrativas - agora já 
tradicionais-, seguem a mesma estrutura produtiva. Naquele mesmo ano de 2003, quando das negociações sobre os seriados televisivos, El Deseo também havia diversificado seus negócios, associando-se à Transglobe para produzir documentários, dos quais o primeiro - 'Eyengui, el Dios del sueño' - estreou no final de novembro. Somam-se a este empreendimento os filmes que a produtora financiou para incentivar novos diretores. Sem grandes alardes nos investimentos - atitude oposta à estratégia para anunciar novos filmes - os irmãos Almodóvar avançam com seus projetos dentro do restrito mercado espanhol ancorado em pequenas produtoras, porém com vistas no mercado internacional. Ambos sabem de seus limites. Mantêm, assim, sua estrutura administrativa - quase caseira - entretanto com a dimensão de avanços graduais e, claro, carregando o estigma que acompanha o diretor: cineasta manchego.

A recorrência à classe social continua aparecendo na relação associada a essa discussão. Ainda que tenham enriquecido, os irmãos movimentam seu negócios a passos comedidos, num ritmo que lembra a estrutura familiar marcada pelo controle dos gastos e pelo uso necessário dos benefícios. O caráter polêmico presente no discurso do cineasta - como visto -, também resultado da forma como entrou nesse campo, hoje apenas acompanha e complementa seu modo direto de se expressar, sem rodeios. Almodóvar dá respostas que não deixam margem para meio termo e que nem ficam incompletas. Como roteirista, certamente incorporou em sua vida a necessidade de explicar detalhadamente cada situação sem deixar "pontas" para que, no final, tudo pudesse ter sentido e "amarração" certeiros, ainda que provoquem calorosas discussões e que ele já não tenha mais a mesma energia para longos debates.

As declarações são intrigantes. Abarcam de um só golpe as diversas facetas da vida e do perfil do diretor de forma demarcada. Em suas auto-entrevistas isso é previsível, pois Almodóvar tem o domínio do texto, podendo perguntar e responder o que lhe convier e construir interessantes discussões revelando ou não esse conjunto de elementos de sua vida. Mas o curioso é perceber, nos textos dos entrevistadores ou nos artigos elaborados pela imprensa sobre ele, essa mesma densidade de informações. Num mesmo texto sobre Almodóvar encontram-se provavelmente sua vida pessoal, seu trabalho, seu comportamento, sua moral, seus filmes e suas perspectivas sobre a sociedade.

Os autores sistematizam as informações de uma maneira que as temáticas apareçam quase homogêneas. Resumem, assim, não só a vida do cineasta como a própria postura dos meios de comunicação. Em todas as construções persistem as marcas da origem, seja ela supostamente mitificada ou constatada sociológica e 
antropológicamente.

A sequência 29 de La flor de mi secreto sintetiza vários desses elementos que traçam o perfil geral de sua vida. Urbano, como todos os outros, o filme desenvolve sua trama entre personagens que possuem origem nos pueblos, e nesse momento, emergem muitas das características do comportamento e das regras da vida rural. $\mathrm{O}$ filme causou tão bom impacto e surpresas que mesmo Pedro Almodóvar reconheceu até aquele momento - que havia feito sua obra mais manchega e autobiográfica ${ }^{411}$, com vários momentos remetidos a costumes do pueblo herdados por sua família e que, por sua vez, também permaneciam guardados em sua memória. Nessa sequência transitam os valores e crenças religiosos, o lugar social da mãe e dos filhos numa vida metropolitana que contrasta com o modelo familiar do campo, com as crises pessoais da protagonista e com os conflitos entre mãe e filhas.

Na cozinha encontram-se a mãe (Chus Lampreave) de Leo (Marisa Paredes) e Rosa (Rossy de Palma). As três conversam, mas as desavenças e conflitos familiares entre a mãe e Rosa são explícitas. A mãe sente-se continuamente injustiçada por morar com Rosa, que julga ser uma filha ingrata e ter outra filha perfeita - Leo. Numa cultura urbana de uma Madrid moderna onde a vida é acelerada e os valores descartáveis, também os seres humanos deixaram de ter importância. Os filhos vislumbram os pais como "peso morto" dentro de suas casas. Um empecilho a ser retirado para mantê-la em ordem. Rosa vive o conflito de tentar zelar pela mãe, mas os costumes que carrega do campo não permitem sua adaptação à cidade. Por outro lado, também o ritmo da cidade impõe à Rosa um comportamento que contrasta com seu sentimento de zêlo e decarinho.

Este é apenas um dos reflexos de relações contemporâneas ocorridos hoje nas grandes metrópoles e que o filme revela através do choque entre tempos e culturas diferentes. Os pais perdem seu lugar social, transformando-se num incômodo familiar, numa situação corrente e delicada hoje para a Europa. A comparação dos filhos com outros parentes, o condicionamento de olhar mais para a morte do que para a vida como já observou Almodóvar sobre a vida do pueblo -, a mistura das situações cotidianas com os conflitos pessoais das personagens. São estes os tipos de relações muito próximas que fazem dialogar as estruturas sociais familiares de campo e de cidade. A visualização destes aspectos se formaliza na seqüência a seguir:

${ }^{411}$ El Mundo - 27. 08. 1995; El País - 19. 09. 1995; ABC - 22. 09. 1995; El país - 22. set. 1995; El Periódico 23. 09. 1995; La Vanguardia - 24. 09. 1995; El País - 08. mar. 2003. 
La madre irrumpe gritando en la cocina.

Madre: qué, criticándome?

Rosa: qué susto me há dado! Por poco rompo las tazas!

Entra en la diminuta cocina.

Madre (a Leo): No le hagas caso, Leo ... Que yo estoy muy centrá ... (hace un gesto de dolor) Ojalá tuviera los pies tan bien como la cabeza ... Estoy fatal de los remos ... No puedo tirar de ellos ...

Rosa: no debería comer tanto "salao" ... tiene la tensión por las nubes [nuvens] Madre: que cruz tengo con ésta! [referindo-se a precisar viver com Rosa]

Leo: Dejad ya de discutir! Mamá, por qué no se pone la bata que le regalé? [ que te dei de presente]

Madre:es muy hermosa, ésa es para el museo.

Leo: se la compré para que se la pusiera.

Madre: está mucho mejor guardada ...

Rosa: parece una pordiosera [mendiga]. Me da vergüenza salir a la calle [rua] con ella ... en efecto. El atuendo [vestido] no pude estar más usado ni parcheado. (andrajos)

Madre (protesta a Leo): No hago [não faço] nada a gusto de tu hermana. Tiene las mismas rarezas que mi hermana Petra, que en paz descanse ... Es igualica que ella ...

La madre se direge al fondo: la zona del frigorífico y los armarios y encimeras que terminan en la pared de la estrecha cocina.

Rosa: usted sí que há salido a su hermana y a sus tías!

Y a su abuela!

Madre: y a quien más?

Leo: por favor, dejad nuestros genes en paz!

Madre (mientras [enquanto] busca algo junto al frigorífico, a Leo): el día menos pensado me voy al pueblo! Así no le estorbo a nadie! [a ninguém] (a Leo) Ay, qué pena, hija mía!

El lamento se refiere a la vejez [velhice], en abstracto, y concretamente a la suya

Rosa (molesta): quién há dicho que aquí estorba?

Madre: después de comer, si me quedo un poco traspuesta [se cochilo un pouco] ... ya está ella, como un sargento, despertándome ...

Rosa: es que si no por la noche no duerme ...

Madre: que me mueva ... que mueva ... leche! [mal educada]

qué quiere que haga, aeróbic? a ver si me muero pronto y así no molesto a nadie! (grita) dónde lo habrá puesto ... lo guarda todo como una urraca ...! [gralha]

Rosa (a grito pelao): qué busca?!

La madre le responde en la misma tesitura, es decir, a grito limpio.

Madre: los pimientos asados !!!

Rosa Le indica con la mano el rincón, justo delante de donde está la madre.

Rosa: ahí tiene los pimientos!

Madre (a Leo): no te lo dije? Si es que no veo ni gota!

La madre busca uma bolsa de plástico donde meter el frasco de cristal que contiene pimientos asados.

Rosa: pues ciega y todo quiere irse al pueblo ... Sin esperar siquiera que les den vacaciones a los niños ...

Madre: no quiero Madrid!

Leo (conciliadora): mamá, en el pueblo no puede estar sola. Tenemos que buscarle una mujer para que le haga las cosas de la casa, y la acompañe por las noches ...

Madre: Sí. Y que me hurgue [mexe] en los armarios y se coma las morcillas ... [embutidos]! Ni pensarlo!

Rosa: no hay quien se lo meta en la cabeza!

La madre envuelve el bote de pimientos en una bolsa de plástico.

Leo: mamá, para usted el pueblo es más sano [bom para a saúde]. Pero a partir de ahora no puede estar sola!

${ }^{412}$ Roteiro do filme La flor de mi secreto. Círculo de lectores, 2000. p. 56-61. 
La madre no le hace caso y cambia de tono; posee uma destreza increíble para pasar de la ira a la ternura, y viceversa.

Madre: toma. Te he hecho estos pimientos asados. Van dentro de la bolsa.

Leo coge [pega] de manos de su madre el tarro [vidro] de pimientos.

Leo: para qué se molesta? Tengo cocinera ...

Madre: a saber cómo guisará esa gitana! [como cozinhará esta cigana!]

Rosa: qué racista!

Leo:muy bien! Y no sabes cómo plancha! Paco dice que nadie le plancha las camisas como ella. Ni yo.

Madre (la interrumpe): pues en la guerra no creo que esté mejor asistido que en su casa.

Rosa escucha. Es el único momento en que se muestra cómplice de la madre, y no la contradice. Con su silencio la está apoyando. Leo cambia de expresión, pero tampoco dice nada.

Madre: te veo muy estropeada, Leo ... Irse a la guerra! (mira a Rosa, que asienta con la cabeza) por si tuviéramos pocos quebraderos de cabeza ...

Con su silencio Leo parece darle la razón a la madre ...

Madre: rezo por él todos los días ... para que no le pase nada ... [refere-se a Paco, marido de Leo, um militar que vive em missão de paz na Bósnia]

Leo: rece también por mí ...

Madre: claro que sí, hija mía, por ti la primera ...

Rosa: por mí es por quien no reza ...

Madre: tú eres atea.

Rosa: y a usted qué más le da. Usted rece! Quítese que le voy a dar! [dê-se por satisfeita pelo que te dou!]

Rosa busca un recipiente de plástico entre los armarios que hay sobre la cabeza de su madre.

Madre (a Leo): Oye, a propósito. Tienes que darme un achuchoncillo [ajudinha] para la contribución del pueblo.

Leo saca otro sobre [estojo] y se lo entrega ...

Leo: no me he olvidado ... aquí lo tiene.

Rosa: no quires más flan?

Leo: No.

Rosa: te lo meto en el tupeware y te lo llevas ... en otro te pongo los calamares. Madre: tampoco te olvides que el niño cumple años la semana que viene ...

Rosa: mamá, por Dios! Deje de pedir! El niño no necesita nada ...

Madre: unos vaqueros le vendrían muy bien [uma calça jeans lhe cairia muito bem] que siempre está con los mismos ... y ya es un hombrecillo! No sabes lo estudioso y formal que ha salido ... no como la loca de la hermana ... que no es capaz ni de lavarse las bragas ...[calcinhas]

Rosa: son las dos de la misma edad. La abuela y la nieta (a Leo) toma, el flan. Da un golpe a la mesa, com el tuperware. La madre cuenta el dinero que hay dentro del sobre [estojo] que Leo le há dado.

Madre (sin dejar de contar): Leocadia! Que cruz tengo com ésta!

Se refiere a su hermana Rosa.

Nessa longa passagem pode-se verificar a indissociabilidade existente entre o perfil pessoal do autor e sua vida revelados na obra. Drama, riso, conflitos pessoais e sociais, as origens. Ou seja, o cineasta busca compartilhar seus valores, suas experiências e suas perspectivas com seu público. Há uma condição posta: a cumplicidade que já ocorre entre ele e os membros de sua equipe está presente também na relação das personagens e precisa do público para ser completa.

Estoy muy satisfecho de estas escenas. Para mí son como un retrato de família. Leo pertenece a una clase social diferente, pero cuando entra en casa de su madre y su hermana, se ve que tienen las mismas raíces. [...] La relación que encarnan Chus y Rossy es típica de ciertas famílias españolas. La madre y la hija se adoran cuando tienen que separarse, entonce se produce la gran tragedia con sollozos y lágrimas. Pero cuando están juntas, no dejan de discutir 
y se dicen las cosas más horribles. Y se pasan así toda la vida. Tiene su gracia, pero es terrible. ${ }^{413}$

Um conjunto de elementos que leva película e público a se encontrarem mediados por relações cotidianas de conflitos afetivos entre pais e filhos, de encontro com temporalidades fragmentadas e desejos que denunciam laços independentes de classe social ou de origem cultural. Este conjunto de elementos sugere que o diretor busca algo além de espectadores e de colegas de trabalho.Deseja possuir amigos fiéis e pessoas com quem possa contar, como ocorreu em sua trajetória madrilenha em que compôs sua família fictícia a partir dos diversos amigos que - desde o primeiro filme contribuíram para seu sucesso. A motivação que o inspira para novos trabalhos precisa desses atos de cumplicidade, tão comuns à amizade:

[...] me he relacionado mucho, sobre todo al principio de mi carrera. Siempre he tenido [tive] muchos amigos, y las cosas no te llegan solamente por tu propia experiencia. De un modo natural, instintivo, siempre me ha gustado el espetáculo más simple: mirar a los demás. Me he descubierto en el autobús cuando - viajaba en autobús - pendiente de la conversación de dos señoras, es un deseo difícil de satisfacer, pero que yo sigo sintiendo muchísimo, daría algo porque pudiera comprarse lo que dicen. En efecto [na realidade], la primera época de mi vida en Madrid estuvo llena de relaciones, así que las historias que han ido apareciendo tienen mucho que ver con mis amigos. Inevitablemente, el trabajo y la situación que vives te van aislando [isolando] y las posibilidades de observación cada vez son menores. Pero sí, hay tonos [idéias] que se crean en grupo ${ }^{414}$

Apesar da mudança radical de vida depois da Movida e de seu sucesso, Almodóvar procura preservar os amigos, fazendo com que os vínculos não se percam totalmente. Amigo de Almodóvar do período da Movida, dos tempos do bar Rockola onde cantavam juntos, personagem Paty Diphusa das fotonovelas que o diretor escrevia para El Víbor" e parte do elenco de Laberinto de pasiones, Fábio MacNamara revê as mudanças que tiveram em suas vidas e o olhar que possui sobre o amigo após tantos anos passados:

Pedro es un tío muy listo, siempre lo ha sido, y la fauna entre la que vivíamos era muy de punks, [...] de rockers [...] cuando Pedro descubrió todo aquello, flipó [entusiasmou-se] y tuvo muy ganas que quería rodar allí. [...] en aquellos años todos, Pedro el primero, teníamos la necessidad de comunicarle a la gente cuanto nosotros éramos unos genios [...] Hoy no hay dos Pedros [...] Lo que pasa es que todos hemos cambiado, está claro que con aquel ritmo no pondríamos seguir siempre. Tuvo que ponerse serio [...] sus películas aunque sean diferentes, siguen con ese tono ácido tan suyo. [...] Pedro está ya muy curtido [experiente], no es ninguna Barbie que pueda lesionarse. Le veo equilibrado, tranquilo, maduro. Tiene la sartén [o controle da situação] cogida por el mango ${ }^{415}$

\footnotetext{
${ }^{413}$ STRAUSS, 2001. p. 132.

${ }^{414}$ LINDO, 26. set. 1992. p. 6.

${ }^{415}$ FERNANDÉZ, 19. mar. 2000. p. 24.
} 
As idéias de pessoas que continuam suas amigas, como MacNamara, possuem uma formulação já distanciada. Entre a nostalgia e o presente permanece a figura do Pedro, diretor. Em outra ocasião, no ano de 1989, em um curso de verão sobre Pedro Almodóvar promovido pela Universidade de El Escorial, ele e outros amigos da Movida refletiam com certa mágoa a distância estabelecida entre eles em detrimento da fama do diretor:

[...] Cree que ese mundo algunas veces marginal y otras irreal ha dejado de serlo por las propias películas del director. Así 'Que he hecho para merecer esto?' marca, a juicio de los participantes en el coloquio, el salto de Almodóvar y el cambio de su mundo. Los amigos del director no creen que cualquier tiempo pasado fuera mejor porque al añoranza [nostalgia] no tiene cabida en ese mundo, pero sí opinaron que ahora Pedro 'está en un ambiente elitista' y que ha perdido el contacto con la calle. $Y$ aunque no hubo reproches [ainda que não tenha havido censura] 'porque nadie le ha regalado [ninguém o presenteou] nada, todo se lo ha ganado trabajando mucho ${ }^{416}$

Marisa Paredes, que já era uma atriz famosa quando começou a trabalhar com o diretor, diz ter a impressão de que o conhecera sempre. Em meio ao sucesso de Todo sobre mi madre, observou a trajetória do amigo de maneira racional e curiosamente afetiva:

Es el momento justo. Si esta avalancha de premios le cae encima hace 10 años, no habría sabido digerirla. Ahora conoce lo efímero que es el éxito y sabe asumir lo que le está pasando [...] el que conocí cuando de la movida era un chico inquieto, brillante, lleno de ganas, pero con menor experiencia. Estos años ha pasado con los ojos muy abiertos y ahora hace detrás todo lo que ha aprendido y lo veo con más colores, más rico, con mayor capacidad para el goce [o prazer]. Ahora tiene la lucidez que da la inteligencia y experiencia [...] sigue siendo un gran transgressor. Lo que ocurre es que ya no le apetece transgredir con los mismos argumentos. Pedro se sigue riendo, pero a los 30 hacía con inconsciencia. Ahora con ironía. ${ }^{417}$

Os depoimentos se remetem à Movida ao se referirem aos vínculos de amizade. Claro, por algumas razões óbvias. Os que começaram suas carreiras no mesmo período de Almodóvar, que o conheceram em meio àquela efervescência cultural e comportamental ou ainda dada sua fama posterior, já se aproximaram dele em decorrência das afinidades profissionais. O que não deixa de ser um elemento significativo. A cada declaração, novos aspectos e reconstruções do passado - tanto da Movida como do cineasta - são resgatados e reinventados, pois reelaboram as lembranças com fatos e sentimentos vividos até o presente das relações.

Todas as referências apresentadas neste capítulo passam pelo contato de atividades profissionais exercidas entre as pessoas e o diretor. Trabalho, vida pessoal e cinema resumem uma mesma imagem de Pedro Almodóvar. Percebe-se que em toda sua obra a importância delegada à amizade não é casual. E pode-se notar que,

${ }^{416}$ BELTRÁN, Mercê. La Vanguardia, Barcelona, 27. set. 1989. p. 49. 
nas histórias onde ela não existe ou é abalada, a ação dramática se desenvolve no sentido de desestruturar as relações construídas entre as personagens.

Fechando esta discussão, acredito que tenha ficado claro por que metaforicamente gazpacho não é coca-cola. Sobretudo pelo que representa para as relações culturais e afetivas na Espanha e diante do mercado internacional. Para Almodóvar, esta distinção já foi definida e incorporada na sua proposta cinematográfica em todos os sentidos. E, num território onde não apenas conhece a receita, mas também domina sua fabricação - ao menos até o momento -, não Ihe interessa mudar de vez seu paladar, ainda que nas exceções ele experimente o sabor padronizado norte-americano.

${ }^{417}$ Ibid, p. 22-23. 


\section{CONCLUSÃO}

No final dos anos 80, com o sucesso conquistado nacionalmente, os trabalhos de Pedro Almodóvar já eram observados fora do país, na Europa e nos Estados Unidos. Pareciam regionais e específicos da cultura desenvolvida na Espanha, ao mesmo tempo em que mostravam sua entrada na vida moderna. Por mais que os próprios espanhóis vissem neles elementos pejorativos, foi com aqueles filmes que o cineasta projetou seu nome internacionalmente e reintroduziu seu país no mercado cinematográfico mundial.

Mesmo com inúmeras dificuldades para entrar em mercados "agressivos", ou seja, competitivos, ganhar a adesão do público mundial requeria uma linguagem mais universal e ao mesmo tempo o desenvolvimento de articulações cada vez mais estreitas com os participantes da indústria cinematográfica. Os festivais e as mostras foram e são apenas alguns dos caminhos encontrados para garantir um diálogo mais seguro e comprometido com distribuidores, produtores e críticos.

A experiência de proprietário da produtora El deseo, juntamente ao irmão Agustín, não teria sentido se a ousadia comedida - aparentemente um grande paradoxo - de suas práticas não tivesse ocorrido da forma como a exerceram. La Ley del deseo, mais do que representar a liberdade de realizar o que sua criatividade desejava, foi o grande teste internacional para medir o poder de negociação que os irmãos Almodóvar poderiam demonstrar dentro de seus papéis específicos. Em seu desdobramento, o filme Mujeres al borde de un ataque de nervios trouxe algumas chaves de ascensão para suas perspectivas e modificou radicalmente o panorama de suas vidas.

Seu sucesso estrondoso em vários lugares de significativa expressão para os interesses mercadológicos cinematográficos chegou à tona pelas mãos do diretor e de sua equipe. Lançamento em festivais, prêmios em Cannes, Veneza, Berlim, uma indicação para o Oscar de melhor filme estrangeiro (na época ainda não havia sido substituído pelo politicamente correto: 'de língua não inglesa'). Sem cenas eróticas polêmicas, com um humor leve e corriqueiro, com cenas dinâmicas, uma comédia de costumes agradável para toda família. Estes seriam alguns dos códigos estratégicos para continuar avançando com prestígio junto ao público e ao mercado. Porém, não seria essa a fórmula para sua legitimidade, e Almodóvar, apesar de tentado a entrar nos moldes do dinheiro garantido, sabia de seu desejo e não se sentia seduzido por isso. 
Se aquela película continha - com imagens temperadas - todos os ingredientes que apareciam nas anteriores: os dilemas femininos, cenas ligadas à diversidade da cultura espanhola, a impulsividade comportamental, o inusitado - 0 incêndio no quarto de Pepa e a hilária seqüência do gazpacho já se tornaram antológicos - isto ainda não significava sua realização. E o que seria? Uma mescla entre o gosto pela conquista cada vez maior de público e o receio em sucumbir às regras do grande mercado. Uma angústia de continuar revelando seu presente e suas mudanças pessoais e sociais, ampliando seus espectadores, sem perder a fidelidade daqueles que já o seguiam. Tarefa arriscada e marcada pelo exagero, que só alguém com o perfil do diretor para tentar tamanha empreitada.

Não abrir mão de sua visceralidade nas abordagens significava, agora, também ceder à lógica do universo cinematográfico, reelaborando uma imagem pública assimilável, mas ao mesmo tempo polêmica, sem cair no estereótipo. Todos estes elementos o diretor possuía e cabia somente a ele articulá-los. E conseguiu. Seu processo de maturidade o levou a compreender os momentos corretos para tomar atitudes e decisões adequadas.

Os filmes que lhe deram projeção representaram para ele um grande exercício profissional em vários patamares simultâneos. Mujeres al borde de un ataque de nervios vinha na seqüência de La ley Del deseo, uma película densa e dolorosa. Traduziu-se num filme que permitia ao diretor respirar depois de um trabalho que despendeu tanto desgaste emocional. Convinha agora dar ao público um pouco de alegria para que pudesse também pensar nas relações de maneira mais tranqüila e até rir-se delas, um recado que também dizia para si mesmo.

Apesar do sucesso, Mujeres al borde de un ataque de nervios se constitui numa obra menor dentro da filmografia de Almodóvar, como bem analisa Núria Vidal, mesmo reconhecendo nela a continuidade de obras anteriores.

Con Pepi... hay una relación evidente. Pepi se há hecho mayor [envelheceu] y se há converteu en Pepa. La chica desocupada y divertida, que se inventaba fantásticas maneras de sobrevivir, ha encontrado su profesión como dobladora y ha triunfado en la vida. Sus problemas son distintos, pero siguen siendo problemas de comunicación con el entorno. Aún tiene una amiga del alma [do peito] que se ha transformado de Bom en Candela y sus encuentros con la policía continúam siendo poco amistosos [...] con Laberinto... también hay puntos de contacto. Los terroristas chítas de Laberinto... siguen asolando Madrid. Por lo visto siguen siendo guapos y atractivos [bonitos e atraentes], aunque que sus gustos han cambiado de Riza Niro a la inocente Candela. [...] Entre tinieblas, la más negra [noir] de las películas de Almodóvar, parece estar muy lejos [distante] de esta blanca comédia de mujeres nerviosas y si embargo hay algo de ella. Por ejemplo, el uso de la música. La ranchera que Pepa no soporta oírr equivale al bolero que cantan la madre superiora y 
Mais do que haver prolongamentos ou diálogos entre as várias personagens de seus filmes, cabe assinalar que Almodóvar nunca abandonou determinadas bases em seus trabalhos, especialmente as abordagens sobre o desejo. Um desejo que percorre toda sua vida e entra na maturidade com filmes contendo personagens peculiares que buscam realizar suas vontades cada vez mais sentimentais por caminhos imprevisíveis. Frédéric Strauss observa que em suas películas esse elemento as resume:

[...] todas cuentan histórias sinuosas donde el amor y los deseos se pierden y se aventuran libremente por los entresijos [meandros] de una imaginación muy fértil. Lo que no impide que el deseo siempre pueda identificarse al instante en ellas y declararse categóricamente como una ley que dirigirá a los personagens. ${ }^{419}$

O desejo que aparece construído nos filmes de Almodóvar não é o resgate do instinto, nem sua motivação. É um desejo que busca integrar os impulsos e os sentimentos criados pelo ser humano numa tradução e elaboração que encontra o instinto para dar-Ihe um novo significado. E isso se desdobra nas tramas. Até Kika suas personagens são falantes, porque Almodóvar é falante. Após este filme aparecem outras mais reflexivas, espelhando seu novo momento. São sempre personagens identificadas diretamente com o diretor. Como escreve e dirige seus filmes, ele pode garantir que toda a concepção da história e das cenas se realize segundo sua vontade. Seu domínio é total.

Talvez poucas sejam as críticas daqueles que por não apreciarem seus trabalhos acabem por não vislumbrar esse aspecto. Muitos preferem enquadrá-lo num cinema militante de minorias ou num perfil que psicologiza a objetividade dos fatos correntes nas relações ou no universo imaginário das pessoas para transformá-los em desvios sociais. Porém, não é isso que se vê hoje na totalidade de seus trabalhos. As personagens marginais não resumem as histórias, apenas fazem parte do conjunto narrativo que se ocupa em falar de sentimentos e de resgate de trajetórias.

Todo sobre mi madre (1999), ao penetrar nos sentimentos femininos, procura homenagear e ao mesmo tempo compreender o universo materno no qual o próprio diretor sempre esteve mergulhado, envolto nos afetos de sua mãe. Hable con ella (2001) reúne os vários elementos da cumplicidade masculina por intermédio de um personagem - Benigno - que deixa inúmeras ambigüidades no ar sobre seu perfil pessoal. No entanto, não é sobre ele e seu caráter que se desenrola a ação dramática. A afinidade masculina em torno do amor e de experiências comuns, a necessidade de compreensão da outra pessoa e, por isso, a importância do diálogo são explicitadas

${ }^{418}$ VIDAL, Nuria. 1989, p. 312-313. 
desde a primeira cena do filme e tomam proporções gigantescas nas relações limite com as abordagens apresentadas sobre a vida e a morte.

La mala educación (2003), penúltimo trabalho do diretor, faz referência direta a sua história pessoal. Seu passado, misturado ao presente, rediscute temas que vem amadurecendo em sua carreira desde o início, mas que ao mesmo tempo traduzem um fluxo de reflexão sobre sua trajetória. Seu último trabalho, Volver (2006), começa a fechar este círculo próprio buscando compreender-se: suas origens, volta aos pueblos, o resgate de antigas amizades profissionais como Carmem Maura e Penélope Cruz. Vida e arte se misturam ampliando a imagem cinematográfica do diretor.

As personagens de Almodóvar também indicam a vida de grupos sociais dentro de uma metrópole em que antes praticavam o exercício da transição: ditadurademocracia e depois pessoas que amadurecem suas buscas na realização de desejos que incidem sobre as crises do mundo contemporâneo. Pedro Almodóvar, ainda encantado, não mais com a Madrid da Movida, mas em buscar explicações sobre a vida, segue na direção de compreender seus caminhos trilhados utilizando-se do próprio instrumento que o projetou.

Ainda permanecem os perfis de personagens marginais - mesmo pertencentes à elite -, mas a linha reflexiva acena para o diálogo e pede a ponderação. O autor, agora, em sua fase madura, busca equilibrar sua ironia com os vários dilemas pessoais humanos que, entretanto, obviamente incidem diretamente sobre os medos e desafios da vida moderna. Ainda que surjam algumas situações inverossímeis percorrendo várias de suas seqüências, não se vê em seus trabalhos uma fuga diante dos dramas que nos afligem. Já respeitado no seu universo artístico-profissional, seus desafios diante da mídia e da crítica hoje são melhor contornados e suas posturas compreendidas, tanto pelo público como pelos vários pesquisadores que ao menos há duas décadas seguem analisando seu trabalho.

Apesar de algumas objeções perante a crítica espanhola, Pedro Almodóvar mantém sua fidelidade temática e sua autonomia criativa, apresentando uma Espanha que já não choca os insatisfeitos com sua visão. Fica difícil saber o que mudou: se o país ou ele. Uma evidência se sustenta: a forma pouco incisiva com que hoje é visto. Almodóvar apaziguou seus ânimos e, diferente do processo histórico e político do país, não frustrou seus caminhos. Seus projetos se ampliam financiando produções de novos diretores e seu campo artístico se sustenta com sua produtora e ramificações ligadas aos filmes.

${ }^{419}$ STRAUSS, Frédéric. 2001, p. 10. 
Sua dosagem irônica, seu temperamento eufórico - características pessoais que também cooptou em função de seu trabalho - ainda sustentam sua imagem e ele sabe que é por intermédio desse conjunto de fatores, associando o trabalho com 0 irmão e uma equipe de base familiar, que mantém sua produção. Usa fórmulas simples, mas eficazes, que o fortalecem para não abrir mão de seus desejos. As duas máximas apresentadas pelo próprio diretor na introdução desta tese só reafirmam a hipótese e os objetivos iniciais que visavam a provar sua autenticidade. O ego que se equipara a Deus - que não crê existir - e a firmeza em seguir sempre fazendo o que gosta lhe garantem a liberdade para negociar.

Não há contradição. Aqui se revelam alguns dos aspectos do seu perfil autêntico. Com ironia em comparar-se ao que não existe, com ousadia para expor a situação que acredita tocar nos sentimentos, livre da moral e das regras, Almodóvar produz suas histórias e mantém seu trânsito ajustado às orientações do universo cinematográfico. Para cada grupo, seja entre os próprios cineastas, produtores, distribuidores, críticos, acadêmicos, jornalistas ou espectadores, o diretor possui atitudes adequadas que lhe favoreçam a um diálogo contínuo e direto. Ao mesmo tempo, sua preocupação em estabelecer conexões entre estes atores sociais facilita a manutenção de seu espaço e as boas relações para futuros contatos e investimentos.

$E$ isso não se processa somente nos filmes, mas em todo o desenvolvimento de sua vida. Falar de um cineasta que se encontra em plena atividade como Pedro Almodóvar e ainda mais com um perfil marcado por tantas polêmicas, torna-se um desafio. Sua contribuição para o cinema espanhol e mundial, como visto, não ocorreu apenas na mudança da linguagem cinematográfica, mas na forma de desenvolver mercados, na criação de alternativas mostrando que é possível fazer cinema de maneiras peculiares, escolhendo seu próprio caminho. Inevitavelmente ele se tornou um paradigma para tais práticas.

Longe de se constituir num gênio, ainda que em vários momentos já mitificado, foram as próprias circunstâncias e sua percepção aguçada, unidas a uma grande sensibilidade sobre seu entorno, que construíram este cineasta ao longo de sua trajetória. Suas estratégias e projeções sobre a vida que presencia atuam de maneira condensada em suas ações. A indissociabilidade entre diretor, artista, história e ficção em sua prática contínua revela o autor autêntico, garantindo a Pedro Almodóvar um lugar próprio na cinematografia contemporânea. 


\section{BIBLIOGRAFIA}

ALLISON, Mark. Un laberinto español. Madrid: Ocho y medio, 2003.

ALMODÓVAR, PEDRO. Patty diphusa y otros textos. 3. ed. Barcelona: Anagrama, 1995.

ALVAREZ, José Luis; SVEJENOVA, Silviya. Symbiotic carees in movie making: Pedro and Agustín Almodóvar. In: PEIPERL, M. et al. (org.). Career creativity - explorations in the remaking of work. New York: Oxford, 2002.

ARISTÓTELES. Poética. In: Os Pensadores. São Paulo: Abril Cultural, 1979.

ARMSTRONG, Karen. Breve História do mito. São Paulo: Cia. das Letras, 2005.

ARNHEIM, R. A arte do cinema. Lisboa: Edições 70, 1989.

ARONICA, Daniela. Pedro Almodóvar. 2. ed., accresciuta. Milano: Editrice II Castoro, 2000.

ARRUDA, Maria A. N. Mitologia da mineiridade. São Paulo: Brasiliense, 1990.

AUMONT, J.; MARIE, M. Dicionário teórico e crítico de cinema. Campinas: Papirus, 2003.

BARTHES, Roland. Mitologias. 5. ed. São Paulo: Difel, 1982.

BECKER, Howard S. Les mondes de L'art. Paris: Flammarion, 1988.

BENJAMIN, Walter. Obras escolhidas: magia e técnica, arte e política. São Paulo: Brasiliense, 1985.

BERNARDET, Jean-Claude. O autor no cinema. São Paulo: Brasiliense, 1994.

BUÑUEL, Luis. Meu último suspiro. Rio de Janeiro: Nova Fronteira, 1982.

BOURDIEU, Pierre. As regras da arte. São Paulo: Cia. das Letras, 1996.

. A economia das trocas simbólicas. 5. ed. São Paulo: Perspectiva, 2004.

. O poder simbólico. 3 ed. Rio de Janeiro: Bertrand Brasil, 2000.

BOSI, Alfredo. Fenomenologia do olhar. In: O Olhar. 9. reimpressão. São Paulo: Cia. das Letras, 2002.

CAMPBELL, J. Isto és tu. São Paulo: Landy, 2002.

CARAVELA, Gabriela B. M. O espetáculo do grotesco nos filmes de Almodóvar. 1997. Dissertação (Mestrado em Comunicação e Semiótica), Pontifícia Universidade Católica de São Paulo, São Paulo, 1997.

CASANOVA, Pascale. Beckett l'abstracteur: anatomie d' une révolution littéraire. Paris: Du Seuil, 1997.

DELEUZE, Gilles. Cinema: a imagem-movimento. São Paulo: Brasiliense, 1985.

ELIAS, Norbert. Mozart, sociologia de um gênio. Rio de Janeiro: Jorge Zahar, 1997. 
FABRIS, Mariarosaria. O neo-realismo cinematográfico italiano. São Paulo: Edusp/Fapesp, 1996.

GARCIA DE LEON, María Antónia. MALDONATO, Teresa. Pedro Almodóvar, la outra España Cañí (sociologia y crítica cinematográfica). Madrid: B. A. M., 1989.

et al. El cine de Pedro Almodóvar y su mundo: curso de verano de El Escorial, Universidad Complutense, 1989.

$\mathrm{HEINICH}$, Natalie. The glory of Van Gogh: an anthropology of admiration. New Jersey: Princeton University Press, 1997.

HOBSBAWM, Eric J. Era dos extremos - o breve século XX. 2. ed. São Paulo: Cia. das Letras, 2000.

HOLGUÍN, Antonio. Pedro Almodóvar. 2. ed. aumentada, Madrid: Cátedra, 1999.

HOPEWELL, John. El cine español después de Franco: 1973 - 1988. Madrid: El Arquero, 1989.

HUPPES, Ivete. Melodrama: o gênero e sua permanência. São Paulo: Ateliê Editorial, 2000.

JAMESON, Fredric. Espaço e imagem: teorias do pós-moderno e outros ensaios. Rio de Janeiro: UFRJ, 2004.

LEFEBVRE, Henri. Critique a la vie quotidiéne. Paris: Livro II, 1968.

LERA, José Maria Caparrós. El cine de los años 70. Pamplona: Ediciones da Universidad de Navarra, 1976.

LIPSITZ, G. Contra el viento: aspectos dialógicos del rock and roll. Revista de Occidente, 1995.

LÉVY, Pierre. Cibercultura. São Paulo: Editora 34, 2005.

LOPERA, José Alvarez et al. História geral da arte - Pintura IV. Madrid: Ediciones del Prado, ago. 1996.

MARKUS, Sasa. La poética de Pedro Almodóvar. Barcelona: Littera, 2001.

MICELI, Sérgio. Imagens negociadas. São Paulo: Cia. das Letras, 1996.

MORIN, Edgar. A alma do cinema. In: A experiência do cinema. XAVIER, Ismail (org.). Rio de Janeiro: Graal, 1983.

MONTERDE, José Enrique. Veinte años de cine español: un cine bajo la paradoja. Barcelona, 1993.

NERLICH, Michael. In BRICOUT, Bernadette (org.). O olhar de Orfeu: os mitos literários do Ocidente. São Paulo: Cia. das Letras, 2003.

OROZ, Silvia. Melodrama: o cinema de lágrimas da América Latina. 2. ed. rev. e ampliada. Rio de Janeiro: Funarte, 1999.

ORTIZ, Renato. Mundialização e cultura. 2. ed. São Paulo: Brasiliense, 1996. 
ORTIZ, Renato (org.). Pierre Bourdieu. Coleção Grandes Cientistas Sociais n 39. São Paulo, Ática, 1983.

PEÑUELA, Cañizal (org.). Urdidura de sigilos: ensaios sobre o cinema de Almodóvar. São Paulo: Anna Blume / ECA-USP, 1996.

POLIMENI, Carlos. Pedro Almodóvar y el Kitsch español. Madrid: Campo de Ideas. 2004.

RAFOLS, J. F. História del arte. 2. ed. Barcelona: Optima, 2000.

RUBIO, Pablo Pérez. El cine melodramático. Barcelona: Paidós, 2004.

SALGADO, Silvia Comenero. Pedro Almodóvar, Todo sobre mi madre. Barcelona: Paidós, 2001.

SÁNCHEZ VÁSQUEZ, Adolfo. Convite à estética. Rio de Janeiro: Civilização Brasileira, 1999.

SILVA, Wilson Honório da. Uma poética do desejo: o cinema de Pedro Almodóvar na transição espanhola. 1999. Dissertação (Mestrado) - Escola de Comunicação e Artes, Universidade de São Paulo, São Paulo,1999.

SORLIN, Pierre. Sociologia del cine. México: Fondo de Cultura Económica, 1985.

SOUZA, Gilda de Mello. A idéia e o figurado. São Paulo: Editora 34, 2005.

STRAUSS, Frédéric. Conversaciones con Pedro Almodóvar. Madrid: Akal, 2001.

SUNDAHL, Ingo Michael von. El sector cinematográfico barcelonés. 2005. Tese (Doutorado) - Universitat de Barcelona, Barcelona, 2005.

THOMASSEAU, Jean-Marie. El melodrama. México: Fondo de Cultura Econòmica, 1989.

VIDAL, Nuria. El cine de Pedro Almodóvar. Barcelona: Destino, 1988.

WAIZBORT, Leopoldo (org.). Dossiê Norbert Elias. 2. ed. São Paulo: EDUSP, 2001.

YARZA, Alejandro. Un caníbal en Madrid: la sensibilidad camp y el reciclage de la historia en el cine de Pedro Almodóvar. Madrid: Ediciones Libertarias, 1999.

ZURIÁN, Fran A.; VARELA, Carmen V. Almodóvar: el cine como pasión. Cuenca: Ediciones de la Universidad de Castilla-La Mancha, 2005.

\section{PERIÓDICOS}

ALCAZÁR, Mariángel. El Periódico del Verano, Palma, 20 ago. 1996. Enviada especial.

ALMODÓVAR, Pedro. Almodóvar traspasa fronteras. El Periódico, Madrid, 22 mai. 1988. Espetáculos.

ALMODÓVAR, P. Testimonio. La Esfera, Madrid, 11 out. 1997.

ALMODÓVAR, Pedro. Es Almodóvar un genio ? - autobiografía. El País, Madrid, 17 out. 1993. 
BAETA, Fernando. Almodóvar, ten ciudado con el cerdo. El Mundo, Madrid, 23 out. 1993.

BASTERRA, Francisco G. No sé com que cara volveré. El País, Los Ángeles, 29 mar. 1989. La cultura.

BAYÓN, Miguel. El hombre del año - Pedro Almodóvar, el ingenioso manchego. Cambio 16, Madrid, 23 jan. 1989, n. 895. Especial.

BELTRÁN, Mercê. La Vanguardia, Barcelona, 27 set. 1989.

CABEZA, Elisabet. Almodóvar agrada a França perquè ha renovat el clixé folklòric espanyol. Avui, Paris, 13 fev. 1994.

CAPDEVILA, Montse. Kika se estrena em Francia com duras críticas - la prensa dice que Almodóvar se repite. El Periódico, Paris, 21 jan. 1994.

CASAS, Quim. Una mezcla sin ideas. El Periódico, Madrid, 6 nov. 1993.

CELIS, Bárbara. Pedro Almodóvar defiende el artificio en su cine en Nueva York. EI País, Nova York, 9 out. 2004. Espetáculos.

COMAS, Àngels. Kika - confirmanción de la decadencia de Almodóvar. La

Vanguardía, Barcelona, 14 out. 1996. Revista 8.

COSTA, J.J. Sánchez. El Periódico, Madrid, 19 set. 1995.

Diari de Barcelona, 18 jan. 1992.

Diari de Barcelona, 2 mar. 1992.

El tema de la semana, El periódico, 21 maio 1989.

El País, 29 dez. 1990.

El periódico, 30 jun.. 1991. Espetáculos.

E. S. Expertos internacionales sobre Pedro Almodóvar se reunirán en Cuenca. El País, Madrid, 24 out. 2003.

FALCON, Pilar. Entrevista con Pedro Almodóvar. He perdido el Oscar pero mi película es la más taquillera. Tribuna, Madrid, 3 abr. 1989.

FERNÁNDEZ, Juan. Entrevista con Esther García. El Periódico, Madrid, 19 mar. 2000.

FERNÁNDEZ, Juan.Entevista con Pedro Almodóvar: Por vez primera me toman en serio. El Periódico, Madrid, 19 mar. 2000.

FERNÁNDEZ-SANTOS, Ángel. La ley del desatre. El País, Madrid, 6 nov. 1993.

FERNÁNDEZ-SANTOS, Elsa. La fama me ha hecho polvo. El País, Madrid, 15 mar. 2002.

FLORES, Felix. Entrevista com Pedro Almodóvar. La Vanguardia, Barcelona, 25 out. 1991.

FOUCE, Héctor. La cultura juvenil como fenómeno dialógico: reflexiones em torno a la Movida madrileña. Universidad Complutense de Madrid. CIC- Cuadernos de Información y Comunicación, Madrid, ISSN 1135-7991, n. 5, p. 267, 2000. 
FRANCIA, Juan I. Entrevista com Pedro Almodóvar. La Vanguardia, Barcelona, 30 jan. 2000.

FRESNEDA, Carlos. Pedro Almodóvar pierde su batalla americana. El Mundo, Madrid, 30 abr. 1994. Cultura.

GARCÍA, Luis Alonso. Revista ABC Cultural, Madrid, p.42,16 mar.2002.

GARCÍA, Rocio. De dónde ha salido el mandil que usa Chus Lampreave en 'La flor de mi secreto'? El País de Las Tentaciones, Madrid, 22 set. 1995.

GARCIA, M.A. e HERNÁNDEZ, Víctor. Un antecedent a la LPRS, la "Ley de Vagos y Maleantes"; La "Ley de Peligrosidad y Rehabilitación Social"; L'ambient gai i el moviment clandestí homosexual durant el fraquisme. Lambda, n. 53, primavera 2005, any XXVII, Barcelona, p. 11-16.

GONZÁLEZ, Enric. Almodóvar cree que Italia es más generosa con su cine que España. El País, Roma. 06 fev. 2005. Espetáculos.

GUBERN, Román. El Periódico, Madrid, 31 jan. 1996.

GUITART, Manuel. Almodóvar rechaza ofertas para dirigir em hollywood. El Periódico, Londres, $1^{\circ}$ abr. 1991.

HARGUINDEY, Ángel S. Toma la fama y corre. Entrevista. El Pais Semanal, Madrid, 30 set. 1984.

HARGUINDEY, Angel S. Las chicas de Pedro. Avui, Barcelona, 28 mar. 1999.

IBORRA, Juan Ramón. Entevista com Pedro Almodóvar. El Periódico, Madrid, 26 out. 1997.

JOLONCH, C. Entrevista com Pedro Almodóvar. La Vanguardia Magazine, Barcelona, 18 jul. 1993.

LA TORRE, losu de. Entrevista com Pedro Almodóvar. El Periódico, Madrid, 7 nov. 1993. La gente.

La Vanguardia., 21 fev.. 1991.

La Vanguardia. n. 39, 20 ago. 1999.

LINDO, Elvira. Entrevista com Pedro Almodóvar. Babelia. El País, Madrid, 26 set. 1992.

LLOPIS, Silvia. Entrevista com Pedro Almodóvar. Cambio 16, Madrid, n. 941, 11 dez. 1989.

MARINQUE, Diego A. La Movida 25 años después. El País semanal, Madrid, n. 1492, $1^{\circ}$ maio 2005.

MANRIQUE, Diego A. Laberinto de pasiones. EI País, Madrid, 11 dez. 2004.

MARSÉ, Juan. Señoras y señores. El País, Madrid, 30 ago. 1987.

MARTín, Ana. Almodóvar y su clan se acercan a Hollywood. Cambio 16, Madrid, n. 889, 12 dez. 1988.

MARTÍN, Javier. La academia de Hollywood hace universal el cine de un manchego hijo de mulero. El País, Madrid, 20 fev. 2003. 
MARTIN-LUNAS, Milagros. El Mundo, Madrid, 24 set. 1998.

MAHIEU, José A. El único premio posible es el dinero. Fotogramas, Madrid, n. 1705, fev. 1985.

MOJICA, Luís Bonet. La Vanguardia, Barcelona, 13 fev. 2006.

MOJICA, Luis B.Entrevista com Pedro Almodóvar. La Vanguardia, Barcelona, 8 maio 1988.

MONTERO, Manuel. El Periodico, Madrid, 11 mar. 1993.

MONTERO, Manuel. Las cuentas del mago Almodóvar. El Periódico, Madrid, 30 jun. 1991. Espetáculos.

MONTERO, Rosa. Entrevista com Pedro Almodóvar. El Pais Semanal, Madrid, 28 set. 1986.

MUÑOZ, Diego. El líder de los Talking Heads compondrá la banda sonora de la próxima película de Pedro Almodóvar. La Vanguardia, Barcelona, 17 abr. 1989. Espetáculos.

MONTAGUT, Albert. Jodie Foster y Glenn Close quieren trabajar con Almodóvar. El País, New York, 21dez. 1991. Espetáculos.

MORA, Miguel. Almodóvar tiñe de negro La Croisette. El País, Madrid, 13 maio 2004. La Cultura.

MUÑOS, Diego. Pedro y Agustín Almodóvar se dan baja de la Academina del cine de España. La Vanguardia, Barcelona, 8 fev. 2005. Cultura.

NARVAÉS, Raquel. El héroe gordito ataca de nuevo. El Periodico, Madrid, 21 maio 1989. El tema de la semana.

NIEVES, Rosa de las. 6 toros para Almodóvar: una película que nace con polémica. Interviú, Madrid, 23 jul. 2001.

NIEVES, Rosa de las. La faena de Almodóvar. Interviú, Madrid, 30 jul. 2001.

PARRONDO, Jorge. La Vanguardia, Barcelona, $1^{\circ}$ maio 1994. Espetáculos.

PIÑA, Begoña. La Vanguardia, Barcelona, 24 set. 1998.

RIVERA DE LA CRUZ, Marta. Así nacieron dos 'Oscars'. El País, Madrid, 17 set. 2000, Cine 4, p.28.

PONGA, Paula. Entevista com Pedro Almodóvar: Estoy me haciendo mayor.

Fotogramas, n. 1760, Madrid, fev. 1990.

ROVIRA, Bru. Entrevista com Pedro Almodóvar. La Vanguardia, Barcelona, 27 out. 1984.

RUBIO, Teresa. El Periodico, Madrid, 14 mar. 1999.

SANCRISTÓVAL, Piedad. Pedro Almodóvar vende todas sus películas a Televisión Española. El País, Madrid, 29 dez. 1990. Televisión / radio.

SARTORI, B. El público español me comprende. El Mundo, Madrid, año II, n. 30, 15 jan. 1994. Cinelandia. 
STRAUSS, Frédéric. La conquista de Europa. EI Pais, Madrid, 17 out. 1993.

TOLEDO. Adiós a una madre. La Vanguardia, Barcelona, 12 set. 1999.

TORREIRO, M. Las críticas a 'Kika' no me afectan. El País, Madrid, 3 nov. 1993. Espetáculos.

TORRELLAS, María. Entrevista com Pedro Almodóvar. Lo mismo voy a una tasca que a una fiesta que dé el Rey. Diario de Barcelona, Barcelona, 1986.

TORRES, Maruja. Entrevista com Pedro Almodóvar. El País, Madrid, 25 set. 1993. La Cultura.

TOPOUNET, Rafael. Els Almodóvar obren un cisma em el cine espanyol. El Periodico, Madrid, 8 fev. 2005.

Trapiello, Andrés. Cosas de brujos - IV centenário del Quijote in Babélia, EI País, Madrid, 23 abr. 2005.

XAXÀS, Xavier Mas de. Almodóvar abre Nueva York. La Vanguardia, New York, 27 set. 1999.

En portada. La Vanguardia, Barcelona, 27 ago. 1989, p. 28-36.

\section{DOCUMENTOS ELETRÔNICOS}

CAMPAÑA, Mario. Memória y sueño: entrevista con Victor Erice. La Jornada Semanal, Ciudad de México, 6 fev. 2000. Disponível em:

<http://www.jornada.unam.mx/2000/02/06/sem-erice.html>.

MARTOS, Bárbara. Entrevista con el director de Belle Epoque. Disponível em:

<http://www.terra.es/cine/actualidad/articulo.cfm?ID=906>.

Produtora El Deseo. Disponível em: <http://www.egeda.es/eldeseo>.

Pedro Almodóvar. Página Oficial. Disponível em:

<http://www.clubcultura.com/clubcine/clubcineastas/almodovar>.

Bibliografia da Universidade de Berkeley. Disponível em:

<http://www.lib.berkeley.edu/MRC/almodovar.html/>.

<http://www.w3.elmundo.es/encuentros/invitados/2004/04/1054/>.

<http:// www.clubcultura.com/clubcine/clubcineastas/trueba/index.htm>.

<http:// www.galeon.com/carpleg/gutierrezbio.htm>.

<http:// www.culturalianet.com/art/ver.php?art=22527>.

<http:// www. elpais.es/publicidad/2003/cine/PAGINAS/40_erice.htm>.

<http:// www. encadenados.org/n33/el_valor_del_cine.htm>.

<http:// www.elpais.es/publicidad/203/cine/PAGINAS/30_chavarri.htm>.

<http: // www.clubcultura.com/clubcine/clubcineastas/bigas/bi-info/bio.pdf>. 
<http: // www.galeria-metropolitana.com/artists/blum.index.html>.

$<$ http://www.e-

barcelona. org $/$ modules . php?op=modload\&name=News\&file=article\&sid=7355>.

$<$ <ttp://www.venturapons.com/biografia.html>.

$<$ http://www.es.wikipedia.org/wiki/Navajeros>.

$<$ http://www.es.wikipedia.org/wiki/ El pico>.

$<$ http://www.seminci.com/plantillasphp/catalogo.php?id_pelicula=707>.

<http://www.es.wikipedia.org/wiki/Colegas>.

<http://www.venturapons.com/filmografia/morironop.html>.

<http://www.cinestel.com/41701/1901.html?*session*id*key*="session*id*val*> .

<http://galeon.com/cantabriag/Biografias/CarpG/GutAragon/GAragon.htm\#Demonios\% 20en\%20el\%20jardín>.

<http://es.wikipedia.org/wiki/Cine_quinquil>.

<http://es.wikipedia.org/wiki/La estanquera de Vallecas>.

$<$ http://www.venturapons.com/eindex.html>.

$<$ http://www.lenguaensecundaria.com/resenas/besos.html>.

<http:// www.rtve.es/rne/r3//pr/7vicios/testim/art_mm_01.htm>.

<http:// www.el-mundo.es/magazine/m78/textos/eloy1.html>.

<http://<www.elmundo.es-encuentros digitales>. Acesso em: 23 abr. 2004.

<http://es.movies.yahoo.com/a/animales-heridos/index-160937.html>.

$<$ http://<www.premiosondas.com/historia/index.html>.

<http://www.mailxmail.com/curso/vida/historiacineespanol/capitulo9.htm>.

<http://www.televisiondigital.electronicafacil.net/programaciontv/Article604.html>.

$<$ http://es.wikipedia.org/wiki/Eloy de la Iglesia>.

<http://www.cinestel.com/41701/1901.html>.

<http://www.canalok.com/cine/venturapons.htm>.

<http://www.terra.es/cine/actualidad/articulo.cfm?lD=906>.

$<$ http://www.clubcultura.com/noticias/leer.php?not_id=4477 - 05. 07. 2006>. 


\section{FILMOGRAFIA}

ALLEN, Woody

Noivo neorótico, noiva nervosa (Annie Hall) (1977)

Manhatan (1979)

Hanna e suas irmãs (1986)

Misterioso assassinato em Manhatan (1993)

Poderosa Afrodite (1995)

Desconstruindo Harry (1997)

Ponto final (Match Point) (2005)

\section{ALMODÓVAR, Pedro}

Pepi, Luci, Boom y otras chicas del montón (1980)

Laberinto de pasiones (1982)

Entre tinieblas (1983)

Qué he hecho yo para merecer esto? (1984)

Matador (1985-1986)

La ley del deseo (1986)

Mujeres al borde de un ataque de nervios (1987)

Átame (1989)

Tacones lejanos (1991)

Kika (1993)

La flor de mi secreto (1995)

Carne trêmula (1997)

Todo sobre mi madre (1999)

Hable com ella (2002)

La mala educación (2004)

Volver (2006)

ANTONIONI, Michelangelo

O eclipse (1962)

Blow-up (1966) 
ARANDA, Vicente

Cambio de sexo (1977)

Amantes (1991)

ARAGÓN, Manolo Gutiérrez

Demonios en el jardin (1982)

BARDEM, Juan Antonio

Esa Pareja feliz (1951)

Muerte de un cliclista (1955)

Calle mayor (1956)

BERGMAN, Ingmar

O sétimo selo (1956)

A fonte da donzela (1959)

Sonata de outono (1978)

BERLANGA, Luis García

Bienvenido Mrs.Marshall (1952) - com Bardem

Placido (1961)

Verdugo (1964)

La escopeta nacional (1977)

Patrimônio nacional (1981)

BERTOLUCCI, Bernardo

La luna (1979)

BUÑUEL, Luis

Un chien andalou (1928)

Os esquecidos (1950)

Extraña pasión (ou: Él) (1952) 
Abismos de pasión (1954)

Ensaio de um crime (1955)

Viridiana (1961)

Anjo exterminador (1962)

A bela da tarde (1967)

O discreto charme da burguesia (1972)

O fantasma da liberdade (1974)

Esse obscuro objeto do desejo (1977)

CAMUS, Mario

Los santos inocentes (1984)

CAPRA, Frank

Arsenic and old lace (1944)

CASSAVETES, John

Opening night (1977)

CHÁVARRI, Jaime

El desencanto (1976)

A un Dios desconocido (1977)

Las bicicletas son para el verano (1983)

Bearn (1983)

Las cosas del querer (1989)

COLOMO, Fernando

Qué hace una chica como tú en sitio como éste? (1978)

O efeito mariposa (1995)

El cuarteto de La Habana (1998)

Cosas que hacen que la vida valga la pena (2004)

El próximo oriente (2006) 
CURTIS, Michael

Casablanca (1942)

DONEN, Stanley

Cantando na chuva (1952)

Cinderela em Paris (1957)

EDWARDS, Blake

Bonequinha de luxo (Breakfast at tiffany`s) (1961)

ERICE, Victor

El espírito de la colmena (1973)

El sur (1983)

FASSBINDER, Rainer Werner

Berlin Alexanderplatz (1980)

Lili Marlene (1980)

Querelle (1982)

FELLINI, Federico

O sheik branco (1952)

As Noites de Cabíria (1957)

A doce vida (1960)

Oito e meio (1963)

Julieta dos espíritos (1965)

Satyricon (1969)

Roma de Fellini (1972)

Ensaio de orquestra (1979)

E la nave va (1983)

A entrevista (1987)

A voz da lua (1990) 
FERNÁN-GÓMEZ, Fernando

El extraño viaje (1964)

GAY, Sesc

Kràmpack (2000)

GODARD, Jean-Luc

Acossado (1959)

A chinesa (1967)

GUERIN, José Luis

En construción (2000) - documentário

HITCHCOCK, Alfred

Rebecca, a mulher inesquecível (1940)

Suspeita (Suspicion) (1941)

Spellbound (1945)

Pacto sinistro (Strangers on a train) (1951)

Vertigo (1958)

Cortina rasgada (1960)

Psicose (1960)

JORDAN, Neil

Café da manhã em Plutão (2005)

LA IGLESIA, Eloy De

El diputado (1978)

Navajeros (1981)

El Pico I (1983)

El Pico II (1984)

La estanquera de Vallecas (1987) 
LEROY, Mervyn

A ponte de Waterloo (1940)

LUBITSH, Ernst

Ninotchka (1939)

LUNA, Bigas

Bilbao (1978)

Renacer (1981)

Jamon, Jamon (1992)

Huevos de oro (1993)

La Teta y la Luna (1994)

MANKIEWICZ, Joseph L.

Malvada (All about Eve) (1950)

MINNELLI, Vincent

The Bad and the Beautiful (1952)

OLEA, Pedro

Pim, pam, pum, fuego! (1975)

PASOLINI, Pier Paolo

Teorema (1968)

Saló ou os 120 dias de Sodoma (1975)

POLANSKI, Roman

Repulsa ao sexo (1965)

PONS, Ventura

Ocaña - retrato intermitente (1978) - documentário 
La Rossa del bar (1986)

Puta Miséria (1989)

Què t'hi jugues, Mari Pili ? (1990)

El perqué de tot plegat (o porque de todas as coisas) (1994)

Actrius (1996)

Carícies (1997)

Ami/amat (1998)

Morir (o no) (1999)

Anita no perd el tren (2000)

Amor idiota (2004)

PREMINGER, Otto

Bom dia tristeza (1958)

ROSSELINI, Roberto

Roma, cidade aberta (1945)

Paisà (1946)

SALLES, Walter

Central do Brasil (1998)

Diários de motocicleta (2004)

SAURA, Carlos

Los ojos vendados (1978)

Deprissa, deprissa (1980)

Bodas de sangre (1980)

La caza (1990)

SIRK, Douglas

Imitação da vida (1959)

Escrito sobre el viento (written on the Wind) (1956) 
SCOTT, Tony

Fome de viver (1983)

TRUEBA, Fernando

Opera prima (1980)

Sedução (Belle époque) (1992)

La niña de tus ojos (1998)

Calle 54 (2000)

URIBE, Imanol

El rey pasmado (1991)

VIDOR, Charles

Adeus às armas (1957)

VISCONTI, Luchino

La terra trema (1948)

Belíssima (1951)

Gatopardo (1963)

Morte em Veneza (1971)

WELLS, Orson

Cidadão Kane (1941)

WENDERS, Win

Paris Texas (1984)

WILDER, Billy

Crepúsculo dos deuses (Sunset Boulevard) (1950)

Quanto mais quente melhor (1959)

Se meu apartamento falasse (The apartament) (1960) 